\title{
Enantioselective Synthesis of (-)-Paeonilide
}

\author{
Dissertation \\ Zur Erlangung des Doktorgrades \\ Dr. rer. nat. \\ an der Fakultät für Chemie und Pharmazie \\ der Universität Regensburg
}

vorgelegt von

Klaus Harrar

aus Straubing

Regensburg 2011 
Die Arbeit wurde angeleitet von: Prof. Dr. Oliver Reiser

Promotionsgesuch eingereicht am: 15.11.2011

Promotionskolloquium am: 13.12.2011

Prüfungsausschuss:

Vorsitz: Prof. Dr. Axel Jacobi von Wangelin

1. Gutachter: Prof. Dr. Oliver Reiser

2. Gutachter: Priv. Doz. Dr. Kirsten Zeitler

3. Prüfer: Prof. Dr. Henri Brunner 
Der experimentelle Teil der vorliegenden Arbeit wurde in der Zeit von Oktober 2007 bis August 2011 unter der Leitung von Prof. Dr. Oliver Reiser am Institut für Organische Chemie der Universität Regensburg angefertigt.

Herrn Prof. Dr. Oliver Reiser möchte ich herzlich für die Überlassung des äußerst interessanten Themas, die anregenden Diskussionen und seine stete Unterstützung während der Durchführung dieser Arbeit danken. 

Meiner Familie 
"Wissen ist Nacht."

Prof. Dr. Abdul Nachtigaller 


\section{Table of contents}

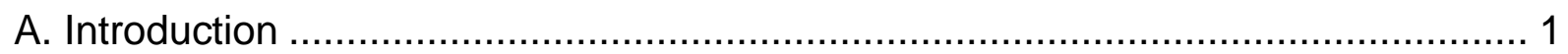

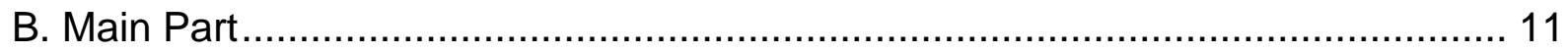

1. Preparatory work for the asymmetric cyclopropanation ................................. 13

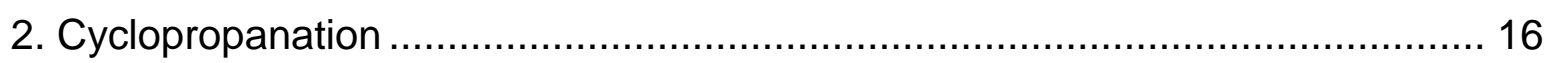

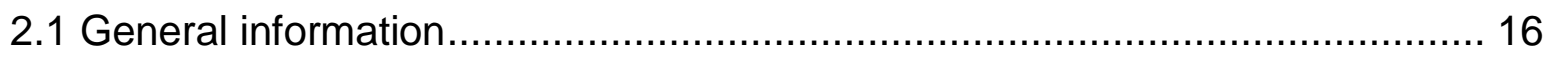

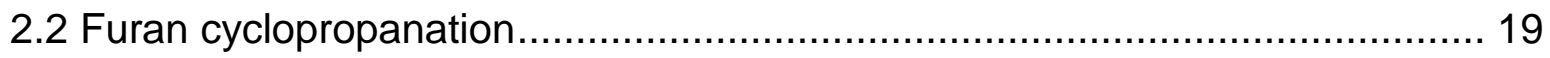

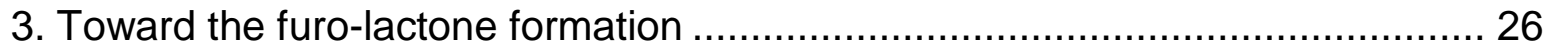

4. Side chain introduction by $\mathrm{C}-\mathrm{H}$ insertion .................................................... 40

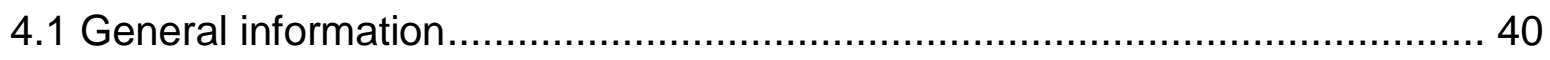

4.2 Preparatory work for the $\mathrm{C}-\mathrm{H}$ insertion reaction ...................................... 45

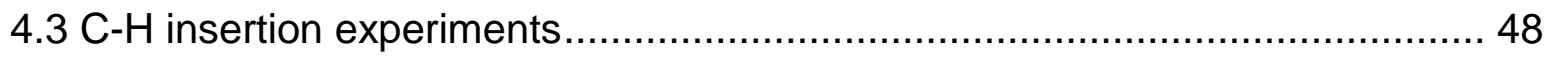

5. Side chain introduction by established chemistry ....................................... 53

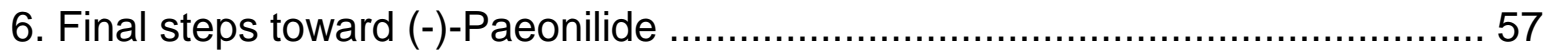

7. Characterization and biological evaluation of (-)-Paeonilide ...........................6 65

C. Summary \& Schematic Overview............................................................... 67

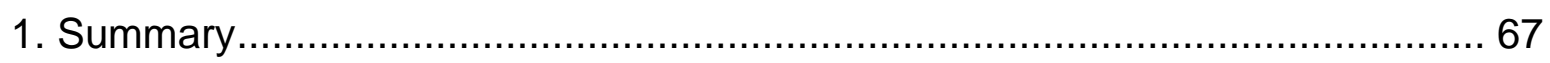

2. Schematic overview of synthesized compounds ........................................... 72

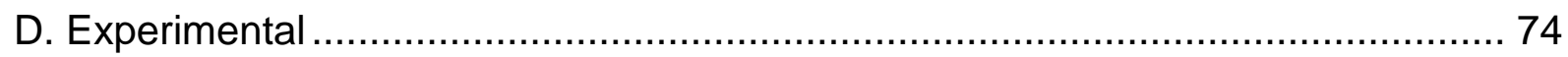

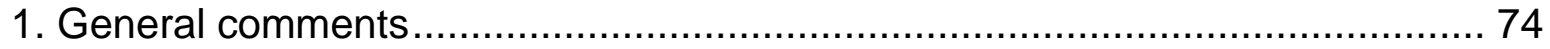

2. Synthesis of literature-known compounds and reagents ................................ 76

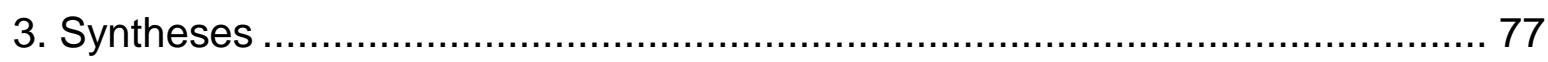

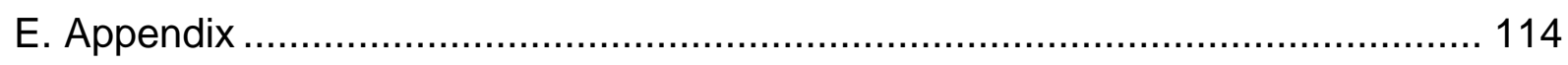

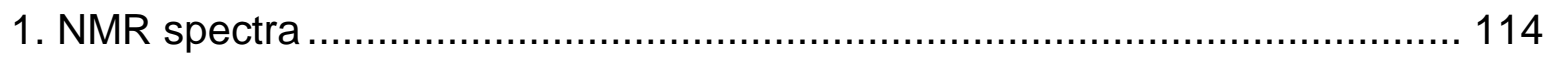

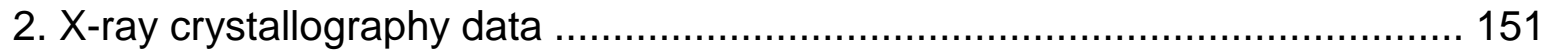

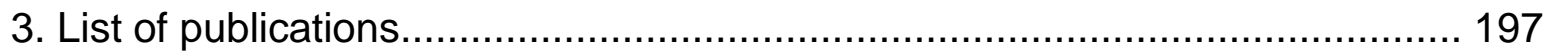

4. Poster presentations and scientific meetings ............................................. 197

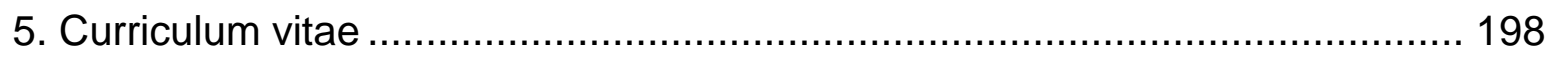

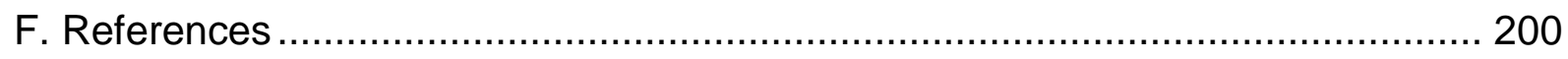

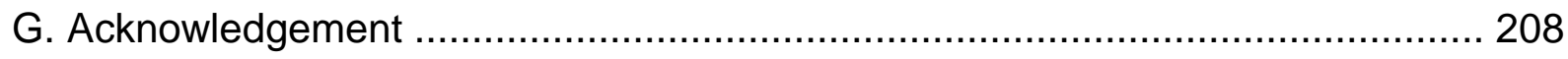





\section{Abbreviations}

\begin{tabular}{|c|c|c|c|}
\hline abs & absolute & M & molar \\
\hline acac & acetylacetonate & $\mathrm{Me}$ & methyl \\
\hline AIBN & aza-isobutyronitrile & $\min$ & minute \\
\hline $\mathrm{Bn}$ & benzyl & $\mathrm{mp}$ & melting point \\
\hline bp & boiling point & MS & mass spectroscopy \\
\hline brine & saturated $\mathrm{NaCl}$ solution & NBS & $\mathrm{N}$-bromosuccinimide \\
\hline brsm & $\begin{array}{l}\text { based on recovered starting } \\
\text { material }\end{array}$ & $\begin{array}{l}\text { NMR } \\
\text { NOE }\end{array}$ & $\begin{array}{l}\text { nuclear magnetic resonance } \\
\text { nuclear Overhauser effect }\end{array}$ \\
\hline BTS & bis(trimethylsilyl)sulfate & OTf & triflate \\
\hline $\mathrm{Bu}$ & butyl & $p$ & para \\
\hline $\mathrm{Bz}$ & benzoyl & PE & hexanes \\
\hline CAN & $\begin{array}{l}\text { cerium(IV) ammonium } \\
\text { nitrate }\end{array}$ & $\begin{array}{l}\text { PPTS } \\
\text { Pr }\end{array}$ & $\begin{array}{l}\text { pyridinium } p \text {-toluenesulfate } \\
\text { propyl }\end{array}$ \\
\hline cat & catalytic & $p$-TSA & para-toluenesulfonic acid \\
\hline conc & concentrated & py & pyridine \\
\hline d & day & ref & reference \\
\hline DBU & $\begin{array}{l}\text { 1,8-diazabicyclo[5.4.0] } \\
\text { undec-7-ene }\end{array}$ & & $\begin{array}{l}\text { room temperature } \\
\text { tert }\end{array}$ \\
\hline DCM & dichloromethane & TBAF & tetrabutylammonium fluoride \\
\hline DMA & dimethylacetamide & TBDMS & tert-butyldimethylsilyl \\
\hline DMAP & $\begin{array}{l}\mathrm{N}, \mathrm{N} \text {-dimethyl-4- } \\
\text { aminopyridine }\end{array}$ & $\begin{array}{l}\text { TFA } \\
\text { THF }\end{array}$ & $\begin{array}{l}\text { trifluoroacetic acid } \\
\text { tetrahydrofuran }\end{array}$ \\
\hline DME & dimethoxyethane & TLC & thin layer chromatography \\
\hline DMF & dimethyl formamide & TMS & trimethylsilyl \\
\hline DMPU & $\begin{array}{l}\text { 1,3-dimethyl-3,4,5,6-tetra } \\
\text { hydro-2(1H)-pyrimidinone }\end{array}$ & $\begin{array}{l}\text { Ts } \\
\text { vol\% }\end{array}$ & $\begin{array}{l}\text { tosyl } \\
\text { volume \% }\end{array}$ \\
\hline$d r$ & diastereomeric ratio & wt $\%$ & weight \% \\
\hline EA & ethyl acetate & & \\
\hline$e e$ & enantiomeric excess & & \\
\hline eq & equivalent & & \\
\hline $\mathrm{Et}$ & ethyl & & \\
\hline$f l$ & fluid & & \\
\hline h & hour & & \\
\hline HMBC & $\begin{array}{l}\text { heteronuclear multible-bond } \\
\text { correlation }\end{array}$ & & \\
\hline HPLC & $\begin{array}{l}\text { high-pressure liquid } \\
\text { chromatography }\end{array}$ & & \\
\hline HSQC & $\begin{array}{l}\text { heteronuclear single- } \\
\text { quantum correlation }\end{array}$ & & \\
\hline$i$ & iso & & \\
\hline$m$ & meta & & \\
\hline
\end{tabular}





\section{A. Introduction}

Traditional herbal prescriptions attracted worldwide attention within the last years, due to their effectiveness against many afflictions and their low toxicity. In some instances they provide an even more effective way to heal diseases where western therapies failed or were insufficient to provide a palliative cure. ${ }^{1-4}$

Natural products of herbal origin had an indisputable impact in modern medicinal chemistry and still break ground for new drugs. Peony root bark (chinese: "mu-dan-pi" or "dan-pi") containing prescriptions like the multiherbal formula GuiZhiFuLing-Wan are employed in China, Japan and Korea to alleviate the syndromes of blood stasis and stiffness of abdominal muscles. ${ }^{5-7}$ Since Peony roots are under phytochemical investigation for many years, several new monoterpenoids could be isolated, characterized and pharmacologically analyzed (Figure 1): ${ }^{8-9}$

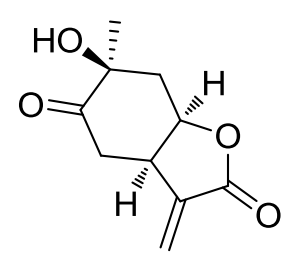

1: Paeonilactone $B$

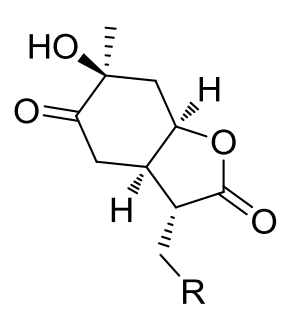

2: $\mathrm{R}=\mathrm{H}$, Paeonilactone $A$

3: $\mathrm{R}=\mathrm{OBz}$, Paeonilactone $\mathrm{C}$

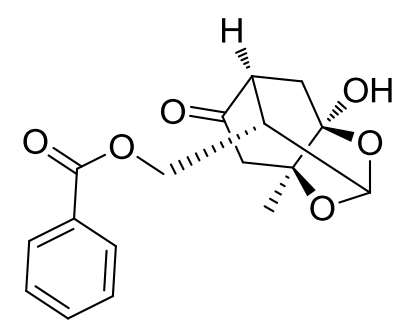

4: Paeoniflorigenone

Figure 1: Examples of natural products isolated from peony roots.

For example, Paeonilactone C (3) suppresses both directly and indirectly stimulated muscle twitching of sciatic nerve-sartorius muscle preparations from frogs, ${ }^{10}$ while Paeoniflorigenone (4) has a blocking effect on the neuromuscular junction in phrenic nerve diaphragm preparations of mice. ${ }^{5}$

The highly oxygenated monoterpenoid (+)-Paeonilide (+)-(5) was isolated from Paeonia delavayi in 2000 (Figure 2), ${ }^{11}$ which is endemic to the chinese provinces Likiang and Yunnan. ${ }^{12} 1.13 \mathrm{~kg}$ of Paeonia delavayi roots were necessary to obtain $8 \mathrm{mg}$ of pure (+)-Paeonilide (+)-(5). Its new monoterpenoid skeleton could be confirmed by the combination of spectroscopic and crystallographic analyses. ${ }^{11}$ 

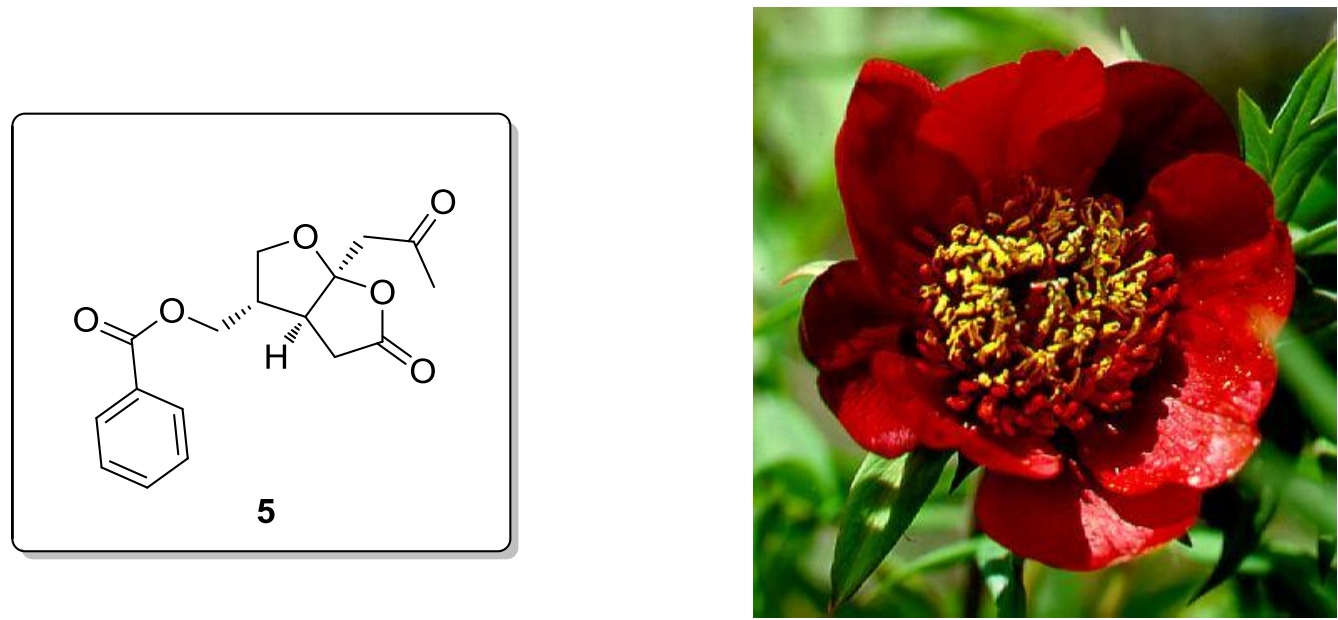

Figure 2: Structure of (-)-Paeonilide (5) and photo of Paeonia delavayi (photo by courtesy of Walter Good). ${ }^{13}$

(+)-5 bears a sub-structural unit of the privileged class of ginkgolides 6 (Table 1), which themselves have very interesting properties. Ginkgolides 6 are diterpenoids derived from the dioecious "living fossil" Ginkgo biloba L., the last living member of a family of trees that appeared more than 250 million years ago. ${ }^{14}$ Due to the medicinal interest in the Ginkgo biloba extracts over 8000 tons of dried leaves are produced each year. ${ }^{15}$

Table 1: Ginkgolide structure and photo of Ginkgo biloba L.; Paeonilide substructure marked in red (photo by courtesy of Armin Jagel, Bochumer Botanischer Verein). ${ }^{16}$
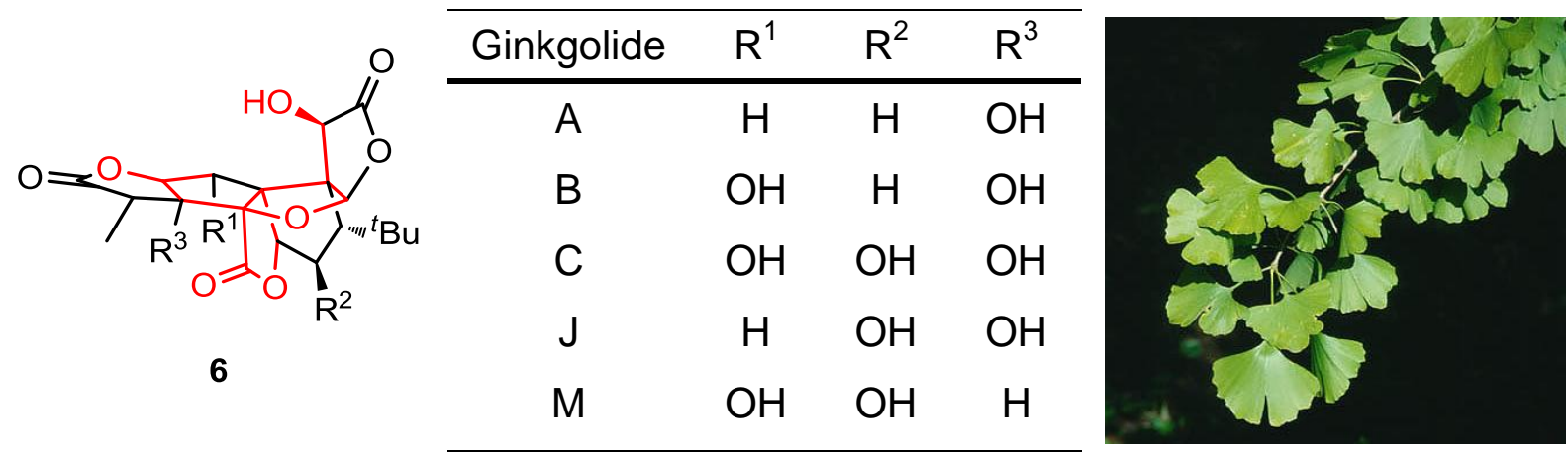

These extracts are used in the treatment of cardiac and cerebral vascular and peripheral circulatory disorders, ${ }^{17}$ diverse neurological disorders ${ }^{18} \quad$ (e.g. cerebrovascular insufficiency with symptoms of vertigo, tinnitus, short term memory loss, headache, hearing loss and depression) and early senile dementia (Alzheimer's disease). ${ }^{19}$ Ginkgolides are inhibiting the human platelet aggregation by inhibition of the binding of $(3 \mathrm{H})$-PAF-acether to its membrane platelet receptor. 
The pharmacological properties are, inter alia, antagonism on PAF induced thrombosis, lung anaphylaxis, cardiac anaphylaxis and inhibition of transplant rejection. ${ }^{20}$

Due to the structural similarity between Ginkgolides and Paeonilide (+)-(5), it was tested in bioassays. ${ }^{11}$ The results showed a selective inhibition of the platelet aggregation induced by the phospholipide PAF (7) (platelet activating factor, 1-O-alkyl-2-acetyl-sn-glycero-3-phosphocholine) with an $\mathrm{IC}_{50}$ value of $25 \mu \mathrm{M}$ $(8 \mu \mathrm{g} / \mathrm{mL})$, but no effect on the platelet aggregation induced by adenoside diphosphate (ADP) (8) or arachidonic acid (AA) (9) (Figure 3).<smiles>CCCCCCCCCCCCCCCCOCC(COP(=O)([O-])OC(C)=O)OCC[N+](C)(C)C</smiles><smiles>CCCCC/C=C\C/C=C\C/C=C/C/C=C/CCCC(=O)O</smiles><smiles>Nc1ncnc2c1ncn2[C@@H]1O[C@H](COP(=O)([O-])OP(=O)([O-])[O-])[C@@H](O)[C@H]1O</smiles>

9

8

Figure 3: Structure of PAF (7), AA (8) and ADP (9).

The PAF receptor is a 7-transmembrane $G$ protein receptor belonging to the rhodopsin family. ${ }^{21} \mathrm{~A}$ feature of this family is that critical residues, which are in charge of binding ligands, are located in the membrane spanning helices within the lipid double-layer and not exclusively on the surface. When PAF is binding to the PAF-receptor it starts a transduction cascade that facilitates the conformational change of glycoprotein (GP) Illb and IIla (50000-80000 copies of this receptor on platelet surface), which is necessary to enable the binding of the receptor to fibrinogen (Figure 4). This is by far the most important ligand for GP IIb and IIla. In this way fibrinogen cross-links two separate platelets which is critical for their aggregation. $^{22}$ 


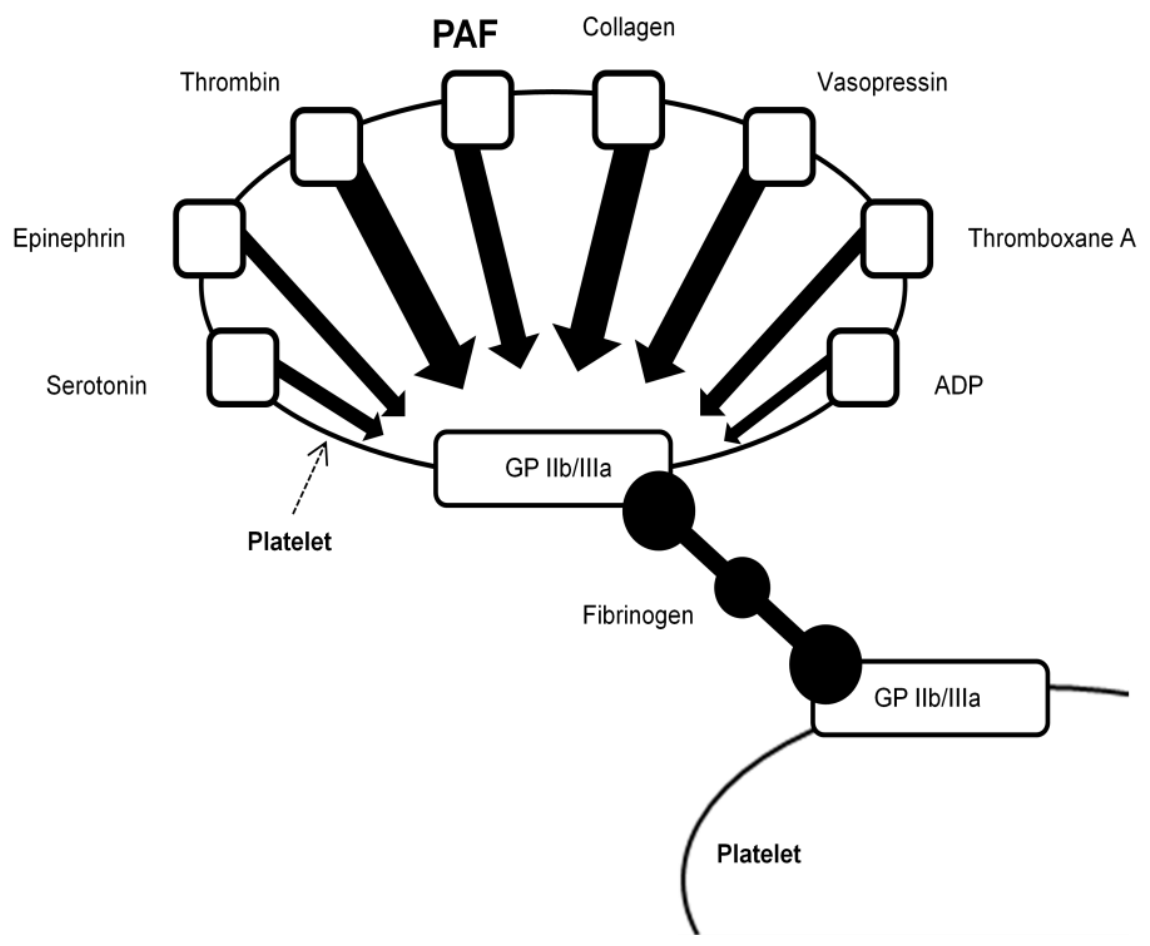

Figure 4: Pathway of platelet activation (the thickness of arrows indicates the strength of the activator). ${ }^{23}$

So far, the bio-synthetic pathway of Paeonilide is still not clarified. It belongs to a group of irregular acyclic monoterpenoids which seems to descend from re-arrangements of isoprene units via cleavage of the cyclic monoterpenoid p-menthan (10). A subsequent ring formation between $\mathrm{C} 1, \mathrm{C} 4$ and $\mathrm{C} 10$ would give rise to the core structure of Paeonilide (Scheme 1).

Scheme 1: Proposed biosynthetic route to Paeonilide rac-(5). ${ }^{11}$<smiles>CC1CCC(C(C)C)CC1</smiles>

10<smiles>CCCCC(CC)C(C)(C)C</smiles>

11

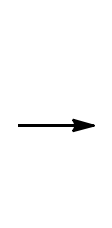

8<smiles>[3H]CCC(CC)C(C)C</smiles>

12<smiles>CC(=O)CC12OCC(COC(=O)O)C1CC(=O)O2</smiles>

rac-5 
Up to now three syntheses of Paeonilide are published, two delivering the racemic product $^{24-25}$ and one diastereoselective. ${ }^{26}$

The first total synthesis was accomplished by Zhang et al. in 2006, consisting of 16 steps and an overall yield of $15 \% .{ }^{24}$ The synthesis started from commercially available 2-hydroxy-4-methylacetophenone (13) (Scheme 2), benzyl protection and Rubottom oxidation ${ }^{27}$ lead to $\alpha$-hydroxy ketone 15. A further conversion of the intermediate via Wittig olefination, hydroboration of the resulting C-C double bond and a deprotection-protection step of the hydroxyl groups afforded the TBDMS protected acetal 20.

Scheme 2: Zhang's racemic synthesis of rac-5.

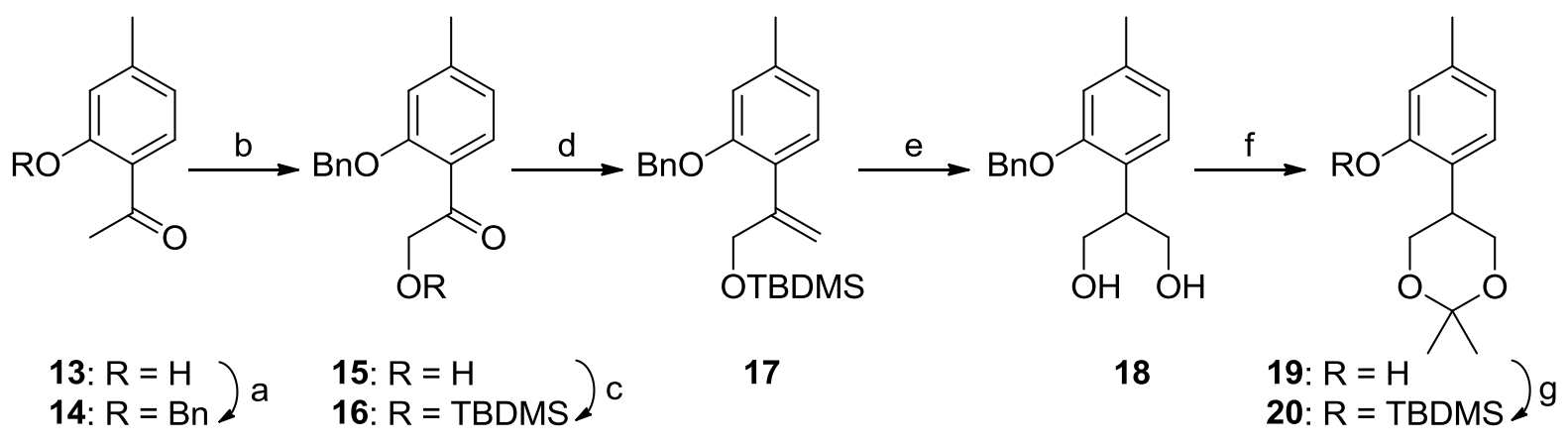

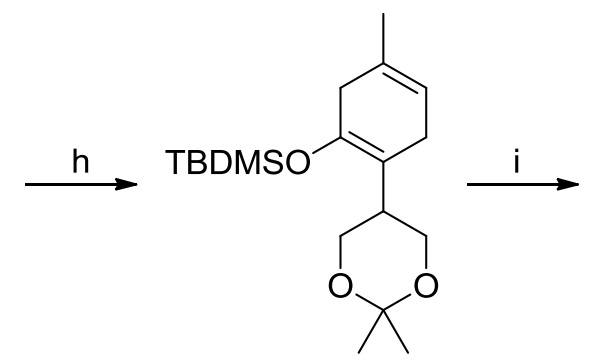

21<smiles>CC1=CCC(C2COC(C)(C)OC2)C(=O)C1</smiles>

22<smiles>CC1(C)OCC([C@H]2C[C@H](O)[C@@](C)(O)CC2=O)CO1</smiles>

23<smiles>[Y]C1CC1C1COC(C)(C)OC1</smiles>

24<smiles>[R6]C[C@H](C)[C@@]12CC(=O)O[C@@]1(CC(C)=O)OC[C@@H]2C[R6]</smiles>

Reagents and Conditions: a) $\mathrm{K}_{2} \mathrm{CO}_{3}, \mathrm{KI}, \mathrm{BnCl}, \mathrm{MeCN}, 95 \%$; b) i. LDA, THF, TMSCl; ii. mCPBA, DCM, $\mathrm{NaHCO}_{3}$; iii. $\mathrm{HCl}, 95 \%$; c) TBDMSCl, Imidazole, DMF, quant.; d) $\mathrm{Ph}_{3} \mathrm{PCH}_{3}$ l, $t \mathrm{BuOK}, \mathrm{THF}, 95 \%$; e) i. $\mathrm{BH}_{3} \cdot \mathrm{THF}$; ii. $\mathrm{H}_{2} \mathrm{O}_{2}, \mathrm{NaOH}, 90 \%$; f) i. $\mathrm{Pd} / \mathrm{C}, \mathrm{H}_{2}$; ii. DMP, PPTS; $94 \%$ over two steps based on $18 ; \mathrm{g}$ ) TBDMSCl, $\mathrm{NEt}_{3}, \mathrm{DCM}$, quant; h) $\mathrm{Li}, \mathrm{NH}_{3}(f f)$, THF/EtOH, 90\%; i) $\mathrm{H}_{3} \mathrm{BO}_{3}, \mathrm{TBAF}, \mathrm{THF} / \mathrm{H}_{2} \mathrm{O}, 87 \%$; j) $\mathrm{OsO}_{4}, \mathrm{NMO}, \mathrm{THF}, \mathrm{tBuOH}, \mathrm{H}_{2} \mathrm{O}, 92 \%$; k) IBX, EA, 94\%; I) $\left.\mathrm{H}_{5} \mathrm{IO}_{6}, \mathrm{EA} ; \mathrm{m}\right) \mathrm{BzCl}, \mathrm{py}, \mathrm{DCM}, 46 \%$ over four steps based on 24. 
Acetal 20 was subjected to a Birch reduction and the resulting enol ether 21 was hydrolyzed to ketone 22. The subsequent Osmium mediated syn-dihydroxylation of the remaining $\mathrm{C}-\mathrm{C}$ double bond afforded selectively $\mathbf{2 3}$, since the six-membered acetal ring shielded the back side of 22. Afterwards the secondary alcohol was oxidized by IBX to $\mathbf{2 4}$, which was afterwards cleaved in an oxidative pathway to generate the intermediate 25 . A subsequent intramolecular cyclization delivered the alcohol 26. Final benzoyl protection of the free hydroxyl group yielded racemic Paeonilide rac-(5).

The first diastereoselective synthesis was also established by Zhang et al. starting from $(R)-(-)$-Carvone (27), which is readily available from the chiral pool, providing $(+)-5$ within 16 steps and $6.2 \%$ overall yield (Scheme 3 ). ${ }^{26}$

Scheme 3: Part one of Zhang's diastereoselective synthesis of (+)-Paeonilide (+)-(5).

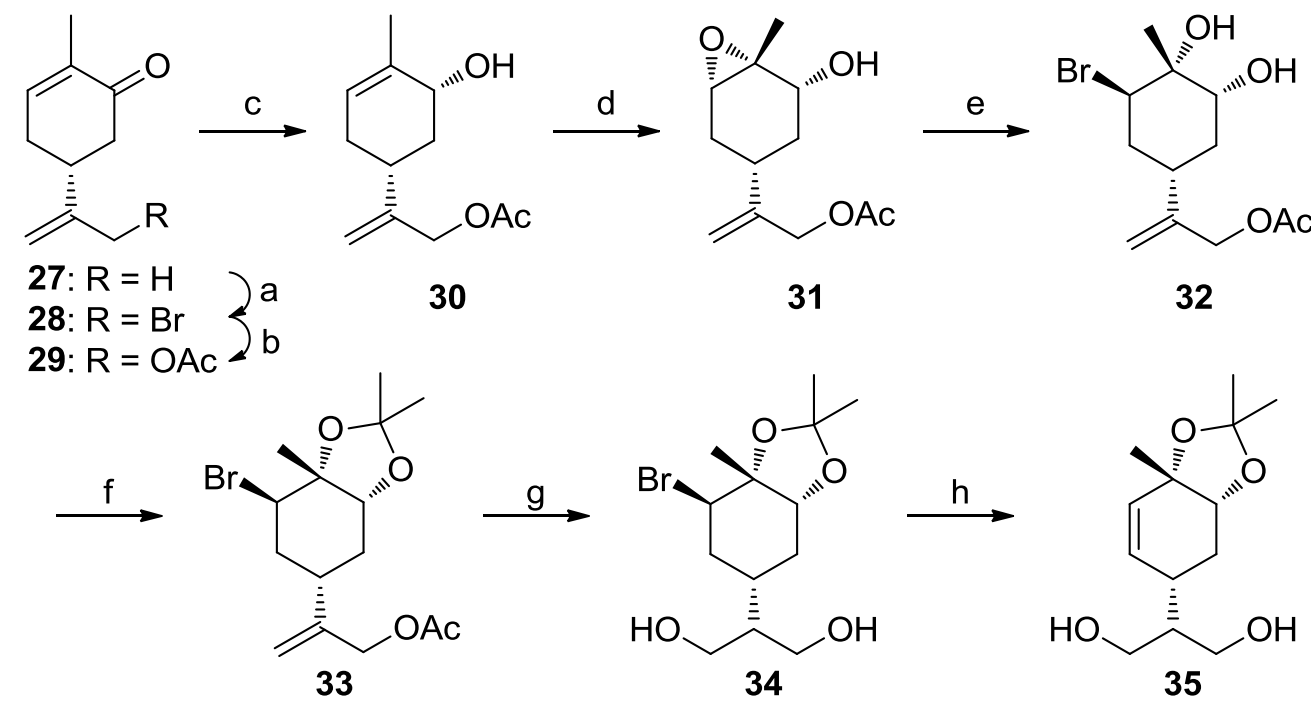

Reagents and Conditions: a) NBS, $\mathrm{NaOAc}, \mathrm{AcOH}, \mathrm{DCM}, 35 \%$; b) AgOAc, acetone, $92 \%$; c) $\mathrm{NaBH}_{4}$, $\mathrm{CeCl}_{3}, \mathrm{MeOH}, 95 \%$; d) mCPBA, DCM, $\mathrm{NaHCO}_{3}, 93 \%$; e) LiBr (in situ), THF, AcOH, 97\%; f) DMP, DCM, TsOH, 95\%; g) $\mathrm{BH}_{3} \cdot \mathrm{SMe}_{2}, \mathrm{THF}, \mathrm{H}_{2} \mathrm{O}_{2}, \mathrm{NaOH}, 89 \%$; h) tBuOK, DMF, $95 \%$.

Carvone 27 was transformed to acetyl protected 29 by the allyl bromide intermediate 28, which was further subjected to a Luche-reduction of the carbonyl group and an epoxidation by $m C P B A$. Since the hydroxyl group of $\mathbf{3 0}$ exhibits a directing effect, the epoxide is formed chemo- and stereoselectively. Therefore, the resulting oxirane ring is located on the same side as the hydroxyl group in 31. In situ generated $\mathrm{LiBr}$ opened the epoxide to the corresponding vicinal syn-diol 32, which was ketal 
protected, hydroborated and treated with the strong base $t \mathrm{BuOK}$ to eliminate $\mathrm{HBr}$ and form the diol 35. The reaction with NBS lead to the formation of the cis-fused rings 36 as a single diastereomer, which was subsequently benzoyl protected on the free hydroxyl group to afford 37, which was deprotected under acidic conditions to yield diol 38 (Scheme 4). The additional treatment with IBX created ketone 39, which was cleaved oxidatively to furan $\mathbf{4 0}$ and subsequent $\mathrm{HBr}$ elimination by DBU yielded the key intermediate $\mathbf{4 1}$. Finally $\mathbf{4 1}$ was submitted to an acidic furan opening, subsequent cyclization to the hemiacetal $\mathbf{4 3}$ and the formation of the lactone afforded (+)-Paeonilide (+)-(5) in a diastereoselective manner.

Scheme 4: Part two of Zhang's diastereoselective synthesis of (+)-Paeonilide (+)-(5).

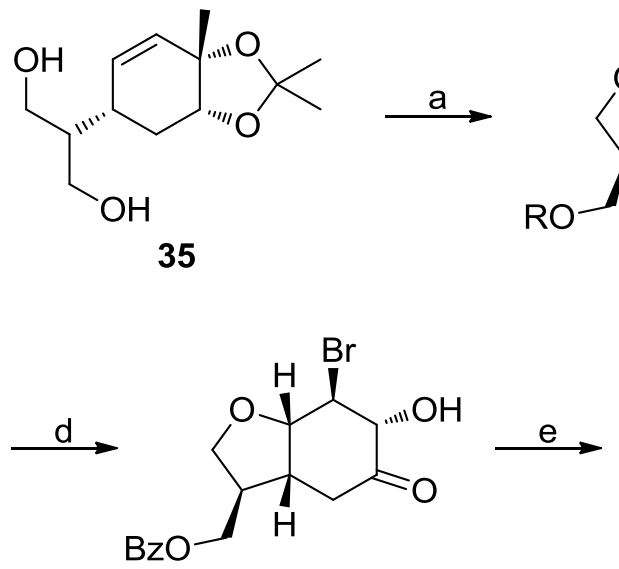

39

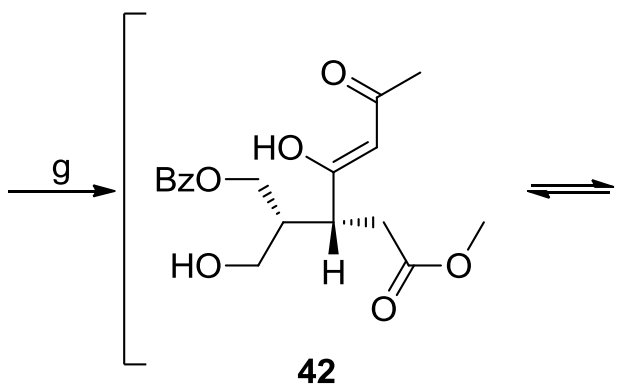

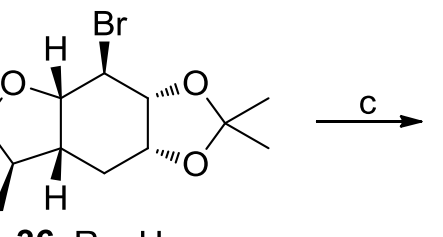

36: $\mathrm{R}=\mathrm{H}$

37: $\mathrm{R}=\mathrm{Bz}$<smiles>O=C(O)CC1CO[C@@H]2[C@@H]1C[C@H](O)[C@@H](O)[C@H]2Br</smiles>

38<smiles>COC(=O)C[C@H]1[C@@H](COC(=O)OCc2ccccc2)CO[C@H]1[C@H](Br)C(C)=O</smiles>

40<smiles>COC(=O)C[C@H]1C(=CC(C)=O)OCC1COC(=O)OCc1ccccc1</smiles><smiles>COC(=O)C[C@H]1C(COC(C)(C)C)CO[C@]1(O)CC(C)=O</smiles><smiles>C1CCC1</smiles><smiles>CC(=O)CC12OCC(COC(=O)OCc3ccccc3)[C@H]1CC(=O)O2</smiles>

$(+)-5$

Reagents and conditions: a) NBS, THF, 95\%; b) $\mathrm{BzCl}$, py, DCM, 99\%; c) $\mathrm{HCl}, \mathrm{MeOH}, 92 \%$; d) IBX, $\mathrm{EA}, 90 \%$; e) $\mathrm{H}_{5} \mathrm{IO}_{6}$, $\mathrm{EA}, \mathrm{CH}_{2} \mathrm{~N}_{2}$, $\mathrm{Et}_{2} \mathrm{O}$; f) $\mathrm{DBU}$, benzene; g) $\mathrm{HCl}, \mathrm{EA}, 40 \%$.

The latest and so far shortest synthesis of Paeonilide rac-(5) was published by Du et al. providing racemic rac-5 in five steps in an overall yield of $59 \%$ starting from commercially available tris(hydroxymethyl)methane (44) (Scheme 5). This triol 44 was converted to the corresponding acetal 45 and submitted to an one-pot Swern-Wittig-reaction to furnish the desired $(E)$-olefin 46 . Subsequently, 46 and aldehyde $\mathbf{4 7}$ were subjected to a benzoyl peroxide promoted radical addition to give 
rise to the critical ketone-ester 48, which undergoes an in situ deprotection/hemiacetal-formation/lactonization cascade while treating it with $\mathrm{HCl}$. This three-reaction-one-pot approach delivers $\mathbf{2 6}$ which is finally benzoyl protected to the desired racemic Paeonilide rac-(5).

Scheme 5: Du's racemic synthesis of Paeonilide rac-(5).<smiles>CCOC(=O)C=CC1COC(C)(C)OC1</smiles>

44<smiles>CCOC(=O)C=CC1COC(C)(C)OC1</smiles>

46

45

47

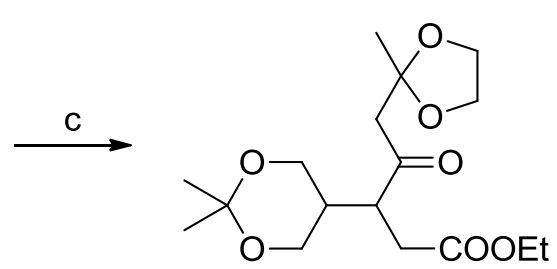<smiles>CCOC(=O)CC(C(=O)CC(C)=O)C(CO)CO</smiles>

49
48

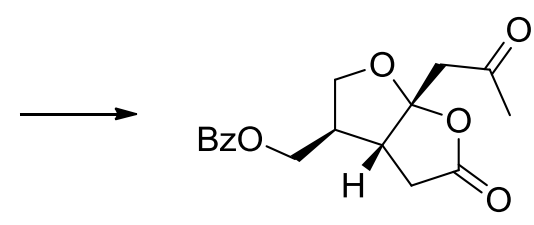

$\left.\begin{array}{rl}26: & R=H \\ \text { ac-5: } R & =B z\end{array}\right)$ e

Reagents and conditions: a) DMP, TsOH, THF; b) i. $(\mathrm{COCl})_{2}, \mathrm{DMSO} \mathrm{Et}_{3} \mathrm{~N}$; ii. $\mathrm{Ph}_{3} \mathrm{P}=\mathrm{CHCO}_{2} \mathrm{Et}$, DCM, 84\% over two steps based on 44; c) $(\mathrm{BzO})_{2}$, benzene, 79\%; d) $\mathrm{HCl}, \mathrm{EA}, 91 \%$; e) $\mathrm{BzCl}, \mathrm{py}, 98 \%$.

In conclusion, both syntheses of Zhang et al. start from a monoterpene (diastereoselective synthesis) or a comparable carbon skeleton (racemic synthesis). This starting materials, 27 and 13, are both transferred over several steps virtually to almost the same aliphatic key intermediate (42 and 25), which undergo a hemiacetalformation/lactonization cascade to accomplish the final steps toward Paeonilide in one-pot. The most recently published synthesis by Du et al., employs again the furolactone formation via the same aliphatic intermediate, but not starting from an (almost) monoterpenoide carbon body. In contrast to Zhang et al., the C-10 skeleton is constructed by the combination of a C- 6 and a C-4 building block.

Despite of these results no enantioselective total synthesis is known so far, neither for (+)- nor for (-)-Paeonilide. 


\section{Aim of this work}

This work seeks to explore a synthetic way to create the unnatural enantiomer of the wanted monoterpene in an enantioselective manner, without starting from the chiral pool. Since there are only studies of the biological activity of (+)-Paeonilide it is still of great interest to synthesize and investigate the potential of the opposite, unnatural enantiomer (-)-Paeonilide (5).

Scheme 6: Transfer of an established method to a new substrate scope (similarities to Paeonilide structure are marked in red).<smiles>[R]OC(=O)c1ccco1</smiles>

50<smiles>[R]OC(=O)c1ccoc1</smiles>

53<smiles>[R]OC(=O)C1=C[C@H]2C(C([R])=O)O[C@H]12</smiles>

51<smiles>[R]OC(=O)C1=CO[C@@H]2C(C(=O)O[R2])[C@H]12</smiles>

54
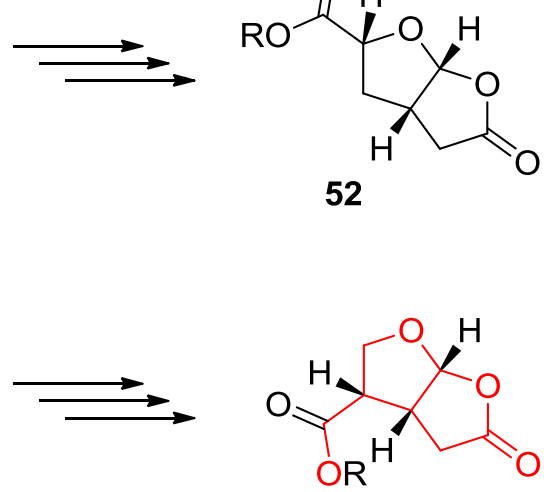

55

The idea was to modify an already well established method for building a fused ring system, consisting of a 2 -substituted furan and a $\gamma$-lactone, ${ }^{28}$ and utilizing this approach to get access to a ring system bearing a 3-substituted furan (Scheme 6).

The retro synthetic analysis (Scheme 7) of the target compound $\mathbf{5}$ does not start from a chiral starting material in contrast to the published diastereoselective synthesis, but employs commercially available 3 -furoic acid (59). The chiral information is introduced by a copper(I)-catalyzed cyclopropanation reaction using a chiral bis(oxazoline) ligand to yield the bi-cycle 58 . The subsequent lactonization gives rise to the core skeleton $\mathbf{5 7}$ of the desired monoterpenoid. Key step of this synthesis is the so far literature unknown side chain introduction proceeding under substrate control concerning the stereochemistry and providing the functionalized furo-lactone 56, which is finally transformed to the unnatural enantiomer (-)-Paeonilide (5) 
Scheme 7: Retrosynthesis of (-)-Paeonilide (5).<smiles>CC(=O)C[C@@]12OC[C@@H](COC(=O)c3ccccc3)[C@H]1CC(=O)O2</smiles><smiles>C=CC=C</smiles><smiles>C=CC[C@]12OC[C@H](C(=O)O)[C@]1([15CH3])CC(=O)O2</smiles>

(-)-Paeonilide (5)<smiles>O=C(O)c1ccoc1</smiles>

59

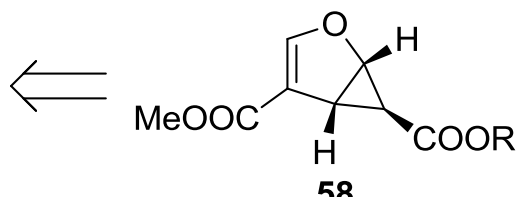

58

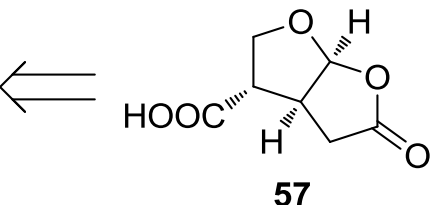

57 


\section{B. Main Part}

Although cyclopropanes are a highly strained entity, they are found as a pivotal structural element in a wide range of natural products, including pheromones, unnatural amino acids, fatty acid metabolites and terpenes. ${ }^{29-33}$ This interesting moiety is also present in biologically active compounds, as natural and synthetic cyclopropanes are endowed with a large range of biological properties, such as enzyme inhibition, insecticidal, antifungal, herbicidal, antimicrobial, antibiotic, antibacterial, antitumor and antiviral activities. ${ }^{34}$

The history of cyclopropanations of furans started already more than two decades ago. In 1988 Saltykova et al. reported the first racemic synthesis of cyclopropanated 2 -furoic ethyl ester $\mathbf{6 0}$, catalyzed by rhodium acetate dimer (Scheme 8 , top). ${ }^{35}$

Scheme 8: First reported syntheses of cyclopropanated furan esters.<smiles>CCOC(=O)c1ccco1</smiles>

60<smiles>COC(=O)c1ccco1</smiles>

62
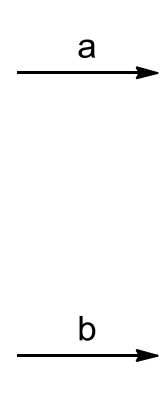

61

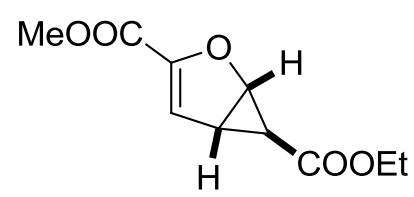

63

Reagents and conditions: a) $\mathrm{N}_{2} \mathrm{CHCOOMe}(1 \mathrm{eq}), 60$ (3 - 5 eq), $\mathrm{Rh}_{2}(\mathrm{OAc})_{4}(0.5-10 \mathrm{~mol} \%)$, r.t., 18 - 22\%; b) $\mathrm{N}_{2} \mathrm{CHCOOEt}(1 \mathrm{eq}), \mathrm{Rh}_{2}(\mathrm{OAc})_{4}(0.3 \mathrm{~mol} \%)$, r.t., $12 \mathrm{~h}, 55 \%$.

Two years later, in 1990, Wenkert et al. published the racemic cyclopropanation of 2-furoic methyl ester 62 with diazo glycine ethyl ester (63), also catalyzed by dirhodium acetate, but providing higher yields than Saltykova et al (Scheme 8, bottom). ${ }^{36}$

As this scaffold is an interesting and very convenient gateway for natural product synthesis it was extensively utilized to enter a several natural product families (Scheme 9). 64 provided an access to the core nuclei of trans seven-membered sesquiterpenes 66 (Xanthanolides). ${ }^{37-38}$ Furthermore, the core structure of 5,6,5tricyclic (Eudesmanolides) ${ }^{37-38}$ and 5,7,5-tricyclic (Guaianolides) ${ }^{37}$ sesquiterpenes 67 
and 68 became available. In 2007 Reiser et al. reported the enantioselective synthesis of Arglabin ${ }^{\mathrm{TM}}(65)^{39}$, a member of the guaianolide family. 65 is already successfully used for the treatment of breast, colon, ovarian and lung cancer in Kazakhstan. 64 was also used as starting material for the total synthesis of paraconic acids, ${ }^{40}$ i.e. roccellaric acid (69), ${ }^{41}$ nephrosteranic acid (70) and protopraesorediosic acid (71). Methylenolactocin (73) and protolichesterinic acid (72) were accessed in a formal total synthesis. ${ }^{40}$ The $\gamma$-lactone moiety in these natural products and natural product skeletons mentioned before, was synthesized via ozonolysis of 64 and subsequent retro-aldol reaction. Contrary to those lactones, the furo-lactones $\mathbf{7 6}$ and 77 were built via a lactonization of the cyclopropane ring. ${ }^{28}$

Scheme 9: 64 as versatile building block for natural product synthesis ( $E=$ ester).
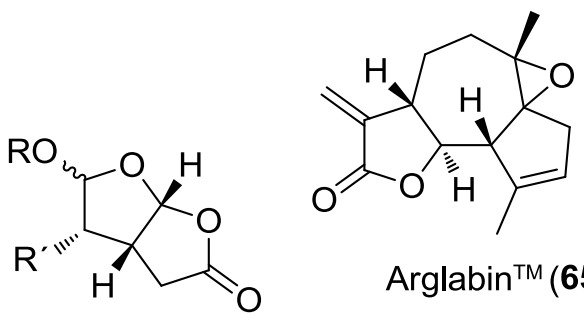

Core Nucleus (77) of Macfarlandin C and Norrisolide

$\mathrm{R}=\mathrm{H}, \mathrm{Ac}$

$\mathrm{R}^{\prime}=$ Alkyl, Alkenyl<smiles>[R]C1[C@H]([R])O[C@H]2OC(=O)C[C@@H]12</smiles>

Core Nucleus (76) of Cheloviolene A and Cheloviolene $\mathrm{B}$<smiles>CCOC(=O)C1=C[C@H]2CC(=O)O[C@H]2[C@H]2CCC[C@H]2C1</smiles><smiles>[R]C[C@H]1CC(=O)C[C@H]2OC(=O)C[C@H]12</smiles>

$\mathrm{R}=\mathrm{COOEt}$, COMe, CN

Core nulcei (74) and (75) of a large family of terpenes<smiles>[R][C@H]1OC(=O)C(=C)[C@@H]1C(=O)O</smiles>

$\mathrm{R}=n-\mathrm{C}_{13} \mathrm{H}_{27}:(-)$-Roccellaric acid (69)

$\mathrm{R}=n-\mathrm{C}_{11} \mathrm{H}_{23}$ : (-)-Nephrosteranic acid (70)

$\mathrm{R}=n-\mathrm{C}_{12} \mathrm{H}_{24} \mathrm{COOH}$ : (-)-Protopraesorediosic acid (71)

$\mathrm{R}=n-\mathrm{C}_{13} \mathrm{H}_{27}:(-)$-Protolichesterinic acid (72)

$\mathrm{R}=n-\mathrm{C}_{5} \mathrm{H}_{11}:(-)-$ Methylenolactocin (73) 


\section{Preparatory work for the asymmetric cyclopropanation}

By choosing commercially available 3-furoic acid (59) as starting material for the planned synthesis of (-)-Paeonilide (5) a protection of the free carboxylic acid by esterification proved to be necessary to avoid unwanted side reactions. ${ }^{42}$ The ester was formed under strongly acidic conditions, i.e. in the presence of sulfuric acid (Scheme 10).

Scheme 10: Esterification of 3-furoic acid (59). ${ }^{43}$

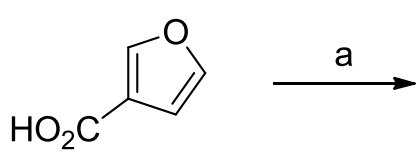

59<smiles>CC(=O)c1ccoc1</smiles>

78

Reagents and conditions: a) $\mathrm{MeOH}, \mathrm{H}_{2} \mathrm{SO}_{4}$, r.t., 24 h, $82 \%$.

The tool that brings chirality in the copper(I) mediated cyclopropanation is a complex of a chiral ligand and a metal center. A plethora of these catalytic systems has been applied for the cyclopropanation of olefins, e.g. bis(oxazoline)-ligands. Alternative ligands and cyclopropanation shall be discussed later in this chapter. The bis(oxazoline)-ligands were already successfully applied in the transformation of 2-furoic esters with diazo esters, ${ }^{40}$ but a few reactions concerning 3-furoic esters were published as well. ${ }^{40,44}$ Therefore, a bis(oxazoline) system was chosen for the asymmetric reaction between 3 -furoic ester $\mathbf{7 8}$ and a diazo compound.

(4S,4'S)-2,2'-(propane-2,2-diyl)bis(4-isopropyl-4,5-dihydrooxazole) (82) was prepared starting from L-valinol (80) and 2,2-dimethylpropanedioyl dichloride (79) reacting under amide formation to intermediate $\mathbf{8 1}$, which was cyclized to afford ligand $\mathbf{8 2}$ (Scheme 11). ${ }^{45}$ 
Scheme 11: Synthesis of (4S,4'S)-2,2'-(propane-2,2-diyl)bis(4-isopropyl-4,5dihydrooxazole) (82).

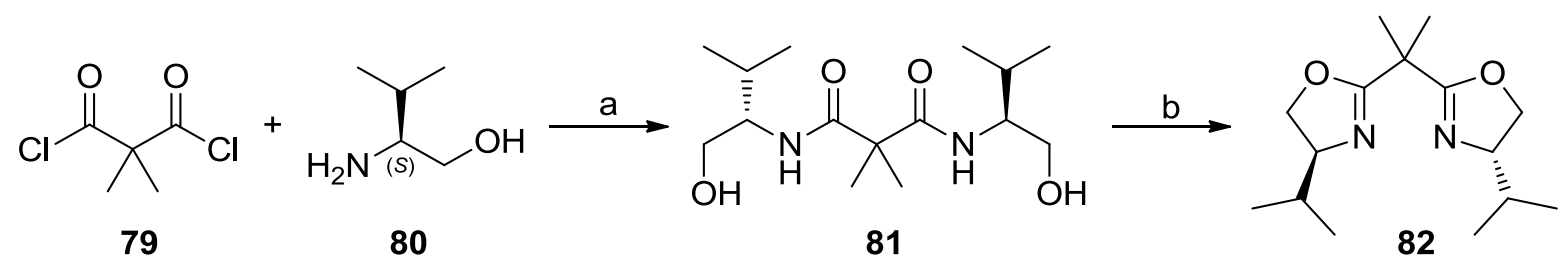

Reagents and conditions: a) L-valinol (2.0 eq), $\mathrm{NEt}_{3}(2.5 \mathrm{eq}), \mathrm{DCM} 0{ }^{\circ} \mathrm{C}$ to r.t., $70 \mathrm{~min}, 84 \%$; b) DMAP (10 mol \%), $\mathrm{NEt}_{3}(4.0 \mathrm{eq}), \mathrm{TsCl}(2.0 \mathrm{eq})$, DCM, r.t., $27 \mathrm{~h}, 83 \%$.

The second ligand used for cyclopropanation within this thesis was also a bis(oxazoline)-ligand, possessing a secondary binding site. It was synthesized from the amino alcohol (1S,2S)-2-amino-1-phenyl-1,3-propanediol (84), which is not derived from a natural amino acid. This amino alcohol 84 was converted with 2,2-dimethylmalononitrile $(\mathbf{8 3})^{46}$ in an one-pot reaction to $\left(\left(4 S, 4^{\prime} S, 5 S, 5^{\prime} S\right)\right.$ 2,2'-(propane-2,2-diyl) bis (5-phenyl-4,5-dihydrooxazole-4,2-diyl)) dimethanol (85), catalyzed by cadmium acetate (Scheme 12). ${ }^{44,47}$

Scheme 12: Synthesis of $\left(\left(4 S, 4{ }^{\prime} S, 5 S, 5^{\prime} S\right)-2,2^{\prime}\right.$-(propane-2,2-diyl)bis(5-phenyl-4,5dihydrooxazole-4,2-diyl))dimethanol (85).

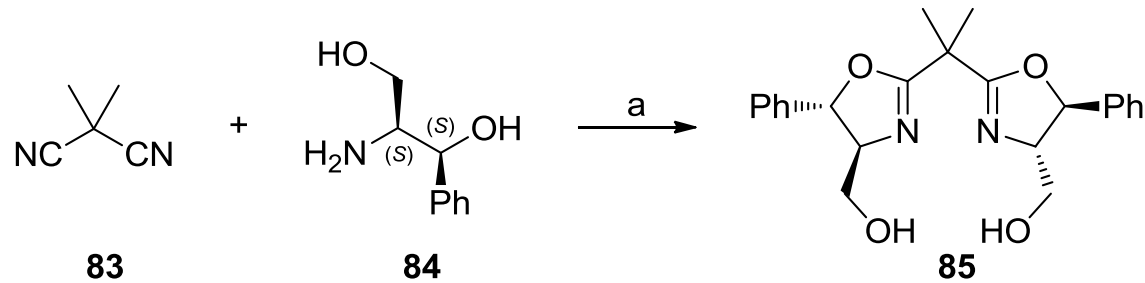

Reagents and conditions: a) amino alcohol 84 (2.5 eq), $\mathrm{Cd}(\mathrm{OAc})_{2} 2 \mathrm{H}_{2} \mathrm{O}(5 \mathrm{~mol} \%)$, chlorobenzene, reflux, $14 \mathrm{~h}, 39 \%$.

After substrate and ligand, the final compound, which needs to be prepared, is the diazo compound presenting the precursor for the reactive species in the cyclopropanation.

The tert-butyl diazo compound $\mathbf{8 9}$ was synthesized according to literature precedents following a two-step protocol utilizing the Regitz diazo transfer ${ }^{48}$ from tosyl azide (87) to tert-butyl acetoacetate (88) under phase transfer conditions ${ }^{49}$ yielding tert-butyl diazo acetate (89) as a solution in $n$-pentane (Scheme 13). Since this solvent is not suitable for the subsequent reaction due to solubility problems of the 
copper(I)-complex, it was inevitable to remove the solvent. The remaining yellow diazo ester 89 was then diluted with anhydrous DCM. This procedure exhibits the advantage of preparing a diazo ester-DCM solution which can be adjusted to a certain wt\% by calculating the amount of DCM added.

Scheme 13: Synthesis of tert-butyl diazo acetate (89).<smiles>Cc1ccc(S(=O)(=O)Cl)cc1</smiles>

86<smiles>Cc1ccc(S(N)(=O)=O)cc1</smiles>

87<smiles>CCCOC(=O)CC(C)=O</smiles>

88<smiles>CCCOC(=O)C=[W]</smiles>

89

Reagents and conditions: a) $\mathrm{NaN}_{3}(1.1 \mathrm{eq})$, EtOH, r.t., 3 h, 76\%; b) $\mathrm{NaOH}\left(2.8\right.$ eq), $\mathrm{Bu}{ }_{4} \mathrm{NBr}$ (2 mol\%), $\mathrm{H}_{2} \mathrm{O}, n$-pentane, $0^{\circ} \mathrm{C}$ to r.t., $20 \mathrm{~h}, 88 \%$.

The corresponding ethyl diazo ester $\mathbf{9 1}$ was prepared in an one-step procedure starting from glycine ethyl ester hydrochloride (90) (Scheme 14). ${ }^{50}$ This method does not provide the advantage of an adjustable wt\%. It depends on the amount of DCM used for the reaction and work up. Typically, solutions of $10-15 \mathrm{wt} \%$ are obtained.

Scheme 14: Synthesis of ethyl diazo acetate (91).<smiles>CCOC(=O)CNC</smiles>

90<smiles>CCOC(=O)C=N[13CH]=[13CH]</smiles>

91

Reagents and conditions: a) $\mathrm{NaNO}_{2}$ (1.3 eq), $\mathrm{H}_{2} \mathrm{SO}_{4}$ (cat), $\mathrm{H}_{2} \mathrm{O} / \mathrm{DCM},-20^{\circ} \mathrm{C}$ to r.t., $1 \mathrm{~h}, 96 \%$. 


\section{Cyclopropanation}

\subsection{General information}

Although the history of transition metal catalyzed cyclopropanations started in $1906,{ }^{51}$ more than a century ago, there were only small developments until the late 1960s when the catalyst development became more interesting, not only for natural product synthesis.

Besides the biological attributes, cyclopropanes are also of synthetic interest, since they can be used for the formation of highly functionalized cycloalkanes ${ }^{52-58}$ or acyclic compounds. ${ }^{59-62}$ The main reason for the broad interest in this special moiety is the reactivity of cyclopropanes, which is usually associated with electron-donating and/or electron-accepting substituents.

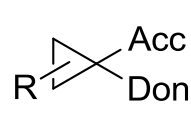

92

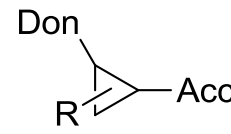

93

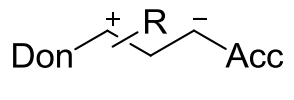

94

Figure 5: Donor (Don) - Acceptor (Acc) substituted cyclopropanes; geminal (92), vicinal (93), 1,3-dipolar synthon (94). ${ }^{63}$

The synthetic use of geminal donor-acceptor substituted cyclopropanes, which have no synergistic substituent effect, is only reported in a few publications. Vicinal substituted cyclopropanes are very attractive for organic synthesis, since they are utilized as 1,3-dipolar synthons in a plethora of organic transformation (Figure 5). ${ }^{64-65}$ Among others, one way en route to donor-acceptor substituted cyclopropanes is the transition-metal catalyzed decomposition of a diazo compound, which results in extrusion of nitrogen and the formation of a transition-metal-carbene complex. Calculations ${ }^{66}$ and Hammett studies ${ }^{67}$ support the addition of a very reactive metalcarbene intermediate in the early transition state to the substrate in a concerted, yet strongly asynchronous pathway with a cationic substrate character on one alkene carbon. This is represented by transition state $A$, rather than in the metallacyclobutane B (Scheme 15). 
Scheme 15: Catalytic cycle of metal-catalyzed carbenoid cyclopropanation reaction with diazo compounds. ${ }^{68}$

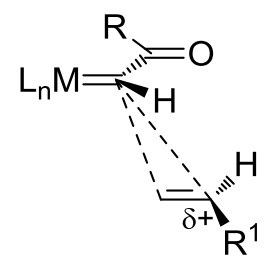

A

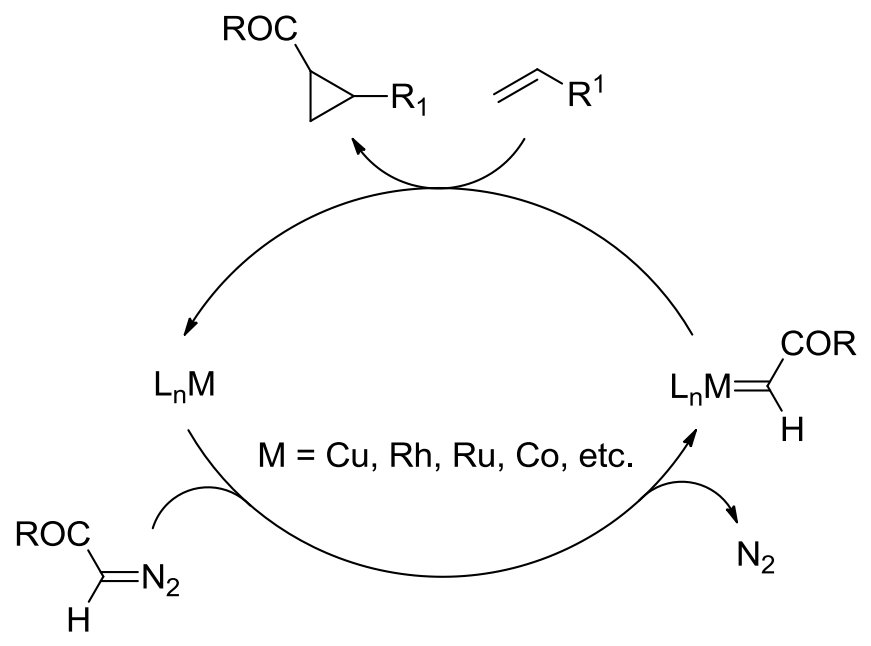

B

The use of copper, rhodium and, more recently, also ruthenium catalysts proved to be highly effective. Palladium catalysts have advantages in reactions with electrondeficient alkenes, while other late transition metals like iron or osmium are only reported occasionally. ${ }^{68}$ Regarding copper, $\mathrm{Kochi}^{69}$ was the first to show that $\mathrm{Cu}(\mathrm{OTf})$ is a highly effective catalyst. $\mathrm{Cu}(\mathrm{II})$-complexes are applicable as well, but need to be reduced in-situ since $\mathrm{Cu}(\mathrm{I})$ is the active species ${ }^{70}$ in carbene reactions. This can be achieved by treatment with DIBAL-H, substituted hydrazines, or the diazo agent itself. In order to perform the cyclopropanations in an enantioselective manner, a chiral environment is needed to transfer stereochemical information to the olefin substrate. This is achieved by using chiral ligands for complexing the metal ion. A short overview is provided in Figure 6. 
<smiles>CC(/N=C/c1ccccc1O)c1ccccc1</smiles>

95, Nozaki 1966<smiles>[R]C([R])(O)[C@@H](C)N=Cc1ccccc1O</smiles>

96, Aratani 1975

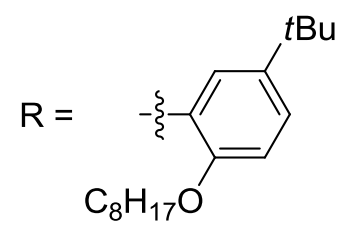<smiles>CC(C)(O)[C@@H]1CCC(/C(C#N)=C2\CC[C@H](C(C)(C)O)N2)=N1</smiles>

97, Pfaltz 1986<smiles>CC(C)(C)[C@@H]1COC(CC2=N[C@H](C(C)(C)C)CO2)=N1</smiles>

98, Masamune 1990 Pfaltz 1991

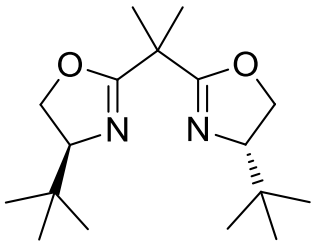

99, Pfaltz 1986

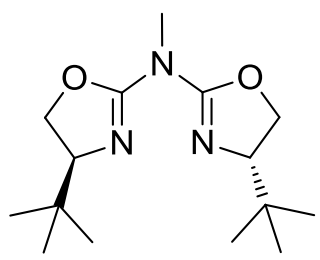

100, Reiser 2000

Figure 6: Short overview of chiral ligands for asymmetric cyclopropanations. ${ }^{68}$

The diazo compounds have a rather broad scope regarding tolerated functional groups and substitution patterns, both, mono- and disubstituted ones (Figure 7). The most exhaustively studied diazo reagents are the $\alpha$-diazo esters (101, $Y=O R$ ).<smiles>[Y]C(=O)C=[W]</smiles>

101<smiles>N#CC=[W]</smiles>

102<smiles>[R20][R](=O)C=[W]</smiles>

103<smiles>[R]OS(=O)C([N])=[Ni]</smiles>

104<smiles>[N]=C[N+](=O)[O-]</smiles>

105

Figure 7: Different $\alpha$-diazo compounds. ${ }^{68}$

Attempts to use diazo compounds containing chiral auxiliaries for asymmetric cyclopropanation of styrene resulted only in poor diastereoselectivity (Figure 8)..$^{71-73}$<smiles>CC1(C)COC(=O)[C@@H]1OC(=O)C=[W]</smiles>

106<smiles>O=C(C=[W])OC1CCCCC1c1ccccc1</smiles>

107<smiles>C[C@H]1[C@H](c2ccccc2)OC(=O)N1C(=O)/C=N\N</smiles>

108<smiles>CSCC1CC2(C)CCC(N1C(=O)C=N)C2(C)C</smiles>

109

Figure 8: Diazo compounds bearing chiral auxiliaries. 


\subsection{Furan cyclopropanation}

The copper(I) catalyzed cyclopropanation of furan derivatives like 62 comes along with some features. It proceeds regioselectively, since the highly electrophilic coppercarbene complex 111 (Figure 9, left) attacks only the less hindered and presumably more electron rich C-C double bond, as long as the diazo compound is not added in a huge excess. Furthermore, the reaction is diastereoselective, as the ester group at the introduced cyclopropanes is exclusively directed to the convex face of the fused ring system. ${ }^{41}$

Scheme 16: Copper(I) catalyzed cyclopropanation of furan ester 62.<smiles>COC(=O)c1ccco1</smiles>

62

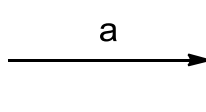

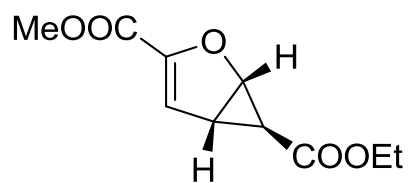

110

Reagents and conditions: a) i. $\mathrm{N}_{2} \mathrm{CHCOOEt}\left(2.67\right.$ eq.), $\mathrm{Cu}(\mathrm{OTf})_{2}(0.66 \mathrm{~mol} \%),(S, S)-\operatorname{Pr}-\mathrm{BOX}$ (0.84 mol\%), $\mathrm{PhNHNH}_{2}$ (0.70 mol\%), DCM, $0{ }^{\circ} \mathrm{C}, 54 \%, 85-90 \%$ ee; ii. recrystallization (DCM, $n$-pentane), $>99 \%$ ee, $37 \%$. 
The stereochemical outcome can be explained by a model for the asymmetric cyclopropanation of olefins as suggested by Pfaltz ${ }^{74}$ and Andersson: ${ }^{75}$

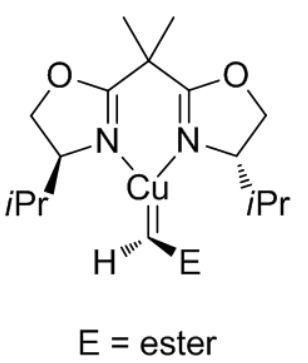

111

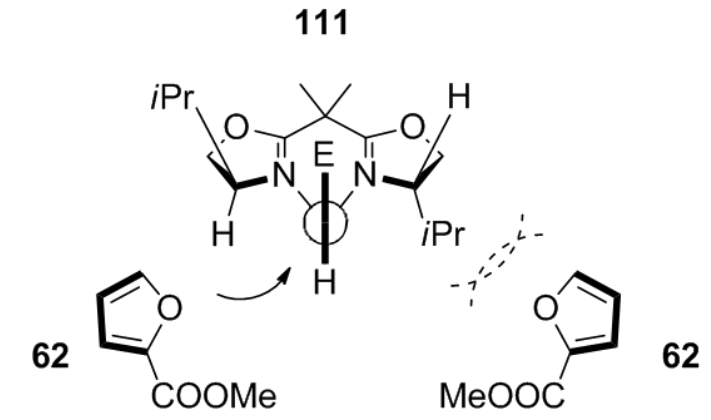

favored<smiles>C1CCC1</smiles>

$\mathrm{MeOOC}$<smiles>FC1=C[C@@H]2[C@H](O1)[C@@H]2F</smiles>

110

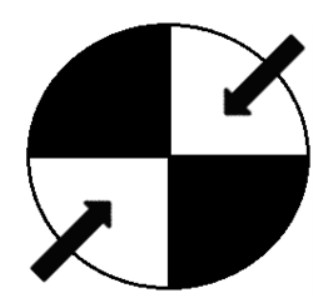

unfavored

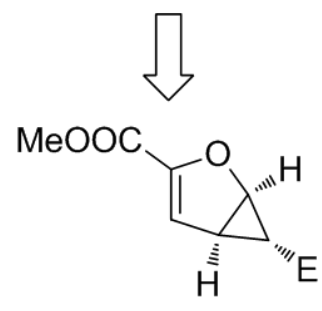

ent-110

Figure 9: Reactive complex 111 (left) in the asymmetric cyclopropanation with $(S, S)-\operatorname{Pr}-\mathrm{BOX}$ ligand $\mathbf{8 2}, \mathrm{Cu}(\mathrm{I})$, and ethyl diazo-acetate $(\mathbf{9 1}, \mathrm{E}=\mathrm{COOEt})$; model for asymmetric cyclopropanation (center and right).

The pathway in which 62 approaches from the left is favored over an approach from the right side of the complex 111 (Figure 9, center), since the latter bears a strong repulsive steric interaction between the approaching olefin and the $\operatorname{Pr}$ group of the ligand. This model indicates that the high enantioselectivity depends also on the structure of the olefin, since the COOMe substituent on the furan tends to be pointing away from the ligand framework which results in high enantioselectivity. As the $\operatorname{Pr}$ groups of the ligand block the upper left and lower right quadrant of the complex, the substrate attacks from the unhindered quadrants (Figure 9, right). With this complex being $\mathrm{C} 2$-symmetric, the approach via these unblocked quadrants leads to the same enantiomer of $\mathbf{1 1 0}$.

The ligand and diazo ester screening for the asymmetric cyclopropanation of 62 showed that the bis(oxazoline) ligands (Table 2, entry 1 - 6) are superior to the azabis(oxazolines) (Table 2, entry $7-10$ ) in terms of isolated yield and slightly superior in 
terms of enantiomeric excess obtained. ${ }^{40}$ It turned out that ligand 99 bearing the bulky tBu groups delivered the best results. However, recrystallization of the product furnished the enantiomerically pure cyclopropanation product $\mathbf{1 1 2}$. Hence, $\mathbf{8 2}$ is the ligand of choice for economic reasons (readily available from L-valine in contrast to ligand 99, which is produced from the expensive unnatural amino acid tert-butyl leucine). The steric demand of the diazo ester is another issue. It turned out that exchanging the ethyl group with a tert-butyl group has a beneficial effect on the stereochemical outcome of the reaction (Table 2, entry 4 and 6 ).

Table 2: Ligand and diazo acetate screening for the conversion of 2-furoic ester $62 .{ }^{40}$<smiles>COC(=O)c1ccco1</smiles>

62

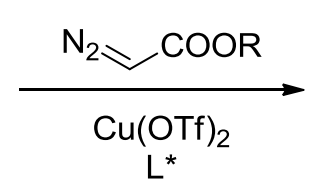

$L^{*}$

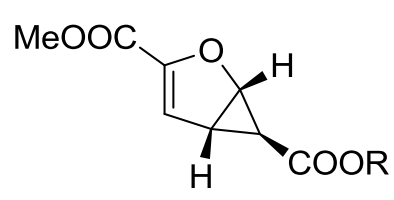

112

\begin{tabular}{ccccc}
\hline Entry & $\begin{array}{c}\text { Diazo acetate } \\
\mathrm{R}\end{array}$ & $\begin{array}{c}\text { Ligand } \\
\mathrm{L}^{*}\end{array}$ & $\begin{array}{c}\text { Yield } \\
{[\%]}\end{array}$ & $\begin{array}{c}\text { Selectivity } \\
{[\%] ~ e e}\end{array}$ \\
\hline 1 & $\mathrm{Me}$ & $\mathbf{8 5}$ & 45 & 69 \\
2 & $\mathrm{Me}$ & $\mathbf{9 9}$ & 55 & 85 \\
3 & $\mathrm{Et}$ & $\mathbf{9 9}$ & 63 & $91^{[\mathrm{a}]}$ \\
4 & $\mathrm{Et}$ & $\mathbf{8 2}$ & 35 & $81^{[\mathrm{a}]}$ \\
5 & $\mathrm{Et}$ & $\mathbf{e n t - 8 2}$ & 33 & $75^{[\mathrm{a}]}$ \\
6 & $\mathrm{BBu}$ & $\mathbf{8 2}$ & 38 & $95^{[\mathrm{a}]}$ \\
7 & $\mathrm{Me}$ & $\mathbf{1 1 3}$ & 23 & 94 \\
8 & $\mathrm{Me}$ & $\mathbf{1 0 0}$ & 36 & 91 \\
9 & $\mathrm{Me}$ & $\mathbf{1 1 4}$ & 18 & 91 \\
10 & $\mathrm{Me}$ & $\mathbf{1 1 5}$ & 31 & 85 \\
\hline
\end{tabular}

[a]: $99 \%$ ee after single recrystallization [isolated yield 53\% (entry 3), 32\% (entry 4), 29\% (entry 5) and $27 \%$ (entry 6)].<smiles>[R]C1N=C(C(C)(C)C2=NC([R])[C@@H]([R])O2)OC1[R]</smiles>

85: $\mathrm{R}=\mathrm{CH}_{2} \mathrm{OH}, \mathrm{R}^{1}=\mathrm{Ph}$

99: $R=t B u, R^{1}=H$

82: $\mathrm{R}=i \mathrm{Pr}, \mathrm{R}^{1}=\mathrm{H}$<smiles>[R]C1COC(N([R])C2=NC([R])CO2)=N1</smiles>

113: $\mathrm{R}=t \mathrm{Bu}, \mathrm{R}^{1}=\mathrm{H}$ 100: $R=t B u, R^{1}=M e$ 114: $\mathrm{R}=i \mathrm{Pr}, \mathrm{R}^{1}=\mathrm{H}$ 115: $\mathrm{R}=i \mathrm{Pr}, \mathrm{R}^{1}=\mathrm{Me}$ 
In order to extend the scope of the asymmetric cyclopropanation of furan derivatives, the copper(I)-bis(oxazoline)-diazo-ester system was also examined with 3-furoic methyl ester (78) (Table 3). In contrast to the 2-substituted cyclopropanation product 112, the 3-substituted $\mathbf{5 8}$ was formed in slightly lower yields but significantly lower enantiomeric excess.

Table 3: Ligand and diazo acetate screening for the conversion of 3-furoic ester 78.

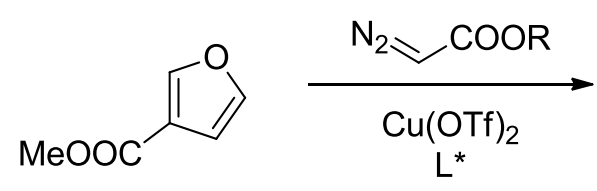

78

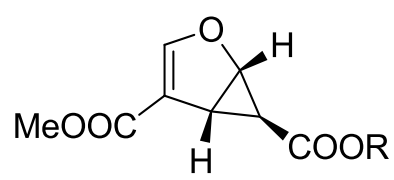

58

\begin{tabular}{lcccc}
\hline Entry & $\begin{array}{c}\text { Diazo acetate } \\
\mathrm{R}\end{array}$ & $\begin{array}{c}\text { Ligand } \\
\mathrm{L}^{*}\end{array}$ & $\begin{array}{c}\text { Yield } \\
{[\%]}\end{array}$ & $\begin{array}{c}\text { Selectivity } \\
{[\%] ~ e e}\end{array}$ \\
\hline $1^{[\mathrm{a}]}$ & $\mathrm{Et}$ & $\mathbf{8 5}$ & 27 & 74 \\
2 & $t \mathrm{Bu}$ & $\mathbf{8 5}$ & 38 & 65 \\
$3^{[\mathrm{b}]}$ & $\mathrm{Et}$ & $\mathbf{1 1 6}$ & 31 & 68 \\
$4^{[\mathrm{b}]}$ & $\mathrm{Et}$ & $\mathbf{1 1 7}$ & 19 & 40 \\
$5^{[\mathrm{a}]}$ & $\mathrm{Et}$ & $\mathbf{9 9}$ & 22 & 74 \\
6 & $\mathrm{Et}$ & $\mathbf{8 2}$ & 31 & 83 \\
7 & $t \mathrm{Bu}$ & $\mathbf{8 2}$ & 38 & 83 \\
\hline
\end{tabular}

[a]: Ref. ${ }^{40} ;\left[\right.$ b]: Ref. ${ }^{76}$.<smiles>[R]C1=NC(C(C)(C)c2nc([R])oc2[R])OC1[R]</smiles>

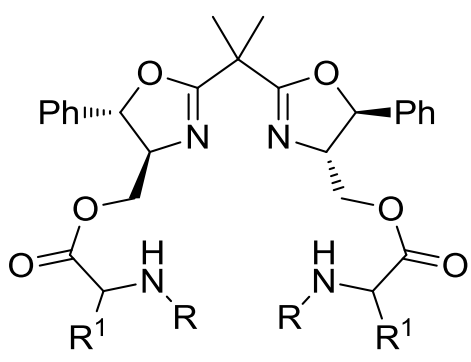

85: $\mathrm{R}=\mathrm{CH}_{2} \mathrm{OH}, \mathrm{R}^{1}=\mathrm{Ph}$
99: $\mathrm{R}=t \mathrm{Bu}, \mathrm{R}^{1}=\mathrm{H}$
82: $\mathrm{R}=i \mathrm{Pr}, \mathrm{R}^{1}=\mathrm{H}$

116: $R=B o c, R^{1}=M e$ 117: $R=T s, R^{1}=M e$

In the case of ligands 85, 116 and 117 (Table 3, entry 1 - 4) carrying secondary binding sites, this difference in selectivity can be explained via the substrate-complex coordination. Since the steric demand of the side chains is relatively low compared to an $\mathrm{Pr}$ or $\mathrm{tBu}$ group, the $\mathrm{OH}$ group of 85 ( $\mathrm{NH}$ for 116 and 117, respectively) is suggested to act as a hydrogen bond donor (Figure 10, left). ${ }^{76}$ This fact explains the 
higher enantiomeric excess of the 2-substituted cyclopropanated furan 112 over the 3-substituted one $\mathbf{5 8}$. The latter is supposed to be unable of forming hydrogen bonds with the ligand- $\mathrm{OH} / \mathrm{NH}$ group, as the distance between the ester and the $\mathrm{OH} / \mathrm{NH}$ group is too long (Figure 10, right). Thus, the missing hydrogen bond cannot compensate the relatively low steric demand of the side chains, which results in lower ee values.

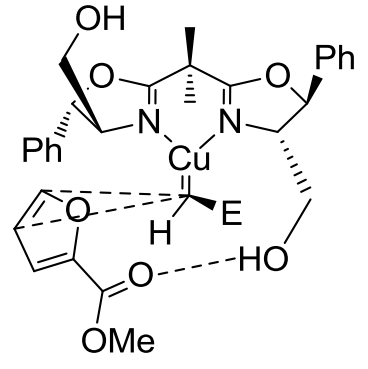

118

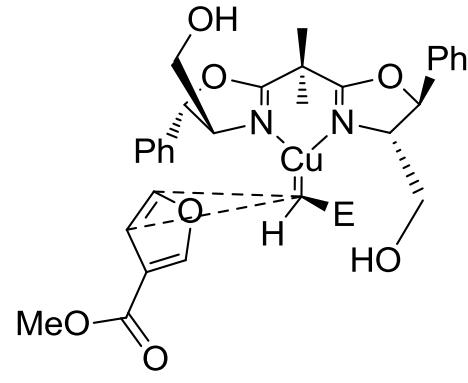

119

Figure 10: Complex of 2-furoic ester 62 (left ${ }^{76}$ and 3-furoic ester 78 (right) with ligand $\mathbf{8 5}$ bearing a secondary binding site (the same applies to ligand $\mathbf{1 1 6}$ and $\mathbf{1 1 7}$ with the $\mathrm{NH}$ groups acting as hydrogen donor); $\mathrm{E}=$ ester.

There is a different explanation for the comparable but mostly lower enantiomeric excess using ligands without secondary binding sites 99 and 82 (Table 3, entry 5 - 7). As mentioned above, the substrate approaches to the complex in a way that the furan-COOMe group points away from the bulky moieties ( $\operatorname{Pr}$ or $t \mathrm{Bu}$ ) of the ligand. This fact, combined with the $\mathrm{C}_{2}$-symmetry of the complex, is responsible for the stereoselectivity (Figure 11, left column). The exchange of 2-furoic ester with 3-furoic ester should lead to a lower steric repulsion between the furan-COOMe group and the ligand residue, due to the lengthened distance. This steric difference can be responsible for an initially unfavored approach turning into a likely pathway (Figure 11 , right column). Although this hypothesis has yet to be proven, it gives an explanation for the lower enantioselectivity of this cyclopropanations and makes the way for further optimization. In order to increase the steric repulsion, more bulky ester groups could be introduced into the 3 -furoic acid (59) to enable a screening process. If the hypothesis is accurate, the ee values should increase with the bulkiness of the ester $(\mathrm{Me}<\mathrm{Et}<\operatorname{Pr}<\mathrm{tBu})$. 


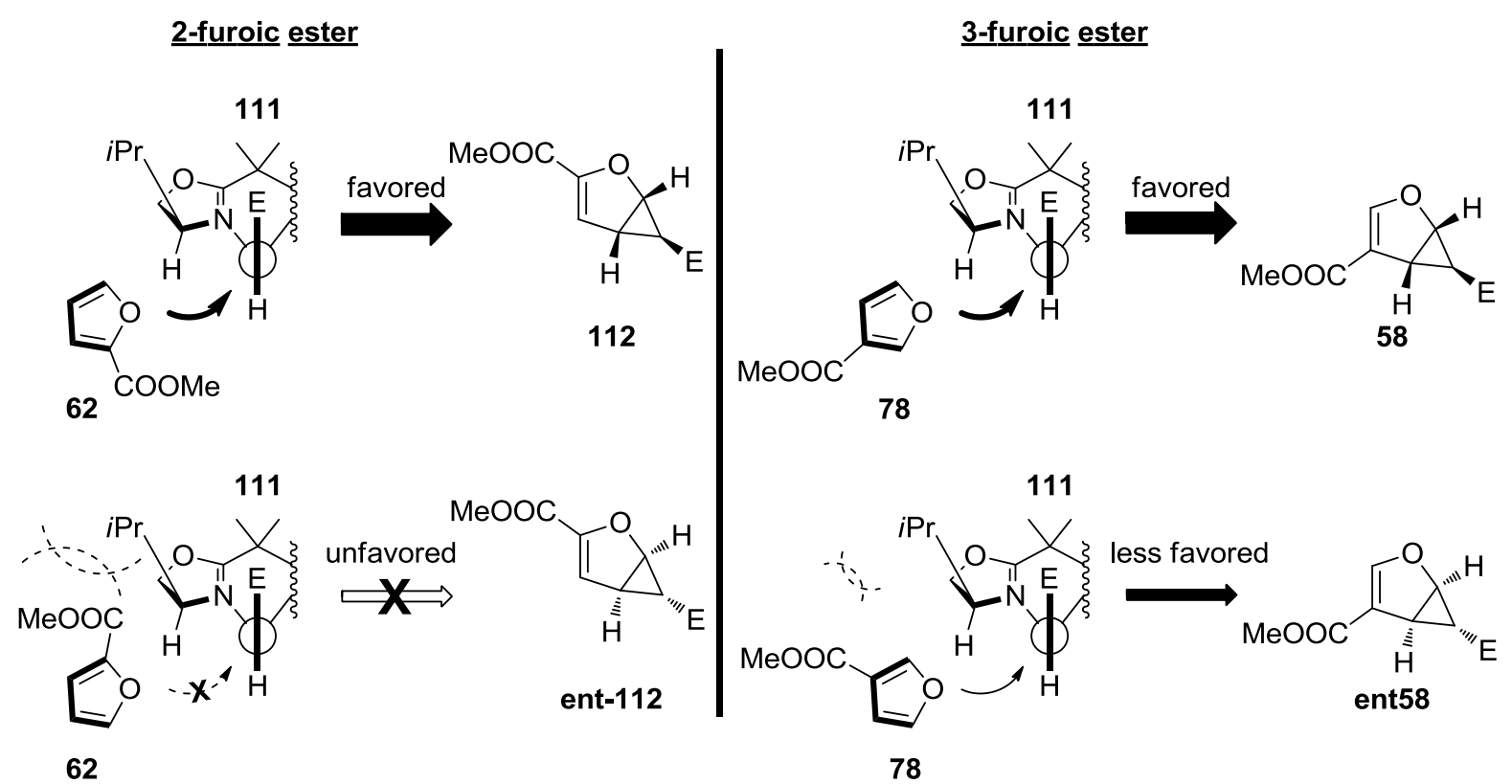

Figure 11: Selectivity comparison of the cyclopropanation of two different substrates ( $\mathrm{E}=$ ester).

In contrast to the diazo compound screening for the conversion of the 2-furoic ester 62, the exchange of ethyl diazo glycine (91) by tert-butyl diazo glycine (89) gave no advantage for the stereoselectivity when using 3-furoic ester 78 (Table 3, entry 6 and 7).

Contrary to the 2-furoic-ester-pathway, the 3-furoic-ester pathway does not allow the purification of the desired enantiomer by crystallization. The ethyl ester derivative $\mathbf{1 1 9}$ did not form a solid and stayed a sticky oil even during storage at $-18^{\circ} \mathrm{C}$ for several weeks. In contrast, the tert-butyl derivative $\mathbf{1 1 8}$ crystallizes already as a white solid, while being concentrated under reduced pressure after column chromatography. All attempts to recrystallize it in order to increase the enantiomeric excess, either in the established $n$-pentane/DCM mixture or other solvent mixtures, failed due to the high solubility in almost all common organic solvents (even in neat $n$-pentane at low temperatures).

The stereochemistry of the tert-butyl substituted cyclopropanation product $\mathbf{1 1 8}$ was confirmed by X-ray crystallography (Figure 12). 

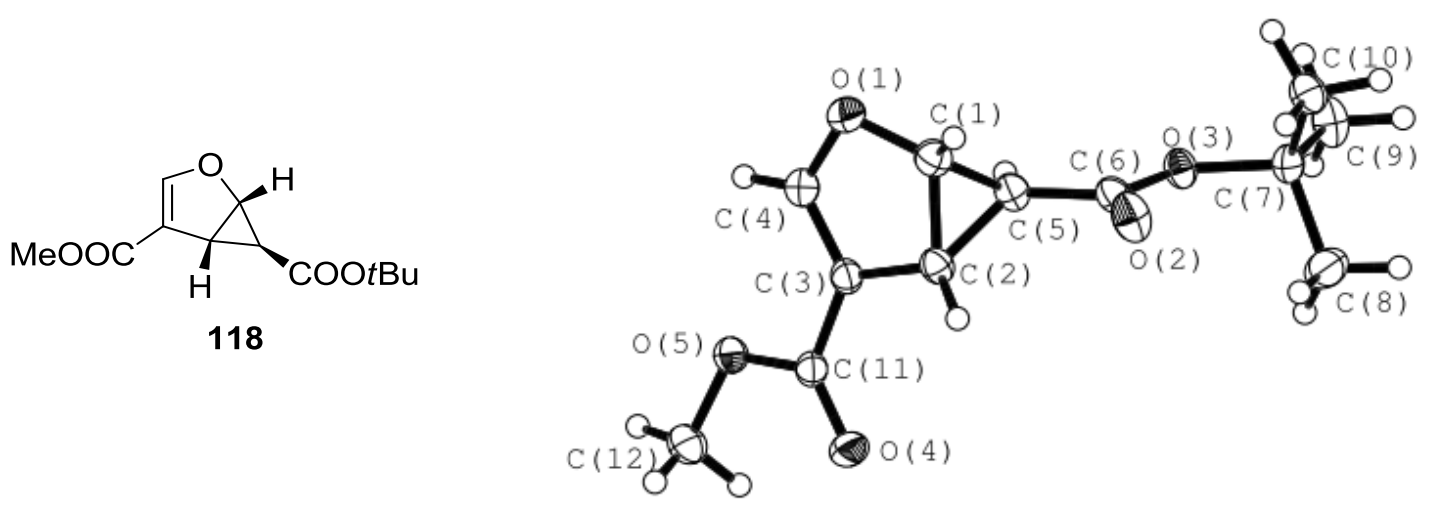

Figure 12: X-ray structure of 118. 


\section{Toward the furo-lactone formation}

Due to the easier accessibility of the ethyl diazo glycine (91), even on multi gram scale, the further experiments toward the furo-lactone 121 were carried out with the ethyl ester derivative $\mathbf{1 1 9}$ of the cyclopropanated furan (Scheme 17).

Scheme 17: From the cyclopropanated furan 119 to the furo-lactone moiety 121, the core structure of Paeonilide (5).<smiles>CCOC(=O)C1=CO[C@@H]2C(C(=O)OCC)C12</smiles>

119

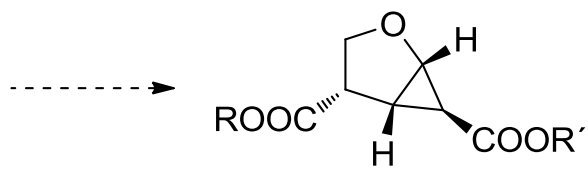

120

$\mathrm{R}=\mathrm{H}$ or $\mathrm{Me}$

$\mathrm{R}^{\prime}=\mathrm{H}$ or $\mathrm{Et}$

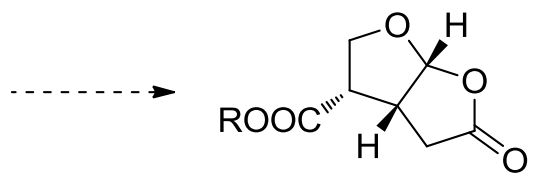

121

$\mathrm{R}=\mathrm{H}$ or $\mathrm{Me}$

A preliminary account was the straightforward direct lactonization of the cyclopropane $\mathbf{1 1 9}$ to the furo-lactone $\mathbf{1 2 1}$ to yield the core skeleton of the desired target molecule. In order to achieve this reaction several literature known lactonization methods were carried out.

Table 4: Direct lactonization attempts.

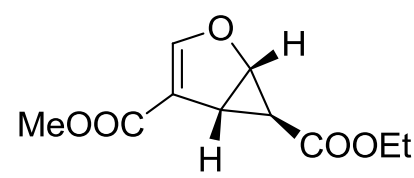

119

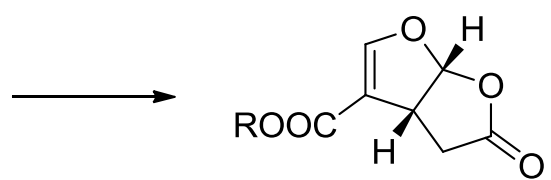

122

$\mathrm{R}=\mathrm{H}$ or $\mathrm{Me}$

\begin{tabular}{|c|c|c|c|c|}
\hline Entry & Reagents & Conditions & Yield [\%] & Observations \\
\hline $1^{[\mathrm{a}]}$ & $6 \mathrm{M} \mathrm{HCl} /$ dioxane & 24 h, r.t. & - & saponification \\
\hline $2^{[\mathrm{b}]}$ & $\begin{array}{c}\mathrm{MeSO}_{3} \mathrm{H}(3.3 \mathrm{eq}), \\
\text { acetone }\end{array}$ & 24 h, r.t. & - & intractable mixture \\
\hline $3^{[c]}$ & BTS (2 eq), DCM & $14 \mathrm{~h}, 0^{\circ} \mathrm{C}$ to r.t. & 87 (127) & $\begin{array}{c}\text { formation of acyclic } \\
\text { isomers }\end{array}$ \\
\hline
\end{tabular}

[a]: $\operatorname{Ref}^{28} ;\left[\right.$ [b]: $\operatorname{Ref}^{77}$; [c]: $\operatorname{Ref}^{78}$. 
The acid mediated lactonization (Table 4, entry 1), already used in the synthesis of the core nuclei $\mathbf{7 6}$ and $\mathbf{7 7}$ of Macfarlandin C, Norrisolide and Cheloviolene A/B (Scheme 9), usually applied on saturated systems afforded in present case, e.g. an unsaturated substrate, only a mixture of partially and completely saponified starting material. The use of methane sulfonic acid, successfully employed in the one-pot ring expansion of cyclopropane rings by Theodorakis et al., resulted in the case of $\mathbf{1 1 9}$ in a complex mixture of components. Hiyama et al. reported the utilization of bis(trimethylsilyl) sulfate (128, BTS, synthesized according to reference ${ }^{79}$ ) for the transformation of activated cyclopropane carboxylates into $\gamma$-butyrolactones. ${ }^{78}$ So far BTS - highly Lewis acidic and less nucleophilic - was limited to the silylation of active hydrogen compounds. ${ }^{80-81}$ According to Hiyama BTS was superior to other Lewis and Brønsted acids like $\mathrm{H}_{2} \mathrm{SO}_{4}$, TMS-OTf, TMS-I, $\mathrm{BF}_{3} \cdot \mathrm{OEt}_{2}$ or $\mathrm{TiCl}_{4}$, which gave unsaturated aliphatic byproducts in different quantities, depending on the acid used (Scheme 18, top). The treatment of $\mathbf{X}$ with BTS did not afford desired lactone but exclusively a mixture of unsaturated aliphatic isomers (Z/E-127 and $E / E-127$ 1.7:1, Scheme 18, bottom). According to Reissig et al., this kind of transformation is one of the most frequently applied reactions in the class of small ring molecules. ${ }^{63}$ Although these reactions usually provide 1,4-dicarbonyl compounds, $\mathbf{1 1 9}$ delivers 1,6-dicarbonyls due to its fused ring system. 
Scheme 18: Lactonization by Hiyama et al., literature example (top) ${ }^{78}$ and application of 119 (bottom).<smiles>C=CC1CC1(C(=O)OCC)C(=O)OCC</smiles><smiles>CCOC(=O)C1CC2CCC1C(C(C)OC)C2</smiles>

119<smiles>CCOCC=CC(C=O)C(C)OC</smiles>

$Z / E-127$<smiles>CCOC(=O)/C=C/C=C(\C=O)C(=O)OCC</smiles>

$E / E-127$<smiles>O=S(=O)(O[As])O[AsH3]</smiles>

Reagents and conditions: a) Lewis or Brønsted acid (2 eq), DCM or DCE, reflux, $98 \% 124$ (for acid = BTS); b) BTS (2 eq), DCM, $0{ }^{\circ} \mathrm{C}$ to r.t., $14 \mathrm{~h}, 87 \%(Z / E-127$ and $E / E-1271.7: 1)$.

Parallel to these efforts on the lactonization, the selective reduction of the furan-COOMe group was attempted, which probably would be advantageous for the later steps, since the COOMe group needs to be transformed into a hydroxyl group anyway.

Scheme 19: Attempted selective methyl ester reduction.<smiles>CCOC(=O)[C@H]1C=C(C(=O)OC)O[C@H]1C</smiles>

110

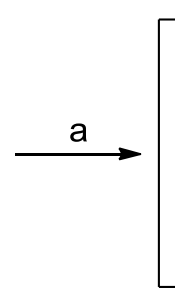

CoOEt

129

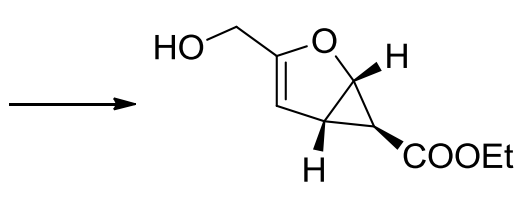

130<smiles>CCOC(=O)C1C2C(C(=O)OC)=CO[C@H]12</smiles>

119<smiles>CCOC(=O)[C@H]1CC(CO)=CO[C@H]1C</smiles>

131<smiles>COC(=O)C1=CO[C@H]2C(CO)C12</smiles>

132

Reagents and conditions: a) $\mathrm{LiAlH}_{4}(0.6 \mathrm{eq}), \mathrm{THF}, 0{ }^{\circ} \mathrm{C}, 1 \mathrm{~h}, 87 \%$; b) $\mathrm{LiAlH}_{4}(0.6 \mathrm{eq}), \mathrm{THF}, 0{ }^{\circ} \mathrm{C}, 1 \mathrm{~h}$, $34 \% 131$ and $32 \% 132$. 
The reduction of the 2-substituted derivative $\mathbf{1 1 0}$ with $\mathrm{LiAlH}_{4}$ proceeded in a selective way, which can be explained via chelating of the oxygen atoms by a lithium ion, probably activating the methyl ester carbonyl (Scheme 19 , top). ${ }^{82}$ Due to the 3-position of the methyl ester in 119, it is not possible to chelate the oxygen atoms, which results in a mixture of both possible alcohols 131 and 132 (Scheme 19, bottom). Because of this selectivity problem, experiments concerning this route were ceased.

To circumvent the problems occurring in the direct lactonization (Table 4) or the selective reduction pathway (Scheme 19), it was envisaged first to reduce the C-C double bond and then implement further modifications toward the furo-lactone core skeleton. In order to achieve this goal, standard methods for $\mathrm{C}-\mathrm{C}$ double bond hydrogenation were applied (Table 5).

Several attempts in different solvents showed the high dependency of this reactions to the applied solvent, e.g. methanol and ethyl acetate proved to be completely ineffective. Moreover, variation of the catalyst (e.g. palladium on charcoal, palladium hydroxide on charcoal, ruthenium on aluminum oxide) did not result in consumption of starting material (Table 5, entry 1 - 4). 
Table 5: C-C double bond hydrogenation.

\begin{tabular}{|c|c|c|c|c|c|}
\hline & 119 & 133 & & & 134 \\
\hline \multirow{2}{*}{ Entry } & \multirow{2}{*}{ Reagents ${ }^{[\mathrm{a}]}$} & \multirow{2}{*}{ Conditions } & \multicolumn{2}{|c|}{ Yield [\%] } & \multirow{2}{*}{ Observation } \\
\hline & & & 133 & 134 & \\
\hline 1 & $\mathrm{Pd} / \mathrm{C}, \mathrm{MeOH}, \mathrm{H}_{2}$ & 24 h, r.t. & \multicolumn{2}{|c|}{-} & no reaction \\
\hline 2 & $\mathrm{Pd}(\mathrm{OH})_{2}, \mathrm{MeOH}, \mathrm{H}_{2}$ & 24 h, r.t. & \multicolumn{2}{|c|}{-} & no reaction \\
\hline 3 & $\mathrm{Pd} / \mathrm{C}, \mathrm{EA}, \mathrm{H}_{2}$ & 24 h, r.t. & \multicolumn{2}{|c|}{-} & no reaction \\
\hline 4 & $\mathrm{Rh} / \mathrm{AlOx}, \mathrm{EA}, \mathrm{H}_{2}$ & 24 h, r.t. & \multicolumn{2}{|c|}{-} & no reaction \\
\hline 5 & $\mathrm{Pd} / \mathrm{C}, \mathrm{EtOH} / \mathrm{H}_{2} \mathrm{O}(95: 5), \mathrm{H}_{2}$ & 24 h, r.t. & 25 & 8 & \\
\hline 6 & entry $5+\mathrm{AcOH}$ (cat) & 12 h, r.t. & 23 & 48 & \\
\hline 7 & $\mathrm{Pd} / \mathrm{C}, \mathrm{EtOH}$ (abs), $\mathrm{H}_{2}$ & $>3 \mathrm{~d}$, r.t. & & & extremely slow \\
\hline \multirow[t]{2}{*}{8} & $\mathrm{Mg}(1 \mathrm{eq}), \mathrm{MeOH}$ & $0.5 \mathrm{~h}, 0^{\circ} \mathrm{C}$ & - & 38 & transesterification \\
\hline & & & & & 2x COOMe (135) \\
\hline 9 & $\begin{array}{c}\mathrm{RhCl}\left(\mathrm{Ph}_{3} \mathrm{P}\right)_{3},{ }^{[\mathrm{b}]} \mathrm{EtOH} / \mathrm{THF} \\
(9: 1), \mathrm{H}_{2}{ }^{[\mathrm{c}]}\end{array}$ & $18 \mathrm{~h}$, r.t. & & & \\
\hline
\end{tabular}

[a]: if not stated otherwise $\mathrm{H}_{2}$ applied via balloon; [b]: Wilkinson's catalyst [c]: balloon $1 \mathrm{~h}$ (no reaction), autoclave 20 bar $2 \mathrm{~h}$ (no reaction), autoclave 30 bar $15 \mathrm{~h}$ (no reaction).

Changing the catalytic system from heterogeneous to homogeneous, i.e. by application of Wilkinson's catalyst, ${ }^{83}$ gave no conversion as well, even when hydrogen pressure was applied up to 30 bar in an autoclave.

The use of aqueous ethanol together with palladium on charcoal finally resulted in conversion of 119. However, the reaction in $\mathrm{EtOH} / \mathrm{H}_{2} \mathrm{O}$ with $\mathrm{Pd} / \mathrm{C}$ provided not only the desired product 133, but also byproduct 134 from hydrogenation of one cyclopropane bond. The structure of 134 could be confirmed by 2D-NMR analysis. A similar byproduct was also observed when derivatives of the 2-substituted cyclopropanated furan $\mathbf{1 1 0}$ was submitted to hydrogenation conditions, albeit opening of the furan occurred next to addition to the cyclopropane ring. ${ }^{84}$ It could be shown that the presence of water promoted the reaction, since the conversion in anhydrous ethanol was negligible even after 3 days (according to TLC control). The addition of catalytic amounts of acetic acid accelerated the product formation but 
gave also an increase in ring opened 134. The same effect was observed when different acids like $p$-TSA, oxalylic acid or TFA were used. Product 133 was formed as expected, exhibiting the methyl ester group on the concave side of the fused ring system, since the hydrogenation takes place from the less hindered, convex side. The stereochemistry of $\mathbf{1 3 3}$ was confirmed by X-ray crystallography (Figure 13).

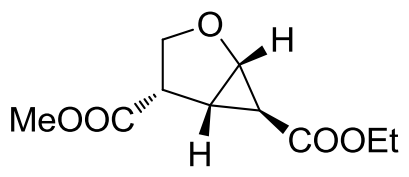

133

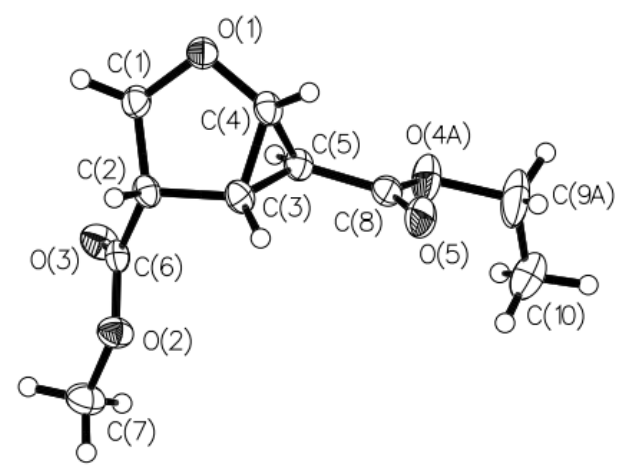

Figure 13: X-ray structure of 133.

A screening should give rise to the origin of the byproduct 134 (Scheme 20). To this end, olefin 119 was stirred in the presence of palladium on charcoal but without any hydrogen to determine whether the side reaction occurs on the catalyst surface itself, but only very slow decomposition could be observed (Scheme 20, top). The desired hydrogenation product 133 reacted fast under hydrogenation conditions to the opened cyclopropane 134 (Scheme 20, middle). Contrary to these results, treatment of 133 only with solvent and catalyst without hydrogen gave no new compounds on TLC, therefore it seems to be stable under these conditions (Scheme 20, bottom). 
Scheme 20: Studies on byproduct formation.

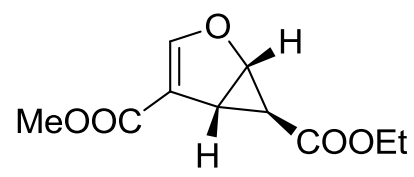

119

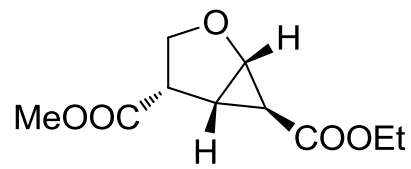

133

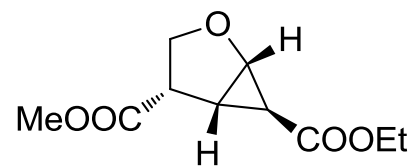

133

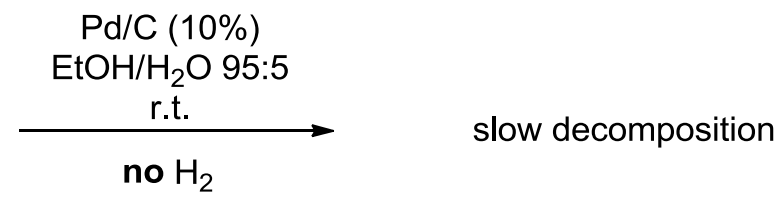

$\mathrm{Pd} / \mathrm{C}(10 \%)$

$\mathrm{EtOH} / \mathrm{H}_{2} \mathrm{O} 95: 5$

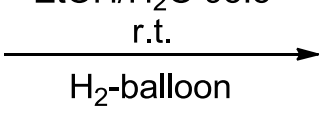

$\mathrm{Pd} / \mathrm{C}(10 \%)$

$\mathrm{EtOH} / \mathrm{H}_{2} \mathrm{O}$ 95:5

r.t.

no $\mathrm{H}_{2}$<smiles>CCOC(=O)C[C@@H]1C[C@@H](C(=O)OC)CO1</smiles>

134

no reaction

A final hydrogenation was attempted with in situ generated hydrogen by treating the starting material 119 with magnesium in methanol. ${ }^{85-86}$ According to literature precedents, this method was successfully applied on $\alpha, \beta$-unsaturated esters and tolerates several functional groups, e.g. esters, epoxides and ethers. The recommended 10 equivalents of magnesium caused a rapid formation of multiple compounds within a few minutes. Changing the conditions to 1 equivalent of magnesium and cooling to $0{ }^{\circ} \mathrm{C}$ gave rise to the opened cyclopropane 135, which is similar to 134 , but transesterificated to a double methyl ester. In contrast to 134 , which was formed as a single diastereomer, 135 was produced as a 1:1 mixture of two diastereomers, which could not be exactly identified yet.

As the aforementioned lactonization directly after cyclopropanation was unsuccessful, the alternative approach of reducing the $\mathrm{C}-\mathrm{C}$ double bond was further envisaged to be optimized, since a product formation was already observed. To circumvent these problems, saponification of the methyl ester was envisaged. In order to perform this reaction selectively, with respect to the COOMe group, very mild conditions were chosen. A small excess of lithium hydroxide in aqueous THF at $0{ }^{\circ} \mathrm{C}$ did not give the desired product but an inseparable 1:1 mixture of both possible mono-saponified products 136 and 137 (Scheme 21). 
Scheme 21: Attempt of selective saponification.

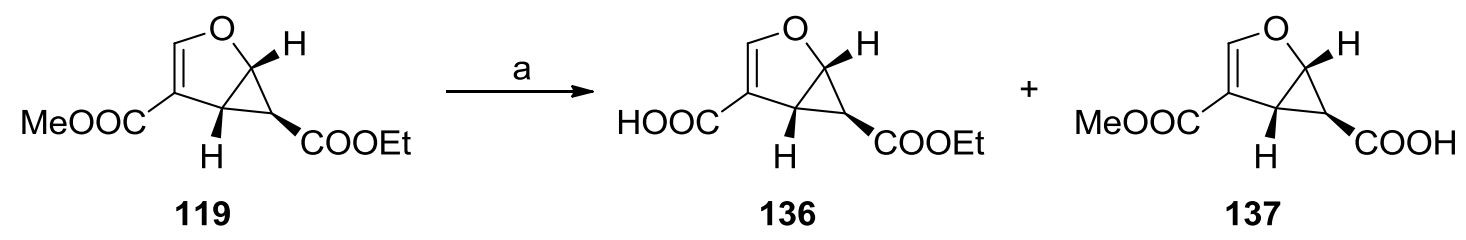

Reagents and conditions: a) $\mathrm{LiOH}(1.1 \mathrm{eq}), \mathrm{H}_{2} \mathrm{O} / \mathrm{THF} 2: 1,0{ }^{\circ} \mathrm{C}, 6 \mathrm{~h}, 85 \%(\mathbf{1 3 6 / 1 3 7}=1: 1)$.

Literature known procedures for a selective conversion of a methyl ester like the reaction of sodium cyanide in DMPU, did not furnish the desired product either, but only a complex mixture which could not be analyzed. ${ }^{87-88}$

Due to the small difference in reactivity regarding the hydrolysis of the methyl and ethyl ester of 119, a change of these groups was needed. For this reason the initial cyclopropanation was performed with tert-butyl diazo glycine (89) to accomplish the cyclopropanated furan 118 (Scheme 22, X-ray structure Figure 12), now bearing a methyl and a tert-butyl ester (for a closer discussion of furan-cyclopropanation see chapter 2.2). All further reactions found on this molecule.

Scheme 22: Asymmetric cyclopropanation with tert-butyl diazo glycine (89).

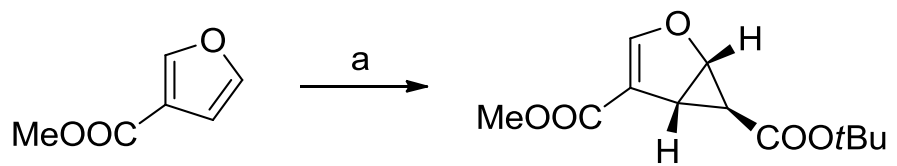

78

118

Reagents and conditions: a) $\mathrm{Cu}(\mathrm{OTf})_{2}(1.12 \mathrm{~mol} \%),(\mathrm{S}, \mathrm{S})-\mathrm{Pr}-\mathrm{BOX}(\mathbf{8 2})(1.5 \mathrm{~mol} \%), \mathrm{PhNHNH}_{2}$ (1.12 mol\%), $\mathrm{N}_{2} \mathrm{CHCOOtBu}\left(1.3 \mathrm{eq}\right.$ ), DCM, $0{ }^{\circ} \mathrm{C}, 38 \%$ (53\% brsm), $83 \%$ ee.

The subsequent hydrolysis of the methyl ester in the presence of the tert-butyl ester performed by the utilization of lithium hydroxide now worked as desired in a chemoselective way, delivering the carboxylic acid 138 in excellent yield (Scheme 23). The synthesis was even applicable on multi gram scale. The following $\mathrm{C}-\mathrm{C}$ double bond hydrogenation was first tested with the so far best solvent-catalyst system according to the prior hydrogenation screening, palladium on charcoal in ethanol-water 95:5. Already the first reaction proceeded smoothly to the product $\mathbf{1 3 9}$ (Scheme 23). Due to steric reasons the reduction should proceed from the less hindered, convex side of the fused ring system, which was confirmed later. 
Scheme 23: Hydrogenation and hydrolysis to 139.<smiles>CCOC(=O)C1=CO[C@@H]2C(C(=O)OCC)C12</smiles>

118

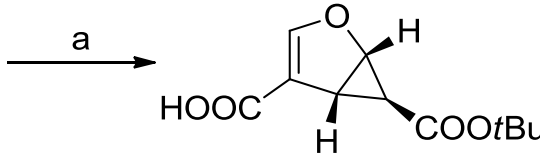

138

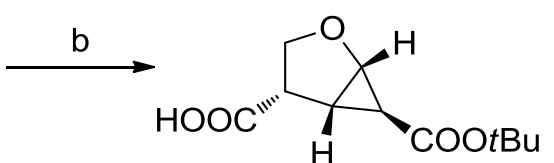

139

Reagents and conditions: a) $\mathrm{LiOH}\left(1.1 \mathrm{eq}\right.$ ), $\mathrm{H}_{2} \mathrm{O} / \mathrm{THF} 3: 1$, r.t., $6 \mathrm{~h}, 85 \%$ (quant. brsm); b) $\mathrm{Pd} / \mathrm{C}$ (10\%), EtOH/ $\mathrm{H}_{2} \mathrm{O} 95: 5, \mathrm{H}_{2}$ (balloon), r.t., $6 \mathrm{~h}$, quant.

Having 139 in hands, there were two alternative routes to proceed in the synthesis. Either reduction of the free carboxylic acid group to the corresponding alcohol, followed by the lactonization, or vice versa. Both ways were examined. The reduction of the acid group was performed in THF by the use of a borane-THF-complex, which selectively reduces carboxylic acids to the corresponding alcohol in the presence of esters if not added in too large excess. ${ }^{89}$ The reaction itself worked as desired but problems during the work up were encountered, since the product 140 seemed to be unstable under these conditions (Scheme 24).

Scheme 24: Different lactonization pathways.<smiles>CCOC(=O)[C@@H]1[C@@H]2[C@@H](C(=O)O)CO[C@H]21</smiles>

139

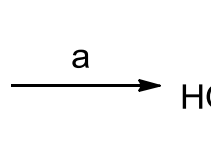

$\mathrm{HO} \backslash$ ("

140

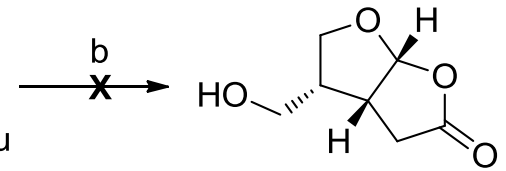

141

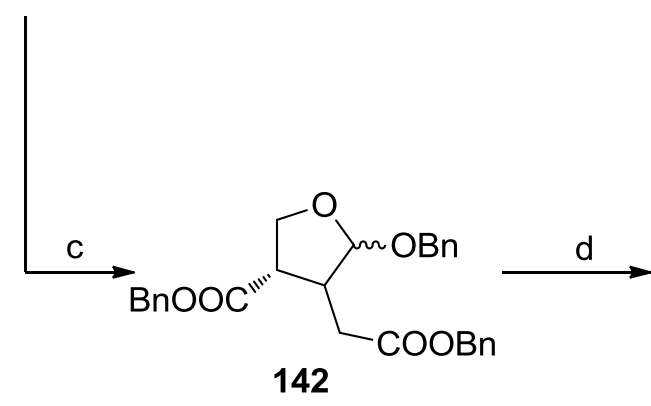

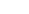


The obtained alcohol $\mathbf{1 4 0}$ was analyzed by X-ray crystallography (Figure 14). This structure proved the assumption that the reduction of the $\mathrm{C}-\mathrm{C}$ double bond occurred in a way that led to the carboxylic acid 139 (Scheme 23) exhibiting the acid group on the concave side of the fused ring system.
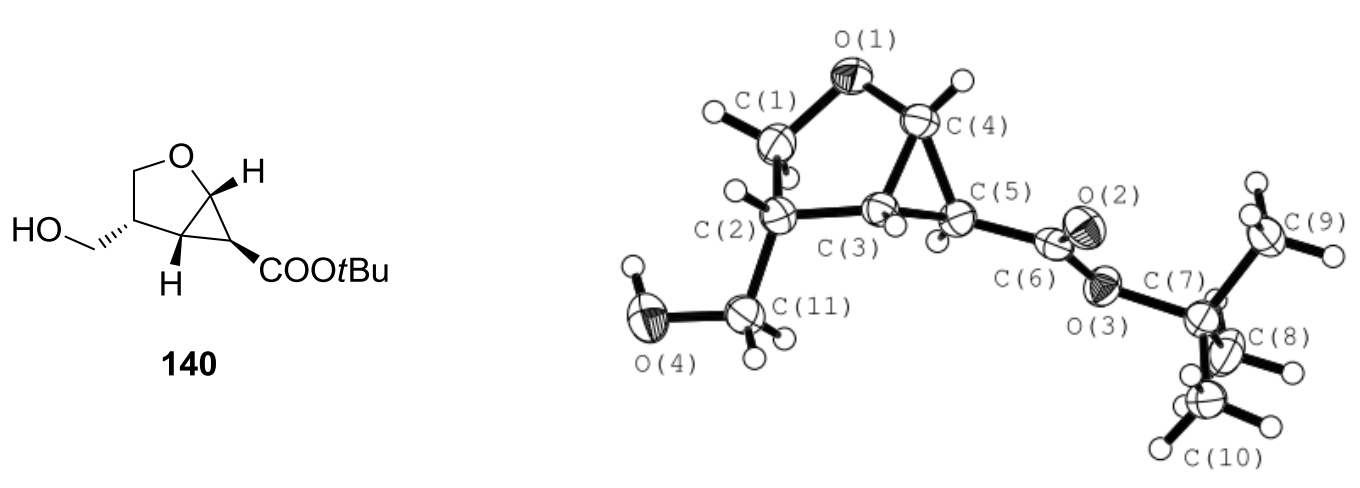

Figure 14: X-ray structure of 140.

The ensuing lactonization attempt of $\mathbf{1 4 0}$, following the acid mediated lactonization protocol, ${ }^{28}$ resulted in a complex mixture of unidentified, highly polar compounds. Since this route seemed incapable of generating the desired fused ring system, the second route was examined.

It is possible to form the bi-cyclic system either in an one-pot acid mediated or a two-step reaction. The latter was published by Theodorakis et al. for the total synthesis of the spongiane diterpene norrisolide and starts with an acidic opening of the cyclopropane moiety to form the acetal $142 .{ }^{90}$ Under these conditions all containing ester or carboxylic acid groups are transesterificated or esterificated respectively, depending on the used alcohol (in this case benzyl alcohol). The product was obtained in a diastereomeric mixture and isolated in an impure form by column chromatography. The subsequent lactone closure was accomplished by using methanesulfonic acid furnishing two different diastereomers 143 and 144 in a 1.4:1 ratio.

The formation of the two appearing diastereomers is illustrated in Scheme 25 and can be explained by a mechanism published by Reiser et $a .^{28}$ The expected diastereomer is lactone 144, which is formed when the backward-directed $\mathrm{CH}_{2} \mathrm{COOBn}$ of 142 substitutes the OBn group on the furan. Under acidic conditions, which occur in the cyclopropane ring opening reaction, benzyl alcohol can be reversibly eliminated from compound $\mathbf{1 4 2}$ to yield the enol 150. This enol can undergo a re-addition of benzyl alcohol to the acetal 149, now possessing the 
$\mathrm{CH}_{2} \mathrm{COOBn}$ group on the steric less hindered upper side of the furan ring. This thermodynamically more favored acetal is converted under benzyl alcohol elimination to the lactone 143 , bearing the benzyl ester on the convex side of the bicycles.

It could also be shown that treatment with DBU shifted the diastereomeric ratio from 1.4:1 to $5: 1$. This can be explained by the base mediated lactone opening of $\mathbf{1 4 4}$ to the hemiacetal 146 and a subsequent water elimination to enol 147, followed by re-addition of water to form again a hemiacetal 148 (Scheme 25, dashed box). Possessing the two substituents in anti position 148 is thermodynamically more favored than 146. The final ring closure gives rise to the furo-lactone $\mathbf{1 4 3}$.

Scheme 25: Acid mediated formation of lactone diastereomers 143 and 144 (boxes); base mediated lactone isomerization (dashed box).

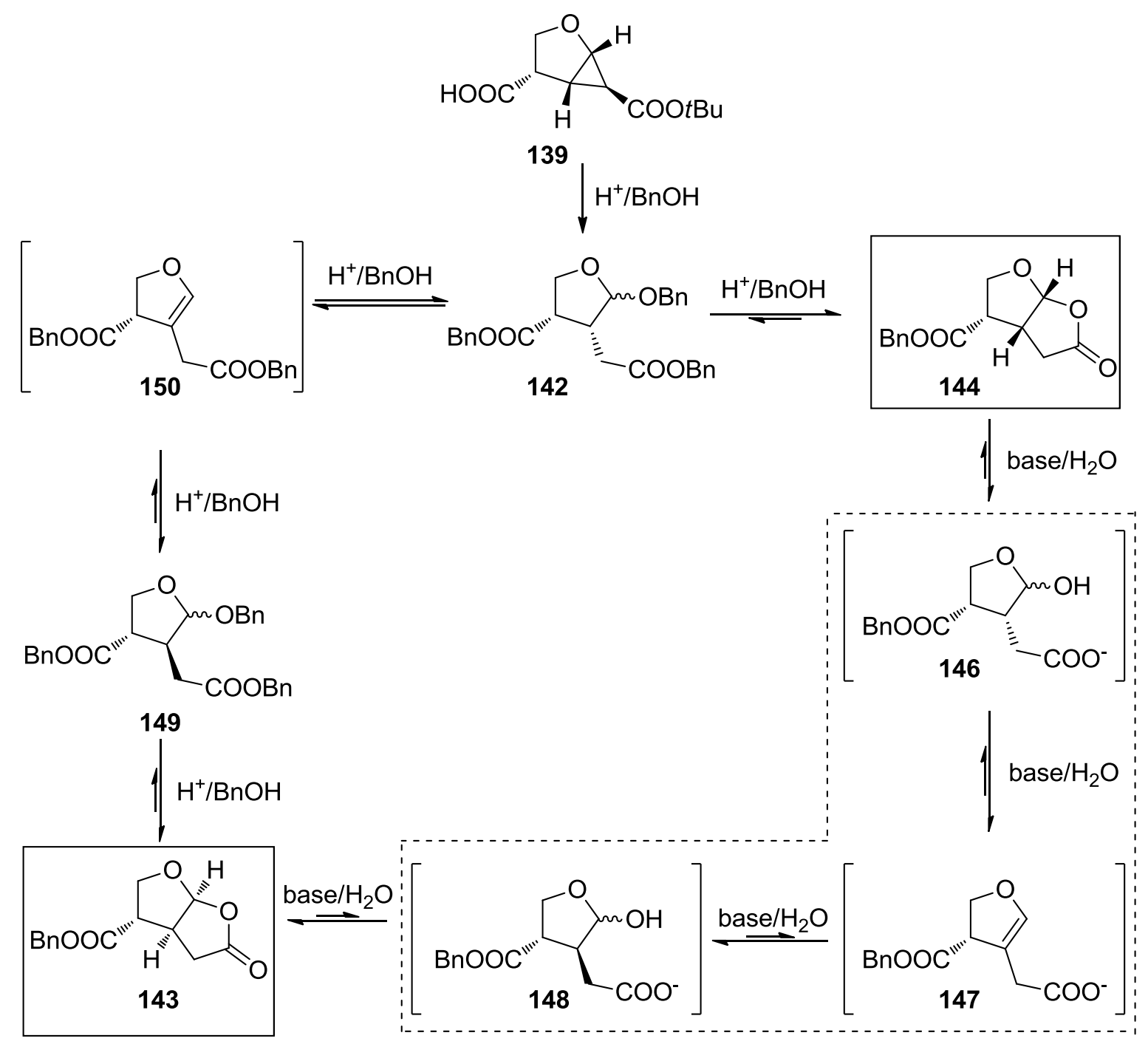


Although the one-pot acid mediated lactonization was never applied to a cyclopropanated furan having the ester substituent in 3-position, like 139, it seemed worthwhile to adopt it for that substrate, since the two-step lactonization procedure lacks diastereoselectivity. First attempts with $6 \mathrm{M}$ hydrochloric acid at ambient temperature afforded the lactone $\mathbf{1 4 5}$, but only as a part of a multi component mixture, which was inseparable due to the high polarity of the compounds. ${ }^{28} \mathrm{~A}$ slight modification of the conditions improved the outcome of this reaction (Scheme 26): using $2 \mathrm{M}$ hydrochloric acid and cooling to $0{ }^{\circ} \mathrm{C}$ during the acid addition made the starting material 139 react smoothly to the desired product 145 . Since the subsequent base mediated transformation to the other lactone diastereomer was already known from the two-step lactonization discussed before (Scheme 24), this methodology was applied as well. In contrast to the use of DBU, pyridine could be employed without refluxing the reaction mixture, thus avoiding the formation of byproducts to give rise to the core ring system of (-)-Paeonilide (5) as the substituent in 3-position was already on the convex side.

Scheme 26: One-pot lactonization and subsequent isomerization.

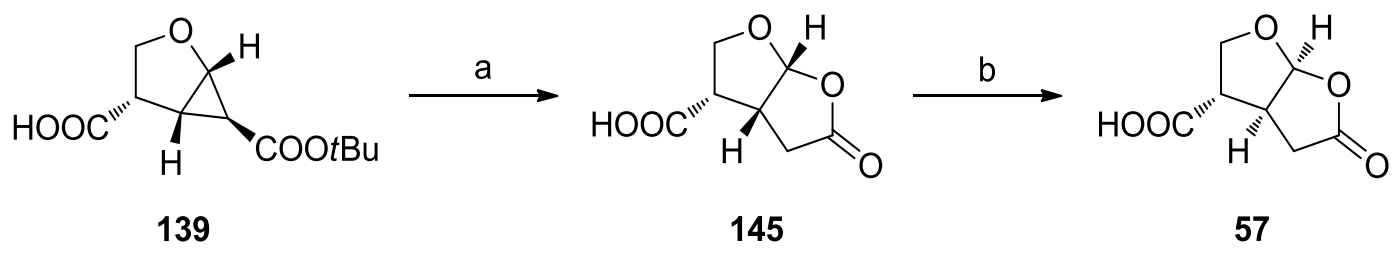

Reagents and conditions: a) $2 \mathrm{M} \mathrm{HCl} / \mathrm{THF} 3: 1,0{ }^{\circ} \mathrm{C}$ to r.t., $12 \mathrm{~h}$, not isolated; b) py, $\mathrm{H}_{2} \mathrm{O}$, r.t., $2 \mathrm{~h}$, $75 \%$ over 2 steps.

The absolute stereochemistry of both lactone isomers was confirmed by X-ray crystallography (Figure 15). It should be mentioned that $\mathbf{5 7}$ could only be crystallized by the following technique: dissolving $\mathbf{5 7}$ in a small amount of acetonitrile on a watch glass, addition of one equivalent of (R)-1-(4-chlorophenyl)ethylamine and slow evaporation of the solvent during storage in the refrigerator. 

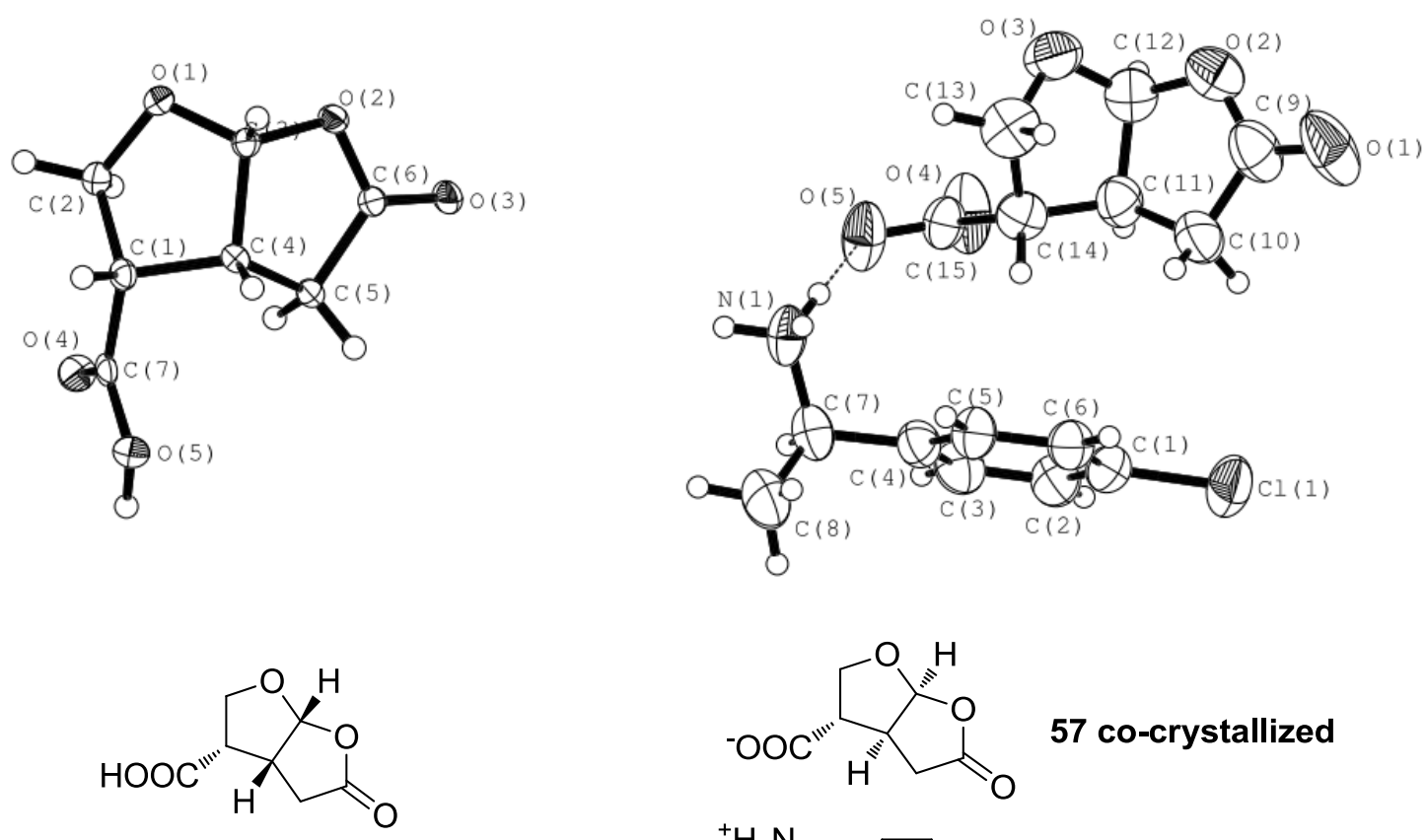

145

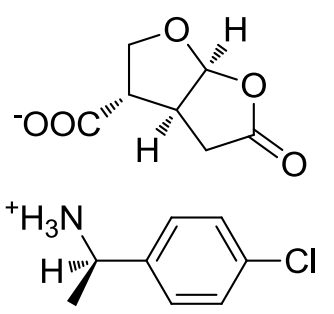

57 co-crystallized

Figure 15: X-ray structures of lactone 145 and 57, the latter co-crystallized with $(R)$-1-(4-chlorophenyl)ethylamine.

The following experiments were performed in parallel with both lactone diastereomers. In order to complete the final steps toward (-)-Paeonilide (5), except for the ketone side chain, the free carboxylic acid was reduced to the corresponding alcohol with the aid of borane. ${ }^{89}$ The best results were obtained when the reaction mixture was heated up to $40^{\circ} \mathrm{C}$ once the addition of the reducing agent was finished. Using this procedure, both alcohols 141 and 152 could be obtained in good to excellent yield. The subsequent protection step of the alcohol to the final benzoyl ester was done following the literature reaction of the already published Paeonilide synthesis by Du et al. ${ }^{25}$ The measurement of the optical rotation of both products of the protection reactions gave the same $\alpha$ value, which indicated the isomerization of one of both alcohols, either $\mathbf{1 4 1}$ or $\mathbf{1 5 2}$. The absolute stereochemistry of the obtained isomer could be confirmed by X-ray crystallography (Scheme 27). 
Scheme 27: Reduction and protection reaction; X-ray structure of 153.<smiles>O=C(O)[C@H]1CC(=O)[C@H]2CO[C@H]1O2</smiles>

145<smiles>O=C1C[C@H]2OC[C@H](C(=O)O)[C@H]2O1</smiles>

52<smiles>C[13CH2][13CH3]</smiles>

141<smiles>O=C1C[C@H]2OC[C@H](CO)[C@H]2O1</smiles>

152

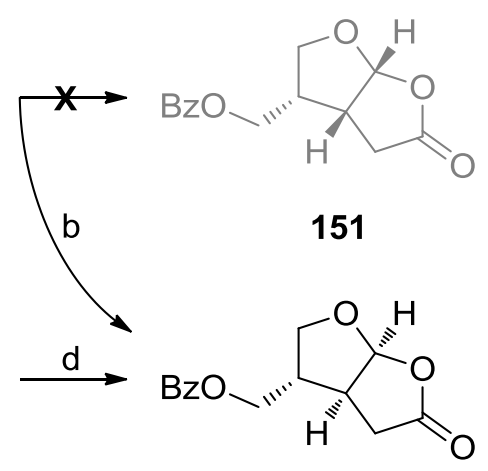

153

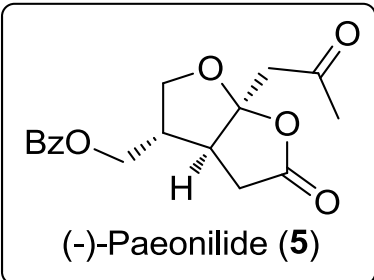

Reagents and conditions: a) $\mathrm{BH}_{3} \cdot \mathrm{THF}(1 \mathrm{eq}), \mathrm{THF}, 0{ }^{\circ} \mathrm{C}$ to $40{ }^{\circ} \mathrm{C}, 3 \mathrm{~h}, 68 \%$; b) $\mathrm{BzCl}(2 \mathrm{eq})$, py, r.t., $3 \mathrm{~h}, 36 \%$; c) $\mathrm{BH}_{3} \cdot \mathrm{THF}(1 \mathrm{eq})$, THF, $0{ }^{\circ} \mathrm{C}$ to $40{ }^{\circ} \mathrm{C}, 3 \mathrm{~h}, 97 \%$; d) $\mathrm{BzCl}(2 \mathrm{eq})$, py, r.t., 3 h, $39 \%$.<smiles>O=C1C[C@H]2OC[C@H](COC(=O)c3ccccc3)[C@@H]2O1</smiles>

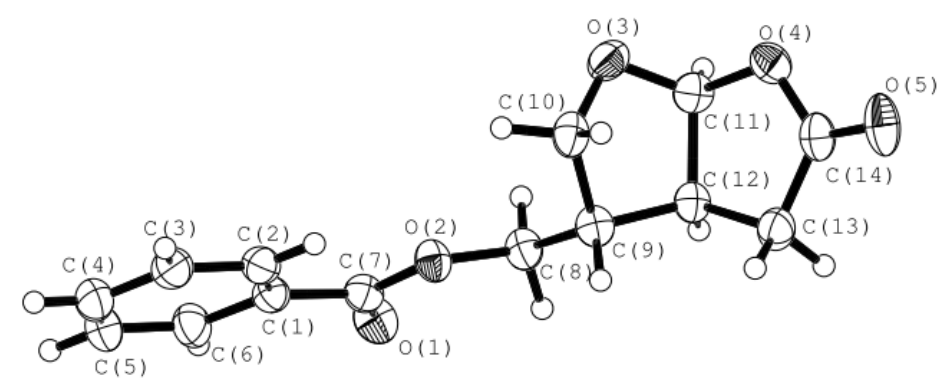

This means both protection reactions provide the same product 153 . The isomerization is supposed to proceed in the same way as previously discussed, especially concerning the base mediated lactone-isomerization (Scheme 25, dashed box). Like in that case, the formation of the steric less hindered and therefore thermodynamically favored lactone $\mathbf{1 5 3}$ is privileged. 


\section{Side chain introduction by $\mathrm{C}-\mathrm{H}$ insertion}

\subsection{General information}

The final transformation to the target compound $\mathbf{5}$ was planned to be accomplished by the utilization of a metal catalyzed carbene $\mathrm{C}-\mathrm{H}$ insertion in the acetal-like $\mathrm{C}-\mathrm{H}$ bond (Scheme 28).

Scheme 28: Planned C-H insertion in acetal-like position.

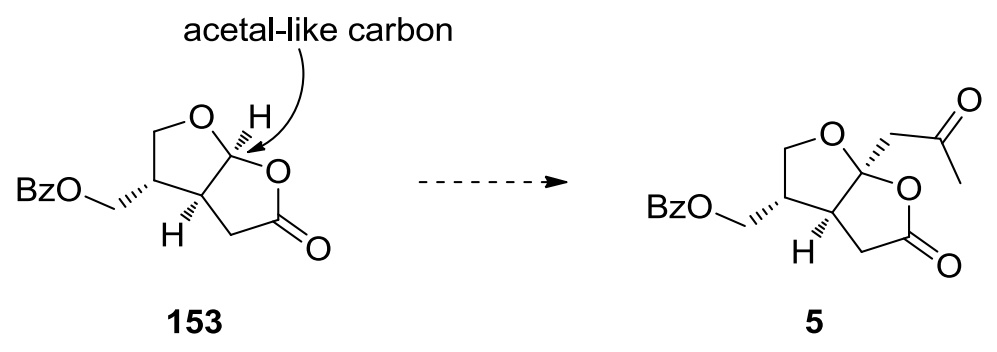

Since its first observation more than 60 years ago ${ }^{91}$ and due to its novel chemistry at that time described as unusual reaction, $\mathrm{C}-\mathrm{H}$ insertions became of great interest not only because of mechanistic implications but also in natural product synthesis. In the latter case, this kind of conversion exhibits huge benefits: Traditional reactions take advantage of functional groups which can hamper the synthesis due to the formation of unwanted byproducts. In contrast to functional group conversions, $\mathrm{C}-\mathrm{H}$ insertions can be utilized to streamline reaction sequences and to diminish the generation of byproducts. Despite years of investigation in this area, the number of known catalytic processes for these transformations is still limited. ${ }^{92-94}$ Several reasons might account for this: $:^{95}$

First, predominant investigations on "classic" $\mathrm{C}-\mathrm{H}$ activations including the formation of an organometallic compound, and second, the big energy requirement for cleaving a C-H bond combined with the arising selectivity problems.

Regarding the first point, most effort in this field was put in studies concerning "classic" $\mathrm{C}-\mathrm{H}$ activation reaction including the formal insertion of a metal center into the $\mathrm{C}-\mathrm{H}$ bond to form a $\sigma$-organyl derivative (Scheme 29, top). In this case, the relative stability of the newly formed carbon-metal and carbon-hydrogen bonds gave rise to an inert organometallic compound 156, which paralyzes subsequent 
transformations. In contrast to this fact, the transient metallo-carbene 157 with a $\mathrm{C}-\mathrm{H}$ bond would give rise to the formation of a new carbon-carbon bond $\mathbf{1 5 8}$ by a formal insertion of a carbene into a carbon-hydrogen bond (Scheme 29, middle). Simultaneously, the metal center is released and reused in the catalytic cycle by the in situ reaction of the metal complex 154 with an diazo compound 159 (Scheme 29, bottom). ${ }^{96-97}$

Scheme 29: $\mathrm{C}-\mathrm{H}$ activation: C-M bond formation (top), carbene insertion (middle), in situ formation of metallo-carbene intermediate (bottom). ${ }^{95}$

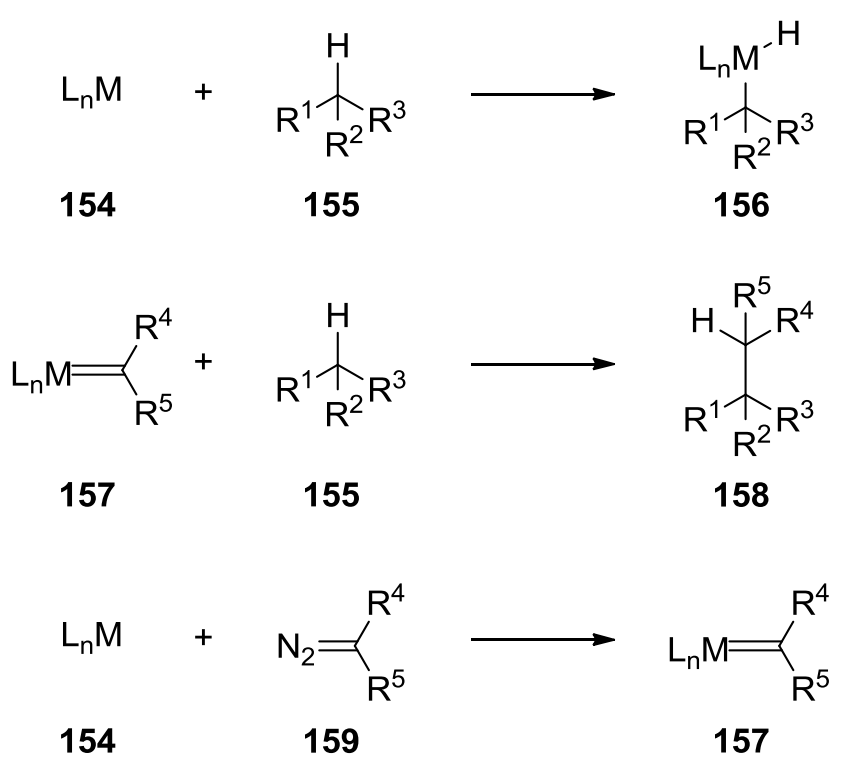

This alternative route via the transient metal-carbene was first reported by Scott et al. using inorganic copper sulfate and chloride as catalyst for the insertion of an ethyl diazo glycine (91) derived carbene into a $\mathrm{C}-\mathrm{H}$ bond of cyclohexane. ${ }^{98}$ The employment of $\mathrm{Cu}(\mathrm{acac})_{2}$, as published by Wulfmann et al. in 1976, gave similar results. ${ }^{99}$ Besides copper also rhodium complexes, like $\mathrm{Rh}_{2}(\mathrm{TFA})_{4}$, were employed. Focusing on Rh containing catalysts, Teyssié, Noels and co-workers reported several articles, which showed superior yields compared to the copper catalyzed reaction mentioned before. ${ }^{100-104}$ Therefore, many related rhodium catalysts were applied within the following years, which might be considered as interesting from the mechanistic point of view, but with limited value for synthetic chemistry, at least at that time. ${ }^{105}$

The second reason why $\mathrm{C}-\mathrm{H}$ insertion chemistry had a rather small impact in recent years is regioselectivity. While established methods rely on selectivity control by 
steric and electronic means, the biggest challenge within $\mathrm{C}-\mathrm{H}$ insertions is to reach comparable level of selectivity as in functional-group based chemistry. This is especially true, because there are typically more than one $\mathrm{C}-\mathrm{H}$ bond in a common organic substrate molecule. Additionally, the required energy for $\mathrm{C}-\mathrm{H}$ bond cleavage is quite high. Studies showed that the $\mathrm{C}-\mathrm{H}$ bond energy values are as follows: ${ }^{106}$

$\begin{array}{ccccc}\text { carbon center: } & \mathrm{CH}_{4} & \text { primary } & \text { secondary } & \text { tertiary } \\ \mathrm{C}-\mathrm{H} \text { bond energy }[\mathrm{kcal} / \mathrm{mol}]: & 105 & 101 & 99 & 97\end{array}$

For this reason, reactive reagents like the applied metal carbenes, generated by the decomposition of diazo compounds under nitrogen evolution by transition metals, are required. It is assumed that the newly formed carbon-carbon bond is generated by the interaction of the empty p-orbital of the metal-carbene complex and the filled $\sigma$-molecule orbital of the $\mathrm{C}$-H bond (Scheme 30 ).

Scheme 30: Interaction of metal-carbene complex with a C-H bond.

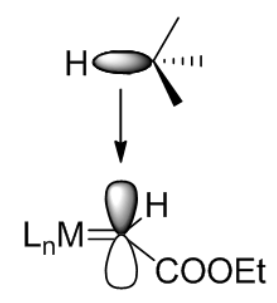

The first transition metal carbene was reported by Greuter et al. in 1958 utilizing copper oxide. ${ }^{107}$ Although the origins of transition metal catalyzed $\mathrm{C}-\mathrm{H}$ insertion chemistry started with the employment of copper, ${ }^{108}$ nowadays dirhodium complexes are the most utilized catalysts. This originates from the increased conversion attained by dirhodium complexes at mild reaction conditions compared to the copper counterparts. ${ }^{109}$

Within the last years, there were a few reports on $\mathrm{C}-\mathrm{H}$ insertions, dealing with furans or acetals as substrates, which are of great interest for the key step in the synthesis of (-)-Paeonilide (5), since it was necessary to find a C-H insertion reaction which can be applied to the acetal-like position in 153 (Scheme 28).

In 2007, Mayoral and Fraile reported an enantioselective $\mathrm{C}-\mathrm{H}$ insertion of methyl phenyldiazoacetate (161) in 2-position of THF (160) catalyzed by bis(oxazoline) ligand 163 immobilized on laponite clay (Scheme 31). ${ }^{110}$ It is worth to mention, that 
the immobilized ligand was superior to the homogeneous counterpart, both, in terms of enantiomeric excess and diastereoselectivity. Due to the fact, that THF was used as solvent and as substrate, this methodology is not suitable for natural product synthesis and therefore it needs to be adjusted.

Scheme 31: Copper catalyzed $\mathrm{C}-\mathrm{H}$ insertion using an immobilized bis(oxazoline) ligand 163 by Fraile and Mayoral. ${ }^{110}$
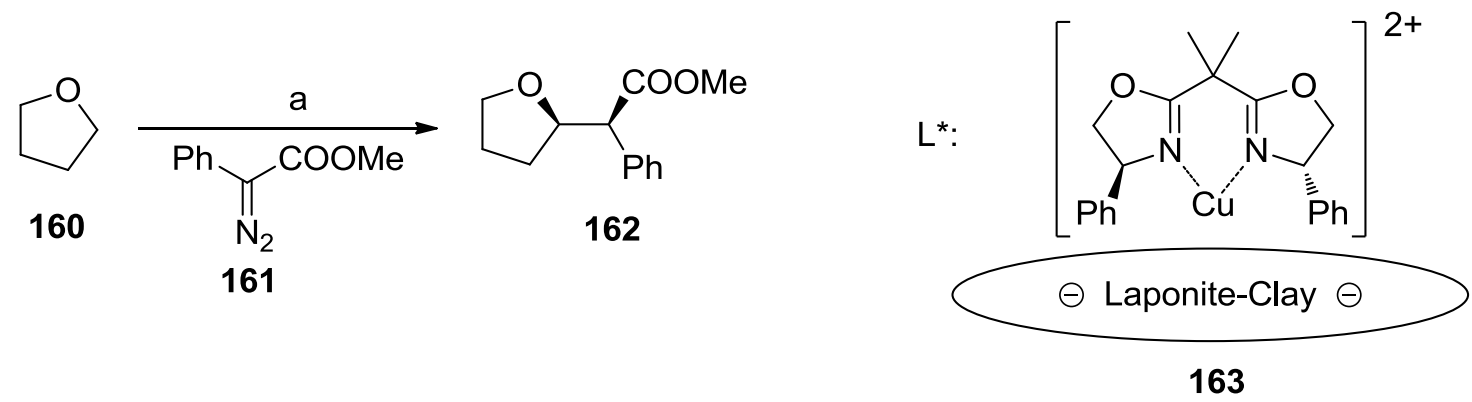

Reagents and conditions: a) THF excess, L* (2 mol\%), diazo compound 161 (1 eq), reflux, 2 h,66\% based on 161, up to $88 \%$ ee (dr $75: 25)$.

The same reaction as described in Scheme 31 was also reported by Davies et al. using optimized conditions and a $\mathrm{Rh}_{2}(\mathrm{~S} \text {-DOSP })_{4}$ ligand, which provided the product 162 in $67 \%$ yield and $97 \%$ ee $(d r 2: 1) .{ }^{111}$

A second study came from Pérez et al. in 2002, utilizing a different class of ligand, employed on a broader substrate scope, albeit in racemic rections. ${ }^{112}$ The substrate scope could be even extended according to a related publication in $2003 .{ }^{95}$ They applied a homoscorpionate-copper(I) catalyst (164) to the successful functionalization of (mostly cyclic) aliphatic ethers and also of acetals by ethyl diazo glycine (91) (Table 6). In all cases, only the carbon center adjacent to the oxygen was functionalized, which is in agreement with the results of Adams et al., who reported the same observation using a rhodium catalyst more than ten years ago. ${ }^{113}$ The high reactivity of these $\alpha$-carbons is expounded by its bond energy, since methanol, bearing a comparable electronic environment, exhibits a value of $96 \mathrm{kcal} / \mathrm{mol}$ for the $\mathrm{H}-\mathrm{CH}_{2} \mathrm{OH}$ bond, which is very close to the energy of the reactive tertiary, aliphatic $\mathrm{C}-\mathrm{H}$ bonds $(97 \mathrm{kcal} / \mathrm{mol}){ }^{106}$ The inert behavior of the $\beta$-carbon center can be explained by the contribution of Nakatani, who showed the deactivation of the $\mathrm{C}-\mathrm{H}$ bond in $\beta$-position to a electron-withdrawing group. ${ }^{114}$ This fact might give an 
explanation for the comparable low yield of the conversion of dioxane (Table 6, entry 6), since in this molecule each carbon center is in the activated $\alpha$-position as well as the deactivated $\beta$-position.

Table 6: Functionalization of ethers and acetals by using a homoscorpionatecopper(I) catalyst 164.

\begin{tabular}{|c|c|c|c|}
\hline Entry & Substrate & Product & Yield [\%] ${ }^{[\mathrm{a}]}$ \\
\hline $1^{[b]}$ & & & $>99$ \\
\hline & & & 38 \\
\hline $3^{[b]}$ & & & 41 \\
\hline $4^{[\mathrm{b}]}$ & & & no reaction \\
\hline $5^{[c]}$ & & & 84 \\
\hline $6^{[c]}$ & & & 20 \\
\hline $7^{[b]}$ & & & $>99$ \\
\hline $8^{[b]}$ & & & $>99$ \\
\hline
\end{tabular}

[a]: Determined at the end of the reaction by GC after total consumption of $\mathrm{N}_{2} \mathrm{CHCOOEt}$. Diethyl fumarate and maleate accounted for $100 \%$ of $\mathrm{N}_{2} \mathrm{CHCOOEt}[\mathrm{b}]$ : Ref ${ }^{95}$; [c]: Ref ${ }^{12}$; [d]: Third pyrazole ring indicated by $\mathrm{N}-\mathrm{N}$ for better lucidity.

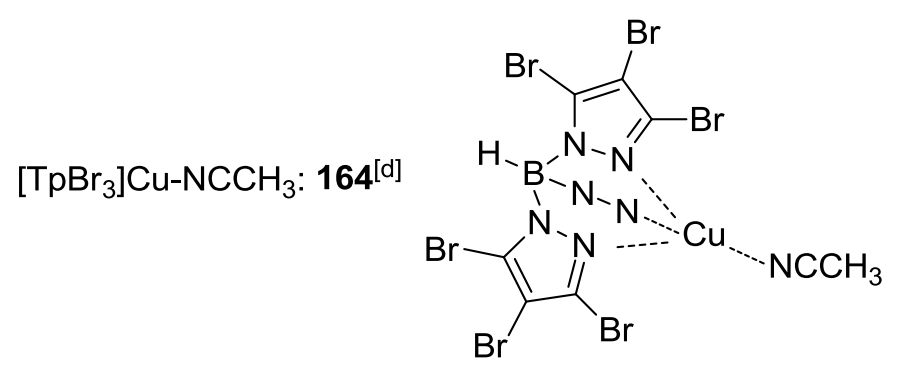




\subsection{Preparatory work for the $\mathrm{C}-\mathrm{H}$ insertion reaction}

In order to find a model system for the $\mathrm{C}-\mathrm{H}$ insertion an unsubstituted furo-lactone system was chosen, bearing the same acetal-like position as compound 153, but being easily producible, even on gram scale. ${ }^{115}$ The first step involved the formation of tin ester 166 by the neat reaction of hexabutyldistannoxane (165) with iodoacetic acid. The subsequent radical reaction with 2,3-dihydrofuran gave the desired, unsubstituted furo-lactone 167. As $\mathrm{C}-\mathrm{H}$ insertion reactions in the acetal-like $\mathrm{C}-\mathrm{H}$ of furo-lactones have not been published so far, a second model compound was prepared, exhibiting a "real" acetal $\mathrm{C}-\mathrm{H}$ position. This was accomplished by the aforementioned method already employed for the two-step lactonization (Scheme 24) using benzyl alcohol under strongly acidic conditions to furnish 168 as a diastereomeric mixture.

Scheme 32: Synthesis of model substrates.

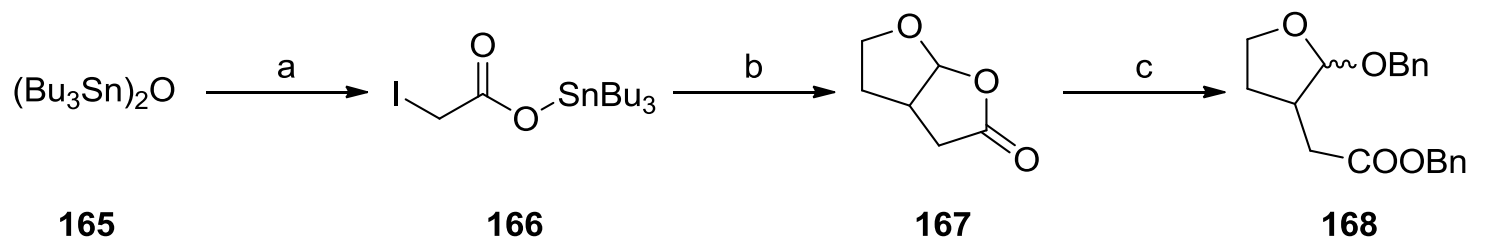

Reagents and conditions: a) $\mathrm{ICH}_{2} \mathrm{COOH}$ (2 eq), $130{ }^{\circ} \mathrm{C}, 30$ min, quant; b) 2,3-dihydrofuran (3 eq), AIBN (5 mol\%), benzene, reflux, 8 h, $68 \%$; c) $\mathrm{H}_{2} \mathrm{SO}_{4}$ (3 eq), $\mathrm{BnOH}$, r.t., $12 \mathrm{~h}, 86 \%$.

Besides the model substrates, also the homoscorpionate-copper(I) catalyst 164 was prepared as acetonitrile complex. According to literature procedures, ${ }^{116}$ commercially available $1 \mathrm{H}$-pyrazole (169) was converted to perbromo pyrazole 170 , which was subsequently treated with a shortfall of $\mathrm{NaBH}_{4}$ at $260{ }^{\circ} \mathrm{C}$ by the help of a metal bath (Wood's metal). ${ }^{117}$ Remaining 170 was removed by multiple sublimation from the caramel-like sodium boropyrazole $\left(\mathbf{1 7 1},\left[\mathrm{TpBr}_{3}\right] \mathrm{Na}\right)$. In order to exchange the sodium cation by $\mathrm{Cu}(\mathrm{I})$ yielding the catalytically active catalyst, 171 was stirred with $\mathrm{Cul}$ in degassed solvents. ${ }^{118}$ The final complex $\left[\mathrm{TpBr}_{3}\right] \mathrm{Cu}-\mathrm{NCCH}_{3}(\mathbf{1 6 4})$, is very sensitive to moisture and oxygen, but can be stored under inert atmosphere at ambient temperature. 
Scheme 33: Synthesis of homoscorpionate $\left[\mathrm{TpBr}_{3}\right] \mathrm{Cu}-\mathrm{NCCH}_{3}(\mathbf{1 6 4})$.

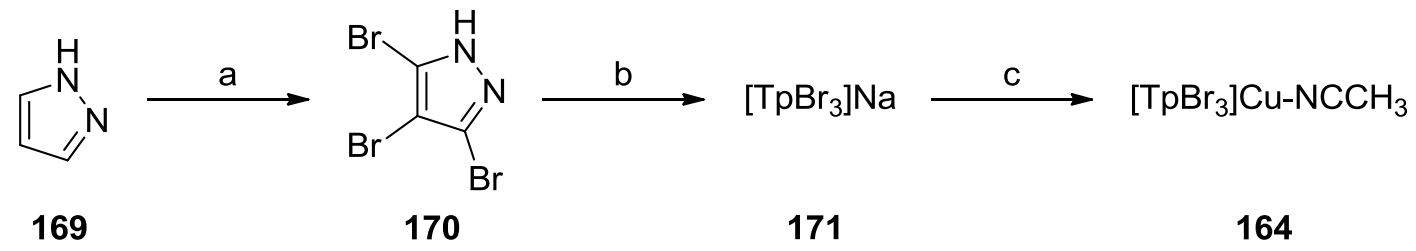

Reagents and conditions: a) $\mathrm{NaOH}$ (4 eq), $\mathrm{Br}_{2}$ (3 eq), $\mathrm{H}_{2} \mathrm{O}$, r.t., 4 h, $76 \%$; b) $\mathrm{NaBH}_{4}(0.25$ eq), $260{ }^{\circ} \mathrm{C}, 82 \%$; c) Cul (1 eq), MeCN (degassed), r.t., 10 h, $75 \%$.

Although the $\mathrm{C}-\mathrm{H}$ bond of substrate 167 , which is the target of the planned functionalization, is an acetal-like moiety, there might arise several problems. Due to the fact that it is not a "real" acetal, since one of the oxygen atoms belongs to the lactone moiety, the electronic properties of this carbon center are different. There is so far no literature precedence for this kind of conversion, employing such an acetallike position for $\mathrm{C}-\mathrm{H}$ insertion chemistry. Therefore, various metal salts were tested in the decomposition of diazo compounds, being the key step in the subsequent reactivity studies (Figure 16 and Table 7). For this reason each salt was treated with ethyl diazo glycine (91) and screened for the evolution of nitrogen gas. As a benchmark, established catalysts for this reaction, such as $\mathrm{Sc}(\mathrm{OTf})_{3}, \mathrm{Cu}(\mathrm{OTf})_{2}$, and $\mathrm{Rh}_{2}(\mathrm{OAc})_{4}$ were tested. It is worth mentioning, that $\mathrm{FeCl}_{3}$ and $\mathrm{SbCl}_{5}$ showed the most violent nitrogen gas evolution among the tested metal salts.

Besides transition metal salts, a handful of lanthanoide salts were also tested since they might have been interesting, due to their high oxophilic properties and large ionic radii, which would make them suitable for coordinating the oxygen atoms of the constrained substrates 167 (Scheme 28). ${ }^{119}$ However, from the tested lanthanoide salts, only $\mathrm{Gd}(\mathrm{OTf})_{3}$ catalyzed the decomposition of the diazo compound. 


\begin{tabular}{|c|c|c|c|c|c|c|c|c|c|c|c|c|c|c|c|c|c|}
\hline $\mathrm{H}$ & & & & & & & & & & & & \multirow[b]{2}{*}{ B } & \multirow[b]{2}{*}{ C } & \multirow[b]{2}{*}{$\mathrm{N}$} & \multirow[b]{2}{*}{0} & \multirow[b]{2}{*}{$\mathrm{F}$} & \multirow{2}{*}{$\frac{\mathrm{He}}{\mathrm{Ne}}$} \\
\hline $\mathrm{Li}$ & $\mathrm{Be}$ & & & & & & & & & & & & & & & & \\
\hline $\mathrm{Na}$ & $\mathrm{Mg}$ & & & & & & & & & & & Al & $\mathrm{Si}$ & $P$ & $S$ & $\mathrm{Cl}$ & $\mathrm{Ar}$ \\
\hline $\mathrm{K}$ & $\mathrm{Ca}$ & Sc & $\mathrm{Ti}$ & & $\mathrm{Cr}$ & $\mathrm{Mn}$ & $F$ & & $\mathrm{Ni}$ & $\mathrm{Cu}$ & $\mathrm{Zn}$ & $\mathrm{Ga}$ & $\mathrm{Ge}$ & As & $\mathrm{Se}$ & $\mathrm{Br}$ & $\mathrm{Kr}$ \\
\hline $\mathrm{Rb}$ & $\mathrm{Sr}$ & $Y$ & $\mathrm{Zr}$ & & Mo & Tc & $R$ & & $\mathrm{Pd}$ & $\mathrm{Ag}$ & $\mathrm{Co}$ & In & Sn & $\mathrm{Sb}$ & $\mathrm{Te}$ & 1 & $\mathrm{Xe}$ \\
\hline Cs & $\mathrm{Ba}$ & * & $\mathrm{Hf}$ & & W & $\operatorname{Re}$ & 0 & & $\mathrm{Pt}$ & $\mathrm{Au}$ & $\mathrm{Hg}$ & $\mathrm{TI}$ & $\mathrm{Pb}$ & $\mathrm{Bi}$ & Po & At & $\mathrm{Rn}$ \\
\hline $\mathrm{Fr}$ & $\mathrm{Ra}$ & ** & $\mathrm{Rf}$ & & $\mathrm{Sg}$ & $\mathrm{Bh}$ & $\mathrm{H}$ & & Ds & $\mathrm{Rg}$ & $\mathrm{Cr}$ & & & & & & \\
\hline & & * & Le & & $\operatorname{Pr}$ & $\mathrm{Nd}$ & $P$ & & Eu & $\mathrm{Gd}$ & $\mathrm{Tb}$ & Dy & Ho & $\mathrm{Er}$ & $\mathrm{Tm}$ & $\mathrm{Yb}$ & Lu \\
\hline & & ** & $A c$ & & $\mathrm{~Pa}$ & U & $\mathrm{N}$ & & Am & $\mathrm{Cm}$ & Bk & $\mathrm{Cf}$ & Es & $\mathrm{Fm}$ & $\mathrm{Md}$ & No & $\mathrm{Lr}$ \\
\hline
\end{tabular}

Figure 16: Periodic table of elements, salts of marked elements were employed for diazo compound decomposition screening.

Table 7: Screened metal salts.

\begin{tabular}{|c|c|c|c|c|}
\hline \multicolumn{2}{|c|}{ no $\mathrm{N}_{2}$ gas evolution observed } & \multicolumn{3}{|c|}{$\mathrm{N}_{2}$ gas evolution observed } \\
\hline $\mathrm{LiBF}_{4}$ & $\mathrm{NaBF}_{4}$ & $\mathrm{NaSbF}_{6}$ & $\mathrm{MgBr}_{2} \cdot \mathrm{OEt}_{2}$ & $\mathrm{Sc}(\mathrm{OTf})_{3}$ \\
\hline $\mathrm{K}_{2} \mathrm{PtCl}_{4}$ & $\mathrm{CaCl}_{2}$ & $\mathrm{Cp}_{2} \mathrm{TiCl}_{2}$ & $\mathrm{CrCl}_{2}$ & $\mathrm{MnCl}_{2}$ \\
\hline $\mathrm{Ca}(\mathrm{O} / \mathrm{Pr})_{2}$ & $\mathrm{CrCl}_{3}$ & $\mathrm{FeCl}_{3}$ & $\left(\mathrm{NH}_{4}\right)_{2} \mathrm{Fe}\left(\mathrm{SO}_{4}\right)_{2}$ & $\mathrm{Fe}\left(\mathrm{BF}_{4}\right)_{2}$ \\
\hline $\mathrm{Fe}(\mathrm{OAc})_{2}$ & $\mathrm{NH}_{4} \mathrm{Fe}(\text { citrate })_{2}$ & $\mathrm{Fe}(\mathrm{acac})_{3}$ & $\mathrm{Ni}(\mathrm{acac})_{2}$ & $\mathrm{Cu}(\mathrm{OTf})_{2}$ \\
\hline $\mathrm{Co}(\mathrm{OAc})_{2}$ & $\mathrm{NiCl}_{2}$ & Cul & $\mathrm{Cu}(\mathrm{MeCN})_{4} \mathrm{BF}_{4}$ & $\mathrm{ZnBr}_{2}$ \\
\hline $\mathrm{NbCl}_{5}$ & $\left(\mathrm{NH}_{4}\right)_{6}\left(\mathrm{Mo}_{7} \mathrm{O}_{24}\right)$ & $\mathrm{YCl}_{3}$ & $\mathrm{RuCl}_{3}$ & $\mathrm{Rh}_{2}(\mathrm{OAc})_{4}$ \\
\hline $\mathrm{Sb}_{2} \mathrm{~S}_{3}$ & $\mathrm{LaCl}_{3}$ & $\mathrm{PdBr}_{2}$ & $\mathrm{AgClO}_{4}$ & $\mathrm{SbCl}_{5}$ \\
\hline $\mathrm{CeCl}_{3}$ & $\mathrm{Eu}\left(\mathrm{NO}_{3}\right)_{3}$ & $\mathrm{TaCl}_{5}$ & $\mathrm{IrCl}_{3}$ & $\mathrm{Gd}(\mathrm{OTf})_{3}$ \\
\hline $\mathrm{EuCl}_{3}$ & & & & \\
\hline
\end{tabular}




\subsection{C-H insertion experiments}

The first screening with the evaluated metal salts was performed by employing $10 \mathrm{~mol} \%$ of catalyst and 2 equivalents of ethyl diazo glycine (91) in dichloromethane at ambient temperatures as a standard procedure for the furo-lactone substrate (Table 8). According to TLC control, in most cases no conversion of the starting material could be observed, only the dimerization of $\mathbf{9 1}$ to diethyl maleate and diethyl fumarate was found. The two very strong Lewis acids $\mathrm{FeCl}_{3}$ and $\mathrm{SbCl}_{5}$ showed lactone opening reactions, very rapidly in the latter case. The only catalyst, which was somewhat active, was $\mathrm{Fe}\left(\mathrm{BF}_{4}\right)_{2} \cdot 6 \mathrm{H}_{2} \mathrm{O}$. However, this reaction proceeded not in a clean way.

Table 8: First reaction screening.

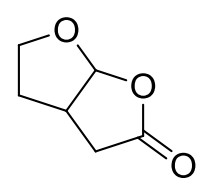

167

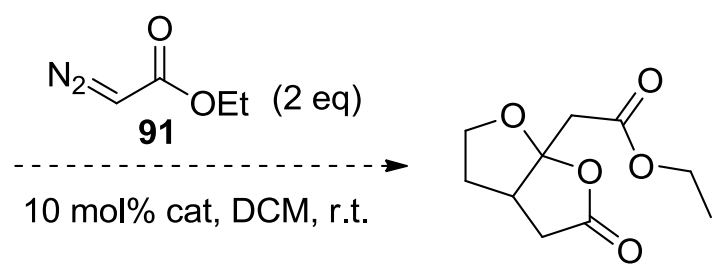

172

\begin{tabular}{ccc}
\hline Entry & Catalyst & Observations \\
\hline 1 & $\mathrm{FeCl}_{3}$ & lactone opening \\
2 & $\mathrm{Fe}\left(\mathrm{BF}_{4}\right)_{2} \cdot 6 \mathrm{H}_{2} \mathrm{O}$ & slow conversion, complex mixture \\
3 & $\mathrm{Cu}(\mathrm{OTf})_{2}$ & no reaction \\
4 & $\mathrm{MgBr}_{2} \cdot \mathrm{OEt}_{2}$ & no reaction \\
5 & $\mathrm{Sc}(\mathrm{OTf})_{3}$ & no reaction \\
6 & $\mathrm{ZnBr}_{2}$ & no reaction \\
7 & $\mathrm{Cp}_{2} \mathrm{TiCl}_{2}$ & no reaction \\
8 & $\mathrm{PdBr}_{2}$ & no reaction \\
9 & $\mathrm{TaCl}_{5}$ & no reaction \\
10 & $\mathrm{AgOCl}_{4}$ & no reaction \\
11 & $\mathrm{SbCl}_{5}$ & rapid lactone opening \\
12 & $\mathrm{Rh}$ & no reaction \\
13 & $\mathrm{Gd}(\mathrm{OAc})_{4}{ }^{[\mathrm{b}]}$ & no reaction \\
\hline
\end{tabular}

[a]: Plenty of dimerization products observed in all cases; [b]: 2 mol\%. 
To optimize this reaction, it was carried out at $0^{\circ} \mathrm{C}$, which was envisaged to lead to the formation of less byproducts.

Scheme 34: Lewis acid catalyzed lactone opening of 167 in the presence of ethyl diazo glycine (91).

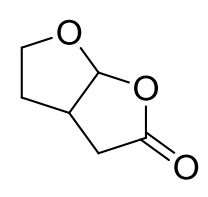

167

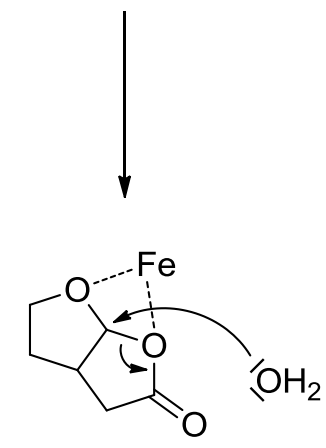

173
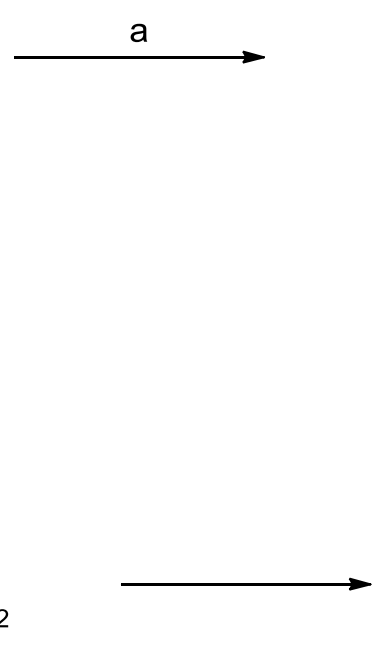

\footnotetext{
-
}
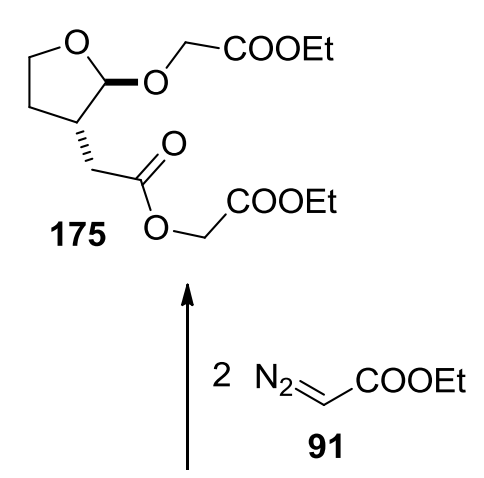

174

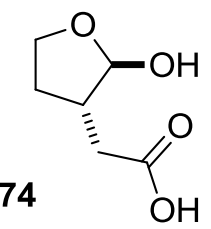

Reagents and Conditions: a) $\mathrm{N}_{2} \mathrm{CHCOOEt}(2 \mathrm{eq}), \mathrm{Fe}\left(\mathrm{BF}_{4}\right)_{2} \cdot 6 \mathrm{H}_{2} \mathrm{O}(10 \mathrm{~mol} \%)$, DCM, r.t., 6 h, $32 \%$ (combined yield).

Although the reaction provided still many byproducts, two diastereomers of a lactone opening product could be isolated from the mixture (Scheme 34). The Lewis acidic iron(II) salt catalyzes the lactone opening by water, which is originating from the catalyst. The new hydroxyl group and the free carboxylic acid of $\mathbf{1 7 4}$ react with $\mathbf{9 1}$ to the corresponding esterified acetal $\mathbf{1 7 5}$, which was formed as a 1:1 mixture of diastereomers, possessing the two substituents in anti conformation to each other. As the iron catalyst showed some activity it was also tested on the second model compound 168 (Scheme 35). This reaction was carried out at ambient temperatures and at $0{ }^{\circ} \mathrm{C}$, but in both cases TLC control showed massive byproduct formation and an incomplete conversion of the starting material 168. The ${ }^{13} \mathrm{C}-\mathrm{NMR}$ of the crude reaction mixture showed no indication for the presence of desired product, which was expected to give a signal at about $110 \mathrm{ppm}$ for the newly formed quaternary acetal carbon center. Besides the iron catalyst, dirhodium was also tested, since rhodium complexes are the most used catalysts for $\mathrm{C}-\mathrm{H}$ insertion reactions (see chapter 4.1). 
Therefore, rhodium(II) acetate dimer was employed in the following reactions (Scheme 35).

Scheme 35: Insertion test reaction.

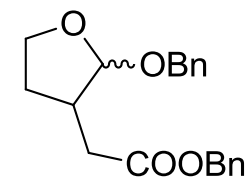

168<smiles>O=C1CC2CCOC2O1</smiles>

167<smiles>O=C(CC1CCO[C@@H]1Oc1ccccc1)Oc1ccccc1</smiles>

168<smiles>O=C(CC1CCOC1Oc1ccccc1)Oc1ccccc1</smiles>

168

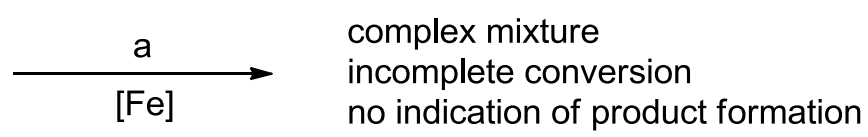

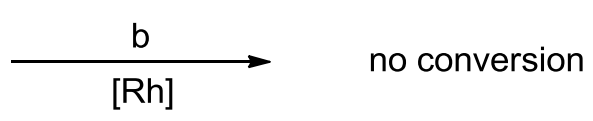

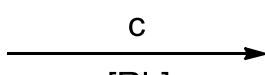

[Rh]

complexe mixture incomplete conversion crude NMR: aldehyde, 1x COOEt, 1x OBn

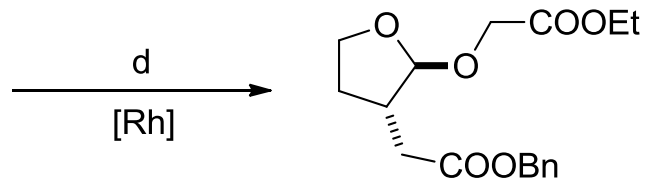

anti-176<smiles>CCOC(=O)CO[C@H]1OCC[C@H]1CC(=O)OCc1ccccc1</smiles>

syn-176

Reagents and conditions: a) $\mathrm{N}_{2} \mathrm{CHCOOEt}(2 \mathrm{eq}), \mathrm{Fe}\left(\mathrm{BF}_{4}\right)_{2}{ }^{\circ} 6 \mathrm{H}_{2} \mathrm{O}(10 \mathrm{~mol} \%)$, DCM, r.t. and $0^{\circ} \mathrm{C}, 6 \mathrm{~h}$; b) $\mathrm{N}_{2} \mathrm{CHCOOEt}(2 \mathrm{eq}), \mathrm{Rh}_{2}(\mathrm{OAc})_{4}\left(2 \mathrm{~mol} \%\right.$ ), DCM, r.t. 6 h; c) $\mathrm{N}_{2} \mathrm{CHCOOEt}(2 \mathrm{eq}), \mathrm{Rh}_{2}(\mathrm{OAc})_{4}$ (2 mol\%), DCM, r.t., ${ }^{\circ} \mathrm{C}, 6 \mathrm{~h}$; d) $\mathrm{N}_{2} \mathrm{CHCOOEt}$ (2 eq), $\mathrm{Rh}_{2}(\mathrm{OAc})_{4}(2 \mathrm{~mol} \%), \mathrm{DCM}, 0{ }^{\circ} \mathrm{C}, 6 \mathrm{~h}$, anti-176/syn-176 = 1:1, 38\% (combined yield).

The expected conversion of furo-lactone $\mathbf{1 6 7}$ did not proceed at all, except for the dimerization of ethyl diazo glycine (91). Using acetal-substrate 168 at room temperature, many spots occurred on TLC, although the starting material was not converted completely. The analysis of the crude NMRs showed that the main compound possesses an aldehyde, one ethyl ester and one benzyl group, but it could not be isolated from the other compounds. The same reaction at $0{ }^{\circ} \mathrm{C}$ gave less spots on TLC and a diastereomeric compound mixture could be isolated by column chromatography. It turned out, that the benzyl ether was cleaved within the reaction, followed by ether formation by the reaction with the diazo ester 91 yielding 176 as a $1: 1$ mixture of diastereomers. 
The literature known reaction conditions were screened as well. The reactions, utilizing the homoscorpionate-copper(I) complex 164 (Table 6), were performed in degassed dichloromethane, due to the instability of 164 against oxygen. ${ }^{95}$ The reaction with furo-lactone $\mathbf{1 6 7}$ afforded only the dimerization products of the diazo ester 91 , as mentioned before in the dirhodium catalyzed reaction. When using the acetal substrate 168 a new compound was furnished and separated form few other byproducts. It turned out, that also in this case no desired acetal-insertion occurred. The insertion took place on the $\alpha$-position of the benzyl ester, which seems to be the most active site in this molecule. According to literature, the acetal-position of $\mathbf{1 6 8}$ and the acetal-like position of $\mathbf{1 6 7}$ should be privileged for $\mathrm{C}-\mathrm{H}$ insertion reactions, as they are tertiary centers with comparable low $\mathrm{C}-\mathrm{H}$ bond energy $(97 \mathrm{kcal} / \mathrm{mol}$, see chapter 4.1). ${ }^{106}$ Additionally, they are in $\alpha$-position to the oxygen atoms, electron withdrawing groups, which should activate these $\mathrm{C}-\mathrm{H}$ bonds even more. ${ }^{106}$ Nonetheless, the most active site bears 168 on the $\alpha$-carbon of the benzyl ester, being the only site where an insertion reaction took place providing 177 as a diastereomeric mixture. In contrast, the $\alpha$-position of the lactone moiety of 167 was absolutely inactive.

Scheme 36: Insertion attempts by employing homoscorpionate-copper(I) complex $164 .^{95}$

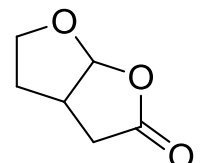

167<smiles>O=C(CC1CCOC1Oc1ccccc1)Oc1ccccc1</smiles>

168
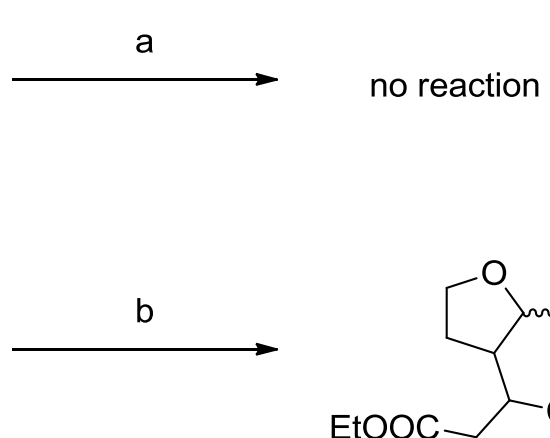

EtOOC

177

Reagents and conditions: a) $\mathrm{N}_{2} \mathrm{CHCOOEt}$ (2 eq), $\left[\mathrm{TpBr}_{3}\right] \mathrm{Cu}-\mathrm{NCCH}_{3}$ (164) (5 mol\%), DCM (degassed), r.t., $6 \mathrm{~h}$; b) $\mathrm{N}_{2} \mathrm{CHCOOEt}(2 \mathrm{eq})$, [ $\left.\mathrm{TpBr}_{3}\right] \mathrm{Cu}-\mathrm{NCCH}_{3}(\mathbf{1 6 4})(5 \mathrm{~mol} \%)$, DCM (degassed) r.t., $6 \mathrm{~h}, 27 \%$.

Finally, the $\mathrm{C}-\mathrm{H}$ insertion conditions of Mayoral were applied to both test substrates. As in the original conditions THF was utilized as substrate and as solvent, the conditions needed to be adjusted for natural product synthesis. For this reason the 
substrate was dissolved together with the catalyst in a small amount of dichloromethane, refluxed and dropwise treated with diazo ester 91. As Mayoral et al. mentioned in their publication, even $\mathrm{Cu}(\mathrm{OTf})_{2}$ itself was catalytically active in this insertion reaction, therefore both, the $\mathrm{Cu}(\mathrm{OTf})_{2}$ alone and the corresponding aza-bis(oxazoline)-complex were tested (Table 9). All experiments provided exclusively the dimerization products of the diazo compound 91 but no conversion of the starting material could be observed. As this might have been a result of the maximal applicable reaction temperature, dichloromethane was exchanged by chloroform, exhibiting almost the same boiling point as THF (Table 9, entry 3 and 6). However, the higher temperature provided again no conversion of the starting material.

Table 9: $\mathrm{C}-\mathrm{H}$ insertion screening applying $\mathrm{Cu}(\mathrm{OTf})_{2} \cdot{ }^{110}$<smiles>O=C1CC2CCOC2O1</smiles>

167<smiles>O=C(CC1CCO[C@@H]1OCc1ccccc1)OCc1ccccc1</smiles>

168

\begin{tabular}{cccc}
\hline Entry & Substrate & Reagents and conditions ${ }^{[a]}$ & Observation $^{[\mathrm{b}]}$ \\
\hline 1 & 167 & $\mathrm{Cu}(\mathrm{OTf})_{2}, \mathrm{DCM}$, reflux & no reaction \\
2 & 167 & $\mathrm{Cu}(\mathrm{OTf})_{2}, \mathrm{~L}^{*}, \mathrm{DCM}$, reflux & no reaction \\
3 & 167 & $\mathrm{Cu}(\mathrm{OTf})_{2}, \mathrm{~L}^{*}, \mathrm{CHCl}_{3}$, reflux & no reaction \\
4 & 168 & $\mathrm{Cu}(\mathrm{OTf})_{2}, \mathrm{DCM}$, reflux & no reaction \\
5 & 168 & $\mathrm{Cu}(\mathrm{OTf})_{2}, \mathrm{~L}^{*}, \mathrm{DCM}$, reflux & no reaction \\
6 & 168 & $\mathrm{Cu}(\mathrm{OTf})_{2}, \mathrm{~L}^{*}, \mathrm{CHCl}_{3}$, reflux & no reaction
\end{tabular}

[a]: All reactions carried out with $4 \mathrm{~mol} \%$ of $\mathrm{Cu}(\mathrm{OTf})_{2}, 4.4 \mathrm{~mol} \%$ of ligand $\mathrm{L}^{*} \mathbf{1 7 8}$ (if mentioned), and 2 eq of $\mathrm{N}_{2} \mathrm{CHCOOEt}$; [b]: formation of diazo ester dimerization products in all reactions.<smiles>CC(C)C1COC(N(C)C2=NC(C(C)C)CO2)=N1</smiles> 


\section{Side chain introduction by established chemistry}

As the $\mathrm{C}-\mathrm{H}$ activation turned out to give not the desired results for the side chain introduction, the attempts concerning this approach were ceased. The focus was put on the utilization of "traditional" chemistry for the transformation of furo-lactone $\mathbf{5 7}$ into an intermediate that gives rise to the acetal-functionalized skeleton $\mathbf{1 7 9}$ (Scheme 37).

Scheme 37: Functionalization via an intermediate.<smiles>O=C1CC2COC(OC2)[C@H]1O</smiles>

57

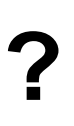

$+\cdots$

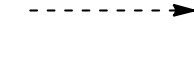

Matsuda et al. reported in 2008 within their synthesis of a partially benzylated derivative of the anhydro-D-altro-heptulose the functionalization of $\delta$-lactone using Grignard-reagents attacking the lactone carbonyl center (Scheme 38). ${ }^{120}$

Scheme 38: Conversion of a hydrocarbon lactone derivative with allyl-MgBr.

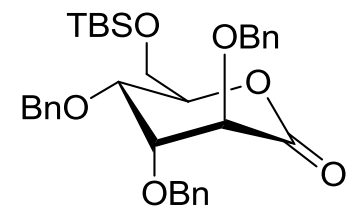

180

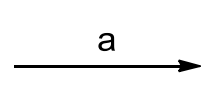

OBn

181

Reagents and conditions: a) allyl-MgBr (1.2 eq), THF, $-78^{\circ} \mathrm{C}, 1.5 \mathrm{~h}, 92 \%$.

According to this consideration, an acidic lactone opening under oxidative conditions should force the formation of a $\alpha, \beta$-substituted $\gamma$-lactone as synthon for 179 . To reach this intermediate, the model substrate 167 , already applied for the $\mathrm{C}-\mathrm{H}$ insertion attempts, was treated with $2.5 \mathrm{M}$ Jones-reagent in acetone (Scheme 39). The applied conditions opened the lactone moiety, setting free a hemiacetal which was further on oxidized to the corresponding lactone 183 by $\mathrm{Cr}(\mathrm{VI})$ oxide in excellent yield. 
Scheme 39: Conversion of model substrate 167 to lactone 183 by Jones-reagent.<smiles>O=C1CC2CCOC2O1</smiles>

167

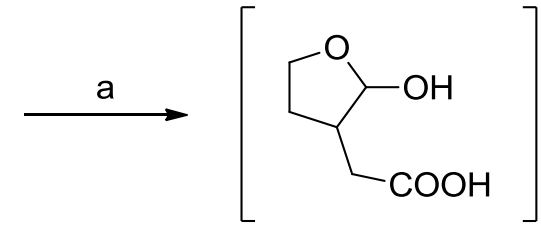

182

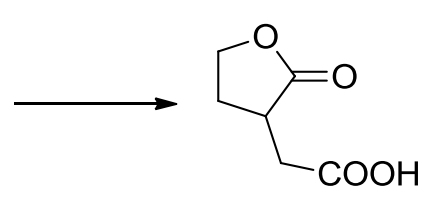

183

Reagents and conditions: a) Jones-reagent ( $3.5 \mathrm{eq})$, acetone, $0^{\circ} \mathrm{C}$ to r.t., $3 \mathrm{~h}, 94 \%$.

This $\alpha$-substituted lactone $\mathbf{1 8 3}$ was subsequently treated with a Grignard-reagent that was envisaged to preferentially attack the lactone carbonyl in presence of the carboxylate. As the free carboxylic acid consumes one equivalent of the Grignard-reagent, at least two equivalents are needed to be employed for the planned conversion. Already the first test reactions provided the desired, functionalized furo-lactone 185 , using 2.5 equivalents of $\mathrm{Me}-\mathrm{MgBr}$ at $-78{ }^{\circ} \mathrm{C}$ (Scheme 40). It should be noted that the final product 185 was formed during the acidic quenching of the residual Grignard-reagent, by the addition of $2 \mathrm{M}$ hydrochloric acid. Since the nucleophilic attack of $\mathrm{Me}-\mathrm{MgBr}$ at the lactone carbonyl center delivers a hemiacetal as intermediate, the proton source is needed to enable the lactone closure.

Scheme 40: Side chain introduction by utilizing the methyl Grignard-reagent.<smiles>O=C(O)CC1CCOC1=O</smiles>

183

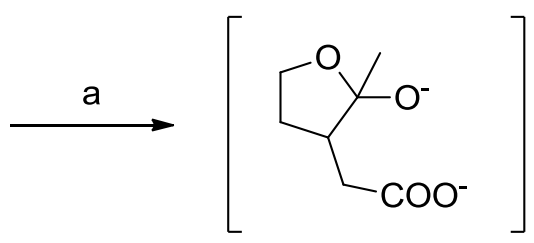

184

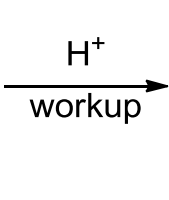

(8)

Reagents and conditions: a) $\mathrm{Me}-\mathrm{MgBr}(2.5 \mathrm{eq}), \mathrm{THF},-78^{\circ} \mathrm{C}$ to $0{ }^{\circ} \mathrm{C}, 2 \mathrm{~h}, 19 \%$.

The isolated product showed the characteristic quaternary carbon peak at $117 \mathrm{ppm}$ in the ${ }^{13} \mathrm{C}-\mathrm{NMR}$. Although the yield was relatively low, this sequence was tested on the actual furo-lactone 57. As described before, it was necessary to open the lactone moiety first under oxidative conditions, which was again accomplished by employing Jones-reagent to lactone $\mathbf{5 7}$, deriving the desired $\alpha, \beta$-substituted $\gamma$-lactone 186 in excellent yield. 
Scheme 41: Oxidative lactone opening.

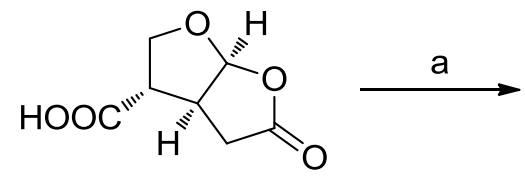

57<smiles>O=C(O)CC1C(=O)OCC1C(=O)O</smiles>

186

Reagents and conditions: a) Jones-reagent $(2.5 \mathrm{eq})$, acetone, $0^{\circ} \mathrm{C}$ to r.t., $6 \mathrm{~h}, 88 \%$.

Having this precursor in hands, it was essential to find an appropriate Grignard-reagent that introduces a side chain being convertible to the final keto-group. For that reason allyl-MgBr was chosen to introduce the allyl side chain which should be oxidizable to the necessary methyl ketone moiety. First attempts were carried out by employing 3.2 equivalents of the reagent, since theoretically 2 equivalents are decomposed by the two free carboxylic acid functions, affording the allylated product 187 in 68\% yield (Table 10). Further tests proved, that 2.5 equivalents are the optimal amount for this conversion giving an enhanced yield of $73 \%$ for 187 .

Table 10: Allyl side chain introduction and reaction optimization.<smiles>C[13CH]C(=O)O</smiles>

186<smiles>C=CC[C@]12OCC(=O)C[C@H]1CC2=O</smiles>

187

Reagents and conditions: a) allyl-MgBr, $\mathrm{THF},-78^{\circ} \mathrm{C}$ to $0^{\circ} \mathrm{C}, 2 \mathrm{~h}$.

\begin{tabular}{ccc}
\hline Entry & Allyl-MgBr (eq) & Yield [\%] \\
\hline 1 & 2 & 53 \\
2 & 2.5 & 73 \\
3 & 3.2 & 68 \\
\hline
\end{tabular}

$$
\mathrm{pK}_{\mathrm{B}}=-42^{[\mathrm{a}]} \quad \mathrm{pK}_{\mathrm{B}}=-30^{[\mathrm{a}]}
$$

[a]: $\mathrm{pK}_{\mathrm{B}}$ values calculated from corresponding $\mathrm{pK}_{\mathrm{A}}$ values of methane and propene in DMSO; Ref ${ }^{121}$ 
The increased yield of the allyl-Grignard reaction (Table 10) compared to the $\mathrm{Me}-\mathrm{MgBr}$ one (Scheme 40) might be ascribed to the stronger basicity of the methyl-anion and therefore the resulting higher reactivity (Table 10, bottom). This fact is in compliance with the TLC monitoring of the reactions: the $\mathrm{Me}-\mathrm{MgBr}$ reaction showed much more byproduct formation than the reaction using allyl-MgBr.

According to literature, there is no precedence of a furo-lactone functionalized on the acetal-like center. To the best of knowledge, this is a new methodology, using well-established chemistry for this kind of side chain introduction. 


\section{Final steps toward (-)-Paeonilide}

The final section of the synthesis of (-)-Paeonilide (5) was envisaged to start with a selective reduction of the carboxylic acid in presence of the lactone moiety and the terminal olefin. For this reason a procedure of Fludzinski et al., ${ }^{122}$ who reported the reduction of a carboxylic acid in the presence of a $\mathrm{C}-\mathrm{C}$ double bond by utilizing a borane-THF complex at low temperatures, was applied. Moreover, this borane-THF complex was already successfully applied on the reduction of the carboxylic acid in the presence of a lactone moiety, as discussed earlier (Scheme 27). Employing Fludzinski's conditions to carboxylic acid 187 afforded besides some byproducts the desired alcohol 188 (Table 11, entry 1). After quenching and aqueous workup the amount of byproducts increased drastically. However, column chromatography yielded only traces of the impure product 188 , which turned out to be not stable under purification conditions. Furthermore, a modified protocol, using lower temperatures, achieved a relatively clean reaction (according to TLC monitoring) (Table 11, entry 2). In order to avoid too long contact time of the product with water during the workup, the reaction was quenched by the addition of slightly wet silica gel. Furthermore, the solvent was removed under reduced pressure to provide directly a dry-load for column chromatography. Nevertheless, only impure traces of the target compound $\mathbf{1 8 8}$ were isolated again.

Table 11: Envisaged reduction by $\mathrm{BH}_{3} \cdot \mathrm{THF}$.

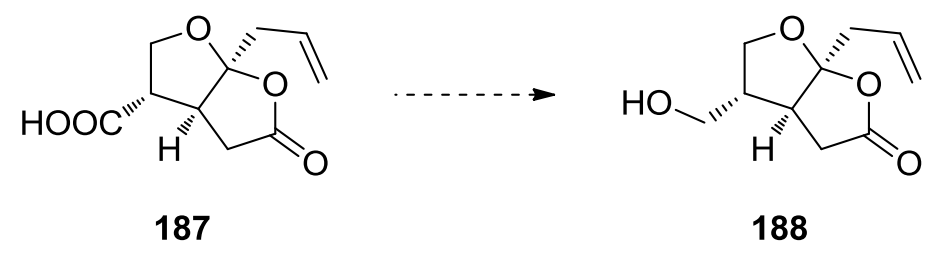

\begin{tabular}{lcc}
\hline Entry & Reagents and conditions & Yield [\%] \\
\hline $1^{[\mathrm{a}]}$ & $\mathrm{BH}_{3} \cdot \mathrm{THF}(1 \mathrm{eq}), \mathrm{THF},-10^{\circ} \mathrm{C}$ to r.t., $6 \mathrm{~h}$ & traces \\
2 & $\mathrm{BH}_{3} \cdot \mathrm{THF}(1 \mathrm{eq}), \mathrm{THF},-30^{\circ} \mathrm{C}$ to r.t., $8 \mathrm{~h}$ & traces \\
$3^{[\mathrm{b}]}$ & $\mathrm{Zn}\left(\mathrm{BH}_{4}\right)_{2}(1 \mathrm{eq}), \mathrm{ClCOOEt}(1$ eq $)$, & traces \\
& $\mathrm{NEt}_{3}(1$ eq $) \mathrm{THF}, 0^{\circ} \mathrm{C}$ to r.t., $1 \mathrm{~h}$ & \\
\end{tabular}

[a]: $\operatorname{Ref}^{122} ;[\mathrm{b}]: \operatorname{Ref}^{123}$. 
A third method was the application of zinc borohydride to accomplish the reaction, which was prepared following a literature protocol. ${ }^{124}$ This reagent was already successfully used for the reduction of a carboxylic acid in the presence of a lactone by Helmchen et al., although the acid group was in situ converted to a mixed anhydride before $\mathrm{Zn}\left(\mathrm{BH}_{4}\right)_{2}$ was added. ${ }^{123}$ Additionally, this borohydride reagent was used by Crimmins et al. for ketone reduction on a molecule bearing a terminal olefin, without harming the latter. ${ }^{125}$ Although the reaction looked promising according to TLC monitoring, 188 proved to be unstable during workup.

Therefore, one additional reaction step was crucial in the sequence toward (-)-Paeonilide (5) (Scheme 42). The allyl chain was planned to be oxidized using Wacker-chemistry, followed by a reduction to the corresponding diol 190. This compound allows two ways to the target molecule 5: either selective oxidation of a secondary alcohol, followed by a benzyl protection, or selective protection of the primary alcohol followed by oxidation of the secondary alcohol.

Scheme 42: Final reaction sequence incorporating diol 190.

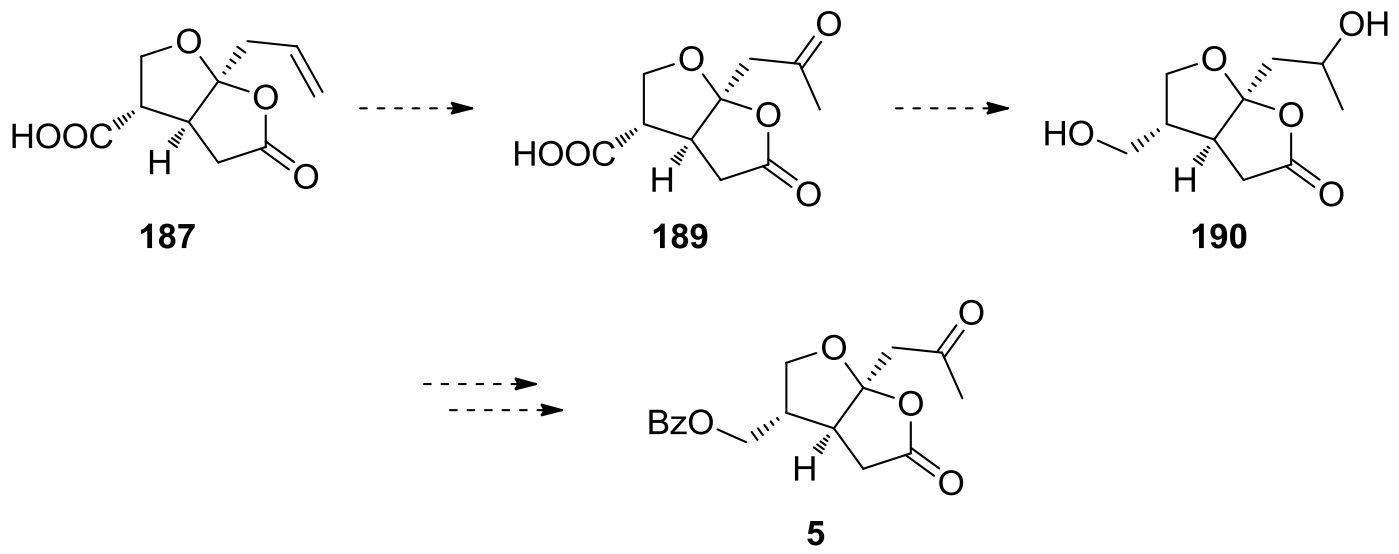

The conversion of the olefin was envisaged to be accomplished by the Wacker-oxidation to give rise to the keto-moiety (Table 12). This reaction is one of the best studied palladium promoted reactions and has important applications in industry ${ }^{126-128}$ as well as in academia. ${ }^{129-130}$

Common Wacker-oxidation protocols apply $\mathrm{PdCl}_{2}$ or $\mathrm{Pd}(\mathrm{OAc})_{2}$ as catalyst together with a stoichiometric co-catalyst (e.g. $\mathrm{CuCl}$ ), under one atmosphere of oxygen gas in a DMF/water- or DMA/water-mixture. 
The first tests were carried out according to these conditions, following a procedure by Lowary et al., who employed the Wacker-oxidation for the total synthesis of Buergerinin $F$ and $G$ (Table 12, entry 1 ). ${ }^{131}$ It turned out, that his protocol afforded only low conversion of the starting material 187, although additional catalyst and co-catalyst were added after five hours. Rising the temperature did not give any advantage either. The isolated product showed impurities of the corresponding aldehyde, which was inseparable from the desired product by column chromatography. This lack of product selectivity was also described by Lowary et al. Additionally, the product mixture contained small amounts of DMA, exhibiting almost the same $R_{\mathrm{f}}$ value like 189 .

Table 12: Olefin oxidation.

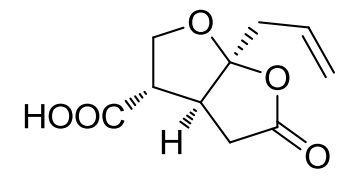

187

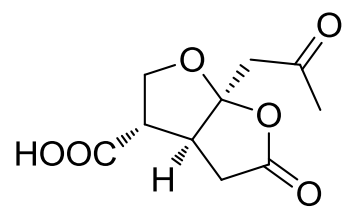

189

\begin{tabular}{|c|c|c|}
\hline Entry & Reagents and conditions $^{[\mathrm{a}]}$ & Yield [\%] \\
\hline $1^{[b]}$ & $\begin{array}{c}\mathrm{PdCl}_{2}(10 \mathrm{~mol} \%), \mathrm{CuCl}(1 \mathrm{eq}) \mathrm{O}_{2}, \mathrm{DMF} / \mathrm{H}_{2} \mathrm{O} 3: 1, \\
\text { r.t. to } 70^{\circ} \mathrm{C}, 10 \mathrm{~h}\end{array}$ & $19 \%{ }^{[\mathrm{c}][\mathrm{d}]}$ \\
\hline $2^{[e]}$ & $\mathrm{PdCl}_{2}(10 \mathrm{~mol} \%), \mathrm{O}_{2}, \mathrm{DMA} / \mathrm{H}_{2} \mathrm{O} 15: 1,70^{\circ} \mathrm{C}, 6 \mathrm{~h}$ & $62 \%{ }^{[\mathrm{d}]}$ \\
\hline $3^{[f]}$ & $\begin{array}{c}\text { Jones-reagent }(2.5 \mathrm{eq}), \mathrm{Hg}(\mathrm{OAc})_{2}(0.25 \mathrm{eq}) \\
\text { acetone } / \mathrm{H}_{2} \mathrm{O} 4: 1,0^{\circ} \mathrm{C} \text { to r.t., } 15 \mathrm{~h}\end{array}$ & $79 \%$ \\
\hline
\end{tabular}

[a]: $\mathrm{O}_{2}$ applied via balloon; [b]: Ref ${ }^{131}$ [c]: mixture of ketone and aldehyde; [d]: containing inseparable solvent residues; [e]: $\operatorname{Ref}^{132}$; [f]: $\operatorname{Ref}^{133}$.

A second approach, following the procedure of Kaneda et al., where the copper co-catalyst was abandoned, which is usually used to facilitate the re-oxidation of the $\operatorname{Pd}(0)$ by oxygen and to prevent the formation of palladium black. ${ }^{132}$ Kaneda et al. showed the beneficial effect of using DMA instead of DMF for this reaction, which provides the advantage of faster catalyst regeneration. Their proposed catalytic cycle (Scheme 43) illustrates the competition between the rate determining step of catalyst recycling ( $\left.\mathrm{k}_{\mathrm{cat}}\right)$ and catalyst decomposition, which forms inactive $\mathrm{Pd}(0)$ metal $\left(\mathrm{k}_{\mathrm{dec}}\right)$. It was demonstrated that $k_{c a t} / k_{\text {dec }}$ in DMA was almost 2.3 times higher than observed in DMF. 
These data showed the ability of DMA to promote the re-oxidation of $\operatorname{Pd}(0)$ to the active catalyst and to suppress the competing $\operatorname{Pd}(0)$ aggregation.

Scheme 43: Proposed catalytic cycle by Kaneda et al. $\left(k_{\text {cat }}=\right.$ rate of the re-oxidation, $\mathrm{k}_{\mathrm{dec}}=$ rate of the decomposition). ${ }^{132}$

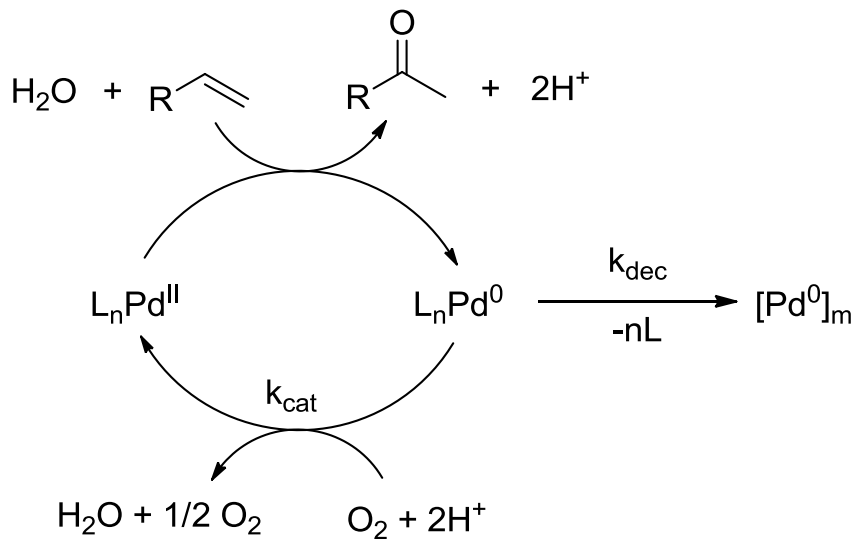

The application of this protocol to substrate 189 afforded the desired product in significantly higher yield compared to the procedure before, delivering only the desired ketone 189 without formation of the corresponding aldehyde (Table 12, entry 2). However, the problem of inseparable DMA contamination in the isolated product after column chromatography arose once more.

Another method, also delivering the desired Wacker-product, utilizes a $\mathrm{Hg}(\mathrm{OAc})_{2}$ mediated oxymercuration combined with subsequent oxidation by Jones-reagent. ${ }^{134}$ As $\mathrm{Hg}$ (II) resembles $\mathrm{Pd}$ (II) in its ability to activate a C-C double bond for nucleophilic attack, it is an interesting candidate for catalytic oxidation. ${ }^{135}$

Scheme 44: Catalytic cycle of $\mathrm{Hg}(\mathrm{II}) .{ }^{134}$

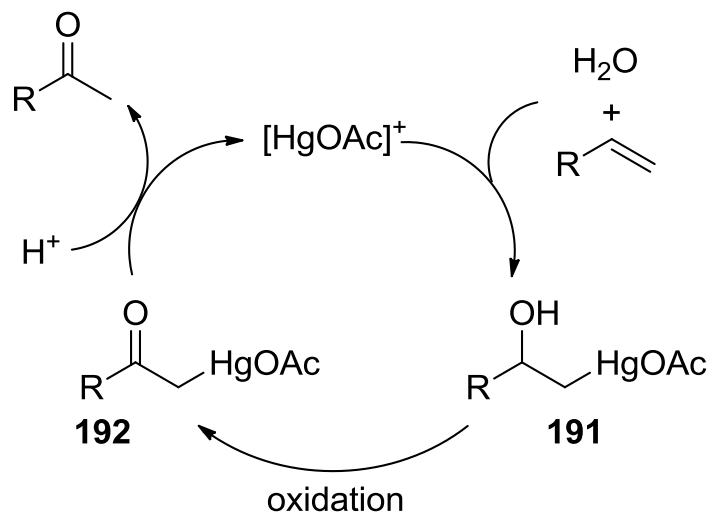


The reaction is driven in the direction of the thermodynamically less stable hydrated form 191, by trapping this intermediate with the help of the oxidation to the corresponding ketone 192.

The actual experiment, using 187 as starting material, was carried out following the procedure of Zou et al., who used this methodology for the oxidation of an allyl group connected to carbohydrate derivatives. ${ }^{133,136}$ Already the first tests showed a cleaner reaction compared to the Wacker-oxidations applied before (Table 12, entry 3). There was also no problem during the isolation of the product concerning solvent residues after column chromatography, as occurred when using DMF or DMA, respectively. In this way the desired ketone $\mathbf{1 8 9}$ was obtained in good yields.

Having ketone 189 in hands, both, the free carboxylic acid and the ketone needed to be reduced to the diol 190 , as a selective reduction of the $\mathrm{COOH}$ group in presence of the ketone moiety was not possible, due to the higher reactivity of the latter. The reduction was again achieved by using the $\mathrm{BH}_{3} \cdot \mathrm{THF}$-complex at lower temperatures (Scheme 45).

Scheme 45: Reduction of ketone 189 to diol 190.

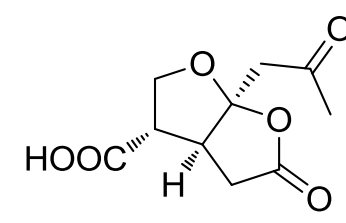

189

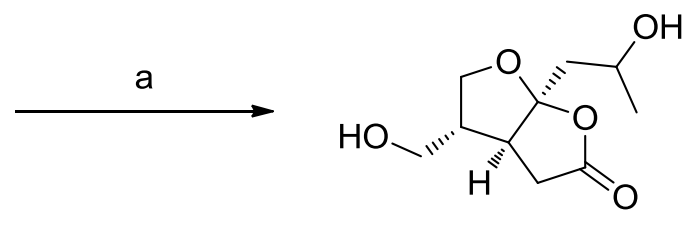

190

Reagents and conditions: a) $\mathrm{BH}_{3} \cdot \mathrm{THF}(2.1 \mathrm{eq}), \mathrm{THF},-15^{\circ} \mathrm{C}$ to r.t., $4 \mathrm{~h}, 16 \%$.

Unfortunately, this diol $\mathbf{1 9 0}$ proved to be unstable against the purification procedures like the alcohol 188 mentioned before (Table 11), although the reaction itself proceeded smoothly to the desired product (according to TLC monitoring). Nevertheless, a small amount of $\mathbf{1 9 0}$ could be isolated in an impure manner, but was tried to be converted in a selective oxidation of the secondary $\mathrm{OH}$ group in presence of the primary $\mathrm{OH}$. For this reason, several oxidation procedures were implemented (Table 13). First attempts employed cerium(IV) catalysis, applicable for selective oxidation of secondary alcohols in the presence of primary ones. ${ }^{137}$ Either cerium(IV) sulfate (Table 13,entry 1 ) or cerium(IV) ammonium nitrate (CAN) (Table 13, entry 2) was used as catalyst and sodium bromate as co-catalyst. 
This method was also applied by Meinwald et al., who used cerium sulfate for the synthesis of $\left( \pm\right.$ )-Palasonin. ${ }^{138}$ However, in the case of the diol 190 both reagents did not give success. While cerium sulfate showed only traces in the NMR of the crude mixture, CAN gave no conversion at all. Applying more equivalents of oxidation reagent and longer reaction times, afforded a mixture of highly polar components in both cases.

Table 13: Attempts for the selective oxidation of the secondary alcohol group.

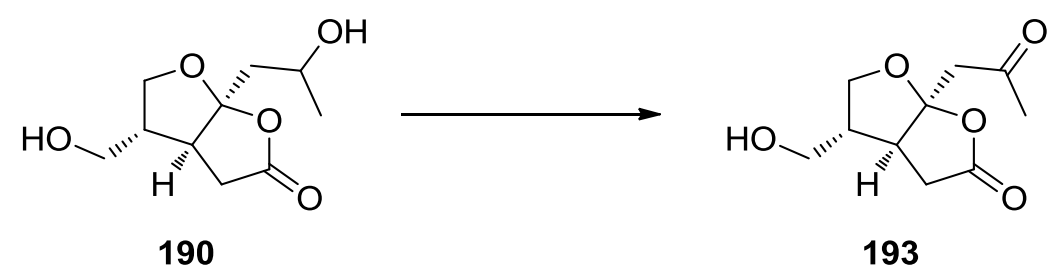

\begin{tabular}{ccc}
\hline Entry & Reagents and conditions & Yield [\%] \\
\hline $1^{[a][b]}$ & $\mathrm{Ce}\left(\mathrm{SO}_{4}\right)_{2} \cdot \mathrm{H}_{2} \mathrm{SO}_{4}(10 \mathrm{mo} \%), \mathrm{NaBrO}_{3}(1 \mathrm{eq})$, & traces \\
& $\mathrm{MeCN} / \mathrm{H}_{2} \mathrm{O} 7: 3,80^{\circ} \mathrm{C}, 3 \mathrm{~h}$ \\
$2^{[\mathrm{aa}]}$ & $\mathrm{CAN}(10 \mathrm{~mol} \%), \mathrm{NaBrO}_{3}(1 \mathrm{eq}), \mathrm{MeCN} / \mathrm{H}_{2} \mathrm{O} 7: 3$, & no reaction \\
& $80{ }^{\circ} \mathrm{C}, 6 \mathrm{~h}$ & \\
$3^{[\mathrm{c}]}$ & $\mathrm{NaOCl}(1 \mathrm{eq}), \mathrm{HOAc}, 0{ }^{\circ} \mathrm{C}$ to r.t., $1.5 \mathrm{~h}$ & slow decomposition \\
$4^{[\mathrm{d}]}$ & $\mathrm{NBS}(1.5 \mathrm{eq}), \mathrm{DME} / \mathrm{H}_{2} \mathrm{O} 9: 1,0{ }^{\circ} \mathrm{C}$ to r.t., $1 \mathrm{~h}$ & complex mixture \\
\hline
\end{tabular}

[a]: $\operatorname{Ref}{ }^{137}$; [b]: $\operatorname{Ref}{ }^{138}$; [c]: $\operatorname{Ref}^{139}$; [d]: $\operatorname{Ref}{ }^{140}$.

The utilization of a sodium hypochlorite solution in acetic acid, a common mixture for selective oxidation of secondary alcohols, resulted in slow decomposition of the starting material 190 (Table 13, entry 3). ${ }^{139,141}$ The last applied protocol was the use of $\mathrm{N}$-bromosuccinimide in aqueous DME generating a complex mixture of compounds in short time (Table 13, entry 4). ${ }^{140}$

As the approach of a selective oxidation of the secondary $\mathrm{OH}$ group of diol $\mathbf{1 9 0}$ did not deliver the desired results, a selective protection of the primary alcohol moiety of 190 as a benzoyl ester was planned, as this group is finally required in (-)-Paeonilide 5. A subsequent oxidation of the remaining $\mathrm{OH}$ group would then give rise to the target monoterpenoid $\mathbf{5}$. An advantage of this procedure is the possibility to use a bigger variety of oxidative agents, since the primary $\mathrm{OH}$ would already be converted to the final $\mathrm{OBz}$ group. To reach this goal, the following steps were carried 
out in an one-pot manner, without purification of the intermediates by column chromatography, as the alcohol 188 and the diol 190 proved to give problems during their purification.

Scheme 46: The endgame.
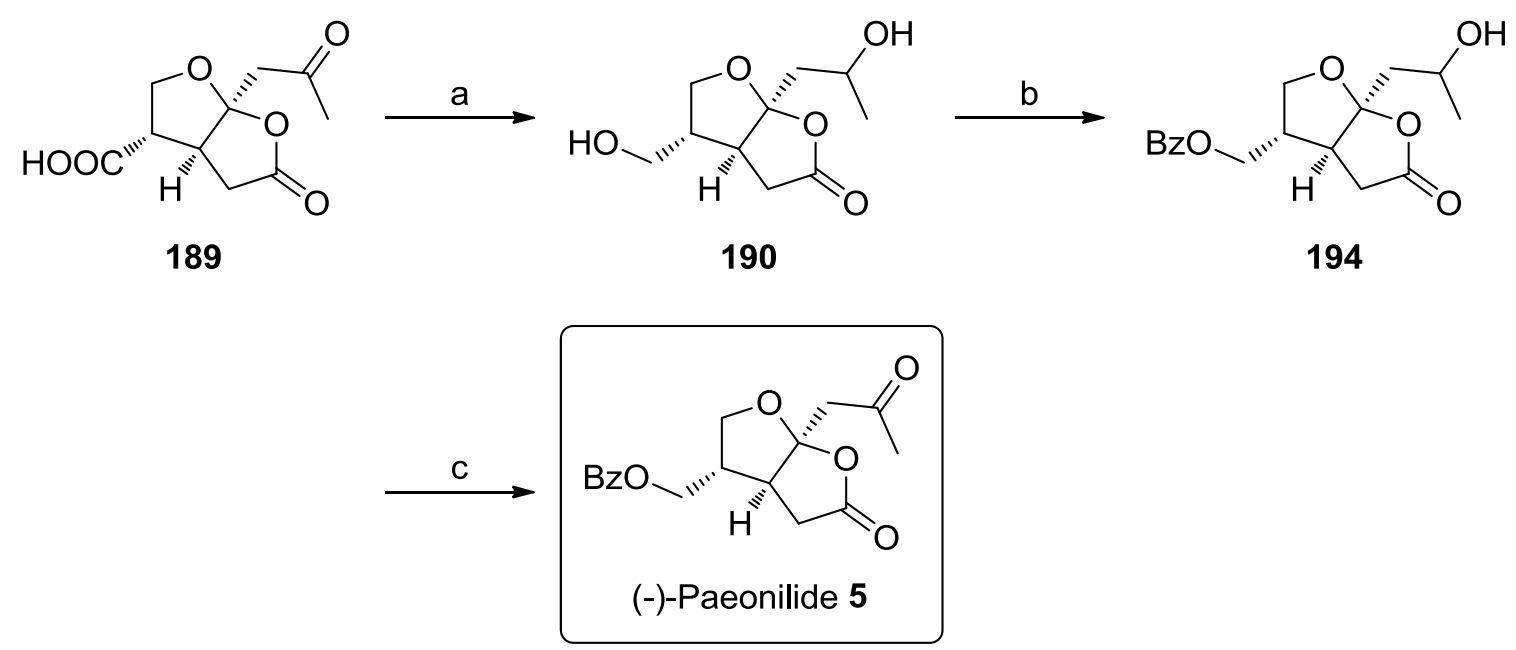

Reagents and conditions: a) $\mathrm{BH}_{3} \cdot \mathrm{THF}(2.1 \mathrm{eq})$, THF, $-15^{\circ} \mathrm{C}$ to r.t., $4 \mathrm{~h}$; b) $\mathrm{BzCl}(1.05 \mathrm{eq}), \mathrm{NEt}_{3}$ (6 eq), DMAP (0.1 eq), DCM, $-40{ }^{\circ} \mathrm{C}$ to $-10{ }^{\circ} \mathrm{C}, 1.5 \mathrm{~d}$; c) DMP ( 1 eq), DCM, $0{ }^{\circ} \mathrm{C}, 3 \mathrm{~h}, 44 \%$ over 3 steps, based on 189.

The final steps started again with a simultaneous reduction of the ketone and the carboxylic acid of $\mathbf{1 8 9}$ by $\mathrm{BH}_{3} \cdot$ THF-complex, which smoothly provided diol 190 (Scheme 46). After removing the solvent under reduced pressure, the crude mixture was dissolved in DCM and treated with a small excess of benzoyl chloride in the presence of an excess of triethylamine and catalytic amounts of DMAP. This procedure of selectively protecting a primary $\mathrm{OH}$ followed the protocol of Schlessinger et al., who applied this methodology to the racemic synthesis of Senepoxide. ${ }^{142}$ These conditions afforded one new compound with negligible byproduct formation, according to TLC monitoring. In order to remove the amines, the crude mixture was washed with an ammonium chloride solution, to give rise to crude 194, which was again dissolved in dichloromethane and finally treated with Dess-Martin periodinane for the oxidation of the secondary alcohol. ${ }^{143}$ The oxidation reaction was purified by column chromatography and subsequent crystallization from methanol. ${ }^{11}$ This reaction sequence gave rise to the target monoterpenoid (-)-Paeonilide 5 in an overall yield of $44 \%$ over the last 3 steps, based in 189 correlating with an average yield of $76 \%$ for each of the last 3 reactions. 
The complete synthesis, starting from commercially available 3-furoic acid (59) afforded (-)-Paeonilide (5) in a 12 step, straightforward synthesis with an overall yield of $4.4 \%(7.7 \% \mathrm{brsm})$.

In comparison to the so far published syntheses (see chapter A. Introduction), the most significant difference of this work is the way of introducing enantioselectivity. Starting from an achiral substrate and implementing the chiral information in a later step, instead of applying an already chiral starting material and maintaining its stereoinformation throughout the complete synthetic route. Another important distinction is the introduction of a new way for the construction of the bi-cyclic system to the Paeonilide-chemistry. This new strategy ceases ring formation, which applies a reaction sequence used in all of the so far published Paeonilide-syntheses. Last but not least, the installation of the keto-side chain is performed in a novel way, instead of using a starting material, which already contains the required functional groups. 


\section{Characterization and biological evaluation of (-)-Paeonilide}

(-)-Paeonilide (5) was obtained as thin, colorless needles. The ${ }^{1} \mathrm{H}$ - and ${ }^{13} \mathrm{C}-\mathrm{NMR}$ spectroscopic data are in accordance with the published data as well as the HMBC-correlations (Scheme 47, left). The assignment of the NOE signals were complicated by the overlap of the signals of the protons $\mathrm{H}^{\mathrm{a}}$ and $\mathrm{H}^{\mathrm{b}}$ by other proton signals. But there is an unambiguous NOE signal between the two side chains of the furo-lactone core skeleton (Scheme 47, right), which indicates the position of those two arms on the same side of the bi-cycle. Nevertheless, the absolute stereochemistry was confirmed by X-ray crystallography.

Scheme 47: Significant C-H correlations by HMBC (indicated by arrows, left); NOE signal (indicated by arrow, right); X-ray structure of (-)-Paeonilide (5).

HMBC

NOE
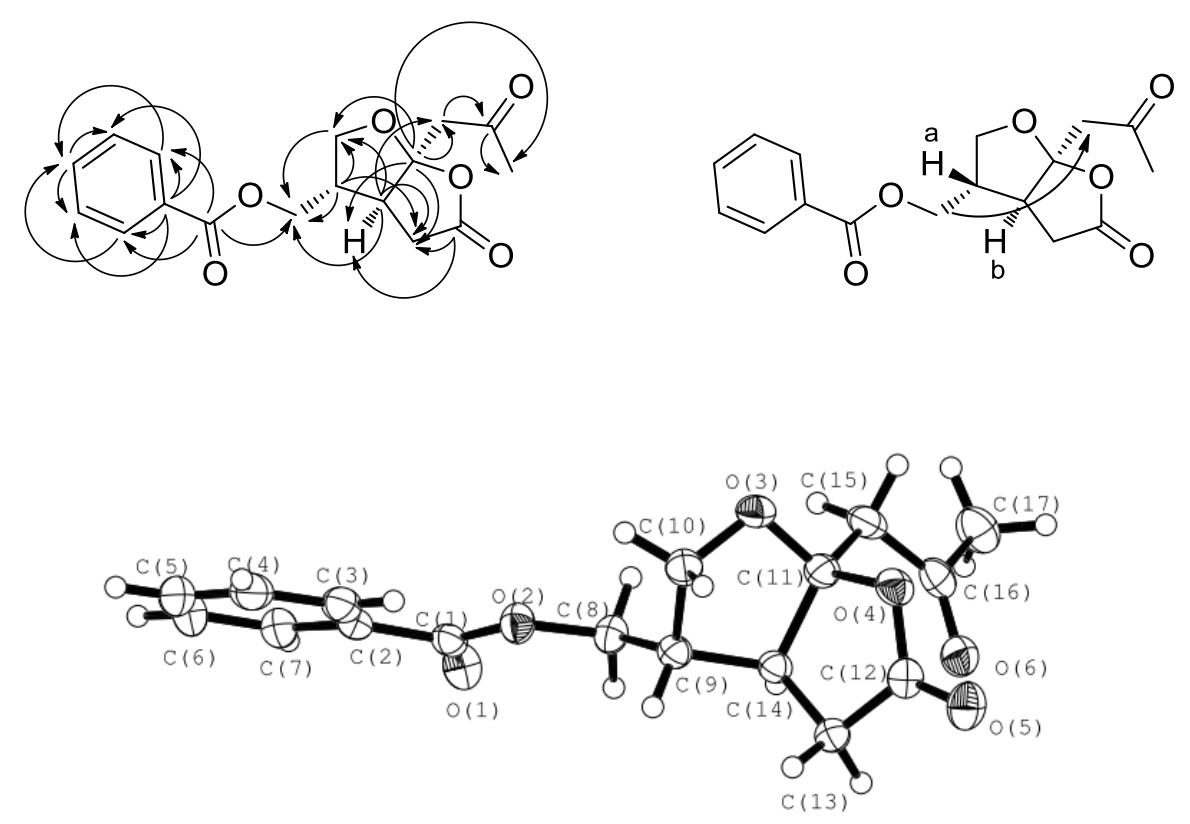

The measured optical rotation of the obtained sample of (-)-Paeonilide (5) showed a $[\alpha]_{\mathrm{D}}^{20}$ value of $-42.0^{\circ}\left(\mathrm{CHCl}_{3}, \mathrm{C}=0.14\right)$ which differs from the measured value of the originally isolated $(+)$-Paeonilide $\left([\alpha]_{\mathrm{D}}^{20}=+54.3^{\circ} ; \mathrm{CHCl}_{3}, \mathrm{C}=0.44\right)$, published by Liu et al., concerning the absolute value. ${ }^{11}$ This observation is in accordance with the fact, that the copper(I)-catalyzed asymmetric cyclopropanation delivered the cyclopropane 118 with an ee value of $83 \%$. Furthermore, the enantiomeric excess could not be enriched during the synthesis, as (re)crystallization of the respective 
compounds was either not possible or resulted in the same optical rotation values as before.

Attempts to measure the enantiomeric excess of one of the final compounds via chiral HPLC were not successful, since all applied columns and conditions did not provide a separation of the two enantiomers.

Anyway, if the ee value of the obtained (-)-Paeonilide (5) is calculated from the measured optical rotation, which is of course only a rule of thumb and not accurate for all chiral compounds, ${ }^{144}$ one expects an ee of approximately $85 \%$, which would be in accordance with the enantiomeric excess, achieved from the cyclopropanation.

So far, only the natural enantiomer (+)-Paeonilide (+)-(5) was applied for investigating the biological activities (see chapter A. Introduction). As (+)-5 shows structural similarities to the ginkgolide family, it was tested against the PAF induced thrombocyte-aggregation and provided an $\mathrm{IC}_{50}$ value of $8 \mu \mathrm{g} / \mathrm{mL}(25 \mu \mathrm{M})$. Having the enantiomerically enriched (-)-Paeonilide (5) in hands, it was submitted for biological assays in order to compare the behavior of both Paeonilide enantiomers (Table 14).

Table 14: Obtained data from rabbit-thrombocyte-aggregation assay (kindly measured by Schwabe GmbH \& Co. KG, Karlsruhe, Germany).

\begin{tabular}{ccccc}
\hline Entry & $\begin{array}{c}\text { Concentration } \\
\text { of } \mathbf{5}[\mu \mathrm{g} / \mathrm{mL}]\end{array}$ & $\begin{array}{c}\text { Inhibited aggregation [\%] } \\
\text { experiment 1 }\end{array}$ & $\begin{array}{c}\text { Average value of } \\
\text { experiment 2 }\end{array}$ & \begin{tabular}{c} 
inhibition [\%] \\
\hline 1
\end{tabular} \\
1 & 5.9 & 8.6 & 7.3 \\
2 & 3 & -12.5 & 24.9 & 6.2 \\
3 & 10 & -10.4 & 20.2 & 4.9 \\
4 & 30 & 26.8 & 13.2 & 20 \\
\hline
\end{tabular}

The thrombocyte aggregation was inhibited by $20 \%$ at a concentration of $30 \mu \mathrm{g} / \mathrm{mL}$ $(94 \mu \mathrm{M})$ of 5 , hence (-)-Paeonolide (5) seems to be much less active than the eutomeric (+)-5 ( $\mathrm{IC}_{50}=8 \mu \mathrm{g} / \mathrm{mL}, 25 \mu \mathrm{M}$ respectively). Presumably, the antagonism is caused by the impurity of the eutomeric $(+)-5$ in the investigated sample. These results imply that the unnatural distomer of Paeonilide is not active against the PAF receptor, at least not up to concentrations of $30 \mu \mathrm{g} / \mathrm{mL}$. 


\section{Summary \& Schematic Overview}

\section{Summary}

A plethora of new interesting compounds was discovered in the realm of plants. One of them was the monoterpenoid (+)-Paeonilide (+)-(5), which was isolated, characterized and submitted to biological assays. The target of this thesis was the development of an enantioselective synthesis of the monoterpenoid (-)-Paeonilide (5) (Figure 17) based on commercially available 3 -furoic acid (59). This goal was envisaged to be achieved by the application of an asymmetric copper(I)-catalyzed cyclopropanation introducing the stereochemical information into the achiral precursor.

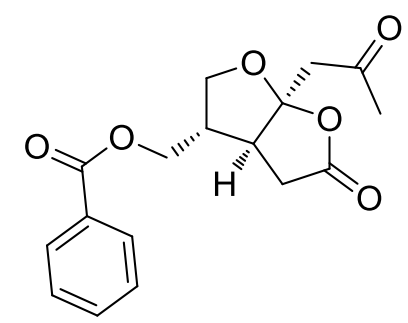

(-)-Paeonilide (5)

Figure 17: Structure of (-)-Paeonilide (5).

The cyclopropanation utilizing diazo glycine ethyl ester (91) and the corresponding tert-butyl ester 89 in the presence of different bis(oxazoline)-ligands 82 or 85 provided the cyclopropanated product 58. It was possible to improve the achieved yields and ee-values within this screening, compared to literature precedents (Table 15). 
Table 15: Ligand and diazo ester screening.

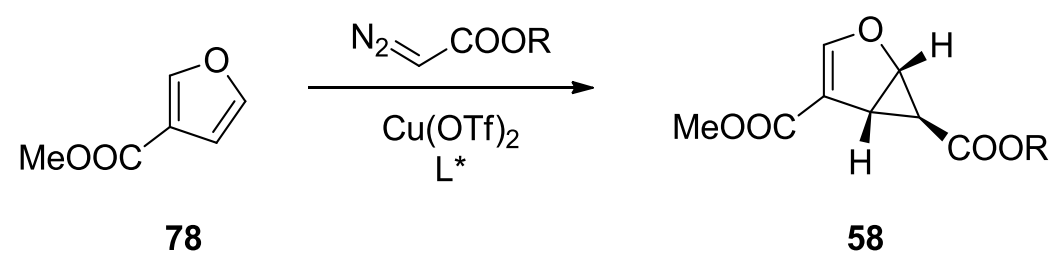

\begin{tabular}{ccccc}
\hline Entry & $\begin{array}{c}\text { Diazo acetate } \\
\mathrm{R}\end{array}$ & $\begin{array}{c}\text { Ligand } \\
\mathrm{L}^{*}\end{array}$ & $\begin{array}{c}\text { Yield } \\
{[\%]}\end{array}$ & $\begin{array}{c}\text { Selectivity } \\
{[\%] ~ e e}\end{array}$ \\
\hline $1^{[\mathrm{a}]}$ & $\mathrm{Et}$ & $\mathbf{8 5}$ & 27 & 74 \\
2 & $\mathrm{tBu}$ & $\mathbf{8 5}$ & 38 & 65 \\
3 & $\mathrm{Et}$ & $\mathbf{8 2}$ & 31 & 83 \\
4 & $t \mathrm{Bu}$ & $\mathbf{8 2}$ & 38 & 83 \\
\hline
\end{tabular}

[a]: Ref. ${ }^{40}$.

$$
\begin{array}{ll}
\text { 82: } \mathrm{R}=i \mathrm{Pr}, \mathrm{R}^{1}=\mathrm{H} \\
\text { 85: } \mathrm{R}=\mathrm{CH}_{2} \mathrm{OH}, \mathrm{R}^{1}=\mathrm{Ph}
\end{array}
$$

Using the ethyl substituted cyclopropane derivative 119, the straightforward synthesis via $\mathrm{C}-\mathrm{C}$ double bond hydrogenation and subsequent lactonization failed due to byproduct formation during the hydrogenation and inappropriate lactonization conditions (Scheme 48).

Scheme 48: Employment of the ethyl substituted cyclopropane 119.
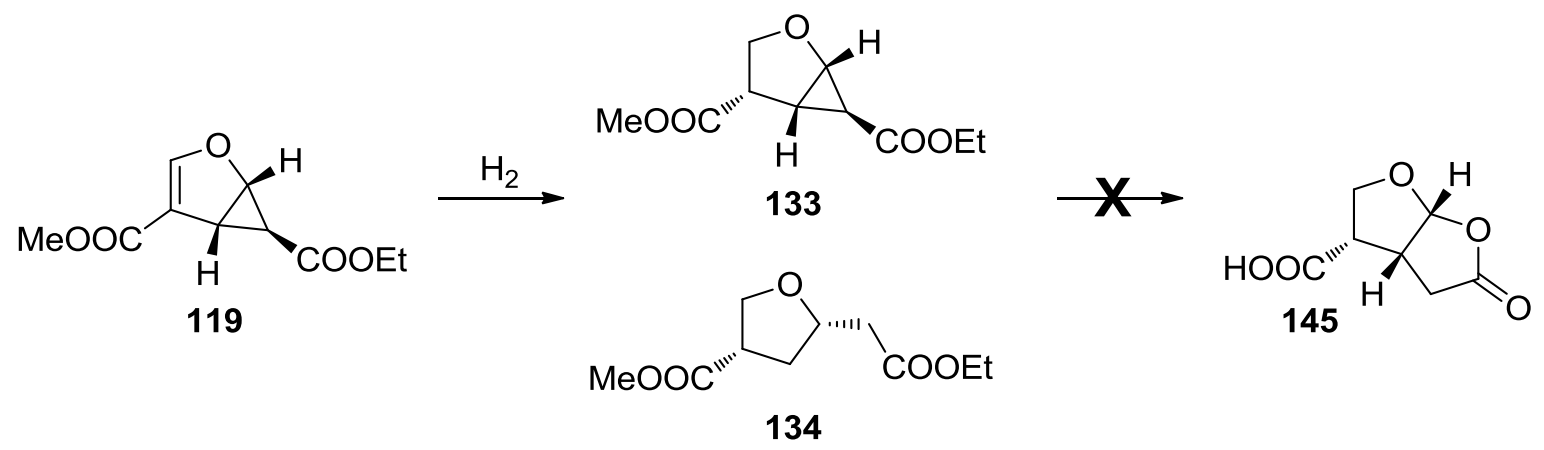

Changing the used diazo ester to the $t B u$-substituted $\mathbf{8 9}$ provided a straightforward synthesis toward the lactone $\mathbf{1 4 5}$, which could be converted into lactone 57 , applying a base (Scheme 49). 
The further steps included an oxidative lactone opening giving rise to the disubstituted lactone 186. A subsequent treatment with a Grignard-reagent afforded the allyl-substituted furo-lactone 187. Having the substituted lactone $\mathbf{1 8 7}$ in hands, oxymercuration-oxidation chemistry provided the ketone 189 , which was converted in a three-step-one-pot manner to the final compound, since the intermediates proved to be unstable when purified (Scheme 50).

Scheme 49: Synthetic route employing tBu-substituted cyclopropane 118.<smiles>CCOC(=O)C1C2COC=C(C(C)=O)C21</smiles>

118

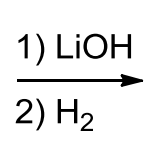

$\mathrm{HOOC}$

139

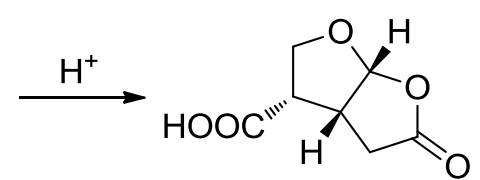

145

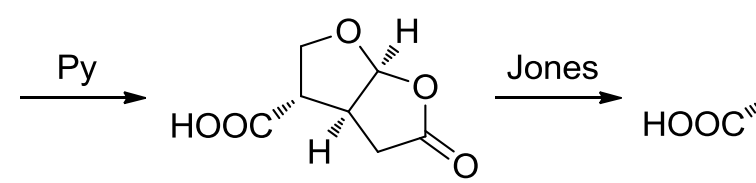

57<smiles>O=C(O)CC1CCOC1=O</smiles>

186<smiles>C=CC[C@]12OC[C@@H](C(=O)O)[C@H]1CC(=O)O2</smiles>

187

Ketone 189 was reduced to the corresponding diol, which was selectively protected on the primary hydroxyl group and finally the secondary alcohol was re-oxidized to the ketone, to yield the target monoterpenoid (-)-Paeonilide (5).

Scheme 50: Completion of the synthesis of (-)-Paeonilide (5).<smiles>C=CC[C@]12OCC(=O)O[C@H]1CC2C(=O)O</smiles>

187

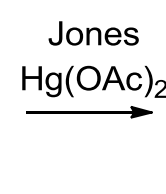

$\mathrm{HOOC}$

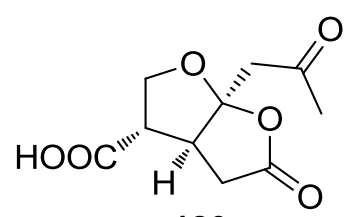

189 \begin{tabular}{l} 
1) $\mathrm{BH}_{3}$ \\
2) $\mathrm{BzCl}$ \\
\hline $\overrightarrow{\mathrm{DMP}}$
\end{tabular}

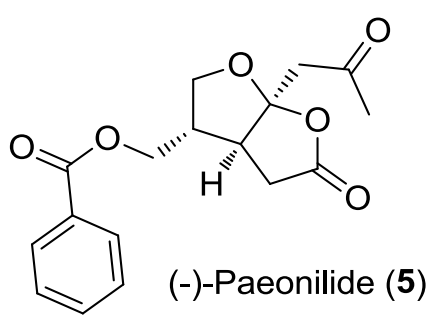

This synthetic route presents a straightforward access to the synthesis of the unnatural (-)-Paeonilide (5) within 12 steps and an overall yield of $4.4 \%(7.7 \% \mathrm{brsm})$. Although this synthesis did not provided absolutely enantiomerically pure (-)-Paeonilide (obtained $[\alpha]_{\mathrm{D}}^{20}=$ of $-42.0^{\circ}\left(\mathrm{CHCl}_{3}, \quad \mathrm{c}=0.14\right)$; literature value $\left.[\alpha]_{\mathrm{D}}^{20}=+54.3^{\circ}\left(\mathrm{CHCl}_{3}, \mathrm{C}=0.44\right)\right)$, it was submitted for biological assays in order to get an inkling of the activity of the unnatural enantiomer. The target compound 5 
showed activity against the thrombocyte aggregation although the inhibition was much less than found for the natural enantiomer (+)-5. Presumably, this small measured effect is caused by the impurity of the eutomeric (+)-5 in the measured sample. These results imply that the unnatural distomer of Paeonilide is not active against the PAF receptor, at least not in the tested range of concentrations. 


\section{Schematic overview of synthesized compounds}<smiles>CCOC(=O)C1=CO[C@H]2C(CO)[C@H]1[C@H]2CO</smiles>

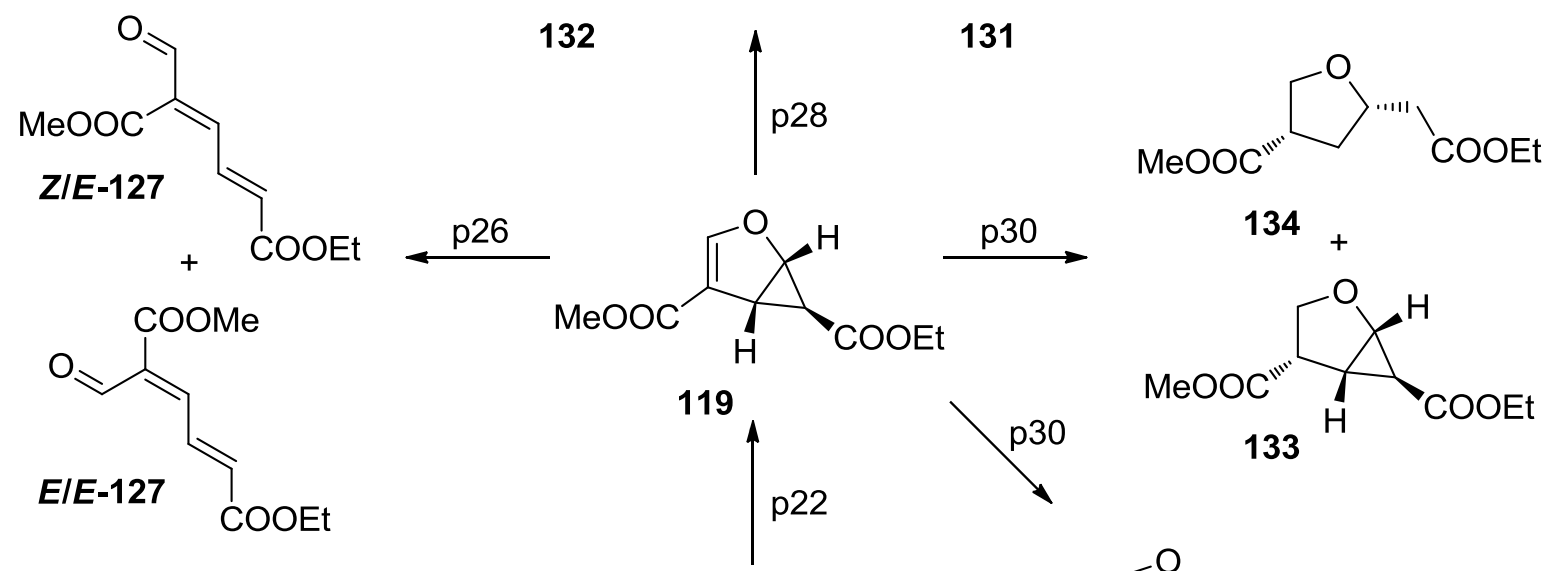<smiles>COC(=O)c1ccoc1CCCCC(=O)c1ccc(Br)cc1</smiles><smiles>CCOC(=O)C1C2OC=C(C(=O)O)C21</smiles><smiles>[134IH]</smiles><smiles>CCOC(=O)C1C2OC=C(C(OC)OCC)C21[10IH]</smiles><smiles>CCOC(=O)C1C2OC[C@@H](C(=O)O)C21</smiles>

139

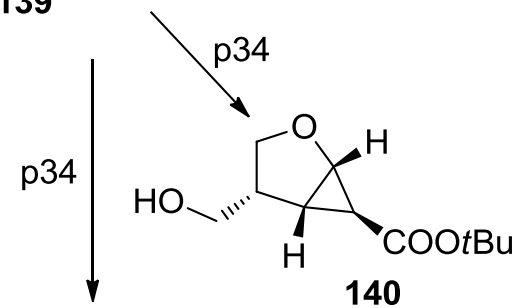<smiles>CC1CC1[18OH]</smiles>

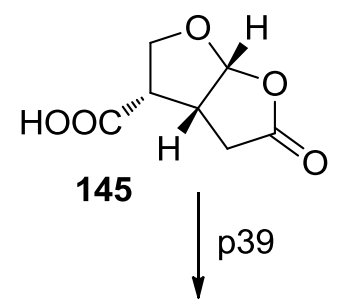<smiles>[PbH2]</smiles><smiles>OCCO</smiles><smiles>O=C1C[C@H]2CCO[C@H]2O1</smiles>
141<smiles>COC(=O)C[C@@H]1[C@H](OCc2ccccc2)CO[C@@H]1OCc1ccccc1</smiles><smiles>C[131In]</smiles><smiles>O=C1C[C@H]2OC[C@H](CO)[C@H]2O1</smiles>

57

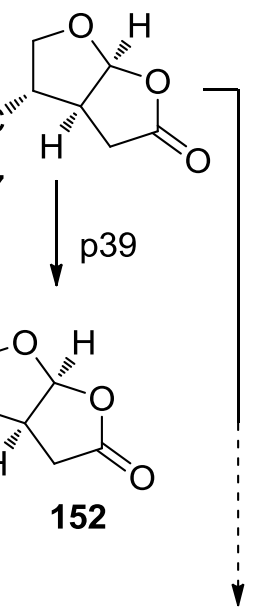<smiles>O=C1CO[C@@H]2CC(=O)O[C@@H]2C1</smiles> 

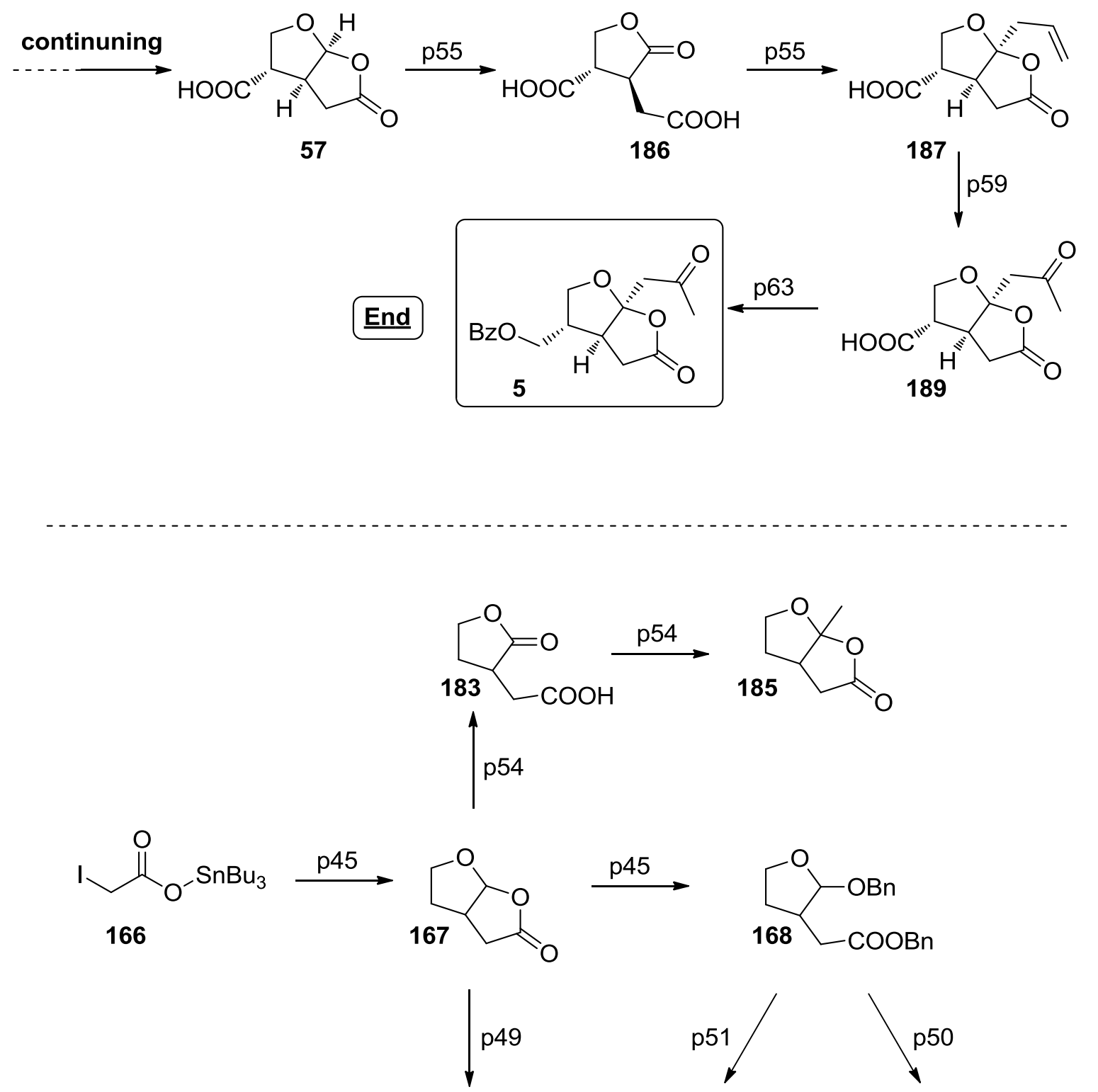

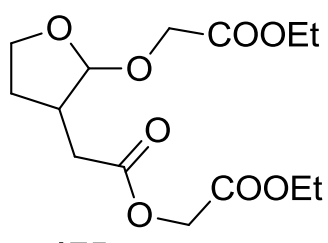

175

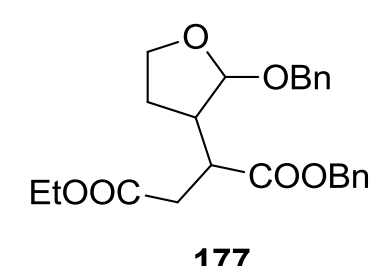

177

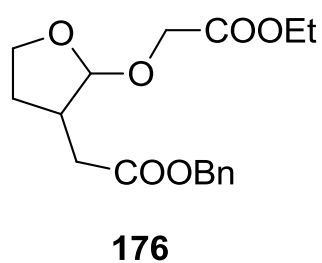




\section{Experimental}

\section{General comments}

All reactions were carried out in oven dried glassware under atmospheric conditions unless otherwise stated. Commercially available chemicals were used as received, without any further purification.

The following solvents and reagents were purified prior to use:

Dichloromethane $\left(\mathrm{CH}_{2} \mathrm{Cl}_{2}\right)$ was distilled from SICAPENT ${ }^{\circledR}$. Ethanol $(\mathrm{EtOH})$ and methanol $(\mathrm{MeOH})$ were distilled from magnesium and stored over molecular sieves (3 $\AA$ ). Tetrahydrofuran (THF) was distilled from sodium wire. Toluene was dried with $\mathrm{CaH}_{2}$, distilled and stored over sodium wire. Ethyl acetate (EA) and hexanes (PE) for chromatographic separations were distilled prior to use. Benzoyl chloride was distilled prior to use. Triethylamine and pyridine were distilled from $\mathrm{KOH}$.

Analytical thin layer chromatography was performed on Merck TLC aluminium sheets silica gel $60 \mathrm{~F}$ 254. Visualization was accomplished with UV light $(254 \mathrm{~nm})$. For staining vaniline or permanganate solutions followed by heating were used. Liquid chromatography was performed using Merck flash silica gel 60 (0.040-0.063 mm).

\section{${ }^{1} \mathrm{H}$ - and ${ }^{13} \mathrm{C}$-NMR:}

NMR-spectra were recorded on FT-NMR-spectrometers of the type Bruker Avance $300\left(300 \mathrm{MHz}\right.$ for ${ }^{1} \mathrm{H}, 75 \mathrm{MHz}$ for $\left.{ }^{13} \mathrm{C}\right)$, Avance $400\left(400 \mathrm{MHz}\right.$ for ${ }^{1} \mathrm{H}, 101 \mathrm{MHz}$ for $\left.{ }^{13} \mathrm{C}\right)$ or Avance III $600\left(600 \mathrm{MHz}\right.$ for ${ }^{1} \mathrm{H}, 151 \mathrm{MHz}$ for $\left.{ }^{13} \mathrm{C}\right)$ at ambient temperature. Data are as follows: Chemical shift in ppm from internal $\mathrm{CHCl}_{3}$ (7.26 ppm) as standard on the $\delta$ scale, multiplicity $(s=$ singlet, $b s=$ broad singlet, $d=$ doublet, $t=$ triplet, $\mathrm{q}=$ quartet, $\mathrm{dd}=$ doublet of doublet, $\mathrm{ddd}=$ doublet of doublet of doublet, dddd $=$ doublet of doublet of doublet of doublet, $\mathrm{dt}=$ doublet of triplet, $\mathrm{td}=$ triplet of doublet, $\mathrm{tt}=$ triplet of triplet, $\mathrm{tdd}=$ triplet of doublet of doublet, $\mathrm{tdt}=$ triplet of doublet of triplet, $\mathrm{ddt}=$ doublet of doublet of triplet, $\mathrm{dtd}=$ doublet of triplet of doublet, $\mathrm{dq}=$ doublet of quartet, $q d=$ quartet of doublet and $\mathrm{m}=$ multiplet), integration and coupling constant $(\mathrm{Hz}) .{ }^{13} \mathrm{C}$ chemical shifts are reported in ppm from internal $\mathrm{CHCl}_{3}(77 \mathrm{ppm})$ as standard on the $\delta$ scale. The ${ }^{13} \mathrm{C}$ signals were assigned with the help of DEPT 90, DEPT 135 or HSQC techniques $\left((+)=\mathrm{CH}\right.$ or $\mathrm{CH}_{3},(-)=\mathrm{CH}_{2},\left(\mathrm{C}_{\mathrm{q}}\right)=$ quaternary carbon). 


\section{X-ray analysis:}

All X-ray measurements were performed by the crystallographic department of the University of Regensburg.

\section{Melting points:}

The melting points were measured on a Büchi SMP-20 apparatus in a silicon oil bath or on a SRS MPA 100 OptiMelt. Values thus obtained were not corrected.

\section{Mass spectrometry:}

Mass spectrometry was performed using Varian MAT 311A, Finnigan MAT 95, Thermoquest Finnigan TSQ 7000 or Agilent Technologies 6540 UHD Accurate-Mass Q-TOF LC/MS at the Central Analytical Laboratory (University of Regensburg).The percentage set in brackets gives the peak intensity related to the basic peak (I=100\%). High resolution mass spectrometry (HRMS): The molecular formula was proven by the calculated precise mass.

\section{Elemental analysis:}

Elemental analysis was measured on a Vario EL III or Mikro-Rapid CHN (Heraeus) (micro analytic section of the University of Regensburg).

\section{IR spectroscopy:}

ATR-IR spectroscopy was carried out on a Biorad Excalibur FTS 3000 spectrometer, equipped with a Specac Golden Gate Diamond Single Reflection ATR-System.

\section{Optical rotation:}

The optical rotation was determined in a Perkin Elmer 241 polarimeter at $589 \mathrm{~nm}$ wavelength (sodium-d-line) in a $1.0 \mathrm{dm}$ measuring cell of ca. $2 \mathrm{~mL}$ volume.

\section{HPLC:}

High performance liquid chromatography was carried out using Varian 920-LC with DAD.

Phenomenex Lux Cellulose-2 or Chiralcel OD-H served as chiral stationary phase. 


\section{Synthesis of literature-known compounds and reagents}

2,2-dimethylmalonyl dichloride $\quad(\mathbf{7 9}),{ }^{145} \quad$ (S)-2-amino-3-methylbutan-1-ol $\quad(\mathbf{8 0}),{ }^{145}$ $N 1, N 3$-bis((S)-1-hydroxy-3-methylbutan-2-yl)-2,2-dimethylmalonamide $(\mathbf{8 1}),{ }^{45}$ (4S, 4'S)-2,2'-(propane-2,2-diyl)bis(4-isopropyl-4,5-dihydrooxazole) $\quad(\mathbf{8 2}),{ }^{45} \quad$ 2,2dimethyl-malononitrile (83), ${ }^{46}$ ethyl 2-diazoacetate (91), ${ }^{50}$ bis(trimethylsilyl) sulfate (BTS, 128) ${ }^{79} 3,4,5$-tribromo-1H-pyrazole (170), ${ }^{117}(S)$-4-isopropyl- $N$-((S)-4-isopropyl4,5-dihydrooxazol-2-yl)- $N$-methyl-4,5-dihydrooxazol-2-amine $\quad(\mathbf{1 7 8}),{ }^{146}$ Jonesreagent, ${ }^{147} \mathrm{Zn}\left(\mathrm{BH}_{4}\right)_{2} .{ }^{124}$ 


\section{Syntheses}

((4S,4' S,5S,5' S)-2,2'-(propane-2,2-diyl)bis(5-phenyl-4,5-dihydrooxazole-4,2diyl))dimethanol (85)<smiles>CC(C)(C1=N[C@H](CO)[C@H](c2ccccc2)O1)C1=N[C@H](c2ccccc2)[C@H](CO)O1</smiles>

Dinitrile 83 (791 mg, $8.41 \mathrm{mmol}, 1 \mathrm{eq}),(1 S, 2 S)$-2-amino-1-phenyl-1,3-propanediol (84) (3.52 g, $21.03 \mathrm{mmol}, 2.5 \mathrm{eq})$ and $\mathrm{Cd}(\mathrm{OAc})_{2} \cdot 2 \mathrm{H}_{2} \mathrm{O}$ (112 mg, $\left.0.42 \mathrm{mmol}, 5 \mathrm{~mol} \%\right)$ were put together with $40 \mathrm{~mL}$ chlorobenzene. While refluxing it for $14 \mathrm{~h}$ it became a clear solution. The solvent was removed under reduced pressure and the remaining residue was dissolved in $20 \mathrm{~mL}$ DCM and washed with water $(3 \times 15 \mathrm{~mL})$. The combined aqueous layers were washed with $20 \mathrm{~mL}$ DCM. The combined organic layers were dried over $\mathrm{Na}_{2} \mathrm{SO}_{4}$, filtered and concentrated under reduced pressure. The crude product was purified by silica column chromatography $(\mathrm{DCM} / \mathrm{MeOH}=95: 5)$ to afford the product as yellow solid which was re-crystallized from EA to obtain the clean 85 as white crystals $(1.29 \mathrm{~g}, 3.28 \mathrm{mmol}, 39 \%)$.

$\mathrm{R}_{\mathrm{f}}(\mathrm{EA} / \mathrm{MeOH}=10: 1)=0.23 .-[\alpha]_{D}^{20}=-84.5(\mathrm{DCM}, \mathrm{c}=1)$.

${ }^{1} \mathrm{H}$ NMR $\left(300 \mathrm{MHz}, \mathrm{CDCl}_{3}\right): \delta=7.42-7.22(\mathrm{~m}, 10 \mathrm{H}), 5.52(\mathrm{~d}, J=6.3 \mathrm{~Hz}, 2 \mathrm{H}), 4.32$ (d, $J=5.8 \mathrm{~Hz}, 2 \mathrm{H}), 4.11(\mathrm{dt}, J=6.3,3.1 \mathrm{~Hz}, 2 \mathrm{H}), 3.93(\mathrm{~d}, J=11.8 \mathrm{~Hz}, 2 \mathrm{H}$ ), $3.74-3.61(\mathrm{~m}, 2 \mathrm{H}), 1.68(\mathrm{~s}, 6 \mathrm{H}) .{ }^{13} \mathrm{C}$ NMR $\left(75 \mathrm{MHz}, \mathrm{CDCl}_{3}\right): \delta=171.1\left(\mathrm{C}_{\mathrm{q}}\right)$, 140.4(C $\left.\mathrm{C}_{\mathrm{q}}\right), \quad 128.8(+), \quad 128.4(+), \quad 125.6(+), \quad 83.3(+), \quad 75.7(+), \quad 63.7(-), \quad 39.7\left(\mathrm{C}_{\mathrm{q}}\right)$, 23.8(+). - IR (neat): $\tilde{v}=3335,3288,2923,2821,1650,1459,1333,1270,1150$, $1117,1088,972,935,762,695,635 \mathrm{~cm}^{-1}$. - mp: $153^{\circ} \mathrm{C}$. 


\section{methyl furan-3-carboxylate (78)}<smiles>CC(=O)c1ccoc1</smiles>

Furan-3-carboxylic acid $(25 \mathrm{~g}, 223.3 \mathrm{mmol})$ was dissolved in $120 \mathrm{~mL} \mathrm{MeOH}$. After cooling to $0^{\circ} \mathrm{C}, 25 \mathrm{~mL}$ conc. $\mathrm{H}_{2} \mathrm{SO}_{4}$ were added dropwise. The reaction was stirred for $1 \mathrm{~d}$ at room temperature, $50 \mathrm{~mL}$ distilled water were added and transferred in a separation funnel. The mixture was extracted with 3 potions of $100 \mathrm{~mL} \mathrm{Et} \mathrm{t}_{2} \mathrm{O}$. The combined organic layers were washed with a saturated $\mathrm{NaHCO}_{3}$ solution, dried over $\mathrm{Na}_{2} \mathrm{SO}_{4}$ and concentrated under reduced pressure. The crude product was distilled at $15 \mathrm{mbar}, 85{ }^{\circ} \mathrm{C}$ oil bath and $55-60^{\circ} \mathrm{C}$ boiling point to yield the ester in $82 \%$ as colorless oil, which crystallized while storing at $-18^{\circ} \mathrm{C}$.

$R_{f}(P E / E A=3: 1): 0.69$.

${ }^{1} \mathbf{H}$ NMR $\left(300 \mathrm{MHz}, \mathrm{CDCl}_{3}\right): \delta=8.05-7.97(\mathrm{~m}, 1 \mathrm{H}), 7.42(\mathrm{t}, J=1.7 \mathrm{~Hz}, 1 \mathrm{H})$, $6.78-6.70(\mathrm{~m}, 1 \mathrm{H}), 3.84(\mathrm{~s}, 3 \mathrm{H}) .-{ }^{13} \mathrm{C}$ NMR $\left(75 \mathrm{MHz}, \mathrm{CDCl}_{3}\right): \delta=163.4\left(\mathrm{C}_{\mathrm{q}}\right)$, 147.6(+), 143.7(+), 119.2( $\left.\mathrm{C}_{\mathrm{q}}\right), 109.7(+), 51.4(+)$. - IR (neat): $\tilde{\mathrm{v}}=3153,3000,2954$, $1725,1579,1508,1440,1310,1194,1156,1075,984,874,793,760,601 \mathrm{~cm}^{-1}$. 
(1S,5R,6S)-6-ethyl 4-methyl 2-oxabicyclo[3.1.0]hex-3-ene-4,6-dicarboxylate (119)<smiles>CCOC(=O)C1COC=C1C(OC)OC</smiles>

A flame dried flask under nitrogen atmosphere was charged with $1 \mathrm{~mL}$ of dry DCM and $\mathrm{Cu}(\mathrm{OTf})_{2}$ (32 mg, $0.089 \mathrm{mmol}, 0.56 \mathrm{~mol} \%$ ). To this suspension $(S, S)-\mathrm{Pr}$ bis(oxazoline)-ligand (82) (31.7 mg, $0.12 \mathrm{mmol}, 0.75 \mathrm{~mol} \%$ ) was added, which caused the suspension to turn into a blue solution, which was stirred for $1 \mathrm{~h}$. This solution was transferred using a syringe filter to another flame dried flask under nitrogen atmosphere, equipped with a mineral oil bubbler and containing 78 ( $2 \mathrm{~g}$, $15.07 \mathrm{mmol}$ ) dissolved in $1 \mathrm{~mL}$ dry $\mathrm{DCM}$ at $0{ }^{\circ} \mathrm{C}$. Penylhydrazine $(8.5 \mu \mathrm{L}, 0.089$ $\mathrm{mmol}, 0.56 \mathrm{~mol} \%$ ) was added dropwise turning the solution to a dark red-brown color. After $15 \mathrm{~min}$ the dropwise addition of ethyl diazo glycine $(20.2 \mathrm{~g}$ solution of $11.6 \mathrm{wt} \%, 20.6 \mathrm{mmol}, 1.3 \mathrm{eq}$ ) in DCM was started (one drop every $10 \mathrm{sec}$ ). During the addition of diazo-compound at $0^{\circ} \mathrm{C}$ nitrogen was evolved. After completion of the reaction, the mixture was allowed to warm to room temperature and was filtered through a plug of basic alumina followed by $50 \mathrm{~mL}$ of DCM. The organic layers were concentrated under reduced pressure to afford a yellow-brown oil. The residue was purified by fractioned distillation under reduced pressure $(p=15 \mathrm{mbar}, \mathrm{bp}=55-66$ ${ }^{\circ} \mathrm{C}$ ) in order to recover the starting material $(607 \mathrm{mg}, 4.8 \mathrm{mmol}, 32 \%)$. The brown residue was purified by column chromatography $(\mathrm{PE} / \mathrm{EA}=10: 1)$ to yield the desired product as a slightly yellow solid (990 mg, $4.67 \mathrm{mmol}, 31 \%$, brsm: 45\%, 83\% ee).

$\mathrm{R}_{\mathrm{f}}(\mathrm{PE} / \mathrm{EA}=3: 1)=0.47 .-[\alpha]_{D}^{20}=-21.8(\mathrm{DCM}, \mathrm{c}=1)$.

${ }^{1} \mathrm{H}$ NMR $\left(300 \mathrm{MHz}, \mathrm{CDCl}_{3}\right): \delta=7.18(\mathrm{~s}, 1 \mathrm{H}), 4.99(\mathrm{~d}, J=5.7 \mathrm{~Hz}, 1 \mathrm{H}), 4.12(\mathrm{q}, J=7.1$ $\mathrm{Hz}, 2 \mathrm{H}$ ), $3.73(\mathrm{~s}, 3 \mathrm{H}), 3.06(\mathrm{dd}, J=5.6,2.9 \mathrm{~Hz}, 1 \mathrm{H}), 1.24(\mathrm{t}, J=7.1 \mathrm{~Hz}, 3 \mathrm{H}), 1.11(\mathrm{~d}$, $J=2.7 \mathrm{~Hz}, 1 \mathrm{H}) .-{ }^{13} \mathrm{C}$ NMR $\left(75 \mathrm{MHz}, \mathrm{CDCl}_{3}\right): \delta=171.5\left(\mathrm{C}_{\mathrm{q}}\right), 164.0\left(\mathrm{C}_{\mathrm{q}}\right), 156.4(+)$, 115.7( $\left.\mathrm{C}_{\mathrm{q}}\right), 68.9(+), 61.0(-), 51.5(+), 29.5(+), 21.5(+), 14.1(+)$. - IR (neat): $\tilde{v}=3104$, 2984, 2956, 2912, 1708, 1602, 1440, 1375, 1320, 1263, 1171, 1096, 1030, 1008, 961, 933, 896, 834, 791, 764, $729 \mathrm{~cm}^{-1}$. - MS (El-MS, $\left.70 \mathrm{eV}\right): \mathrm{m} / \mathrm{z}(\%)=212\left(\mathrm{M}^{+}\right.$, 10), 139 (100), 108 (15), 107 (24), 95 (12), 79 (13), 52 (10), 51 (17). - HRMS (EI-MS, $\mathrm{m} / \mathrm{z}): 212.0684\left(\mathrm{C}_{10} \mathrm{H}_{19} \mathrm{O}_{5}\right.$, calc. $\left.212.0685\left[\mathrm{M}^{+}\right]\right)$. - HPLC analysis (Chiralcel OD-H, $n$-heptane/PrOH 95:5, $1.0 \mathrm{~mL} / \mathrm{min}, 254 \mathrm{~nm}): \mathrm{t}_{\mathrm{r}}=6.07, \mathrm{t}_{\mathrm{r}}=7.26 ; 83 \%$ ee. 
(2Z,4E)-6-ethyl 1-methyl 2-formylhexa-2,4-dienedioate (Z/E-127) and (2E,4E)-6ethyl 1-methyl 2-formylhexa-2,4-dienedioate (E/E-127)
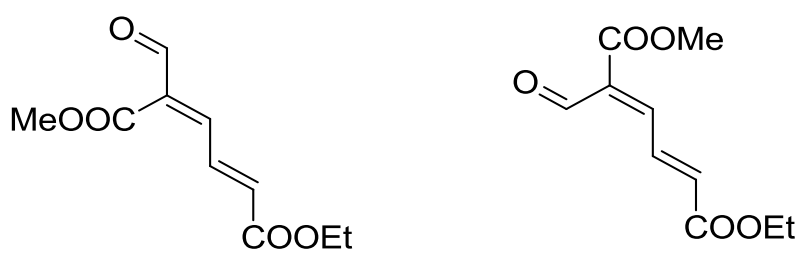

In a flame dried flask under nitrogen atmosphere 119 (300 mg, $1.41 \mathrm{mmol})$ was dissolved in $5 \mathrm{~mL}$ of dry DCM and 10 pieces of $3 \AA$ molecular sieves were added. The solution was cooled to $0^{\circ} \mathrm{C}$ and BTS (128) (686 mg, $2.82 \mathrm{mmol}, 2$ eq) dissolved in $2 \mathrm{~mL}$ of dry DCM was added dropwise. The reaction was allowed to warm to room temperature and stirred for $14 \mathrm{~h}$. The mixture was transferred to a separation funnel and diluted with $20 \mathrm{~mL}$ of $\mathrm{DCM}$ and washed with a saturated $\mathrm{NaHCO}_{3}$ solution (2 $\times 5 \mathrm{~mL}$ ). The organic layer was dried over $\mathrm{Na}_{2} \mathrm{SO}_{4}$, filtered and concentrated under reduced pressure. The crude product was purified by silica column chromatograph $(P E / E A=10: 1)$ to afford a 1.7:1 (Z/E-127 / E/E-127) mixture of isomers (260 mg, $1.22 \mathrm{mmol}, 87 \%)$.

$\mathrm{R}_{\mathrm{f}}(\mathrm{PE} / \mathrm{EA}=3: 1)=0.43$.

${ }^{1} \mathbf{H}$ NMR $\left(600 \mathrm{MHz}, \mathrm{CDCl}_{3}\right): \delta=10.12(\mathrm{~d}, J=2.7 \mathrm{~Hz}, 1 \mathrm{H}$, minor), $9.84(\mathrm{~s}, 1.7 \mathrm{H}$, major), 8.25 (dd, $J=15.5,12.0 \mathrm{~Hz}, 1 \mathrm{H}$, minor), 8.00 (dd, $J=15.4,12.0$ $\mathrm{Hz}, 1.7 \mathrm{H}$, major), 7.51 (ddd, $J=12.0,2.7,0.8 \mathrm{~Hz}, 1 \mathrm{H}$, minor), 7.37 (dd, $J=12.0,0.7$ $\mathrm{Hz}, 1.7 \mathrm{H}$, major), 6.42 (dd, $J=15.4,0.8 \mathrm{~Hz}, 1.7 \mathrm{H}$, major), 6.38 (dd, $J=15.5,0.8 \mathrm{~Hz}$, $1 \mathrm{H}$, minor), 4.21 (dq, $J=2.8,7.1 \mathrm{~Hz}, 5.4 \mathrm{H}$, major+minor), 3.89 (s, $5.1 \mathrm{H}$, major), 3.85 (s, 3H, minor), 1.27 (dt, $J=1.1,7.1 \mathrm{~Hz}, 8.1 \mathrm{H}$, major+minor). $-{ }^{13} \mathrm{C} \mathrm{NMR}(151 \mathrm{MHz}$, $\left.\mathrm{CDCl}_{3}\right): \delta=190.1\left(\mathrm{C}_{\mathrm{q}}\right.$, minor), 188.9( $\mathrm{C}_{\mathrm{q}}$, major), 165.3( $\mathrm{C}_{\mathrm{q}}$, minor), 165.0( $\mathrm{C}_{\mathrm{q}}$, minor), 165.0( $\mathrm{C}_{\mathrm{q}}$, major), 164.2( $\mathrm{C}_{\mathrm{q}}$, major), 145.9(+, minor), 145.4(+, major), 137.0(+, major), 136.8(+, minor), 136.0(+, minor), 135.2(+, major), 132.7( $\mathrm{C}_{\mathrm{q}}$, major), 129.7( $\mathrm{C}_{\mathrm{q}}$, minor), 61.1(-, major),61.1(-, minor), 52.4(+, minor), 52.3(+, major), 14.0(+). - IR (neat): $\tilde{v}=3411,2982,1711,1583,1438,1369,1303,1267,1235,1196,1148,1103,1029$, 984, 858, $734 \mathrm{~cm}^{-1}$. - MS (Cl-MS, $\left.\mathrm{NH}_{3}\right): \mathrm{m} / \mathrm{z}(\%)=230\left(\mathrm{MNH}^{4+}, 100\right), 213\left(\mathrm{MH}^{+}, 10\right)$. - HRMS (EI-MS, m/z): $212.0684\left(\mathrm{C}_{10} \mathrm{H}_{12} \mathrm{O}_{5}\right.$, calc. $\left.212.0685\left[\mathrm{M}^{+}\right]\right)$. 
(1S,5R,6S)-ethyl 4-(hydroxymethyl)-2-oxabicyclo[3.1.0]hex-3-ene-6-carboxylate (131)<smiles>CCOC(=O)C1COC=C(CO)C1</smiles>

In a flame dried flask under an atmosphere of nitrogen $119(300 \mathrm{mg}, 1.45 \mathrm{mmol}, 1$ eq) was dissolved in dry THF $(5.7 \mathrm{~mL})$ and cooled to $0{ }^{\circ} \mathrm{C}$. $\mathrm{LiAlH}_{4}(32 \mathrm{mg}, 0.85 \mathrm{mmol}$, $0.6 \mathrm{eq}$ ) was added carefully, which caused hydrogen evolution. After $1 \mathrm{~h}$ the reaction was quenched by the addition on $1 \mathrm{~mL}$ water, transferred to a separation funnel and

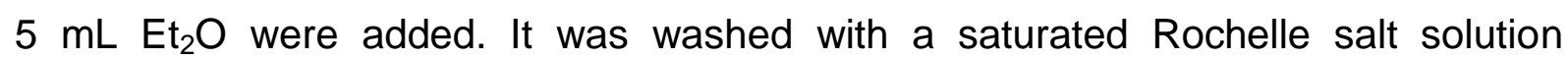
$(3 \times 2 \mathrm{~mL})$. The organic layer was dried over $\mathrm{Na}_{2} \mathrm{SO}_{4}$, filtered and concentrated under reduced pressure. The purification by silica column chromatography $(P E / E A=1: 1)$ afforded alcohol 131 as colorless solid (90 $\mathrm{mg}, 0.49 \mathrm{mmol} 34 \%$ )

$\mathrm{R}_{\mathrm{f}}(\mathrm{PE} / \mathrm{EA}=1: 1)=0.39 .-[\alpha]_{D}^{20}=-59.1(\mathrm{DCM}, \mathrm{C}=1)$.

${ }^{1} \mathrm{H}$ NMR $\left(300 \mathrm{MHz}, \mathrm{CDCl}_{3}\right): \delta=6.37(\mathrm{~s}, 3 \mathrm{H}), 4.87(\mathrm{dt}, J=5.5,0.8 \mathrm{~Hz}, 3 \mathrm{H}), 4.30(\mathrm{~s}$, $6 \mathrm{H}$ ), $4.13(\mathrm{q}, J=7.1 \mathrm{~Hz}, 7 \mathrm{H}$ ), $2.84(\mathrm{dd}, J=5.6,2.7 \mathrm{~Hz}, 3 \mathrm{H}$ ), $1.63(\mathrm{~s}, 2 \mathrm{H}), 1.26$ (t, $J=7.1 \mathrm{~Hz}, 11 \mathrm{H}), 1.08(\mathrm{~d}, J=2.6 \mathrm{~Hz}, 3 \mathrm{H}) .{ }^{13} \mathbf{C} \mathbf{N M R}\left(75 \mathrm{MHz}, \mathrm{CDCl}_{3}\right): \delta=$ 172.6 $\left(\mathrm{C}_{\mathrm{q}}\right), 143.8(+), 121.2\left(\mathrm{C}_{\mathrm{q}}\right), 67.6(+), 60.8(-), 57.3(-), 32.0(+), 22.0(+), 14.2(+)$. IR (neat): $\tilde{\mathbf{v}}=3412,2952,2879,1703,1600,1442,1378,1312,1173,1105,1034$, 976, 784, 760, $722 \mathrm{~cm}^{-1}$. - MS (EI-MS, $\left.70 \mathrm{eV}\right): \mathrm{m} / \mathrm{z}(\%)=184\left(\mathrm{M}^{+}, 17\right), 166(15), 127$ (11), 111 (100), 81 (14), 55 (12), 53 (13), 39 (12). - HRMS (PI-EIMS, m/z): 184.0738 $\left(\mathrm{C}_{9} \mathrm{H}_{12} \mathrm{O}_{4}\right.$, calc. $\left.184.0736\left[\mathrm{M}^{+}\right]\right)$. - $\mathbf{m p}: 66^{\circ} \mathrm{C}$. 
(1S,5R,6R)-methyl 6-(hydroxymethyl)-2-oxabicyclo[3.1.0]hex-3-ene-4-carboxylate (132)<smiles>COC(OC)C1COCC1CO</smiles>

In a flame dried flask under nitrogen atmosphere, 119 (300 mg, $1.45 \mathrm{mmol}, 1 \mathrm{eq}$ ) was dissolved in dry THF $\left(5.7 \mathrm{~mL}\right.$ ) and cooled to $0{ }^{\circ} \mathrm{C}$. $\mathrm{LiAlH}_{4}(32 \mathrm{mg}, 0.85 \mathrm{mmol}, 0.6 \mathrm{eq})$ was added carefully, which caused hydrogen evolution. After $1 \mathrm{~h}$ the reaction was quenched by the addition on $1 \mathrm{~mL}$ water, transferred to a separation funnel and $5 \mathrm{~mL}$ $\mathrm{Et}_{2} \mathrm{O}$ were added. It was washed with a saturated Rochelle salt solution $(3 \times 2 \mathrm{~mL})$. The organic layer was dried over $\mathrm{Na}_{2} \mathrm{SO}_{4}$, filtered and concentrated under reduced pressure. The purification by silica column chromatography $(P E / E A=1: 1)$ afforded alcohol 132 as colorless oil ( $79 \mathrm{mg}, 0.46 \mathrm{mmol}, 32 \%$ )

$\mathrm{R}_{\mathrm{f}}(\mathrm{PE} / \mathrm{EA}=1: 1)=0.27 .-[\alpha]_{D}^{20}=+15.2(\mathrm{DCM}, \mathrm{C}=1)$.

${ }^{1} \mathrm{H}$ NMR $\left(300 \mathrm{MHz}, \mathrm{CDCl}_{3}\right): \delta=7.11(\mathrm{~s}, 1 \mathrm{H}), 4.62(\mathrm{~d}, J=6.8 \mathrm{~Hz}, 1 \mathrm{H}), 3.73(\mathrm{~s}, 3 \mathrm{H})$, 3.53 (dd, $J=7.1,1.6 \mathrm{~Hz}, 2 \mathrm{H}$ ), $2.56(\mathrm{~s}, 1 \mathrm{H}$ ), 2.44 (dd, $J=5.9,3.1 \mathrm{~Hz}, 1 \mathrm{H}$ ), 0.75 (tdd, $J=7.1,3.1,1.0 \mathrm{~Hz}, 1 \mathrm{H}) .-{ }^{13} \mathrm{C}$ NMR $\left(75 \mathrm{MHz}, \mathrm{CDCl}_{3}\right): \delta=165.2\left(\mathrm{C}_{\mathrm{q}}\right), 155.9(+)$, 115.6( $\left(\mathrm{C}_{\mathrm{q}}\right), 66.7(+), 61.6(-), 51.4(+), 23.7(+), 22.0(+)$. - IR (neat): $\tilde{v}=3401,3106$, 3003, 2952, 2883, 1688, 1599, 1441, 1377, 1313, 1172, 1100, 1031, 974, 783, 760, $724 \mathrm{~cm}^{-1}$. - MS (EI-MS, $\left.70 \mathrm{eV}\right): \mathrm{m} / \mathrm{z}(\%)=169(\mathrm{M}-\mathrm{H}, 1), 152\left(\left(\mathrm{M}-\mathrm{H}_{2} \mathrm{O}\right)^{+*}, 2\right), 139$ $\left(\left(\mathrm{M}-\mathrm{CH}_{2} \mathrm{OH}\right)^{+}, \quad 100\right), 53$ (12). - HRMS (PI-EIMS, m/z): $170.0577 \quad\left(\mathrm{C}_{8} \mathrm{H}_{10} \mathrm{O}_{4}\right.$, calc. $\left.170.0579\left[\mathrm{M}^{+}\right]\right)$. 

(133)<smiles>CCOC(=O)C1CC(C(C)OC)CO1</smiles>

119 (200 mg, $0.94 \mathrm{mmol}, 1 \mathrm{eq}$ ) was dissolved in $4 \mathrm{~mL}$ of a EtOH/water mixture (95:5) and $20 \mathrm{~g} \mathrm{Pd} / \mathrm{C}(10 \%)$ were added. The reaction mixture was stirred at room temperature for $24 \mathrm{~h}$ under an atmosphere of hydrogen applied via a balloon. After filtration the solution was concentrated under reduced pressure. The purification by silica column chromatography $(\mathrm{PE} / \mathrm{EA}=5: 1)$ afforded the product as colorless crystals (50 mg, $0.24 \mathrm{mmol}, 25 \%$ ).

$\mathrm{R}_{\mathrm{f}}(\mathrm{PE} / \mathrm{EA}=3: 1)=0.52 .-[\alpha]_{D}^{20}=+58.3(\mathrm{DCM}, \mathrm{c}=0.6)$.

${ }^{1} \mathrm{H}$ NMR $\left(300 \mathrm{MHz}, \mathrm{CDCl}_{3}\right): \delta=4.24(\mathrm{dd}, J=5.4,1.2 \mathrm{~Hz}, 1 \mathrm{H}), 4.20-4.05(\mathrm{~m}, 3 \mathrm{H})$, 3.75 (s, 3H), 3.73 (dd, $J=21.3,11.4 \mathrm{~Hz}, 1 \mathrm{H}$ ), 3.40 (td, $J=9.5,5.3 \mathrm{~Hz}, 1 \mathrm{H}$ ), 2.42 (td, $J=5.3,3.8 \mathrm{~Hz}, 1 \mathrm{H}), 2.27(\mathrm{dd}, J=3.8,0.9 \mathrm{~Hz}, 1 \mathrm{H}), 1.24(\mathrm{t}, J=7.1 \mathrm{~Hz}$, $3 \mathrm{H}) .-{ }^{13} \mathrm{C} \mathrm{NMR}\left(75 \mathrm{MHz}, \mathrm{CDCl}_{3}\right): \delta=171.8\left(\mathrm{C}_{\mathrm{q}}\right), 170.6\left(\mathrm{C}_{\mathrm{q}}\right), 67.9(-), 65.8(+), 60.7(-)$, 52.3(+), 44.2(+), 27.9(+), 21.7(+), 14.1(+). - IR (neat): $\tilde{v}=3063,3002,2170,1732$, 1707, 1440, 1407, 1381, 1312, 1261, 1207, 1180, 1119, 1078, 1029, 988, 922, 865, $780,694 \mathrm{~cm}^{-1}$. - MS (EI-MS, $\left.70 \mathrm{eV}\right): \mathrm{m} / \mathrm{z}(\%)=214\left(\mathrm{M}^{+}, 1\right), 182(23), 169(18), 168$ (70), 155 (11), 154 (32), 141 (67), 140 (34), 126 (16), 125 (15), 111 (24), 109 (37), 10 (32), 100 (21), 99 (43), 97 (17), 82 (29), 81 (100), 69 (28), 59 (37), 55 (75), 53 (58), 45 (68). - HRMS (PI-EIMS, m/z): $214.0835\left(\mathrm{C}_{10} \mathrm{H}_{14} \mathrm{O}_{5}\right.$, calc. $\left.214.0841\left[\mathrm{M}^{+}\right]\right)$; mp: $68^{\circ} \mathrm{C}$. 
<smiles>CCOC(=O)C[C@H]1C[C@@H](COC)CO1</smiles>

119 (250 mg, $1.18 \mathrm{mmol}, 1$ eq) was dissolved in $5 \mathrm{~mL}$ of a $\mathrm{EtOH} /$ water mixture (95:5) and $25 \mathrm{mg} \mathrm{Pd} / \mathrm{C}(10 \%)$ were added. The mixture was stirred for $72 \mathrm{~h}$ at room temperature under an atmosphere of hydrogen applied via a balloon. After filtration and the solution was concentrated under reduced pressure and purified by silica column chromatography (PE/EA $=5: 1)$ to afford the product as colorless oil $(255 \mathrm{mg}$, $1.18 \mathrm{mmol}$, quant.).

$\mathrm{R}_{\mathrm{f}}(\mathrm{PE} / \mathrm{EA}=3: 1)=0.31 .-[\alpha]_{D}^{20}=-10.4\left(\mathrm{CHCl}_{3}, \mathrm{C}=1\right)$.

${ }^{1} \mathrm{H}$ NMR $\left(600 \mathrm{MHz}, \mathrm{CDCl}_{3}\right): \delta=4.26(\mathrm{dq}, J=8.4,6.3 \mathrm{~Hz}, 3 \mathrm{H}), 4.13(\mathrm{q}, J=7.1 \mathrm{~Hz}$, $7 \mathrm{H}$ ), 4.04 (dd, $J=8.9,6.0 \mathrm{~Hz}, 3 \mathrm{H}$ ), 3.92 (t, $J=8.5 \mathrm{~Hz}, 3 \mathrm{H}$ ), 3.68 (s, 10H), 3.13 (qd, $J=8.2,6.0 \mathrm{~Hz}, 3 \mathrm{H}$ ), 2.67 (dd, $J=15.7,7.2 \mathrm{~Hz}, 3 \mathrm{H}$ ), $2.53(\mathrm{dd}, J=15.7,6.0 \mathrm{~Hz}, 3 \mathrm{H}$ ), 2.36 (ddd, $J=12.7,8.8,6.3 \mathrm{~Hz}, 3 \mathrm{H}$ ), 1.89 (dt, $J=12.7,8.2 \mathrm{~Hz}, 3 \mathrm{H}$ ), 1.24 (t, $J=7.2 \mathrm{~Hz}, 11 \mathrm{H}) .-{ }^{13} \mathrm{C}$ NMR $\left(151 \mathrm{MHz}, \mathrm{CDCl}_{3}\right): \delta=173.8\left(\mathrm{C}_{\mathrm{q}}\right), 170.9\left(\mathrm{C}_{\mathrm{q}}\right), 75.9(+)$, 69.8(-), 60.5(-), 52.0(+), 44.0(+), 40.0(-), 34.8(-), 14.1(+). - IR (neat): $\tilde{\mathrm{v}}=2983,1729$, 1438, 1370, 1155, 1064, 1201, 936, 850, $673 \mathrm{~cm}^{-1}$. - MS $\left(\mathrm{Cl}-\mathrm{MS}, \mathrm{NH}_{3}\right): \mathrm{m} / \mathrm{z}(\%)=$ 235 (21), $234\left(\mathrm{MNH}_{4}^{+}, 100\right), 217\left(\mathrm{MH}^{+}, 35\right)$. - HRMS (ESI, m/z): $217.1069\left(\mathrm{C}_{10} \mathrm{H}_{17} \mathrm{O}_{5}\right.$, calc. $\left.217.1071\left[\mathrm{MH}^{+}\right]\right)$. 
(3S,5S)-methyl 5-(2-methoxy-2-oxoethyl)tetrahydrofuran-3-carboxylate (135)

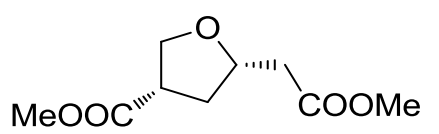

In a flame dried flask under nitrogen atmosphere $119(50 \mathrm{mg}, 0.236 \mathrm{mmol})$ was dissolved in $2.5 \mathrm{~mL} \mathrm{MeOH}$. The flask was cooled to $0{ }^{\circ} \mathrm{C}$ and $\mathrm{Mg}$ turnings $(5.7 \mathrm{mg}$, $0.236 \mathrm{mmol}, 1 \mathrm{eq})$ were added. When the reaction started hydrogen was evolved (mineral oil bubbler) and white precipitate occurred. After $30 \mathrm{~min}$ the precipitate and the remaining $\mathrm{Mg}$ were filtered off. The solution was concentrated under reduced pressure. The crude mixture was purified by silica column chromatography $(\mathrm{PE} / \mathrm{EA}=3: 1)$ to afford the product as $1: 1$ mixture of diastereomers (18 $\mathrm{mg}, 0.089$ $\mathrm{mmol}, 38 \%)$.

$\mathrm{R}_{\mathrm{f}}(\mathrm{PE} / \mathrm{EA}=3: 1)=0.39 .-[\alpha]_{D}^{20}=+17.6(\mathrm{DCM}, \mathrm{c}=1)$.

${ }^{1} \mathrm{H}$ NMR $\left(600 \mathrm{MHz}, \mathrm{CDCl}_{3}\right): \delta=4.40-4.34(\mathrm{~m}, 1 \mathrm{H}$, diast. 1), 4.29 (tt, $J=7.2,6.2 \mathrm{~Hz}$, $1 \mathrm{H}$, diast. 2), $4.16-4.11(\mathrm{~m}, 1 \mathrm{H}$, diast. 1), 4.07 (dd, $J=8.9,6.0 \mathrm{~Hz}, 1 \mathrm{H}$, diast. 2), 3.94 (t, $J=8.5 \mathrm{~Hz}, 1 \mathrm{H}$, diast. 2), 3.87 (dd, $J=8.9,6.7 \mathrm{~Hz}, 1 \mathrm{H}$, diast. 1), $3.70(\mathrm{~s}, 6 \mathrm{H})$, $3.69(\mathrm{~s}, 6 \mathrm{H}), 3.19-3.11(\mathrm{~m}, 2 \mathrm{H}), 2.70$ (dd, $J=15.7,7.4 \mathrm{~Hz}, 1 \mathrm{H}$, diast. 2), 2.61 (dd, $J$ $=15.3,7.3 \mathrm{~Hz}, 1 \mathrm{H}$, diast. 1), 2.57 (dd, $J=15.7,5.8 \mathrm{~Hz}, 1 \mathrm{H}$, diast. 2), 2.52 (dd, $J=15.3,5.8 \mathrm{~Hz}, 1 \mathrm{H}$, diast. 1), $2.46-2.40$ (m,1H, diast. 1), 2.38 (ddd, $J=12.7,8.8$, $6.4 \mathrm{~Hz}, 1 \mathrm{H}$, diast. 2), 1.91 (dt, $J=12.7,8.2 \mathrm{~Hz}, 1 \mathrm{H}$, diast. 2), 1.83 (ddd, $J=12.8,9.5$, $7.7 \mathrm{~Hz}, 1 \mathrm{H}$, diast. 1). - ${ }^{13} \mathrm{C}$ NMR (151 MHz, $\left.\mathrm{CDCl}_{3}\right): \delta=173.8\left(\mathrm{C}_{\mathrm{q}}\right), 171.4\left(\mathrm{C}_{\mathrm{q}}\right.$, diast. 2), 171.2( $\mathrm{C}_{\mathrm{q}}$, diast. 1), 75.9(+,diast. 2), 75.4(+, diast. 1), 70.1(-,diast. 1), 69.9(-,diast. 2), 52.1(+), 52.1(+), 51.8(+), 51.7(+), 44.1(-,diast. 2), 43.6(-,diast. 1), 39.9(-,diast. 1), 39.9(-,diast. 2), 34.9(-,diast. 2), 34.7(-,diast. 1). IR (neat): $\tilde{v}=2989,2955,1731$, 1437, 1371, 1263, 1197, 1171, 1062, 1016, 936, $847 \mathrm{~cm}^{-1}$. - MS (EI-MS, $\left.70 \mathrm{eV}\right)$ : $\mathrm{m} / \mathrm{z}(\%)=203\left(\mathrm{MH}^{+}, 1\right), 171$ (41), 170 (16), 142 (62), 129 (92), 116 (54), 102 (12), 101 (61), 97 (13), 87 (18), 83 (11), 82 (14), 81 (14), 74 (18), 69 (100), 59 (53), 55 (23), 45 (13), 43 (22). 


\section{4-methylbenzenesulfonyl azide (87)}<smiles>Cc1ccc(S(N)(=O)=O)cc1</smiles>

A $2 \mathrm{~L}$ flask was charged with sodium azide $(71.5 \mathrm{~g}, 1.1 \mathrm{~mol}, 1.1 \mathrm{eq})$ and $400 \mathrm{~mL}$ of 90\% aqueous EtOH. In an additional $2 \mathrm{~L}$ flask tosyl chloride $(190.5 \mathrm{~g}, 1 \mathrm{~mol}, 1 \mathrm{eq})$ was dissolved in $1 \mathrm{~L}$ of $\mathrm{EtOH}$ (it was warmed up to $50^{\circ} \mathrm{C}$ for complete dissolving if necessary) and was added to the azide solution. After $3 \mathrm{~h}$ the formed $\mathrm{NaCl}$ was filtered off. The solvent was removed under reduced pressure (bath temperature $35^{\circ} \mathrm{C}$, minimum applied pressure $110 \mathrm{mbar}$ ). The crude product was transferred to a separation funnel, $1 \mathrm{~L}$ water was added (without shaking) to induce phase separation. The product phase (lower one) was separated and washed with water ( $2 \times 100 \mathrm{~mL}$ ), dried over $\mathrm{Na}_{2} \mathrm{SO}_{4}$ and filtered to afford the desired product as an oil, which crystallized while storing at $-18{ }^{\circ} \mathrm{C}(150 \mathrm{~g}, 0.76 \mathrm{~mol}, 76 \%)$.

${ }^{1} \mathbf{H}$ NMR $\left(300 \mathrm{MHz}, \mathrm{CDCl}_{3}\right): \delta=7.83(\mathrm{~d}, J=8.3 \mathrm{~Hz}, 2 \mathrm{H}), 7.40(\mathrm{~d}, J=8.3 \mathrm{~Hz}, 2 \mathrm{H})$, $2.47(\mathrm{~s}, 3 \mathrm{H}) .-{ }^{13} \mathrm{C}$ NMR $\left(75 \mathrm{MHz}, \mathrm{CDCl}_{3}\right): \delta=146.3\left(\mathrm{C}_{\mathrm{q}}\right), 135.4\left(\mathrm{C}_{\mathrm{q}}\right), 130.0(+)$, 127.5(+), 21.7(+). - IR (neat): $\tilde{v}=2121,1595,1366,1161,1084,813,743,655 \mathrm{~cm}^{-1}$. 
tert-butyl 2-diazoacetate (89)<smiles>CCCOC(=O)C=N</smiles>

A three-necked $2 \mathrm{~L}$ flask, equipped with an internal thermometer, a mineral oil bubbler and a stopper was charged with $900 \mathrm{~mL} n$-pentane and cooled to $0{ }^{\circ} \mathrm{C}$. At that temperature tosyl azide (87) $(62.6 \mathrm{~g}, 318 \mathrm{mmol}, 1 \mathrm{eq})$, tert-butyl acetoacetate (88) $(52.8 \mathrm{~mL}, 318 \mathrm{mmol}, 1 \mathrm{eq})$ and $\mathrm{Bu}_{4} \mathrm{NBr}(2.05 \mathrm{~g}, 6.36 \mathrm{mmol}, 2 \mathrm{~mol} \%)$ were added. The resulting mixture was treated with a cold sodium hydroxide solution ( $36 \mathrm{~g}$, $0.9 \mathrm{~mol}, 2.8 \mathrm{eq}$, dissolved in $300 \mathrm{~mL}$ water), which was added in portions over a period of $15 \mathrm{~min}$. When the addition was finished, the ice bath was removed, the flask was equipped with a mineral oil bubbler and stirring was continued for $20 \mathrm{~h}$. The resulting white solid was removed via suction by the help of Celite, and the pad was washed with $100 \mathrm{~mL} n$-pentane. The filtrate was transferred to a separation funnel, the phases were separated and the aqueous phase was washed with $n$-pentane $(3 \times 100 \mathrm{~mL})$. The combined organic layers were washed with water $(2 \times 200 \mathrm{~mL})$ and brine $(1 \times 200 \mathrm{~mL})$ and dried over $\mathrm{MgSO}_{4}$. After filtration the solvent was removed under reduced pressure (water bath $15{ }^{\circ} \mathrm{C}$, minimum pressure $110 \mathrm{mbar}$ ) to afford pure product 89 as yellow liquid (39.6 g, $279 \mathrm{mmol}, 88 \%$ ). This liquid was diluted in the necessary amount of DCM to adjust the required wt\% in DCM for the further reaction.

${ }^{1} \mathrm{H}$ NMR $\left(300 \mathrm{MHz}, \mathrm{CDCl}_{3}\right): \delta=4.55(\mathrm{~s}, 1 \mathrm{H}), 1.40(\mathrm{~s}, 9 \mathrm{H})$. 
(1S,5R,6S)-6-tert-butyl 4-methyl 2-oxabicyclo[3.1.0]hex-3-ene-4,6-dicarboxylate (118)<smiles>CCOC(=O)C1CC2OC=C(C(C)OC)C1O2</smiles>

A flame dried flask under nitrogen atmosphere was charged with $3 \mathrm{~mL}$ of dry DCM and $\mathrm{Cu}(\mathrm{OTf})_{2}(884 \mathrm{mg}, 2.28 \mathrm{mmol}, 1.12 \mathrm{~mol} \%)$. To this suspension $(\mathrm{S}, \mathrm{S})-\mathrm{Pr}$ bis(oxazoline)-ligand (813 mg, $3.05 \mathrm{mmol}, 1.5 \mathrm{~mol} \%$ ) was added, which caused the suspension to turn into a blue solution, which was stirred for $1 \mathrm{~h}$. This solution was transferred using a syringe filter to another flame dried flask under nitrogen atmosphere, equipped with a mineral oil bubbler and containing 78 (25.64 g, $203.5 \mathrm{mmol}$ ) dissolved in $10 \mathrm{~mL} \mathrm{DCM}$ at $0{ }^{\circ} \mathrm{C}$. Penylhydrazine $(225 \mathrm{~mL}, 2.28 \mathrm{mmol}$, $1.12 \mathrm{~mol} \%$ ) was added dropwise turning the solution to a dark red-brown color. After $15 \mathrm{~min}$ the dropwise addition of tert-butyl diazo glycine $(561.5 \mathrm{~g}$ solution of $6.7 \mathrm{wt} \%$, $264.6 \mathrm{mmol}, 1.3 \mathrm{eq}$ ) in DCM was started (one drop every $10 \mathrm{sec}$ ). During the addition of diazo-compound at $0^{\circ} \mathrm{C}$ nitrogen is evolved. After completion, the mixture was allowed to warm to room temperature and was filtered through a plug of basic alumina followed by $500 \mathrm{~mL}$ of DCM. The organic layers were concentrated under reduced pressure to afford a yellow-brown oil. The residue was purified by fractioned distillation under reduced pressure $\left(p=15 \mathrm{mbar}, b p=55-66^{\circ} \mathrm{C}\right)$ to recover starting material $(7.26 \mathrm{~g}, 77.3 \mathrm{mmol}, 38 \%)$. The brown residue was purified by column chromatography $(P E / E A=15: 1)$ to yield the desired product as a slightly yellow solid (18.56 g, $77.3 \mathrm{mmol}, 38 \%$, brsm: 53\%, 83\% ee).

$\mathrm{R}_{\mathrm{f}}(\mathrm{PE} / \mathrm{EA}=5: 1)=0.61 .-[\alpha]_{D}^{20}=-20.5(\mathrm{DCM}, \mathrm{c}=1)$.

${ }^{1} \mathrm{H}$ NMR $\left(300 \mathrm{MHz}, \mathrm{CDCl}_{3}\right): \delta=7.15(\mathrm{~s}, 1 \mathrm{H}), 4.91(\mathrm{dt}, J=5.6,0.8 \mathrm{~Hz}, 1 \mathrm{H}), 3.72(\mathrm{~s}$, $3 \mathrm{H}), 2.99(\mathrm{dd}, J=5.6,2.9 \mathrm{~Hz}, 1 \mathrm{H}), 1.42(\mathrm{~d}, J=9.0 \mathrm{~Hz}, 9 \mathrm{H}), 1.05-0.97(\mathrm{~m}$, $1 \mathrm{H}) . \quad{ }^{13} \mathrm{C} \mathrm{NMR}\left(75 \mathrm{MHz}, \mathrm{CDCl}_{3}\right): \delta=170.7\left(\mathrm{C}_{\mathrm{q}}\right), 164.1\left(\mathrm{C}_{\mathrm{q}}\right), 156.3(+), 115.7\left(\mathrm{C}_{\mathrm{q}}\right)$, 81.3( $\left.\mathrm{C}_{\mathrm{q}}\right), 68.8(+), 51.4(+), 29.0(+), 28.0(+), 22.4(+) .-$ IR (neat): $\tilde{\mathbf{v}}=3109,3071,2977$, 1699, 1599, 1444, 1367, 1271, 1157, 1097, 1045, 975, 830, 792, 760, $720 \mathrm{~cm}^{-1}$. - MS (El-MS, $70 \mathrm{eV}): \mathrm{m} / \mathrm{z}(\%)=240\left(\mathrm{M}^{+}, 1\right), 184(78), 176$ (30), 166 (14), $155(12), 152$ (17), 139 (100), 108 (19), 107 (19), 57 (91). - HRMS (PI-EIMS, m/z): 240.0999 $\left(\mathrm{C}_{12} \mathrm{H}_{16} \mathrm{O}_{5}\right.$, calc. $\left.240.0998\left[\mathrm{M}^{+}\right]\right)$. - mp: $72{ }^{\circ} \mathrm{C}$. - HPLC analysis (Phenomenex Lux Cellulose-2, nheptane/PrOH 99:1, $1.0 \mathrm{~mL} / \mathrm{min}, 254 \mathrm{~nm}): \mathrm{t}_{\mathrm{r}}=13.17, \mathrm{t}_{\mathrm{r}}=17.81$; $83 \%$ ee. 
(1S,5R,6S)-6-(tert-butoxycarbonyl)-2-oxabicyclo[3.1.0]hex-3-ene-4-carboxylic acid (138)<smiles>O=C(O)C1C=CC(C(=O)OCc2ccccc2)C1</smiles>

118 (12.31 g, $51.3 \mathrm{mmol}$ ) was dissolved in $400 \mathrm{~mL}$ of a $3: 1$ water-THF mixture. To the resulting turbid solution $\mathrm{LiOH}(1.35 \mathrm{~g}, 56.4 \mathrm{mmol}, 1.1 \mathrm{eq})$ was slowly added, which turns the color to yellow. After $6 \mathrm{~h}$ of stirring, the reaction mixture was transferred to a separation funnel and washed with $\mathrm{Et}_{2} \mathrm{O}(2 \times 150 \mathrm{~mL})$ to recover remaining starting material (15\%). The aqueous layer was acidified with $\mathrm{HCl}(2 \mathrm{M})$ to a pH of about 2 and extracted with $\mathrm{Et}_{2} \mathrm{O}(3 \times 150 \mathrm{~mL})$. The combined organic layers were dried over $\mathrm{Na}_{2} \mathrm{SO}_{4}$, filtered and concentrated under reduced pressure to afford the desired product as a colorless solid (9.85 g, $43.6 \mathrm{mmol}, 85 \%$, brsm: 100\%).

$\mathrm{R}_{\mathrm{f}}(\mathrm{PE} / \mathrm{EA}=1: 1)=0.26 .-[\alpha]_{D}^{20}=-23.8(\mathrm{MeOH}, \mathrm{c}=1)$.

${ }^{1} \mathrm{H}$ NMR (300 MHz, Acetone): $\delta=10.23(\mathrm{~s}, 1 \mathrm{H}), 7.36(\mathrm{~s}, 1 \mathrm{H}), 5.03(\mathrm{~d}, J=5.6 \mathrm{~Hz}$, $1 \mathrm{H}), 2.92(\mathrm{dd}, J=5.6,2.8 \mathrm{~Hz}, 1 \mathrm{H}), 1.44(\mathrm{~s}, 10 \mathrm{H}), 1.05(\mathrm{~d}, J=2.6 \mathrm{~Hz}, 1 \mathrm{H}) .-{ }^{13} \mathrm{C} \mathrm{NMR}$ (75 MHz, Acetone): $\delta=171.2\left(\mathrm{C}_{\mathrm{q}}\right), 164.8\left(\mathrm{C}_{\mathrm{q}}\right), 157.5(+), 116.6\left(\mathrm{C}_{\mathrm{q}}\right), 81.5\left(\mathrm{C}_{\mathrm{q}}\right), 69.2(+)$, 29.7(+), 28.2(+), 22.9(+). - IR (neat): $\tilde{\mathbf{v}}=3038,2976,1711,1655,1602,1447,1385$, 1365, 1275, 1159, 1107, 975, 897, 836, 760, $717 \mathrm{~cm}^{-1}$. - MS (EI-MS, $70 \mathrm{eV}$ ): $\mathrm{m} / \mathrm{z}(\%)=226\left(\mathrm{M}^{+}, 1\right), 170(45), 153(24), 152(15), 125(58), 107(10), 57(100), 51$ (11), 41 (32), 39 (10). - HRMS (El-MS, m/z): $226.0841\left(\mathrm{C}_{11} \mathrm{H}_{14} \mathrm{O}_{5}\right.$, calc. 226.0841 $\left.\left[\mathrm{M}^{+}\right]\right)$. - mp: $142^{\circ} \mathrm{C}$. 
(1S,4S,5S,6S)-6-(tert-butoxycarbonyl)-2-oxabicyclo[3.1.0]hexane-4-carboxylic acid (139)<smiles>CCOC(=O)C1COCC1C(=O)O</smiles>

$138(9.3 \mathrm{~g}, 41.2 \mathrm{mmol})$ was dissolved in $200 \mathrm{~mL}$ of an EtOH/water mixture (95:5) and $900 \mathrm{mg} \mathrm{Pd} / \mathrm{C}$ (10\%) were added. After two times vacuum-hydrogen-spilling hydrogen was applied via a balloon. When the starting material was consumed (about $4 \mathrm{~h}$ ), the mixture was filtered through celite and washed with $100 \mathrm{~mL} \mathrm{EtOH}$, twice. The organic layer was concentrated under reduced pressure to afford the desired product as colorless oil (9.4 g, $41.2 \mathrm{mmol}, 100 \%)$ which crystallizes at ambient temperature after some days.

$\mathrm{R}_{\mathrm{f}}(\mathrm{PE} / \mathrm{EA}=1: 1)=0.2 .-[\alpha]_{D}^{20}=+62.4(\mathrm{MeOH}, \mathrm{c}=1)$.

${ }^{1} \mathrm{H}$ NMR $\left(300 \mathrm{MHz}, \mathrm{CDCl}_{3}\right): \delta=8.77(\mathrm{~s}, 1 \mathrm{H}), 4.23-4.11(\mathrm{~m}, 2 \mathrm{H}), 3.69(\mathrm{t}, J=9.8 \mathrm{~Hz}$, $1 \mathrm{H}$ ), 3.42 (td, $J=9.5,5.4 \mathrm{~Hz}, 1 \mathrm{H}$ ), 2.41 (td, $J=5.4,3.8 \mathrm{~Hz}, 1 \mathrm{H}$ ), 2.21 (dd, $J=3.7,0.8$ $\mathrm{Hz}, 1 \mathrm{H}), 1.42(\mathrm{~s}, 9 \mathrm{H}) .{ }^{13} \mathrm{C}$ NMR $\left(75 \mathrm{MHz}, \mathrm{CDCl}_{3}\right): \delta=176.9\left(\mathrm{C}_{\mathrm{q}}\right), 169.8\left(\mathrm{C}_{\mathrm{q}}\right)$, 81.2( $\left.\mathrm{C}_{q}\right), 67.7(-), 65.7(+), 44.2(+), 28.0(+), 27.4(+), 22.7(+) .-$ IR (neat): $\tilde{v}=3192$, 2984, 1703, 1401, 1366, 1320, 1197, 1152, 1116, 1073, 981, 952, 870, 841, 779, 725, $674 \mathrm{~cm}^{-1}$. - MS (ESI-MS): m/z (\%) = 456 (19), $455\left((2 \mathrm{M}-\mathrm{H})^{-}, 82\right), 274(14), 273$ $\left(\mathrm{M}+\mathrm{HCOO}^{-}, 100\right), 227\left((\mathrm{M}-\mathrm{H})^{-}, 3\right)$. - HRMS (ESI-MS, m/z): $227.0927\left(\mathrm{C}_{11} \mathrm{H}_{15} \mathrm{O}_{5}\right.$, calc. $227.0925[(\mathrm{M}-\mathrm{H})])$. $-\mathbf{m p :} 92^{\circ} \mathrm{C}$. 
(1S,4R,5S,6S)-tert-butyl-4-(hydroxymethyl)-2-oxabicyclo[3.1.0]hexane-6carboxylate (140)

HO_N"

In a flame dried flask under nitrogen atmosphere $139(377 \mathrm{mg}, 1.65 \mathrm{mmol})$ was dissolved in $30 \mathrm{~mL}$ of dry THF and cooled to $0^{\circ} \mathrm{C}$. $\mathrm{BH}_{3} \cdot \mathrm{THF}$ ( $2 \mathrm{~mL}$ of $1 \mathrm{M}$ solution in THF, $1.2 \mathrm{eq}$ ) was added dropwise, which caused hydrogen evolution. The reaction was stirred for $1 \mathrm{~h}$ at $0{ }^{\circ} \mathrm{C}$, warmed to room temperature and stirred for additional $12 \mathrm{~h}$. The reaction was quenched by the addition of $1 \mathrm{~mL}$ of water. It was transferred to a separation funnel, mixed with $2 \mathrm{~mL}$ of a saturated $\mathrm{NH}_{4} \mathrm{Cl}$ solution and extracted with EA $(3 \times 40 \mathrm{~mL})$. The combined organic layers were dried over $\mathrm{Na}_{2} \mathrm{SO}_{4}$, filtered and concentrated under reduced pressure. The crude product was purified by silica column chromatography $(\mathrm{PE} / \mathrm{EA}=3: 1)$ to afford the product as colorless crystals (78 $\mathrm{mg}, 0.363 \mathrm{mmol}, 22 \%)$.

$\mathrm{R}_{\mathrm{f}}(\mathrm{PE} / \mathrm{EA}=1: 1)=0.40 .-[\alpha]_{D}^{20}=+54.8(\mathrm{MeOH}, \mathrm{C}=1)$.

${ }^{1} \mathrm{H}$ NMR $\left(300 \mathrm{MHz}, \mathrm{CDCl}_{3}\right): \delta=4.16(\mathrm{~d}, J=5.5 \mathrm{~Hz}, 1 \mathrm{H}), 4.07(\mathrm{t}, J=9.1 \mathrm{~Hz}, 1 \mathrm{H}), 3.77$ (dd, $J=10.6,6.9 \mathrm{~Hz}, 1 \mathrm{H}$ ), $3.64(\mathrm{dd}, J=10.6,6.9 \mathrm{~Hz}, 1 \mathrm{H}), 3.14(\mathrm{t}, J=9.8 \mathrm{~Hz}, 1 \mathrm{H}$ ), 2.88 - $2.73(\mathrm{~m}, 1 \mathrm{H}), 2.13(\mathrm{dd}, J=9.3,5.2 \mathrm{~Hz}, 1 \mathrm{H}), 1.97(\mathrm{~s}, 1 \mathrm{H}), 1.93(\mathrm{~d}, J=3.9 \mathrm{~Hz}$, $1 \mathrm{H}), 1.41(\mathrm{~s}, 9 \mathrm{H}) .-{ }^{13} \mathrm{C}$ NMR $\left(75 \mathrm{MHz}, \mathrm{CDCl}_{3}\right): \delta=170.3\left(\mathrm{C}_{\mathrm{q}}\right), 80.7\left(\mathrm{C}_{\mathrm{q}}\right), 69.1(-)$, 65.6(+), 62.9(-), 42.3(+), 28.1(+), 26.8(+), 21.8(+). - IR (neat): $\tilde{v}=3503,3389,3314$, 2977, 2823, 1705, 1691, 1398, 1368, 1314, 1261, 1153, 1106, 1064, 1038, 981, 947, 924, 883, 837, 719, 694, $658 \mathrm{~cm}^{-1}$. - MS $\left(\mathrm{Cl}-\mathrm{MS}, \mathrm{NH}_{3}\right): \mathrm{m} / \mathrm{z}(\%)=232\left(\mathrm{MNH}_{4}^{+}, 100\right)$, $215\left(\mathrm{MH}^{+}, 14\right), 176$ (45). - HRMS (LSI-MS, m/z): $215.1278\left(\mathrm{C}_{11} \mathrm{H}_{19} \mathrm{O}_{4}\right.$, calc. 215.1283 $\left.\left[\mathrm{MH}^{+}\right]\right)$. - mp: $55-70{ }^{\circ} \mathrm{C}$. 
(3S,4R)-benzyl-5-(benzyloxy)-4-(2-(benzyloxy)-2-oxoethyl)tetrahydrofuran-3carboxylate (142)

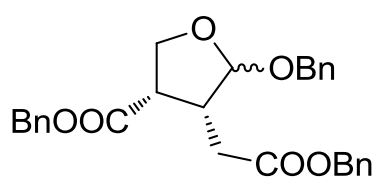

139 (500 mg, $2.19 \mathrm{mmol}$ ) was dissolved in $25 \mathrm{~mL} \mathrm{BnOH}$ cooled to $0{ }^{\circ} \mathrm{C}$ and conc. $\mathrm{H}_{2} \mathrm{SO}_{4}(0.33 \mathrm{~mL}, 6.19 \mathrm{mmol}, 2.8 \mathrm{eq})$ was added by an addition funnel over $15 \mathrm{~min}$. The mixture was allowed to warm to room temperature and stirred over night. $\mathrm{NEt}_{3}$ (1.72 $\mathrm{mL}, 12.4 \mathrm{mmol}, 2$ eq based on $\mathrm{H}_{2} \mathrm{SO}_{4}$ ) was added dropwise and the solvent was removed by distillation under reduced pressure. The set of diastereomers was separated from by-products by silica column chromatography $(P E / E A=15: 1)$ to afford 142 (303 mg, $0.66 \mathrm{mmol}, 30 \%$ ) as yellow oil, which was used in the next reaction without further separation.

$R_{f}(P E / E A=10: 1)=0.25-0.14$

${ }^{1} \mathrm{H}$ NMR $\left(300 \mathrm{MHz}, \mathrm{CDCl}_{3}\right): \delta=7.40-7.21(\mathrm{~m}, 15 \mathrm{H}), 5.30-4.95(\mathrm{~m}, 5 \mathrm{H}), 4.68(\mathrm{dd}$, $J=11.9,5.4 \mathrm{~Hz}, 1 \mathrm{H}), 4.42(\mathrm{dd}, J=20.8,11.9 \mathrm{~Hz}, 1 \mathrm{H}), 4.25-4.09(\mathrm{~m}, 2 \mathrm{H}), 3.70-$ $3.51(\mathrm{~m}, 1 \mathrm{H}), 3.13-2.92(\mathrm{~m}, 1 \mathrm{H}), 2.77-2.31(\mathrm{~m}, 2 \mathrm{H}) .-{ }^{13} \mathrm{C} \mathrm{NMR}\left(75 \mathrm{MHz}, \mathrm{CDCl}_{3}\right)$ : $\delta=172.9\left(\mathrm{C}_{\mathrm{q}}\right), \quad 171.8\left(\mathrm{C}_{\mathrm{q}}\right), \quad 171.5\left(\mathrm{C}_{\mathrm{q}}\right), \quad 171.5\left(\mathrm{C}_{\mathrm{q}}\right), \quad 137.9\left(\mathrm{C}_{\mathrm{q}}\right), \quad 137.8\left(\mathrm{C}_{\mathrm{q}}\right), \quad 135.7\left(\mathrm{C}_{\mathrm{q}}\right)$, 135.5(C $\left.\mathrm{C}_{\mathrm{q}}\right), 128.6(+), 128.6(+), 128.6(+), 128.4(+), 128.4(+), 128.4,128.3(+), 128.3(+)$, 128.2(+), 127.7(+), 127.7(+), 127.6(+), 106.8(+), 103.3(+), 69.2(-), 68.9(-), 68.5(-), 67.8(-), 66.9(-), 66.7(-), 66.5(-), 66.4(-), 46.9(+), 45.2(+), 44.0(+), 43.9(+), 33.2(-), 32.2(-). - IR (neat): $\tilde{v}=3033,2944,2898,1731,1497,1455,1388,1347,1245,1166$, 1098, 1055, 1006, 948, 913, 734, $695 \mathrm{~cm}^{-1}$. - MS (ESI-MS, m/z): 943 (18), 939 (37), $938\left(2 \mathrm{MNH}_{4}{ }^{+}, 45\right), 479(11), 478\left(\mathrm{MNH}_{4}{ }^{+}, 58\right), 354(27), 353\left(\mathrm{MNH}_{4}{ }^{+}-\mathrm{BnOH}, 100\right)$. 
(3S,3aR,6aR)-5-oxohexahydrofuro[2,3-b]furan-3-carboxylic acid (145)

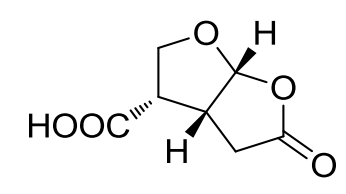

$139(2.64 \mathrm{~g}, 11.6 \mathrm{mmol})$ was dissolved in $30 \mathrm{~mL}$ THF and cooled to $0{ }^{\circ} \mathrm{C}$. To the cooled solution $90 \mathrm{~mL} \mathrm{HCl}(2 \mathrm{M})$ were added dropwise within $1 \mathrm{~h}$. The resulting mixture was allowed to warm to room temperature and stirred for $12 \mathrm{~h}$. The solvent was evaporated under reduced pressure to afford the crude product as brownish solid which was used without further purification. For analytic reasons the crude product can be purified by silica column chromatography (toluene/ethyl formate/formic acid $=5: 4: 1$ ).

$\mathrm{R}_{\mathrm{f}}(\mathrm{PE} / \mathrm{EA}=1: 1)=0.09 .-[\alpha]_{D}^{20}=-52.2(\mathrm{MeOH}, \mathrm{c}=1)$.

${ }^{1} \mathrm{H}$ NMR (600 MHz, DMSO): $\delta=12.85$ (s, 2H), 6.07 (d, J = 5.4 Hz, 2H), 4.11 (dd, $J=9.0,7.6 \mathrm{~Hz}, 2 \mathrm{H}$ ), 3.86 (dd, $J=10.9,9.1 \mathrm{~Hz}, 2 \mathrm{H}$ ), 3.40 (ddd, $J=15.4,10.3,5.0 \mathrm{~Hz}$, 2H), 3.29 (ddd, $J=10.9,9.0,7.6 \mathrm{~Hz}, 3 \mathrm{H}$ ), 2.80 (dd, $J=18.8,10.6 \mathrm{~Hz}, 2 \mathrm{H}$ ), 2.36 (dd, $J=18.8,4.7 \mathrm{~Hz}, 2 \mathrm{H}) .-{ }^{13} \mathrm{C}$ NMR (151 MHz, DMSO): $\delta=175.1\left(\mathrm{C}_{\mathrm{q}}\right), 171.4\left(\mathrm{C}_{\mathrm{q}}\right)$, 107.7(+), 67.3(-), 46.2(+), 39.8(+), 29.9(-). - IR (neat) $\tilde{v}=3086,3008,2904,1773$, 1711, 1416, 1367, 1295, 1244, 1182, 1132, 1103, 966, 843, 802, 735, $664 \mathrm{~cm}^{-1}$. MS (El-MS, $70 \mathrm{eV}): \mathrm{m} / \mathrm{z}(\%)=173\left(\mathrm{MH}^{+}, 1\right), 98$ (15), 86 (16), 85 (27), 83 (76), 82 (100), 81 (12), 73 (10), 69 (10), 68 (16), 55 (50), 54 (10). - HRMS (El-MS, m/z): $173.0454\left(\mathrm{C}_{7} \mathrm{H}_{9} \mathrm{O}_{5}\right.$, calc. $\left.173.0450\left[\mathrm{MH}^{+}\right]\right) .-\mathrm{mp}=170{ }^{\circ} \mathrm{C}$. 
(3S,3aS,6aS)-5-oxohexahydrofuro[2,3-b]furan-3-carboxylic acid (57)

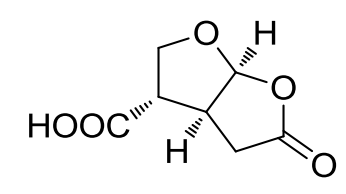

Crude 145 (2 g, $11.6 \mathrm{mmol})$ was dissolved in $10 \mathrm{~mL}$ pyridine together with 10 drops of water and was stirred for $2 \mathrm{~h}$ at room temperature. Pyridine was removed by co-distillation with toluene $(3 \times 5 \mathrm{~mL})$ under reduced pressure. The crude mixture was purified by silica column chromatography (toluene/ethylformate/formic acid $=5: 4: 1$ ) to afford the desired product as slightly yellow solid $(1.49 \mathrm{~g}, 8.66 \mathrm{mmol}, 75 \%$ based on 139).

$\mathrm{R}_{\mathrm{f}}(\mathrm{PE} / \mathrm{EA}=1: 1)=0.09 .-[\alpha]_{D}^{20}=-19.2(\mathrm{MeOH}, \mathrm{c}=1)$.

${ }^{1} \mathrm{H}$ NMR (400 MHz, MeOD): $\delta=6.09$ (d, $\left.J=5.5 \mathrm{~Hz}, 1 \mathrm{H}\right), 4.30$ (dd, $J=9.5,2.5 \mathrm{~Hz}$, $1 \mathrm{H}), 4.11(\mathrm{dd}, J=9.5,6.5 \mathrm{~Hz}, 1 \mathrm{H}), 3.60-3.49(\mathrm{~m}, 1 \mathrm{H}), 3.02(\mathrm{dt}, J=6.4,2.5 \mathrm{~Hz}, 1 \mathrm{H})$, $2.97(\mathrm{dd}, J=18.8,10.6 \mathrm{~Hz}, 1 \mathrm{H}), 2.60(\mathrm{dd}, J=18.8,3.7 \mathrm{~Hz}, 1 \mathrm{H})$. ${ }^{13} \mathrm{C}$ NMR (101 MHz, MeOD): $\delta=177.5\left(\mathrm{C}_{\mathrm{q}}\right), 175.3\left(\mathrm{C}_{\mathrm{q}}\right), 110.1(+), 70.6(-), 51.2(+)$, 43.1(+), 34.7(-). - IR (neat): $\tilde{v}=2994,1771,1695,1416,1358,1295,1178,1103$, 966, 929, 885, 855, 803, 670, $614 \mathrm{~cm}^{-1}$. - MS (ESI-MS): m/z (\%) = $515\left(\left(3 \mathrm{M}-\mathrm{H}^{+}\right)^{-}, 10\right)$, 344 (17), $343\left(\left(2{\mathrm{M}-\mathrm{H}^{+}}^{-}\right)^{-}, 100\right), 217$ (M-HCOO', 17), 137 (12). - HRMS (ESI-MS, m/z): $171.0298\left(\mathrm{C}_{7} \mathrm{H}_{7} \mathrm{O}_{5}\right.$, calc. $\left.171.0299\left[(\mathrm{M}-\mathrm{H})^{-}\right]\right)$. - mp: $143^{\circ} \mathrm{C}$. 
(3aR,4R,6aR)-4-(hydroxymethyl)tetrahydrofuro[2,3-b]furan-2(6aH)-one (141)<smiles>O=C1C[C@H]2OC[C@H](CO)[C@H]2O1</smiles>

In a flame dried flask under nitrogen atmosphere 145 (1 g, $5.81 \mathrm{mmol})$ was dissolved in $20 \mathrm{~mL}$ of dry THF and cooled to $0{ }^{\circ} \mathrm{C}$. $\mathrm{BH}_{3} \cdot \mathrm{THF}(5.81 \mathrm{~mL}$ of a $1 \mathrm{M}$ solution in THF, $5.81 \mathrm{mmol}, 1 \mathrm{eq})$ was added dropwise. After the addition was finished, the reaction was allowed to warm to room temperature and was then slowly heated up to $40{ }^{\circ} \mathrm{C}$. After $3 \mathrm{~h}$ at that temperature, it was cooled to room temperature and $5 \mathrm{~g}$ of a slightly wet silica slurry were added to quench the reaction. The solvent was removed under reduced pressure in order to produce the dry-load for silica column chromatography (EA), which afforded the desired product as colorless oil (617 mg, $3.91 \mathrm{mmol}, 68 \%)$.

$\mathrm{R}_{\mathrm{f}}(\mathrm{EA})=0.26 .-[\alpha]_{D}^{20}=-2.2(\mathrm{MeOH}, \mathrm{c}=1)$.

${ }^{1} \mathrm{H}$ NMR (300 MHz, MeOD): $\delta=6.08(\mathrm{~d}, J=4.7 \mathrm{~Hz}, 1 \mathrm{H}), 3.96(\mathrm{ddd}, J=12.0,9.5,4.2$ $\mathrm{Hz}, 2 \mathrm{H}), 3.47(\mathrm{dd}, J=7.4,1.1 \mathrm{~Hz}, 2 \mathrm{H}), 3.06-2.88(\mathrm{~m}, 2 \mathrm{H}), 2.65-2.49(\mathrm{~m}, 1 \mathrm{H}), 2.31$ - $2.17(\mathrm{~m}, 1 \mathrm{H}) .-{ }^{13} \mathrm{C}$ NMR (75 MHz, MeOD): $\delta=178.3\left(\mathrm{C}_{\mathrm{q}}\right), 110.5(+), 70.2(-), 63.5(-)$, 49.2(+), 49.0(+), 42.5(+), 35.3(-). - IR (neat) $\tilde{v}=3335,2910,1744,1641,1410,1316$, 1199, 1107, 1035, 968, 928, 819, $744 \mathrm{~cm}^{-1}$. - HRMS (ESI-MS, m/z): 159.0653 $\left(\mathrm{C}_{7} \mathrm{H}_{11} \mathrm{O}_{4}\right.$, calc. $\left.159.0652\left[\mathrm{MH}^{+}\right]\right)$. 
(3aS,4R,6aS)-4-(hydroxymethyl)tetrahydrofuro[2,3-b]furan-2(6aH)-one (152)<smiles>O=C1CO[C@@H]2CC(=O)O[C@@H]2C1</smiles>

In a flame dried flask under nitrogen atmosphere $57(250 \mathrm{mg}, 1.45 \mathrm{mmol})$ was dissolved in $5 \mathrm{~mL}$ of dry THF and cooled to $0^{\circ} \mathrm{C}$. $\mathrm{BH}_{3} \cdot \mathrm{THF}(1.45 \mathrm{~mL}$ of a $1 \mathrm{M}$ solution in THF, $1.45 \mathrm{mmol}, 1 \mathrm{eq}$ ) was added dropwise. After the addition was finished, the reaction was allowed to warm to room temperature and was then slowly heated up to $40{ }^{\circ} \mathrm{C}$. After $3 \mathrm{~h}$ at that temperature, it was cooled to room temperature and $1.3 \mathrm{~g}$ of a slightly wet silica slurry were added to quench the reaction. The solvent was removed under reduced pressure to produce the dry-load for silica column chromatography $(E A)$, which afforded the desired product 152 as colorless oil $(222 \mathrm{mg}, 1.41 \mathrm{mmol}$, $97 \%)$.

$\mathrm{R}_{\mathrm{f}}(\mathrm{EA})=0.26 .-[\alpha]_{D}^{20}=-9.0(\mathrm{MeOH}, \mathrm{c}=1)$.

${ }^{1} \mathrm{H}$ NMR (300 MHz, MeOD): $\delta=6.06$ (d, $J=4.6 \mathrm{~Hz}, 1 \mathrm{H}$ ), 3.97 (ddd, $J=11.9,9.4$, $4.2 \mathrm{~Hz}, 2 \mathrm{H}$ ), 3.46 (d, $J=7.4 \mathrm{~Hz}, 2 \mathrm{H}$ ), $3.02-2.87$ (m, 2H), 2.55 (ddd, $J=15.8,11.6$, $7.7 \mathrm{~Hz}, 1 \mathrm{H}), 2.28-2.16(\mathrm{~m}, 1 \mathrm{H}) \cdot-{ }^{13} \mathrm{C}$ NMR $(75 \mathrm{MHz}, \mathrm{MeOD}): \delta=178.0\left(\mathrm{C}_{\mathrm{q}}\right)$, 110.5(+), 70.3(-), 63.7(-), 49.5(+), 42.7(+), 35.4(-). - IR (neat) $\tilde{v}=3331,2960,2884$, 1772, 1392, 1353, 1191, 1132, 1101, 1046, 1025, 977, 930, $896 \mathrm{~cm}^{-1}$. HRMS (ESI-MS, m/z): $159.0651\left(\mathrm{C}_{7} \mathrm{H}_{11} \mathrm{O}_{4}\right.$, calc. $\left.159.0652\left[\mathrm{MH}^{+}\right]\right)$. 
((3S,3aS,6aS)-5-oxohexahydrofuro[2,3-b]furan-3-yl)methyl benzoate (153)<smiles>O=C1C[C@@H]2OC3C(=O)C[C@H]3CO[C@H]2O1</smiles>

In a flame dried flask under nitrogen atmosphere 152 (158 mg, $0.69 \mathrm{mmol})$ was dissolved in $10 \mathrm{~mL}$ of dry pyridine and benzoyl chloride (160 $\mu \mathrm{L}, 1.38 \mathrm{mmol}, 2 \mathrm{eq})$ was added dropwise. After $3 \mathrm{~h}$ the solvent was removed under reduced pressure by co-distillation with toluene $(3 \times 10 \mathrm{~mL})$. The residue was purified by silica column chromatography (PE/EA = 1:1) to afford 153 as yellow oil $(72 \mathrm{mg}, 0.27 \mathrm{mmol}, 39 \%)$.

$\mathrm{R}_{\mathrm{f}}(\mathrm{PE} / \mathrm{EA}=1: 1)=0.57 .-[\alpha]_{D}^{20}=-15(\mathrm{DCM}, \mathrm{c}=1)$.

${ }^{1} \mathrm{H}$ NMR $\left(300 \mathrm{MHz}_{\mathrm{CDCl}}\right): \delta=8.06-7.97(\mathrm{~m}, 2 \mathrm{H}), 7.65-7.54(\mathrm{~m}, 1 \mathrm{H}), 7.52-7.41$ $(\mathrm{m}, 2 \mathrm{H}), 6.15(\mathrm{~d}, J=5.1 \mathrm{~Hz}, 1 \mathrm{H}), 4.29$ (qd, $J=11.1,7.3 \mathrm{~Hz}, 2 \mathrm{H}), 4.10$ (ddd, $J=12.2$, 9.8, 4.1 Hz, 2H), $3.08-2.90(\mathrm{~m}, 2 \mathrm{H}), 2.62-2.52(\mathrm{~m}, 2 \mathrm{H}) .-{ }^{13} \mathrm{C}$ NMR $(75 \mathrm{MHz}$, $\left.\mathrm{CDCl}_{3}\right): \delta=174.4\left(\mathrm{C}_{\mathrm{q}}\right), 166.3\left(\mathrm{C}_{\mathrm{q}}\right), 133.4(+), 129.6(+), 129.4\left(\mathrm{C}_{\mathrm{q}}\right), 128.5(+), 108.0(+)$, 69.2(-), 64.8(-), 45.3(+), 41.8(+), 34.5(-). - IR (neat) $\tilde{v}=2970,2898,1780,1717$, $1451,1355,1315,1274,1176,1112,1071,981,937,897,712 \mathrm{~cm}^{-1}$. HRMS (ESI-MS, m/z): $285.0734\left(\mathrm{C}_{14} \mathrm{H}_{14} \mathrm{NaO}_{5}\right.$, calc. $\left.285.0733\left[(\mathrm{M}+\mathrm{Na})^{+}\right]\right)$. 
tributylstannyl 2-iodoacetate (166)<smiles></smiles>

lodoacetic acid (11.15 g, $60 \mathrm{mmol}, 2$ eq) was heated together with bis(tributyltin) oxide (165) (17.88 g, $30 \mathrm{mmol}, 1 \mathrm{eq})$ at $130{ }^{\circ} \mathrm{C}$ for $30 \mathrm{~min}$. During that time a clear solution was formed, containing some drops of water. After cooling to room temperature the mixture was transferred with hot PE to a separation funnel where the water was separated. The solvent was removed under reduced pressure to afford the clean product as a white solid ( $26.25 \mathrm{~g}, 55.14 \mathrm{mmol}, 92 \%$ based on iodoacetic acid).

${ }^{1} \mathbf{H}$ NMR $\left(300 \mathrm{MHz}, \mathrm{CDCl}_{3}\right): \delta=3.70(\mathrm{~s}, 2 \mathrm{H}), 1.78-1.45(\mathrm{~m}, 7 \mathrm{H}), 1.42-1.16$ $(\mathrm{m}, 13 \mathrm{H}), 0.91$ (t, $J=7.3 \mathrm{~Hz}, 10 \mathrm{H}) .-{ }^{13} \mathrm{C}$ NMR $\left(75 \mathrm{MHz}, \mathrm{CDCl}_{3}\right): \delta=175.7\left(\mathrm{C}_{\mathrm{q}}\right)$, 30.0(-), 29.3(-), 18.9(+), 15.9(-). - IR (neat): $\tilde{v}=2954,2922,2855,1571,1428,1380$, $1290,1159,1078,869,769,670,603 \mathrm{~cm}^{-1}$. 
tetrahydrofuro[2,3-b]furan-2(6aH)-one (167)

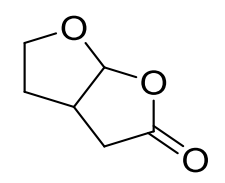

Tin ester 166 (51.18 g, $107.5 \mathrm{mmol}, 1 \mathrm{eq})$, 2,3-dihydrofuran (24.4 mL, $322.5 \mathrm{mmol}$, $3 \mathrm{eq}$ ) and AIBN (984 mg, $6 \mathrm{mmol}, 5 \mathrm{~mol} \%$ ) were refluxed in $120 \mathrm{~mL}$ benzene for $8 \mathrm{~h}$. The reaction mixture was transferred to a separation funnel and partitioned between acetonitrile $(100 \mathrm{~mL})$ and PE $(100 \mathrm{~mL})$. The acetonitrile phase was washed with PE $(3 \times 100 \mathrm{~mL})$ and concentrated under reduced pressure. The crude product was purified by silica column chromatography $(\mathrm{PE}: E A=2: 1$ ) to afford the desired product $\mathbf{X}$ as yellowish oil $(9.35 \mathrm{~g}, 73.1 \mathrm{mmol}, 68 \%)$.

$\mathrm{R}_{\mathrm{f}}(\mathrm{PE} / \mathrm{EA}=1: 1)=0.31$.

${ }^{1} \mathrm{H}$ NMR $\left(300 \mathrm{MHz}, \mathrm{CDCl}_{3}\right): \delta=6.04(\mathrm{~d}, J=5.4 \mathrm{~Hz}, 1 \mathrm{H}), 4.10-4.00(\mathrm{~m}, 1 \mathrm{H}), 3.96-$ $3.84(\mathrm{~m}, 1 \mathrm{H}$ ), 3.11 (dddd, $J=12.1,9.0,5.9,3.2 \mathrm{~Hz}, 1 \mathrm{H}$ ), 2.83 (dd, $J=18.6,10.2 \mathrm{~Hz}$, $1 \mathrm{H}$ ), 2.39 (dd, $J=18.6,3.6 \mathrm{~Hz}, 1 \mathrm{H}$ ), 2.16 (dddd, $J=12.8,10.3,9.2,8.2 \mathrm{~Hz}, 1 \mathrm{H}$ ), 1.73 (ddt, $J=12.8,5.7,2.7 \mathrm{~Hz}, 1 \mathrm{H}) .{ }^{13} \mathrm{C}$ NMR $\left(75 \mathrm{MHz}, \mathrm{CDCl}_{3}\right): \delta=175.3\left(\mathrm{C}_{\mathrm{q}}\right), 108.2(+)$, 67.3(-), 38.3(+), 34.7(-), 32.2(-). - IR (neat): $\tilde{v}=2982,2882,1770,1356,1298,1250$, $1170,1106,1003,963,935,869,832,648 \mathrm{~cm}^{-1}$. 


\section{benzyl 2-(2-(benzyloxy)tetrahydrofuran-3-yl)acetate (168)}

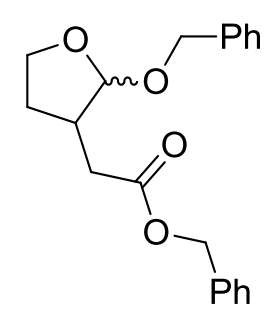

$167(1.5 \mathrm{~g}, 11.7 \mathrm{mmol})$ was dissolved in $50 \mathrm{~mL} \mathrm{BnOH}$ at $0{ }^{\circ} \mathrm{C}$ and conc. $\mathrm{H}_{2} \mathrm{SO}_{4}$ ( $2 \mathrm{~mL}, 37.5 \mathrm{mmol}, 3.2 \mathrm{eq}$ ) were added by an addition funnel over $15 \mathrm{~min}$. The mixture was allowed to warm to room temperature and was stirred over night. $\mathrm{NEt}_{3}(15.5 \mathrm{~mL}$, $112 \mathrm{mmol}, 3$ eq based on $\mathrm{H}_{2} \mathrm{SO}_{4}$ ) was added dropwise and the solvent was removed by distillation under reduced pressure. The sticky residue was purified by silica column chromatography ( $P E / E A=8: 1)$ to afford the product as $1: 1.3$ mixture of diastereomers (3.1 g, $9.51 \mathrm{mmol}, 82 \%)$.

$R_{f}(P E / E A=5: 1)=0.36$.

${ }^{1} \mathrm{H}$ NMR $\left(600 \mathrm{MHz}, \mathrm{CDCl}_{3}\right): \delta=7.39-7.26(\mathrm{~m}, 23 \mathrm{H}), 5.14(\mathrm{~d}, J=4.4 \mathrm{~Hz}, 1.3 \mathrm{H}$, major), $5.13-5.09(\mathrm{~m}, 4 \mathrm{H}), 4.95(\mathrm{~d}, J=1.2 \mathrm{~Hz}, 1 \mathrm{H}$, minor), $4.73-4.69(\mathrm{~m}, 2.3 \mathrm{H})$, 4.44 (dd, $J=28.1,12.0 \mathrm{~Hz}, 2 \mathrm{H}$ ), 4.02 (td, $J=8.8,3.6 \mathrm{~Hz}, 1.3 \mathrm{H}$, major), $3.99-3.95$ (m, $2 \mathrm{H}$, minor), 3.90 (dd, $J=16.2,8.2 \mathrm{~Hz}, 1.4 \mathrm{H}$, major), $2.77-2.68(\mathrm{~m}, 2.3 \mathrm{H}), 2.61$ $2.53(\mathrm{~m}, 2.3 \mathrm{H}$ ), 2.51 (dd, $J=15.7,7.3 \mathrm{~Hz}, 1 \mathrm{H}$, minor), 2.34 (dd, $J=15.7,8.2 \mathrm{~Hz}, 1 \mathrm{H}$, minor), 2.29 (dtd, $J=13.6,7.8,6.0 \mathrm{~Hz}, 1 \mathrm{H}$, minor), $2.13-2.06$ (m, 1.3H, major), 1.78 (ddd, $J=22.4,11.2,9.1 \mathrm{~Hz}, 1.3 \mathrm{H}$, major), $1.63-1.57$ (m, $1 \mathrm{H}$, minor). $-{ }^{13} \mathrm{C}$ NMR $\left(151 \mathrm{MHz}, \mathrm{CDCl}_{3}\right): \delta=172.6\left(\mathrm{C}_{\mathrm{q}}\right.$, major), $171.8\left(\mathrm{C}_{\mathrm{q}}\right.$, minor), 138.4( $\left.\mathrm{C}_{\mathrm{q}}\right)$, 138.1( $\left.\mathrm{C}_{\mathrm{q}}\right)$, 135.9( $\left.\mathrm{C}_{\mathrm{q}}\right), 135.8\left(\mathrm{C}_{\mathrm{q}}\right), 128.5(+), 128.5(+), 128.3(+), 128.3(+), 128.2(+), 128.2(+)$, 128.2(+), 127.8(+), 127.5(+), 127.5(+), 127.4(+), 106.8(+, minor), 102.6(+, major), 68.9(-, minor), 68.6(-, major), 66.6(-, major), 66.5(-, minor), 66.4(-, minor), 66.2(-, major), 41.8(+, minor), 39.9(+, major), 37.1(-, minor), 33.7(-, major), 29.8(-, minor), 29.0(-, major). - IR (neat): $\tilde{\mathrm{v}}=2942,2892,1732,1497,1454,1347,1263,1212$,

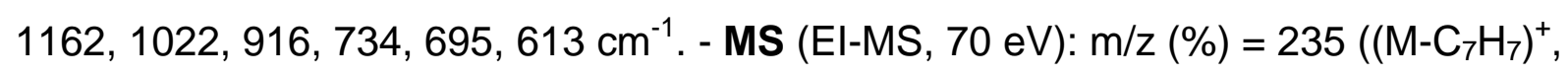
1), $219\left(\left(\mathrm{M}-\mathrm{OCC}_{7} \mathrm{H}_{7}\right)^{+}, 24\right), 129(18), 91\left(\mathrm{C}_{7} \mathrm{H}_{7}{ }^{+}, 100\right)$. - Elemental analysis calcd. (\%) for $\mathrm{C}_{20} \mathrm{H}_{22} \mathrm{O}_{4}$ (326.15): C 73.60, $\mathrm{H} 6.79$, found $\mathrm{C} 73.55, \mathrm{H} 6.69$. 
copper(I) tris(3,4,5-tribromo-1H-pyrazole-1-yl)hydroborate acetonitrile complex (164) (third pyrazole ring indicated by N-N for better lucidity)<smiles>CN(C)CCNC(=O)N1NC(Br)=C(Br)C1Br</smiles>

Perbromo pyrazole $170(4.41 \mathrm{~g}, 14.6 \mathrm{mmol}, 4 \mathrm{eq})$ and $\mathrm{NaBH}_{4}(138 \mathrm{mg}, 3.65 \mathrm{mmol}$, 1 eq) are molten in a sublimation apparatus under nitrogen atmosphere at $265{ }^{\circ} \mathrm{C}$ (metal bath) until cessation of hydrogen evolution. After cooling to room temperature the resulting solid was crushed. The remaining perbromo pyrazole (170) was removed by sublimation under reduced pressure $\left(100^{\circ} \mathrm{C}, 15 \mathrm{mbar}\right)$. The crushingsublimation procedure was done thrice. This provided the crude $\left[\mathrm{TpBr}_{3}\right] \mathrm{Na}$ (171) $(3,31 \mathrm{~g}, 3.50 \mathrm{mmol}, 96 \%)$, which was used without further purification. For the following procedure all solvents were degassed thrice via pump-freeze-method and all steps were one under nitrogen atmosphere. In a flame dried flask under nitrogen atmosphere $\left[\mathrm{TpBr}_{3}\right] \mathrm{Na}(\mathbf{1 7 1})(946 \mathrm{mg}, 1 \mathrm{mmol})$ and $\mathrm{Cul}(190 \mathrm{mg}, 1 \mathrm{mmol}, 1 \mathrm{eq})$ were dissolved in $60 \mathrm{~mL}$ dry $\mathrm{MeCN}$ and stirred over night at room temperature. After removing the solvent under reduced pressure the remaining solid was dissolved in 40 $\mathrm{mL}$ dry DCM and filtered to remove Nal. The solvent was removed under reduced pressure until an thick oil was remaining. To this residue $5 \mathrm{~mL}$ of PE were added and white crystals $(750 \mathrm{mg}, 0.73 \mathrm{mmol}, 73 \%)$ were formed while storing at $-18{ }^{\circ} \mathrm{C}$. The complex was stable at room temperature when stored under exclusion of moister and oxygen.

${ }^{1} \mathbf{H}$ NMR $\left(300 \mathrm{MHz}, \mathrm{CD}_{2} \mathrm{Cl}_{2}\right): \delta=10.87(\mathrm{~s}, 1 \mathrm{H}), 2.18(\mathrm{~s}, 2 \mathrm{H}) .-{ }^{13} \mathbf{C} \mathbf{~ N M R}$ $\left(75 \mathrm{MHz}, \mathrm{CD}_{2} \mathrm{Cl}_{2}\right): \delta=129.7\left(\mathrm{C}_{\mathrm{q}}\right), 122.8\left(\mathrm{C}_{\mathrm{q}}\right), 116.1\left(\mathrm{C}_{\mathrm{q}}\right), 100.1\left(\mathrm{C}_{\mathrm{q}}\right), 3.0(+)$. - IR (neat): $\tilde{v}=3094,3011,2855,2771,1527,1479,1389,1349,1323,1178,1123,1003,969$, $730 \mathrm{~cm}^{-1}$. 
ethyl 2-(2-(2-(2-ethoxy-2-oxoethoxy)-5-oxotetrahydrofuran-3-yl)ethoxy)acetate (175)<smiles>CCOC(=O)COC(=O)CC1CCOC1OCC(=O)OCC</smiles>

In a flame dried flask under nitrogen atmosphere $167(250 \mathrm{mg}, 1.95 \mathrm{mmol})$ was dissolved in $2 \mathrm{~mL}$ of dry $\mathrm{DCM}$ and $\mathrm{Fe}\left(\mathrm{BF}_{4}\right)_{2} \cdot 6 \mathrm{H}_{2} \mathrm{O}(66 \mathrm{mg}, 0.195 \mathrm{mmol}, 0.1 \mathrm{eq})$ was added at $0{ }^{\circ} \mathrm{C}$. The mixture was treated with ethyl diazo glycine $(1.96 \mathrm{~g}$ of a solution in DCM with $12.7 \mathrm{wt} \%, 2 \mathrm{eq})$ by the help of a syringe pump $(0.25 \mathrm{~mL} / \mathrm{h})$. During the reaction nitrogen was evolved (mineral oil bubbler). After about $6 \mathrm{~h}$, at the end of the addition, the solvent was removed under reduced pressure and the crude mixture was purified by silica column chromatography (PE/EA $=5: 1$ ) to afford 175 (two diastereomers) as yellow oil (197 mg, $0.62 \mathrm{mmol}, 32 \%$ combined yield).

Isomer 1 (92 mg, $0.29 \mathrm{mmol}, 15 \%): R_{f}(P E / E A=3: 1)=0.16$.

${ }^{1} \mathrm{H}$ NMR $\left(600 \mathrm{MHz}, \mathrm{CDCl}_{3}\right): \delta=4.97(\mathrm{~d}, J=1.1 \mathrm{~Hz}, 1 \mathrm{H}), 4.61(\mathrm{~s}, 2 \mathrm{H}), 4.21$ (q, $J=7.1$ $\mathrm{Hz}, 4 \mathrm{H}), 4.13(\mathrm{~d}, J=2.3 \mathrm{~Hz}, 2 \mathrm{H}), 3.95(\mathrm{t}, J=7.1 \mathrm{~Hz}, 2 \mathrm{H}), 2.86-2.71(\mathrm{~m}, 1 \mathrm{H}), 2.61$ (dd, $J=15.8,6.8 \mathrm{~Hz}, 1 \mathrm{H}$ ), 2.39 (dd, $J=15.8,8.6 \mathrm{~Hz}, 1 \mathrm{H}$ ), 2.33 (ddd, $J=14.6,12.6$, $7.1 \mathrm{~Hz}, 1 \mathrm{H}$ ), 1.65 (dtd, $J=12.5,7.3,4.2 \mathrm{~Hz}, 1 \mathrm{H}), 1.27(\mathrm{t}, J=7.1 \mathrm{~Hz}, 3 \mathrm{H}), 1.27$ (t, $J=7.1 \mathrm{~Hz}, 3 \mathrm{H}) .{ }^{13} \mathrm{C}$ NMR $\left(151 \mathrm{MHz}, \mathrm{CDCl}_{3}\right): \delta=171.2\left(\mathrm{C}_{\mathrm{q}}\right), 170.4\left(\mathrm{C}_{\mathrm{q}}\right), 167.6\left(\mathrm{C}_{\mathrm{q}}\right)$, 107.3(+), 66.9(-), 64.0(-), 61.4(-), 60.7(-), 41.6(+), 36.3(-), 29.4(-), 14.1(+), 14.0(+). IR (neat): $\tilde{\mathbf{v}}=2980,2939,2909,1741,1424,1382,1277,1198,1155,1119,1054$, 1028, 957, $924 \mathrm{~cm}^{-1}$. - MS (ESI-MS): $\mathrm{m} / \mathrm{z}(\%)=654\left(2 \mathrm{MNH}_{4}{ }^{+}, 28\right), 336\left(\mathrm{MNH}_{4}{ }^{+}, 100\right)$. - HRMS (ESI-MS, m/z): $341.1205\left(\mathrm{C}_{14} \mathrm{H}_{22} \mathrm{NaO}_{8}\right.$, calc. $\left.341.1207\left[(\mathrm{M}+\mathrm{Na})^{+}\right]\right)$. 
Isomer 2 (105 mg, $0.33 \mathrm{mmol}, 17 \%): \mathrm{R}_{\mathrm{f}}(\mathrm{PE} / \mathrm{EA}=3: 1)=0.27$.

${ }^{1} \mathrm{H}$ NMR $\left(600 \mathrm{MHz}, \mathrm{CDCl}_{3}\right): \delta=5.09(\mathrm{~d}, J=4.4 \mathrm{~Hz}, 1 \mathrm{H}), 4.61(\mathrm{dd}, J=50.2,15.9 \mathrm{~Hz}$, $2 \mathrm{H}$ ), 4.20 (q, $J=7.2 \mathrm{~Hz}, 2 \mathrm{H}$ ), 4.16 (dd, $J=7.2,1.5 \mathrm{~Hz}, 2 \mathrm{H}$ ), 4.10 (dd, $J=38.4,16.5$ $\mathrm{Hz}, 2 \mathrm{H}$ ), 4.00 (ddd, $J=9.3,8.5,3.2 \mathrm{~Hz}, 1 \mathrm{H}$ ), $3.86(\mathrm{dd}, J=16.4,8.2 \mathrm{~Hz}, 1 \mathrm{H}$ ), 2.83 (dd, $J=16.6,7.1 \mathrm{~Hz}, 1 \mathrm{H}), 2.62(\mathrm{dd}, J=16.6,7.7 \mathrm{~Hz}, 1 \mathrm{H}), 2.59-2.50(\mathrm{~m}, 1 \mathrm{H}), 2.16-2.09$ $(\mathrm{m}, 1 \mathrm{H}), 1.81$ (tt, $J=11.4,9.1 \mathrm{~Hz}, 1 \mathrm{H}), 1.27(\mathrm{t}, 7.3 \mathrm{~Hz}, 3 \mathrm{H}), 1.25(\mathrm{t}, 7.6 \mathrm{~Hz}, 3 \mathrm{H})$. ${ }^{13} \mathrm{C}$ NMR $\left(151 \mathrm{MHz}, \mathrm{CDCl}_{3}\right): \delta=172.1\left(\mathrm{C}_{\mathrm{q}}\right), 170.4\left(\mathrm{C}_{\mathrm{q}}\right), 167.7\left(\mathrm{C}_{\mathrm{q}}\right), 103.3(+), 67.1(-)$, 63.9(-), 61.3(-), 60.6(-), 60.6(-), 40.0(+), 32.9(-), 28.6(-), 14.1(+), 14.0(+). - IR (neat): $\tilde{\mathrm{v}}=2983,2949,2902,1742,1423,1381,1279,1198,1158,1125,1092,1027,984$, $900 \mathrm{~cm}^{-1}$. - MS (ESI-MS): m/z (\%) = $341\left(\mathrm{MNa}^{+}, 26\right), 336\left(\mathrm{MNH}_{4}^{+}\right.$, 100). - HRMS (ESI-MS, m/z): $341.1205\left(\mathrm{C}_{14} \mathrm{H}_{22} \mathrm{NaO}_{8}\right.$, calc. $\left.341.1207\left[(\mathrm{M}+\mathrm{Na})^{+}\right]\right)$. 


\section{benzyl 2-(2-(2-ethoxy-2-oxoethoxy)tetrahydrofuran-3-yl)acetate (176)}<smiles>CCOC(=O)COC1OCCC1CC(=O)OCC</smiles><smiles>CCOC(=O)COC1OCCC1CC(=O)OCC</smiles>

In a flame dried flask under nitrogen $168(200 \mathrm{mg}, 0.613 \mathrm{mmol})$ was mixed with $1 \mathrm{~mL}$ of dry DCM and $\mathrm{Rh}_{2}(\mathrm{OAc})_{4}(5.4 \mathrm{mg}, 0.012 \mathrm{mmol}, 2 \mathrm{~mol} \%)$. The mixture was cooled to $0{ }^{\circ} \mathrm{C}$ and treated with ethyl diazo glycine $(1.2 \mathrm{~g}$ of a solution in DCM with $12 \mathrm{wt} \%$, 2 eq) by the help of a syringe pump $(0.25 \mathrm{~mL} / \mathrm{h})$. During the reaction nitrogen was evolved (mineral oil bubbler). At the end of the addition the solvent was removed under reduced pressure and the crude mixture was purified by silica column chromatography (1:1) to afford two diastereomers as yellow oil $(75 \mathrm{mg}, 0.23 \mathrm{mmol}$, $38 \%$ combined yield).

anti-isomer (176) (39 mg, $0.12 \mathrm{mmol}, 20 \%): \mathrm{R}_{\mathrm{f}}(\mathrm{PE} / \mathrm{EA}=1: 1)=0.60$.

${ }^{1}$ H NMR $\left(300 \mathrm{MHz}, \mathrm{CDCl}_{3}\right): \delta=7.43-7.27(\mathrm{~m}, 4 \mathrm{H}), 5.37(\mathrm{~d}, J=2.5 \mathrm{~Hz}, 1 \mathrm{H}), 4.73$ (dd, $J=75.9,11.6 \mathrm{~Hz}, 2 \mathrm{H}$ ), 4.20 (q, $J=7.1 \mathrm{~Hz}, 2 \mathrm{H}), 4.00(\mathrm{~s}, 2 \mathrm{H}), 3.64-3.48(\mathrm{~m}, 2 \mathrm{H})$, 2.89 (dd, $J=17.7,8.7 \mathrm{~Hz}, 1 \mathrm{H}), 2.69-2.54(\mathrm{~m}, 1 \mathrm{H}), 2.29(\mathrm{dd}, J=17.8,4.6 \mathrm{~Hz}, 1 \mathrm{H})$, $1.87(\mathrm{dtd}, J=12.3,6.8,5.6 \mathrm{~Hz}, 1 \mathrm{H}), 1.73-1.57(\mathrm{~m}, 1 \mathrm{H}), 1.28(\mathrm{t}, J=7.2 \mathrm{~Hz}, 3 \mathrm{H})$. ${ }^{13} \mathrm{C}$ NMR $\left(75 \mathrm{MHz}, \mathrm{CDCl}_{3}\right): \delta=175.8\left(\mathrm{C}_{\mathrm{q}}\right), 170.1\left(\mathrm{C}_{\mathrm{q}}\right), 136.4\left(\mathrm{C}_{\mathrm{q}}\right), 128.9(+), 128.5(+)$, 128.1(+), 107.2(+), 71.2(-), 69.0(-), 68.2(-), 60.9(-), 39.1(+), 33.7(-), 31.7(-), 14.2(+). IR (neat): $\tilde{\mathbf{v}}=2982,2935,1784,1746,1451,1276,1205,1131,1025,938 \mathrm{~cm}^{-1}$. MS (ESI-MS): $\mathrm{m} / \mathrm{z} \quad(\%)=345\left(\mathrm{MNa}^{+}, 26\right), 340\left(\mathrm{MNH}_{4}^{+}, 100\right), 323\left(\mathrm{MH}^{+}\right.$, 73). - HRMS (ESI-MS, m/z): $345.1306\left(\mathrm{C}_{17} \mathrm{H}_{22} \mathrm{NaO}_{6}\right.$, calc. $345.1309\left[(\mathrm{M}+\mathrm{Na})^{+}\right]$. 
syn-isomer (176) (36 mg, $0.11 \mathrm{mmol}, 18 \%): R_{f}(P E / E A=1: 1)=0.70$.

${ }^{1} \mathrm{H}$ NMR $\left(300 \mathrm{MHz}, \mathrm{CDCl}_{3}\right): \delta=7.44-7.27(\mathrm{~m}, 5 \mathrm{H}), 5.55(\mathrm{~d}, J=5.2 \mathrm{~Hz}, 1 \mathrm{H}), 4.71$ (dd, $J=78.2,11.8 \mathrm{~Hz}, 2 \mathrm{H}), 4.19(\mathrm{q}, J=7.1 \mathrm{~Hz}, 2 \mathrm{H}), 4.01(\mathrm{~s}, 2 \mathrm{H}), 3.61-3.46(\mathrm{~m}, 2 \mathrm{H})$, $2.84-2.70(\mathrm{~m}, 1 \mathrm{H}), 2.60(\mathrm{dd}, J=17.1,8.2 \mathrm{~Hz}, 1 \mathrm{H}), 2.41(\mathrm{dd}, J=17.1,12.0 \mathrm{~Hz}, 1 \mathrm{H})$, 1.97 (dtd, $J=12.0,6.9,5.1 \mathrm{~Hz}, 1 \mathrm{H}), 1.90-1.76(\mathrm{~m}, 1 \mathrm{H}), 1.27(\mathrm{t}, J=7.1 \mathrm{~Hz}, 3 \mathrm{H})$. ${ }^{13} \mathrm{C}$ NMR $\left(75 \mathrm{MHz}, \mathrm{CDCl}_{3}\right): \delta=176.5\left(\mathrm{C}_{\mathrm{q}}\right), 170.3\left(\mathrm{C}_{\mathrm{q}}\right), 136.6\left(\mathrm{C}_{\mathrm{q}}\right), 128.9(+), 128.5(+)$, 128.0(+), 103.3(+), 70.5(-), 69.4(-), 68.1(-), 60.8(-), 37.7(+), 32.6(-), 28.4(-), 14.2(+). IR (neat): $\tilde{v}=2925,1786,1748,1455,1358,1205,1175,1139,1024,961,926 \mathrm{~cm}^{-1}$. - MS (ESI-MS): m/z (\%) = $345\left(\mathrm{MNa}^{+}, 28\right), 340\left(\mathrm{MNH}_{4}{ }^{+}, 100\right), 323\left(\mathrm{MH}^{+}\right.$, 58). - HRMS (ESI-MS, m/z): $345.1305\left(\mathrm{C}_{17} \mathrm{H}_{22} \mathrm{NaO}_{6}\right.$, calc. $345.1309\left[(\mathrm{M}+\mathrm{Na})^{+}\right]$. 


\section{1-benzyl 4-ethyl 2-(2-(benzyloxy)tetrahydrofuran-3-yl)succinate (177)}<smiles>CCOC(=O)CC(C(=O)OCc1ccccc1)C1CCOC1Cc1ccccc1</smiles>

A flame dried flask under nitrogen atmosphere, was filled with $8 \mathrm{~mL}$ of dry DCM and 168 (326 mg, $1 \mathrm{mmol}$ ). The resulting solution was degassed thrice by pump-freeze method and treated with $\left[\mathrm{TpBr}_{3}\right] \mathrm{Cu}-\mathrm{MeCN}$ (164) (51 mg, $\left.0.05 \mathrm{mmol}, 5 \mathrm{~mol} \%\right)$. Ethyl diazo glycine (770 mg of $14.8 \mathrm{wt} \%$ DCM solution, $1 \mathrm{mmol}, 1 \mathrm{eq}$ ) was added by a syringe pump, $0.25 \mathrm{~mL} / \mathrm{h}$. During the reaction nitrogen gas was evolved (mineral oil bubbler). When the addition was finished the reaction was stirred for further $30 \mathrm{~min}$, concentrated under reduced pressure. The residue was purified by silica column chromatography $(\mathrm{PE} / \mathrm{EA}=5: 1)$ to afford a mixture of diastereomers $(1: 1)$ as colorless oil (111 mg, $0.27 \mathrm{mmol}, 27 \%)$.

$R_{f}(P E / E A=5: 1)=0.25$.

${ }^{1} \mathbf{H}$ NMR $\left(600 \mathrm{MHz}, \mathrm{CDCl}_{3}\right): \delta=7.39-7.25(\mathrm{~m}, 20 \mathrm{H}), 5.17-5.03(\mathrm{~m}, 5 \mathrm{H}), 4.92(\mathrm{~s}, 1 \mathrm{H}$, isomer 2), $4.74(\mathrm{~d}, J=4.0 \mathrm{~Hz}, 1 \mathrm{H}), 4.72(\mathrm{~d}, J=4.3 \mathrm{~Hz}, 1 \mathrm{H}), 4.67-4.61(\mathrm{~m}, 1 \mathrm{H}$, isomer 1), 4.55 (ddd, $J=14.6,8.1,6.6 \mathrm{~Hz}, 1 \mathrm{H}$, isomer 2), $4.42(\mathrm{~d}, J=11.6 \mathrm{~Hz}, 1 \mathrm{H})$, $4.37(\mathrm{~d}, J=11.9 \mathrm{~Hz}, 1 \mathrm{H}), 4.23-4.09(\mathrm{~m}, 4 \mathrm{H}), 2.81-2.75(\mathrm{~m}, 1 \mathrm{H}$, isomer 2), 2.72 (dd, $J=7.8,3.9 \mathrm{~Hz}, 1 \mathrm{H}), 2.71-2.68(\mathrm{~m}, 2 \mathrm{H}), 2.67$ (d, $J=7.8 \mathrm{~Hz}, 1 \mathrm{H}), 2.63$ (ddd, $J=8.7$, 7.5, 4.7 Hz, $1 \mathrm{H}$, isomer 1), $2.58-2.46(\mathrm{~m}, 3 \mathrm{H}), 2.38-2.29(\mathrm{~m}, 2 \mathrm{H}), 2.05(\mathrm{dt}, J=12.9$, 7.6 Hz, $1 \mathrm{H}$, isomer 1), 1.93 (ddd, $J=12.9,7.1,2.1 \mathrm{~Hz}, 1 \mathrm{H}$, isomer 1), 1.55 (td, $J=12.0,9.0 \mathrm{~Hz}, 1 \mathrm{H}$, isomer 2), $1.27(\mathrm{dt}, J=1.6,7.1 \mathrm{~Hz}, 8 \mathrm{H}) .-{ }^{13} \mathrm{C}$ NMR $(151 \mathrm{MHz}$, $\left.\mathrm{CDCl}_{3}\right): \delta=172.3\left(\mathrm{C}_{\mathrm{q}}\right), \quad 171.6\left(\mathrm{C}_{\mathrm{q}}\right), 171.2\left(\mathrm{C}_{\mathrm{q}}\right), 171.1\left(\mathrm{C}_{\mathrm{q}}\right), 138.2\left(\mathrm{C}_{\mathrm{q}}\right), 137.8\left(\mathrm{C}_{\mathrm{q}}\right)$, 135.8 $\left(\mathrm{C}_{\mathrm{q}}\right), 135.7\left(\mathrm{C}_{\mathrm{q}}\right), 128.5(+), 128.5(+), 128.3(+), 128.3(+), 128.2(+), 128.2(+)$, 128.2(+), 128.2(+), 127.9(+), 127.6(+), 106.9(+, isomer 2), 102.8(+, isomer 1), 75.8(+, isomer 2), 75.6(+, isomer 1), 68.8(-), 68.6(-), 66.4(-), 66.2(-), 60.5(-), 60.4(-), 43.1(-), 42.9(-), 42.2(+, isomer 2), 40.7(+, isomer 1), 36.4(-), 35.2(-, isomer 2), 34.8(-, isomer 1), 33.5(-), 14.2(+).- IR (neat): $\tilde{v}=2963,2360,2340,1733,1454,1261,1160,1094$, 1024, 799, 736, $697 \mathrm{~cm}^{-1}$. - MS (ESI-MS): m/z (\%) = 431 (27), $430\left(\mathrm{MNH}_{4}^{+}, 100\right), 306$ (10), 305 (52). - HRMS (ESI-EIC-MS, m/z): $430.2223\left(\mathrm{C}_{24} \mathrm{H}_{32} \mathrm{NO}_{6}\right.$, calc. 430.2224 $\left.\left[\left(\mathrm{M}+\mathrm{NH}_{4}\right)^{+}\right]\right)$. 


\section{2-(2-oxotetrahydrofuran-3-yl)acetic acid (183)}<smiles>O=C(O)CC1CCOC1=O</smiles>

$167(1 \mathrm{~g}, 7.8 \mathrm{mmol})$ was dissolved in $15 \mathrm{~mL}$ acetone and cooled in an ice bath. $2.5 \mathrm{M}$ Jones reagent $(11 \mathrm{~mL}, 27.5 \mathrm{mmol}, 3.5 \mathrm{eq})$ was added by an addition funnel over a period of $1 \mathrm{~h}$. When the addition was finished the reaction was stirred for further $2 \mathrm{~h}$ at room temperature. The green mixture was transferred to a separation funnel. After addition of $10 \mathrm{~mL}$ of water, the crude product was extracted with $\mathrm{EA}(4 \times 10 \mathrm{~mL})$. The combined organic layers were dried with $\mathrm{Na}_{2} \mathrm{SO}_{4}$, filtered and concentrated under reduced pressure. The product $(1.06 \mathrm{~g}, 7.35 \mathrm{mmol}, 94 \%)$ was used without further purification.

$\mathrm{R}_{\mathrm{f}}(\mathrm{PE} / \mathrm{EA}=1: 1)=0.23$.

${ }^{1} \mathrm{H}$ NMR (300 MHz, MeOD): $\delta=4.39$ (td, $J=8.9,2.1 \mathrm{~Hz}, 1 \mathrm{H}$ ), 4.25 (ddd, $J=10.2$, 8.9, $6.7 \mathrm{~Hz}, 1 \mathrm{H}), 3.04-2.90(\mathrm{~m}, 1 \mathrm{H}), 2.77(\mathrm{dd}, J=17.3,4.3 \mathrm{~Hz}, 1 \mathrm{H}), 2.59(\mathrm{dd}, J=$ 17.3, $7.7 \mathrm{~Hz}, 1 \mathrm{H}$ ), 2.48 (dddd, $J=12.2,8.9,6.8,2.1 \mathrm{~Hz}, 1 \mathrm{H}$ ), 2.10 (dtd, $J=12.4$, 10.6, 9.0 Hz, 1H). - ${ }^{13} \mathrm{C}$ NMR $(75 \mathrm{MHz}, \mathrm{MeOD}): \delta=181.3\left(\mathrm{C}_{\mathrm{q}}\right), 174.7\left(\mathrm{C}_{\mathrm{q}}\right), 68.3(-)$, 37.2(+), 34.9(-), 29.2(-). - IR (neat) $\tilde{v}=3460,3984,2924,1701,1404,1381,1266$, 1158, 1020, 960, 897, 830, 782, 713, 668, $616 \mathrm{~cm}^{-1}$. - MS (El-MS, $\left.70 \mathrm{eV}\right): \mathrm{m} / \mathrm{z}(\%)=$ $144\left(\mathrm{M}^{+}, 1\right), 100$ (12), 82 (13), 58 (29), 57 (10), 56 (22), 55 (100), 54 (31), 45 (19), 43 (24), 42 (19), 41 (46), 39 (26). - HRMS (ESI-MS, m/z): $145.0492\left(\mathrm{C}_{6} \mathrm{H}_{9} \mathrm{O}_{4}\right.$, calc. $\left.145.0495\left[\mathrm{MH}^{+}\right]\right)$. 
6a-methyltetrahydrofuro[2,3-b]furan-2(6aH)-one (185)

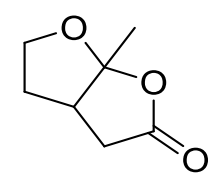

In a flame dried flask under nitrogen atmosphere $183(100 \mathrm{mg}, 0.69 \mathrm{mmol})$ was dissolved in $2 \mathrm{~mL}$ of dry THF and cooled to $-78{ }^{\circ} \mathrm{C}$. Me- $\mathrm{MgBr}(913 \mu \mathrm{L}$ of a $22 \mathrm{wt} \%$ solution in THF, $1.725 \mathrm{mmol}, 2.5 \mathrm{eq}$ ) was added dropwise. After the turbid solution was kept at that temperature for $2 \mathrm{~h}$, it was allowed to warm to $0{ }^{\circ} \mathrm{C}$. Then it was transferred to a separation funnel and $1 \mathrm{~mL}$ of water was added. The mixture was acidified to a $\mathrm{pH}$ of 2 by $\mathrm{HCl}(2 \mathrm{M})$ and extracted with $\mathrm{Et}_{2} \mathrm{O}(4 \times 5 \mathrm{~mL})$. The combined organic layers were dried over $\mathrm{Na}_{2} \mathrm{SO}_{4}$, filtered and concentrated under reduced pressure. The crude product was purified by silica column chromatography $(\mathrm{PE} / \mathrm{EA}=1: 1)$ to afford the desired product as colorless oil (18 mg, $0.13 \mathrm{mmol}, 19 \%)$.

$R_{f}(P E / E A=1: 1)=0.47$.

${ }^{1} \mathrm{H}$ NMR $\left(300 \mathrm{MHz}_{\mathrm{CDCl}}\right): \delta=4.07(\mathrm{td}, J=8.7,2.5 \mathrm{~Hz}, 1 \mathrm{H}), 3.93(\mathrm{td}, J=9.7,6.2$ $\mathrm{Hz}, 1 \mathrm{H}$ ), 2.94 (dd, $J=18.2,9.8 \mathrm{~Hz}, 1 \mathrm{H}), 2.80$ (tt, $J=9.6,2.7 \mathrm{~Hz}, 1 \mathrm{H}$ ), 2.50 (dd, $J=18.1,2.6 \mathrm{~Hz}, 1 \mathrm{H}), 2.28(\mathrm{ddd}, J=18.1,12.9,9.3 \mathrm{~Hz}, 1 \mathrm{H}), 1.83-1.70(\mathrm{~m}, 1 \mathrm{H}), 1.65$ $(\mathrm{s}, 3 \mathrm{H}) .-{ }^{13} \mathrm{C}$ NMR $\left(75 \mathrm{MHz}, \mathrm{CDCl}_{3}\right): \delta=174.6\left(\mathrm{C}_{\mathrm{q}}\right), 117.4\left(\mathrm{C}_{\mathrm{q}}\right), 67.4(-), 42.7(+), 36.5(-$ ), 33.1(-), 23.8(+). - IR (neat) $\tilde{v}=2987,2939,2888,1761,1387,1323,1259,1219$, 1129, 1084, 1014, 899, 832, 682, $606 \mathrm{~cm}^{-1}$. - MS (El-MS, $\left.70 \mathrm{eV}\right): \mathrm{m} / \mathrm{z}(\%)=141(\mathrm{M}-$ $\mathrm{H}^{*}$, 1), 127 (M-Me;, 5), 98 (38), 97 (16), 83 (12), 55 (31), 54 (14), 43 (100). - HRMS (ESI-MS, m/z): $143.0702\left(\mathrm{C}_{7} \mathrm{H}_{11} \mathrm{O}_{3}\right.$, calc. $\left.143.0703\left[(\mathrm{M}+\mathrm{H})^{+}\right]\right)$. 
(3S,4S)-4-(carboxymethyl)-5-oxotetrahydrofuran-3-carboxylic acid (186)<smiles>O=C(O)C[C@H]1C(=O)OC[C@@H]1C(=O)O</smiles>

$57(1.41 \mathrm{~g}, 8.2 \mathrm{mmol})$ was dissolved in $25 \mathrm{~mL}$ of acetone and cooled to $0{ }^{\circ} \mathrm{C}$. Within $30 \mathrm{~min}, 8.2 \mathrm{~mL}$ of Jones-reagent $(2.5 \mathrm{M})$ were added. The mixture turned slowly from orange to green. After $6 \mathrm{~h}$ it was transferred to a separation funnel, $10 \mathrm{~mL}$ of water were added and it was washed with EA (4 × $25 \mathrm{~mL})$. The combined organic layers were dried over $\mathrm{Na}_{2} \mathrm{SO}_{4}$, filtered and concentrated under reduced pressure. The crude mixture was purified by silica column chromatography (PE/EA = 1:2 + 1 vol\% $\mathrm{HOAc}$ ) to afford the desired product (1.36 g, $7.23 \mathrm{mmol}, 88 \%)$.

$\mathrm{R}_{\mathrm{f}}(\mathrm{EA})=0.27 .-[\alpha]_{D}^{20}=-29.5(\mathrm{MeOH}, \mathrm{c}=1)$.

${ }^{1} \mathrm{H}$ NMR (600 MHz, Acetone): $\delta=4.57(\mathrm{t}, J=9.0 \mathrm{~Hz}, 1 \mathrm{H}), 4.33(\mathrm{t}, J=9.0 \mathrm{~Hz}, 1 \mathrm{H})$, 3.64 - $3.53(\mathrm{~m}, 1 \mathrm{H}), 3.19(\mathrm{dt}, J=10.3,5.1 \mathrm{~Hz}, 1 \mathrm{H}), 2.86(\mathrm{~d}, J=5.2 \mathrm{~Hz}, 2 \mathrm{H})$. ${ }^{13} \mathrm{C}$ NMR (151 MHz, MeOD): $\delta=179.2\left(\mathrm{C}_{\mathrm{q}}\right), 174.2\left(\mathrm{C}_{\mathrm{q}}\right), 174.0\left(\mathrm{C}_{\mathrm{q}}\right), 68.6(-), 45.5(+)$, 40.3(+), 33.4(-). - IR (neat) $\tilde{v}=3506,3321,2977,1721,1699,1408,1380,1259$, 1188, 1158, 1085, 1029, 861, 714, 692, $648 \mathrm{~cm}^{-1}$. - MS (ESI-MS): m/z (\%) = 563 $\left((3 \mathrm{M}-\mathrm{H})^{-}, 5\right), 375$ ((2M-H)-, 100), $233\left(\mathrm{M}^{\left.-\mathrm{HCOO}^{-}, 18\right),} 187\left((\mathrm{M}-\mathrm{H})^{-}, 14\right)\right.$. - HRMS (ESI-MS, m/z): $187.0247\left(\mathrm{C}_{7} \mathrm{H}_{7} \mathrm{O}_{6}\right.$, calc. $\left.187.0248\left[(\mathrm{M}-\mathrm{H})^{-}\right]\right)$. 
(3S,3aS,6aS)-6a-allyl-5-oxohexahydrofuro[2,3-b]furan-3-carboxylic acid (187)

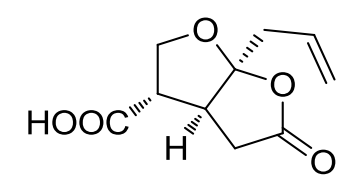

In a flame dried flask under nitrogen atmosphere 186 (603 $\mathrm{mg}, 3.32 \mathrm{mmol})$ was dissolved in $50 \mathrm{~mL}$ of dry THF and cooled to $-78{ }^{\circ} \mathrm{C}$. Allyl-MgBr $(8.02 \mathrm{~mL}$ of a $1 \mathrm{M}$ solution in $\mathrm{Et}_{2} \mathrm{O}, 8.02 \mathrm{mmol}, 2.5 \mathrm{eq}$ ) was added dropwise. After the turbid solution was kept at that temperature for $2 \mathrm{~h}$, it was allowed to warm to $0{ }^{\circ} \mathrm{C}$. Then it was transferred to a separation funnel, $20 \mathrm{~mL}$ of water were added. The mixture was acidified to a $\mathrm{pH}$ of 2 by $\mathrm{HCl}(2 \mathrm{M})$. It was extracted with $\mathrm{Et}_{2} \mathrm{O}(4 \times 50 \mathrm{~mL})$. The combined organic layers were dried over $\mathrm{Na}_{2} \mathrm{SO}_{4}$, filtered and concentrated under reduced pressure. The crude product was purified by silica column chromatography (toluene/ethyl formate/formic acid $=5: 4: 1$ ) to afford the desired product as colorless oil (514 mg, $2.42 \mathrm{mmol}, 73 \%$ ).

$\mathrm{R}_{\mathrm{f}}$ (toluene/ethyl formate/formic acid $\left.=5: 4: 1\right)=0.35 .-[\alpha]_{D}^{20}=-16.2(\mathrm{MeOH}, \mathrm{c}=1)$.

${ }^{1} \mathrm{H}$ NMR $(300 \mathrm{MHz}$, Acetone): $\delta=5.81$ (ddt, $J=17.3,10.2,7.1 \mathrm{~Hz}, 1 \mathrm{H}), 5.29-5.08$ $(\mathrm{m}, 2 \mathrm{H}), 4.32(\mathrm{dd}, J=9.5,2.2 \mathrm{~Hz}, 1 \mathrm{H}), 4.15(\mathrm{dd}, J=9.5,6.6 \mathrm{~Hz}, 1 \mathrm{H}), 3.38(\mathrm{dt}$, $J=10.4,2.7 \mathrm{~Hz}, 1 \mathrm{H}), 3.21-3.09(\mathrm{~m}, 1 \mathrm{H}), 3.02(\mathrm{dd}, J=18.7,10.4 \mathrm{~Hz}, 1 \mathrm{H}), 2.73-$ $2.60(\mathrm{~m}, 3 \mathrm{H}) .-{ }^{13} \mathrm{C}$ NMR $\left(75 \mathrm{MHz}\right.$, Acetone): $\delta=174.6\left(\mathrm{C}_{\mathrm{q}}\right), 173.6\left(\mathrm{C}_{\mathrm{q}}\right), 132.3(+)$, 120.1(-), 118.6( $\left.\mathrm{C}_{\mathrm{q}}\right), 70.1(-), 51.6(+), 44.6(+), 41.9(-), 35.9(-)$. - IR (neat) $\tilde{\mathrm{v}}=3402$, 2930, 2848, 1716, 1648, 1414, 1263, 1208, 1089, 1017, 972, 924, $866 \mathrm{~cm}^{-1}$. - MS

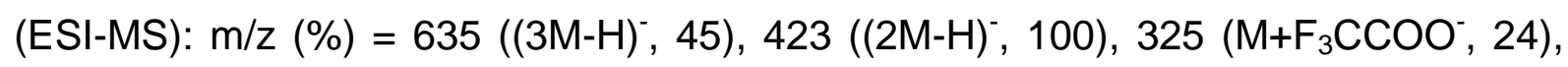
257 (M+HCOO, 52). - HRMS (ESI-MS, m/z): $211.0612\left(\mathrm{C}_{10} \mathrm{H}_{11} \mathrm{O}_{5}\right.$, calc. 211.0612 $\left.\left[(\mathrm{M}-\mathrm{H})^{-}\right]\right)$. 
(3S,3aS,6aS)-5-oxo-6a-(2-oxopropyl)hexahydrofuro[2,3-b]furan-3-carboxylic acid (189)<smiles>CC(=O)C[C@@]12OCC(C(=O)O)C1CC(=O)O2</smiles>

187 (100 mg, $0.47 \mathrm{mmol}$ ) was dissolved in $2 \mathrm{~mL}$ of acetone/water (4:1) and cooled to $0^{\circ} \mathrm{C}$. At that temperature $\mathrm{Hg}(\mathrm{OAc})_{2}(37.4 \mathrm{mg}, 0.118 \mathrm{mmol}, 0.25 \mathrm{eq})$ was added, which turned the solution yellow. After $15 \min 470 \mu \mathrm{L}$ of Jones-reagent $(2.5 \mathrm{M})$ were added dropwise. The mixture was allowed to warm to room temperature and was stirred for additional $15 \mathrm{~h}$. After that time it was transferred to a separation funnel, mixed with $1 \mathrm{~mL}$ of water and extracted with $\mathrm{Et}_{2} \mathrm{O}(4 \times 3 \mathrm{ml})$. The crude product was purified by silica column chromatography (toluene/ethyl formate/formic acid $=5: 4: 1$ ) to afford the desired product as yellow oil ( $85 \mathrm{mg}, 0.37 \mathrm{mmol}, 79 \%$ ).

$\mathrm{R}_{\mathrm{f}}$ (toluene/ethyl formate/formic acid $\left.=5: 4: 1\right)=0.22 .-[\alpha]_{D}^{20}=-30.7(\mathrm{MeCN}, \mathrm{c}=1)$.

${ }^{1} \mathrm{H}$ NMR $\left(600 \mathrm{MHz}, \mathrm{CD}_{3} \mathrm{CN}\right): \delta=4.22(\mathrm{~d}, J=9.7 \mathrm{~Hz}, 1 \mathrm{H}), 4.02(\mathrm{dd}, J=9.8,6.0 \mathrm{~Hz}$, $1 \mathrm{H}$ ), 3.35 (dd, $J=21.5,10.6 \mathrm{~Hz}, 2 \mathrm{H}$ ), 3.15 (dd, $J=18.7,10.9 \mathrm{~Hz}, 1 \mathrm{H}$ ), 3.00 (dd, $J=27.8,12.1 \mathrm{~Hz}, 2 \mathrm{H}), 2.54(\mathrm{dd}, J=18.7,3.6 \mathrm{~Hz}, 1 \mathrm{H}), 2.12(\mathrm{~s}, 3 \mathrm{H}) .-{ }^{13} \mathrm{C}$ NMR $(151$ $\left.\mathrm{MHz}, \mathrm{CD}_{3} \mathrm{CN}\right): \delta=206.2\left(\mathrm{C}_{\mathrm{q}}\right), 175.8\left(\mathrm{C}_{\mathrm{q}}\right), 174.0\left(\mathrm{C}_{\mathrm{q}}\right), 116.1\left(\mathrm{C}_{\mathrm{q}}\right), 69.3(-), 51.8(+)$, 49.9(-), 45.2(+), 36.3(-), 30.8(+).- IR (neat) $\tilde{v}=3503,2998,2919,1766,1712,1404$, 1373, 1275, 1205, 1173, 1112, 1036, 999, 949, 926, 862, 653, $609 \mathrm{~cm}^{-1}$. HRMS (ESI-MS, m/z): $227.0563\left(\mathrm{C}_{10} \mathrm{H}_{11} \mathrm{O}_{6}\right.$, calc. $\left.227.0561\left[(\mathrm{M}-\mathrm{H})^{-}\right]\right)$. 


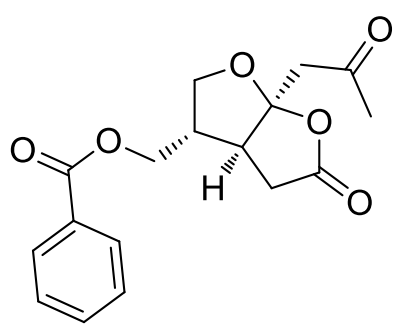

In a flamed dried flask under nitrogen atmosphere $189(18 \mathrm{mg}, 0.079 \mathrm{mmol})$ was dissolved in $1 \mathrm{~mL}$ of dry THF and cooled to $-15{ }^{\circ} \mathrm{C}$. To this solution $\mathrm{BH}_{3} \cdot \mathrm{THF}$ (solution $1 \mathrm{M}$ in THF, $166 \mu \mathrm{L}, 0.166 \mathrm{mmol}, 2.1 \mathrm{eq}$ ) was added dropwise. After $4 \mathrm{~h}$ at $-15^{\circ} \mathrm{C}$ it was allowed to warm to room temperature. The solvent was evaporated under reduced pressure. The obtained crude product was dissolved in $1.5 \mathrm{~mL}$ of dry DCM, cooled to $-40{ }^{\circ} \mathrm{C}$ and treated with DMAP $(1 \mathrm{mg}, 0.008 \mathrm{mmol}, 0.1 \mathrm{eq})$, triethylamine (66 $\mu \mathrm{L}, 0.474 \mathrm{mmol}, 6 \mathrm{eq}$ ) and benzoyl chloride (10 $\mu \mathrm{L}, 0.083 \mathrm{mmol}, 1.05 \mathrm{eq})$. The reaction was allowed to warm to $-10^{\circ} \mathrm{C}$. After $1.5 \mathrm{~d}$ it was transferred to a separation funnel, treated with $1 \mathrm{~mL}$ of a half saturated $\mathrm{NH}_{4} \mathrm{Cl}$ solution and extracted with $\mathrm{Et}_{2} \mathrm{O}$ $(3 \times 2 \mathrm{~mL})$. The combined organic layers were dried over $\mathrm{Na}_{2} \mathrm{SO}_{4}$, filtered and concentrated under reduced pressure. The crude product was again dissolved in $2 \mathrm{~mL}$ of dry DCM, cooled to $0^{\circ} \mathrm{C}$ and treated with solid DMP $(33.5 \mathrm{mg}, 0.079 \mathrm{mmol}$, $1 \mathrm{eq}$ ). After $3 \mathrm{~h}$ at that temperature it was warmed to room temperature and transferred to a separation funnel. The mixture was washed with saturated $\mathrm{NaHCO}_{3}$ solution $(2 \times 1 \mathrm{~mL})$. The combined aqueous layers were extracted with DCM $(2 \times 1 \mathrm{~mL})$. The combined organic layers were dried over $\mathrm{Na}_{2} \mathrm{SO}_{4}$, filtered and concentrated under reduced pressure. The crude product was purified by silica column chromatography ( $P E / E A=2: 1)$ to afford the clean 5 as white needles $(11 \mathrm{mg}$, $0.035 \mathrm{mmol}, 44 \%$ based on 189 ).

$\mathrm{R}_{\mathrm{f}}(\mathrm{PE} / \mathrm{EA}=1: 1)=0.50 .-[\alpha]_{D}^{20}=-42.0\left(\mathrm{CHCl}_{3}, \mathrm{C}=0.17\right)$.

${ }^{1} \mathrm{H}$ NMR $\left(600 \mathrm{MHz}, \mathrm{CDCl}_{3}\right): \delta=8.02(\mathrm{dd}, J=8.1,1.0 \mathrm{~Hz}, 2 \mathrm{H}), 7.60(\mathrm{tt}, J=7.2,1.2$ $\mathrm{Hz}, 1 \mathrm{H}$ ), 7.47 (t, $J=7.8 \mathrm{~Hz}, 2 \mathrm{H}), 4.29(\mathrm{dd}, J=11.0,7.3 \mathrm{~Hz}, 1 \mathrm{H}), 4.19$ (dd, $J=11.0$, $8.0 \mathrm{~Hz}, 1 \mathrm{H}), 4.03(\mathrm{qd}, J=9.9,3.4 \mathrm{~Hz}, 2 \mathrm{H}), 3.40(\mathrm{~d}, J=17.7 \mathrm{~Hz}, 1 \mathrm{H}), 3.34(\mathrm{dd}$, $J=18.6,10.5 \mathrm{~Hz}, 1 \mathrm{H}), 2.99-2.93(\mathrm{~m}, 2 \mathrm{H}), 2.58-2.51(\mathrm{~m}, 2 \mathrm{H}), 2.20(\mathrm{~s}, 3 \mathrm{H})$. 
${ }^{13} \mathrm{C}$ NMR $\left(75 \mathrm{MHz}, \mathrm{CDCl}_{3}\right): \delta=204.5\left(\mathrm{C}_{\mathrm{q}}\right), 174.6\left(\mathrm{C}_{\mathrm{q}}\right), 166.5\left(\mathrm{C}_{\mathrm{q}}\right), 133.5(+), 129.7(+)$, 129.6( $\left(\mathrm{C}_{\mathrm{q}}\right)$, 128.7(+), 115.1( $\left.\mathrm{C}_{\mathrm{q}}\right)$, 68.0(-), 65.0(-), 49.6(-), 46.8(+), 44.5(+), 36.7(-), 31.0(+). - IR (neat): $\tilde{v}=2984,1703,1401,1366,1320,1197,1152,1116,1074,981$, 952, 927, 870, 841, 779, 725, $674 \mathrm{~cm}^{-1}$. - MS (ESI-MS, m/z): 456 (19), 455 ((2M-H)', 82), 274 (13), $273\left(\mathrm{M}+\mathrm{HCOO}^{-}, 100\right), 277\left((\mathrm{M}-\mathrm{H})^{-}, 3\right)$. - HRMS (ESI-MS, m/z): $227.0927\left(\mathrm{C}_{11} \mathrm{H}_{15} \mathrm{O}_{5}\right.$, calc. $\left.\left.227.0925[(\mathrm{M}-\mathrm{H}))^{\circ}\right]\right)$ - - mp: $152{ }^{\circ} \mathrm{C}$. 


\section{E. Appendix}

\section{NMR spectra}

${ }^{1} \mathrm{H}-\mathrm{NMR}$ spectra:

upper image

${ }^{13} \mathrm{C}-\mathrm{NMR}$ spectra (DEPT 135 integrated): $\quad$ lower image

Used solvent and $\mathrm{MHz}$ are stated at the actual spectra. 
((4S,4'S,5S,5' S)-2,2'-(propane-2,2-diyl)bis(5-phenyl-4,5-dihydrooxazole-4,2diyl))dimethanol (85)

$\left(\mathrm{CDCl}_{3}, 300 \mathrm{MHz}\right)$

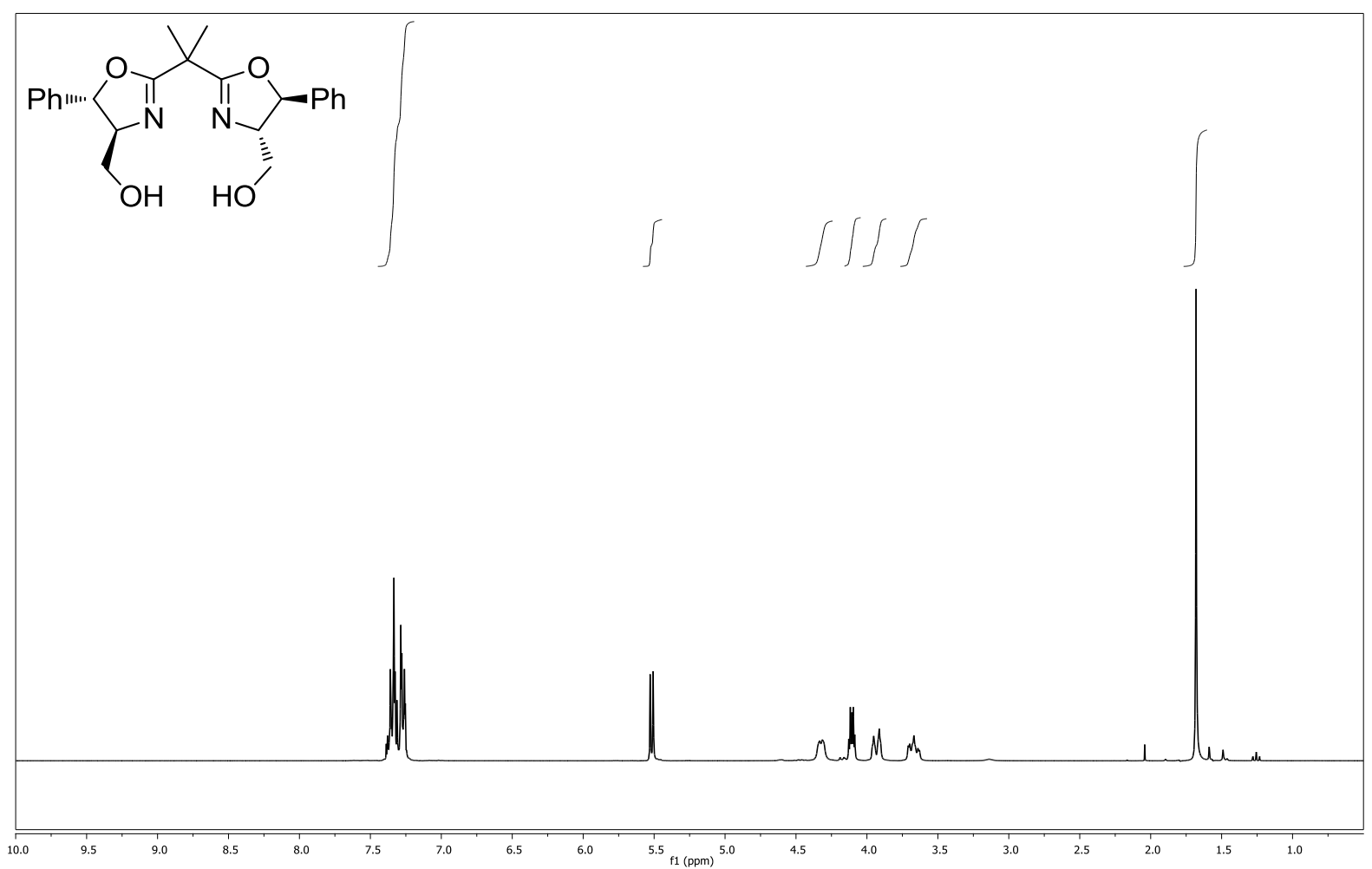

$\left(\mathrm{CDCl}_{3}, 75 \mathrm{MHz}\right)$

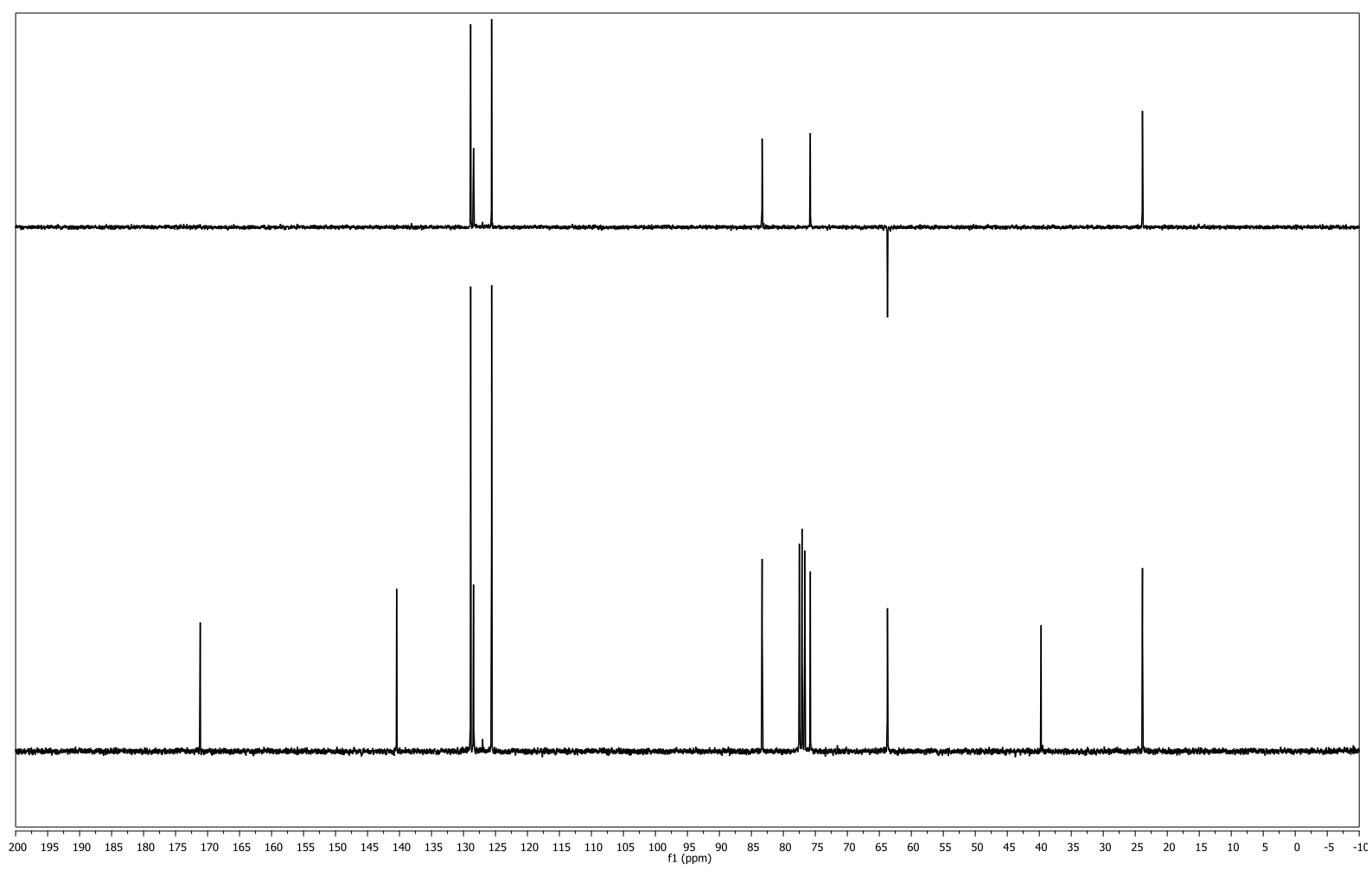


E. Appendix

methyl furan-3-carboxylate (78)

$$
\left(\mathrm{CDCl}_{3}, 300 \mathrm{MHz}\right)
$$

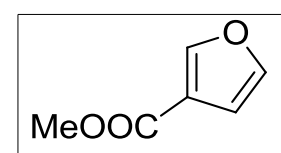

$$
\left(\mathrm{CDCl}_{3}, 75 \mathrm{MHz}\right)
$$

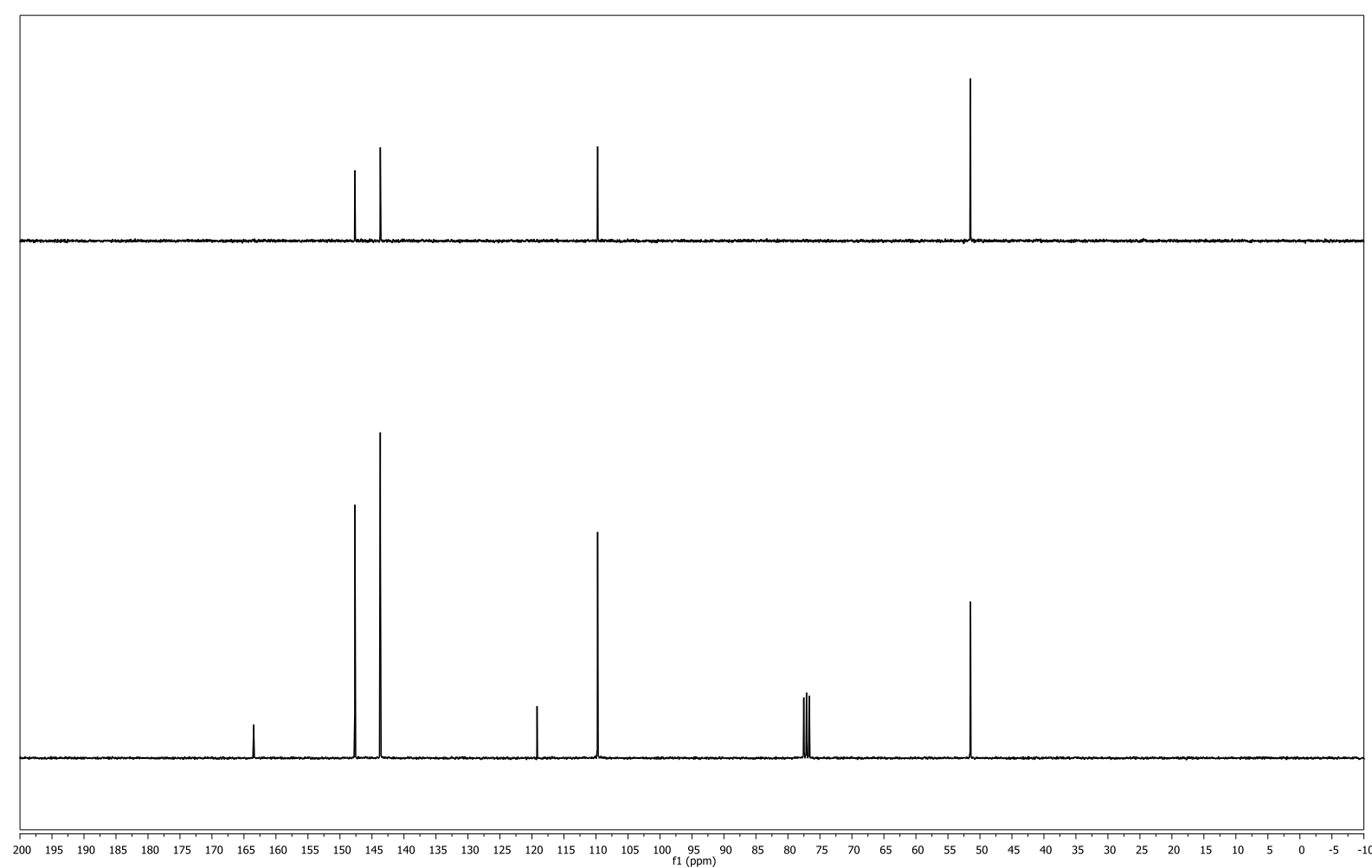

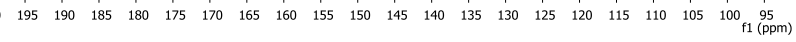

116 
(1S,5R,6S)-6-ethyl 4-methyl 2-oxabicyclo[3.1.0]hex-3-ene-4,6-dicarboxylate (119) $\left(\mathrm{CDCl}_{3}, 300 \mathrm{MHz}\right)$

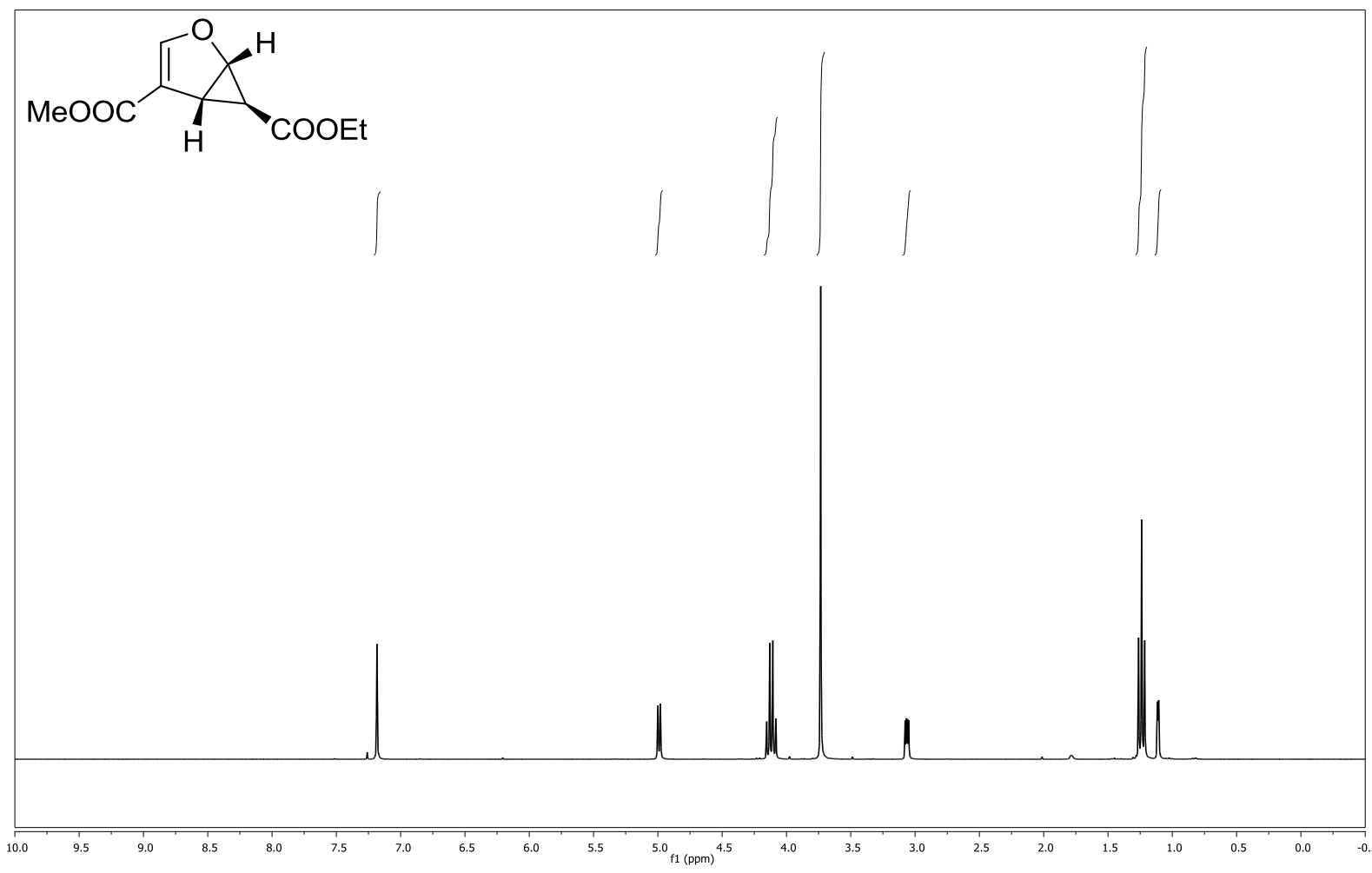

$\left(\mathrm{CDCl}_{3}, 75 \mathrm{MHz}\right)$

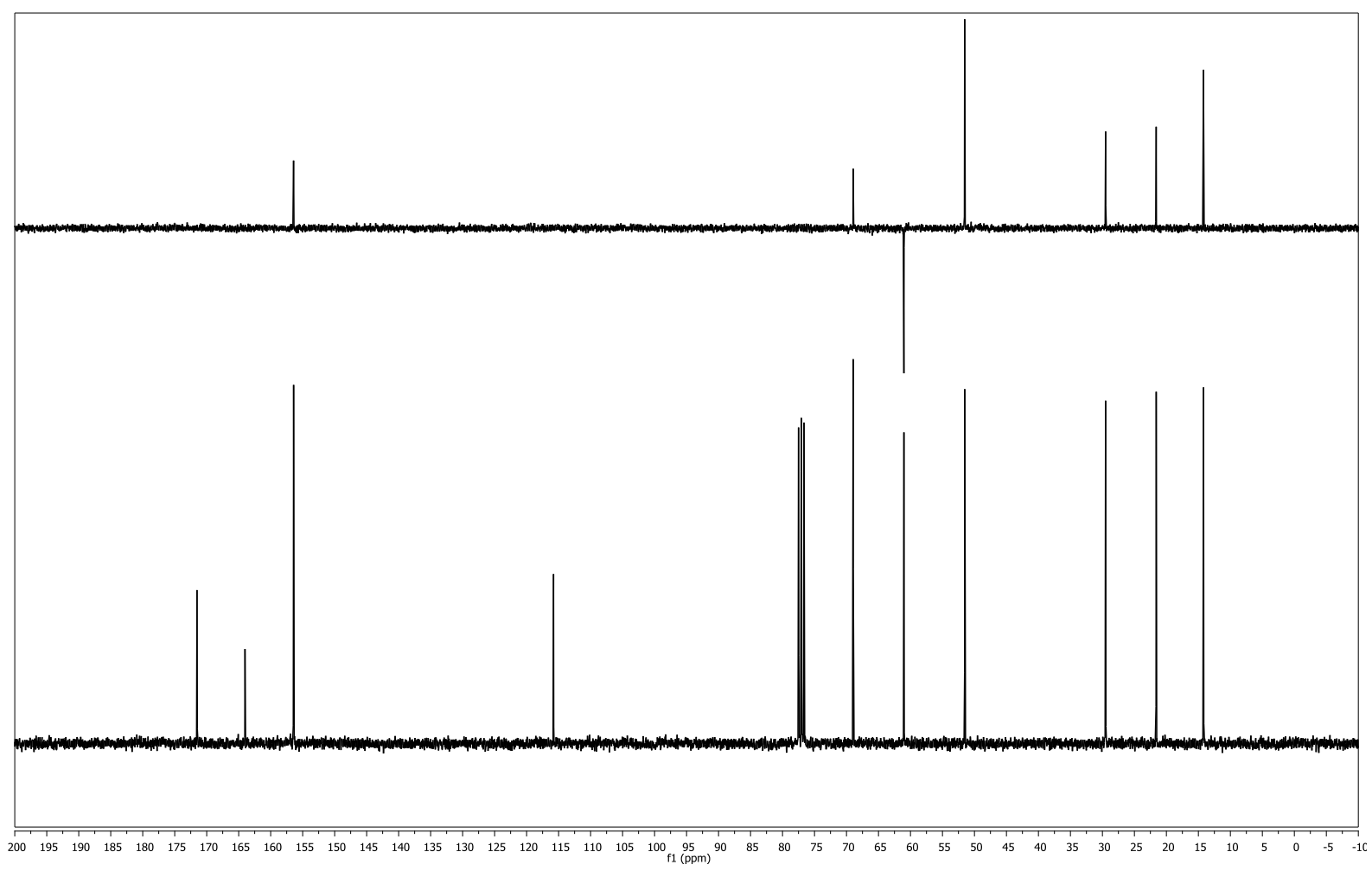


(2Z,4E)-6-ethyl 1-methyl 2-formylhexa-2,4-dienedioate (Z/E-127) and (2E,4E)-6ethyl 1-methyl 2-formylhexa-2,4-dienedioate (E/E-127) $\left(\mathrm{CDCl}_{3}, 600 \mathrm{MHz}\right)$

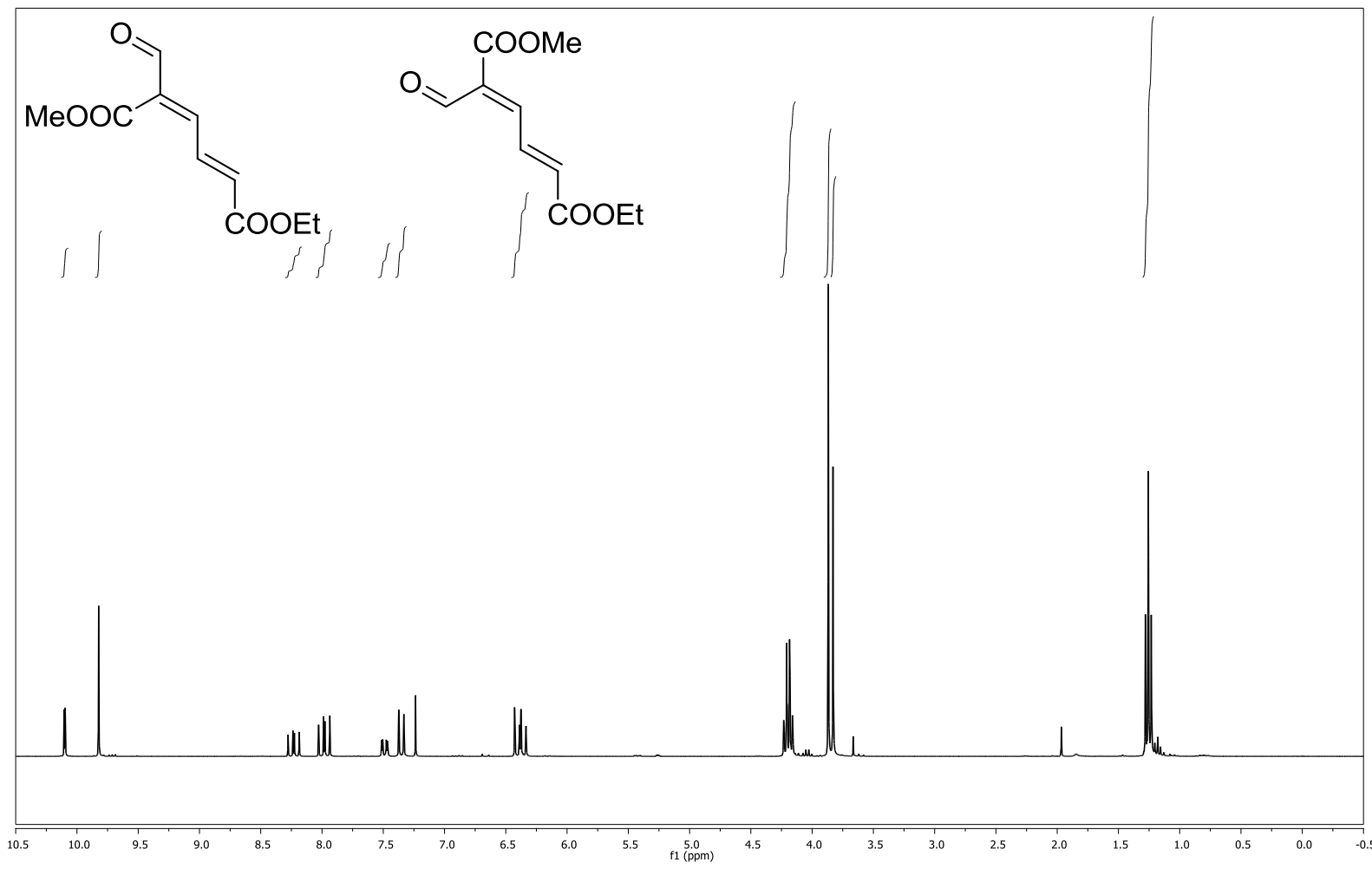

$\left(\mathrm{CDCl}_{3}, 151 \mathrm{MHz}\right)$

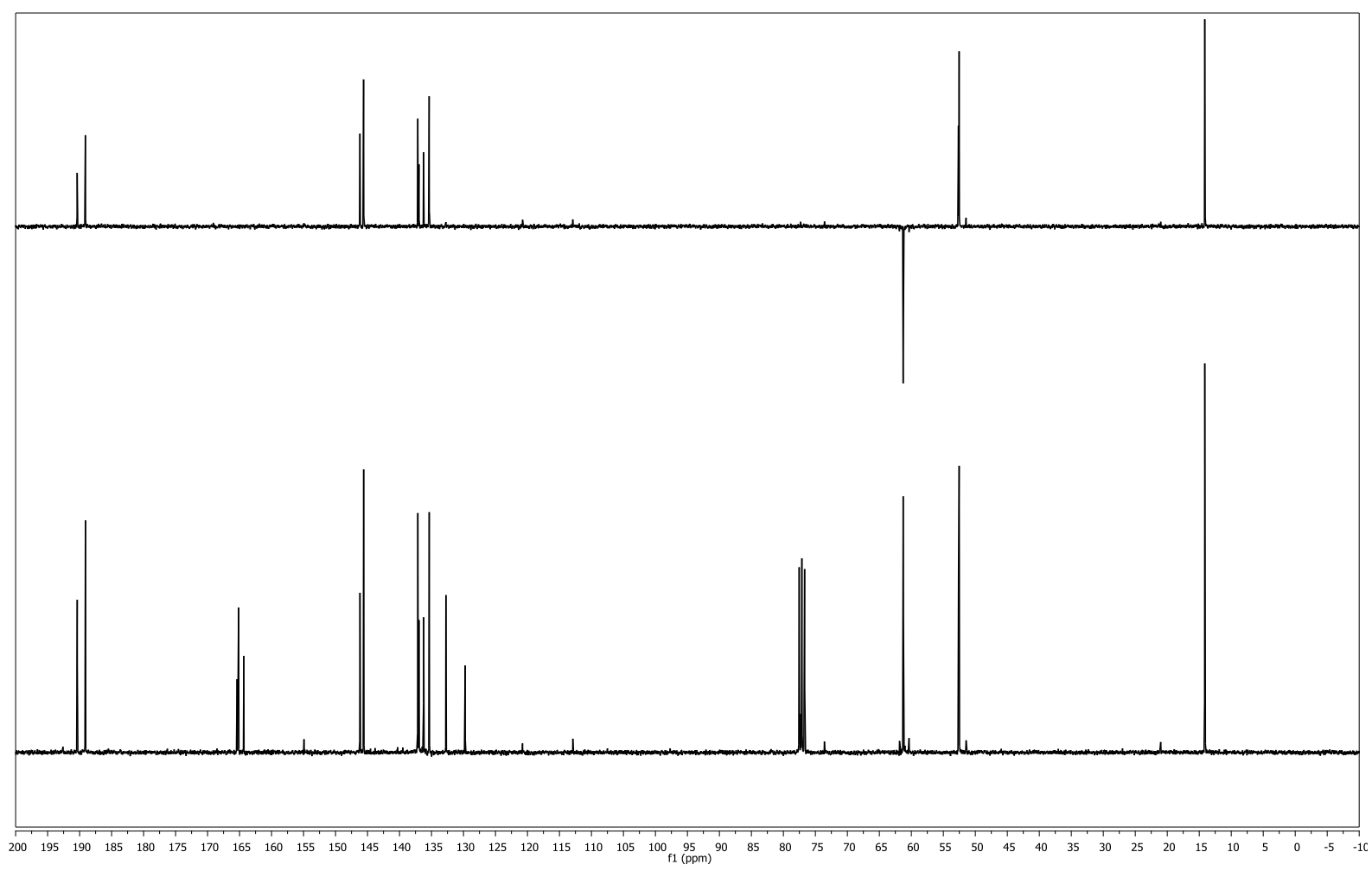


(1S,5R,6S)-ethyl-4-(hydroxymethyl)-2-oxabicyclo[3.1.0]hex-3-ene-6-carboxylate (131)

$\left(\mathrm{CDCl}_{3}, 300 \mathrm{MHz}\right)$

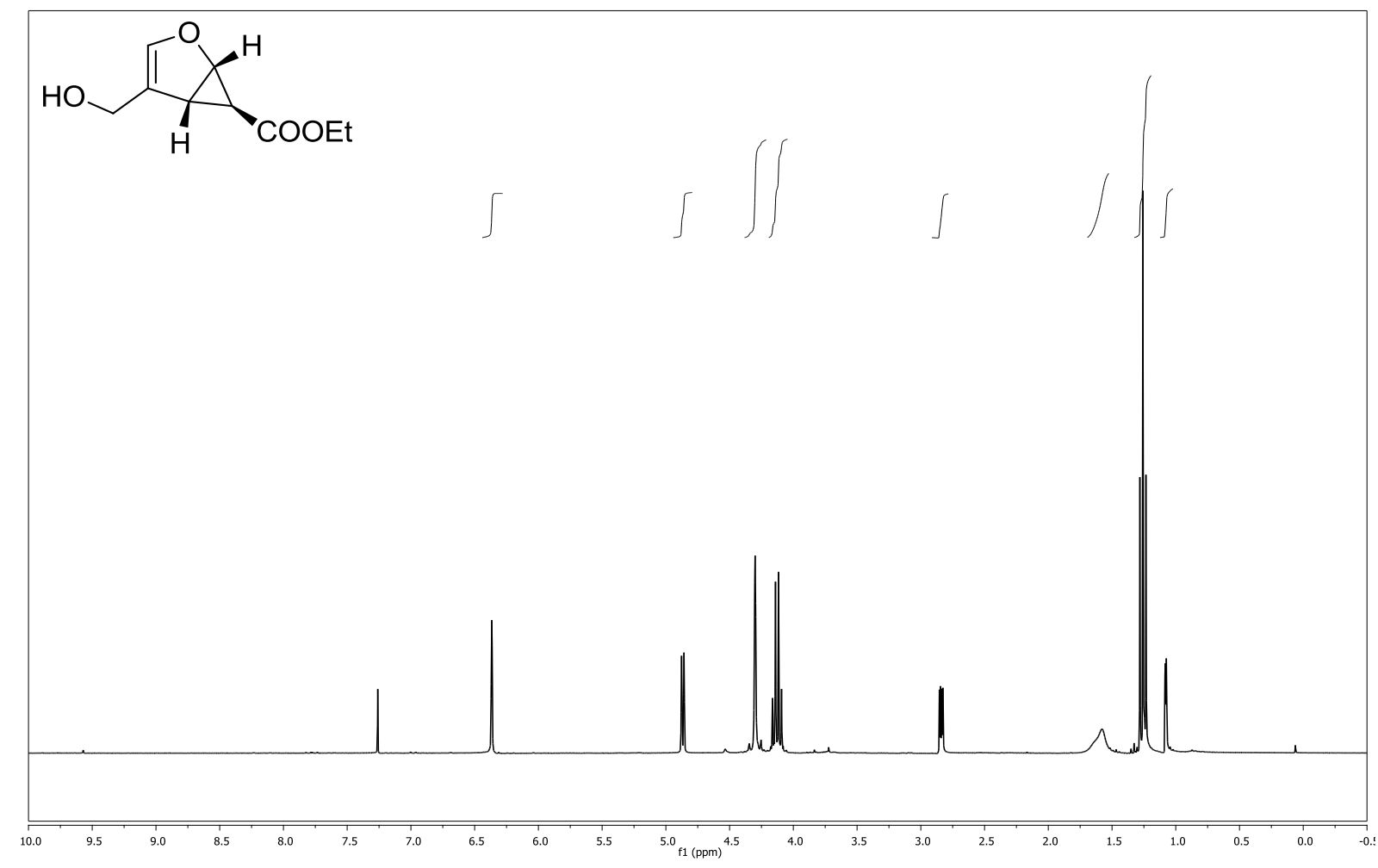

$\left(\mathrm{CDCl}_{3}, 75 \mathrm{MHz}\right)$

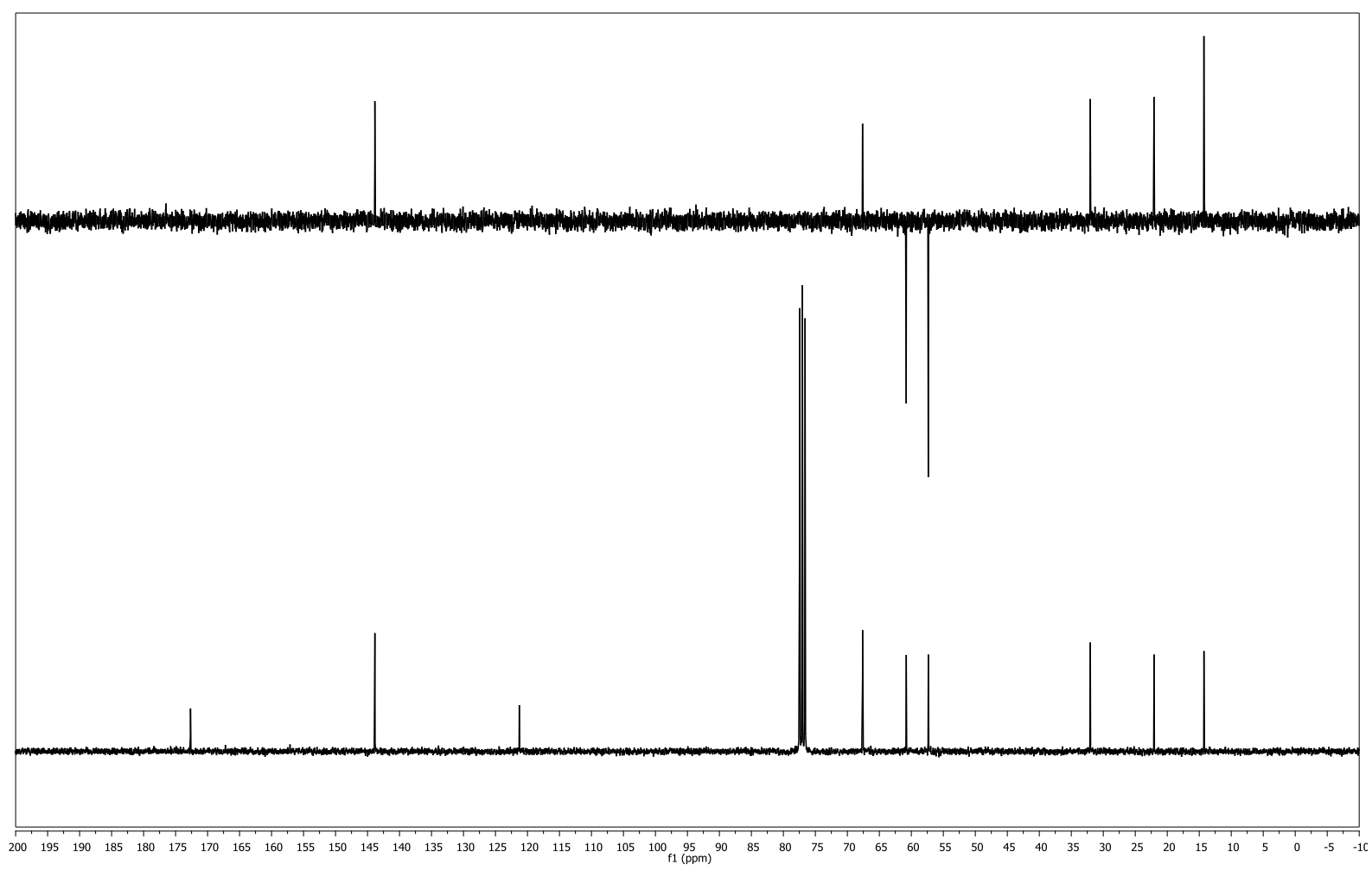


(1S,5R,6R)-methyl-6-(hydroxymethyl)-2-oxabicyclo[3.1.0]hex-3-ene-4carboxylate (132)

$\left(\mathrm{CDCl}_{3}, 300 \mathrm{MHz}\right)$

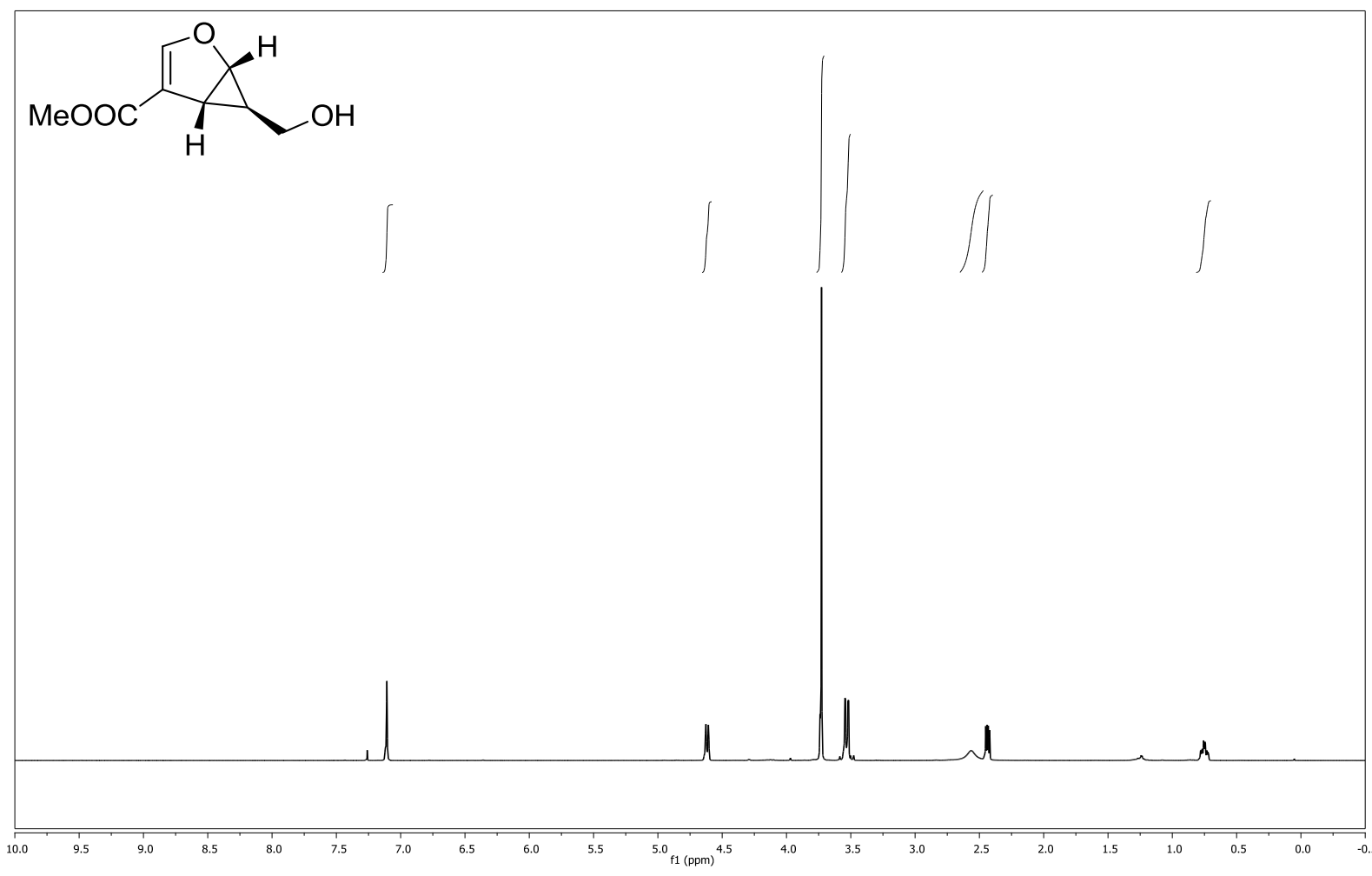

$\left(\mathrm{CDCl}_{3}, 75 \mathrm{MHz}\right)$

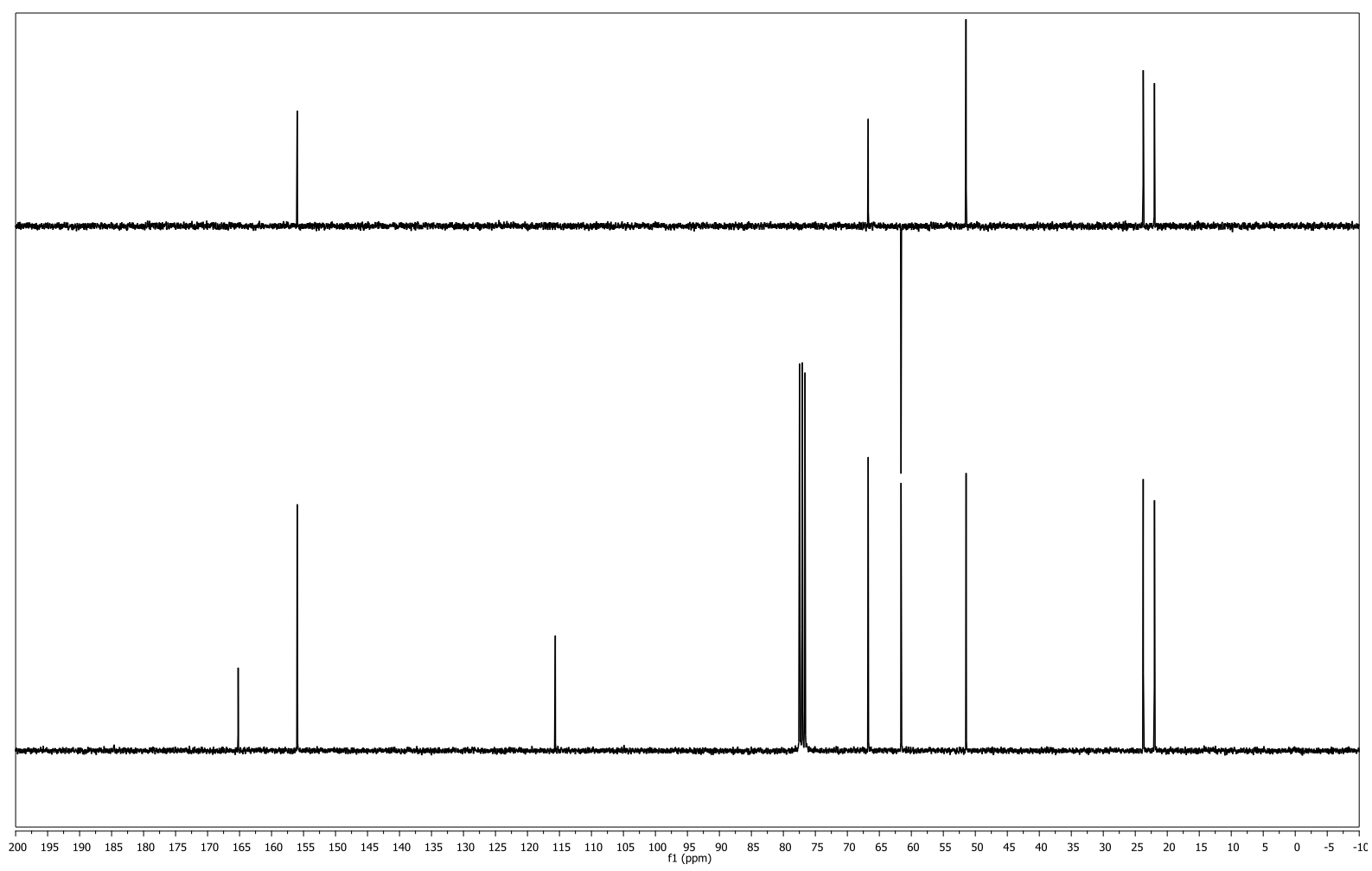


(1S,4S,5S,6S)-6-ethyl 4-methyl 2-oxabicyclo[3.1.0]hexane-4,6-dicarboxylate (133)

$\left(\mathrm{CDCl}_{3}, 300 \mathrm{MHz}\right)$

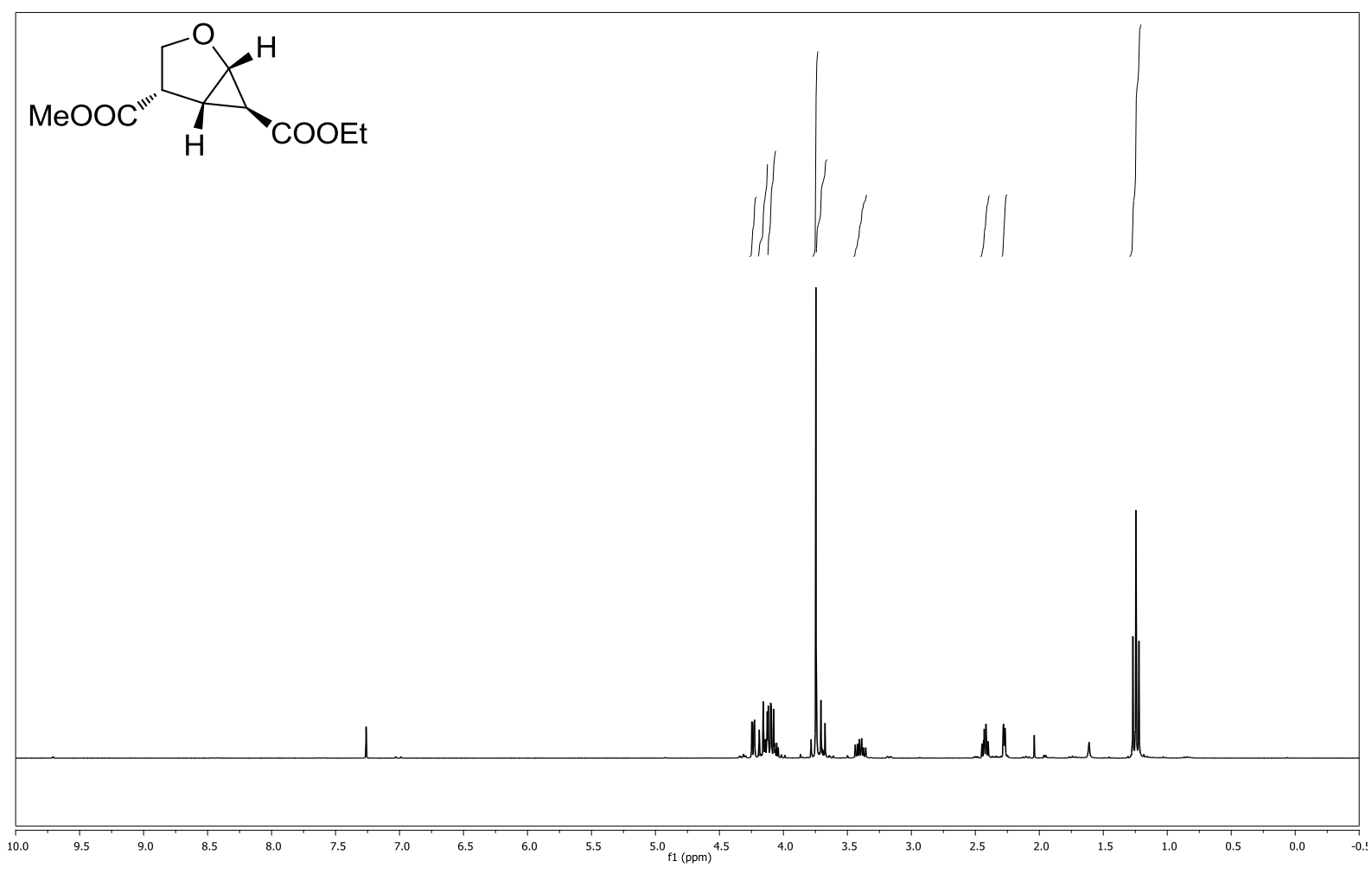

$\left(\mathrm{CDCl}_{3}, 75 \mathrm{MHz}\right)$

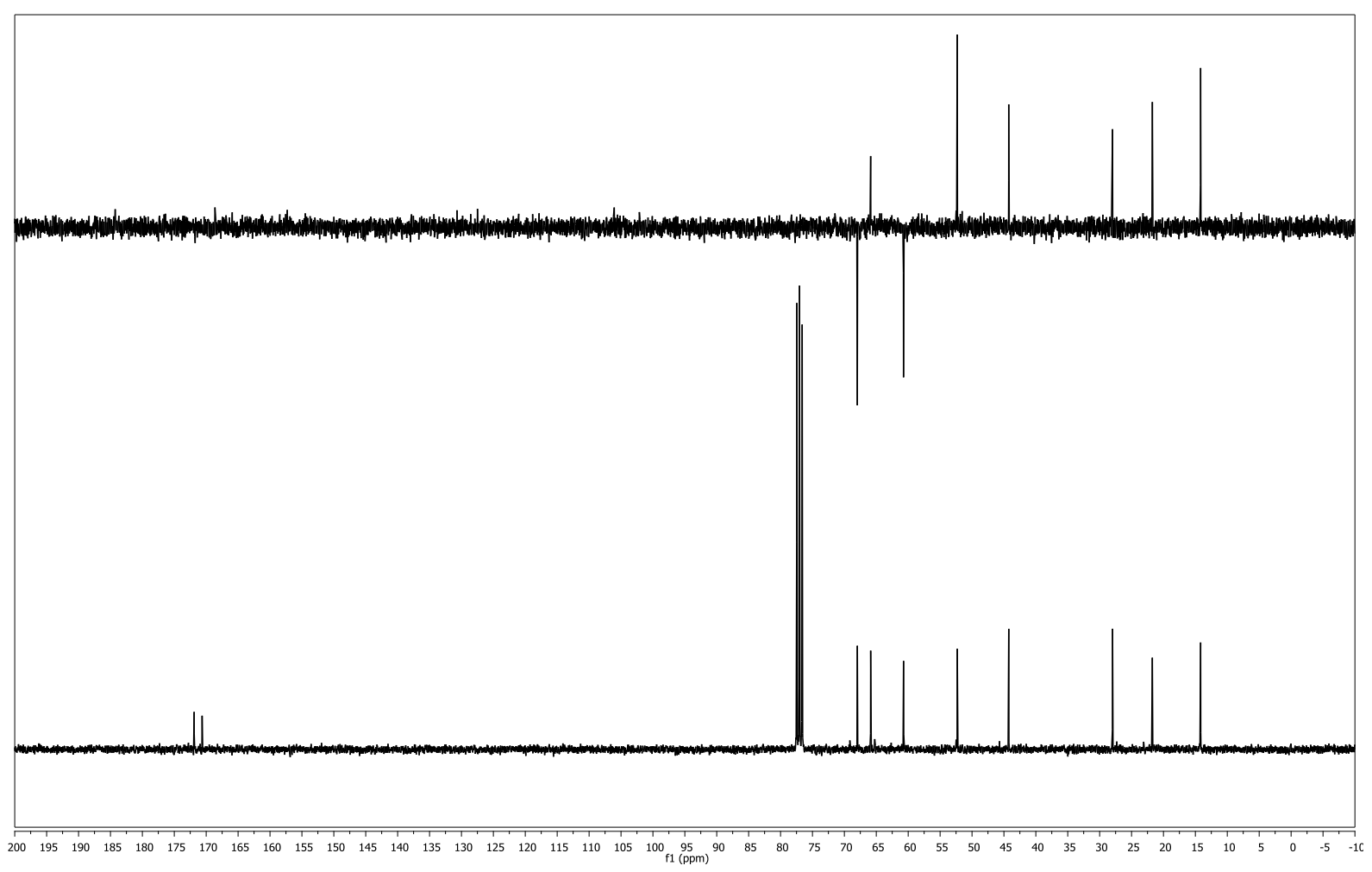


(3S,5S)-methyl 5-(2-ethoxy-2-oxoethyl)tetrahydrofuran-3-carboxylate (134)

$\left(\mathrm{CDCl}_{3}, 600 \mathrm{MHz}\right)$

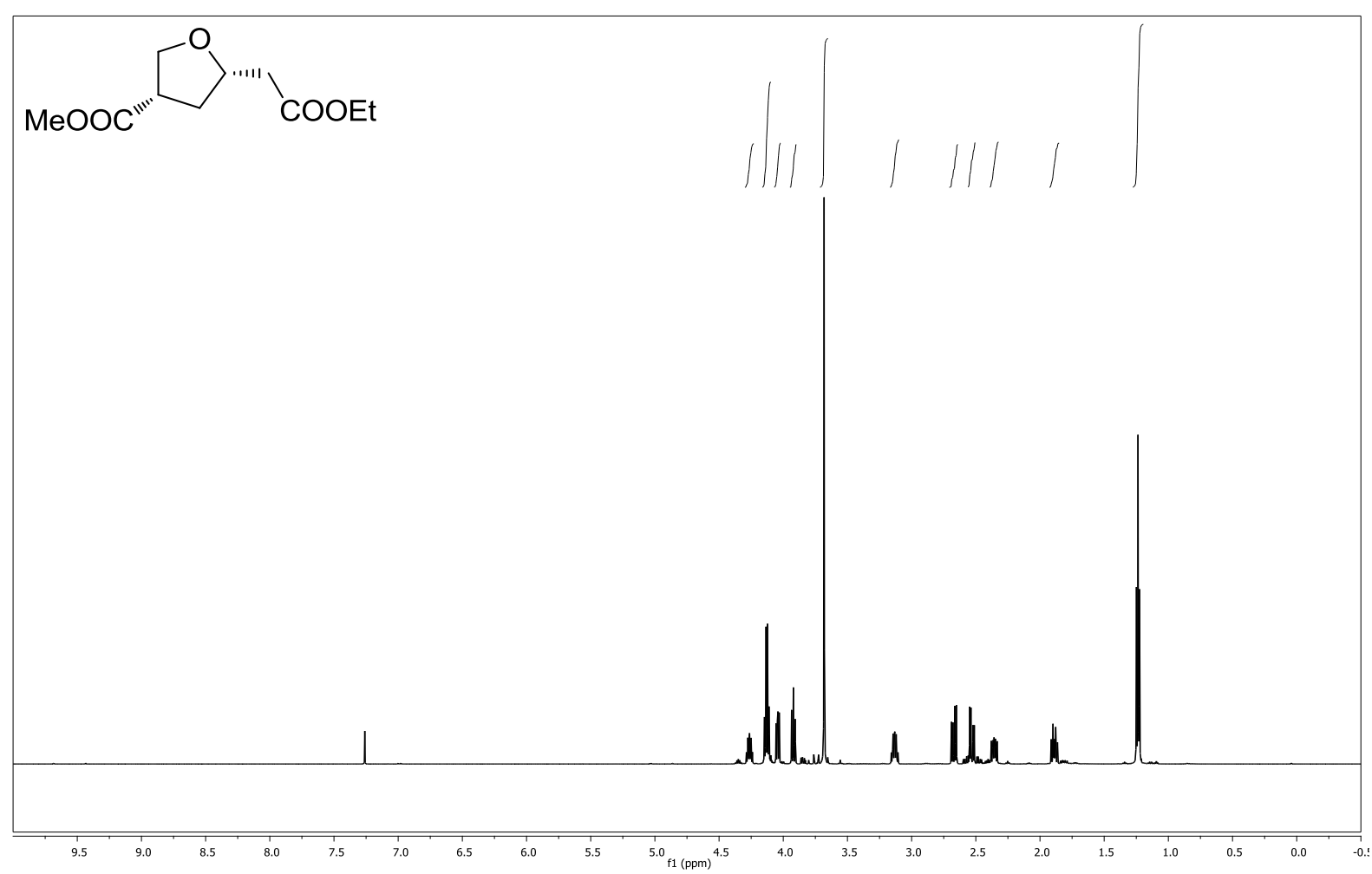

$\left(\mathrm{CDCl}_{3}, 151 \mathrm{MHz}\right)$

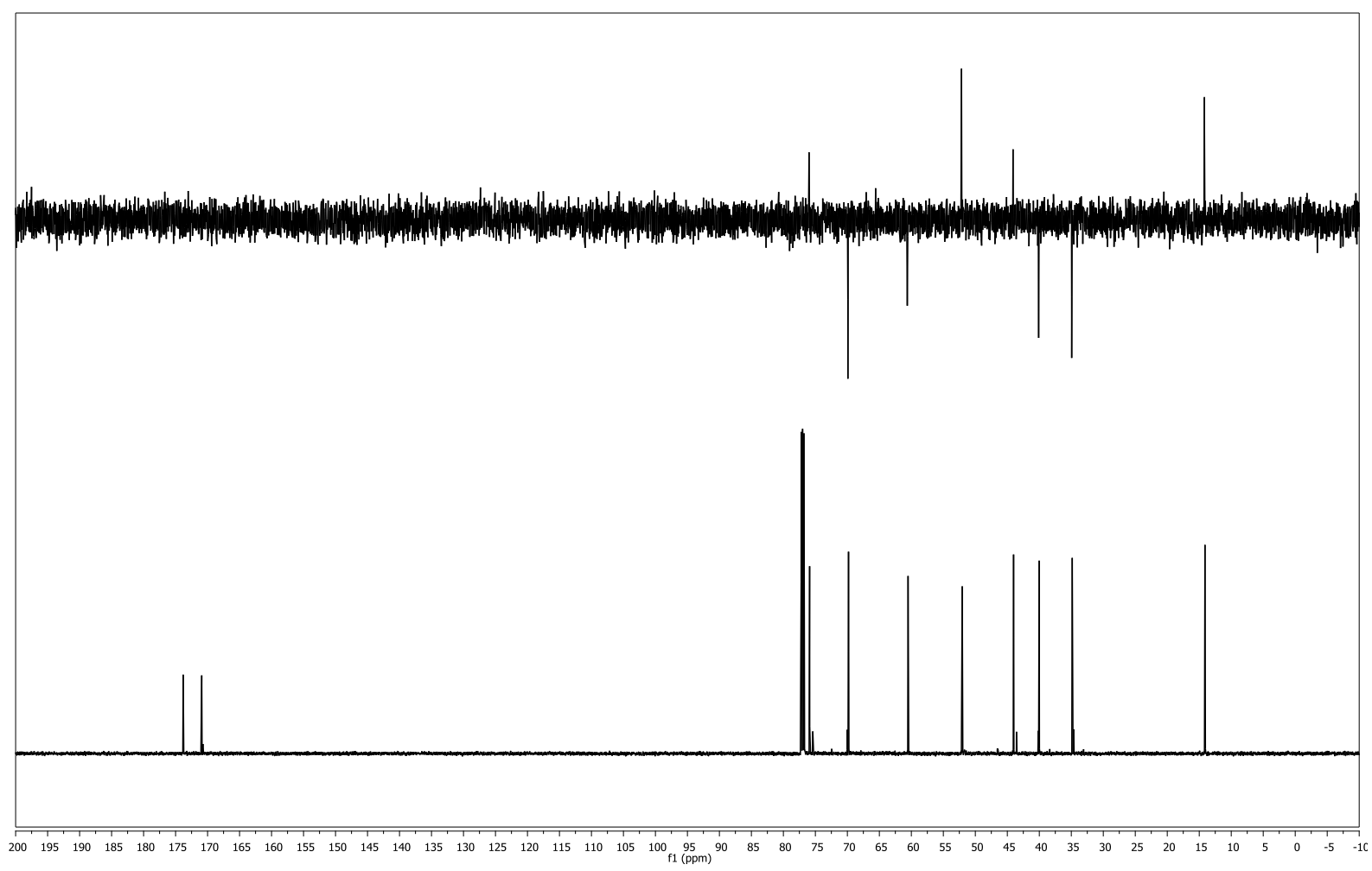


(5S)-methyl 5-(2-methoxy-2-oxoethyl)tetrahydrofuran-3-carboxylate (135)

$\left(\mathrm{CDCl}_{3}, 600 \mathrm{MHz}\right)$

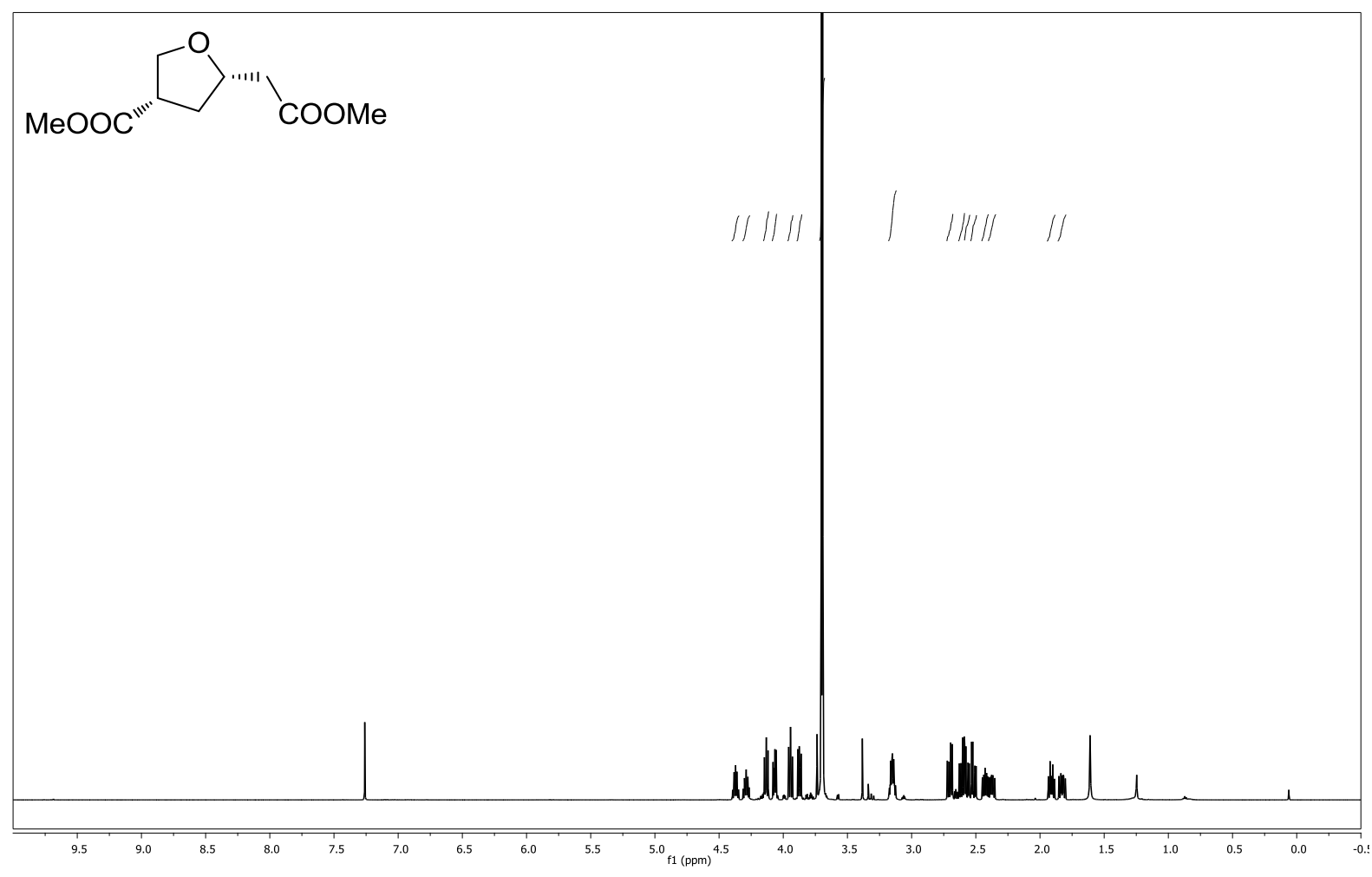

$\left(\mathrm{CDCl}_{3}, 151 \mathrm{MHz}\right)$

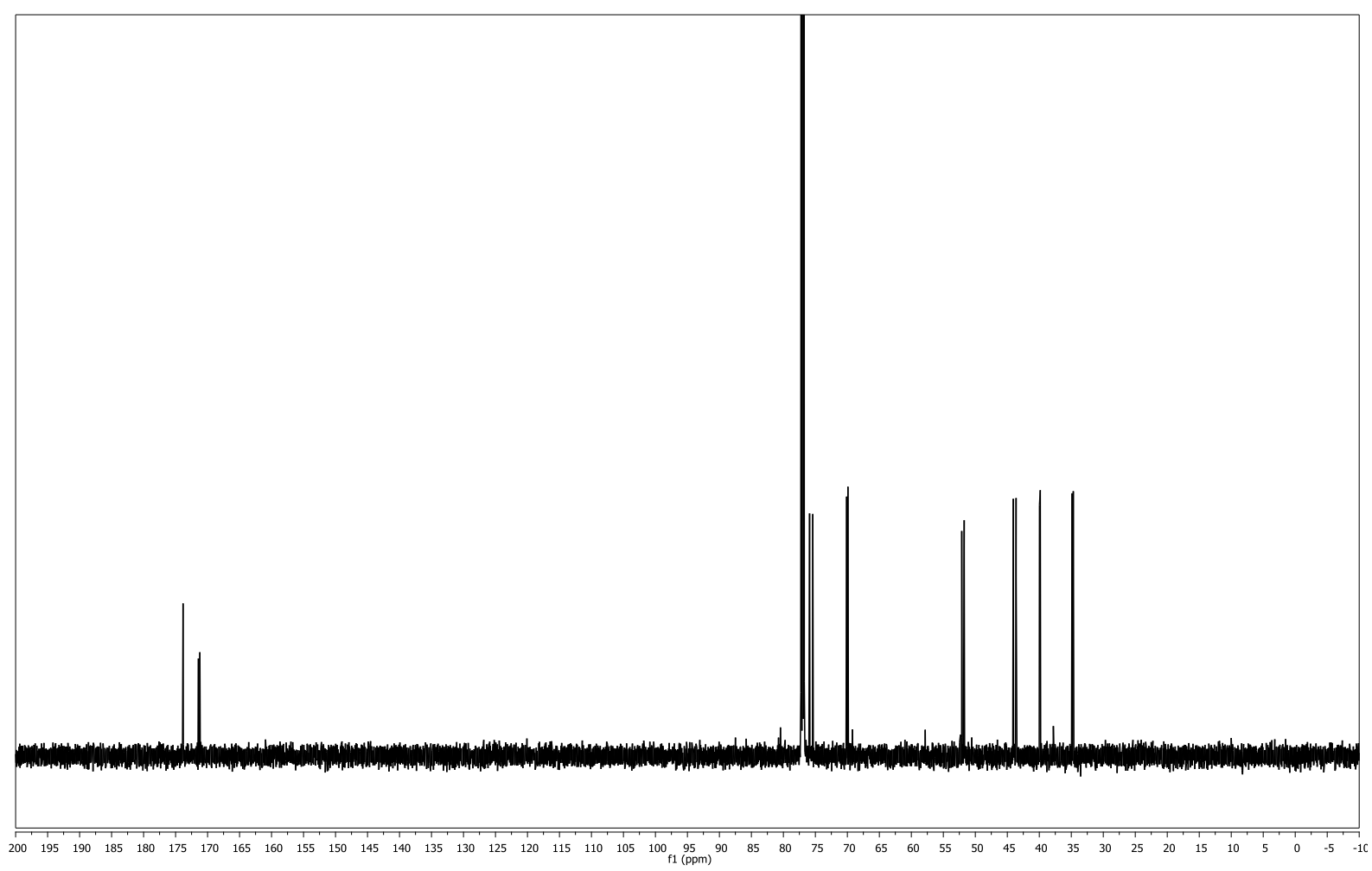


4-methylbenzenesulfonyl azide (87)

$\left(\mathrm{CDCl}_{3}, 300 \mathrm{MHz}\right)$

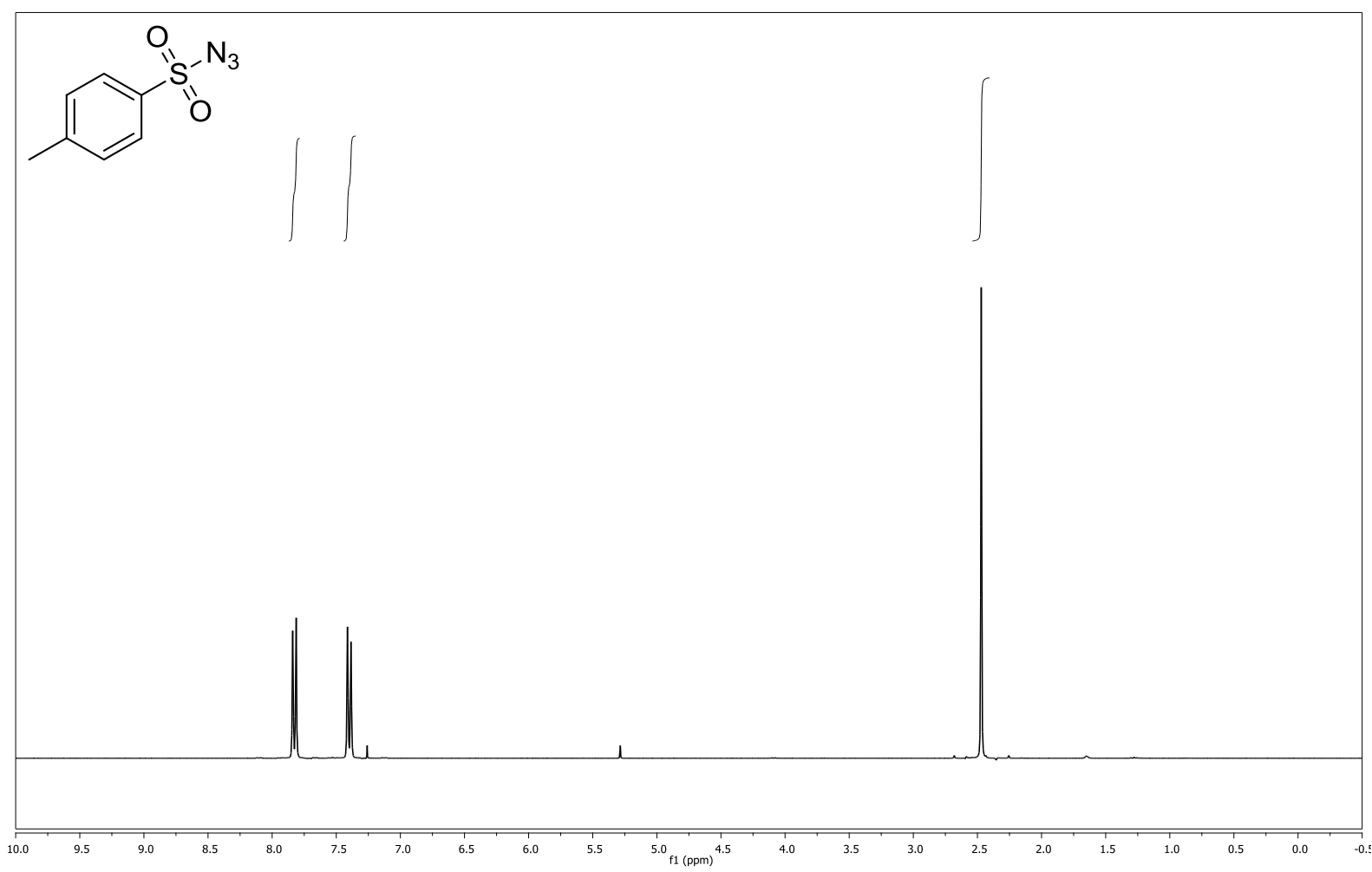

$\left(\mathrm{CDCl}_{3}, 75 \mathrm{MHz}\right)$

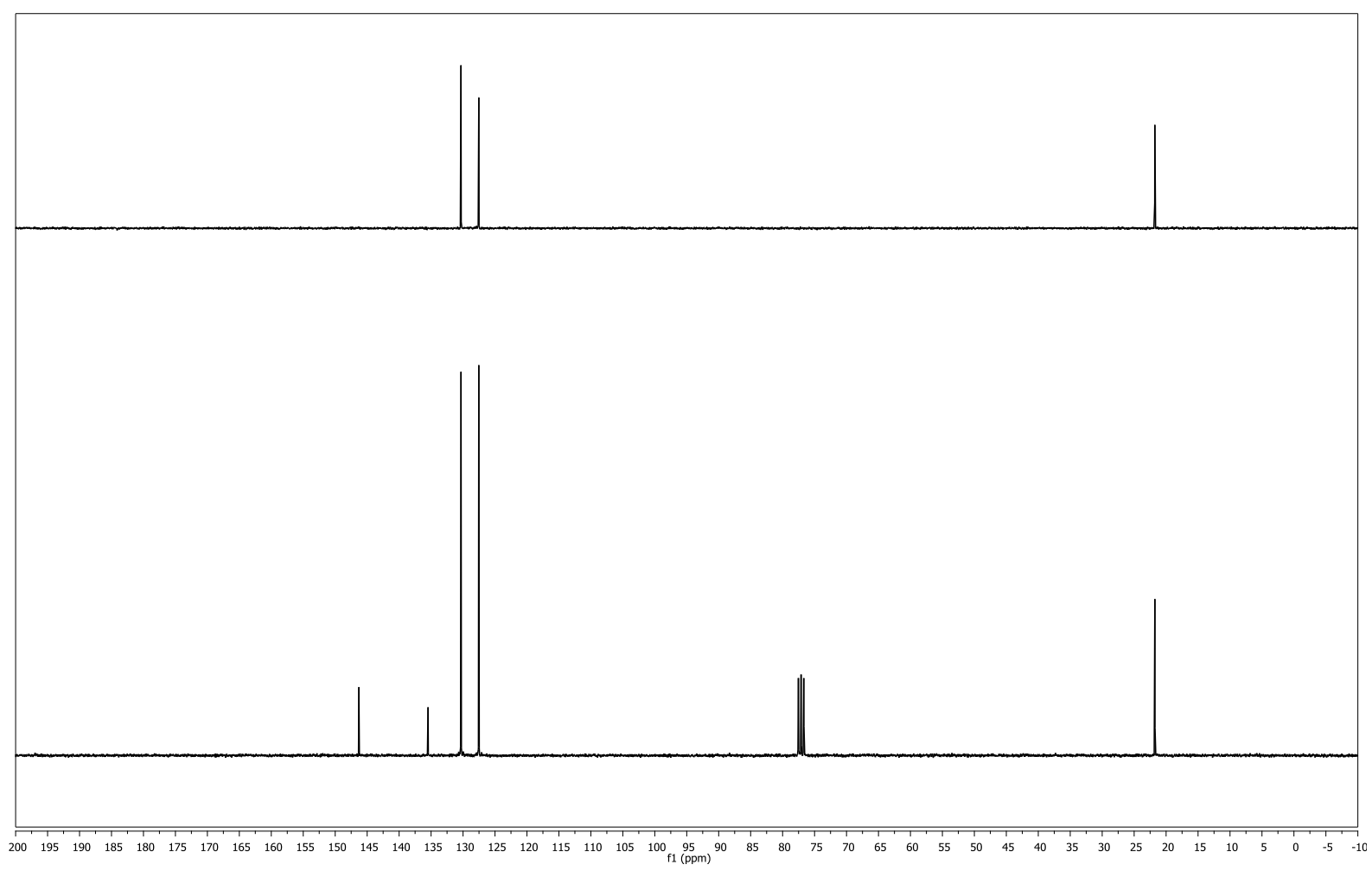


tert-butyl 3-diazo-2-oxopropanoate (89)

$\left(\mathrm{CDCl}_{3}, 300 \mathrm{MHz}\right)$

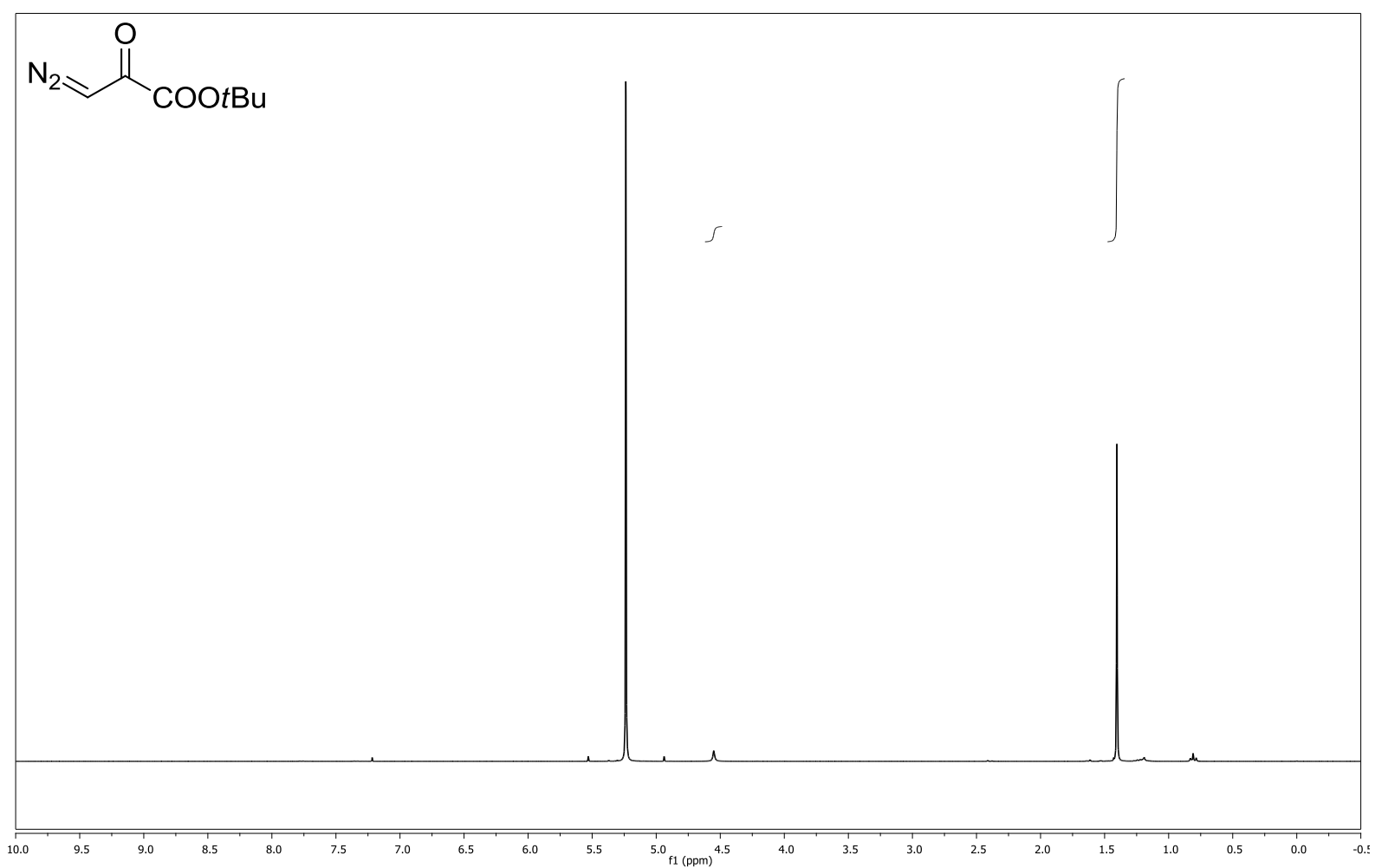


(1S,5R,6S)-6-tert-butyl 4-methyl 2-oxabicyclo[3.1.0]hex-3-ene-4,6-dicarboxylate (118) $\left(\mathrm{CDCl}_{3}, 300 \mathrm{MHz}\right)$

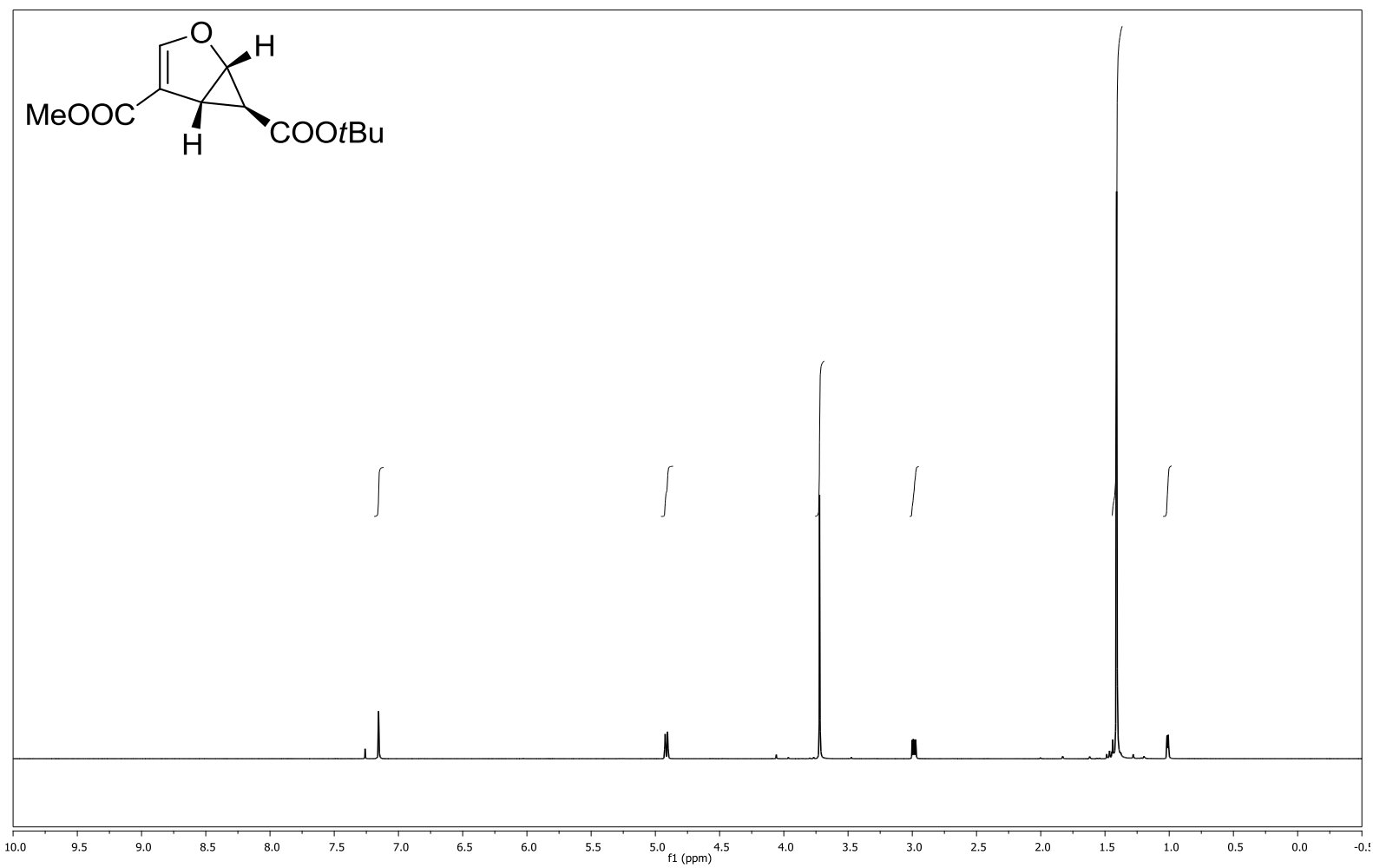

$\left(\mathrm{CDCl}_{3}, 75 \mathrm{MHz}\right)$

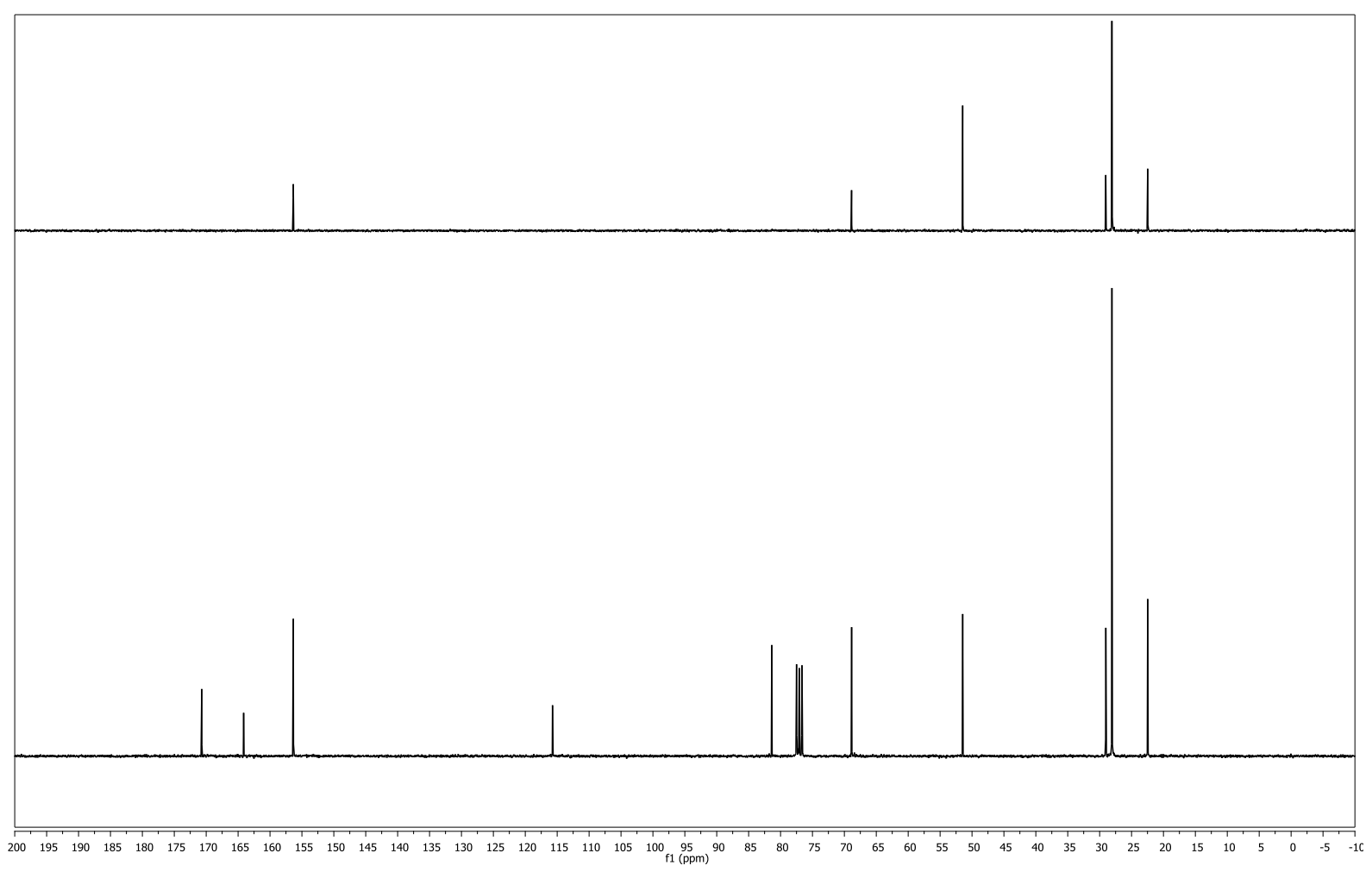


(1S,5R,6S)-6-(tert-butoxycarbonyl)-2-oxabicyclo[3.1.0]hex-3-ene-4-carboxylic acid (138)

(acetone- $\mathrm{d}_{6}, 300 \mathrm{MHz}$ )

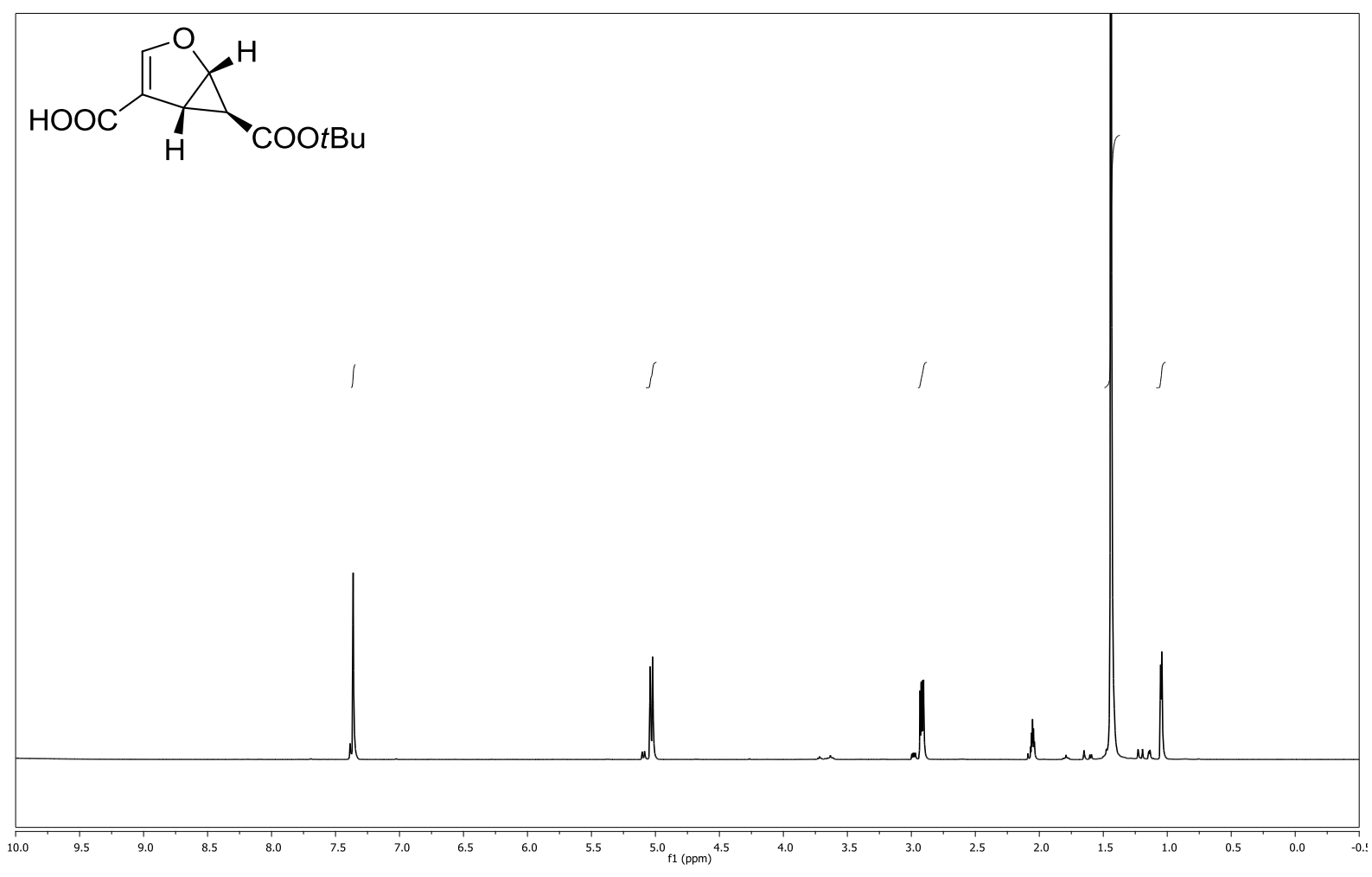

(acetone- $\mathrm{d}_{6}, 75 \mathrm{MHz}$ )

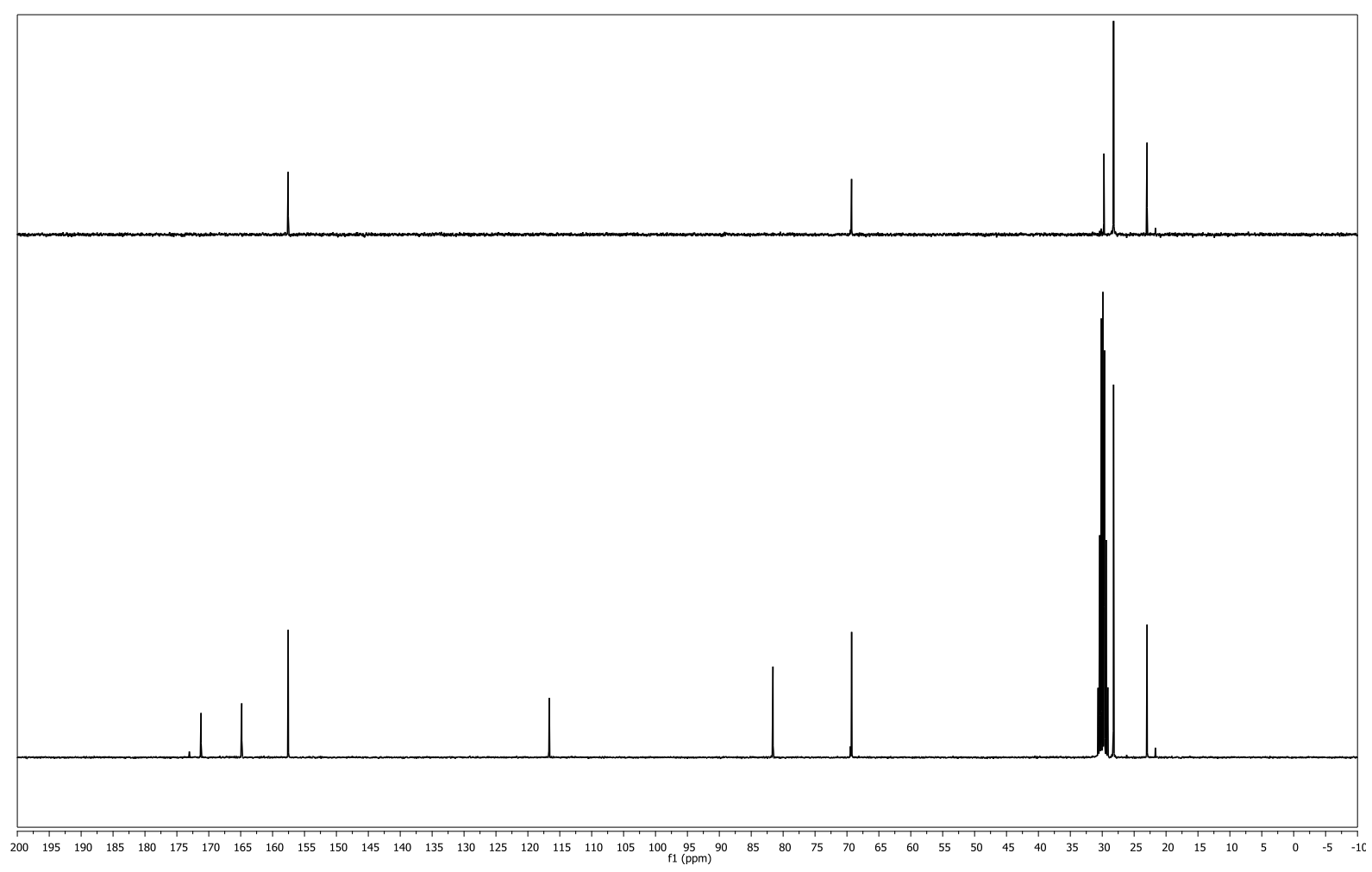


(1S,4S,5S,6S)-6-(tert-butoxycarbonyl)-2-oxabicyclo[3.1.0]hexane-4-carboxylic acid (139) $\left(\mathrm{CDCl}_{3}, 300 \mathrm{MHz}\right)$

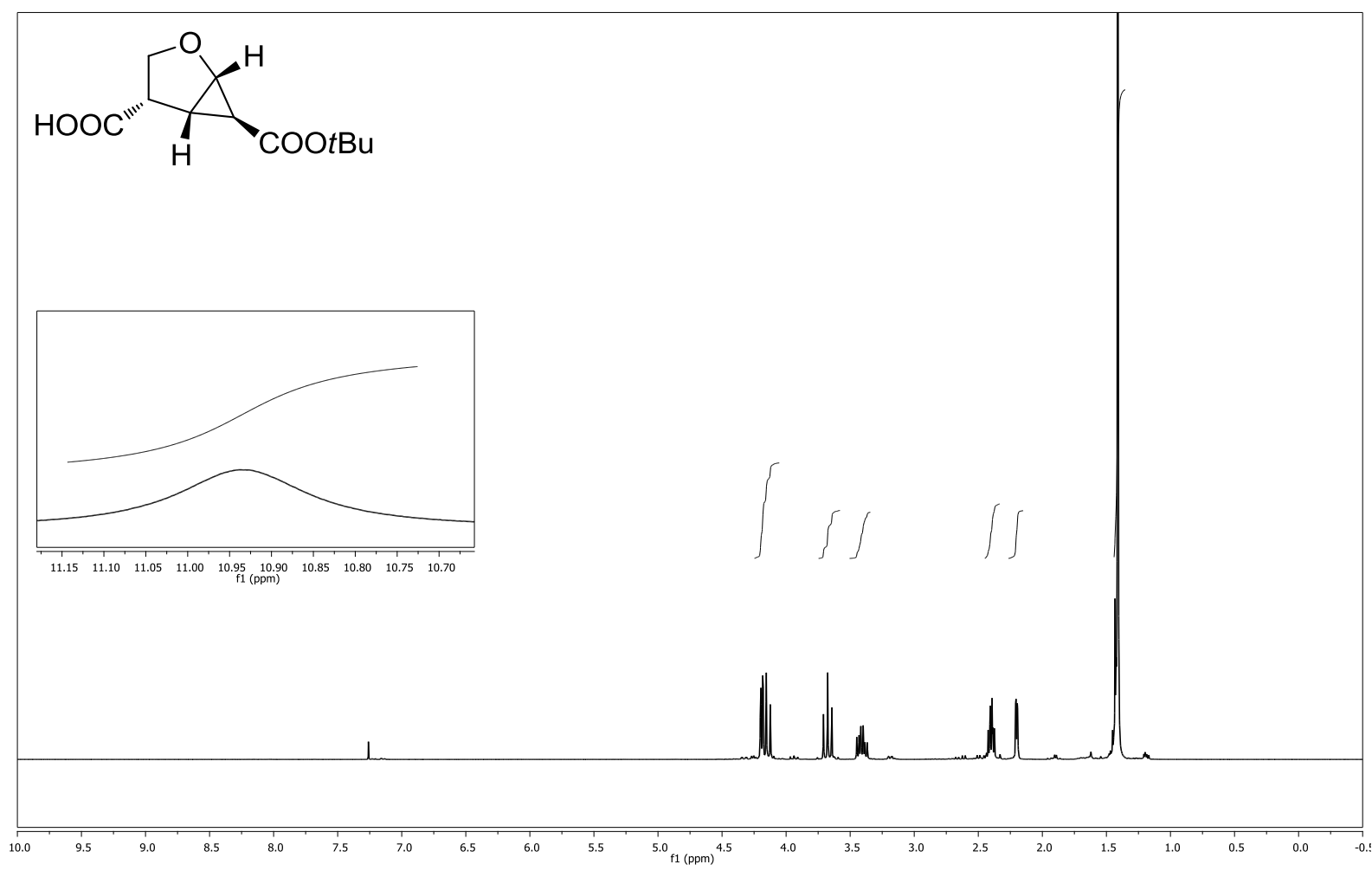

$\left(\mathrm{CDCl}_{3}, 75 \mathrm{MHz}\right)$

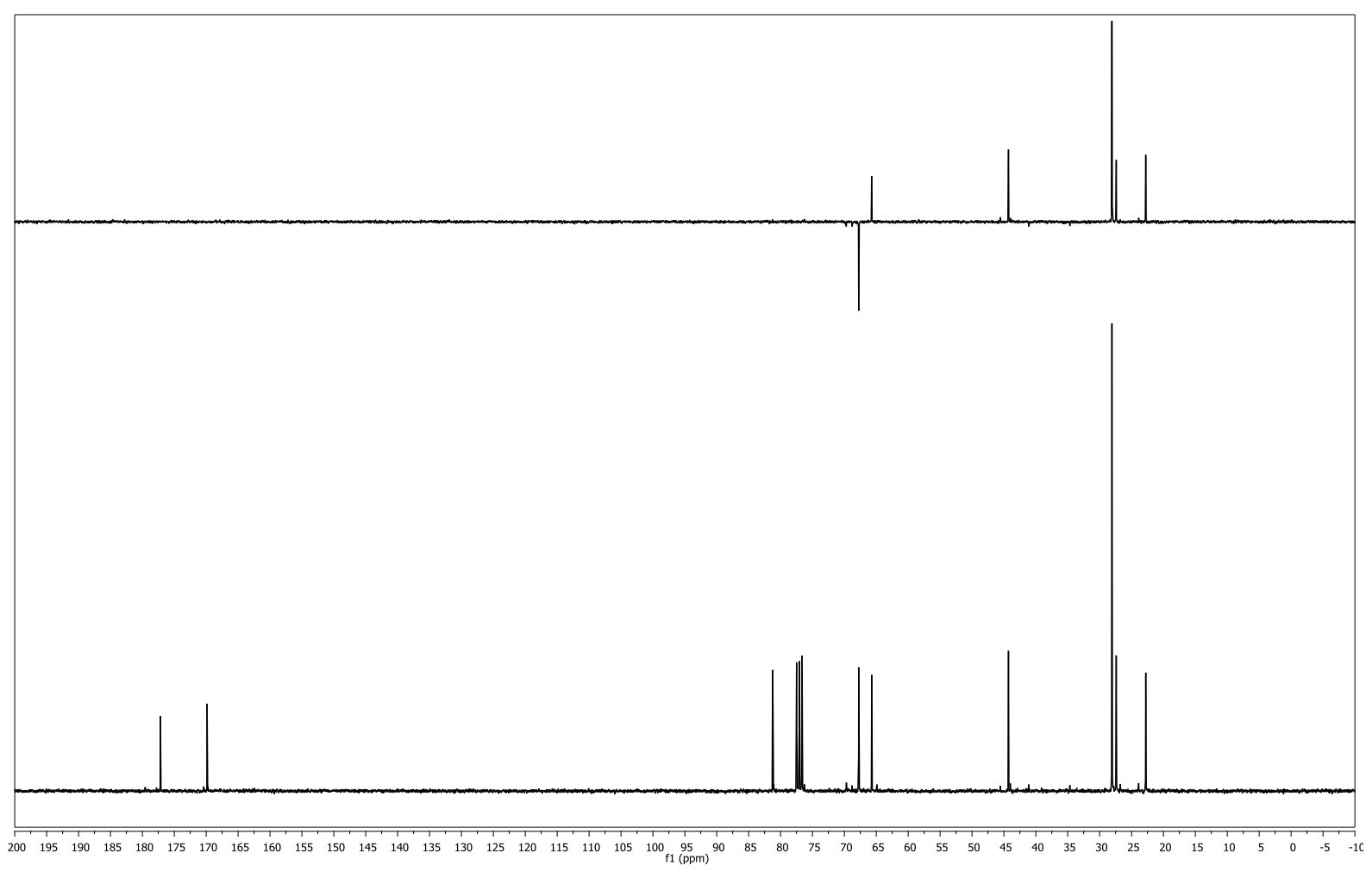


(1S,4R,5S,6S)-tert-butyl-4-(hydroxymethyl)-2-oxabicyclo[3.1.0]hexane-6carboxylate (140) $\left(\mathrm{CDCl}_{3}, 300 \mathrm{MHz}\right)$

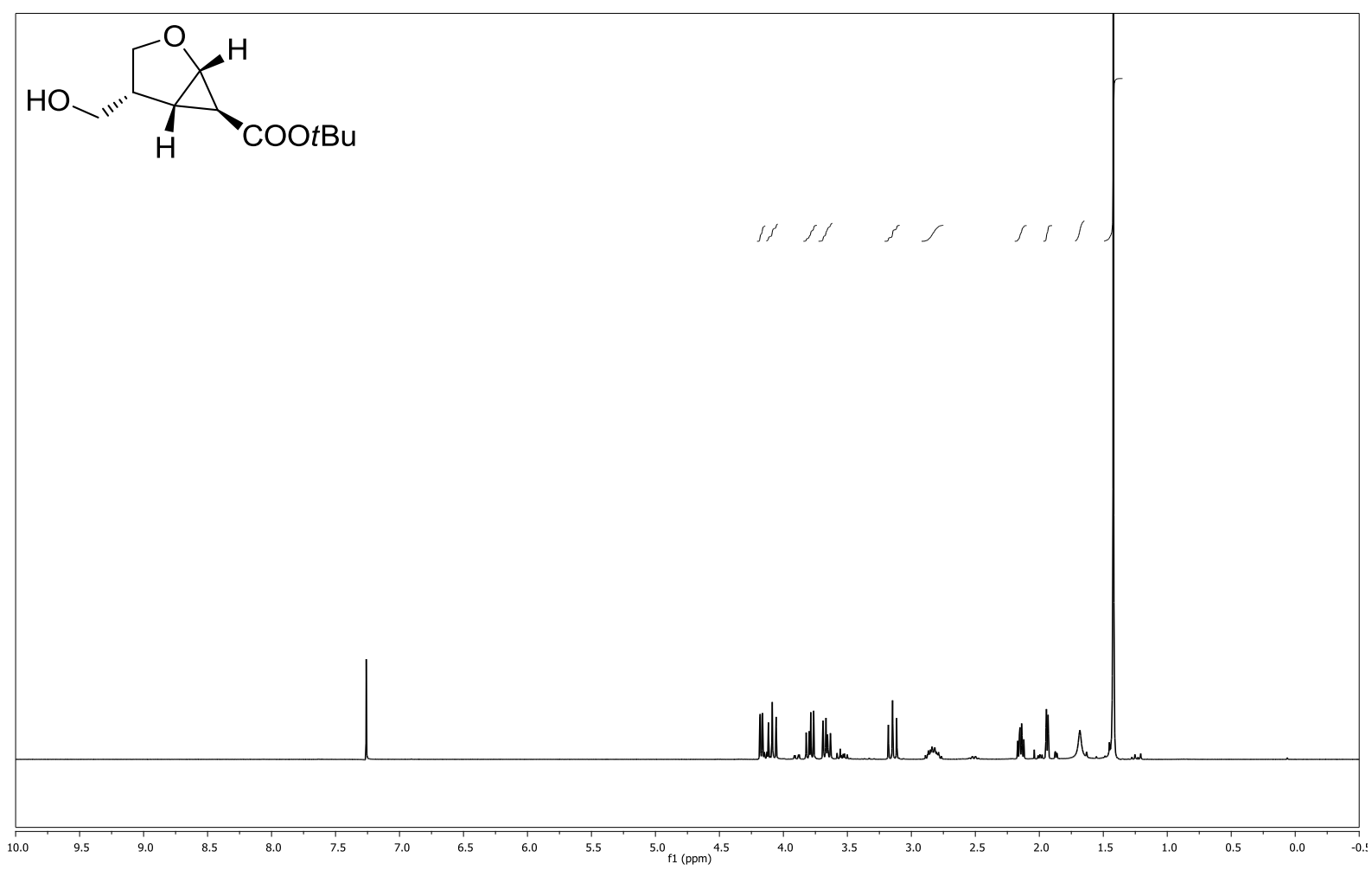

$\left(\mathrm{CDCl}_{3}, 75 \mathrm{MHz}\right)$

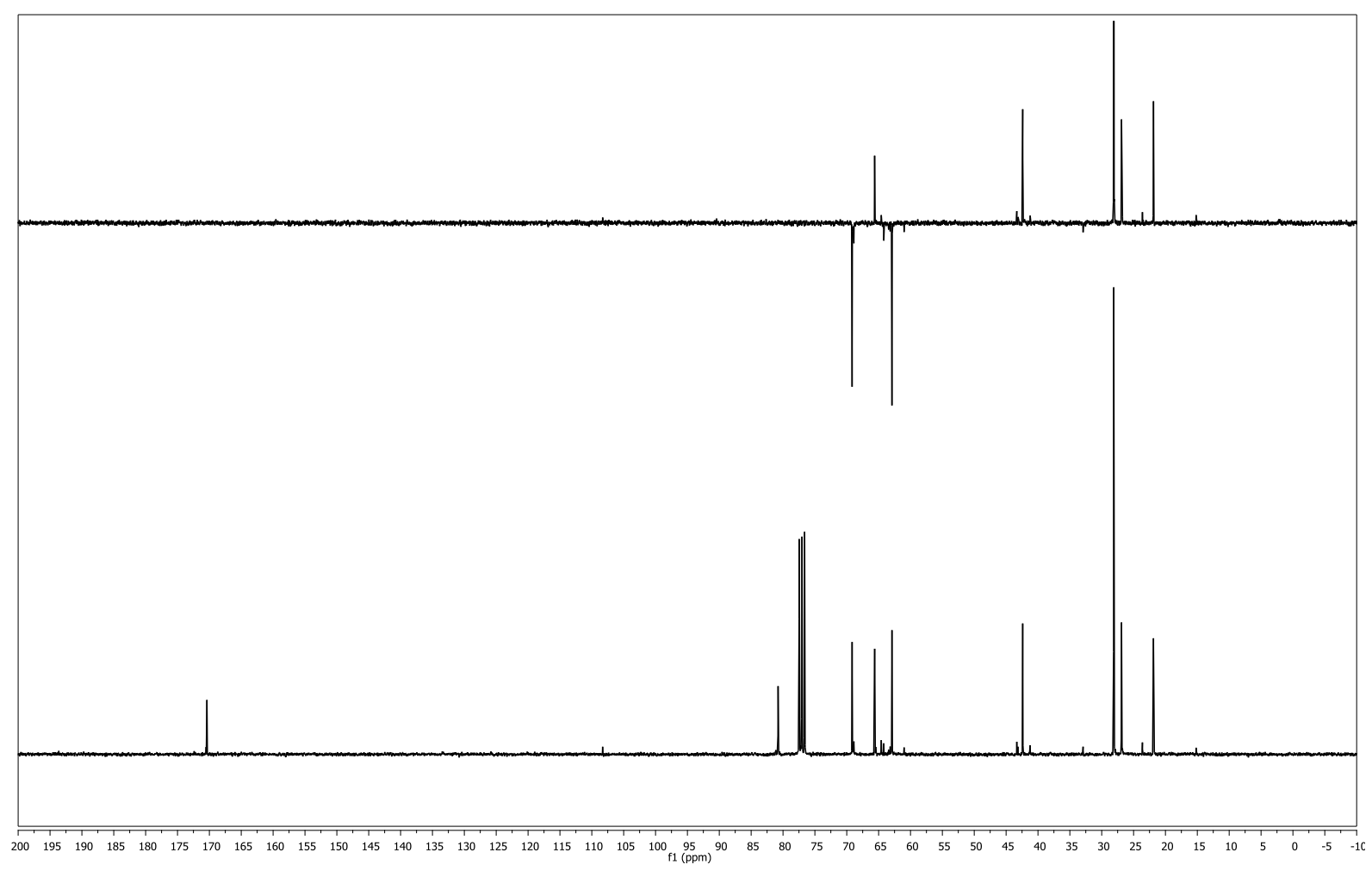


(3S,4R)-benzyl 5-(benzyloxy)-4-(2-(benzyloxy)-2-oxoethyl)tetrahydrofuran-3carboxylate (142) $\left(\mathrm{CDCl}_{3}, 300 \mathrm{MHz}\right)$

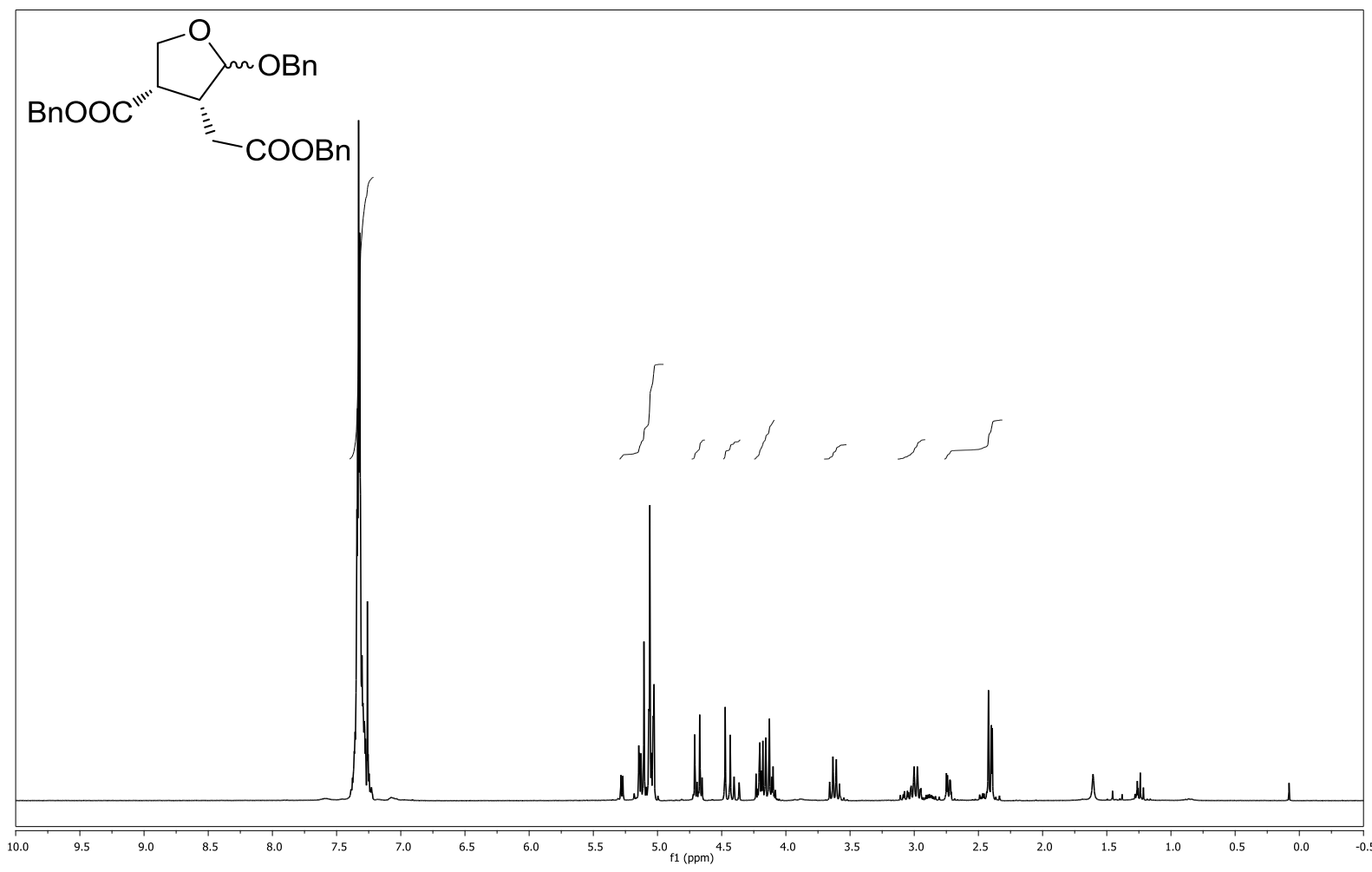

$\left(\mathrm{CDCl}_{3}, 75 \mathrm{MHz}\right)$

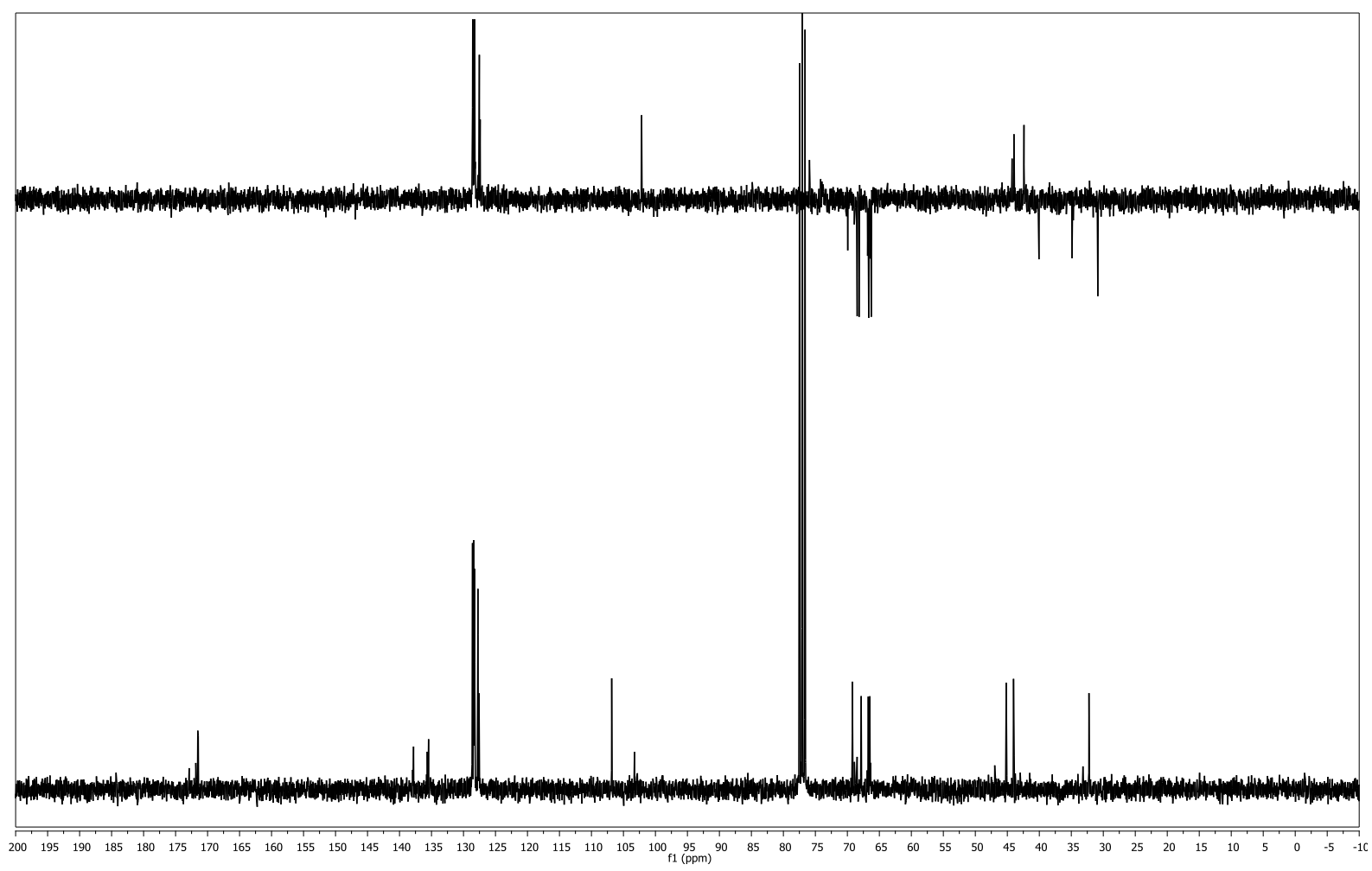


(3S,3aR,6aR)-5-oxohexahydrofuro[2,3-b]furan-3-carboxylic acid (145)

(DMSO-d $6,600 \mathrm{MHz})$

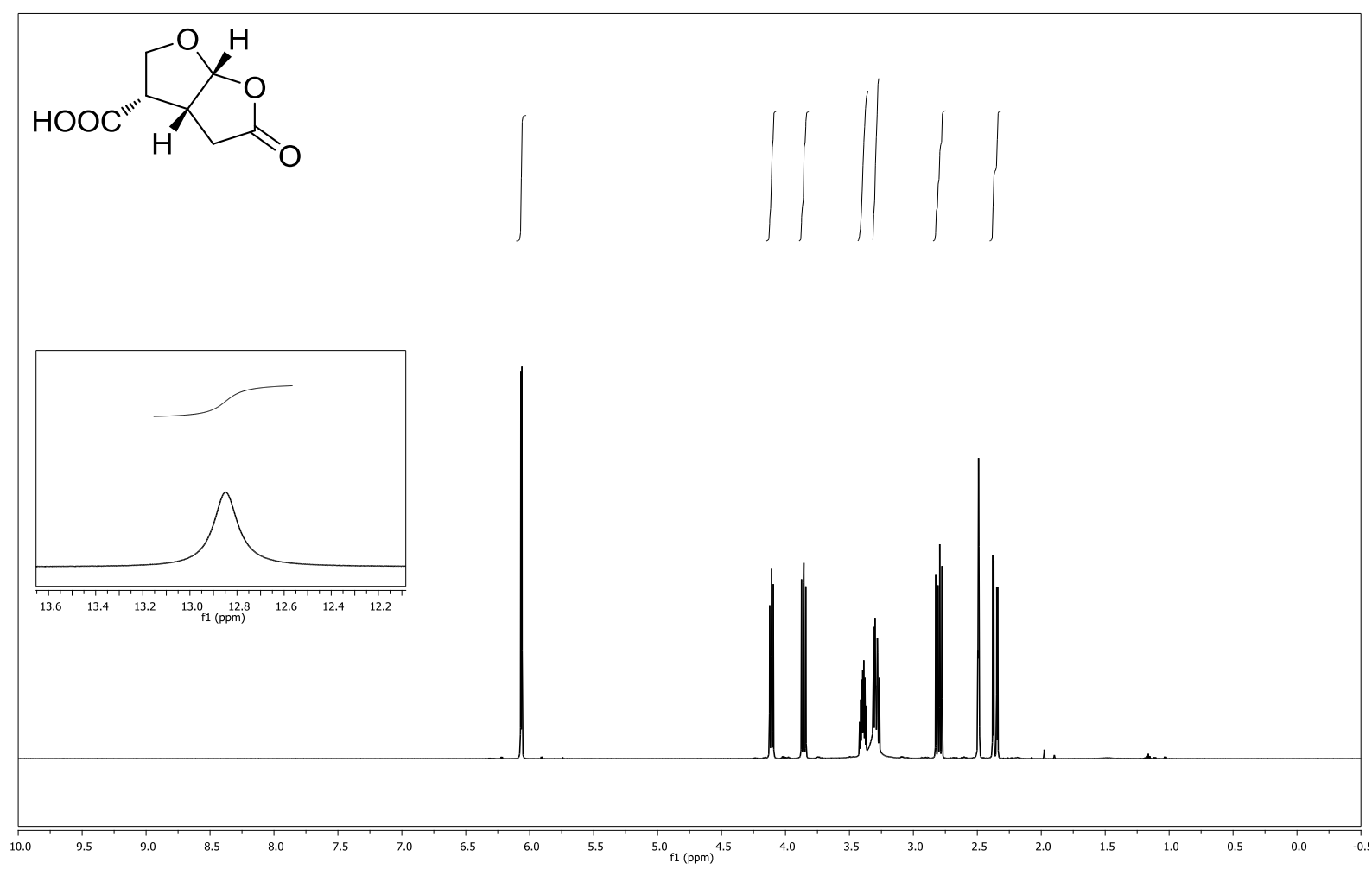

(DMSO-d $6,151 \mathrm{MHz}$ )

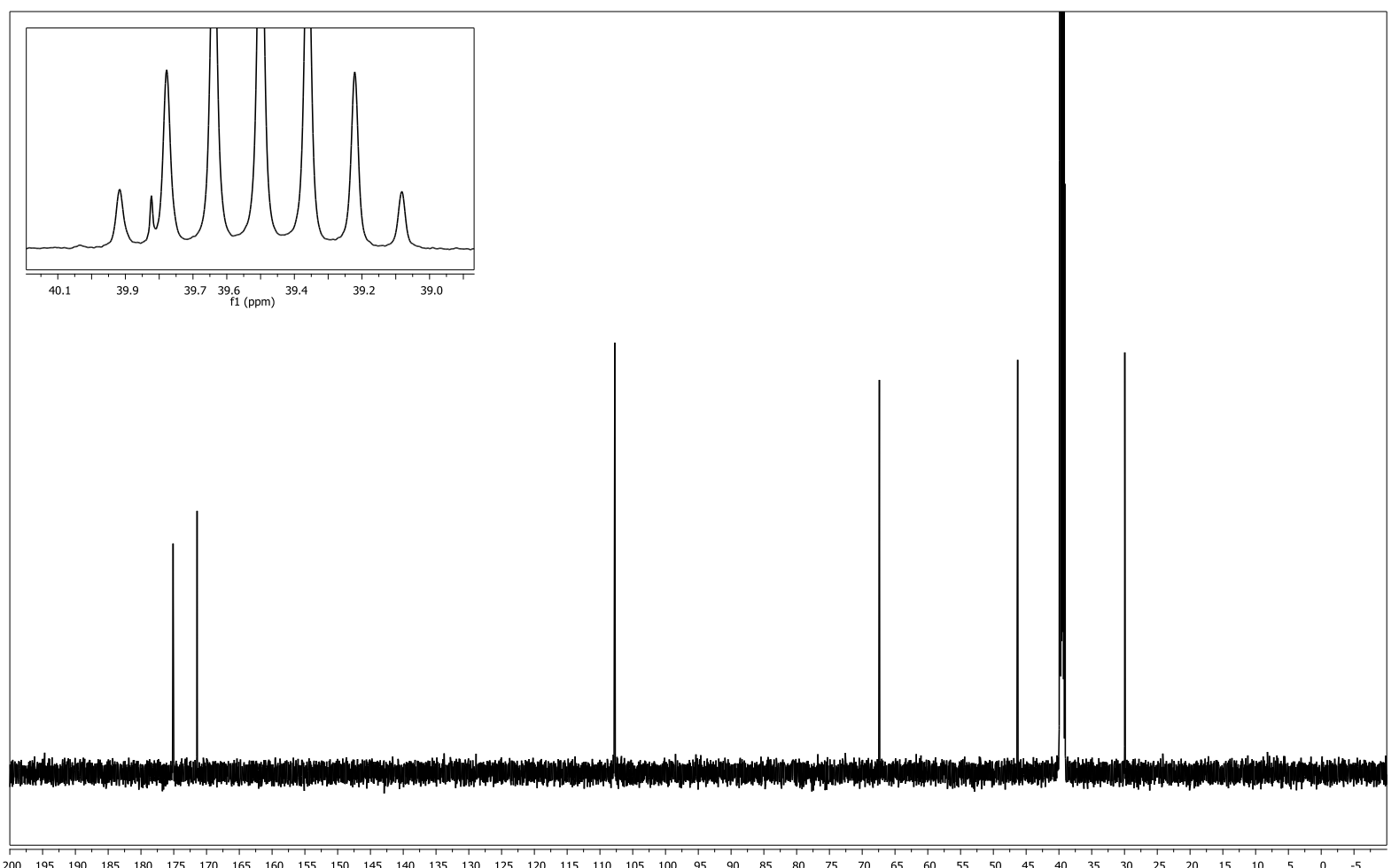

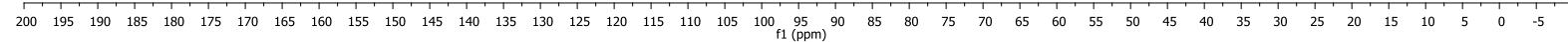


(3S,3aS,6aS)-5-oxohexahydrofuro[2,3-b]furan-3-carboxylic acid (57)

(methanol-d $4,400 \mathrm{MHz}$ )

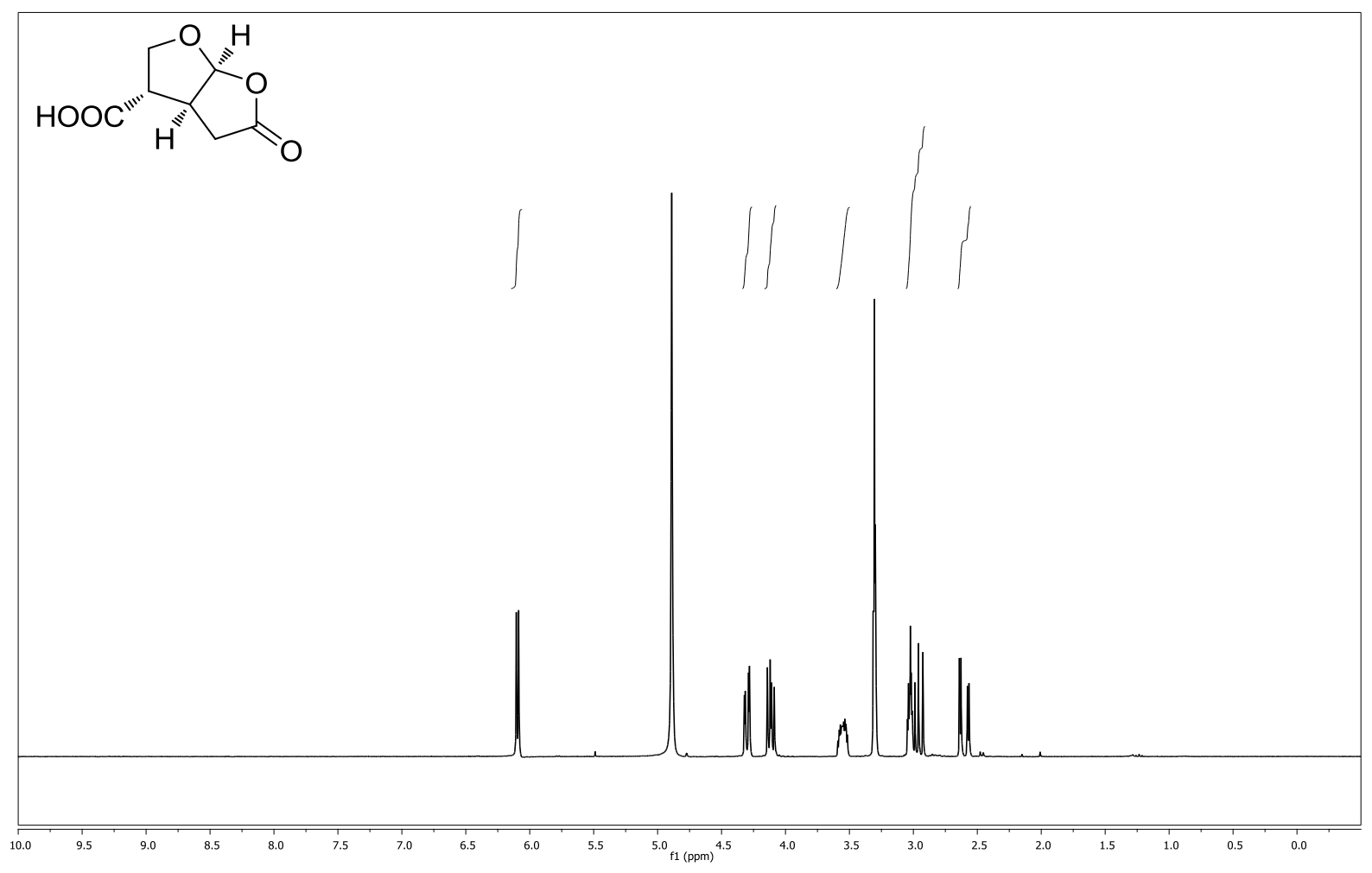

(methanol-d $4,101 \mathrm{MHz}$ )

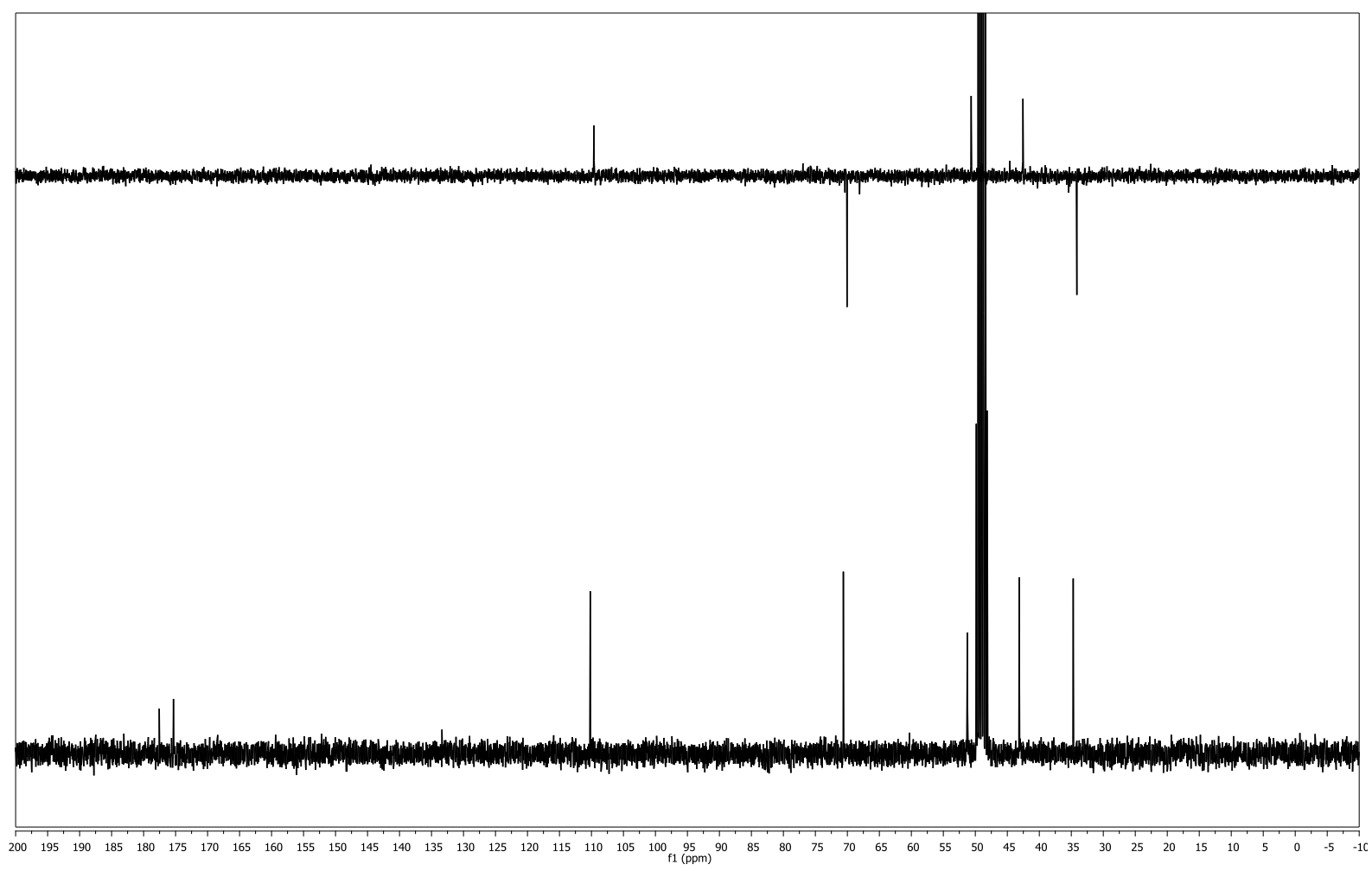


(methanol-d $4,300 \mathrm{MHz}$ )

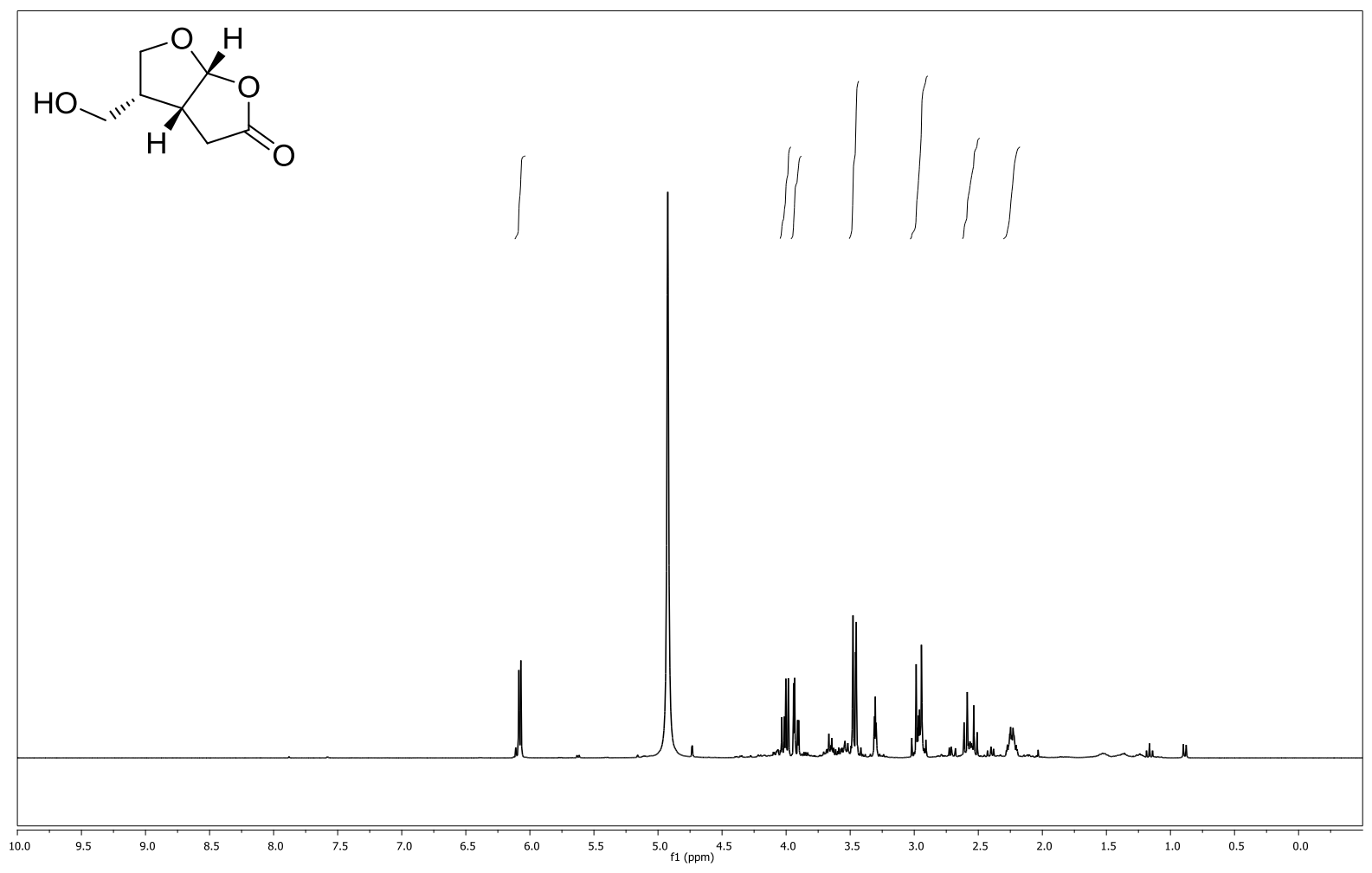

(methanol-d $4,75 \mathrm{MHz}$ )

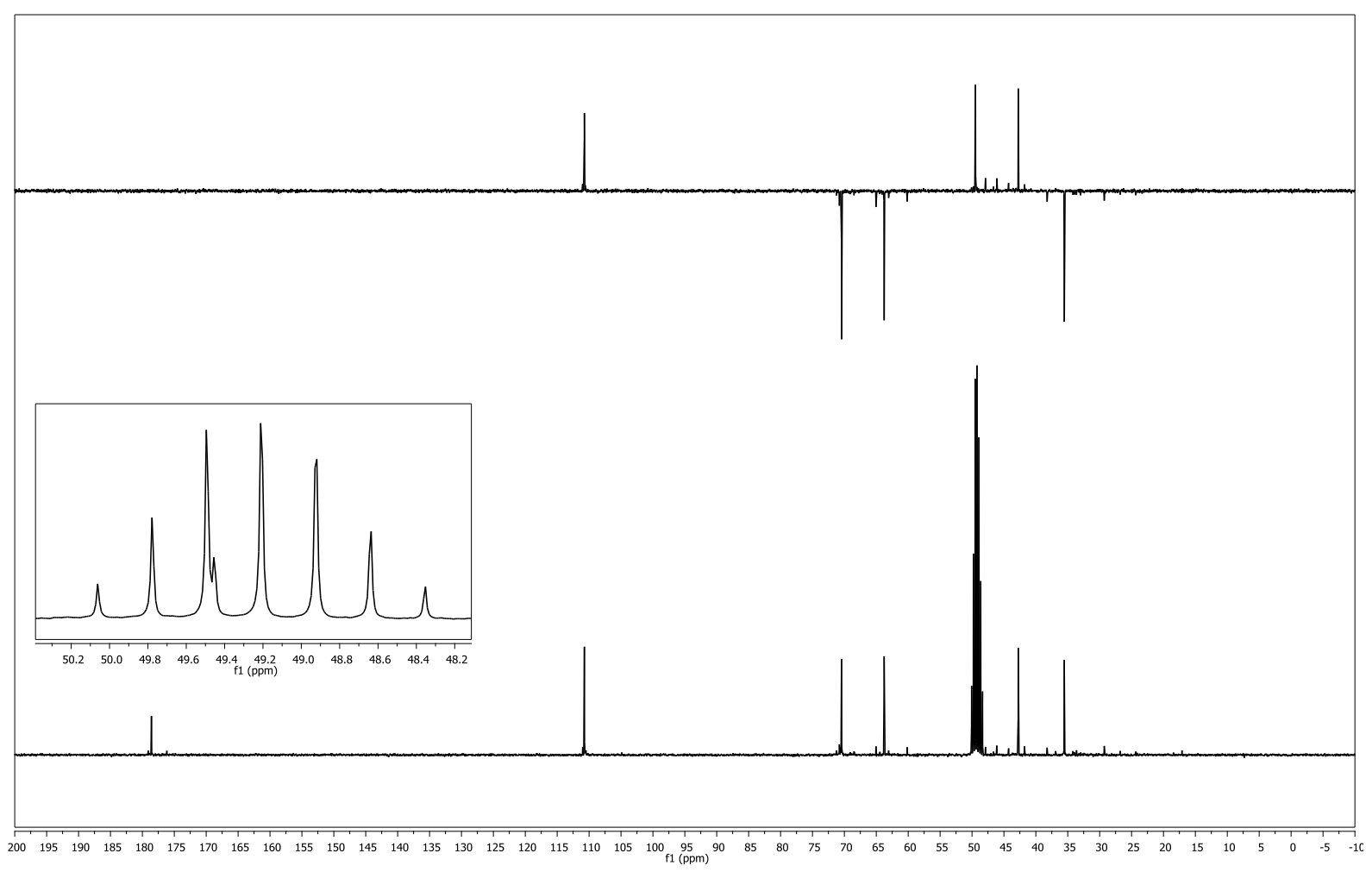


(3aS,4R,6aS)-4-(hydroxymethyl)tetrahydrofuro[2,3-b]furan-2(6aH)-one (152)

(methanol-d $\mathrm{d}_{4}, 300 \mathrm{MHz}$ )

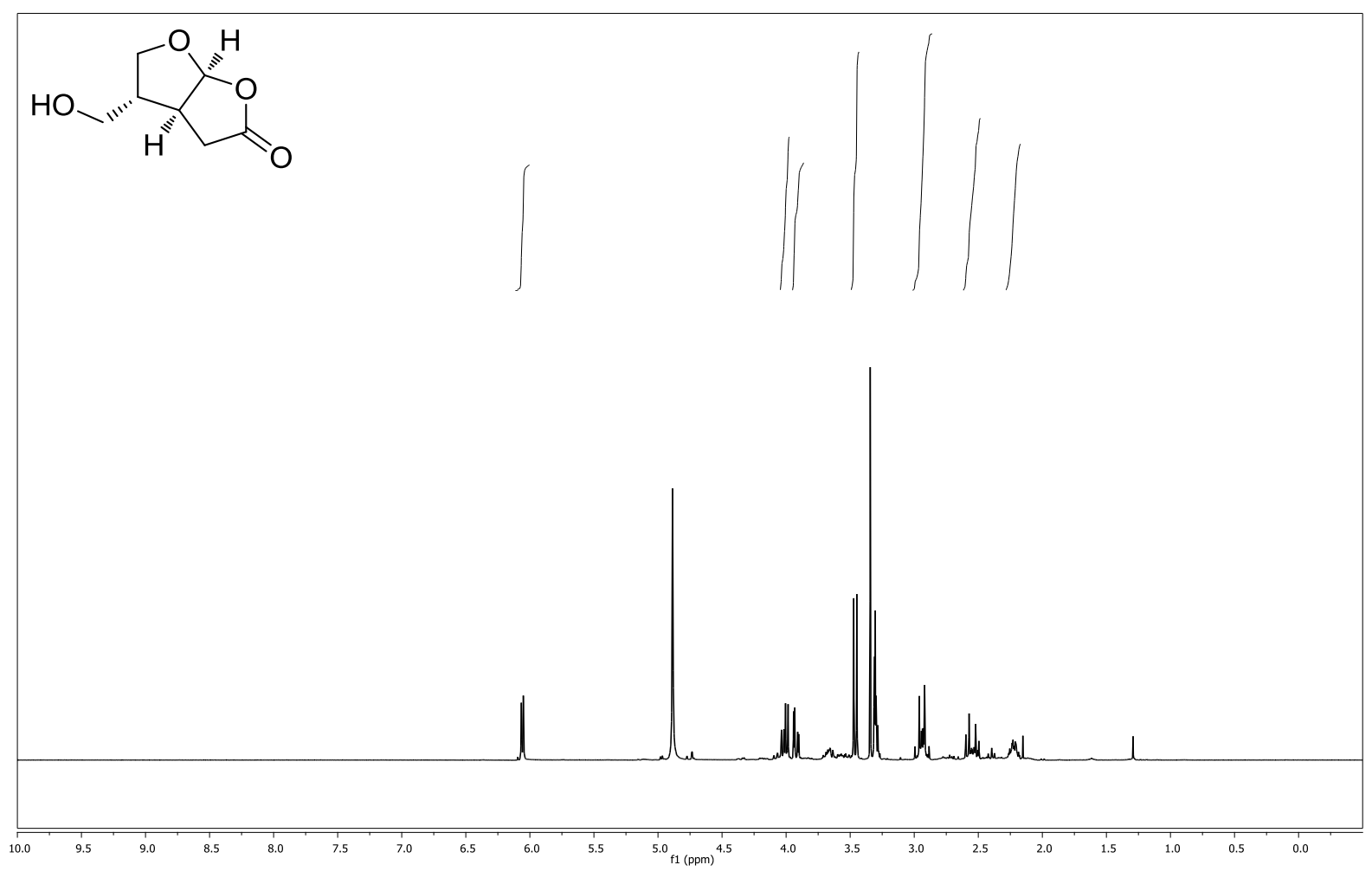

(methanol-d $4,75 \mathrm{MHz}$ )

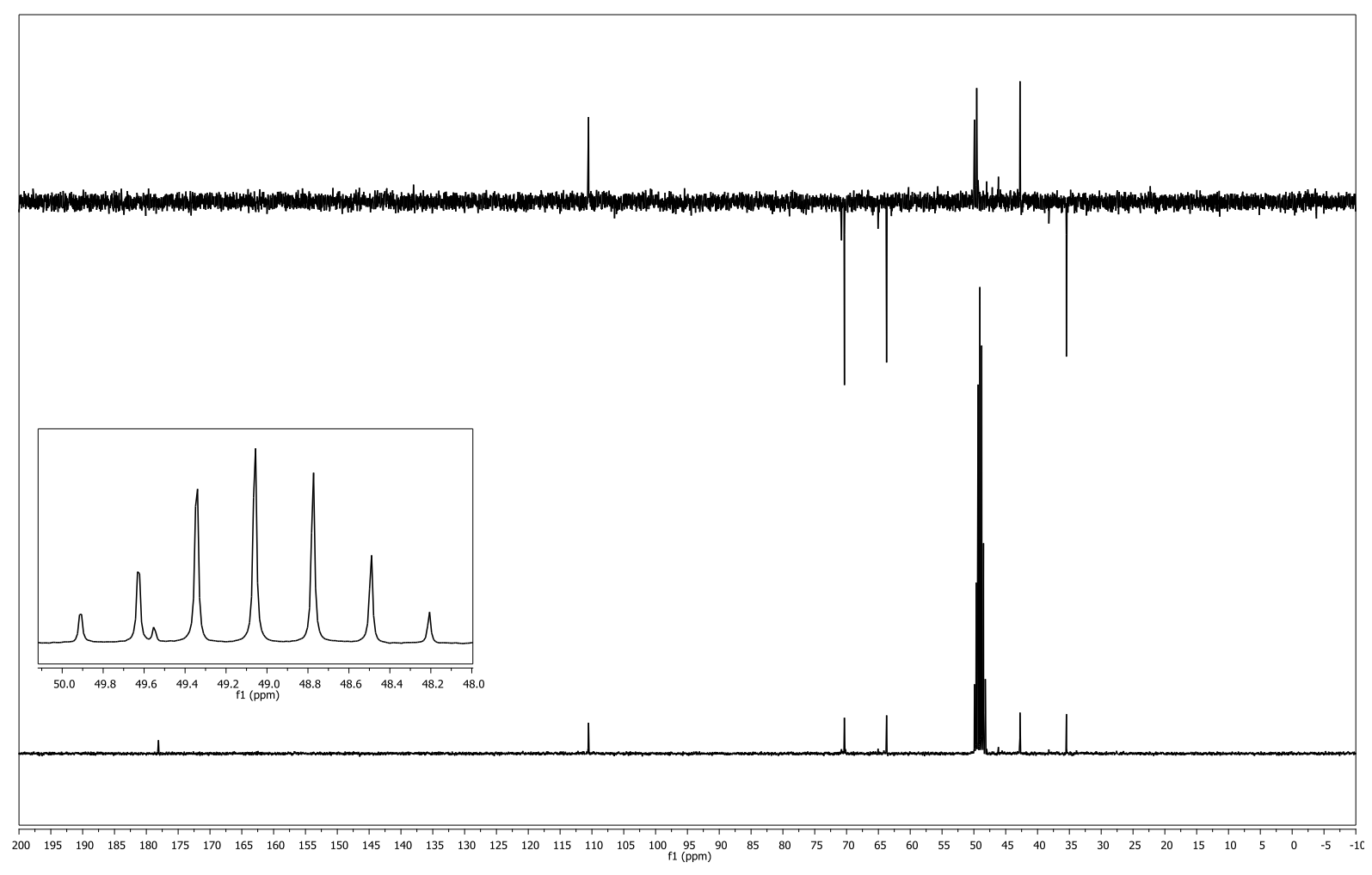


((3S,3aS,6aS)-5-oxohexahydrofuro[2,3-b]furan-3-yl)methyl benzoate (153)

$\left(\mathrm{CDCl}_{3}, 300 \mathrm{MHz}\right)$
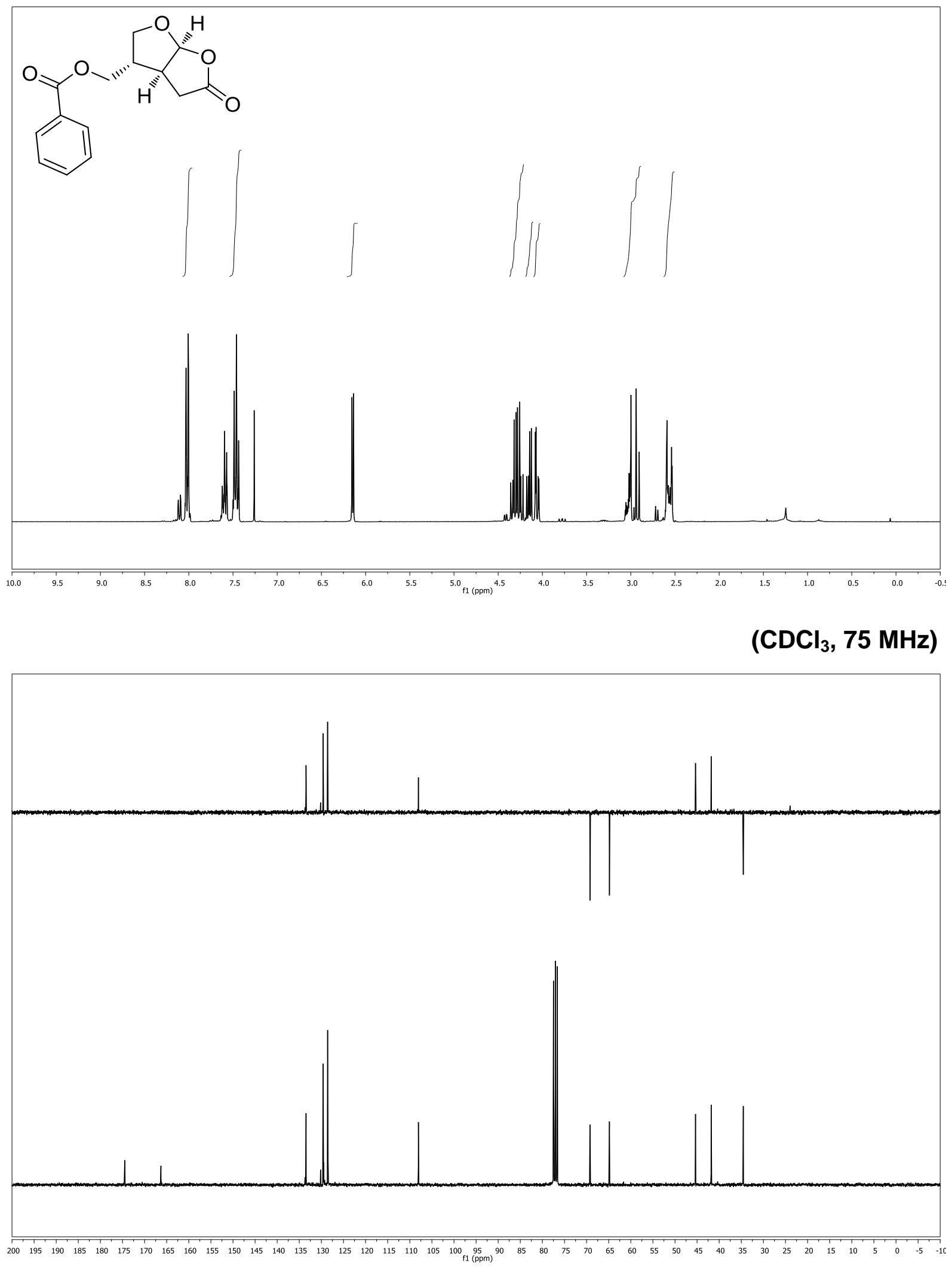
tributylstannyl 2-iodoacetate (166)

$\left(\mathrm{CDCl}_{3}, 300 \mathrm{MHz}\right)$

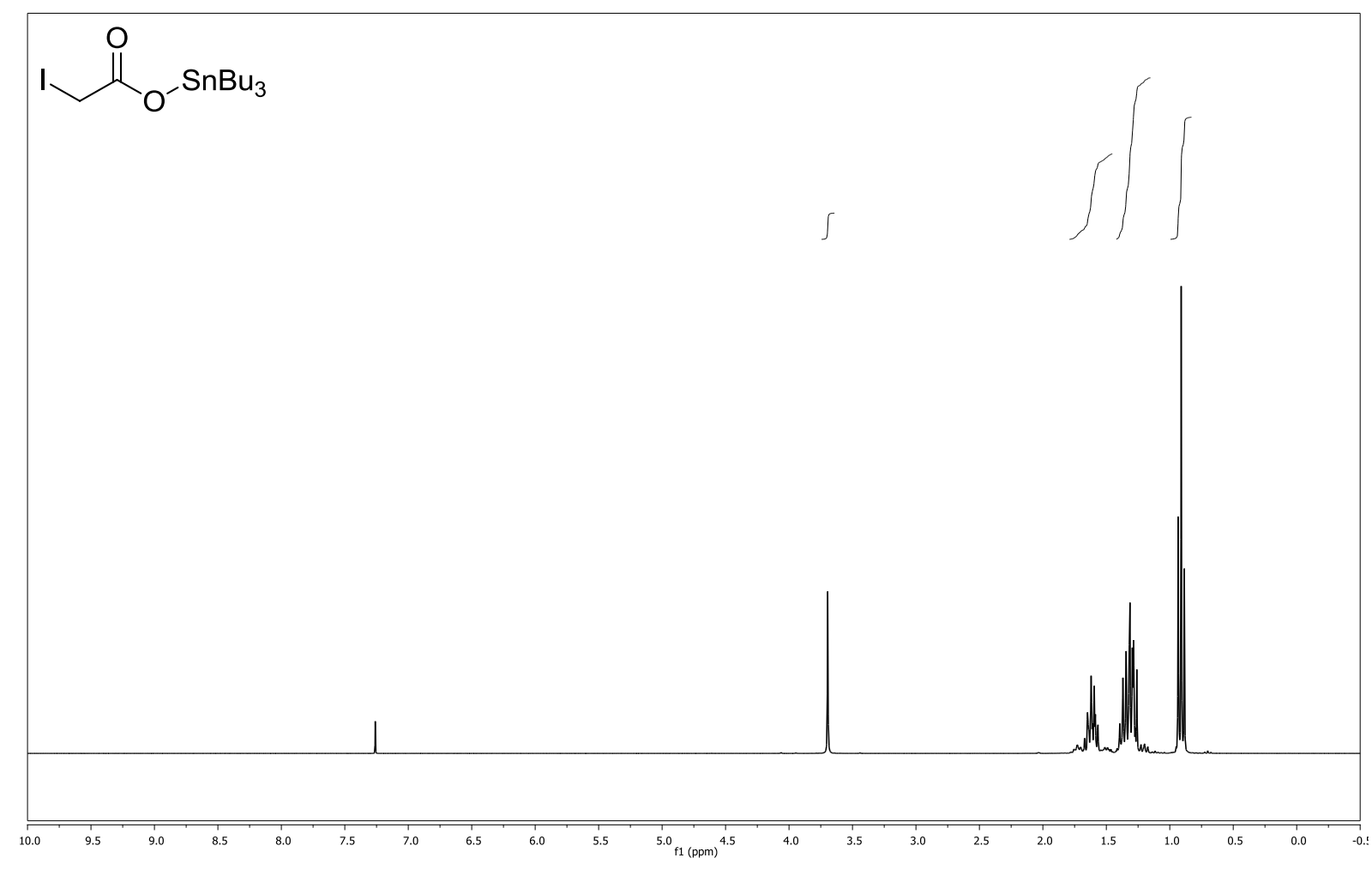

$\left(\mathrm{CDCl}_{3}, 75 \mathrm{MHz}\right)$

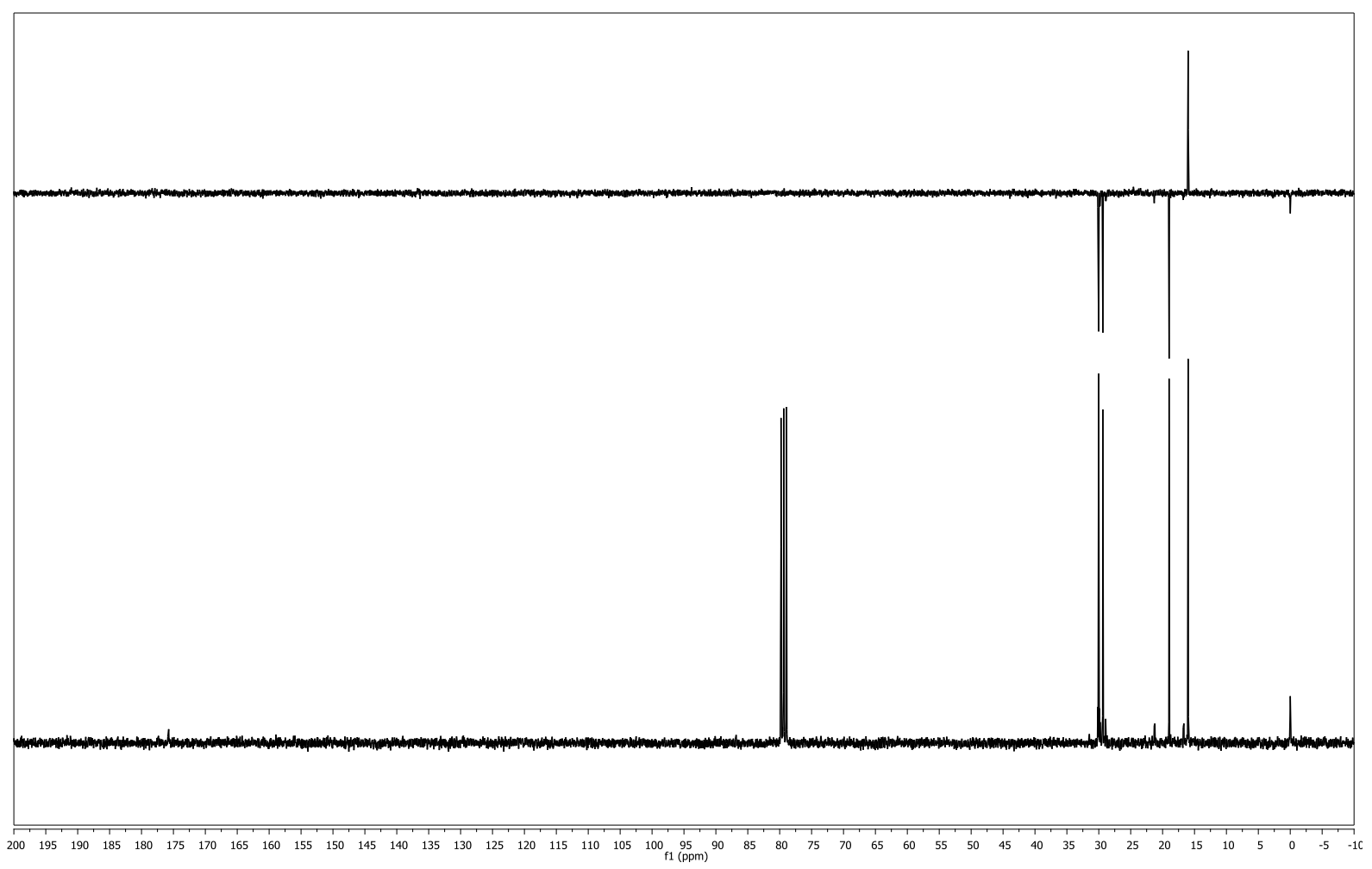


E. Appendix

tetrahydrofuro[2,3-b]furan-2(6aH)-one (167)

( $\left.\mathrm{CDCl}_{3}, 300 \mathrm{MHz}\right)$
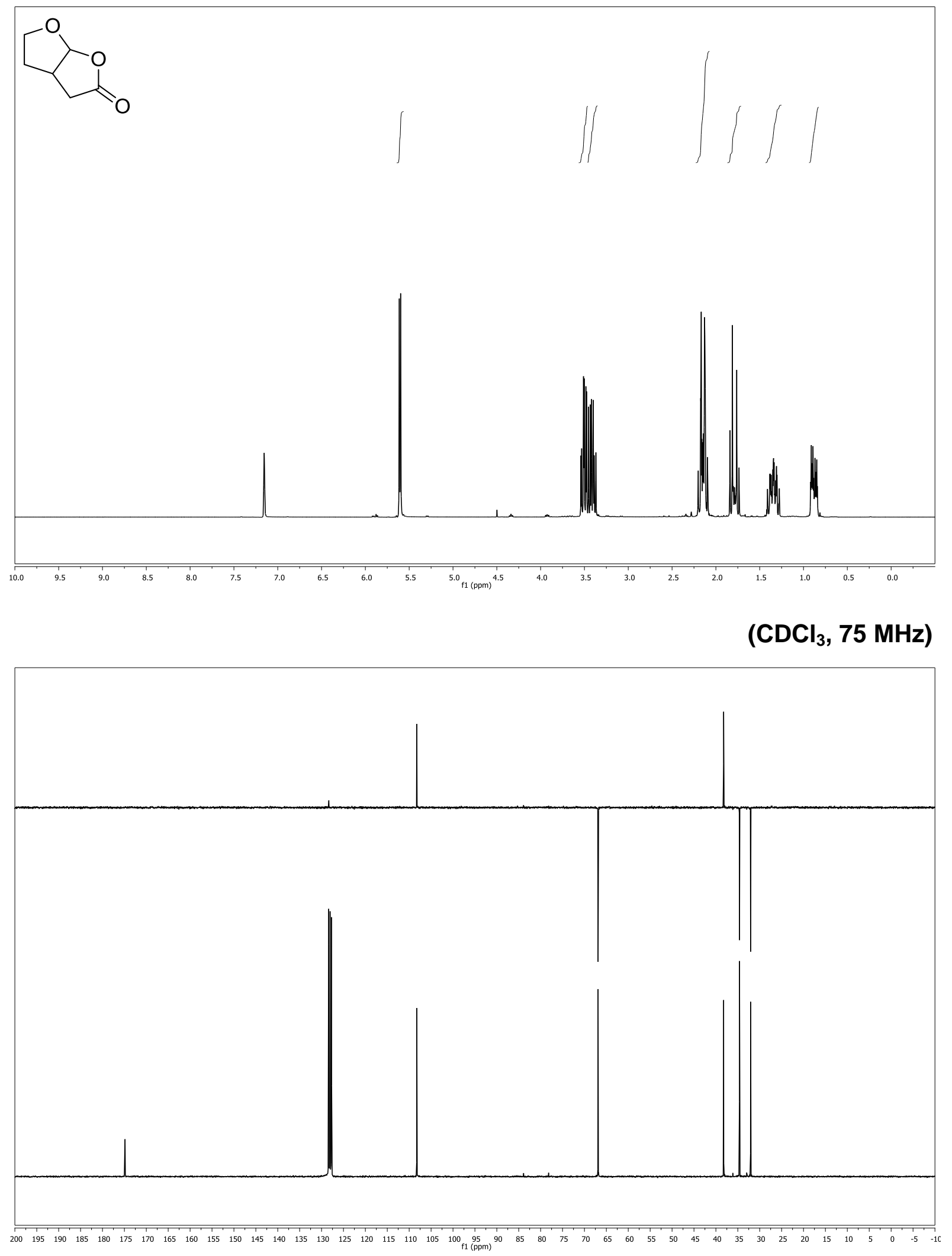

137 
benzyl 2-(2-(benzyloxy)tetrahydrofuran-3-yl)acetate (168)

$\left(\mathrm{CDCl}_{3}, 600 \mathrm{MHz}\right)$

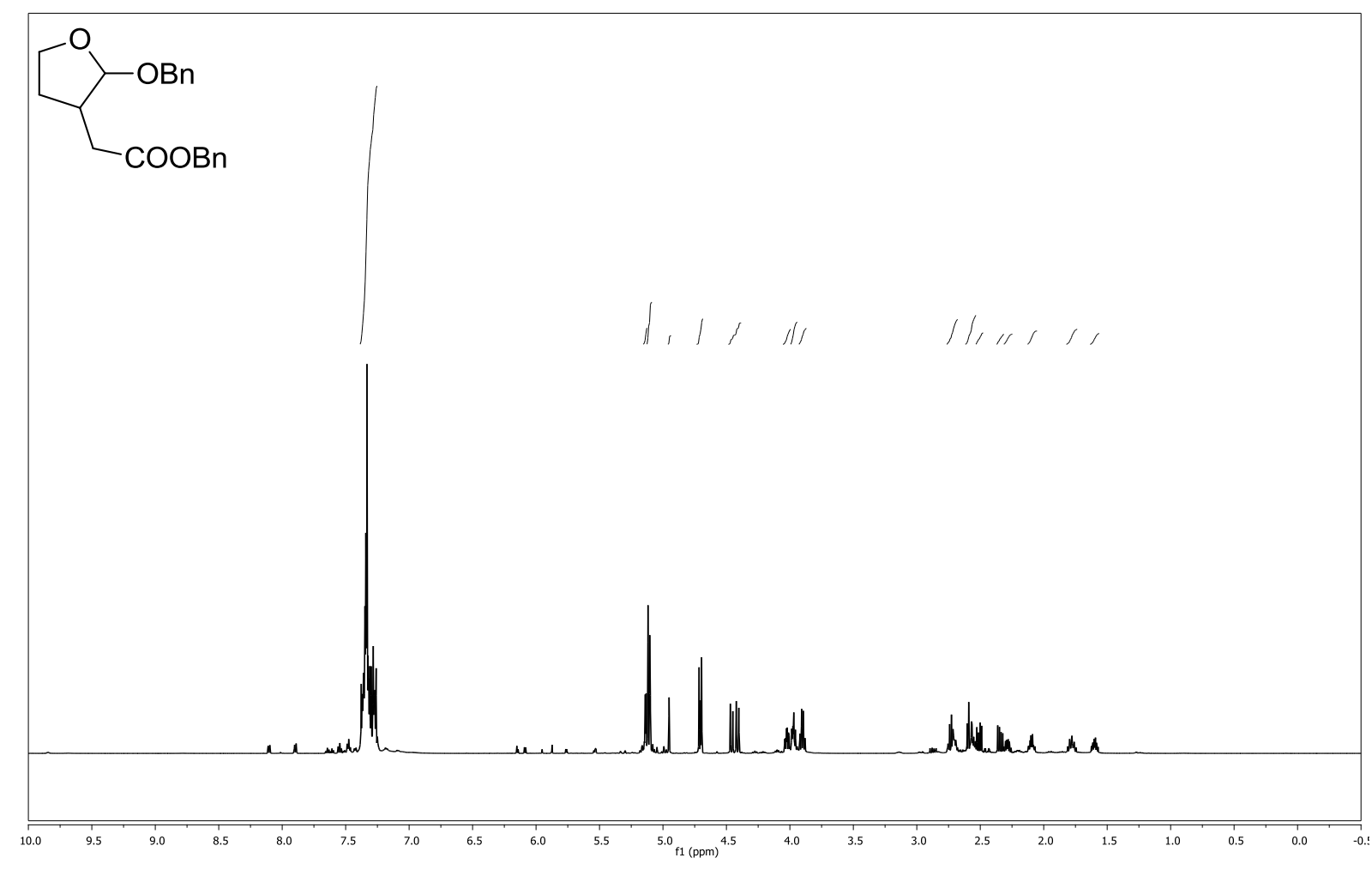

$\left(\mathrm{CDCl}_{3}, 151 \mathrm{MHz}\right)$

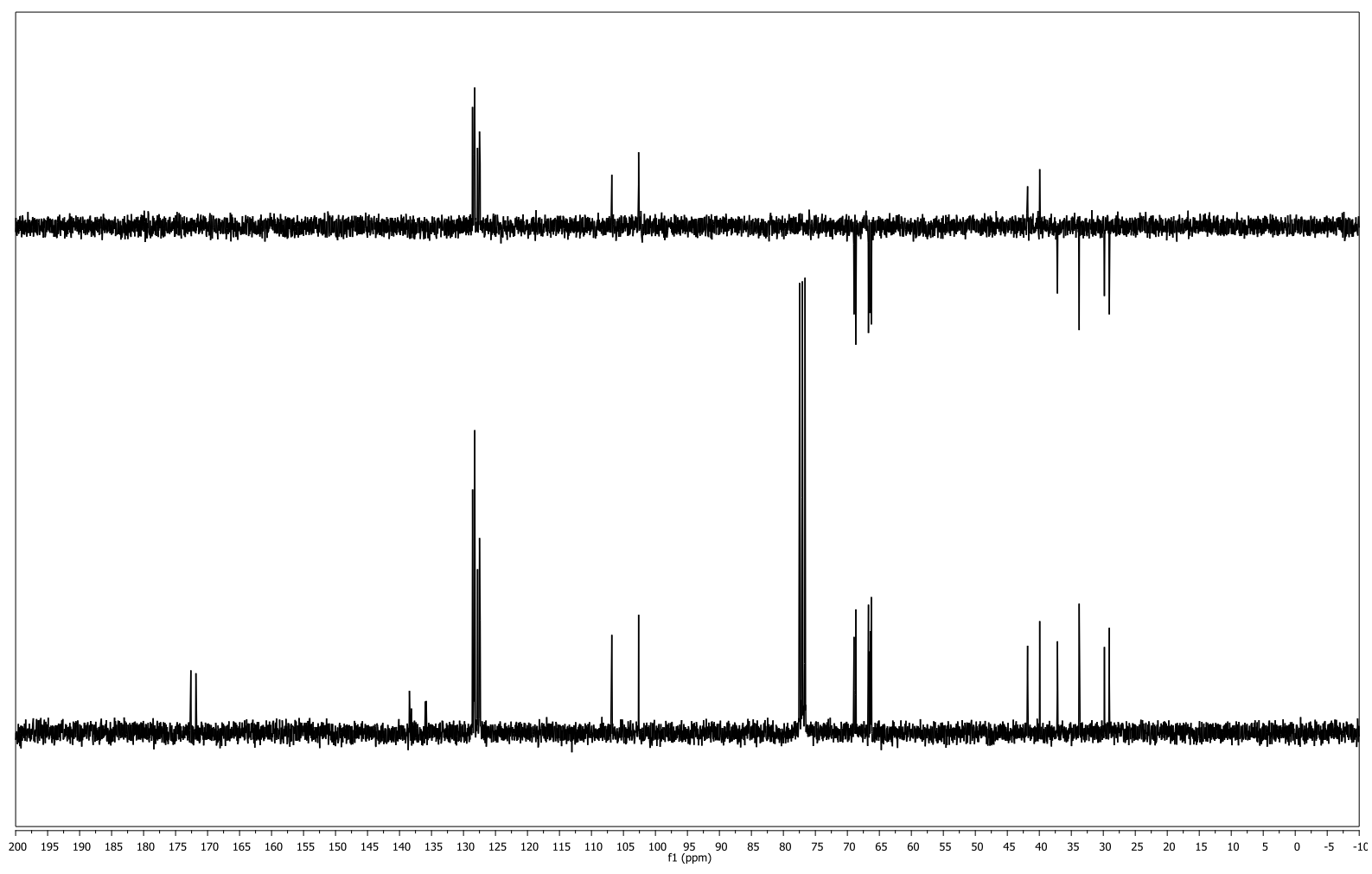


copper(I) tris(3,4,5-tribromo-1H-pyrazole-1-yl)hydroborate acetonitrile complex (164) (third pyrazole ring indicated by N-N for better lucidity)

$\left(\mathrm{CD}_{2} \mathrm{Cl}_{2}, 300 \mathrm{MHz}\right)$

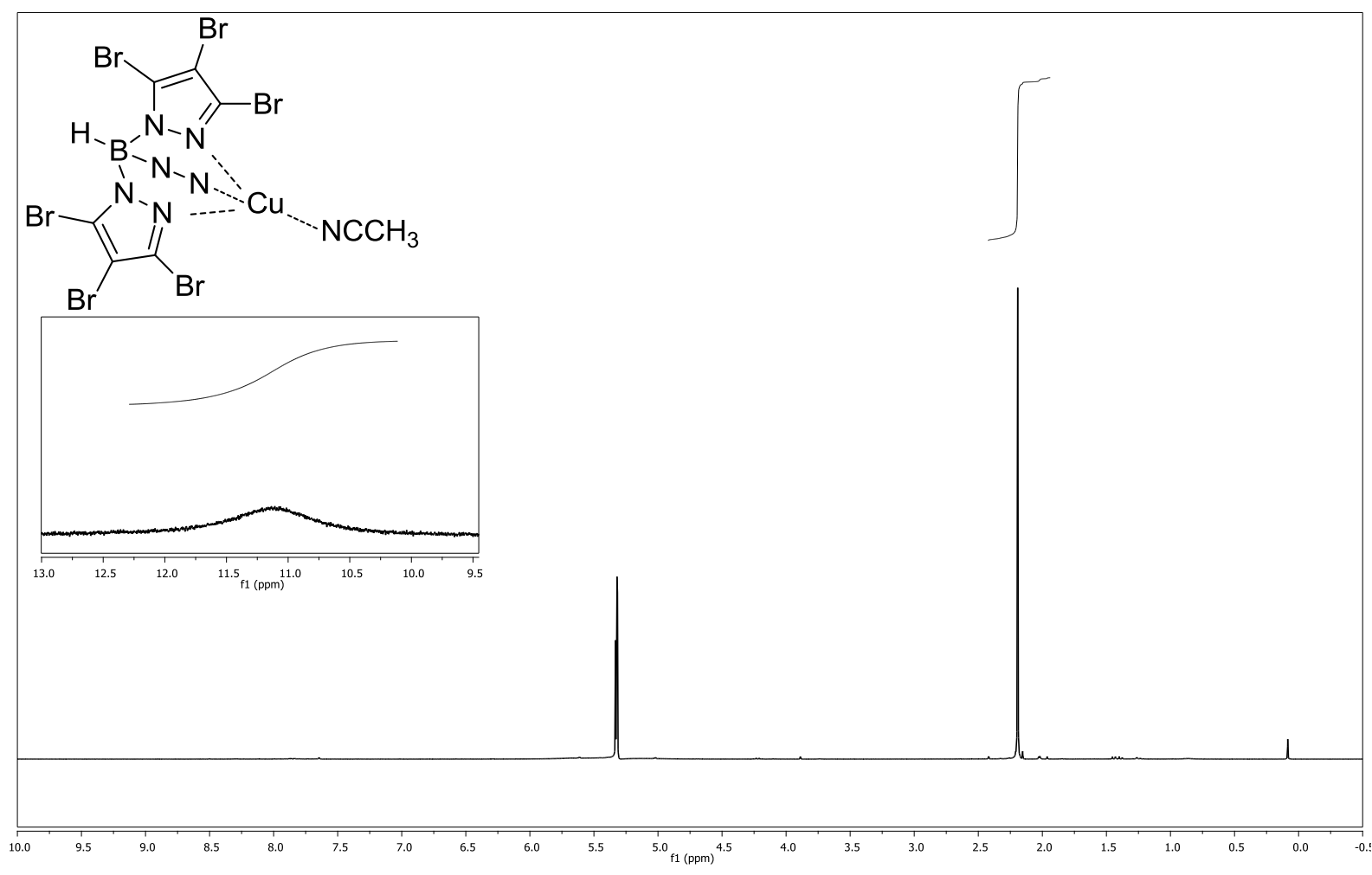

$\left(\mathrm{CD}_{2} \mathrm{Cl}_{2}, 75 \mathrm{MHz}\right)$

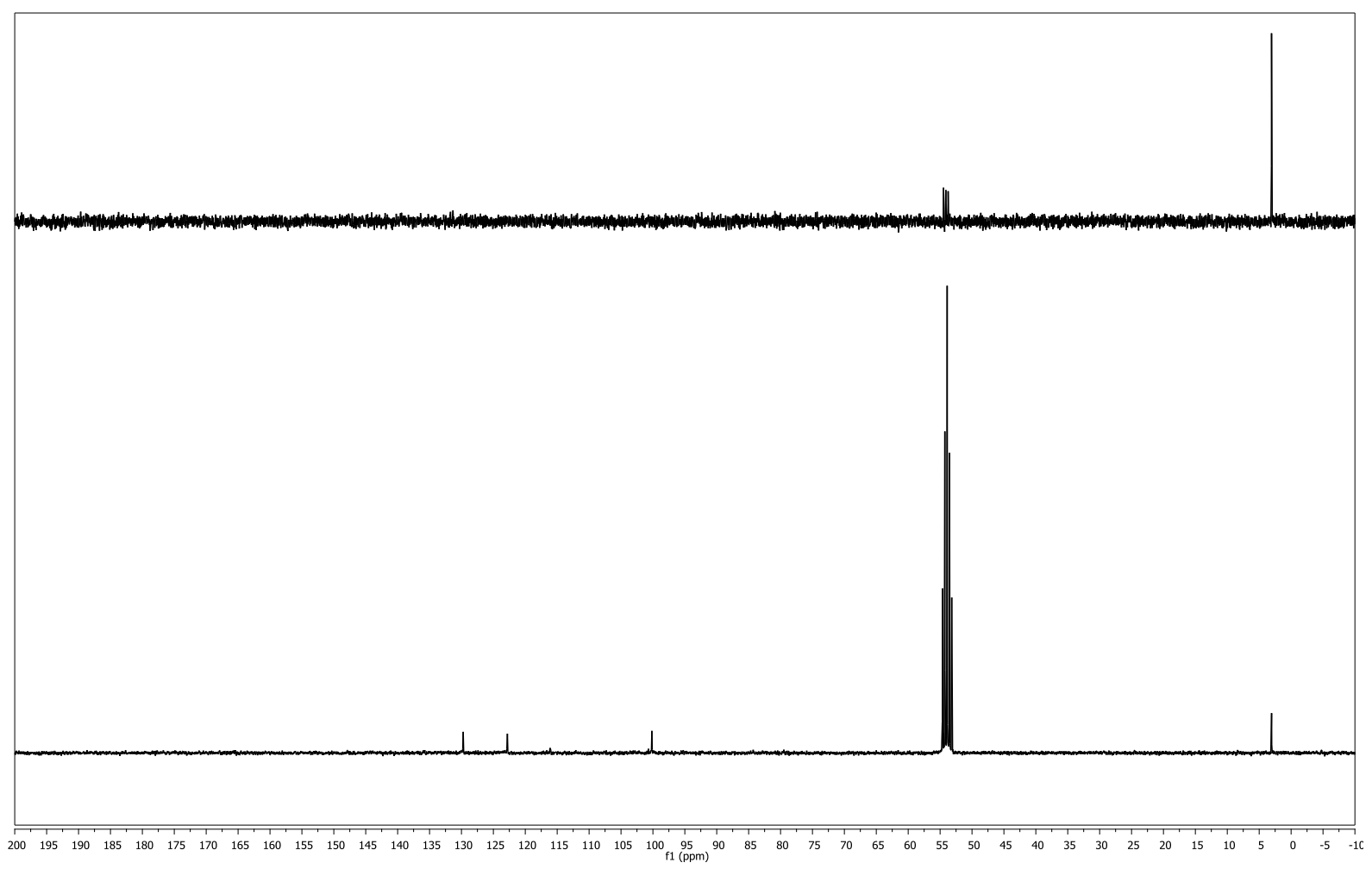


ethyl-2-(2-(2-(2-ethoxy-2-oxoethoxy)-5-oxotetrahydrofuran-3-yl)ethoxy)acetate (175) Isomer 1 $\left(\mathrm{CDCl}_{3}, 600 \mathrm{MHz}\right)$

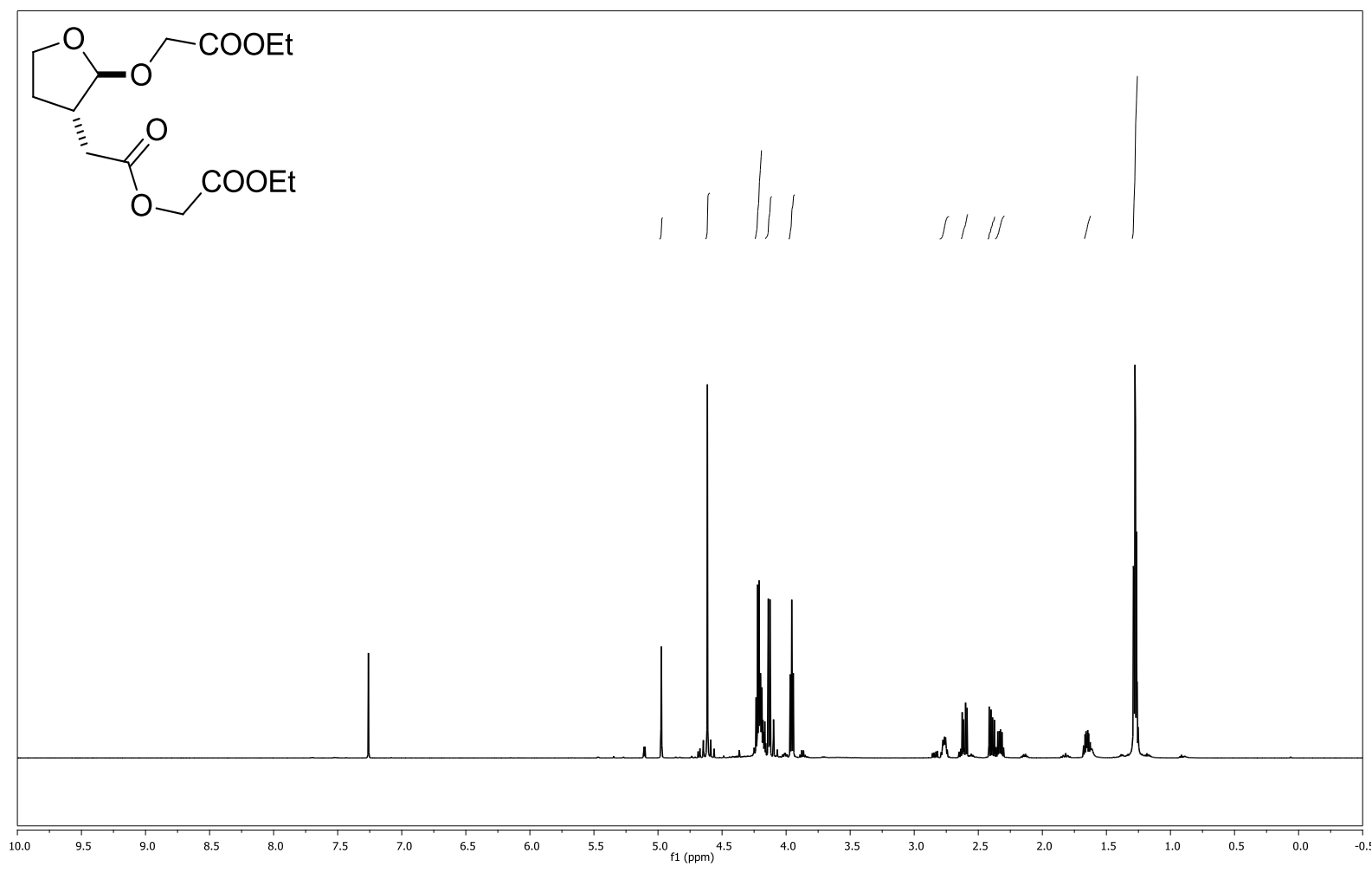

$\left(\mathrm{CDCl}_{3}, 151 \mathrm{MHz}\right)$

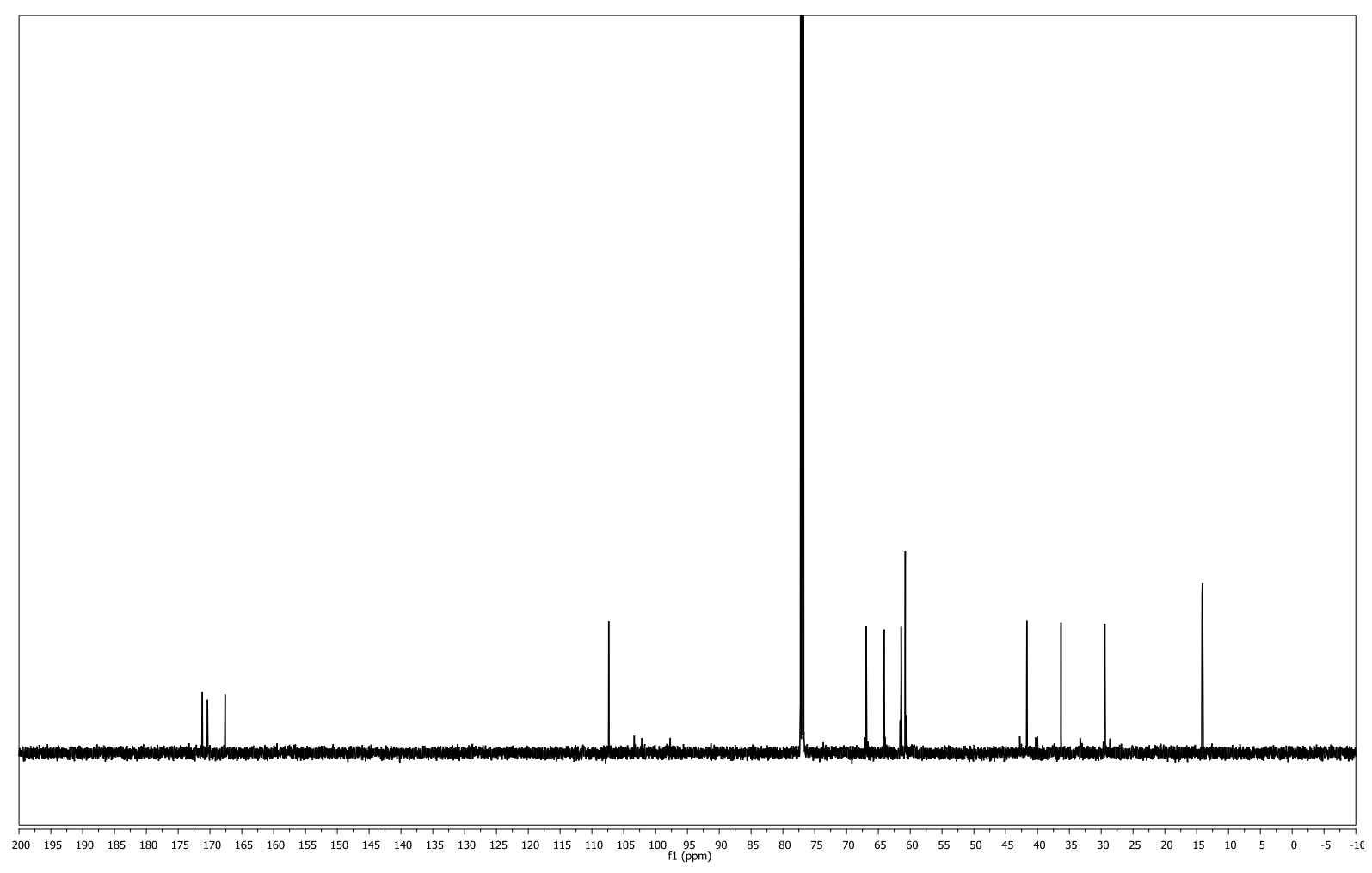


E. Appendix

ethyl-2-(2-(2-(2-ethoxy-2-oxoethoxy)-5-oxotetrahydrofuran-3-yl)ethoxy)acetate (175) Isomer 2

$\left(\mathrm{CDCl}_{3}, 600 \mathrm{MHz}\right)$
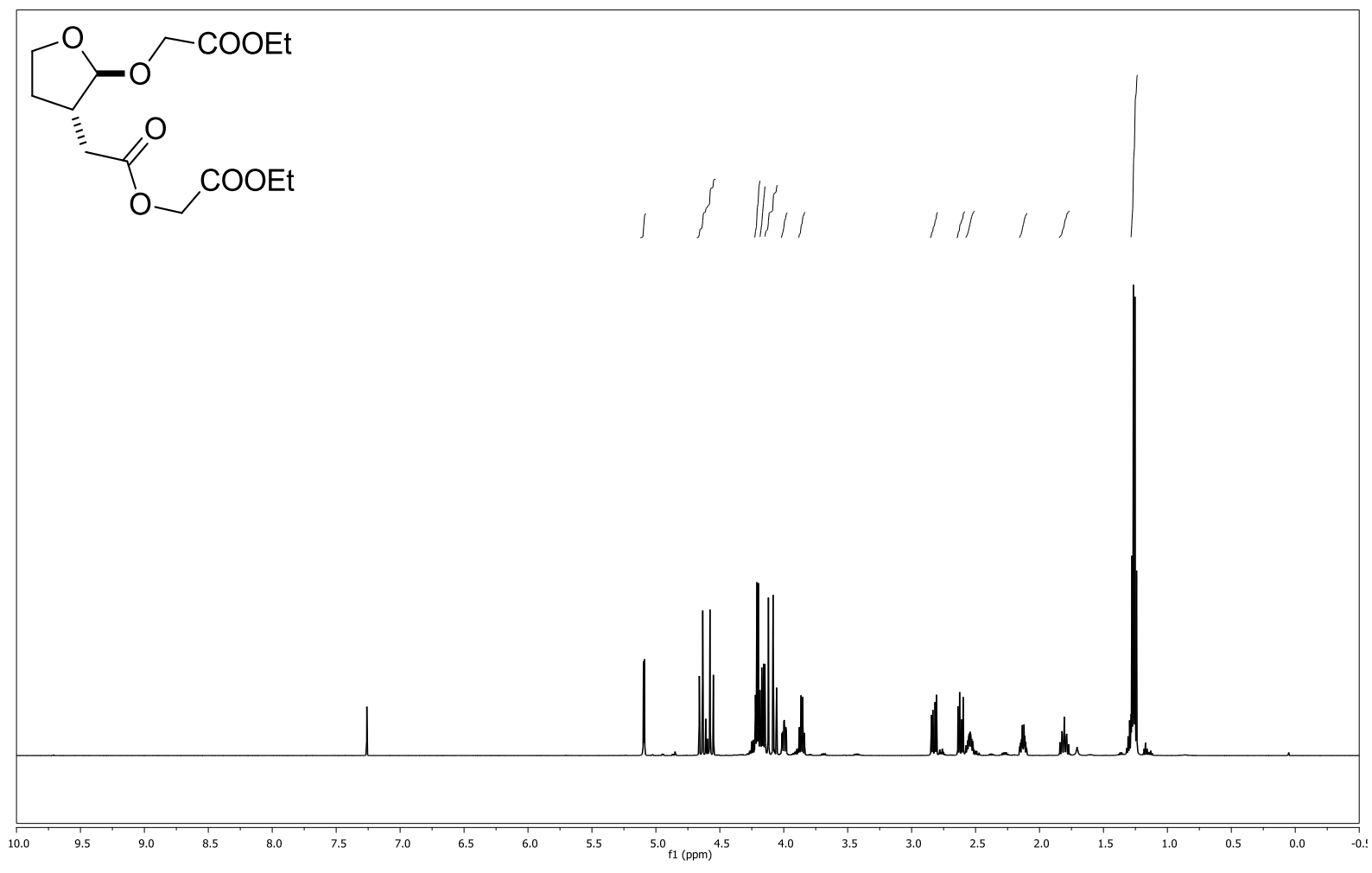

$$
\left(\mathrm{CDCl}_{3}, 151 \mathrm{MHz}\right)
$$

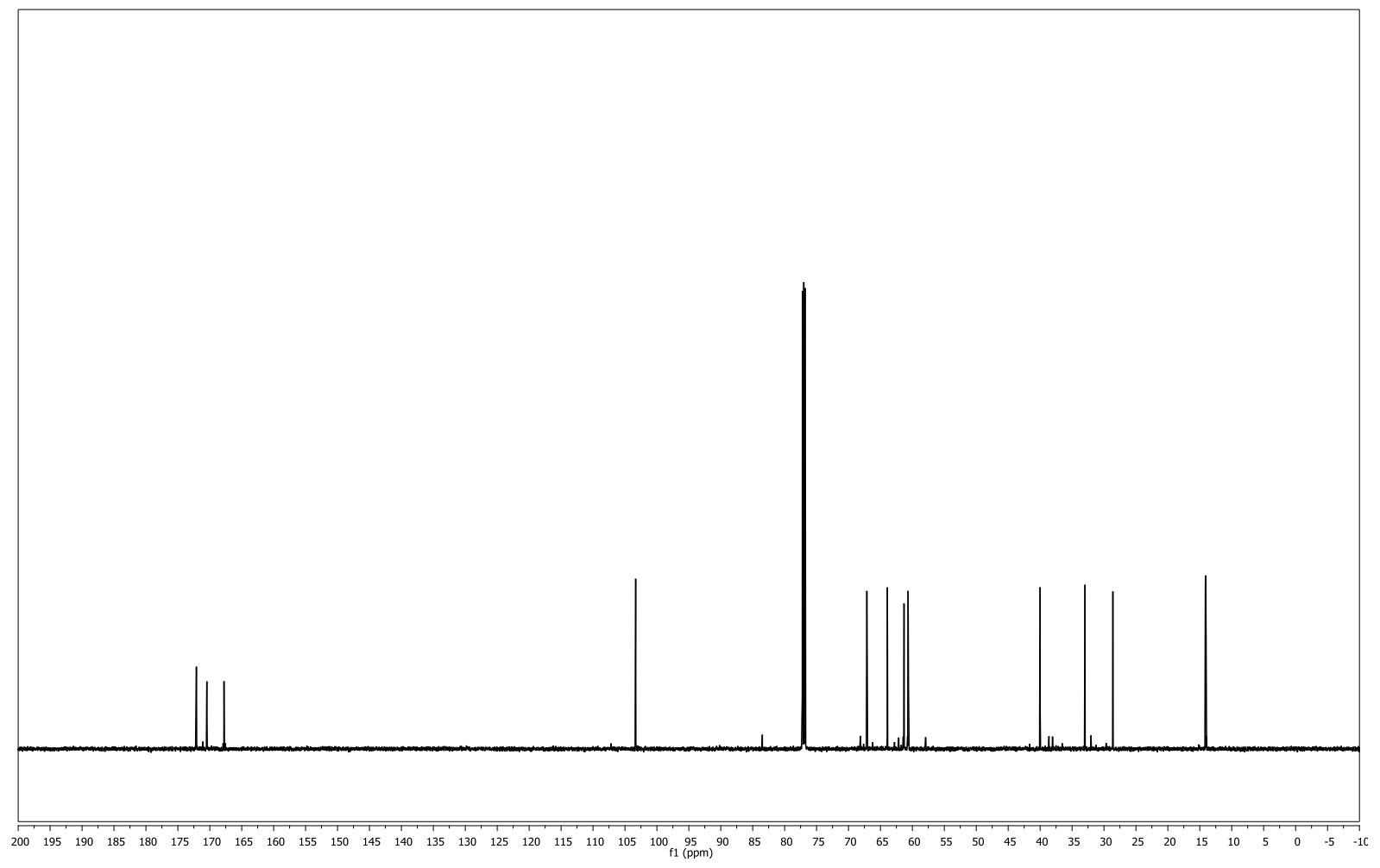

141 
benzyl 2-(2-(2-ethoxy-2-oxoethoxy)tetrahydrofuran-3-yl)acetate (176)

anti-isomer

$\left(\mathrm{CDCl}_{3}, 300 \mathrm{MHz}\right)$

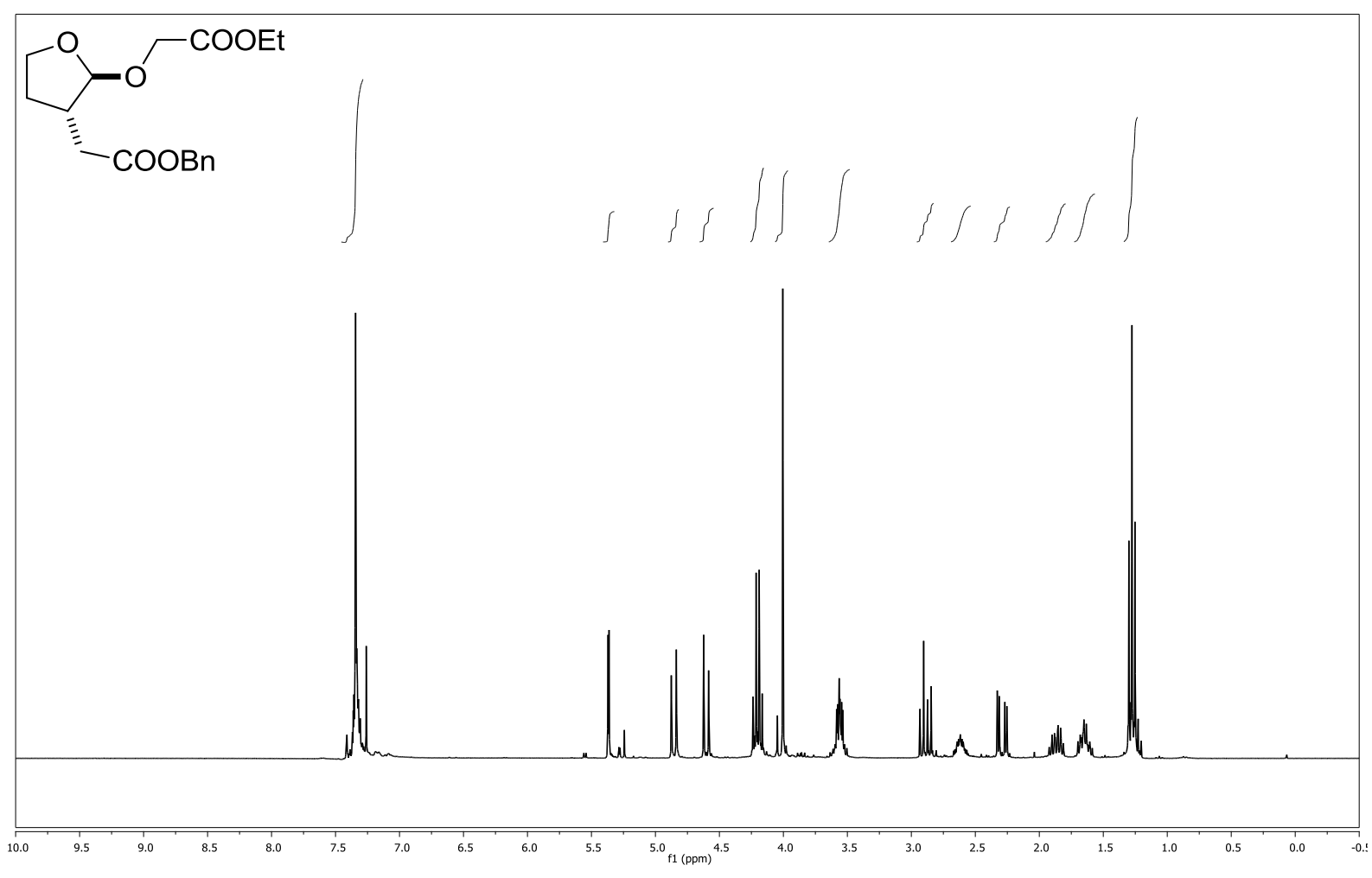

$\left(\mathrm{CDCl}_{3}, 75 \mathrm{MHz}\right)$

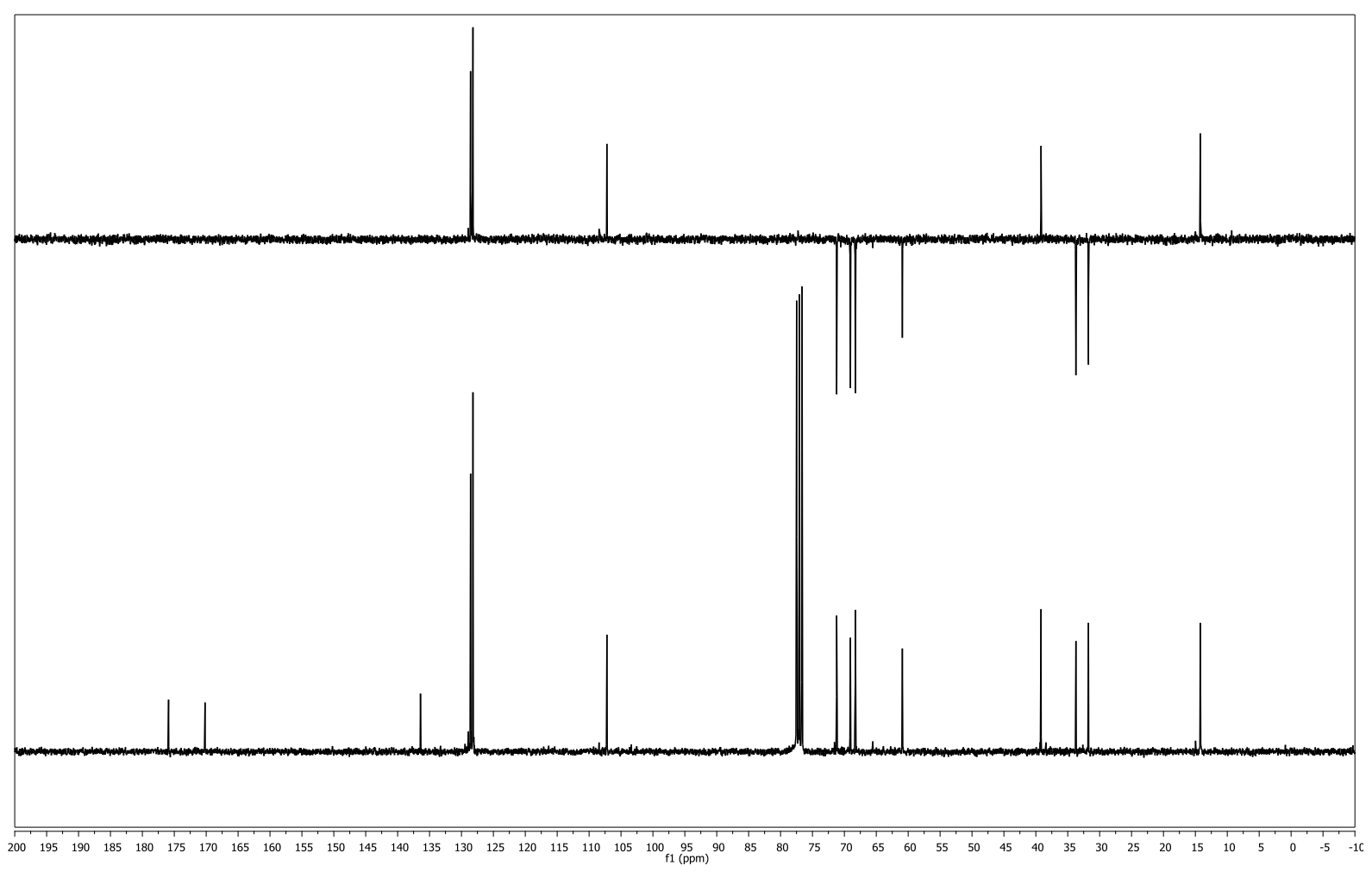


benzyl 2-(2-(2-ethoxy-2-oxoethoxy)tetrahydrofuran-3-yl)acetate (176)

syn-isomer

$\left(\mathrm{CDCl}_{3}, 300 \mathrm{MHz}\right)$

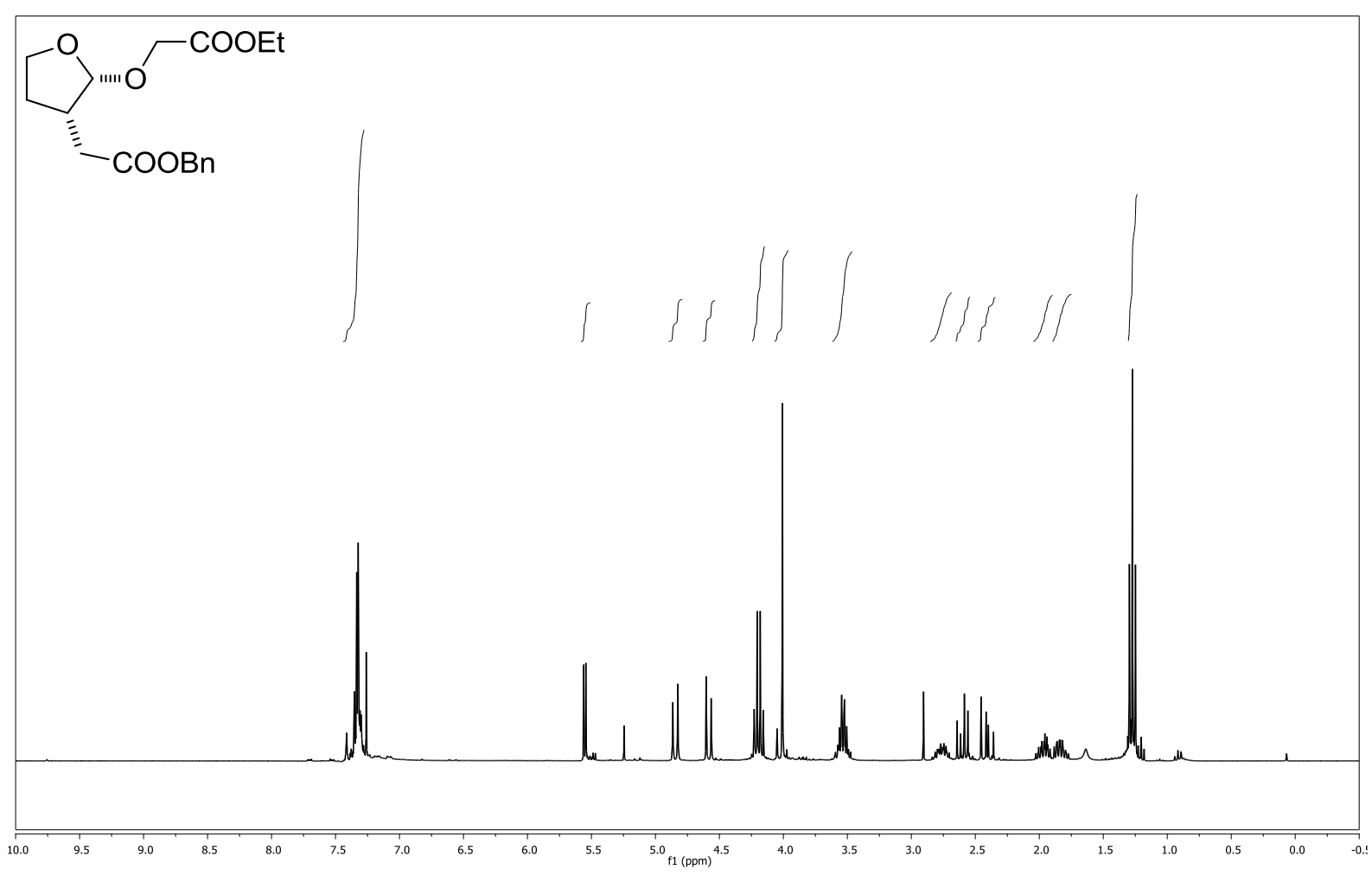

$\left(\mathrm{CDCl}_{3}, 75 \mathrm{MHz}\right)$

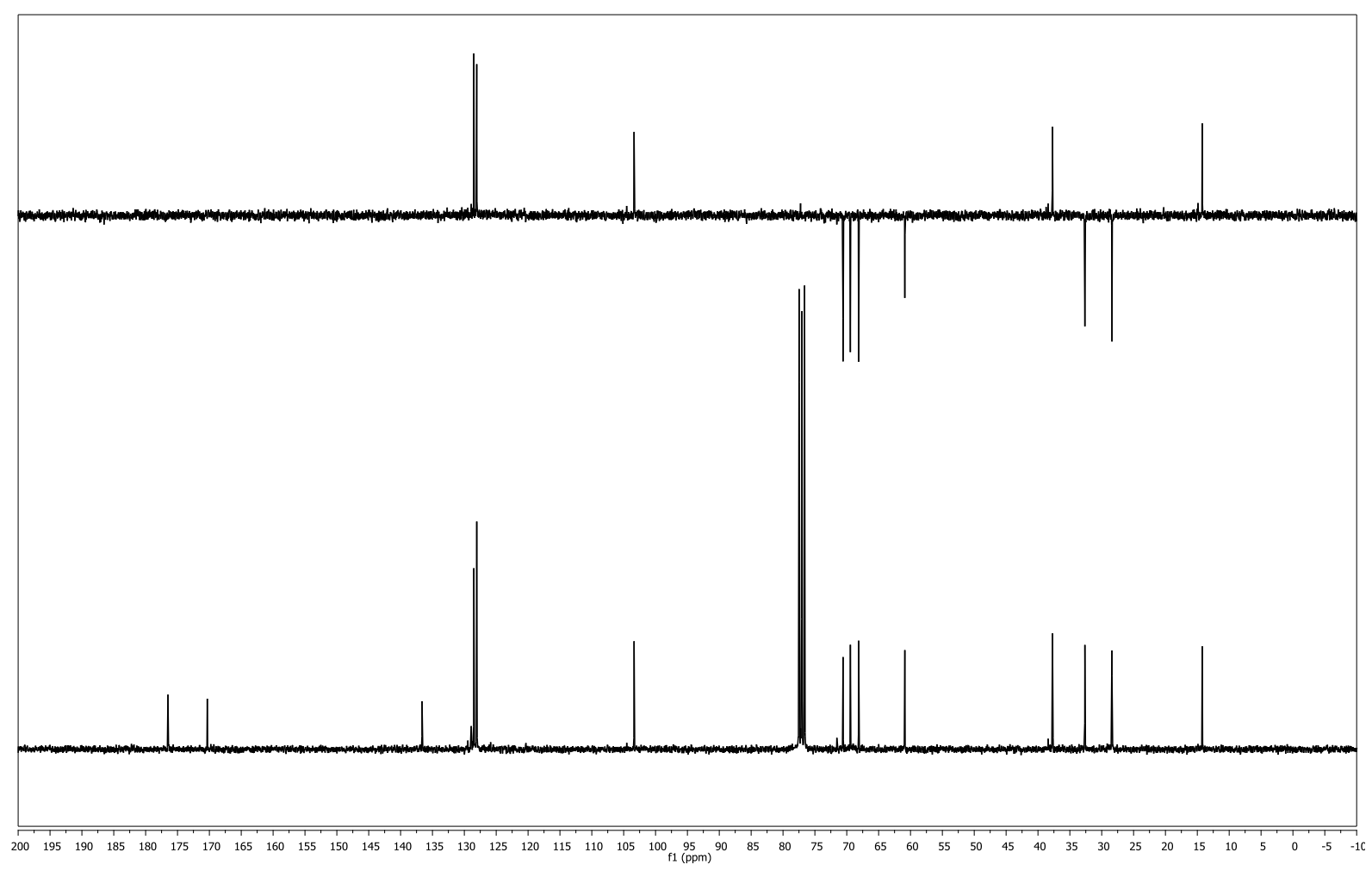


E. Appendix

1-benzyl 4-ethyl 2-(2-(benzyloxy)tetrahydrofuran-3-yl)succinate (177)

$\left(\mathrm{CDCl}_{3}, 600 \mathrm{MHz}\right)$
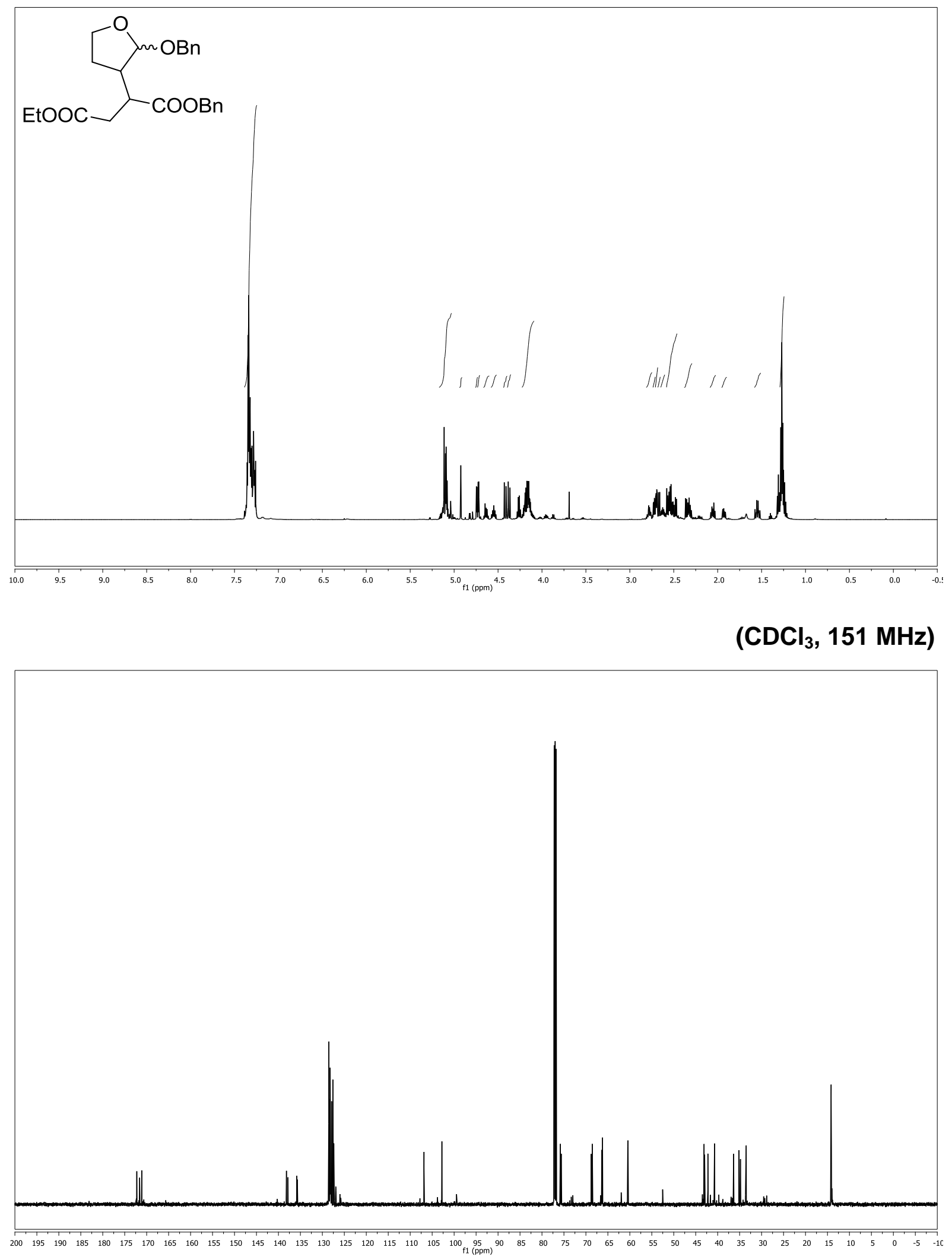

144 
E. Appendix

2-(2-oxotetrahydrofuran-3-yl)acetic acid (183)

(methanol-d $4,300 \mathrm{MHz}$ )

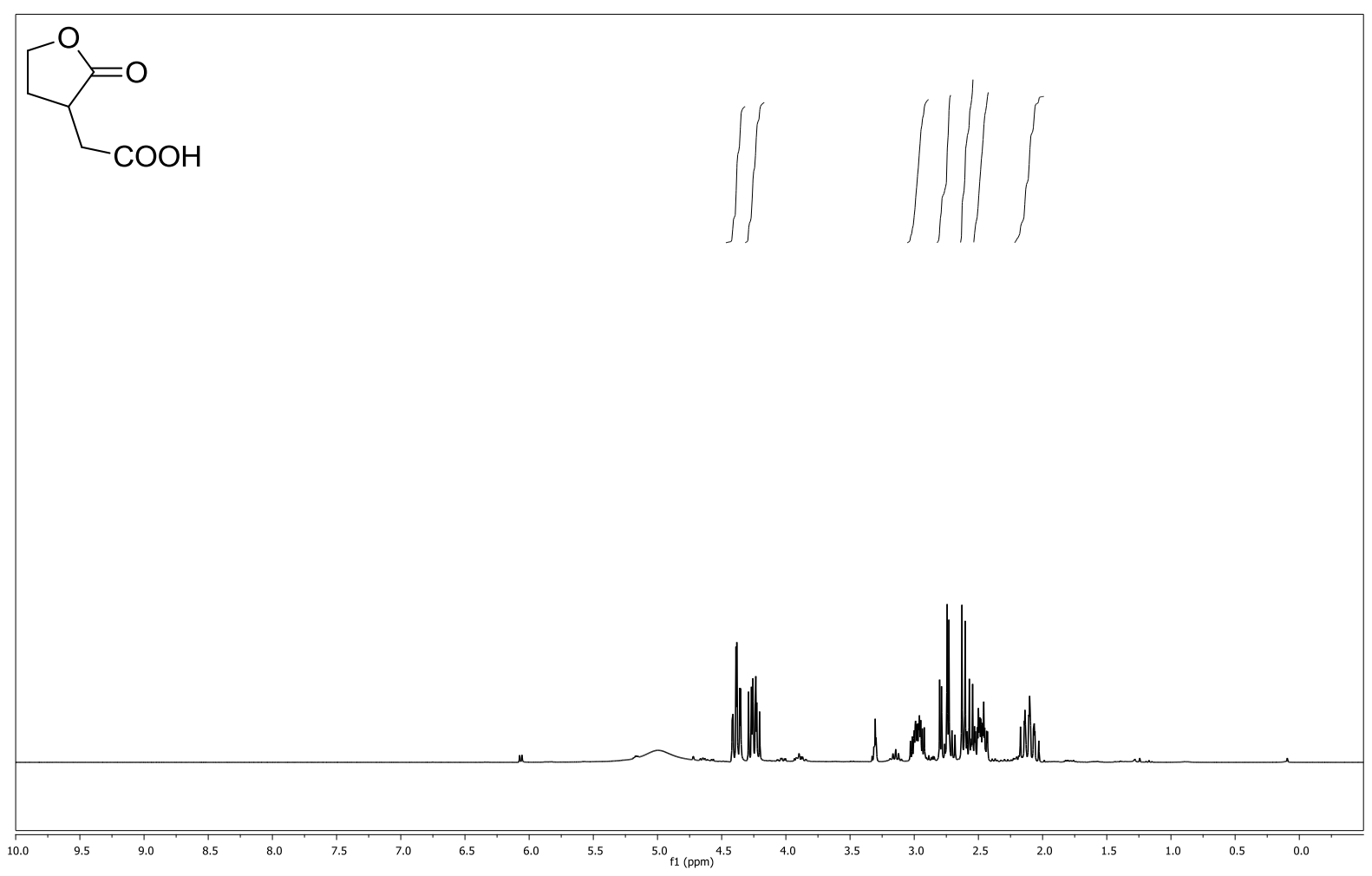

(methanol-d $4,75 \mathrm{MHz}$ )

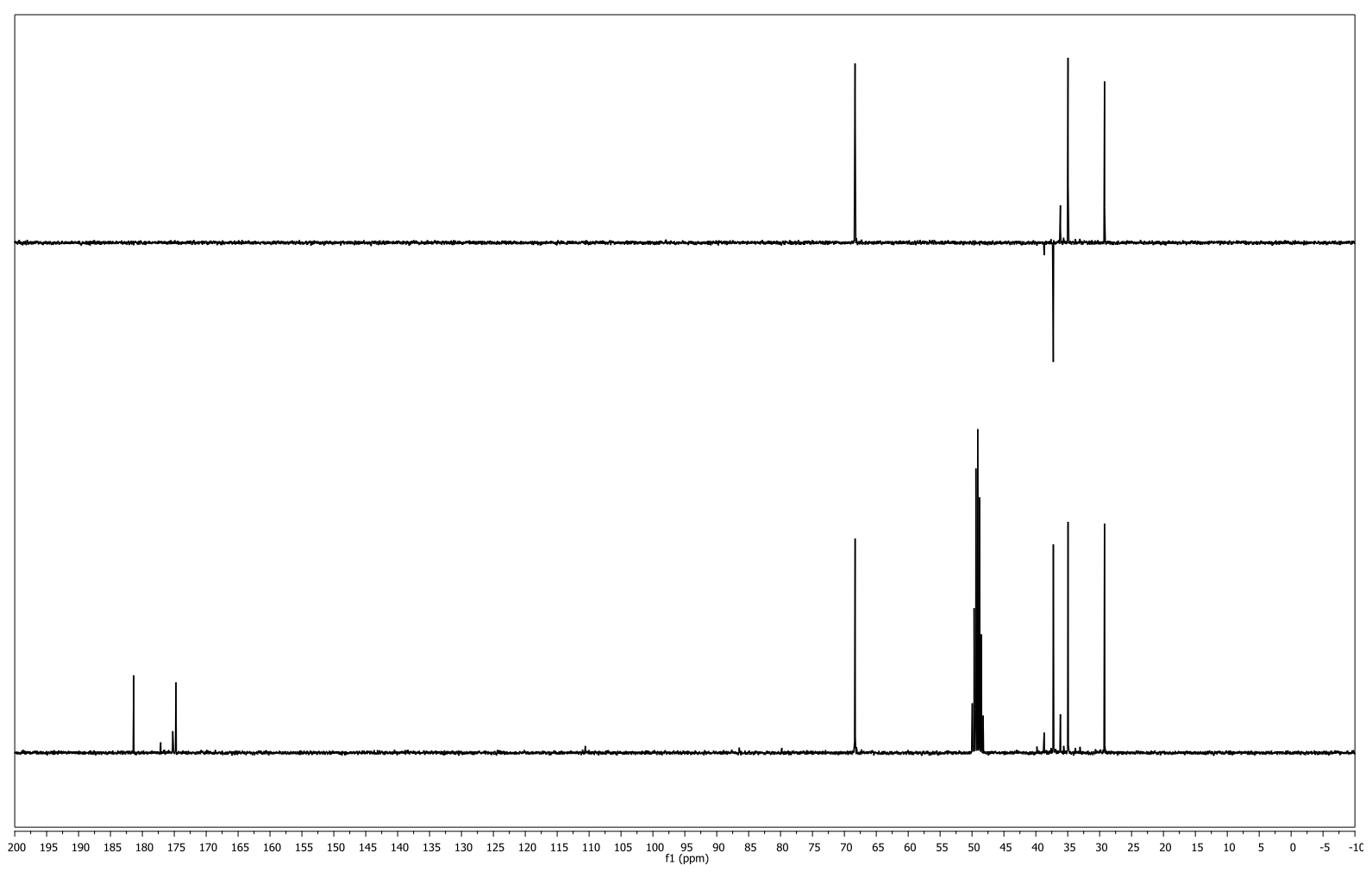


6a-methyltetrahydrofuro[2,3-b]furan-2(6aH)-one (185)

$\left(\mathrm{CDCl}_{3}, 300 \mathrm{MHz}\right)$

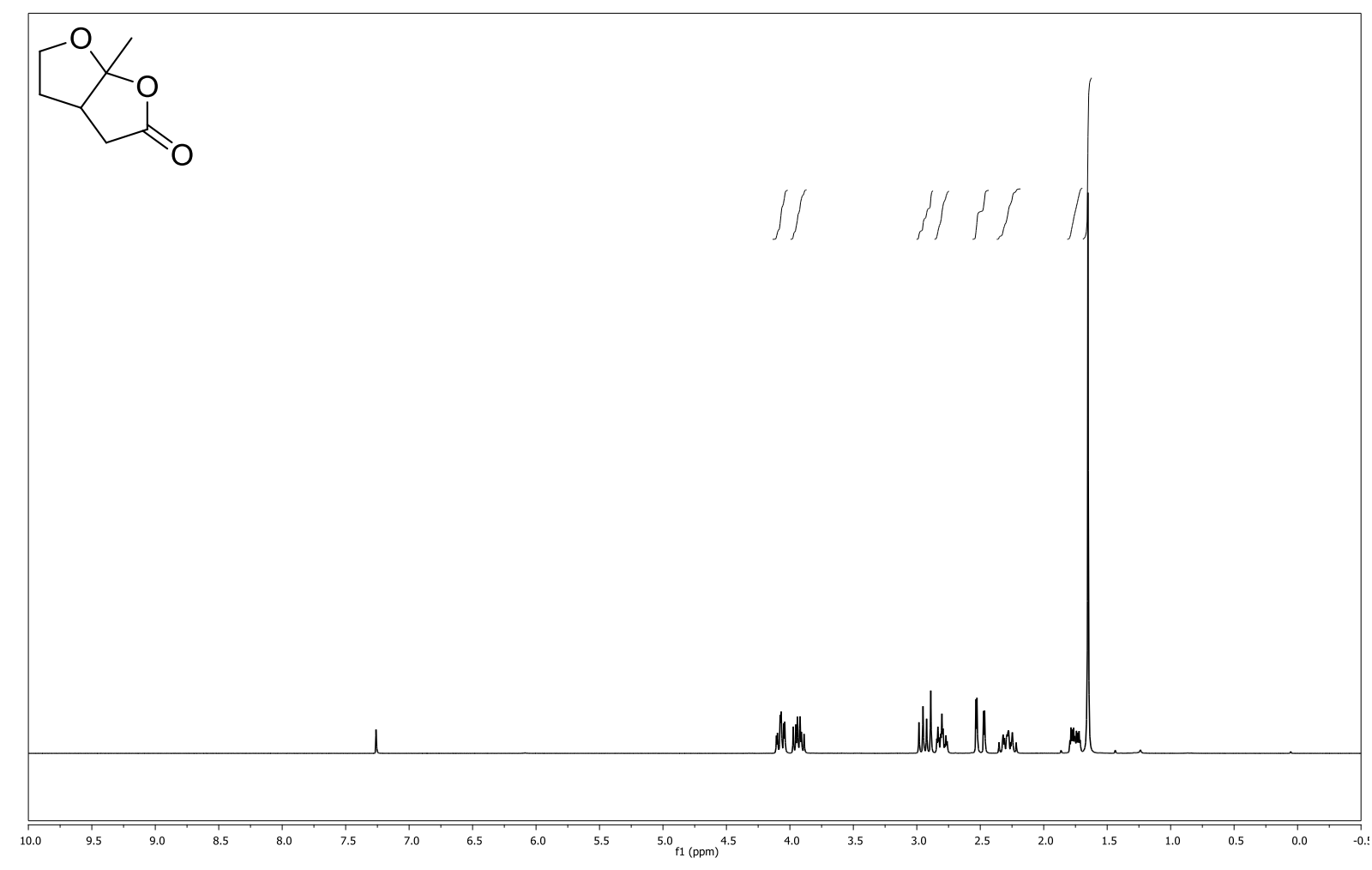

$\left(\mathrm{CDCl}_{3}, 75 \mathrm{MHz}\right)$

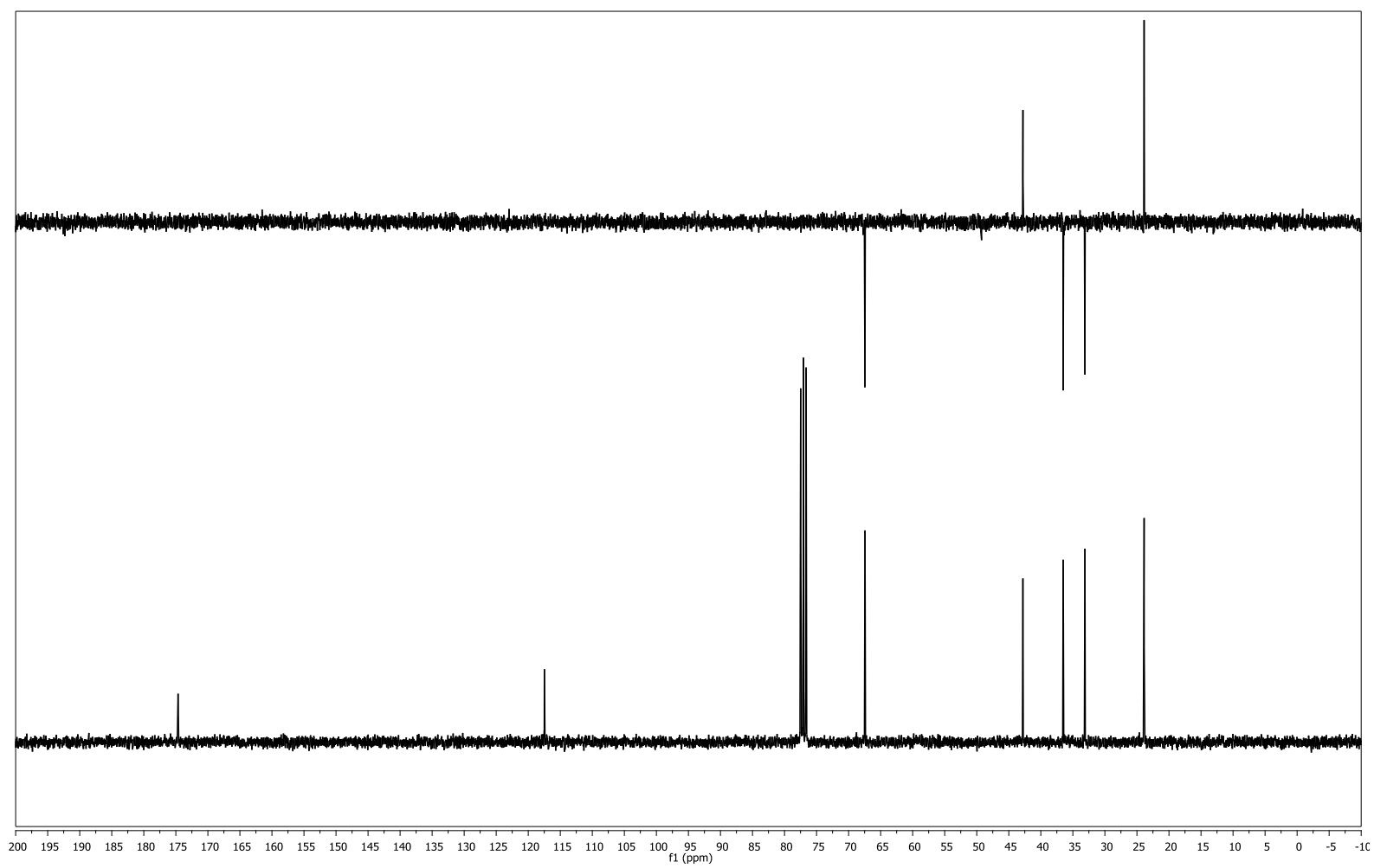


(3S,4S)-4-(carboxymethyl)-5-oxotetrahydrofuran-3-carboxylic acid (186)

(acetone-d $6,600 \mathrm{MHz}$ )

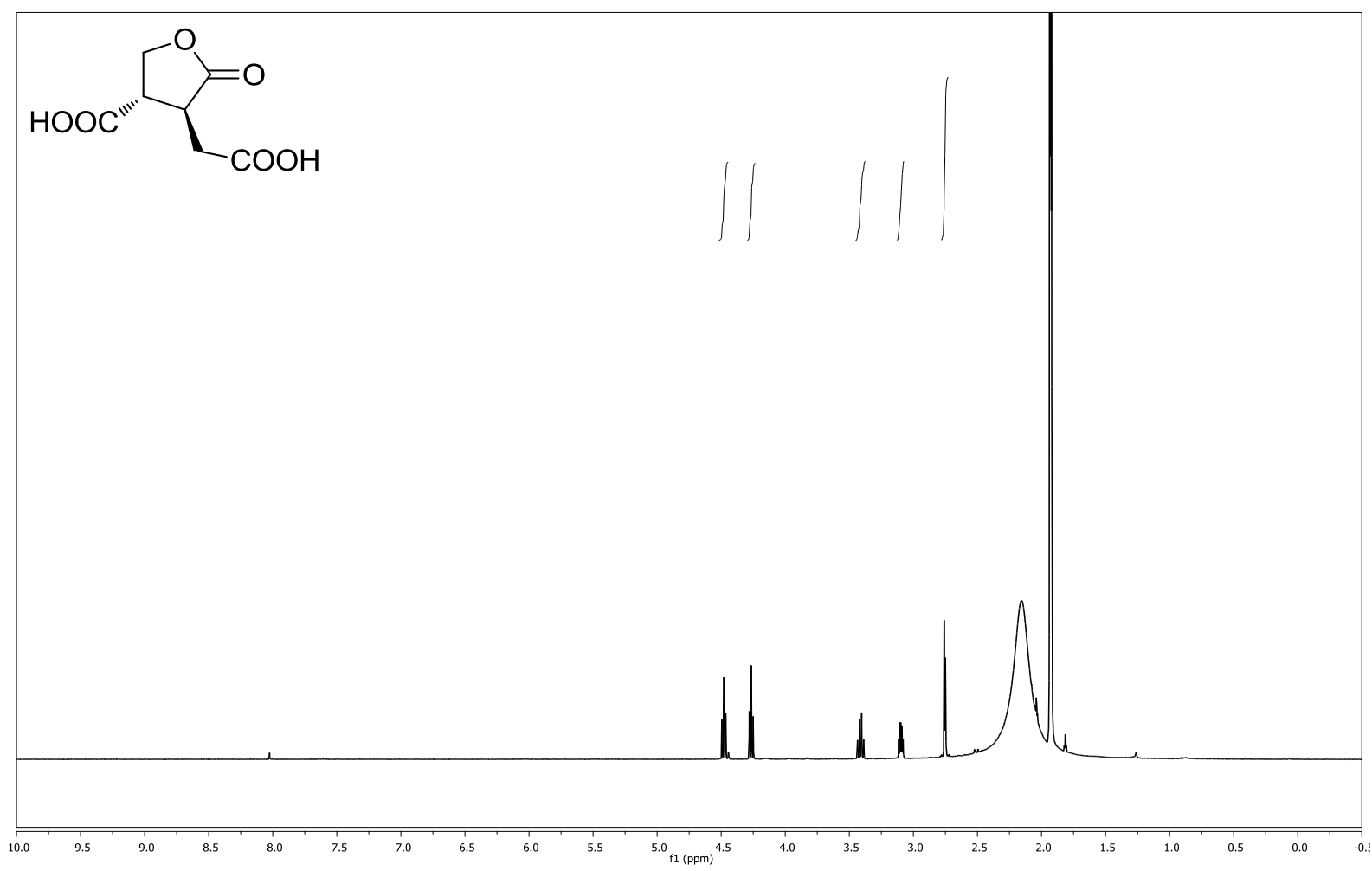

(acetone-d $6,151 \mathrm{MHz}$ )

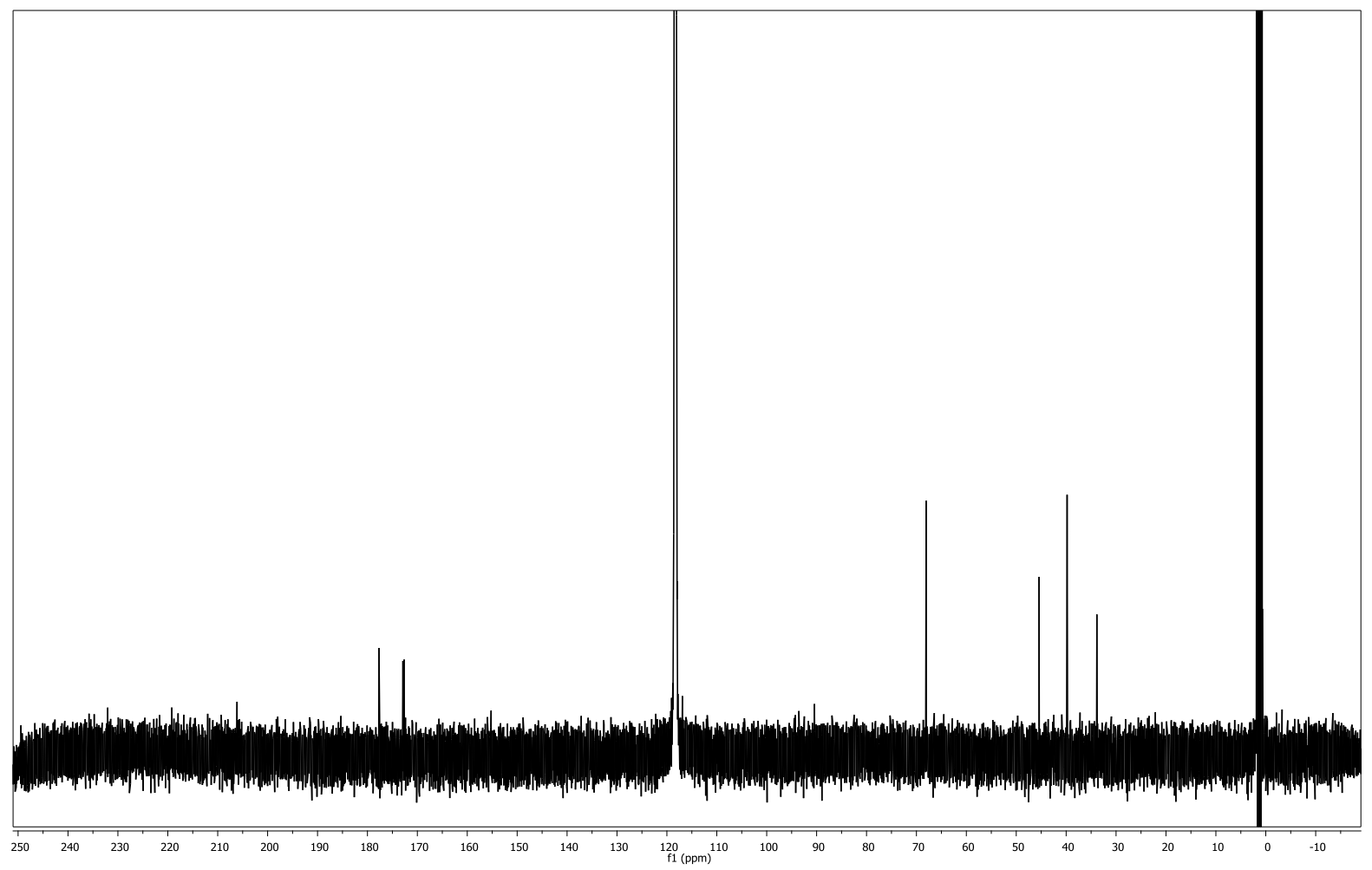


(3S,3aS,6aS)-6a-allyl-5-oxohexahydrofuro[2,3-b]furan-3-carboxylic acid (187)

(acetone- $d_{6}, 300 \mathrm{MHz}$ )

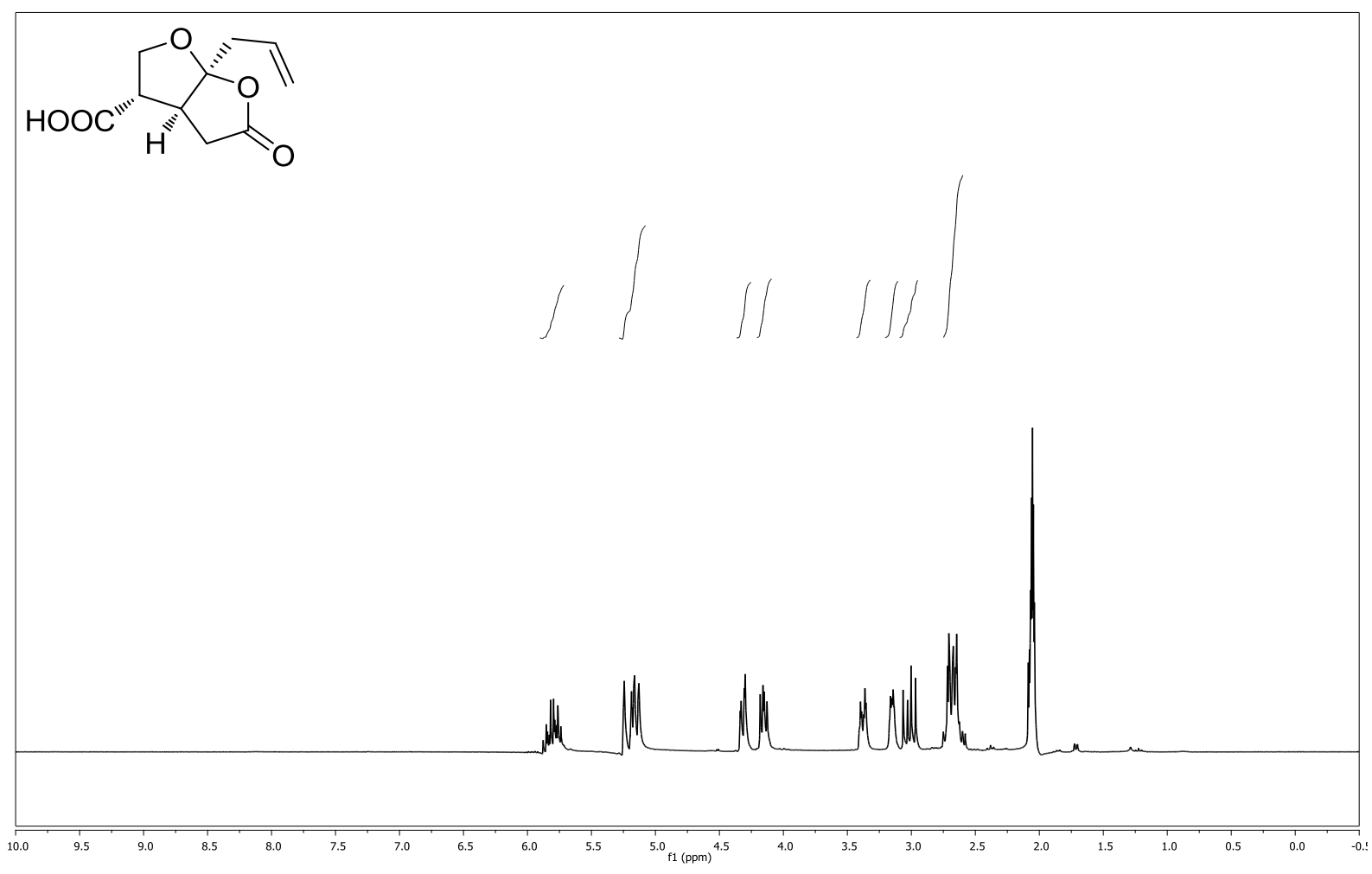

(acetone- $\mathrm{d}_{6}, 75 \mathrm{MHz}$ )

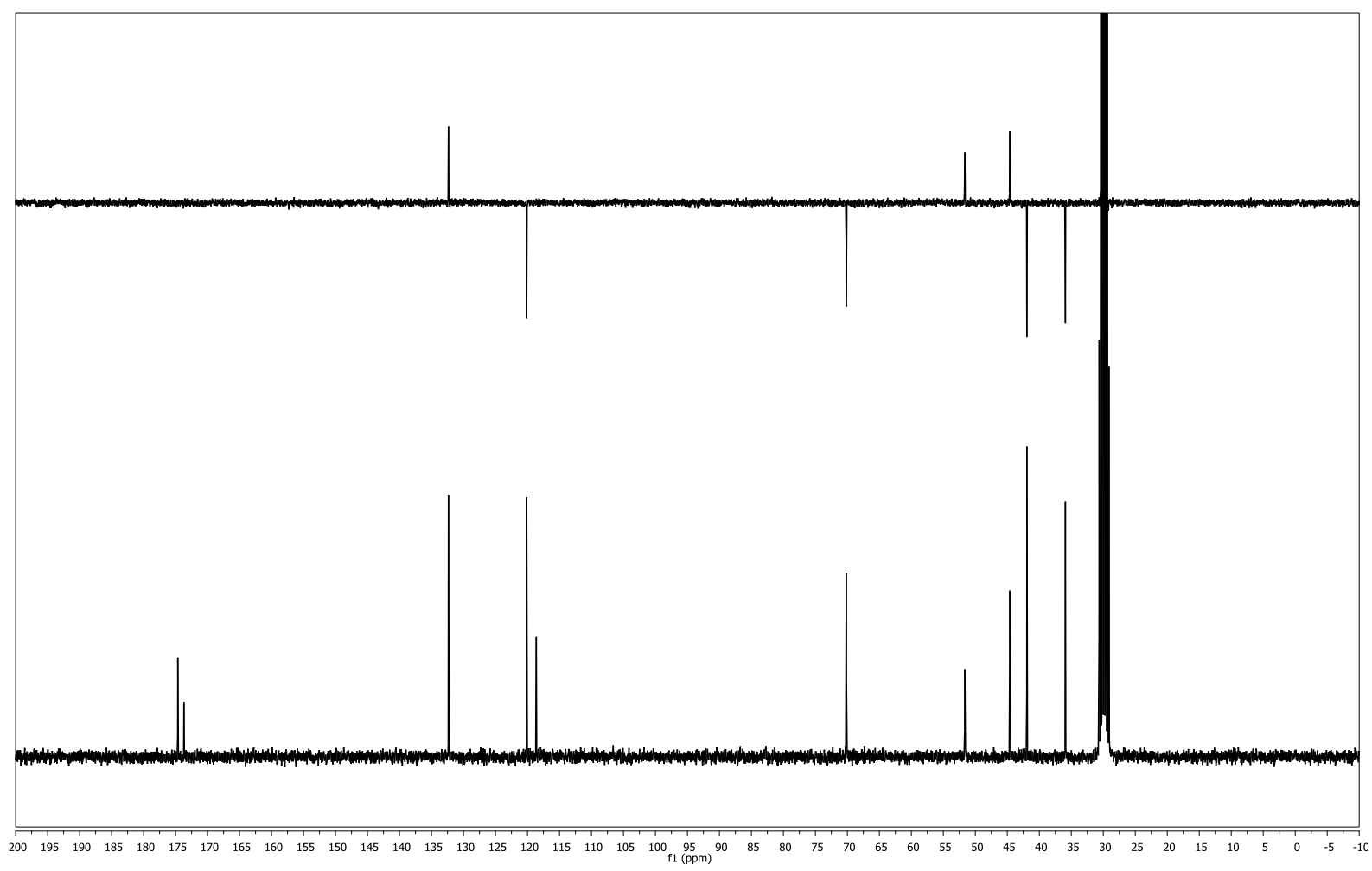


(3S,3aS,6aS)-5-oxo-6a-(2-oxopropyl)hexahydrofuro[2,3-b]furan-3-carboxylic acid (189)

(acetonitrile- $\mathrm{d}_{3}, 600 \mathrm{MHz}$ )

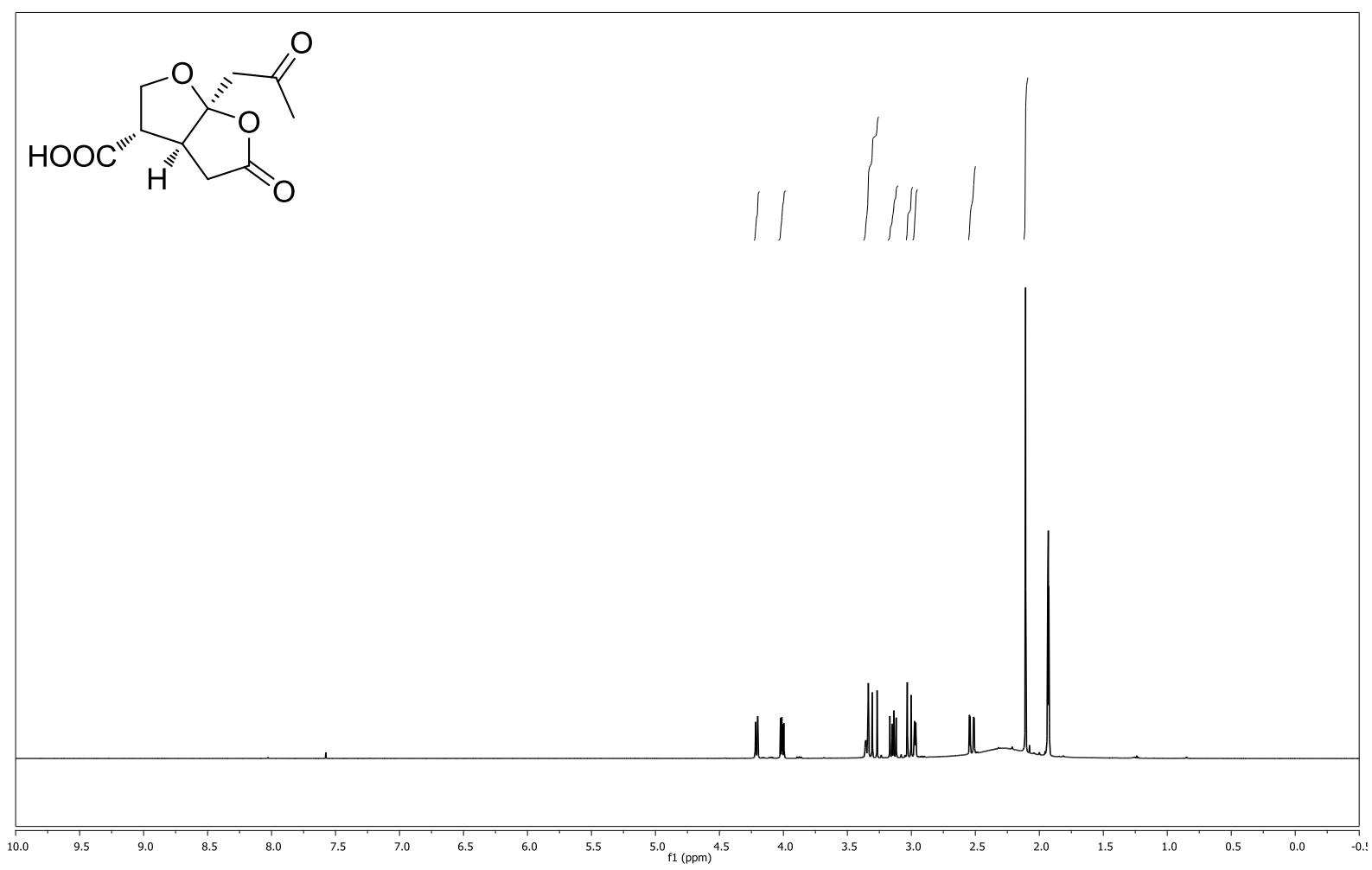

(acetonitrile- $\mathrm{d}_{3}, 151 \mathrm{MHz}$ )

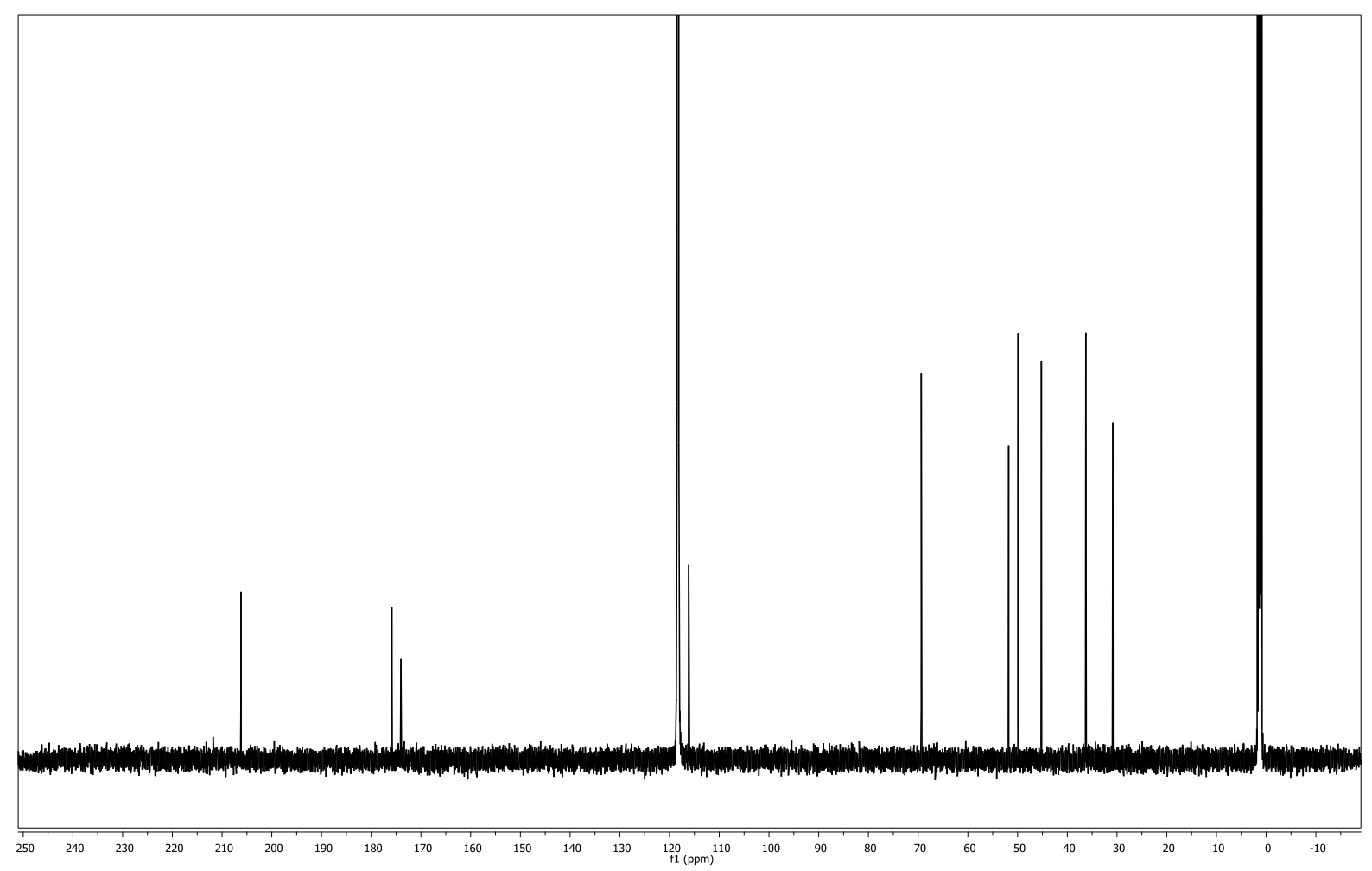


((3S,3aS,6aS)-5-oxo-6a-(2-oxopropyl)hexahydrofuro[2,3-b]furan-3-yl)methyl benzoate (5) (-)-Paeonilide $\left(\mathrm{CDCl}_{3}, 600 \mathrm{MHz}\right)$

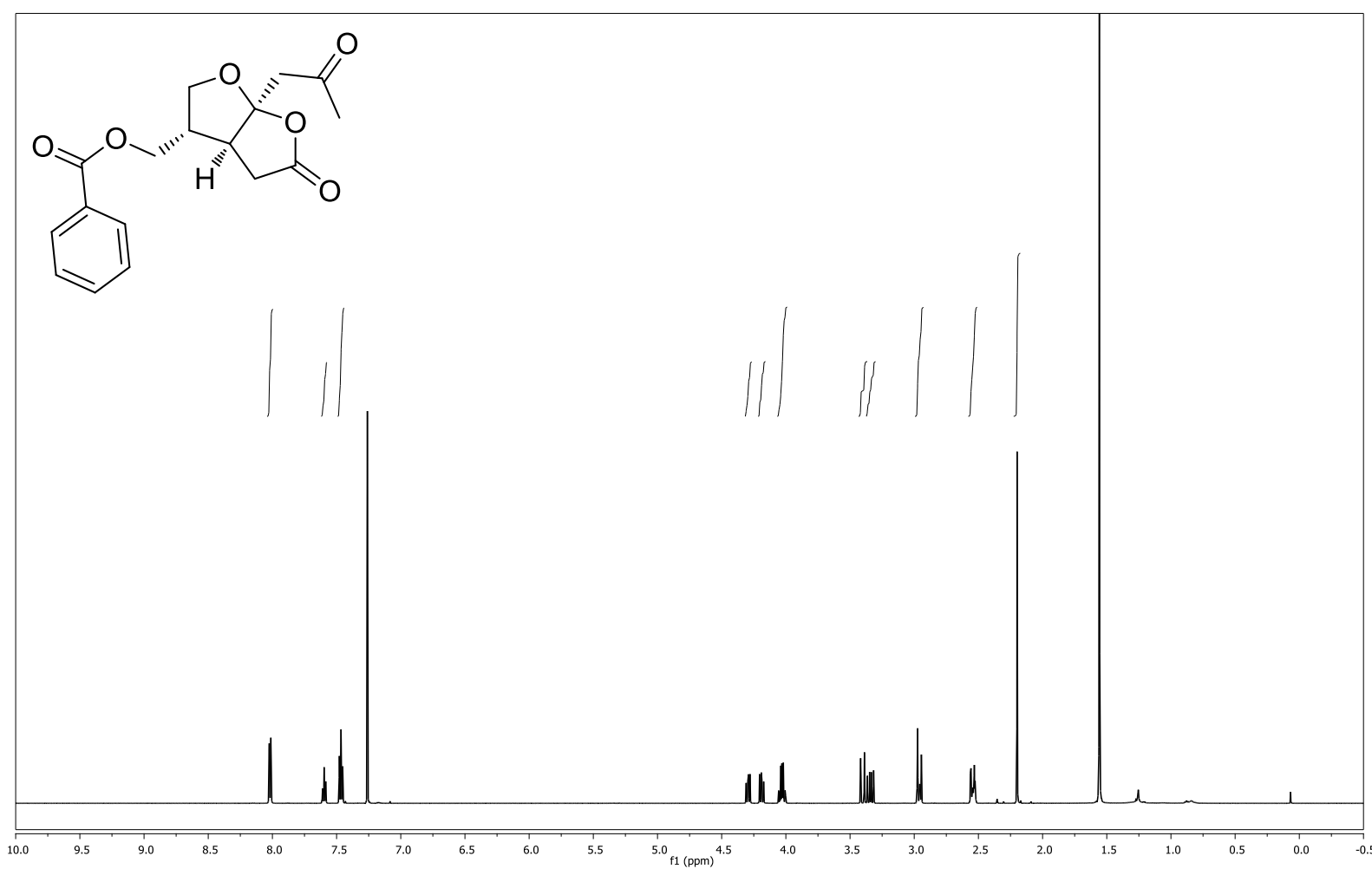

$\left(\mathrm{CDCl}_{3}, 151 \mathrm{MHz}\right)$

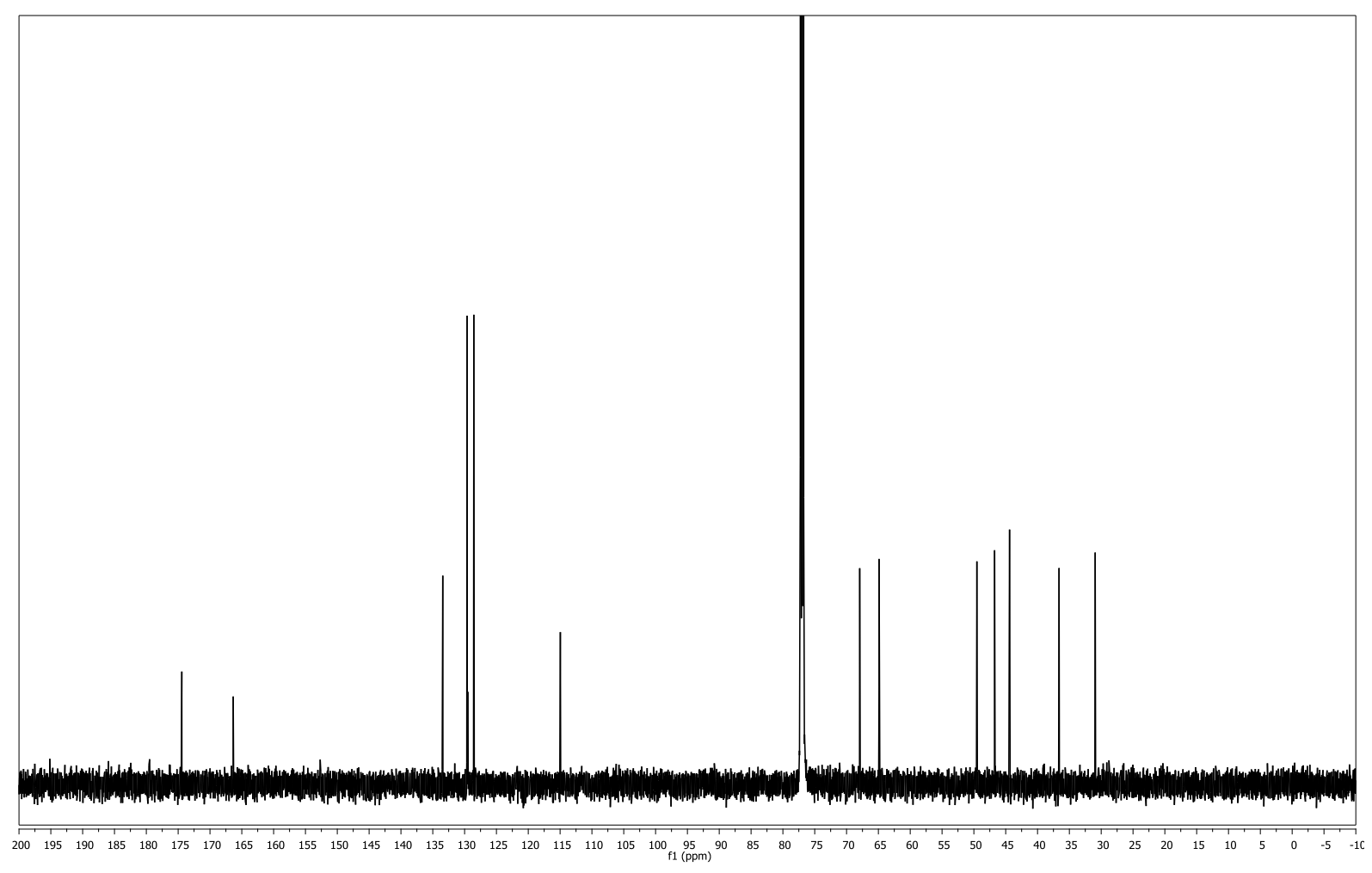




\section{X-ray crystallography data}

\section{(1S,4S,5S,6S)-6-ethyl 4-methyl 2-oxabicyclo[3.1.0]hexane-4,6-dicarboxylate} (133)

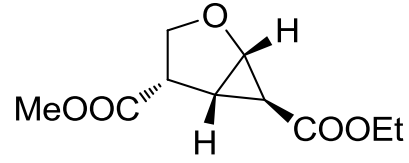

133

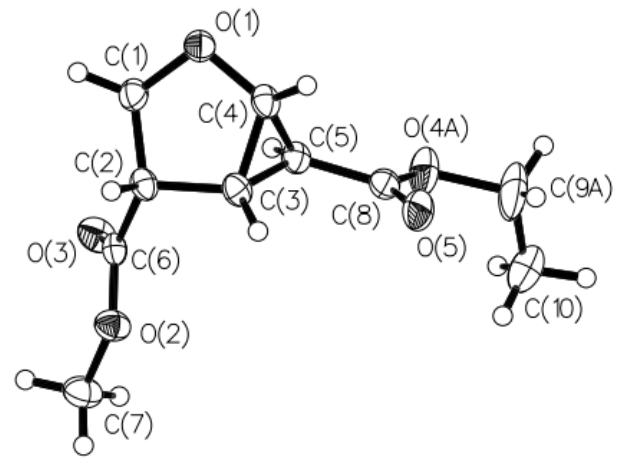

Table 1: Crystal data and structure refinement for 133.

\section{Crystal Data}

Empirical formula

Formula weight

Crystal size

Crystal description

Crystal colour

Crystal system

Space group

Unit cell dimensions

Volume

Z, Calculated density

Absorption coefficient

$F(000)$

\section{Data Collection}

Measurement device type

Measurement method

Temperature

Wavelength

Monochromator

Theta range for data collection

Index ranges

Reflections collected / unique

Reflections greater $\mathrm{I}>2$ । $\mathrm{s}(\mathrm{I})$

Absorption correction

Max. and min. transmission
$\mathrm{C} 10 \mathrm{H} 14 \mathrm{O} 5$

214.21

$0.1790 \times 0.1140 \times 0.1089 \mathrm{~mm}$

stick

colourless

Orthorhombic

P 212121

$a=5.2775(1) A$ alpha $=90 \mathrm{deg}$.

$b=7.4363(1) A \quad$ beta $=90$ deg.

$c=26.0428(4) A$ gamma $=90 \mathrm{deg}$.

1022.05(3) $A^{\wedge} 3$

4, $1.392 \mathrm{Mg} / \mathrm{m}^{\wedge} 3$

$0.950 \mathrm{~mm}^{\wedge}-1$

456

SuperNova, Single source at offset, Atlas

Iw scans

$123 \mathrm{~K}$

$1.54184 \mathrm{~A}$

graphite

3.39 to $76.43 \mathrm{deg}$.

$-6<=\mathrm{h}<=6,-9<=\mathrm{k}<=9,-31<=\mathrm{l}<=32$

$9985 / 2129[\mathrm{R}($ int $)=0.0311]$

2110

Analytical

0.926 and 0.868 


\section{Refinement}

Refinement method

Hydrogen treatment

Data / restraints / parameters

Goodness-of-fit on F^2

Final $R$ indices [l>2sigma(I)]

$R$ indices (all data)

Absolute structure parameter

Largest diff. peak and hole
Full-matrix least-squares on $\mathrm{F}^{\wedge} 2$$$
2129 / 0 / 142
$$

1.077

$\mathrm{R} 1=0.0431, w R 2=0.1113$

$\mathrm{R} 1=0.0434, w R 2=0.1117$

$-0.1(3)$

0.411 and -0.367 e. $\mathrm{A}^{\wedge}-3$

Table 2: Atomic coordinates $\left(x 1^{4}\right)$ and equivalent isotropic displacement parameters $\left(\AA^{2} \times 10^{3}\right)$ for 133. $U(e q)$ is defined as one third of the trace of the orthogonalized Uij tensor.

\begin{tabular}{lllll}
\hline Atom & $\mathrm{X}$ & $\mathrm{y}$ & $\mathrm{z}$ & $\mathrm{U}(\mathrm{eq})$ \\
\hline $\mathrm{O}(1)$ & $1993(3)$ & $9251(2)$ & $2282(1)$ & $30(1)$ \\
$\mathrm{O}(2)$ & $7794(3)$ & $5360(2)$ & $1483(1)$ & $29(1)$ \\
$\mathrm{O}(3)$ & $4026(3)$ & $4302(2)$ & $1729(1)$ & $32(1)$ \\
$\mathrm{O}(4 \mathrm{~A})$ & $-292(4)$ & $9433(2)$ & $605(1)$ & $41(1)$ \\
$\mathrm{O}(5)$ & $3268(3)$ & $11057(2)$ & $709(1)$ & $40(1)$ \\
$\mathrm{C}(1)$ & $2890(4)$ & $7415(3)$ & $2307(1)$ & $27(1)$ \\
$\mathrm{C}(2)$ & $5219(4)$ & $7326(2)$ & $1960(1)$ & $23(1)$ \\
$\mathrm{C}(3)$ & $4753(4)$ & $8817(2)$ & $1571(1)$ & $25(1)$ \\
$\mathrm{C}(4)$ & $2771(4)$ & $9952(2)$ & $1808(1)$ & $26(1)$ \\
$\mathrm{C}(5)$ & $2129(4)$ & $8841(2)$ & $1327(1)$ & $24(1)$ \\
$\mathrm{C}(6)$ & $5565(4)$ & $5488(2)$ & $1719(1)$ & $22(1)$ \\
$\mathrm{C}(7)$ & $8349(5)$ & $3631(3)$ & $1252(1)$ & $35(1)$ \\
$\mathrm{C}(8)$ & $1843(4)$ & $9895(3)$ & $851(1)$ & $28(1)$ \\
$\mathrm{C}(9 A)$ & $-897(8)$ & $10393(4)$ & $134(1)$ & $63(1)$ \\
$\mathrm{C}(10)$ & $-392(14)$ & $9278(8)$ & $-309(2)$ & $48(1)$ \\
$C(9)$ & $-897(8)$ & $10393(4)$ & $134(1)$ & $63(1)$ \\
$C(11)$ & $-1700(20)$ & $9331(14)$ & $-267(3)$ & $48(1)$ \\
$O(4)$ & $-292(4)$ & $9433(2)$ & $605(1)$ & $41(1)$
\end{tabular}

Table 3: Bond lengths $[\AA \AA]$ and angles [deg] for 133.

\begin{tabular}{ll|ll}
$\mathrm{O}(1)-\mathrm{C}(1)$ & $1.447(3)$ & $\mathrm{O}(2)-\mathrm{C}(6)-\mathrm{O}(3)$ & $123.73(16)$ \\
$\mathrm{O}(1)-\mathrm{C}(4)$ & $1.403(2)$ & $\mathrm{O}(2)-\mathrm{C}(6)-\mathrm{C}(2)$ & $111.22(15)$ \\
$\mathrm{O}(2)-\mathrm{C}(6)$ & $1.331(3)$ & $\mathrm{O}(3)-\mathrm{C}(6)-\mathrm{C}(2)$ & $125.04(19)$ \\
$\mathrm{O}(2)-\mathrm{C}(7)$ & $1.450(3)$ & $\mathrm{O}(4 \mathrm{~A})-\mathrm{C}(8)-\mathrm{C}(5)$ & $110.62(18)$ \\
$\mathrm{O}(3)-\mathrm{C}(6)$ & $1.199(2)$ & $\mathrm{O}(5)-\mathrm{C}(8)-\mathrm{C}(5)$ & $125.14(19)$ \\
$\mathrm{O}(4)-\mathrm{C}(8)$ & $1.341(3)$ & $\mathrm{O}(4 \mathrm{~A})-\mathrm{C}(8)-\mathrm{O}(5)$ & $124.19(18)$ \\
$\mathrm{O}(4)-\mathrm{C}(9)$ & $1.455(3)$ & $\mathrm{O}(4)-\mathrm{C}(8)-\mathrm{C}(5)$ & $110.62(18)$ \\
$\mathrm{O}(4 \mathrm{~A})-\mathrm{C}(8)$ & $1.341(3)$ & $\mathrm{O}(4)-\mathrm{C}(8)-\mathrm{O}(5)$ & $124.19(18)$ \\
$\mathrm{O}(4 \mathrm{~A})-\mathrm{C}(9 \mathrm{~A})$ & $1.455(3)$ & $\mathrm{O}(4)-\mathrm{C}(9)-\mathrm{C}(11)$ & $115.2(5)$ \\
$\mathrm{O}(5)-\mathrm{C}(8)$ & $1.204(3)$ & $\mathrm{O}(4 \mathrm{~A})-\mathrm{C}(9 \mathrm{)})-\mathrm{C}(10)$ & $110.5(3)$ \\
$\mathrm{C}(1)-\mathrm{C}(2)$ & $1.527(3)$ & $\mathrm{O}(1)-\mathrm{C}(1)-\mathrm{H}(1 \mathrm{~A})$ & 110.00
\end{tabular}




\begin{tabular}{|c|c|c|c|}
\hline$C(2)-C(6)$ & $1.514(2)$ & $\mathrm{O}(1)-\mathrm{C}(1)-\mathrm{H}(1 \mathrm{~B})$ & 111.00 \\
\hline$C(2)-C(3)$ & $1.521(2)$ & $C(2)-C(1)-H(1 A)$ & 110.00 \\
\hline$C(3)-C(5)$ & $1.523(3)$ & $\mathrm{C}(2)-\mathrm{C}(1)-\mathrm{H}(1 \mathrm{~B})$ & 111.00 \\
\hline$C(3)-C(4)$ & $1.479(3)$ & $H(1 A)-C(1)-H(1 B)$ & 109.00 \\
\hline$C(4)-C(5)$ & $1.537(2)$ & $\mathrm{C}(1)-\mathrm{C}(2)-\mathrm{H}(2)$ & 109.00 \\
\hline$C(5)-C(8)$ & $1.475(3)$ & $\mathrm{C}(3)-\mathrm{C}(2)-\mathrm{H}(2)$ & 109.00 \\
\hline$C(9)-C(11)$ & $1.376(9)$ & $\mathrm{C}(6)-\mathrm{C}(2)-\mathrm{H}(2)$ & 109.00 \\
\hline$C(9 A)-C(10)$ & $1.445(6)$ & $\mathrm{C}(2)-\mathrm{C}(3)-\mathrm{H}(3)$ & 120.00 \\
\hline$C(1)-H(1 A)$ & 0.9900 & $\mathrm{C}(4)-\mathrm{C}(3)-\mathrm{H}(3)$ & 120.00 \\
\hline $\mathrm{C}(1)-\mathrm{H}(1 \mathrm{~B})$ & 0.9900 & $\mathrm{C}(5)-\mathrm{C}(3)-\mathrm{H}(3)$ & 120.00 \\
\hline $\mathrm{C}(2)-\mathrm{H}(2)$ & 10.000 & $\mathrm{O}(1)-\mathrm{C}(4)-\mathrm{H}(4)$ & 118.00 \\
\hline $\mathrm{C}(3)-\mathrm{H}(3)$ & 10.000 & $\mathrm{C}(3)-\mathrm{C}(4)-\mathrm{H}(4)$ & 118.00 \\
\hline $\mathrm{C}(4)-\mathrm{H}(4)$ & 10.000 & $\mathrm{C}(5)-\mathrm{C}(4)-\mathrm{H}(4)$ & 118.00 \\
\hline $\mathrm{C}(5)-\mathrm{H}(5)$ & 10.000 & $\mathrm{C}(3)-\mathrm{C}(5)-\mathrm{H}(5)$ & 118.00 \\
\hline $\mathrm{C}(7)-\mathrm{H}(7 \mathrm{~A})$ & 0.9800 & $\mathrm{C}(4)-\mathrm{C}(5)-\mathrm{H}(5)$ & 118.00 \\
\hline $\mathrm{C}(7)-\mathrm{H}(7 \mathrm{~B})$ & 0.9800 & $\mathrm{C}(8)-\mathrm{C}(5)-\mathrm{H}(5)$ & 118.00 \\
\hline $\mathrm{C}(7)-\mathrm{H}(7 \mathrm{C})$ & 0.9800 & $\mathrm{O}(2)-\mathrm{C}(7)-\mathrm{H}(7 \mathrm{~A})$ & 109.00 \\
\hline $\mathrm{C}(9)-\mathrm{H}(9 \mathrm{D})$ & 0.9900 & $\mathrm{O}(2)-\mathrm{C}(7)-\mathrm{H}(7 \mathrm{~B})$ & 109.00 \\
\hline $\mathrm{C}(9)-\mathrm{H}(9 \mathrm{C})$ & 0.9900 & $\mathrm{O}(2)-\mathrm{C}(7)-\mathrm{H}(7 \mathrm{C})$ & 109.00 \\
\hline $\mathrm{C}(9 \mathrm{~A})-\mathrm{H}(9 \mathrm{~B})$ & 0.9900 & $\mathrm{H}(7 \mathrm{~A})-\mathrm{C}(7)-\mathrm{H}(7 \mathrm{~B})$ & 109.00 \\
\hline $\mathrm{C}(9 \mathrm{~A})-\mathrm{H}(9 \mathrm{~A})$ & 0.9900 & $\mathrm{H}(7 \mathrm{~A})-\mathrm{C}(7)-\mathrm{H}(7 \mathrm{C})$ & 109.00 \\
\hline $\mathrm{C}(10)-\mathrm{H}(10 \mathrm{C})$ & 0.9800 & $\mathrm{H}(7 \mathrm{~B})-\mathrm{C}(7)-\mathrm{H}(7 \mathrm{C})$ & 110.00 \\
\hline $\mathrm{C}(10)-\mathrm{H}(10 \mathrm{~A})$ & 0.9800 & $\mathrm{H}(9 \mathrm{C})-\mathrm{C}(9)-\mathrm{H}(9 \mathrm{D})$ & 107.00 \\
\hline $\mathrm{C}(10)-\mathrm{H}(10 \mathrm{~B})$ & 0.9800 & $\mathrm{O}(4)-\mathrm{C}(9)-\mathrm{H}(9 \mathrm{C})$ & 108.00 \\
\hline$C(11)-H(11 A)$ & 0.9800 & $\mathrm{O}(4)-\mathrm{C}(9)-\mathrm{H}(9 \mathrm{D})$ & 108.00 \\
\hline $\mathrm{C}(11)-\mathrm{H}(11 \mathrm{~B})$ & 0.9800 & $\mathrm{C}(11)-\mathrm{C}(9)-\mathrm{H}(9 \mathrm{C})$ & 109.00 \\
\hline $\mathrm{C}(11)-\mathrm{H}(11 \mathrm{C})$ & 0.9800 & $\mathrm{C}(11)-\mathrm{C}(9)-\mathrm{H}(9 \mathrm{D})$ & 108.00 \\
\hline$C(1)-O(1)-C(4)$ & $107.11(13)$ & $C(10)-C(9 A)-H(9 A)$ & 109.00 \\
\hline $\mathrm{C}(6)-\mathrm{O}(2)-\mathrm{C}(7)$ & $115.70(16)$ & $C(10)-C(9 A)-H(9 B)$ & 110.00 \\
\hline $\mathrm{C}(8)-\mathrm{O}(4)-\mathrm{C}(9)$ & $117.5(2)$ & $\mathrm{O}(4 \mathrm{~A})-\mathrm{C}(9 \mathrm{~A})-\mathrm{H}(9 \mathrm{~B})$ & 110.00 \\
\hline$C(8)-O(4 A)-C(9 A)$ & $117.5(2)$ & $\mathrm{O}(4 \mathrm{~A})-\mathrm{C}(9 \mathrm{~A})-\mathrm{H}(9 \mathrm{~A})$ & 110.00 \\
\hline $\mathrm{O}(1)-\mathrm{C}(1)-\mathrm{C}(2)$ & $106.14(15)$ & $\mathrm{H}(9 \mathrm{~A})-\mathrm{C}(9 \mathrm{~A})-\mathrm{H}(9 \mathrm{~B})$ & 108.00 \\
\hline$C(1)-C(2)-C(6)$ & $112.38(16)$ & $H(10 A)-C(10)-H(10 C)$ & 109.00 \\
\hline$C(3)-C(2)-C(6)$ & $113.73(15)$ & $H(10 B)-C(10)-H(10 C)$ & 110.00 \\
\hline$C(1)-C(2)-C(3)$ & $103.43(16)$ & $C(9 A)-C(10)-H(10 A)$ & 109.00 \\
\hline$C(2)-C(3)-C(5)$ & $115.64(15)$ & $C(9 A)-C(10)-H(10 B)$ & 109.00 \\
\hline$C(4)-C(3)-C(5)$ & $61.57(13)$ & $C(9 A)-C(10)-H(10 C)$ & 109.00 \\
\hline$C(2)-C(3)-C(4)$ & $104.67(16)$ & $H(10 A)-C(10)-H(10 B)$ & 109.00 \\
\hline $\mathrm{O}(1)-\mathrm{C}(4)-\mathrm{C}(5)$ & $116.92(14)$ & $\mathrm{C}(9)-\mathrm{C}(11)-\mathrm{H}(11 \mathrm{~A})$ & 110.00 \\
\hline$C(3)-C(4)-C(5)$ & $60.65(13)$ & $\mathrm{C}(9)-\mathrm{C}(11)-\mathrm{H}(11 \mathrm{~B})$ & 110.00 \\
\hline $\mathrm{O}(1)-\mathrm{C}(4)-\mathrm{C}(3)$ & $111.23(14)$ & $\mathrm{C}(9)-\mathrm{C}(11)-\mathrm{H}(11 \mathrm{C})$ & 110.00 \\
\hline$C(3)-C(5)-C(4)$ & $57.78(12)$ & $H(11 A)-C(11)-H(11 B)$ & 110.00 \\
\hline$C(3)-C(5)-C(8)$ & $116.72(17)$ & $H(11 A)-C(11)-H(11 C)$ & 109.00 \\
\hline$C(4)-C(5)-C(8)$ & $114.92(14)$ & $H(11 B)-C(11)-H(11 C)$ & 109.00 \\
\hline
\end{tabular}


Table 4: Anisotropic displacement parameters $\left(A^{2} \times 10^{3}\right)$ for 133. The anisotropic

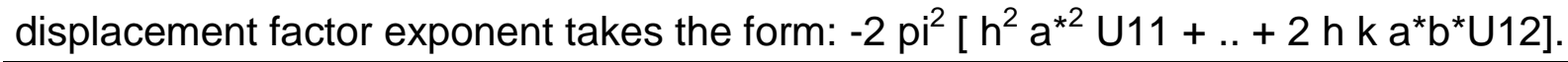

\begin{tabular}{lllllll}
\hline Atom & U11 & U22 & U33 & U23 & U13 & U12 \\
\hline $\mathrm{O}(1)$ & $43(1)$ & $25(1)$ & $23(1)$ & $-4(1)$ & $-2(1)$ & $9(1)$ \\
$\mathrm{O}(2)$ & $30(1)$ & $23(1)$ & $35(1)$ & $-3(1)$ & $5(1)$ & $0(1)$ \\
$\mathrm{O}(3)$ & $31(1)$ & $21(1)$ & $45(1)$ & $-4(1)$ & $2(1)$ & $-4(1)$ \\
$\mathrm{O}(4 \mathrm{~A})$ & $59(1)$ & $34(1)$ & $30(1)$ & $6(1)$ & $-18(1)$ & $-3(1)$ \\
$\mathrm{O}(5)$ & $46(1)$ & $31(1)$ & $42(1)$ & $15(1)$ & $4(1)$ & $1(1)$ \\
$\mathrm{C}(1)$ & $36(1)$ & $22(1)$ & $23(1)$ & $0(1)$ & $-2(1)$ & $4(1)$ \\
$\mathrm{C}(2)$ & $26(1)$ & $18(1)$ & $26(1)$ & $-1(1)$ & $-4(1)$ & $1(1)$ \\
$\mathrm{C}(3)$ & $27(1)$ & $17(1)$ & $32(1)$ & $2(1)$ & $-1(1)$ & $-1(1)$ \\
$\mathrm{C}(4)$ & $33(1)$ & $18(1)$ & $26(1)$ & $-2(1)$ & $-5(1)$ & $2(1)$ \\
$\mathrm{C}(5)$ & $29(1)$ & $19(1)$ & $25(1)$ & $-1(1)$ & $-2(1)$ & $0(1)$ \\
$\mathrm{C}(6)$ & $26(1)$ & $18(1)$ & $23(1)$ & $4(1)$ & $-4(1)$ & $1(1)$ \\
$\mathrm{C}(7)$ & $38(1)$ & $29(1)$ & $39(1)$ & $-7(1)$ & $5(1)$ & $5(1)$ \\
$\mathrm{C}(8)$ & $38(1)$ & $21(1)$ & $25(1)$ & $-2(1)$ & $1(1)$ & $6(1)$ \\
$\mathrm{C}(9 \mathrm{~A})$ & $105(3)$ & $50(2)$ & $33(1)$ & $10(1)$ & $-29(2)$ & $8(2)$ \\
$\mathrm{C}(10)$ & $62(3)$ & $53(2)$ & $28(1)$ & $8(1)$ & $-5(2)$ & $-7(3)$ \\
$\mathrm{C}(9)$ & $105(3)$ & $50(2)$ & $33(1)$ & $10(1)$ & $-29(2)$ & $8(2)$ \\
$\mathrm{C}(11)$ & $62(3)$ & $53(2)$ & $28(1)$ & $8(1)$ & $-5(2)$ & $-7(3)$ \\
$\mathrm{O}(4)$ & $59(1)$ & $34(1)$ & $30(1)$ & $6(1)$ & $-18(1)$ & $-3(1)$
\end{tabular}

Table 5: Hydrogen coordinates $\left(x 10^{4}\right)$ and isotropic displacement parameters $\left(A^{2} \times\right.$ $\left.10^{3}\right)$ for 133.

\begin{tabular}{lllll}
\hline Atom & $x$ & $y$ & $z$ & $U(e q)$ \\
\hline$H(2)$ & 6760 & 7627 & 2166 & 28 \\
$H(3)$ & 6215 & 9389 & 1390 & 30 \\
$H(5)$ & 1035 & 7755 & 1372 & 29 \\
$H(7 A)$ & 7062 & 3353 & 993 & 53 \\
$H(4)$ & 2914 & 11286 & 1772 & 31 \\
$H(7 C)$ & 10022 & 3674 & 1089 & 53 \\
$H(9 A)$ & -2707 & 10742 & 136 & 76 \\
$H(9 B)$ & 132 & 11504 & 113 & 76 \\
$H(10 A)$ & 1438 & 9081 & -340 & 72 \\
$H(10 B)$ & -1019 & 9879 & -619 & 72 \\
$H(10 C)$ & -1251 & 8119 & -268 & 72 \\
$H(7 B)$ & 8339 & 2698 & 1518 & 53 \\
$H(1 A)$ & 1566 & 6575 & 2184 & 32 \\
$H(1 B)$ & 3345 & 7091 & 2664 & 32 \\
$H(9 C)$ & -2235 & 11287 & 210 & 76 \\
$H(9 D)$ & 627 & 11063 & 22 & 76 \\
$H(11 A)$ & -649 & 8249 & -286 & 72 \\
$H(11 B)$ & -1564 & 10004 & -590 & 72 \\
$H(11 C)$ & -3475 & 8984 & -212 & 72
\end{tabular}


Table 6: Torsion angles [deg] for 133.

$C(4)-O(1)-C(1)-C(2)$

$\mathrm{C}(1)-\mathrm{O}(1)-\mathrm{C}(4)-\mathrm{C}(3)$

$\mathrm{C}(1)-\mathrm{O}(1)-\mathrm{C}(4)-\mathrm{C}(5)$

$\mathrm{C}(7)-\mathrm{O}(2)-\mathrm{C}(6)-\mathrm{O}(3)$

$\mathrm{C}(7)-\mathrm{O}(2)-\mathrm{C}(6)-\mathrm{C}(2)$

$\mathrm{C}(8)-\mathrm{O}(4 \mathrm{~A})-\mathrm{C}(9 \mathrm{~A})-\mathrm{C}(10)$

$\mathrm{C}(9 \mathrm{~A})-\mathrm{O}(4 \mathrm{~A})-\mathrm{C}(8)-\mathrm{O}(5)$

$\mathrm{C}(9 \mathrm{~A})-\mathrm{O}(4 \mathrm{~A})-\mathrm{C}(8)-\mathrm{C}(5)$

$\mathrm{O}(1)-\mathrm{C}(1)-\mathrm{C}(2)-\mathrm{C}(3)$

$\mathrm{O}(1)-\mathrm{C}(1)-\mathrm{C}(2)-\mathrm{C}(6)$

$\mathrm{C}(3)-\mathrm{C}(2)-\mathrm{C}(6)-\mathrm{O}(2)$

$\mathrm{C}(1)-\mathrm{C}(2)-\mathrm{C}(3)-\mathrm{C}(5)$

$\mathrm{C}(6)-\mathrm{C}(2)-\mathrm{C}(3)-\mathrm{C}(4)$

$\mathrm{C}(6)-\mathrm{C}(2)-\mathrm{C}(3)-\mathrm{C}(5)$

$\mathrm{C}(1)-\mathrm{C}(2)-\mathrm{C}(6)-\mathrm{O}(2)$

$\mathrm{C}(1)-\mathrm{C}(2)-\mathrm{C}(6)-\mathrm{O}(3)$
26.33(19)

$-15.5(2)$

$51.4(2)$

$-3.1(3)$

$178.28(16)$

$104.8(4)$

$0.6(3)$

$178.1(2)$

$-26.66(18)$

$-149.74(15)$

$72.4(2)$

$-48.08(19)$

139.25(17)

$74.1(2)$

$-170.52(15)$

$10.9(3)$

\begin{tabular}{|l}
$\mathrm{C}(3)-\mathrm{C}(2)-\mathrm{C}(6)-\mathrm{O}(3)$ \\
$\mathrm{C}(1)-\mathrm{C}(2)-\mathrm{C}(3)-\mathrm{C}(4)$ \\
$\mathrm{C}(4)-\mathrm{C}(3)-\mathrm{C}(5)-\mathrm{C}(8)$ \\
$\mathrm{C}(2)-\mathrm{C}(3)-\mathrm{C}(4)-\mathrm{O}(1)$ \\
$\mathrm{C}(2)-\mathrm{C}(3)-\mathrm{C}(4)-\mathrm{C}(5)$ \\
$\mathrm{C}(5)-\mathrm{C}(3)-\mathrm{C}(4)-\mathrm{O}(1)$ \\
$\mathrm{C}(2)-\mathrm{C}(3)-\mathrm{C}(5)-\mathrm{C}(4)$ \\
$\mathrm{C}(2)-\mathrm{C}(3)-\mathrm{C}(5)-\mathrm{C}(8)$ \\
$\mathrm{O}(1)-\mathrm{C}(4)-\mathrm{C}(5)-\mathrm{C}(8)$ \\
$\mathrm{C}(3)-\mathrm{C}(4)-\mathrm{C}(5)-\mathrm{C}(8)$ \\
$\mathrm{O}(1)-\mathrm{C}(4)-\mathrm{C}(5)-\mathrm{C}(3)$ \\
$\mathrm{C}(4)-\mathrm{C}(5)-\mathrm{C}(8)-\mathrm{O}(4 \mathrm{~A})$ \\
$\mathrm{C}(4)-\mathrm{C}(5)-\mathrm{C}(8)-\mathrm{O}(5)$ \\
$\mathrm{C}(3)-\mathrm{C}(5)-\mathrm{C}(8)-\mathrm{O}(4 \mathrm{~A})$ \\
$\mathrm{C}(3)-\mathrm{C}(5)-\mathrm{C}(8)-\mathrm{O}(5)$
\end{tabular}

$-106.2(2)$

17.06(19)

103.91(17)

$-1.7(2)$

$-111.52(15)$

109.80(16)

$93.41(17)$

$-162.68(16)$

$152.56(17)$

$-107.05(19)$

$-100.39(18)$

$-131.63(19)$

$45.9(3)$

$163.48(16)$

$-19.0(3)$

Table 7: Hydrogen-bonds for 133 [Å and deg.].

\begin{tabular}{lcccc}
\hline $\mathrm{D}-\mathrm{H} \ldots \mathrm{A}$ & $\mathrm{d}(\mathrm{D}-\mathrm{H})$ & $\mathrm{d}(\mathrm{H} \ldots \mathrm{A})$ & $\mathrm{d}(\mathrm{D} \ldots \mathrm{A})$ & $<(\mathrm{DHA})$ \\
\hline $\mathrm{C}(1)-\mathrm{H}(1 \mathrm{~A}) \ldots \mathrm{O}(3)$ & 0.9900 & 24.400 & $2.826(3)$ & 103.00 \\
$\mathrm{C}(4)-\mathrm{H}(4) \ldots \mathrm{O}(3) \# 1$ & 10.000 & 23.200 & $3.308(2)$ & 169.00 \\
$\mathrm{C}(5)-\mathrm{H}(5) \ldots \mathrm{O}(2) \# 2$ & 10.000 & 24.900 & $3.478(2)$ & 172.00 \\
$\mathrm{C}(9 \mathrm{~A})-\mathrm{H}(9 \mathrm{~B}) \ldots \mathrm{O}(5)$ & 0.9900 & 22.900 & $2.706(4)$ & 104.00
\end{tabular}


(1S,5R,6S)-6-tert-butyl 4-methyl 2-oxabicyclo[3.1.0]hex-3-ene-4,6-dicarboxylate (118)
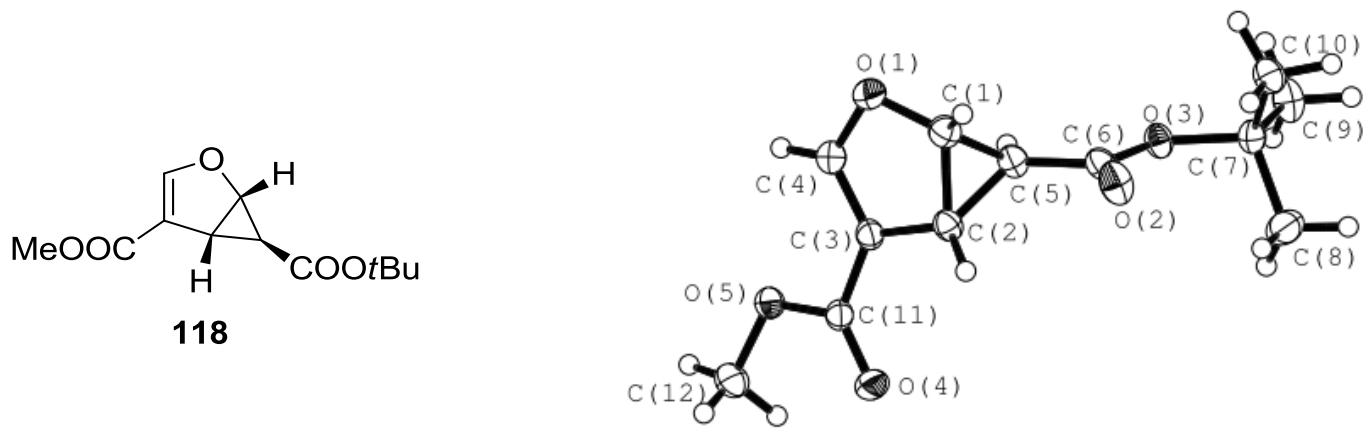

Table 1: Crystal data and structure refinement for 118.

\section{Crystal Data}

Empirical formula

Formula weight

$\mathrm{C} 12 \mathrm{H} 16 \mathrm{O} 5$

Crystal size

Crystal description

240.25

Crystal colour

$0.7024 \times 0.0514 \times 0.0399 \mathrm{~mm}$

stick

Crystal system

translucent colourless

Space group

Unit cell dimensions

Orthorhombic

P 212121

$a=5.54365(8)$ A alpha $=90$ deg.

$\mathrm{b}=23.9596(4) \mathrm{A} \quad$ beta $=90 \mathrm{deg}$.

$\mathrm{c}=28.0869(4) \mathrm{A}$ gamma $=90 \mathrm{deg}$.

Volume

$3730.61(10) A^{\wedge} 3$

Z, Calculated density

12, $1.283 \mathrm{Mg} / \mathrm{m}^{\wedge} 3$

Absorption coefficient

$0.839 \mathrm{~mm}^{\wedge}-1$

$\mathrm{F}(000)$

1536

\section{Data Collection}

Measurement device type

Measurement method

Temperature

SuperNova, Single source at offset, Atlas Iw scans

$123 \mathrm{~K}$

Wavelength

$1.54184 \mathrm{~A}$

Monochromator

graphite

Theta range for data collection

3.15 to $74.07 \mathrm{deg}$.

Index ranges

$-6<=h<=6,-29<=k<=24,-34<=1<=33$

Reflections collected / unique

Reflections greater $\mathrm{I}>2 \mid \mathrm{s}(\mathrm{I})$

$26433 / 7472[\mathrm{R}($ int $)=0.0277]$

7005

Absorption correction

Analytical

Max. and min. transmission

0.974 and 0.785 


\section{Refinement}

Refinement method

Hydrogen treatment

Data / restraints / parameters

Goodness-of-fit on $\mathrm{F}^{\wedge} 2$

Final $R$ indices [l>2sigma(I)]

$R$ indices (all data)

Absolute structure parameter

Largest diff. peak and hole
Full-matrix least-squares on $\mathrm{F}^{\wedge} 2$

7472 / 0 / 472

1.037

$\mathrm{R} 1=0.0290, w R 2=0.0760$

$\mathrm{R} 1=0.0314, \mathrm{wR} 2=0.0778$

$-0.03(8)$

0.151 and -0.165 e. $A^{\wedge}-3$

Table 2: Atomic coordinates $\left(x 1^{4}\right)$ and equivalent isotropic displacement parameters $\left(\AA^{2} \times 10^{3}\right)$ for 118 . $U(e q)$ is defined as one third of the trace of the orthogonalized Uij tensor.

\begin{tabular}{|c|c|c|c|c|}
\hline Atom & $x$ & $y$ & $z$ & $\mathrm{U}(\mathrm{eq})$ \\
\hline $\mathrm{O}(1)$ & $-4200(2)$ & $2228(1)$ & $6214(1)$ & $33(1)$ \\
\hline $\mathrm{O}(2)$ & $-9861(2)$ & $3336(1)$ & $6638(1)$ & $34(1)$ \\
\hline $\mathrm{O}(3)$ & $-6875(1)$ & $3984(1)$ & $6620(1)$ & $24(1)$ \\
\hline $\mathrm{O}(4)$ & $-4295(2)$ & $2115(1)$ & $7856(1)$ & $33(1)$ \\
\hline $\mathrm{O}(5)$ & $-1040(2)$ & $1773(1)$ & $7479(1)$ & $26(1)$ \\
\hline$C(1)$ & $-6253(2)$ & $2528(1)$ & $6383(1)$ & $27(1)$ \\
\hline$C(2)$ & $-6247(2)$ & $2512(1)$ & $6918(1)$ & $23(1)$ \\
\hline$C(3)$ & $-4014(2)$ & $2192(1)$ & $7019(1)$ & $22(1)$ \\
\hline$C(4)$ & $-2954(2)$ & 2063(1) & $6606(1)$ & $28(1)$ \\
\hline$C(5)$ & $-5743(2)$ & $3058(1)$ & $6652(1)$ & $24(1)$ \\
\hline$C(6)$ & $-7754(2)$ & $3468(1)$ & $6639(1)$ & $24(1)$ \\
\hline$C(7)$ & $-8468(2)$ & $4479(1)$ & $6600(1)$ & $24(1)$ \\
\hline$C(8)$ & $-9827(3)$ & $4529(1)$ & $7067(1)$ & $36(1)$ \\
\hline $\mathrm{C}(9)$ & $-6669(2)$ & $4951(1)$ & $6537(1)$ & $34(1)$ \\
\hline$C(10)$ & $-10152(2)$ & $4445(1)$ & $6173(1)$ & $29(1)$ \\
\hline$C(11)$ & $-3175(2)$ & 2033(1) & $7493(1)$ & $22(1)$ \\
\hline$C(12)$ & $-166(2)$ & $1565(1)$ & $7929(1)$ & $32(1)$ \\
\hline $\mathrm{O}(6)$ & $469(2)$ & $3156(1)$ & $7831(1)$ & $35(1)$ \\
\hline $\mathrm{O}(7)$ & $-5065(2)$ & $4316(1)$ & $8208(1)$ & $36(1)$ \\
\hline $\mathrm{O}(8)$ & $-2026(1)$ & $4946(1)$ & $8259(1)$ & $24(1)$ \\
\hline $\mathrm{O}(9)$ & $615(2)$ & $3154(1)$ & $9477(1)$ & $36(1)$ \\
\hline $\mathrm{O}(10)$ & $3777(2)$ & $2770(1)$ & $9099(1)$ & $31(1)$ \\
\hline$C(13)$ & $-1543(2)$ & $3470(1)$ & $7996(1)$ & $29(1)$ \\
\hline$C(14)$ & $-1499(2)$ & $3475(1)$ & $8530(1)$ & $25(1)$ \\
\hline$C(15)$ & $729(2)$ & $3155(1)$ & $8635(1)$ & $26(1)$ \\
\hline$C(16)$ & $1746(2)$ & $3003(1)$ & $8223(1)$ & $31(1)$ \\
\hline$C(17)$ & $-988(2)$ & $4012(1)$ & $8245(1)$ & $25(1)$ \\
\hline$C(18)$ & $-2951(2)$ & $4430(1)$ & $8234(1)$ & $26(1)$ \\
\hline$C(19)$ & $-3595(2)$ & $5442(1)$ & $8281(1)$ & $24(1)$ \\
\hline$C(20)$ & $-5127(3)$ & $5423(1)$ & $8727(1)$ & $35(1)$ \\
\hline$C(21)$ & $-1764(2)$ & $5912(1)$ & $8310(1)$ & $31(1)$ \\
\hline$C(22)$ & $-5093(3)$ & $5492(1)$ & $7830(1)$ & $33(1)$ \\
\hline
\end{tabular}




$\begin{array}{lllll}\mathrm{C}(23) & 1642(2) & 3035(1) & 9111(1) & 25(1) \\ \mathrm{C}(24) & 4771(3) & 2613(1) & 9556(1) & 35(1) \\ \mathrm{O}(11) & 5396(2) & 4191(1) & 9454(1) & 32(1) \\ \mathrm{O}(12) & -347(2) & 5278(1) & 9864(1) & 37(1) \\ \mathrm{O}(13) & 2595(1) & 5924(1) & 9974(1) & 24(1) \\ \mathrm{O}(14) & 5321(2) & 4037(1) & 11094(1) & 36(1) \\ \mathrm{O}(15) & 8658(2) & 3750(1) & 10716(1) & 31(1) \\ \mathrm{C}(25) & 3311(2) & 4473(1) & 9627(1) & 27(1) \\ \mathrm{C}(26) & 3304(2) & 4437(1) & 10160(1) & 25(1) \\ \mathrm{C}(27) & 5567(2) & 4127(1) & 10257(1) & 25(1) \\ \mathrm{C}(28) & 6653(2) & 4019(1) & 9841(1) & 28(1) \\ \mathrm{C}(29) & 3758(2) & 5000(1) & 9908(1) & 23(1) \\ \mathrm{C}(30) & 1752(2) & 5405(1) & 9910(1) & 25(1) \\ \mathrm{C}(31) & 944(2) & 6406(1) & 10010(1) & 25(1) \\ \mathrm{C}(32) & -754(2) & 6334(1) & 10429(1) & 33(1) \\ \mathrm{C}(33) & 2685(3) & 6884(1) & 10095(1) & 40(1) \\ \mathrm{C}(34) & -400(3) & 6485(1) & 9545(1) & 33(1) \\ \mathrm{C}(35) & 6443(2) & 3973(1) & 10730(1) & 25(1) \\ \mathrm{C}(36) & 9618(2) & 3570(1) & 11169(1) & 34(1)\end{array}$

Table 3: Bond lengths $[\AA \AA]$ and angles [deg] for 118.

\begin{tabular}{ll|ll}
$\mathrm{O}(1)-\mathrm{C}(1)$ & $1.4279(15)$ & $\mathrm{C}(2)-\mathrm{C}(5)-\mathrm{H}(5)$ & 118.00 \\
$\mathrm{O}(1)-\mathrm{C}(4)$ & $1.3591(14)$ & $\mathrm{C}(7)-\mathrm{C}(8)-\mathrm{H}(8 \mathrm{~B})$ & 110.00 \\
$\mathrm{O}(2)-\mathrm{C}(6)$ & $1.2095(14)$ & $\mathrm{H}(8 \mathrm{~A})-\mathrm{C}(8)-\mathrm{H}(8 \mathrm{~B})$ & 109.00 \\
$\mathrm{O}(3)-\mathrm{C}(6)$ & $1.3318(14)$ & $\mathrm{H}(8 \mathrm{~A})-\mathrm{C}(8)-\mathrm{H}(8 \mathrm{C})$ & 109.00 \\
$\mathrm{O}(3)-\mathrm{C}(7)$ & $1.4789(14)$ & $\mathrm{H}(8 \mathrm{~B})-\mathrm{C}(8)-\mathrm{H}(8 \mathrm{C})$ & 109.00 \\
$\mathrm{O}(4)-\mathrm{C}(11)$ & $1.2085(14)$ & $\mathrm{C}(7)-\mathrm{C}(8)-\mathrm{H}(8 \mathrm{C})$ & 109.00 \\
$\mathrm{O}(5)-\mathrm{C}(11)$ & $1.3382(14)$ & $\mathrm{C}(7)-\mathrm{C}(9)-\mathrm{H}(9 \mathrm{C})$ & 110.00 \\
$\mathrm{O}(5)-\mathrm{C}(12)$ & $1.4443(14)$ & $\mathrm{C}(7)-\mathrm{C}(9)-\mathrm{H}(9 \mathrm{~B})$ & 109.00 \\
$\mathrm{O}(6)-\mathrm{C}(13)$ & $1.4229(15)$ & $\mathrm{H}(9 \mathrm{~A})-\mathrm{C}(9)-\mathrm{H}(9 \mathrm{~B})$ & 110.00 \\
$\mathrm{O}(6)-\mathrm{C}(16)$ & $1.3593(16)$ & $\mathrm{H}(9 \mathrm{~A})-\mathrm{C}(9)-\mathrm{H}(9 \mathrm{C})$ & 109.00 \\
$\mathrm{O}(7)-\mathrm{C}(18)$ & $1.2057(14)$ & $\mathrm{C}(7)-\mathrm{C}(9)-\mathrm{H}(9 \mathrm{~A})$ & 109.00 \\
$\mathrm{O}(8)-\mathrm{C}(19)$ & $1.4736(14)$ & $\mathrm{H}(9 \mathrm{~B})-\mathrm{C}(9)-\mathrm{H}(9 \mathrm{C})$ & 109.00 \\
$\mathrm{O}(8)-\mathrm{C}(18)$ & $1.3409(14)$ & $\mathrm{H}(10 \mathrm{~A})-\mathrm{C}(10)-\mathrm{H}(10 \mathrm{~B})$ & 109.00 \\
$\mathrm{O}(9)-\mathrm{C}(23)$ & $1.2101(14)$ & $\mathrm{H}(10 \mathrm{~A})-\mathrm{C}(10)-\mathrm{H}(10 \mathrm{C})$ & 109.00 \\
$\mathrm{O}(10)-\mathrm{C}(24)$ & $1.4460(17)$ & $\mathrm{C}(7)-\mathrm{C}(10)-\mathrm{H}(10 \mathrm{C})$ & 109.00 \\
$\mathrm{O}(10)-\mathrm{C}(23)$ & $1.3436(15)$ & $\mathrm{C}(7)-\mathrm{C}(10)-\mathrm{H}(10 \mathrm{~A})$ & 110.00 \\
$\mathrm{O}(11)-\mathrm{C}(28)$ & $1.3557(14)$ & $\mathrm{H}(10 \mathrm{~B})-\mathrm{C}(10)-\mathrm{H}(10 \mathrm{C})$ & 109.00 \\
$\mathrm{O}(11)-\mathrm{C}(25)$ & $1.4238(15)$ & $\mathrm{C}(7)-\mathrm{C}(10)-\mathrm{H}(10 \mathrm{~B})$ & 110.00 \\
$\mathrm{O}(12)-\mathrm{C}(30)$ & $1.2091(14)$ & $\mathrm{H}(12 \mathrm{~A})-\mathrm{C}(12)-\mathrm{H}(12 \mathrm{C})$ & 109.00 \\
$\mathrm{O}(13)-\mathrm{C}(30)$ & $1.3400(14)$ & $\mathrm{H}(12 \mathrm{~B})-\mathrm{C}(12)-\mathrm{H}(12 \mathrm{C})$ & 110.00 \\
$\mathrm{O}(13)-\mathrm{C}(31)$ & $1.4784(14)$ & $\mathrm{O}(5)-\mathrm{C}(12)-\mathrm{H}(12 \mathrm{~A})$ & 109.00 \\
$\mathrm{O}(14)-\mathrm{C}(35)$ & $1.2082(14)$ & $\mathrm{O}(5)-\mathrm{C}(12)-\mathrm{H}(12 \mathrm{~B})$ & 109.00 \\
$\mathrm{O}(15)-\mathrm{C}(36)$ & $1.4459(16)$ & $\mathrm{H}(12 \mathrm{~A})-\mathrm{C}(12)-\mathrm{H}(12 \mathrm{~B})$ & 110.00 \\
$\mathrm{O}(15)-\mathrm{C}(35)$ & $1.3397(14)$ & $\mathrm{O}(5)-\mathrm{C}(12)-\mathrm{H}(12 \mathrm{C})$ & 109.00 \\
$\mathrm{C}(1)-\mathrm{C}(5)$ & $1.5048(17)$ & & \\
& &
\end{tabular}




\begin{tabular}{|c|c|c|c|}
\hline$C(1)-C(2)$ & $1.5015(16)$ & $C(14)-C(13)-C(17)$ & $61.67(8)$ \\
\hline$C(2)-C(5)$ & $1.5332(17)$ & $\mathrm{O}(6)-\mathrm{C}(13)-\mathrm{C}(14)$ & $108.53(9)$ \\
\hline$C(2)-C(3)$ & $1.4837(16)$ & $\mathrm{O}(6)-\mathrm{C}(13)-\mathrm{C}(17)$ & $116.55(9)$ \\
\hline$C(3)-C(11)$ & $1.4607(16)$ & $C(13)-C(14)-C(15)$ & $102.08(9)$ \\
\hline$C(3)-C(4)$ & $1.3373(16)$ & $C(13)-C(14)-C(17)$ & $59.45(8)$ \\
\hline$C(5)-C(6)$ & $1.4855(16)$ & $C(15)-C(14)-C(17)$ & $112.48(9)$ \\
\hline$C(7)-C(9)$ & $1.5177(16)$ & $C(14)-C(15)-C(16)$ & $108.56(10)$ \\
\hline$C(7)-C(8)$ & $1.5183(18)$ & $C(14)-C(15)-C(23)$ & $125.10(10)$ \\
\hline$C(7)-C(10)$ & $1.5202(16)$ & $C(16)-C(15)-C(23)$ & $126.34(11)$ \\
\hline$C(1)-H(1)$ & 10.000 & $\mathrm{O}(6)-\mathrm{C}(16)-\mathrm{C}(15)$ & $114.07(10)$ \\
\hline $\mathrm{C}(2)-\mathrm{H}(2)$ & 10.000 & $C(13)-C(17)-C(14)$ & $58.89(8)$ \\
\hline $\mathrm{C}(4)-\mathrm{H}(4)$ & 0.9500 & $C(13)-C(17)-C(18)$ & $115.08(9)$ \\
\hline $\mathrm{C}(5)-\mathrm{H}(5)$ & 10.000 & $C(14)-C(17)-C(18)$ & $116.18(9)$ \\
\hline $\mathrm{C}(8)-\mathrm{H}(8 \mathrm{C})$ & 0.9800 & $\mathrm{O}(7)-\mathrm{C}(18)-\mathrm{O}(8)$ & $125.82(11)$ \\
\hline $\mathrm{C}(8)-\mathrm{H}(8 \mathrm{~A})$ & 0.9800 & $\mathrm{O}(8)-\mathrm{C}(18)-\mathrm{C}(17)$ & $110.02(9)$ \\
\hline $\mathrm{C}(8)-\mathrm{H}(8 \mathrm{~B})$ & 0.9800 & $\mathrm{O}(7)-\mathrm{C}(18)-\mathrm{C}(17)$ & $124.16(11)$ \\
\hline $\mathrm{C}(9)-\mathrm{H}(9 \mathrm{C})$ & 0.9800 & $\mathrm{O}(8)-\mathrm{C}(19)-\mathrm{C}(22)$ & $110.60(9)$ \\
\hline $\mathrm{C}(9)-\mathrm{H}(9 \mathrm{~B})$ & 0.9800 & $\mathrm{O}(8)-\mathrm{C}(19)-\mathrm{C}(21)$ & $101.86(8)$ \\
\hline $\mathrm{C}(9)-\mathrm{H}(9 \mathrm{~A})$ & 0.9800 & $C(21)-C(19)-C(22)$ & $110.72(10)$ \\
\hline $\mathrm{C}(10)-\mathrm{H}(10 \mathrm{~B})$ & 0.9800 & $C(20)-C(19)-C(21)$ & $110.60(10)$ \\
\hline$C(10)-H(10 A)$ & 0.9800 & $C(20)-C(19)-C(22)$ & $112.69(11)$ \\
\hline $\mathrm{C}(10)-\mathrm{H}(10 \mathrm{C})$ & 0.9800 & $\mathrm{O}(8)-\mathrm{C}(19)-\mathrm{C}(20)$ & $109.86(10)$ \\
\hline $\mathrm{C}(12)-\mathrm{H}(12 \mathrm{~A})$ & 0.9800 & $\mathrm{O}(10)-\mathrm{C}(23)-\mathrm{C}(15)$ & $112.19(10)$ \\
\hline $\mathrm{C}(12)-\mathrm{H}(12 \mathrm{~B})$ & 0.9800 & $\mathrm{O}(9)-\mathrm{C}(23)-\mathrm{O}(10)$ & $123.16(11)$ \\
\hline $\mathrm{C}(12)-\mathrm{H}(12 \mathrm{C})$ & 0.9800 & $\mathrm{O}(9)-\mathrm{C}(23)-\mathrm{C}(15)$ & $124.65(11)$ \\
\hline$C(13)-C(17)$ & $1.5069(17)$ & $\mathrm{O}(6)-\mathrm{C}(13)-\mathrm{H}(13)$ & 119.00 \\
\hline$C(13)-C(14)$ & $1.4981(16)$ & $C(14)-C(13)-H(13)$ & 119.00 \\
\hline$C(14)-C(17)$ & $1.5402(17)$ & $C(17)-C(13)-H(13)$ & 119.00 \\
\hline$C(14)-C(15)$ & $1.4839(16)$ & $C(13)-C(14)-H(14)$ & 122.00 \\
\hline$C(15)-C(23)$ & $1.4568(16)$ & $\mathrm{C}(17)-\mathrm{C}(14)-\mathrm{H}(14)$ & 122.00 \\
\hline$C(15)-C(16)$ & $1.3384(18)$ & $\mathrm{C}(15)-\mathrm{C}(14)-\mathrm{H}(14)$ & 122.00 \\
\hline$C(17)-C(18)$ & $1.4798(16)$ & $\mathrm{O}(6)-\mathrm{C}(16)-\mathrm{H}(16)$ & 123.00 \\
\hline$C(19)-C(20)$ & $1.5155(19)$ & $C(15)-C(16)-H(16)$ & 123.00 \\
\hline$C(19)-C(22)$ & $1.5181(19)$ & $\mathrm{C}(14)-\mathrm{C}(17)-\mathrm{H}(17)$ & 118.00 \\
\hline$C(19)-C(21)$ & $1.5185(16)$ & $\mathrm{C}(13)-\mathrm{C}(17)-\mathrm{H}(17)$ & 118.00 \\
\hline $\mathrm{C}(13)-\mathrm{H}(13)$ & 10.000 & $\mathrm{C}(18)-\mathrm{C}(17)-\mathrm{H}(17)$ & 118.00 \\
\hline $\mathrm{C}(14)-\mathrm{H}(14)$ & 10.000 & $C(19)-C(20)-H(20 A)$ & 109.00 \\
\hline$C(16)-H(16)$ & 0.9500 & $C(19)-C(20)-H(20 B)$ & 109.00 \\
\hline $\mathrm{C}(17)-\mathrm{H}(17)$ & 10.000 & $H(20 B)-C(20)-H(20 C)$ & 109.00 \\
\hline $\mathrm{C}(20)-\mathrm{H}(20 \mathrm{~A})$ & 0.9800 & $\mathrm{C}(19)-\mathrm{C}(20)-\mathrm{H}(20 \mathrm{C})$ & 110.00 \\
\hline $\mathrm{C}(20)-\mathrm{H}(20 \mathrm{~B})$ & 0.9800 & $H(20 A)-C(20)-H(20 B)$ & 110.00 \\
\hline $\mathrm{C}(20)-\mathrm{H}(20 \mathrm{C})$ & 0.9800 & $H(20 A)-C(20)-H(20 C)$ & 109.00 \\
\hline$C(21)-H(21 A)$ & 0.9800 & $C(19)-C(21)-H(21 A)$ & 109.00 \\
\hline $\mathrm{C}(21)-\mathrm{H}(21 \mathrm{C})$ & 0.9800 & $C(19)-C(21)-H(21 B)$ & 109.00 \\
\hline $\mathrm{C}(21)-\mathrm{H}(21 \mathrm{~B})$ & 0.9800 & $C(19)-C(21)-H(21 C)$ & 109.00 \\
\hline $\mathrm{C}(22)-\mathrm{H}(22 \mathrm{~B})$ & 0.9800 & $H(21 B)-C(21)-H(21 C)$ & 109.00 \\
\hline $\mathrm{C}(22)-\mathrm{H}(22 \mathrm{C})$ & 0.9800 & $H(21 A)-C(21)-H(21 B)$ & 109.00 \\
\hline
\end{tabular}




$\begin{array}{ll}\mathrm{C}(22)-\mathrm{H}(22 \mathrm{~A}) & 0.9800 \\ \mathrm{C}(24)-\mathrm{H}(24 \mathrm{~B}) & 0.9800 \\ \mathrm{C}(24)-\mathrm{H}(24 \mathrm{C}) & 0.9800 \\ \mathrm{C}(24)-\mathrm{H}(24 \mathrm{~A}) & 0.9800 \\ \mathrm{C}(25)-\mathrm{C}(26) & 1.4984(16) \\ \mathrm{C}(25)-\mathrm{C}(29) & 1.5097(17) \\ \mathrm{C}(26)-\mathrm{C}(27) & 1.4829(16) \\ \mathrm{C}(26)-\mathrm{C}(29) & 1.5440(17) \\ \mathrm{C}(27)-\mathrm{C}(28) & 1.3403(16) \\ \mathrm{C}(27)-\mathrm{C}(35) & 1.4607(16) \\ \mathrm{C}(29)-\mathrm{C}(30) & 1.4754(16) \\ \mathrm{C}(31)-\mathrm{C}(32) & 1.5170(16) \\ \mathrm{C}(31)-\mathrm{C}(33) & 1.5163(19) \\ \mathrm{C}(31)-\mathrm{C}(34) & 1.5171(18) \\ \mathrm{C}(25)-\mathrm{H}(25) & 10.000 \\ \mathrm{C}(26)-\mathrm{H}(26) & 10.000 \\ \mathrm{C}(28)-\mathrm{H}(28) & 0.9500 \\ \mathrm{C}(29)-\mathrm{H}(29) & 10.000 \\ \mathrm{C}(32)-\mathrm{H}(32 \mathrm{~A}) & 0.9800 \\ \mathrm{C}(32)-\mathrm{H}(32 \mathrm{~B}) & 0.9800 \\ \mathrm{C}(32)-\mathrm{H}(32 \mathrm{C}) & 0.9800 \\ \mathrm{C}(33)-\mathrm{H}(33 \mathrm{~A}) & 0.9800 \\ \mathrm{C}(33)-\mathrm{H}(33 \mathrm{~B}) & 0.9800 \\ \mathrm{C}(33)-\mathrm{H}(33 \mathrm{C}) & 0.9800 \\ \mathrm{C}(34)-\mathrm{H}(34 \mathrm{~A}) & 0.9800 \\ \mathrm{C}(34)-\mathrm{H}(34 \mathrm{~B}) & 0.9800 \\ \mathrm{C}(34)-\mathrm{H}(34 \mathrm{C}) & 0.9800 \\ \mathrm{C}(36)-\mathrm{H}(36 \mathrm{~A}) & 0.9800 \\ \mathrm{C}(36)-\mathrm{H}(36 \mathrm{~B}) & 0.9800 \\ \mathrm{C}(36)-\mathrm{H}(36 \mathrm{C}) & 0.9800 \\ \mathrm{C}(1)-\mathrm{O}(1)-\mathrm{C}(4) & 106.31(9) \\ \mathrm{C}(6)-\mathrm{O}(3)-\mathrm{C}(7) & 121.86(9) \\ \mathrm{C}(11)-\mathrm{O}(5)-\mathrm{C}(12) & 115.47(9) \\ \mathrm{C}(13)-\mathrm{O}(6)-\mathrm{C}(16) & 106.66(9) \\ \mathrm{C}(18)-\mathrm{O}(8)-\mathrm{C}(19) & 121.32(9) \\ \mathrm{C}(23)-\mathrm{O}(10)-\mathrm{C}(24) & 115.93(10) \\ \mathrm{C}(25)-\mathrm{O}(11)-\mathrm{C}(28) & 106.75(9) \\ \mathrm{C}(30)-\mathrm{O}(13)-\mathrm{C}(31) & 121.28(9) \\ \mathrm{C}(35)-\mathrm{O}(15)-\mathrm{C}(36) & 115.50(9) \\ \mathrm{C}(2)-\mathrm{C}(1)-\mathrm{C}(5) & 61.33(8) \\ \mathrm{O}(1)-\mathrm{C}(1)-\mathrm{C}(2) & 108.60(9) \\ \mathrm{O}(1)-\mathrm{C}(1)-\mathrm{C}(5) & 116.26(9) \\ \mathrm{C}(3)-\mathrm{C}(2)-\mathrm{C}(5) & 112.51(9) \\ \mathrm{C}(1)-\mathrm{C}(2)-\mathrm{C}(5) & 59.44(8) \\ \mathrm{C}(1)-\mathrm{C}(2)-\mathrm{C}(3) & 101.96(9) \\ \mathrm{C}(2)-\mathrm{C}(3)-\mathrm{C}(4) & 108.61(10) \\ \mathrm{C}(4)-\mathrm{C}(3)-\mathrm{C}(11) & \\ & \end{array}$

\begin{tabular}{|c|c|}
\hline $\mathrm{H}(21 \mathrm{~A})-\mathrm{C}(21)-\mathrm{H}(21 \mathrm{C})$ & 109.00 \\
\hline $\mathrm{C}(19)-\mathrm{C}(22)-\mathrm{H}(22 \mathrm{~B})$ & 109.00 \\
\hline $\mathrm{H}(22 \mathrm{~A})-\mathrm{C}(22)-\mathrm{H}(22 \mathrm{C})$ & 110.00 \\
\hline $\mathrm{C}(19)-\mathrm{C}(22)-\mathrm{H}(22 \mathrm{C})$ & 109.00 \\
\hline $\mathrm{H}(22 \mathrm{~A})-\mathrm{C}(22)-\mathrm{H}(22 \mathrm{~B})$ & 109.00 \\
\hline $\mathrm{C}(19)-\mathrm{C}(22)-\mathrm{H}(22 \mathrm{~A})$ & 109.00 \\
\hline $\mathrm{H}(22 \mathrm{~B})-\mathrm{C}(22)-\mathrm{H}(22 \mathrm{C})$ & 110.00 \\
\hline $\mathrm{O}(10)-\mathrm{C}(24)-\mathrm{H}(24 \mathrm{C})$ & 110.00 \\
\hline $\mathrm{H}(24 \mathrm{~A})-\mathrm{C}(24)-\mathrm{H}(24 \mathrm{C})$ & 109.00 \\
\hline $\mathrm{H}(24 \mathrm{~B})-\mathrm{C}(24)-\mathrm{H}(24 \mathrm{C})$ & 109.00 \\
\hline $\mathrm{H}(24 \mathrm{~A})-\mathrm{C}(24)-\mathrm{H}(24 \mathrm{~B})$ & 110.00 \\
\hline $\mathrm{O}(10)-\mathrm{C}(24)-\mathrm{H}(24 \mathrm{~A})$ & 109.00 \\
\hline $\mathrm{O}(10)-\mathrm{C}(24)-\mathrm{H}(24 \mathrm{~B})$ & 109.00 \\
\hline $\mathrm{O}(11)-\mathrm{C}(25)-\mathrm{C}(26)$ & $108.39(9)$ \\
\hline $\mathrm{O}(11)-\mathrm{C}(25)-\mathrm{C}(29)$ & $116.21(9)$ \\
\hline$C(26)-C(25)-C(29)$ & $61.76(8)$ \\
\hline$C(25)-C(26)-C(27)$ & $102.18(9)$ \\
\hline$C(25)-C(26)-C(29)$ & $59.48(8)$ \\
\hline$C(27)-C(26)-C(29)$ & $112.57(9)$ \\
\hline$C(26)-C(27)-C(28)$ & $108.42(10)$ \\
\hline$C(26)-C(27)-C(35)$ & $125.13(10)$ \\
\hline$C(28)-C(27)-C(35)$ & $126.45(11)$ \\
\hline $\mathrm{O}(11)-\mathrm{C}(28)-\mathrm{C}(27)$ & $114.15(10)$ \\
\hline$C(25)-C(29)-C(26)$ & $58.76(7)$ \\
\hline$C(25)-C(29)-C(30)$ & $115.34(10)$ \\
\hline$C(26)-C(29)-C(30)$ & $116.73(9)$ \\
\hline $\mathrm{O}(12)-\mathrm{C}(30)-\mathrm{O}(13)$ & $125.58(11)$ \\
\hline $\mathrm{O}(12)-\mathrm{C}(30)-\mathrm{C}(29)$ & $124.08(11)$ \\
\hline$O(13)-C(30)-C(29)$ & $110.34(9)$ \\
\hline $\mathrm{O}(13)-\mathrm{C}(31)-\mathrm{C}(32)$ & $110.40(10)$ \\
\hline $\mathrm{O}(13)-\mathrm{C}(31)-\mathrm{C}(33)$ & $101.99(9)$ \\
\hline $\mathrm{O}(13)-\mathrm{C}(31)-\mathrm{C}(34)$ & $109.95(10)$ \\
\hline$C(32)-C(31)-C(33)$ & $111.12(11)$ \\
\hline$C(32)-C(31)-C(34)$ & $112.23(10)$ \\
\hline$C(33)-C(31)-C(34)$ & $110.69(11)$ \\
\hline $\mathrm{O}(14)-\mathrm{C}(35)-\mathrm{O}(15)$ & $123.22(11)$ \\
\hline $\mathrm{O}(14)-\mathrm{C}(35)-\mathrm{C}(27)$ & $124.51(11)$ \\
\hline $\mathrm{O}(15)-\mathrm{C}(35)-\mathrm{C}(27)$ & $112.27(10)$ \\
\hline $\mathrm{O}(11)-\mathrm{C}(25)-\mathrm{H}(25)$ & 119.00 \\
\hline $\mathrm{C}(26)-\mathrm{C}(25)-\mathrm{H}(25)$ & 119.00 \\
\hline $\mathrm{C}(29)-\mathrm{C}(25)-\mathrm{H}(25)$ & 119.00 \\
\hline $\mathrm{C}(25)-\mathrm{C}(26)-\mathrm{H}(26)$ & 122.00 \\
\hline $\mathrm{C}(27)-\mathrm{C}(26)-\mathrm{H}(26)$ & 122.00 \\
\hline $\mathrm{C}(29)-\mathrm{C}(26)-\mathrm{H}(26)$ & 122.00 \\
\hline $\mathrm{O}(11)-\mathrm{C}(28)-\mathrm{H}(28)$ & 123.00 \\
\hline $\mathrm{C}(27)-\mathrm{C}(28)-\mathrm{H}(28)$ & 123.00 \\
\hline $\mathrm{C}(25)-\mathrm{C}(29)-\mathrm{H}(29)$ & 118.00 \\
\hline
\end{tabular}




\begin{tabular}{ll|ll}
$\mathrm{C}(2)-\mathrm{C}(3)-\mathrm{C}(11)$ & $125.14(10)$ & $\mathrm{C}(26)-\mathrm{C}(29)-\mathrm{H}(29)$ & 118.00 \\
$\mathrm{O}(1)-\mathrm{C}(4)-\mathrm{C}(3)$ & $114.41(10)$ & $\mathrm{C}(30)-\mathrm{C}(29)-\mathrm{H}(29)$ & 118.00 \\
$\mathrm{C}(2)-\mathrm{C}(5)-\mathrm{C}(6)$ & $116.02(9)$ & $\mathrm{C}(31)-\mathrm{C}(32)-\mathrm{H}(32 \mathrm{~A})$ & 109.00 \\
$\mathrm{C}(1)-\mathrm{C}(5)-\mathrm{C}(6)$ & $113.91(9)$ & $\mathrm{C}(31)-\mathrm{C}(32)-\mathrm{H}(32 \mathrm{~B})$ & 109.00 \\
$\mathrm{C}(1)-\mathrm{C}(5)-\mathrm{C}(2)$ & $59.23(8)$ & $\mathrm{H}(31)-\mathrm{C}(32)-\mathrm{H}(32 \mathrm{C})$ & 109.00 \\
$\mathrm{O}(2)-\mathrm{C}(6)-\mathrm{O}(3)$ & $126.52(11)$ & $\mathrm{H}(32 \mathrm{~A})-\mathrm{C}(32)-\mathrm{H}(32 \mathrm{~B})$ & 109.00 \\
$\mathrm{O}(2)-\mathrm{C}(6)-\mathrm{C}(5)$ & $123.57(11)$ & 110.00 \\
$\mathrm{O}(3)-\mathrm{C}(6)-\mathrm{C}(5)$ & $109.90(9)$ & $\mathrm{H}(32 \mathrm{~B})-\mathrm{C}(32)-\mathrm{H}(32 \mathrm{C})$ & 109.00 \\
$\mathrm{C}(8)-\mathrm{C}(7)-\mathrm{C}(9)$ & $111.53(11)$ & $\mathrm{C}(31)-\mathrm{C}(33)-\mathrm{H}(33 \mathrm{~A})$ & 109.00 \\
$\mathrm{C}(8)-\mathrm{C}(7)-\mathrm{C}(10)$ & $112.35(10)$ & $\mathrm{C}(31)-\mathrm{C}(33)-\mathrm{H}(33 \mathrm{~B})$ & 110.00 \\
$\mathrm{C}(9)-\mathrm{C}(7)-\mathrm{C}(10)$ & $110.65(10)$ & $\mathrm{C}(31)-\mathrm{C}(33)-\mathrm{H}(33 \mathrm{C})$ & 109.00 \\
$\mathrm{O}(3)-\mathrm{C}(7)-\mathrm{C}(10)$ & $110.76(9)$ & $\mathrm{H}(33 \mathrm{~A})-\mathrm{C}(33)-\mathrm{H}(33 \mathrm{~B})$ & 109.00 \\
$\mathrm{O}(3)-\mathrm{C}(7)-\mathrm{C}(9)$ & $102.05(8)$ & $\mathrm{H}(33 \mathrm{~A})-\mathrm{C}(33)-\mathrm{H}(33 \mathrm{C})$ & 110.00 \\
$\mathrm{O}(3)-\mathrm{C}(7)-\mathrm{C}(8)$ & $109.02(10)$ & $\mathrm{H}(33 \mathrm{~B})-\mathrm{C}(33)-\mathrm{H}(33 \mathrm{C})$ & 109.00 \\
$\mathrm{O}(4)-\mathrm{C}(11)-\mathrm{C}(3)$ & $124.20(11)$ & $\mathrm{C}(31)-\mathrm{C}(34)-\mathrm{H}(34 \mathrm{~A})$ & 109.00 \\
$\mathrm{O}(5)-\mathrm{C}(11)-\mathrm{C}(3)$ & $112.03(10)$ & $\mathrm{C}(31)-\mathrm{C}(34)-\mathrm{H}(34 \mathrm{~B})$ & 109.00 \\
$\mathrm{O}(4)-\mathrm{C}(11)-\mathrm{O}(5)$ & $123.76(11)$ & $\mathrm{C}(31)-\mathrm{C}(34)-\mathrm{H}(34 \mathrm{C})$ & 109.00 \\
$\mathrm{C}(5)-\mathrm{C}(1)-\mathrm{H}(1)$ & 119.00 & $\mathrm{H}(34 \mathrm{~A})-\mathrm{C}(34)-\mathrm{H}(34 \mathrm{~B})$ & 110.00 \\
$\mathrm{C}(2)-\mathrm{C}(1)-\mathrm{H}(1)$ & 119.00 & $\mathrm{H}(34 \mathrm{~A})-\mathrm{C}(34)-\mathrm{H}(34 \mathrm{C})$ & 109.00 \\
$\mathrm{O}(1)-\mathrm{C}(1)-\mathrm{H}(1)$ & 119.00 & $\mathrm{H}(34 \mathrm{~B})-\mathrm{C}(34)-\mathrm{H}(34 \mathrm{C})$ & 110.00 \\
$\mathrm{C}(1)-\mathrm{C}(2)-\mathrm{H}(2)$ & 122.00 & $\mathrm{O}(15)-\mathrm{C}(36)-\mathrm{H}(36 \mathrm{~A})$ & 109.00 \\
$\mathrm{C}(5)-\mathrm{C}(2)-\mathrm{H}(2)$ & 122.00 & $\mathrm{O}(15)-\mathrm{C}(36)-\mathrm{H}(36 \mathrm{~B})$ & 109.00 \\
$\mathrm{C}(3)-\mathrm{C}(2)-\mathrm{H}(2)$ & 122.00 & $\mathrm{O}(15)-\mathrm{C}(36)-\mathrm{H}(36 \mathrm{C})$ & 109.00 \\
$\mathrm{C}(3)-\mathrm{C}(4)-\mathrm{H}(4)$ & 123.00 & $\mathrm{H}(36 \mathrm{~A})-\mathrm{C}(36)-\mathrm{H}(36 \mathrm{~B})$ & 110.00 \\
$\mathrm{O}(1)-\mathrm{C}(4)-\mathrm{H}(4)$ & 123.00 & $\mathrm{H}(36 \mathrm{~A})-\mathrm{C}(36)-\mathrm{H}(36 \mathrm{C})$ & 109.00 \\
$\mathrm{C}(1)-\mathrm{C}(5)-\mathrm{H}(5)$ & 118.00 & $\mathrm{H}(36 \mathrm{~B})-\mathrm{C}(36)-\mathrm{H}(36 \mathrm{C})$ & 110.00 \\
$\mathrm{C}(6)-\mathrm{C}(5)-\mathrm{H}(5)$ & 118.00 & & \\
& & &
\end{tabular}

Table 4: Anisotropic displacement parameters $\left(A^{2} \times 10^{3}\right)$ for 118 The anisotropic displacement factor exponent takes the form: $-2 \mathrm{pi}^{2}\left[\mathrm{~h}^{2} \mathrm{a}^{\star 2} \mathrm{U} 11+. .+2 \mathrm{~h} \mathrm{k} \mathrm{a}^{*} \mathrm{~b}^{\star} \mathrm{U} 12\right]$.

\begin{tabular}{lllllll}
\hline Atom & $\mathrm{U} 11$ & $\mathrm{U} 22$ & $\mathrm{U} 33$ & $\mathrm{U} 23$ & $\mathrm{U} 13$ & $\mathrm{U} 12$ \\
\hline $\mathrm{O}(1)$ & $41(1)$ & $35(1)$ & $22(1)$ & $-1(1)$ & $1(1)$ & $10(1)$ \\
$\mathrm{O}(2)$ & $20(1)$ & $30(1)$ & $51(1)$ & $8(1)$ & $-3(1)$ & $-1(1)$ \\
$\mathrm{O}(3)$ & $20(1)$ & $22(1)$ & $31(1)$ & $2(1)$ & $-2(1)$ & $1(1)$ \\
$\mathrm{O}(4)$ & $33(1)$ & $42(1)$ & $25(1)$ & $3(1)$ & $7(1)$ & $13(1)$ \\
$\mathrm{O}(5)$ & $24(1)$ & $29(1)$ & $25(1)$ & $3(1)$ & $1(1)$ & $7(1)$ \\
$\mathrm{C}(1)$ & $30(1)$ & $27(1)$ & $26(1)$ & $0(1)$ & $-1(1)$ & $1(1)$ \\
$\mathrm{C}(2)$ & $22(1)$ & $22(1)$ & $26(1)$ & $3(1)$ & $0(1)$ & $-1(1)$ \\
$\mathrm{C}(3)$ & $23(1)$ & $19(1)$ & $25(1)$ & $2(1)$ & $2(1)$ & $1(1)$ \\
$\mathrm{C}(4)$ & $30(1)$ & $25(1)$ & $27(1)$ & $1(1)$ & $2(1)$ & $6(1)$ \\
$\mathrm{C}(5)$ & $20(1)$ & $23(1)$ & $29(1)$ & $4(1)$ & $1(1)$ & $0(1)$ \\
$\mathrm{C}(6)$ & $21(1)$ & $24(1)$ & $27(1)$ & $4(1)$ & $-1(1)$ & $-1(1)$ \\
$\mathrm{C}(7)$ & $22(1)$ & $22(1)$ & $29(1)$ & $0(1)$ & $0(1)$ & $3(1)$ \\
$\mathrm{C}(8)$ & $38(1)$ & $41(1)$ & $30(1)$ & $-5(1)$ & $5(1)$ & $4(1)$ \\
$\mathrm{C}(9)$ & $29(1)$ & $24(1)$ & $50(1)$ & $1(1)$ & $-4(1)$ & $1(1)$ \\
$\mathrm{C}(10)$ & $28(1)$ & $30(1)$ & $30(1)$ & $3(1)$ & $-5(1)$ & $4(1)$
\end{tabular}




$\begin{array}{lllllll}\mathrm{C}(11) & 23(1) & 19(1) & 25(1) & 1(1) & 2(1) & 1(1) \\ \mathrm{C}(12) & 30(1) & 37(1) & 28(1) & 5(1) & -4(1) & 8(1) \\ \mathrm{O}(6) & 45(1) & 32(1) & 29(1) & -2(1) & 5(1) & 12(1) \\ \mathrm{O}(7) & 21(1) & 25(1) & 63(1) & 2(1) & -2(1) & -2(1) \\ \mathrm{O}(8) & 19(1) & 19(1) & 34(1) & 1(1) & 1(1) & 0(1) \\ \mathrm{O}(9) & 37(1) & 42(1) & 30(1) & 0(1) & 9(1) & 12(1) \\ \mathrm{O}(10) & 28(1) & 31(1) & 33(1) & 4(1) & 5(1) & 8(1) \\ \mathrm{C}(13) & 31(1) & 25(1) & 32(1) & -1(1) & 2(1) & 3(1) \\ \mathrm{C}(14) & 24(1) & 20(1) & 31(1) & 2(1) & 4(1) & 1(1) \\ \mathrm{C}(15) & 25(1) & 19(1) & 32(1) & 2(1) & 7(1) & 2(1) \\ \mathrm{C}(16) & 35(1) & 24(1) & 33(1) & 1(1) & 7(1) & 7(1) \\ \mathrm{C}(17) & 22(1) & 21(1) & 32(1) & 2(1) & 3(1) & 1(1) \\ \mathrm{C}(18) & 23(1) & 22(1) & 32(1) & 2(1) & 1(1) & -1(1) \\ \mathrm{C}(19) & 24(1) & 21(1) & 27(1) & 1(1) & 1(1) & 3(1) \\ \mathrm{C}(20) & 35(1) & 34(1) & 35(1) & 1(1) & 11(1) & 4(1) \\ \mathrm{C}(21) & 30(1) & 22(1) & 42(1) & -1(1) & -1(1) & -1(1) \\ \mathrm{C}(22) & 36(1) & 29(1) & 34(1) & 1(1) & -8(1) & 5(1) \\ \mathrm{C}(23) & 25(1) & 19(1) & 32(1) & 2(1) & 6(1) & 1(1) \\ \mathrm{C}(24) & 33(1) & 35(1) & 37(1) & 3(1) & -5(1) & 3(1) \\ \mathrm{O}(11) & 40(1) & 29(1) & 26(1) & -3(1) & 5(1) & 5(1) \\ \mathrm{O}(12) & 19(1) & 29(1) & 63(1) & 0(1) & -1(1) & -3(1) \\ \mathrm{O}(13) & 20(1) & 21(1) & 29(1) & -1(1) & 2(1) & 1(1) \\ \mathrm{O}(14) & 39(1) & 39(1) & 30(1) & 4(1) & 11(1) & 9(1) \\ \mathrm{O}(15) & 27(1) & 36(1) & 32(1) & 6(1) & 5(1) & 5(1) \\ \mathrm{C}(25) & 29(1) & 24(1) & 29(1) & -2(1) & 1(1) & -1(1) \\ \mathrm{C}(26) & 25(1) & 22(1) & 29(1) & 2(1) & 6(1) & 0(1) \\ \mathrm{C}(27) & 25(1) & 20(1) & 31(1) & 1(1) & 6(1) & 0(1) \\ \mathrm{C}(28) & 32(1) & 21(1) & 31(1) & 0(1) & 5(1) & 3(1) \\ \mathrm{C}(29) & 21(1) & 21(1) & 28(1) & 1(1) & 3(1) & 0(1) \\ \mathrm{C}(30) & 23(1) & 24(1) & 27(1) & 2(1) & 3(1) & -2(1) \\ \mathrm{C}(31) & 24(1) & 23(1) & 27(1) & -1(1) & 0(1) & 3(1) \\ \mathrm{C}(32) & 30(1) & 42(1) & 26(1) & -1(1) & 4(1) & 9(1) \\ \mathrm{C}(33) & 31(1) & 26(1) & 62(1) & -9(1) & -1(1) & 2(1) \\ \mathrm{C}(34) & 39(1) & 33(1) & 28(1) & 4(1) & -2(1) & 7(1) \\ \mathrm{C}(35) & 27(1) & 18(1) & 29(1) & 2(1) & 5(1) & -1(1) \\ \mathrm{C}(36) & 32(1) & 34(1) & 34(1) & 6(1) & -2(1) & 0(1)\end{array}$

Table 5. Hydrogen coordinates $\left(x 10^{4}\right)$ and isotropic displacement parameters $\left(A^{2} \times\right.$ $\left.10^{3}\right)$ for 118.

\begin{tabular}{lllll}
\hline Atom & $x$ & $y$ & $z$ & $U($ eq $)$ \\
\hline$H(1)$ & -7822 & 2489 & 6210 & 33 \\
$H(2)$ & -7761 & 2454 & 7105 & 28 \\
$H(4)$ & -1455 & 1872 & 6588 & 33 \\
$H(5)$ & -4054 & 3205 & 6651 & 29 \\
$H(8 A)$ & -10663 & 4889 & 7079 & 44 \\
$H(8 B)$ & -8686 & 4504 & 7333 & 44
\end{tabular}




\begin{tabular}{|c|c|c|c|c|}
\hline $\mathrm{H}(8 \mathrm{C})$ & -11009 & 4226 & 7091 & 44 \\
\hline $\mathrm{H}(9 \mathrm{~A})$ & -5519 & 4947 & 6802 & 41 \\
\hline $\mathrm{H}(9 \mathrm{~B})$ & -7528 & 5308 & 6533 & 41 \\
\hline $\mathrm{H}(9 \mathrm{C})$ & -5798 & 4902 & 6237 & 41 \\
\hline $\mathrm{H}(10 \mathrm{~A})$ & -11386 & 4161 & 6232 & 35 \\
\hline $\mathrm{H}(10 \mathrm{~B})$ & -10930 & 4808 & 6124 & 35 \\
\hline $\mathrm{H}(10 \mathrm{C})$ & -9225 & 4345 & 5889 & 35 \\
\hline $\mathrm{H}(12 \mathrm{~A})$ & -283 & 1861 & 8170 & 38 \\
\hline $\mathrm{H}(12 \mathrm{~B})$ & -1144 & 1245 & 8028 & 38 \\
\hline$H(12 C)$ & 1521 & 1450 & 7896 & 38 \\
\hline $\mathrm{H}(13)$ & -3127 & 3428 & 7830 & 35 \\
\hline $\mathrm{H}(14)$ & -3002 & 3429 & 8723 & 30 \\
\hline $\mathrm{H}(16)$ & 3229 & 2805 & 8206 & 37 \\
\hline $\mathrm{H}(17)$ & 712 & 4151 & 8235 & 30 \\
\hline $\mathrm{H}(20 \mathrm{~A})$ & -5875 & 5788 & 8779 & 42 \\
\hline $\mathrm{H}(20 \mathrm{~B})$ & -4108 & 5328 & 9001 & 42 \\
\hline $\mathrm{H}(20 \mathrm{C})$ & -6387 & 5139 & 8691 & 42 \\
\hline$H(21 A)$ & -754 & 5861 & 8593 & 37 \\
\hline $\mathrm{H}(21 \mathrm{~B})$ & -2610 & 6271 & 8332 & 37 \\
\hline $\mathrm{H}(21 \mathrm{C})$ & -747 & 5909 & 8025 & 37 \\
\hline $\mathrm{H}(22 \mathrm{~A})$ & -6303 & 5193 & 7824 & 40 \\
\hline $\mathrm{H}(22 \mathrm{~B})$ & -5905 & 5855 & 7825 & 40 \\
\hline $\mathrm{H}(22 \mathrm{C})$ & -4039 & 5458 & 7552 & 40 \\
\hline $\mathrm{H}(24 \mathrm{~A})$ & 4639 & 2928 & 9777 & 42 \\
\hline $\mathrm{H}(24 \mathrm{~B})$ & 3875 & 2293 & 9683 & 42 \\
\hline $\mathrm{H}(24 \mathrm{C})$ & 6472 & 2511 & 9518 & 42 \\
\hline $\mathrm{H}(25)$ & 1753 & 4431 & 9451 & 33 \\
\hline $\mathrm{H}(26)$ & 1791 & 4363 & 10343 & 30 \\
\hline $\mathrm{H}(28)$ & 8171 & 3837 & 9819 & 34 \\
\hline $\mathrm{H}(29)$ & 5438 & 5151 & 9913 & 28 \\
\hline$H(32 A)$ & -1575 & 6688 & 10494 & 39 \\
\hline $\mathrm{H}(32 \mathrm{~B})$ & 169 & 6220 & 10711 & 39 \\
\hline $\mathrm{H}(32 \mathrm{C})$ & -1953 & 6046 & 10354 & 39 \\
\hline $\mathrm{H}(33 \mathrm{~A})$ & 3582 & 6818 & 10390 & 48 \\
\hline $\mathrm{H}(33 \mathrm{~B})$ & 1783 & 7235 & 10121 & 48 \\
\hline $\mathrm{H}(33 \mathrm{C})$ & 3817 & 6909 & 9827 & 48 \\
\hline $\mathrm{H}(34 \mathrm{~A})$ & -1537 & 6176 & 9500 & 40 \\
\hline $\mathrm{H}(34 \mathrm{~B})$ & -1286 & 6839 & 9553 & 40 \\
\hline $\mathrm{H}(34 \mathrm{C})$ & 756 & 6490 & 9281 & 40 \\
\hline $\mathrm{H}(36 \mathrm{~A})$ & 9480 & 3875 & 11400 & 40 \\
\hline $\mathrm{H}(36 \mathrm{~B})$ & 8706 & 3246 & 11283 & 40 \\
\hline$H(36 C)$ & 11319 & 3468 & 11131 & 40 \\
\hline
\end{tabular}


Table 6: Torsion angles [deg] for 118.

$\begin{array}{ll}\mathrm{C}(4)-\mathrm{O}(1)-\mathrm{C}(1)-\mathrm{C}(2) & -2.75(12) \\ \mathrm{C}(4)-\mathrm{O}(1)-\mathrm{C}(1)-\mathrm{C}(5) & 63.78(12) \\ \mathrm{C}(1)-\mathrm{O}(1)-\mathrm{C}(4)-\mathrm{C}(3) & 3.55(14) \\ \mathrm{C}(7)-\mathrm{O}(3)-\mathrm{C}(6)-\mathrm{C}(5) & 179.41(9) \\ \mathrm{C}(7)-\mathrm{O}(3)-\mathrm{C}(6)-\mathrm{O}(2) & 0.75(18) \\ \mathrm{C}(6)-\mathrm{O}(3)-\mathrm{C}(7)-\mathrm{C}(10) & -57.27(13) \\ \mathrm{C}(6)-\mathrm{O}(3)-\mathrm{C}(7)-\mathrm{C}(9) & -175.08(10) \\ \mathrm{C}(6)-\mathrm{O}(3)-\mathrm{C}(7)-\mathrm{C}(8) & 66.86(13) \\ \mathrm{C}(12)-\mathrm{O}(5)-\mathrm{C}(11)-\mathrm{O}(4) & 2.87(16) \\ \mathrm{C}(12)-\mathrm{O}(5)-\mathrm{C}(11)-\mathrm{C}(3) & -175.61(10) \\ \mathrm{C}(16)-\mathrm{O}(6)-\mathrm{C}(13)-\mathrm{C}(17) & 63.83(12) \\ \mathrm{C}(13)-\mathrm{O}(6)-\mathrm{C}(16)-\mathrm{C}(15) & 3.53(14) \\ \mathrm{C}(16)-\mathrm{O}(6)-\mathrm{C}(13)-\mathrm{C}(14) & -3.09(12) \\ \mathrm{C}(18)-\mathrm{O}(8)-\mathrm{C}(19)-\mathrm{C}(22) & -62.85(13) \\ \mathrm{C}(18)-\mathrm{O}(8)-\mathrm{C}(19)-\mathrm{C}(20) & 62.17(13) \\ \mathrm{C}(18)-\mathrm{O}(8)-\mathrm{C}(19)-\mathrm{C}(21) & 179.44(10) \\ \mathrm{C}(19)-\mathrm{O}(8)-\mathrm{C}(18)-\mathrm{C}(17) & -176.72(9) \\ \mathrm{C}(19)-\mathrm{O}(8)-\mathrm{C}(18)-\mathrm{O}(7) & 2.95(18) \\ \mathrm{C}(24)-\mathrm{O}(10)-\mathrm{C}(23)-\mathrm{C}(15) & -177.54(10) \\ \mathrm{C}(24)-\mathrm{O}(10)-\mathrm{C}(23)-\mathrm{O}(9) & 2.13(17) \\ \mathrm{C}(28)-\mathrm{O}(11)-\mathrm{C}(25)-\mathrm{C}(26) & -2.84(12) \\ \mathrm{C}(25)-\mathrm{O}(11)-\mathrm{C}(28)-\mathrm{C}(27) & 3.53(14) \\ \mathrm{C}(28)-\mathrm{O}(11)-\mathrm{C}(25)-\mathrm{C}(29) & 64.07(12) \\ \mathrm{C}(30)-\mathrm{O}(13)-\mathrm{C}(31)-\mathrm{C}(33) & 178.15(11) \\ \mathrm{C}(30)-\mathrm{O}(13)-\mathrm{C}(31)-\mathrm{C}(32) & 59.99(13) \\ \mathrm{C}(31)-\mathrm{O}(13)-\mathrm{C}(30)-\mathrm{O}(12) & 2.18(18) \\ \mathrm{C}(30)-\mathrm{O}(13)-\mathrm{C}(31)-\mathrm{C}(34) & -64.38(13) \\ \mathrm{C}(31)-\mathrm{O}(13)-\mathrm{C}(30)-\mathrm{C}(29) & -177.35(9) \\ \mathrm{C}(36)-\mathrm{O}(15)-\mathrm{C}(35)-\mathrm{O}(14) & 1.94(17) \\ \mathrm{C}(36)-\mathrm{O}(15)-\mathrm{C}(35)-\mathrm{C}(27) & -178.13(10) \\ \mathrm{O}(1)-\mathrm{C}(1)-\mathrm{C}(2)-\mathrm{C}(5) & 110.37(10) \\ \mathrm{O}(1)-\mathrm{C}(1)-\mathrm{C}(2)-\mathrm{C}(3) & 1.14(12) \\ \mathrm{C}(2)-\mathrm{C}(1)-\mathrm{C}(5)-\mathrm{C}(6) & -107.12(11) \\ \mathrm{C}(5)-\mathrm{C}(1)-\mathrm{C}(2)-\mathrm{C}(3) & -109.23(10) \\ \mathrm{O}(1)-\mathrm{C}(1)-\mathrm{C}(5)-\mathrm{C}(2) & -97.79(11) \\ \mathrm{O}(1)-\mathrm{C}(1)-\mathrm{C}(5)-\mathrm{C}(6) & 155.09(10) \\ \mathrm{C}(1)-\mathrm{C}(2)-\mathrm{C}(3)-\mathrm{C}(11) & -177.41(11) \\ \mathrm{C}(5)-\mathrm{C}(2)-\mathrm{C}(3)-\mathrm{C}(4) & -60.75(13) \\ \mathrm{C}(1)-\mathrm{C}(2)-\mathrm{C}(5)-\mathrm{C}(6) & 103.55(11) \\ \mathrm{C}(3)-\mathrm{C}(2)-\mathrm{C}(5)-\mathrm{C}(1) & 90.91(10) \\ \mathrm{C}(1)-\mathrm{C}(2)-\mathrm{C}(3)-\mathrm{C}(4) & 0.91(13) \\ \mathrm{C}(3)-\mathrm{C}(2)-\mathrm{C}(5)-\mathrm{C}(6) & -165.54(10) \\ \mathrm{C}(2)-\mathrm{C}(2)-\mathrm{C}(3)-\mathrm{C}(3)-\mathrm{C}(4)-\mathrm{O}(1) & 120.93(12) \\ \mathrm{C}(11)-\mathrm{C}(3)-\mathrm{C}(4)-\mathrm{O}(1) & -2.86(14) \\ \mathrm{C}(2)-\mathrm{C}(3)-\mathrm{C}(11)-\mathrm{O}(4) & 175.44(11) \\ & 4.94(19) \\ & \end{array}$

\begin{tabular}{|ll}
$\mathrm{C}(2)-\mathrm{C}(5)-\mathrm{C}(6)-\mathrm{O}(3)$ & $149.92(10)$ \\
$\mathrm{C}(2)-\mathrm{C}(5)-\mathrm{C}(6)-\mathrm{O}(2)$ & $-31.37(17)$ \\
$\mathrm{C}(1)-\mathrm{C}(5)-\mathrm{C}(6)-\mathrm{O}(2)$ & $34.66(16)$ \\
$\mathrm{C}(14)-\mathrm{C}(13)-\mathrm{C}(17)-\mathrm{C}(18)$ & $-106.65(11)$ \\
$\mathrm{O}(6)-\mathrm{C}(13)-\mathrm{C}(14)-\mathrm{C}(15)$ & $1.66(12)$ \\
$\mathrm{O}(6)-\mathrm{C}(13)-\mathrm{C}(17)-\mathrm{C}(18)$ & $155.64(10)$ \\
$\mathrm{C}(17)-\mathrm{C}(13)-\mathrm{C}(14)-\mathrm{C}(15)$ & $-109.13(10)$ \\
$\mathrm{O}(6)-\mathrm{C}(13)-\mathrm{C}(14)-\mathrm{C}(17)$ & $110.79(10)$ \\
$\mathrm{O}(6)-\mathrm{C}(13)-\mathrm{C}(17)-\mathrm{C}(14)$ & $-97.71(11)$ \\
$\mathrm{C}(13)-\mathrm{C}(14)-\mathrm{C}(15)-\mathrm{C}(23)$ & $179.89(11)$ \\
$\mathrm{C}(17)-\mathrm{C}(14)-\mathrm{C}(15)-\mathrm{C}(16)$ & $-61.32(13)$ \\
$\mathrm{C}(15)-\mathrm{C}(14)-\mathrm{C}(17)-\mathrm{C}(13)$ & $91.07(10)$ \\
$\mathrm{C}(13)-\mathrm{C}(14)-\mathrm{C}(15)-\mathrm{C}(16)$ & $0.38(13)$ \\
$\mathrm{C}(13)-\mathrm{C}(14)-\mathrm{C}(17)-\mathrm{C}(18)$ & $104.77(11)$ \\
$\mathrm{C}(17)-\mathrm{C}(14)-\mathrm{C}(15)-\mathrm{C}(23)$ & $118.19(12)$ \\
$\mathrm{C}(15)-\mathrm{C}(14)-\mathrm{C}(17)-\mathrm{C}(18)$ & $-164.16(10)$ \\
$\mathrm{C}(23)-\mathrm{C}(15)-\mathrm{C}(16)-\mathrm{O}(6)$ & $178.03(11)$ \\
$\mathrm{C}(16)-\mathrm{C}(15)-\mathrm{C}(23)-\mathrm{O}(10)$ & $3.57(17)$ \\
$\mathrm{C}(14)-\mathrm{C}(15)-\mathrm{C}(23)-\mathrm{O}(10)$ & $-175.85(11)$ \\
$\mathrm{C}(16)-\mathrm{C}(15)-\mathrm{C}(23)-\mathrm{O}(9)$ & $-176.10(12)$ \\
$\mathrm{C}(14)-\mathrm{C}(15)-\mathrm{C}(16)-\mathrm{O}(6)$ & $-2.48(14)$ \\
$\mathrm{C}(14)-\mathrm{C}(15)-\mathrm{C}(23)-\mathrm{O}(9)$ & $4.5(2)$ \\
$\mathrm{C}(13)-\mathrm{C}(17)-\mathrm{C}(18)-\mathrm{O}(7)$ & $28.09(17)$ \\
$\mathrm{C}(14)-\mathrm{C}(17)-\mathrm{C}(18)-\mathrm{O}(8)$ & $141.70(10)$ \\
$\mathrm{C}(14)-\mathrm{C}(17)-\mathrm{C}(18)-\mathrm{O}(7)$ & $-37.98(17)$ \\
$\mathrm{C}(13)-\mathrm{C}(17)-\mathrm{C}(18)-\mathrm{O}(8)$ & $-152.23(10)$ \\
$\mathrm{O}(11)-\mathrm{C}(25)-\mathrm{C}(26)-\mathrm{C}(29)$ & $110.47(10)$ \\
$\mathrm{C}(29)-\mathrm{C}(25)-\mathrm{C}(26)-\mathrm{C}(27)$ & $-109.18(10)$ \\
$\mathrm{O}(11)-\mathrm{C}(25)-\mathrm{C}(29)-\mathrm{C}(26)$ & $-97.75(11)$ \\
$\mathrm{O}(11)-\mathrm{C}(25)-\mathrm{C}(26)-\mathrm{C}(27)$ & $1.30(12)$ \\
$\mathrm{C}(26)-\mathrm{C}(25)-\mathrm{C}(29)-\mathrm{C}(30)$ & $-107.15(11)$ \\
$\mathrm{O}(11)-\mathrm{C}(25)-\mathrm{C}(29)-\mathrm{C}(30)$ & $155.11(10)$ \\
$\mathrm{C}(28)-\mathrm{C}(27)-\mathrm{C}(3)-\mathrm{C}(27)-\mathrm{C}(35)-\mathrm{O})-\mathrm{O}(15)$ & $6.43(18)$ \\
$\mathrm{C}(26)-\mathrm{C}(27)-\mathrm{C}(35)-\mathrm{O}(14)$ & $6.8(2)$ \\
$\mathrm{C}(25)-\mathrm{C}(29)-\mathrm{C}(30)-\mathrm{O}(12)$ & $27.64(17)$ \\
$\mathrm{C}(29)-\mathrm{C}(26)-\mathrm{C})-\mathrm{C}(27)-\mathrm{C}(28)$ & $-61.04(13)$ \\
$\mathrm{C}(25)-\mathrm{C}(26)-\mathrm{C}(27)-\mathrm{C}(28)$ & $0.73(13)$ \\
$\mathrm{C}(29)-\mathrm{C}(26)-\mathrm{C}(27)-\mathrm{C}(35)$ & $118.62(12)$ \\
$\mathrm{C}(25)-\mathrm{C}(26)-\mathrm{C}(29)-\mathrm{C}(30)$ & $104.78(11)$ \\
$\mathrm{C}(27)-\mathrm{C}(26)-\mathrm{C}(29)-\mathrm{C}(30)$ & $-164.06(10)$ \\
$\mathrm{C}(27)-\mathrm{C}(26)-\mathrm{C}(29)-\mathrm{C}(25)$ & $91.16(10)$ \\
$\mathrm{C}(26)-\mathrm{C}(27)-\mathrm{C}(35)-\mathrm{O}(15)$ & $-173.17(11)$ \\
$\mathrm{C}(26)-\mathrm{C}(28)-\mathrm{O}(11)$ & $-2.71(14)$ \\
& $-179.61(11)$ \\
&
\end{tabular}




\begin{tabular}{ll|ll}
$\mathrm{C}(2)-\mathrm{C}(3)-\mathrm{C}(11)-\mathrm{O}(5)$ & $-176.58(10)$ & $\mathrm{C}(25)-\mathrm{C}(29)-\mathrm{C}(30)-\mathrm{O}(13)$ & $-152.82(10)$ \\
$\mathrm{C}(4)-\mathrm{C}(3)-\mathrm{C}(11)-\mathrm{O}(4)$ & $-173.08(12)$ & $\mathrm{C}(26)-\mathrm{C}(29)-\mathrm{C}(30)-\mathrm{O}(12)$ & $-38.53(17)$ \\
$\mathrm{C}(4)-\mathrm{C}(3)-\mathrm{C}(11)-\mathrm{O}(5)$ & $5.39(17)$ & $\mathrm{C}(26)-\mathrm{C}(29)-\mathrm{C}(30)-\mathrm{O}(13)$ & $141.00(10)$ \\
$\mathrm{C}(1)-\mathrm{C}(5)-\mathrm{C}(6)-\mathrm{O}(3)$ & $-144.05(10)$ & &
\end{tabular}

Table 7: Hydrogen-bonds for 118 [ $\AA \AA$ and deg.].

\begin{tabular}{lcccc}
\hline $\mathrm{D}-\mathrm{H} \ldots \mathrm{A}$ & $\mathrm{d}(\mathrm{D}-\mathrm{H})$ & $\mathrm{d}(\mathrm{H} \ldots \mathrm{A})$ & $\mathrm{d}(\mathrm{D} \ldots \mathrm{A})$ & $<(\mathrm{DHA})$ \\
\hline $\mathrm{C}(5)-\mathrm{H}(5) \ldots \mathrm{O}(2) \# 1$ & 10.000 & 23.500 & $3.3286(14)$ & 167.00 \\
$\mathrm{C}(8)-\mathrm{H}(8 \mathrm{C}) \ldots \mathrm{O}(2)$ & 0.9800 & 25.600 & $3.1007(17)$ & 115.00 \\
$\mathrm{C}(9)-\mathrm{H}(9 \mathrm{~B}) \ldots \mathrm{O}(14) \# 2$ & 0.9800 & 25.300 & $3.3948(15)$ & 148.00 \\
$\mathrm{C}(10)-\mathrm{H}(10 \mathrm{~A}) \ldots \mathrm{O}(2)$ & 0.9800 & 24.300 & $2.9643(15)$ & 114.00 \\
$\mathrm{C}(16)-\mathrm{H}(16) \ldots \mathrm{O}(4) \# 1$ & 0.9500 & 23.600 & $3.2267(15)$ & 151.00 \\
$\mathrm{C}(17)-\mathrm{H}(17) \ldots \mathrm{O}(7) \# 1$ & 10.000 & 23.800 & $3.3650(14)$ & 170.00 \\
$\mathrm{C}(20)-\mathrm{H}(20 \mathrm{C}) \ldots \mathrm{O}(7)$ & 0.9800 & 25.000 & $3.0280(17)$ & 113.00 \\
$\mathrm{C}(22)-\mathrm{H}(22 \mathrm{~A}) \ldots \mathrm{O}(7)$ & 0.9800 & 24.600 & $3.0107(16)$ & 115.00 \\
$\mathrm{C}(26)-\mathrm{H}(26) \ldots \mathrm{O}(15) \# 3$ & 10.000 & 25.000 & $3.4325(14)$ & 154.00 \\
$\mathrm{C}(28)-\mathrm{H}(28) \ldots \mathrm{O}(9) \# 1$ & 0.9500 & 23.300 & $3.1870(15)$ & 150.00 \\
$\mathrm{C}(29)-\mathrm{H}(29) \ldots \mathrm{O}(12) \# 1$ & 10.000 & 23.600 & $3.3379(14)$ & 166.00 \\
$\mathrm{C}(32)-\mathrm{H}(32 \mathrm{C}) \ldots \mathrm{O}(12)$ & 0.9800 & 24.600 & $2.9941(17)$ & 114.00 \\
$\mathrm{C}(34)-\mathrm{H}(34 \mathrm{~A}) \ldots \mathrm{O}(12)$ & 0.9800 & 24.700 & $3.0273(17)$ & 116.00
\end{tabular}


(1S,4R,5S,6S)-tert-butyl 4-(hydroxymethyl)-2-oxabicyclo[3.1.0]hexane-6carboxylate (140)

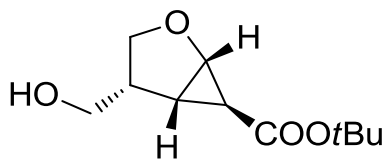

140

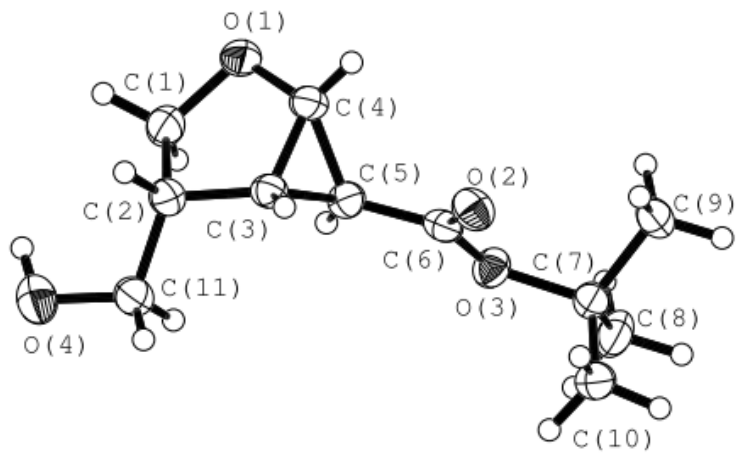

Table 1: Crystal data and structure refinement for $\mathbf{1 4 0}$.

\section{Crystal Data}

Empirical formula

Formula weight

Crystal size

Crystal description

Crystal colour

Crystal system

Space group

Unit cell dimensions

Volume

Z, Calculated density

Absorption coefficient

$\mathrm{F}(000)$

\section{Data Collection}

Measurement device type

Measurement method

Temperature

Wavelength

Monochromator

Theta range for data collection

Index ranges

Reflections collected / unique

Reflections greater I>2।s(I)

Absorption correction

Max. and min. transmission

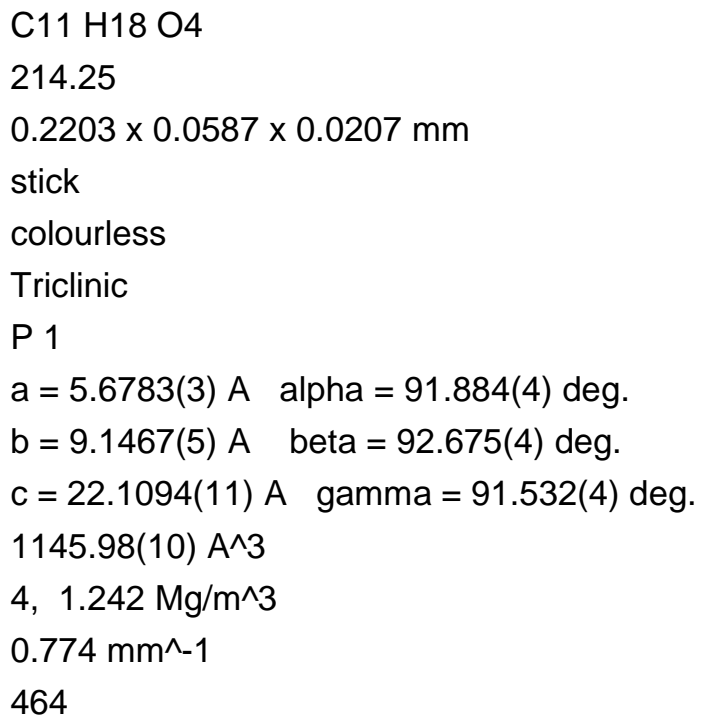

SuperNova, Single source at offset, Atlas Iw scans

$123 \mathrm{~K}$

$1.54184 \mathrm{~A}$

graphite

4.01 to $75.40 \mathrm{deg}$.

$=-7<=\mathrm{h}<=6-11<=\mathrm{k}<=11-21<=\mathrm{l}<=27$

$7732 / 5280[\mathrm{R}($ int $)=0.0338]$

4987

Analytical

0.984 and 0.922 


\section{Refinement}

Refinement method

Hydrogen treatment

Data / restraints / parameters

Goodness-of-fit on $\mathrm{F}^{\wedge} 2$

Final $R$ indices [l>2sigma(I)]

$R$ indices (all data)

Absolute structure parameter

Largest diff. peak and hole
Full-matrix least-squares on $\mathrm{F}^{\wedge} 2$$$
5280 \text { / } 3 \text { / } 542
$$$$
1.030
$$$$
\mathrm{R} 1=0.0554, \mathrm{wR} 2=0.1472
$$$$
\mathrm{R} 1=0.0579, w R 2=0.1518
$$

$0.2(2)$

0.330 and -0.313 e. $A^{\wedge}-3$

Table 2: Atomic coordinates $\left(x 1^{4}\right)$ and equivalent isotropic displacement parameters $\left(\AA^{2} \times 10^{3}\right)$ for 140 . $U(e q)$ is defined as one third of the trace of the orthogonalized Uij tensor.

\begin{tabular}{|c|c|c|c|c|}
\hline Atom & $x$ & $y$ & $z$ & $\mathrm{U}(\mathrm{eq})$ \\
\hline $\mathrm{O}(1)$ & $9415(5)$ & $3089(3)$ & $-2071(1)$ & $43(1)$ \\
\hline $\mathrm{O}(2)$ & $7308(5)$ & $-1462(3)$ & $-1910(1)$ & $35(1)$ \\
\hline $\mathrm{O}(3)$ & $4243(4)$ & $-783(3)$ & $-2522(1)$ & $32(1)$ \\
\hline $\mathrm{O}(4)$ & $4678(5)$ & $4803(3)$ & $-689(1)$ & $42(1)$ \\
\hline$C(1)$ & $7856(7)$ & $3963(4)$ & $-1717(2)$ & $38(1)$ \\
\hline$C(2)$ & $7304(6)$ & $3065(4)$ & $-1161(2)$ & $31(1)$ \\
\hline$C(3)$ & $7663(6)$ & $1505(4)$ & $-1381(1)$ & $28(1)$ \\
\hline$C(4)$ & $8984(6)$ & $1626(4)$ & $-1942(2)$ & $33(1)$ \\
\hline$C(5)$ & $6419(6)$ & $1049(4)$ & $-1993(1)$ & $28(1)$ \\
\hline$C(6)$ & $6071(6)$ & $-535(4)$ & $-2128(2)$ & $29(1)$ \\
\hline$C(7)$ & $3507(6)$ & $-2285(4)$ & $-2742(2)$ & $32(1)$ \\
\hline $\mathrm{C}(8)$ & $1546(7)$ & $-1951(4)$ & $-3210(2)$ & $41(1)$ \\
\hline $\mathrm{C}(9)$ & $5511(7)$ & $-3031(4)$ & $-3050(2)$ & $39(1)$ \\
\hline$C(10)$ & $2590(7)$ & $-3147(4)$ & $-2233(2)$ & $39(1)$ \\
\hline$C(11)$ & $4894(6)$ & $3355(4)$ & $-920(2)$ & $34(1)$ \\
\hline $\mathrm{O}(5)$ & $7819(4)$ & $4535(3)$ & $381(1)$ & $29(1)$ \\
\hline $\mathrm{O}(6)$ & $13057(4)$ & $1215(3)$ & $336(1)$ & $33(1)$ \\
\hline $\mathrm{O}(7)$ & $10021(4)$ & $-263(2)$ & $-36(1)$ & $26(1)$ \\
\hline $\mathrm{O}(8)$ & $7770(4)$ & $1621(3)$ & $2128(1)$ & $31(1)$ \\
\hline$C(12)$ & $6309(6)$ & $4244(4)$ & $871(2)$ & $28(1)$ \\
\hline$C(13)$ & $7809(6)$ & $3499(3)$ & $1361(1)$ & $26(1)$ \\
\hline$C(14)$ & $9806(5)$ & $2886(3)$ & $1014(1)$ & $24(1)$ \\
\hline$C(15)$ & $9714(6)$ & $3575(3)$ & $417(1)$ & $26(1)$ \\
\hline$C(16)$ & $9111(5)$ & $1942(3)$ & $444(1)$ & $25(1)$ \\
\hline$C(17)$ & $10960(6)$ & $939(3)$ & $247(1)$ & $25(1)$ \\
\hline$C(18)$ & $11543(6)$ & $-1471(3)$ & $-236(2)$ & $27(1)$ \\
\hline$C(19)$ & $9739(7)$ & $-2591(4)$ & $-505(2)$ & $37(1)$ \\
\hline$C(20)$ & $12853(8)$ & $-2069(4)$ & $311(2)$ & $42(1)$ \\
\hline$C(21)$ & $13165(7)$ & $-954(4)$ & $-714(2)$ & $36(1)$ \\
\hline $\mathrm{C}(22)$ & $6366(5)$ & $2383(3)$ & $1690(1)$ & $26(1)$ \\
\hline $\mathrm{O}(9)$ & $3928(4)$ & $-4480(3)$ & $2240(1)$ & $31(1)$ \\
\hline $\mathrm{O}(10)$ & $9350(4)$ & $-2677(3)$ & $3455(1)$ & $38(1)$ \\
\hline
\end{tabular}




$\begin{array}{lllll}\mathrm{O}(11) & 6498(4) & -2516(3) & 4136(1) & 28(1) \\ \mathrm{O}(12) & 591(5) & -562(3) & 1731(1) & 41(1) \\ \mathrm{C}(23) & 2372(6) & -3342(4) & 2039(2) & 28(1) \\ \mathrm{C}(24) & 3852(6) & -1925(4) & 2047(2) & 30(1) \\ \mathrm{C}(25) & 5915(6) & -2210(4) & 2488(2) & 30(1) \\ \mathrm{C}(26) & 5849(6) & -3803(4) & 2573(2) & 29(1) \\ \mathrm{C}(27) & 5329(5) & -2797(3) & 3112(1) & 26(1) \\ \mathrm{C}(28) & 7297(6) & -2635(4) & 3581(2) & 28(1) \\ \mathrm{C}(29) & 8160(6) & -2334(4) & 4674(2) & 31(1) \\ \mathrm{C}(30) & 9568(8) & -3707(4) & 4753(2) & 41(1) \\ \mathrm{C}(31) & 6472(8) & -2134(6) & 5184(2) & 52(1) \\ \mathrm{C}(32) & 9746(7) & -991(4) & 4621(2) & 40(1) \\ \mathrm{C}(33) & 2401(6) & -618(4) & 2193(2) & 33(1) \\ \mathrm{O}(13) & 6131(5) & -8447(3) & 4054(1) & 41(1) \\ \mathrm{O}(14) & 3798(4) & -5847(3) & 5575(1) & 33(1) \\ \mathrm{O}(15) & 971(4) & -7649(3) & 5567(1) & 28(1) \\ \mathrm{O}(16) & 1053(5) & -6605(3) & 2724(1) & 38(1) \\ \mathrm{C}(34) & 4518(7) & -8206(4) & 3549(2) & 36(1) \\ \mathrm{C}(35) & 3774(6) & -6611(4) & 3609(2) & 30(1) \\ \mathrm{C}(36) & 4141(6) & -6276(3) & 4284(2) & 27(1) \\ \mathrm{C}(37) & 5619(6) & -7456(4) & 4521(2) & 32(1) \\ \mathrm{C}(38) & 3042(6) & -7381(3) & 4696(2) & 28(1) \\ \mathrm{C}(39) & 2676(6) & -6848(3) & 5323(2) & 27(1) \\ \mathrm{C}(40) & 339(6) & -7386(4) & 6201(1) & 28(1) \\ \mathrm{C}(41) & 2434(6) & -7614(4) & 6632(2) & 34(1) \\ \mathrm{C}(42) & -1587(6) & -8558(4) & 6269(2) & 34(1) \\ \mathrm{C}(43) & -639(6) & -5873(4) & 6279(2) & 36(1) \\ \mathrm{C}(44) & 1288(7) & -6330(4) & 3363(2) & 33(1) \\ & & & & \end{array}$

Table 3: Bond lengths $[\AA]$ and angles [deg] for 140.

$\begin{array}{ll}\mathrm{O}(1)-\mathrm{C}(1) & 1.449(5) \\ \mathrm{O}(1)-\mathrm{C}(4) & 1.395(5) \\ \mathrm{O}(2)-\mathrm{C}(6) & 1.213(4) \\ \mathrm{O}(3)-\mathrm{C}(6) & 1.334(4) \\ \mathrm{O}(3)-\mathrm{C}(7) & 1.485(5) \\ \mathrm{O}(4)-\mathrm{C}(11) & 1.414(5) \\ \mathrm{O}(4)-\mathrm{H}(40) & 0.8400 \\ \mathrm{O}(5)-\mathrm{C}(15) & 1.408(4) \\ \mathrm{O}(5)-\mathrm{C}(12) & 1.441(4) \\ \mathrm{O}(6)-\mathrm{C}(17) & 1.216(4) \\ \mathrm{O}(7)-\mathrm{C}(17) & 1.333(4) \\ \mathrm{O}(7)-\mathrm{C}(18) & 1.489(4) \\ \mathrm{O}(8)-\mathrm{C}(22) & 1.435(4) \\ \mathrm{O}(8)-\mathrm{H}(80) & 0.8400 \\ \mathrm{O}(9)-\mathrm{C}(23) & 1.450(4) \\ \mathrm{O}(9)-\mathrm{C}(26) & 1.405(4) \\ \mathrm{O}(10)-\mathrm{C}(28) & 1.213(4)\end{array}$

\begin{tabular}{|ll}
$H(10 B)-C(10)-H(10 C)$ & 109.00 \\
$H(10 A)-C(10)-H(10 B)$ & 110.00 \\
$H(10 A)-C(10)-H(10 C)$ & 109.00 \\
$\mathrm{C}(7)-C(10)-H(10 B)$ & 109.00 \\
$\mathrm{C}(7)-\mathrm{C}(10)-H(10 C)$ & 109.00 \\
$\mathrm{C}(7)-\mathrm{C}(10)-\mathrm{H}(10 \mathrm{~A})$ & 109.00 \\
$\mathrm{C}(2)-\mathrm{C}(11)-\mathrm{H}(11 \mathrm{~B})$ & 109.00 \\
$\mathrm{H}(11 \mathrm{~A})-\mathrm{C}(11)-\mathrm{H}(11 \mathrm{~B})$ & 108.00 \\
$\mathrm{O}(4)-\mathrm{C}(11)-\mathrm{H}(11 \mathrm{~B})$ & 109.00 \\
$\mathrm{O}(4)-\mathrm{C}(11)-\mathrm{H}(11 \mathrm{~A})$ & 109.00 \\
$\mathrm{C}(2)-\mathrm{C}(11)-\mathrm{H}(11 \mathrm{~A})$ & 109.00 \\
$\mathrm{O}(5)-\mathrm{C}(12)-\mathrm{C}(13)$ & $107.1(3)$ \\
$\mathrm{C}(12)-\mathrm{C}(13)-\mathrm{C}(22)$ & $111.7(3)$ \\
$\mathrm{C}(14)-\mathrm{C}(13)-\mathrm{C}(22)$ & $115.3(2)$ \\
$\mathrm{C}(12)-\mathrm{C}(13)-\mathrm{C}(14)$ & $103.1(2)$ \\
$\mathrm{C}(13)-\mathrm{C}(14)-\mathrm{C}(15)$ & $106.7(2)$ \\
$\mathrm{C}(15)-\mathrm{C}(14)-\mathrm{C}(16)$ & $60.85(19)$
\end{tabular}




\begin{tabular}{|c|c|c|c|}
\hline $\mathrm{O}(11)-\mathrm{C}(28)$ & $1.330(4)$ & $C(13)-C(14)-C(16)$ & $116.5(2)$ \\
\hline $\mathrm{O}(11)-\mathrm{C}(29)$ & $1.486(4)$ & $\mathrm{O}(5)-\mathrm{C}(15)-\mathrm{C}(16)$ & 117.3(3) \\
\hline $\mathrm{O}(12)-\mathrm{C}(33)$ & $1.418(5)$ & $C(14)-C(15)-C(16)$ & $61.33(19)$ \\
\hline $\mathrm{O}(12)-\mathrm{H}(12 \mathrm{O})$ & 0.8400 & $\mathrm{O}(5)-\mathrm{C}(15)-\mathrm{C}(14)$ & $109.9(3)$ \\
\hline $\mathrm{O}(13)-\mathrm{C}(37)$ & $1.397(4)$ & $C(14)-C(16)-C(15)$ & $57.83(19)$ \\
\hline $\mathrm{O}(13)-\mathrm{C}(34)$ & $1.437(5)$ & $C(14)-C(16)-C(17)$ & $114.5(2)$ \\
\hline$O(14)-C(39)$ & $1.207(4)$ & $C(15)-C(16)-C(17)$ & $115.9(3)$ \\
\hline $\mathrm{O}(15)-\mathrm{C}(39)$ & $1.343(4)$ & $\mathrm{O}(6)-\mathrm{C}(17)-\mathrm{C}(16)$ & $122.9(3)$ \\
\hline $\mathrm{O}(15)-\mathrm{C}(40)$ & $1.478(4)$ & $O(7)-C(17)-C(16)$ & $111.5(3)$ \\
\hline $\mathrm{O}(16)-\mathrm{C}(44)$ & $1.426(4)$ & $\mathrm{O}(6)-\mathrm{C}(17)-\mathrm{O}(7)$ & $125.7(3)$ \\
\hline $\mathrm{O}(16)-\mathrm{H}(16 \mathrm{O})$ & 0.8400 & $\mathrm{O}(7)-\mathrm{C}(18)-\mathrm{C}(20)$ & $109.4(3)$ \\
\hline$C(1)-C(2)$ & $1.540(5)$ & $C(19)-C(18)-C(21)$ & $110.7(3)$ \\
\hline$C(2)-C(11)$ & $1.518(5)$ & $C(19)-C(18)-C(20)$ & 110.6(3) \\
\hline$C(2)-C(3)$ & $1.515(5)$ & $\mathrm{O}(7)-\mathrm{C}(18)-\mathrm{C}(19)$ & $102.0(3)$ \\
\hline$C(3)-C(5)$ & $1.537(5)$ & $\mathrm{O}(7)-\mathrm{C}(18)-\mathrm{C}(21)$ & $110.5(2)$ \\
\hline$C(3)-C(4)$ & $1.485(5)$ & $C(20)-C(18)-C(21)$ & $113.1(3)$ \\
\hline$C(4)-C(5)$ & $1.534(5)$ & $\mathrm{O}(8)-\mathrm{C}(22)-\mathrm{C}(13)$ & $112.3(2)$ \\
\hline$C(5)-C(6)$ & $1.476(5)$ & $\mathrm{O}(5)-\mathrm{C}(12)-\mathrm{H}(12 \mathrm{~B})$ & 110.00 \\
\hline$C(7)-C(9)$ & $1.519(5)$ & $C(13)-C(12)-H(12 B)$ & 110.00 \\
\hline$C(7)-C(10)$ & $1.501(6)$ & $\mathrm{O}(5)-\mathrm{C}(12)-\mathrm{H}(12 \mathrm{~A})$ & 110.00 \\
\hline $\mathrm{C}(7)-\mathrm{C}(8)$ & $1.528(5)$ & $C(13)-C(12)-H(12 A)$ & 110.00 \\
\hline$C(1)-H(1 A)$ & 0.9900 & $H(12 A)-C(12)-H(12 B)$ & 109.00 \\
\hline $\mathrm{C}(1)-\mathrm{H}(1 \mathrm{~B})$ & 0.9900 & $\mathrm{C}(12)-\mathrm{C}(13)-\mathrm{H}(13)$ & 109.00 \\
\hline $\mathrm{C}(2)-\mathrm{H}(2)$ & 10.000 & $\mathrm{C}(22)-\mathrm{C}(13)-\mathrm{H}(13)$ & 109.00 \\
\hline $\mathrm{C}(3)-\mathrm{H}(3)$ & 10.000 & $\mathrm{C}(14)-\mathrm{C}(13)-\mathrm{H}(13)$ & 109.00 \\
\hline $\mathrm{C}(4)-\mathrm{H}(4)$ & 10.000 & $C(16)-C(14)-H(14)$ & 119.00 \\
\hline $\mathrm{C}(5)-\mathrm{H}(5)$ & 10.000 & $C(13)-C(14)-H(14)$ & 119.00 \\
\hline $\mathrm{C}(8)-\mathrm{H}(8 \mathrm{~B})$ & 0.9800 & $C(15)-C(14)-H(14)$ & 119.00 \\
\hline $\mathrm{C}(8)-\mathrm{H}(8 \mathrm{~A})$ & 0.9800 & $\mathrm{C}(16)-\mathrm{C}(15)-\mathrm{H}(15)$ & 118.00 \\
\hline $\mathrm{C}(8)-\mathrm{H}(8 \mathrm{C})$ & 0.9800 & $\mathrm{O}(5)-\mathrm{C}(15)-\mathrm{H}(15)$ & 118.00 \\
\hline $\mathrm{C}(9)-\mathrm{H}(9 \mathrm{C})$ & 0.9800 & $\mathrm{C}(14)-\mathrm{C}(15)-\mathrm{H}(15)$ & 118.00 \\
\hline $\mathrm{C}(9)-\mathrm{H}(9 \mathrm{~B})$ & 0.9800 & $\mathrm{C}(17)-\mathrm{C}(16)-\mathrm{H}(16)$ & 118.00 \\
\hline $\mathrm{C}(9)-\mathrm{H}(9 \mathrm{~A})$ & 0.9800 & $\mathrm{C}(14)-\mathrm{C}(16)-\mathrm{H}(16)$ & 118.00 \\
\hline $\mathrm{C}(10)-\mathrm{H}(10 \mathrm{~A})$ & 0.9800 & $\mathrm{C}(15)-\mathrm{C}(16)-\mathrm{H}(16)$ & 118.00 \\
\hline $\mathrm{C}(10)-\mathrm{H}(10 \mathrm{~B})$ & 0.9800 & $C(18)-C(19)-H(19 A)$ & 109.00 \\
\hline$C(10)-H(10 C)$ & 0.9800 & $C(18)-C(19)-H(19 C)$ & 109.00 \\
\hline$C(11)-H(11 A)$ & 0.9900 & $\mathrm{C}(18)-\mathrm{C}(19)-\mathrm{H}(19 \mathrm{~B})$ & 109.00 \\
\hline $\mathrm{C}(11)-\mathrm{H}(11 \mathrm{~B})$ & 0.9900 & $H(19 A)-C(19)-H(19 B)$ & 109.00 \\
\hline$C(12)-C(13)$ & $1.536(5)$ & $H(19 A)-C(19)-H(19 C)$ & 109.00 \\
\hline$C(13)-C(22)$ & $1.517(4)$ & $H(19 B)-C(19)-H(19 C)$ & 109.00 \\
\hline$C(13)-C(14)$ & $1.509(4)$ & $\mathrm{C}(18)-\mathrm{C}(20)-\mathrm{H}(20 \mathrm{~B})$ & 109.00 \\
\hline$C(14)-C(16)$ & $1.534(4)$ & $\mathrm{C}(18)-\mathrm{C}(20)-\mathrm{H}(20 \mathrm{~A})$ & 109.00 \\
\hline$C(14)-C(15)$ & $1.480(4)$ & $H(20 A)-C(20)-H(20 C)$ & 110.00 \\
\hline$C(15)-C(16)$ & $1.527(4)$ & $H(20 A)-C(20)-H(20 B)$ & 109.00 \\
\hline$C(16)-C(17)$ & $1.484(4)$ & $C(18)-C(20)-H(20 C)$ & 109.00 \\
\hline$C(18)-C(19)$ & $1.517(5)$ & $H(20 B)-C(20)-H(20 C)$ & 109.00 \\
\hline$C(18)-C(21)$ & $1.514(5)$ & $\mathrm{C}(18)-\mathrm{C}(21)-\mathrm{H}(21 \mathrm{C})$ & 109.00 \\
\hline
\end{tabular}




\begin{tabular}{|c|c|}
\hline$C(18)-C(20)$ & $1.515(5)$ \\
\hline $\mathrm{C}(12)-\mathrm{H}(12 \mathrm{~A})$ & 0.9900 \\
\hline $\mathrm{C}(12)-\mathrm{H}(12 \mathrm{~B})$ & 0.9900 \\
\hline $\mathrm{C}(13)-\mathrm{H}(13)$ & 10.000 \\
\hline $\mathrm{C}(14)-\mathrm{H}(14)$ & 10.000 \\
\hline $\mathrm{C}(15)-\mathrm{H}(15)$ & 10.000 \\
\hline $\mathrm{C}(16)-\mathrm{H}(16)$ & 10.000 \\
\hline $\mathrm{C}(19)-\mathrm{H}(19 \mathrm{C})$ & 0.9800 \\
\hline $\mathrm{C}(19)-\mathrm{H}(19 \mathrm{~B})$ & 0.9800 \\
\hline $\mathrm{C}(19)-\mathrm{H}(19 \mathrm{~A})$ & 0.9800 \\
\hline $\mathrm{C}(20)-\mathrm{H}(20 \mathrm{C})$ & 0.9800 \\
\hline $\mathrm{C}(20)-\mathrm{H}(20 \mathrm{~B})$ & 0.9800 \\
\hline $\mathrm{C}(20)-\mathrm{H}(20 \mathrm{~A})$ & 0.9800 \\
\hline $\mathrm{C}(21)-\mathrm{H}(21 \mathrm{~B})$ & 0.9800 \\
\hline $\mathrm{C}(21)-\mathrm{H}(21 \mathrm{~A})$ & 0.9800 \\
\hline $\mathrm{C}(21)-\mathrm{H}(21 \mathrm{C})$ & 0.9800 \\
\hline $\mathrm{C}(22)-\mathrm{H}(22 \mathrm{~A})$ & 0.9900 \\
\hline $\mathrm{C}(22)-\mathrm{H}(22 \mathrm{~B})$ & 0.9900 \\
\hline $\mathrm{C}(23)-\mathrm{C}(24)$ & $1.525(5)$ \\
\hline$C(24)-C(33)$ & $1.505(5)$ \\
\hline$C(24)-C(25)$ & $1.523(5)$ \\
\hline$C(25)-C(27)$ & $1.544(5)$ \\
\hline$C(25)-C(26)$ & $1.475(5)$ \\
\hline$C(26)-C(27)$ & $1.526(5)$ \\
\hline$C(27)-C(28)$ & $1.491(4)$ \\
\hline$C(29)-C(31)$ & $1.522(6)$ \\
\hline$C(29)-C(30)$ & $1.517(5)$ \\
\hline $\mathrm{C}(29)-\mathrm{C}(32)$ & $1.515(5)$ \\
\hline $\mathrm{C}(23)-\mathrm{H}(23 \mathrm{~B})$ & 0.9900 \\
\hline $\mathrm{C}(23)-\mathrm{H}(23 \mathrm{~A})$ & 0.9900 \\
\hline $\mathrm{C}(24)-\mathrm{H}(24)$ & 10.000 \\
\hline $\mathrm{C}(25)-\mathrm{H}(25)$ & 10.000 \\
\hline $\mathrm{C}(26)-\mathrm{H}(26)$ & 10.000 \\
\hline $\mathrm{C}(27)-\mathrm{H}(27)$ & 10.000 \\
\hline $\mathrm{C}(30)-\mathrm{H}(30 \mathrm{C})$ & 0.9800 \\
\hline $\mathrm{C}(30)-\mathrm{H}(30 \mathrm{~B})$ & 0.9800 \\
\hline $\mathrm{C}(30)-\mathrm{H}(30 \mathrm{~A})$ & 0.9800 \\
\hline $\mathrm{C}(31)-\mathrm{H}(31 \mathrm{~A})$ & 0.9800 \\
\hline $\mathrm{C}(31)-\mathrm{H}(31 \mathrm{~B})$ & 0.9800 \\
\hline $\mathrm{C}(31)-\mathrm{H}(31 \mathrm{C})$ & 0.9800 \\
\hline $\mathrm{C}(32)-\mathrm{H}(32 \mathrm{~B})$ & 0.9800 \\
\hline $\mathrm{C}(32)-\mathrm{H}(32 \mathrm{C})$ & 0.9800 \\
\hline $\mathrm{C}(32)-\mathrm{H}(32 \mathrm{~A})$ & 0.9800 \\
\hline $\mathrm{C}(33)-\mathrm{H}(33 \mathrm{~B})$ & 0.9900 \\
\hline $\mathrm{C}(33)-\mathrm{H}(33 \mathrm{~A})$ & 0.9900 \\
\hline $\mathrm{C}(34)-\mathrm{C}(35)$ & $1.533(5)$ \\
\hline$C(35)-C(36)$ & $1.517(5)$ \\
\hline
\end{tabular}

\begin{tabular}{|c|c|}
\hline$H(21 A)-C(21)-H(21 B)$ & 110.00 \\
\hline $\mathrm{C}(18)-\mathrm{C}(21)-\mathrm{H}(21 \mathrm{~B})$ & 110.00 \\
\hline$H(21 B)-C(21)-H(21 C)$ & 109.00 \\
\hline$H(21 A)-C(21)-H(21 C)$ & 109.00 \\
\hline$C(18)-C(21)-H(21 A)$ & 109.00 \\
\hline $\mathrm{H}(22 \mathrm{~A})-\mathrm{C}(22)-\mathrm{H}(22 \mathrm{~B})$ & 108.00 \\
\hline $\mathrm{O}(8)-\mathrm{C}(22)-\mathrm{H}(22 \mathrm{~B})$ & 109.00 \\
\hline $\mathrm{C}(13)-\mathrm{C}(22)-\mathrm{H}(22 \mathrm{~B})$ & 109.00 \\
\hline$C(13)-C(22)-H(22 A)$ & 109.00 \\
\hline $\mathrm{O}(8)-\mathrm{C}(22)-\mathrm{H}(22 \mathrm{~A})$ & 109.00 \\
\hline $\mathrm{O}(9)-\mathrm{C}(23)-\mathrm{C}(24)$ & $106.9(3)$ \\
\hline$C(25)-C(24)-C(33)$ & $116.5(3)$ \\
\hline$C(23)-C(24)-C(25)$ & 103.6(3) \\
\hline$C(23)-C(24)-C(33)$ & $111.4(3)$ \\
\hline$C(26)-C(25)-C(27)$ & $60.7(2)$ \\
\hline$C(24)-C(25)-C(27)$ & 117.3(3) \\
\hline$C(24)-C(25)-C(26)$ & $105.6(3)$ \\
\hline $\mathrm{O}(9)-\mathrm{C}(26)-\mathrm{C}(25)$ & 110.9(3) \\
\hline $\mathrm{O}(9)-\mathrm{C}(26)-\mathrm{C}(27)$ & $118.0(3)$ \\
\hline$C(25)-C(26)-C(27)$ & $61.9(2)$ \\
\hline$C(25)-C(27)-C(26)$ & $57.4(2)$ \\
\hline$C(25)-C(27)-C(28)$ & $114.5(3)$ \\
\hline$C(26)-C(27)-C(28)$ & $114.2(3)$ \\
\hline $\mathrm{O}(10)-\mathrm{C}(28)-\mathrm{C}(27)$ & $122.3(3)$ \\
\hline $\mathrm{O}(11)-\mathrm{C}(28)-\mathrm{C}(27)$ & $111.6(3)$ \\
\hline $\mathrm{O}(10)-\mathrm{C}(28)-\mathrm{O}(11)$ & $126.1(3)$ \\
\hline $\mathrm{O}(11)-\mathrm{C}(29)-\mathrm{C}(31)$ & 101.6(3) \\
\hline$C(31)-C(29)-C(32)$ & $111.4(3)$ \\
\hline$C(30)-C(29)-C(32)$ & $111.8(3)$ \\
\hline$C(30)-C(29)-C(31)$ & $111.0(3)$ \\
\hline $\mathrm{O}(11)-\mathrm{C}(29)-\mathrm{C}(30)$ & $110.1(3)$ \\
\hline $\mathrm{O}(11)-\mathrm{C}(29)-\mathrm{C}(32)$ & $110.5(3)$ \\
\hline $\mathrm{O}(12)-\mathrm{C}(33)-\mathrm{C}(24)$ & 107.1(3) \\
\hline $\mathrm{O}(9)-\mathrm{C}(23)-\mathrm{H}(23 \mathrm{~B})$ & 110.00 \\
\hline $\mathrm{H}(23 \mathrm{~A})-\mathrm{C}(23)-\mathrm{H}(23 \mathrm{~B})$ & 109.00 \\
\hline $\mathrm{C}(24)-\mathrm{C}(23)-\mathrm{H}(23 \mathrm{~A})$ & 110.00 \\
\hline $\mathrm{O}(9)-\mathrm{C}(23)-\mathrm{H}(23 \mathrm{~A})$ & 110.00 \\
\hline $\mathrm{C}(24)-\mathrm{C}(23)-\mathrm{H}(23 \mathrm{~B})$ & 110.00 \\
\hline $\mathrm{C}(25)-\mathrm{C}(24)-\mathrm{H}(24)$ & 108.00 \\
\hline $\mathrm{C}(33)-\mathrm{C}(24)-\mathrm{H}(24)$ & 108.00 \\
\hline $\mathrm{C}(23)-\mathrm{C}(24)-\mathrm{H}(24)$ & 108.00 \\
\hline $\mathrm{C}(24)-\mathrm{C}(25)-\mathrm{H}(25)$ & 119.00 \\
\hline $\mathrm{C}(27)-\mathrm{C}(25)-\mathrm{H}(25)$ & 119.00 \\
\hline $\mathrm{C}(26)-\mathrm{C}(25)-\mathrm{H}(25)$ & 119.00 \\
\hline $\mathrm{C}(27)-\mathrm{C}(26)-\mathrm{H}(26)$ & 118.00 \\
\hline $\mathrm{O}(9)-\mathrm{C}(26)-\mathrm{H}(26)$ & 118.00 \\
\hline $\mathrm{C}(25)-\mathrm{C}(26)-\mathrm{H}(26)$ & 118.00 \\
\hline
\end{tabular}




\begin{tabular}{|c|c|c|c|}
\hline$C(35)-C(44)$ & $1.521(5)$ & $\mathrm{C}(25)-\mathrm{C}(27)-\mathrm{H}(27)$ & 119.00 \\
\hline$C(36)-C(38)$ & $1.524(4)$ & $\mathrm{C}(26)-\mathrm{C}(27)-\mathrm{H}(27)$ & 119.00 \\
\hline$C(36)-C(37)$ & $1.479(5)$ & $\mathrm{C}(28)-\mathrm{C}(27)-\mathrm{H}(27)$ & 119.00 \\
\hline$C(37)-C(38)$ & $1.534(5)$ & $\mathrm{C}(29)-\mathrm{C}(30)-\mathrm{H}(30 \mathrm{~A})$ & 109.00 \\
\hline$C(38)-C(39)$ & $1.479(5)$ & $H(30 A)-C(30)-H(30 C)$ & 110.00 \\
\hline$C(40)-C(42)$ & $1.527(5)$ & $H(30 B)-C(30)-H(30 C)$ & 109.00 \\
\hline$C(40)-C(43)$ & $1.512(5)$ & $H(30 A)-C(30)-H(30 B)$ & 109.00 \\
\hline$C(40)-C(41)$ & $1.512(5)$ & $C(29)-C(30)-H(30 C)$ & 109.00 \\
\hline $\mathrm{C}(34)-\mathrm{H}(34 \mathrm{~A})$ & 0.9900 & $\mathrm{C}(29)-\mathrm{C}(30)-\mathrm{H}(30 \mathrm{~B})$ & 109.00 \\
\hline $\mathrm{C}(34)-\mathrm{H}(34 \mathrm{~B})$ & 0.9900 & $C(29)-C(31)-H(31 A)$ & 109.00 \\
\hline $\mathrm{C}(35)-\mathrm{H}(35)$ & 10.000 & $\mathrm{C}(29)-\mathrm{C}(31)-\mathrm{H}(31 \mathrm{~B})$ & 110.00 \\
\hline $\mathrm{C}(36)-\mathrm{H}(36)$ & 10.000 & $H(31 B)-C(31)-H(31 C)$ & 109.00 \\
\hline $\mathrm{C}(37)-\mathrm{H}(37)$ & 10.000 & $H(31 A)-C(31)-H(31 B)$ & 110.00 \\
\hline $\mathrm{C}(38)-\mathrm{H}(38)$ & 10.000 & $\mathrm{C}(29)-\mathrm{C}(31)-\mathrm{H}(31 \mathrm{C})$ & 109.00 \\
\hline $\mathrm{C}(41)-\mathrm{H}(41 \mathrm{~A})$ & 0.9800 & $H(31 A)-C(31)-H(31 C)$ & 109.00 \\
\hline $\mathrm{C}(41)-\mathrm{H}(41 \mathrm{~B})$ & 0.9800 & $\mathrm{C}(29)-\mathrm{C}(32)-\mathrm{H}(32 \mathrm{~A})$ & 109.00 \\
\hline $\mathrm{C}(41)-\mathrm{H}(41 \mathrm{C})$ & 0.9800 & $\mathrm{C}(29)-\mathrm{C}(32)-\mathrm{H}(32 \mathrm{~B})$ & 109.00 \\
\hline $\mathrm{C}(42)-\mathrm{H}(42 \mathrm{~A})$ & 0.9800 & $\mathrm{C}(29)-\mathrm{C}(32)-\mathrm{H}(32 \mathrm{C})$ & 110.00 \\
\hline $\mathrm{C}(42)-\mathrm{H}(42 \mathrm{~B})$ & 0.9800 & $H(32 A)-C(32)-H(32 B)$ & 109.00 \\
\hline $\mathrm{C}(42)-\mathrm{H}(42 \mathrm{C})$ & 0.9800 & $H(32 A)-C(32)-H(32 C)$ & 109.00 \\
\hline $\mathrm{C}(43)-\mathrm{H}(43 \mathrm{~A})$ & 0.9800 & $H(32 B)-C(32)-H(32 C)$ & 110.00 \\
\hline $\mathrm{C}(43)-\mathrm{H}(43 \mathrm{~B})$ & 0.9800 & $\mathrm{O}(12)-\mathrm{C}(33)-\mathrm{H}(33 \mathrm{~B})$ & 110.00 \\
\hline $\mathrm{C}(43)-\mathrm{H}(43 \mathrm{C})$ & 0.9800 & $H(33 A)-C(33)-H(33 B)$ & 109.00 \\
\hline $\mathrm{C}(44)-\mathrm{H}(44 \mathrm{~A})$ & 0.9900 & $\mathrm{C}(24)-\mathrm{C}(33)-\mathrm{H}(33 \mathrm{~A})$ & 110.00 \\
\hline $\mathrm{C}(44)-\mathrm{H}(44 \mathrm{~B})$ & 0.9900 & $\mathrm{C}(24)-\mathrm{C}(33)-\mathrm{H}(33 \mathrm{~B})$ & 110.00 \\
\hline$C(1)-O(1)-C(4)$ & $107.5(3)$ & $\mathrm{O}(12)-\mathrm{C}(33)-\mathrm{H}(33 \mathrm{~A})$ & 110.00 \\
\hline $\mathrm{C}(6)-\mathrm{O}(3)-\mathrm{C}(7)$ & $121.9(3)$ & $\mathrm{O}(13)-\mathrm{C}(34)-\mathrm{C}(35)$ & $106.7(3)$ \\
\hline $\mathrm{C}(11)-\mathrm{O}(4)-\mathrm{H}(4 \mathrm{O})$ & 109.00 & $C(34)-C(35)-C(44)$ & $114.9(3)$ \\
\hline $\mathrm{C}(12)-\mathrm{O}(5)-\mathrm{C}(15)$ & $108.2(3)$ & $C(36)-C(35)-C(44)$ & $113.5(3)$ \\
\hline $\mathrm{C}(17)-\mathrm{O}(7)-\mathrm{C}(18)$ & $120.8(2)$ & $C(34)-C(35)-C(36)$ & 102.6(3) \\
\hline $\mathrm{C}(22)-\mathrm{O}(8)-\mathrm{H}(8 \mathrm{O})$ & 109.00 & $C(35)-C(36)-C(37)$ & $105.7(3)$ \\
\hline $\mathrm{C}(23)-\mathrm{O}(9)-\mathrm{C}(26)$ & $107.8(3)$ & $C(37)-C(36)-C(38)$ & $61.4(2)$ \\
\hline $\mathrm{C}(28)-\mathrm{O}(11)-\mathrm{C}(29)$ & $120.7(3)$ & $\mathrm{C}(35)-\mathrm{C}(36)-\mathrm{C}(38)$ & $115.8(3)$ \\
\hline $\mathrm{C}(33)-\mathrm{O}(12)-\mathrm{H}(12 \mathrm{O})$ & 109.00 & $O(13)-C(37)-C(36)$ & $110.5(3)$ \\
\hline $\mathrm{C}(34)-\mathrm{O}(13)-\mathrm{C}(37)$ & 107.6(3) & $C(36)-C(37)-C(38)$ & $60.7(2)$ \\
\hline $\mathrm{C}(39)-\mathrm{O}(15)-\mathrm{C}(40)$ & $121.3(3)$ & $\mathrm{O}(13)-\mathrm{C}(37)-\mathrm{C}(38)$ & $117.4(3)$ \\
\hline $\mathrm{C}(44)-\mathrm{O}(16)-\mathrm{H}(16 \mathrm{O})$ & 110.00 & $C(36)-C(38)-C(39)$ & $115.9(2)$ \\
\hline $\mathrm{O}(1)-\mathrm{C}(1)-\mathrm{C}(2)$ & $106.2(3)$ & $C(37)-C(38)-C(39)$ & $115.7(3)$ \\
\hline$C(3)-C(2)-C(11)$ & $115.2(3)$ & $C(36)-C(38)-C(37)$ & $57.9(2)$ \\
\hline$C(1)-C(2)-C(11)$ & $113.4(3)$ & $\mathrm{O}(14)-\mathrm{C}(39)-\mathrm{C}(38)$ & $124.0(3)$ \\
\hline$C(1)-C(2)-C(3)$ & 103.1(3) & $\mathrm{O}(15)-\mathrm{C}(39)-\mathrm{C}(38)$ & $110.4(3)$ \\
\hline$C(4)-C(3)-C(5)$ & $61.0(2)$ & $\mathrm{O}(14)-\mathrm{C}(39)-\mathrm{O}(15)$ & $125.6(3)$ \\
\hline$C(2)-C(3)-C(5)$ & $115.8(3)$ & $\mathrm{O}(15)-\mathrm{C}(40)-\mathrm{C}(42)$ & $101.9(3)$ \\
\hline$C(2)-C(3)-C(4)$ & $105.5(3)$ & $\mathrm{O}(15)-\mathrm{C}(40)-\mathrm{C}(43)$ & $109.9(3)$ \\
\hline$O(1)-C(4)-C(3)$ & $110.9(3)$ & $C(41)-C(40)-C(42)$ & $111.1(3)$ \\
\hline$O(1)-C(4)-C(5)$ & $117.7(3)$ & $C(41)-C(40)-C(43)$ & $112.1(3)$ \\
\hline$C(3)-C(4)-C(5)$ & $61.2(2)$ & $C(42)-C(40)-C(43)$ & $110.7(3)$ \\
\hline
\end{tabular}




$\begin{array}{ll}\mathrm{C}(4)-\mathrm{C}(5)-\mathrm{C}(6) & 116.1(3) \\ \mathrm{C}(3)-\mathrm{C}(5)-\mathrm{C}(4) & 57.8(2) \\ \mathrm{C}(3)-\mathrm{C}(5)-\mathrm{C}(6) & 116.9(3) \\ \mathrm{O}(3)-\mathrm{C}(6)-\mathrm{C}(5) & 110.4(3) \\ \mathrm{O}(2)-\mathrm{C}(6)-\mathrm{C}(5) & 123.9(3) \\ \mathrm{O}(2)-\mathrm{C}(6)-\mathrm{O}(3) & 125.7(3) \\ \mathrm{C}(8)-\mathrm{C}(7)-\mathrm{C}(10) & 111.8(3) \\ \mathrm{C}(8)-\mathrm{C}(7)-\mathrm{C}(9) & 110.1(3) \\ \mathrm{O}(3)-\mathrm{C}(7)-\mathrm{C}(9) & 110.7(3) \\ \mathrm{C}(9)-\mathrm{C}(7)-\mathrm{C}(10) & 112.6(3) \\ \mathrm{O}(3)-\mathrm{C}(7)-\mathrm{C}(10) & 110.3(3) \\ \mathrm{O}(3)-\mathrm{C}(7)-\mathrm{C}(8) & 100.8(3) \\ \mathrm{O}(4)-\mathrm{C}(11)-\mathrm{C}(2) & 113.3(3) \\ \mathrm{O}(1)-\mathrm{C}(1)-\mathrm{H}(1 \mathrm{~B}) & 111.00 \\ \mathrm{C}(2)-\mathrm{C}(1)-\mathrm{H}(1 \mathrm{~B}) & 110.00 \\ \mathrm{O}(1)-\mathrm{C}(1)-\mathrm{H}(1 \mathrm{~A}) & 110.00 \\ \mathrm{H}(1 \mathrm{~A})-\mathrm{C}(1)-\mathrm{H}(1 \mathrm{~B}) & 109.00 \\ \mathrm{C}(2)-\mathrm{C}(1)-\mathrm{H}(1 \mathrm{~A}) & 111.00 \\ \mathrm{C}(11)-\mathrm{C}(2)-\mathrm{H}(2) & 108.00 \\ \mathrm{C}(3)-\mathrm{C}(2)-\mathrm{H}(2) & 108.00 \\ \mathrm{C}(1)-\mathrm{C}(2)-\mathrm{H}(2) & 108.00 \\ \mathrm{C}(5)-\mathrm{C}(3)-\mathrm{H}(3) & 120.00 \\ \mathrm{C}(2)-\mathrm{C}(3)-\mathrm{H}(3) & 120.00 \\ \mathrm{C}(4)-\mathrm{C}(3)-\mathrm{H}(3) & 120.00 \\ \mathrm{O}(1)-\mathrm{C}(4)-\mathrm{H}(4) & 118.00 \\ \mathrm{C}(3)-\mathrm{C}(4)-\mathrm{H}(4) & 118.00 \\ \mathrm{C}(5)-\mathrm{C}(4)-\mathrm{H}(4) & 118.00 \\ \mathrm{C}(6)-\mathrm{C}(5)-\mathrm{H}(5) & 117.00 \\ \mathrm{C}(4)-\mathrm{C}(5)-\mathrm{H}(5) & 118.00 \\ \mathrm{C}(3)-\mathrm{C}(5)-\mathrm{H}(5) & 118.00 \\ \mathrm{C}(7)-\mathrm{C}(8)-\mathrm{H}(8 \mathrm{~B}) & 109.00 \\ \mathrm{C}(7)-\mathrm{C}(8)-\mathrm{H}(8 \mathrm{C}) & 109.00 \\ \mathrm{H}(8 \mathrm{~A})-\mathrm{C}(8)-\mathrm{H}(8 \mathrm{C}) & 110.00 \\ \mathrm{H}(8 \mathrm{~A})-\mathrm{C}(8)-\mathrm{H}(8 \mathrm{~B}) & 109.00 \\ \mathrm{H}(8 \mathrm{~B})-\mathrm{C}(8)-\mathrm{H}(8 \mathrm{C}) & 109.00 \\ \mathrm{C}(7)-\mathrm{C}(8)-\mathrm{H}(8 \mathrm{~A}) & 109.00 \\ \mathrm{C}(7)-\mathrm{C}(9)-\mathrm{H}(9 \mathrm{~B}) & 109.00 \\ \mathrm{C}(7)-\mathrm{C}(9)-\mathrm{H}(9 \mathrm{C}) & 109.00 \\ \mathrm{H}(9 \mathrm{~A})-\mathrm{C}(9)-\mathrm{H}(9 \mathrm{C}) & 109.00 \\ \mathrm{H}(9 \mathrm{~A})-\mathrm{C}(9)-\mathrm{H}(9)-\mathrm{H}(9)-\mathrm{B}(9 \mathrm{C}) & 110.00 \\ & 109.00 \\ & 110.00 \\ & \end{array}$

\begin{tabular}{ll} 
O(15)-C(40)-C(41) & $110.7(3)$ \\
$\mathrm{O}(16)-\mathrm{C}(44)-\mathrm{C}(35)$ & $111.5(3)$ \\
$\mathrm{O}(13)-\mathrm{C}(34)-\mathrm{H}(34 \mathrm{~A})$ & 110.00 \\
$\mathrm{O}(13)-\mathrm{C}(34)-\mathrm{H}(34 \mathrm{~B})$ & 110.00 \\
$\mathrm{C}(35)-\mathrm{C}(34)-\mathrm{H}(34 \mathrm{~A})$ & 110.00 \\
$\mathrm{C}(35)-\mathrm{C}(34)-\mathrm{H}(34 \mathrm{~B})$ & 110.00 \\
$\mathrm{H}(34 \mathrm{~A})-\mathrm{C}(34)-\mathrm{H}(34 \mathrm{~B})$ & 109.00 \\
$\mathrm{C}(34)-\mathrm{C}(35)-\mathrm{H}(35)$ & 108.00 \\
$\mathrm{C}(36)-\mathrm{C}(35)-\mathrm{H}(35)$ & 109.00 \\
$\mathrm{C}(44)-\mathrm{C}(35)-\mathrm{H}(35)$ & 109.00 \\
$\mathrm{C}(35)-\mathrm{C}(36)-\mathrm{H}(36)$ & 120.00 \\
$\mathrm{C}(37)-\mathrm{C}(36)-\mathrm{H}(36)$ & 120.00 \\
$\mathrm{C}(38)-\mathrm{C}(36)-\mathrm{H}(36)$ & 120.00 \\
$\mathrm{O}(13)-\mathrm{C}(37)-\mathrm{H}(37)$ & 118.00 \\
$\mathrm{C}(36)-\mathrm{C}(37)-\mathrm{H}(37)$ & 118.00 \\
$\mathrm{C}(38)-\mathrm{C}(37)-\mathrm{H}(37)$ & 118.00 \\
$\mathrm{C}(36)-\mathrm{C}(38)-\mathrm{H}(38)$ & 118.00 \\
$\mathrm{C}(37)-\mathrm{C}(38)-\mathrm{H}(38)$ & 118.00 \\
$\mathrm{C}(39)-\mathrm{C}(38)-\mathrm{H}(38)$ & 118.00 \\
$\mathrm{C}(40)-\mathrm{C}(41)-\mathrm{H}(41 \mathrm{~A})$ & 109.00 \\
$\mathrm{C}(40)-\mathrm{C}(41)-\mathrm{H}(41 \mathrm{~B})$ & 109.00 \\
$\mathrm{C}(40)-\mathrm{C}(41)-\mathrm{H}(41 \mathrm{C})$ & 109.00 \\
$\mathrm{H}(41 \mathrm{~A})-\mathrm{C}(41)-\mathrm{H}(41 \mathrm{~B})$ & 110.00 \\
$\mathrm{H}(41 \mathrm{~A})-\mathrm{C}(41)-\mathrm{H}(41 \mathrm{C})$ & 109.00 \\
$\mathrm{H}(41 \mathrm{~B})-\mathrm{C}(41)-\mathrm{H}(41 \mathrm{C})$ & 109.00 \\
$\mathrm{C}(40)-\mathrm{C}(42)-\mathrm{H}(42 \mathrm{~A})$ & 109.00 \\
$\mathrm{C}(40)-\mathrm{C}(42)-\mathrm{H}(42 \mathrm{~B})$ & 109.00 \\
$\mathrm{C}(40)-\mathrm{C}(42)-\mathrm{H}(42 \mathrm{C})$ & 109.00 \\
$\mathrm{H}(42 \mathrm{~A})-\mathrm{C}(42)-\mathrm{H}(42 \mathrm{~B})$ & 110.00 \\
$\mathrm{H}(42 \mathrm{~A})-\mathrm{C}(42)-\mathrm{H}(42 \mathrm{C})$ & 109.00 \\
$\mathrm{H}(42 \mathrm{~B})-\mathrm{C}(42)-\mathrm{H}(42 \mathrm{C})$ & 109.00 \\
$\mathrm{C}(40)-\mathrm{C}(43)-\mathrm{H}(43 \mathrm{~A})$ & 109.00 \\
$\mathrm{C}(40)-\mathrm{C}(43)-\mathrm{H}(43 \mathrm{~B})$ & 109.00 \\
$\mathrm{C}(40)-\mathrm{C}(43)-\mathrm{H}(43 \mathrm{C})$ & 109.00 \\
$\mathrm{H}(43 \mathrm{~A})-\mathrm{C}(43)-\mathrm{H}(43 \mathrm{~B})$ & 109.00 \\
$\mathrm{H}(43 \mathrm{~A})-\mathrm{C}(43)-\mathrm{H}(43 \mathrm{C})$ & 109.00 \\
$\mathrm{H}(43 \mathrm{~B})-\mathrm{C}(43)-\mathrm{H}(43 \mathrm{C})$ & 110.00 \\
$\mathrm{O}(16)-\mathrm{C}(44)-\mathrm{H}(44 \mathrm{~A})$ & 109.00 \\
$\mathrm{O}(16)-\mathrm{C}(44)-\mathrm{H}(44 \mathrm{~B})$ & 109.00 \\
$\mathrm{C}(35)-\mathrm{C}(44)-\mathrm{H}(44 \mathrm{~A})$ & 109.00 \\
& 109.00 \\
& 108.00 \\
\hline
\end{tabular}


Table 4: Anisotropic displacement parameters $\left(A^{2} \times 10^{3}\right)$ for 140 . The anisotropic

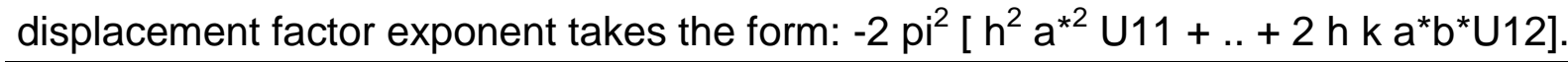

\begin{tabular}{|c|c|c|c|c|c|c|}
\hline Atom & U11 & U22 & U33 & U23 & U13 & U12 \\
\hline $\mathrm{O}(1)$ & $50(2)$ & $43(1)$ & $35(1)$ & $-5(1)$ & $19(1)$ & $-16(1)$ \\
\hline $\mathrm{O}(2)$ & $33(1)$ & $38(1)$ & $36(1)$ & $1(1)$ & $1(1)$ & $9(1)$ \\
\hline $\mathrm{O}(3)$ & $27(1)$ & $29(1)$ & $39(1)$ & $-2(1)$ & $-3(1)$ & $0(1)$ \\
\hline $\mathrm{O}(4)$ & $45(2)$ & $39(1)$ & $43(2)$ & $-6(1)$ & $-1(1)$ & $8(1)$ \\
\hline $\mathrm{C}(1)$ & $46(2)$ & $35(2)$ & $34(2)$ & $-3(1)$ & $8(2)$ & $-9(2)$ \\
\hline $\mathrm{C}(2)$ & $31(2)$ & $34(2)$ & $27(2)$ & $-3(1)$ & $3(1)$ & $-2(1)$ \\
\hline$C(3)$ & $25(2)$ & $35(2)$ & $24(2)$ & $-1(1)$ & $2(1)$ & $-3(1)$ \\
\hline$C(4)$ & $28(2)$ & $41(2)$ & $29(2)$ & $-5(1)$ & $7(1)$ & $-6(1)$ \\
\hline$C(5)$ & $28(2)$ & $31(2)$ & $25(1)$ & $2(1)$ & $0(1)$ & $-2(1)$ \\
\hline$C(6)$ & $24(2)$ & $35(2)$ & $27(2)$ & $0(1)$ & $7(1)$ & $2(1)$ \\
\hline$C(7)$ & $26(2)$ & $28(2)$ & $41(2)$ & $-5(1)$ & $3(1)$ & $0(1)$ \\
\hline $\mathrm{C}(8)$ & $36(2)$ & $31(2)$ & $55(2)$ & $-9(2)$ & $-7(2)$ & $-4(1)$ \\
\hline $\mathrm{C}(9)$ & $34(2)$ & $43(2)$ & $39(2)$ & $-12(2)$ & $7(1)$ & $3(1)$ \\
\hline$C(10)$ & $33(2)$ & $32(2)$ & $53(2)$ & $-3(2)$ & $11(2)$ & $-1(1)$ \\
\hline$C(11)$ & $31(2)$ & $38(2)$ & $34(2)$ & $-3(1)$ & $4(1)$ & $2(1)$ \\
\hline $\mathrm{O}(5)$ & $30(1)$ & $31(1)$ & $27(1)$ & $5(1)$ & $4(1)$ & $3(1)$ \\
\hline $\mathrm{O}(6)$ & $20(1)$ & $39(1)$ & $40(1)$ & $-8(1)$ & $5(1)$ & $-1(1)$ \\
\hline $\mathrm{O}(7)$ & $23(1)$ & $27(1)$ & $28(1)$ & $-3(1)$ & $3(1)$ & $1(1)$ \\
\hline $\mathrm{O}(8)$ & $31(1)$ & $33(1)$ & $30(1)$ & $5(1)$ & $-1(1)$ & $1(1)$ \\
\hline$C(12)$ & $26(2)$ & $28(1)$ & $31(2)$ & $2(1)$ & $5(1)$ & $6(1)$ \\
\hline$C(13)$ & $24(2)$ & $28(1)$ & $25(1)$ & $-4(1)$ & $1(1)$ & $3(1)$ \\
\hline$C(14)$ & $21(1)$ & $28(1)$ & $23(1)$ & $0(1)$ & $1(1)$ & $1(1)$ \\
\hline$C(15)$ & $24(2)$ & $30(2)$ & $25(2)$ & $3(1)$ & $2(1)$ & $1(1)$ \\
\hline$C(16)$ & $17(1)$ & $30(2)$ & $29(1)$ & $-4(1)$ & $2(1)$ & $0(1)$ \\
\hline$C(17)$ & $23(2)$ & $30(1)$ & $24(1)$ & $0(1)$ & $7(1)$ & $2(1)$ \\
\hline $\mathrm{C}(18)$ & $30(2)$ & $25(1)$ & $27(1)$ & $-2(1)$ & $6(1)$ & $5(1)$ \\
\hline$C(19)$ & $41(2)$ & $31(2)$ & $39(2)$ & $-3(1)$ & $3(1)$ & $1(1)$ \\
\hline$C(20)$ & $53(2)$ & $38(2)$ & $35(2)$ & $1(1)$ & $-3(2)$ & $12(2)$ \\
\hline$C(21)$ & $35(2)$ & $38(2)$ & $37(2)$ & $-5(1)$ & $15(1)$ & $3(1)$ \\
\hline$C(22)$ & $22(2)$ & $30(2)$ & $27(1)$ & $0(1)$ & $2(1)$ & $3(1)$ \\
\hline $\mathrm{O}(9)$ & $30(1)$ & $31(1)$ & $30(1)$ & $1(1)$ & $3(1)$ & $1(1)$ \\
\hline $\mathrm{O}(10)$ & $24(1)$ & $58(2)$ & $33(1)$ & $7(1)$ & $3(1)$ & $5(1)$ \\
\hline $\mathrm{O}(11)$ & $25(1)$ & $35(1)$ & $26(1)$ & $2(1)$ & $3(1)$ & $2(1)$ \\
\hline $\mathrm{O}(12)$ & $39(2)$ & $42(1)$ & $43(1)$ & $2(1)$ & $-6(1)$ & $7(1)$ \\
\hline$C(23)$ & $27(2)$ & $30(2)$ & $28(2)$ & $3(1)$ & $1(1)$ & $2(1)$ \\
\hline$C(24)$ & $28(2)$ & $34(2)$ & $28(2)$ & $6(1)$ & $6(1)$ & $2(1)$ \\
\hline$C(25)$ & $25(2)$ & $34(2)$ & $33(2)$ & $5(1)$ & $5(1)$ & $-1(1)$ \\
\hline$C(26)$ & $22(2)$ & $38(2)$ & $28(2)$ & $3(1)$ & $6(1)$ & $2(1)$ \\
\hline$C(27)$ & $20(1)$ & $29(1)$ & $29(2)$ & $3(1)$ & $3(1)$ & $-1(1)$ \\
\hline$C(28)$ & $20(2)$ & $32(2)$ & $30(2)$ & $6(1)$ & $2(1)$ & $2(1)$ \\
\hline$C(29)$ & $30(2)$ & $34(2)$ & $29(2)$ & $-1(1)$ & $3(1)$ & $0(1)$ \\
\hline$C(30)$ & $47(2)$ & $37(2)$ & $39(2)$ & $8(2)$ & $-14(2)$ & $-2(2)$ \\
\hline$C(31)$ & $42(2)$ & $83(3)$ & $31(2)$ & $-11(2)$ & $6(2)$ & $-11(2)$ \\
\hline$C(32)$ & $37(2)$ & $33(2)$ & $48(2)$ & $0(2)$ & $-6(2)$ & $2(1)$ \\
\hline
\end{tabular}




$\begin{array}{lllllll}\mathrm{C}(33) & 30(2) & 32(2) & 38(2) & 4(1) & 4(1) & -1(1) \\ \mathrm{O}(13) & 43(2) & 48(1) & 32(1) & 5(1) & 7(1) & 16(1) \\ \mathrm{O}(14) & 33(1) & 36(1) & 28(1) & 0(1) & 0(1) & -6(1) \\ \mathrm{O}(15) & 28(1) & 33(1) & 25(1) & 0(1) & 5(1) & -1(1) \\ \mathrm{O}(16) & 43(2) & 46(1) & 24(1) & 5(1) & -3(1) & -10(1) \\ \mathrm{C}(34) & 41(2) & 40(2) & 29(2) & 0(1) & 8(1) & 1(2) \\ \mathrm{C}(35) & 31(2) & 34(2) & 24(1) & 4(1) & 3(1) & -1(1) \\ \mathrm{C}(36) & 25(2) & 29(1) & 27(2) & 3(1) & 2(1) & -3(1) \\ \mathrm{C}(37) & 30(2) & 38(2) & 28(2) & 3(1) & 3(1) & 6(1) \\ \mathrm{C}(38) & 30(2) & 27(1) & 27(2) & 3(1) & 2(1) & -3(1) \\ \mathrm{C}(39) & 24(2) & 29(2) & 28(2) & 4(1) & 1(1) & 2(1) \\ \mathrm{C}(40) & 21(2) & 40(2) & 24(1) & 1(1) & 6(1) & 1(1) \\ \mathrm{C}(41) & 26(2) & 48(2) & 28(2) & 6(1) & 7(1) & 3(1) \\ \mathrm{C}(42) & 27(2) & 45(2) & 32(2) & 4(1) & 7(1) & -1(1) \\ \mathrm{C}(43) & 30(2) & 43(2) & 36(2) & -6(1) & 1(1) & 8(1) \\ \mathrm{C}(44) & 37(2) & 36(2) & 25(2) & 2(1) & -1(1) & -1(1)\end{array}$

Table 5: Hydrogen coordinates $\left(x 10^{4}\right)$ and isotropic displacement parameters $\left(A^{2} x\right.$ $\left.10^{3}\right)$ for $\mathbf{1 4 0 .}$

\begin{tabular}{lllll}
\hline Atom & $x$ & $y$ & $z$ & $U(e q)$ \\
\hline$H(1 A)$ & 6388 & 4156 & -1957 & 46 \\
$H(1 B)$ & 8634 & 4912 & -1588 & 46 \\
$H(2)$ & 8526 & 3321 & -831 & 37 \\
$H(3)$ & 8088 & 744 & -1084 & 33 \\
$H(4)$ & 10259 & 916 & -2013 & 39 \\
$H(4 O)$ & 5509 & 5375 & -885 & 51 \\
$H(5)$ & 5201 & 1713 & -2162 & 33 \\
$H(8 A)$ & 2171 & -1300 & -3511 & 50 \\
$H(8 B)$ & 260 & -1474 & -3007 & 50 \\
$H(8 C)$ & 949 & -2866 & -3412 & 50 \\
$H(9 A)$ & 4920 & -3947 & -3252 & 46 \\
$H(9 B)$ & 6757 & -3242 & -2746 & 46 \\
$H(9 C)$ & 6150 & -2384 & -3351 & 46 \\
$H(10 A)$ & 1395 & -2587 & -2029 & 47 \\
$H(10 B)$ & 3893 & -3342 & -1943 & 47 \\
$H(10 C)$ & 1884 & -4077 & -2395 & 47 \\
$H(11 A)$ & 3677 & 3159 & -1250 & 41 \\
$H(11 B)$ & 4588 & 2667 & -595 & 41 \\
$H(8 O)$ & 8631 & 2226 & 2337 & 37 \\
$H(12 A)$ & 4961 & 3595 & 727 & 34 \\
$H(12 B)$ & 5686 & 5168 & 1036 & 34 \\
$H(13)$ & 8463 & 4263 & 1662 & 31 \\
$H(14)$ & 11369 & 2750 & 1229 & 29 \\
$H(15)$ & 11234 & 3879 & 241 & 31 \\
$H(16)$ & 7423 & 1613 & 376 & 30 \\
$H(19 A)$ & 10543 & -3473 & -637 & 45
\end{tabular}




\begin{tabular}{|c|c|c|c|c|}
\hline $\mathrm{H}(19 \mathrm{~B})$ & 8891 & -2180 & -854 & 45 \\
\hline$H(19 C)$ & 8616 & -2844 & -199 & 45 \\
\hline $\mathrm{H}(20 \mathrm{~A})$ & 11725 & -2327 & 615 & 50 \\
\hline $\mathrm{H}(20 \mathrm{~B})$ & 13985 & -1324 & 484 & 50 \\
\hline $\mathrm{H}(20 \mathrm{C})$ & 13696 & -2942 & 187 & 50 \\
\hline$H(21 A)$ & 14012 & -1788 & -877 & 43 \\
\hline $\mathrm{H}(21 \mathrm{~B})$ & 14301 & -221 & -533 & 43 \\
\hline $\mathrm{H}(21 \mathrm{C})$ & 12231 & -518 & -1042 & 43 \\
\hline $\mathrm{H}(22 \mathrm{~A})$ & 5093 & 2886 & 1898 & 31 \\
\hline $\mathrm{H}(22 \mathrm{~B})$ & 5619 & 1665 & 1391 & 31 \\
\hline $\mathrm{H}(12 \mathrm{O})$ & -70 & -1392 & 1678 & 49 \\
\hline $\mathrm{H}(23 \mathrm{~A})$ & 1057 & -3241 & 2315 & 34 \\
\hline $\mathrm{H}(23 \mathrm{~B})$ & 1704 & -3582 & 1625 & 34 \\
\hline $\mathrm{H}(24)$ & 4476 & -1809 & 1635 & 36 \\
\hline $\mathrm{H}(25)$ & 7465 & -1693 & 2440 & 36 \\
\hline $\mathrm{H}(26)$ & 7381 & -4317 & 2585 & 35 \\
\hline $\mathrm{H}(27)$ & 3670 & -2747 & 3242 & 31 \\
\hline $\mathrm{H}(30 \mathrm{~A})$ & 10493 & -3631 & 5138 & 50 \\
\hline $\mathrm{H}(30 \mathrm{~B})$ & 10633 & -3815 & 4419 & 50 \\
\hline $\mathrm{H}(30 \mathrm{C})$ & 8489 & -4561 & 4751 & 50 \\
\hline$H(31 A)$ & 5384 & -2984 & 5185 & 63 \\
\hline $\mathrm{H}(31 \mathrm{~B})$ & 5574 & -1247 & 5122 & 63 \\
\hline $\mathrm{H}(31 \mathrm{C})$ & 7373 & -2043 & 5573 & 63 \\
\hline $\mathrm{H}(32 \mathrm{~A})$ & 10768 & -854 & 4989 & 47 \\
\hline $\mathrm{H}(32 \mathrm{~B})$ & 8777 & -129 & 4570 & 47 \\
\hline $\mathrm{H}(32 \mathrm{C})$ & 10720 & -1120 & 4270 & 47 \\
\hline $\mathrm{H}(33 \mathrm{~A})$ & 1709 & -718 & 2593 & 40 \\
\hline $\mathrm{H}(33 \mathrm{~B})$ & 3396 & 289 & 2204 & 40 \\
\hline$H(160)$ & 1705 & -5916 & 2546 & 46 \\
\hline $\mathrm{H}(34 \mathrm{~A})$ & 3125 & -8878 & 3557 & 44 \\
\hline $\mathrm{H}(34 \mathrm{~B})$ & 5295 & -8380 & 3162 & 44 \\
\hline $\mathrm{H}(35)$ & 4907 & -5986 & 3391 & 36 \\
\hline$H(36)$ & 4454 & -5243 & 4435 & 32 \\
\hline $\mathrm{H}(37)$ & 6887 & -7192 & 4837 & 38 \\
\hline $\mathrm{H}(38)$ & 1888 & -8128 & 4508 & 34 \\
\hline $\mathrm{H}(41 \mathrm{~A})$ & 1926 & -7577 & 7050 & 41 \\
\hline $\mathrm{H}(41 \mathrm{~B})$ & 3634 & -6843 & 6583 & 41 \\
\hline $\mathrm{H}(41 \mathrm{C})$ & 3099 & -8571 & 6543 & 41 \\
\hline $\mathrm{H}(42 \mathrm{~A})$ & -961 & -9525 & 6180 & 41 \\
\hline $\mathrm{H}(42 \mathrm{~B})$ & -2924 & -8383 & 5987 & 41 \\
\hline $\mathrm{H}(42 \mathrm{C})$ & -2113 & -8517 & 6685 & 41 \\
\hline $\mathrm{H}(43 \mathrm{~A})$ & -1154 & -5732 & 6693 & 43 \\
\hline $\mathrm{H}(43 \mathrm{~B})$ & -1985 & -5771 & 5991 & 43 \\
\hline $\mathrm{H}(43 \mathrm{C})$ & 588 & -5137 & 6202 & 43 \\
\hline $\mathrm{H}(44 \mathrm{~A})$ & 153 & -6969 & 3565 & 39 \\
\hline $\mathrm{H}(44 \mathrm{~B})$ & 902 & -5301 & 3457 & 39 \\
\hline
\end{tabular}


Table 6: Torsion angles [deg] for 140.

$\begin{array}{ll}\mathrm{C}(4)-\mathrm{O}(1)-\mathrm{C}(1)-\mathrm{C}(2) & 25.9(4) \\ \mathrm{C}(1)-\mathrm{O}(1)-\mathrm{C}(4)-\mathrm{C}(5) & 51.3(4) \\ \mathrm{C}(1)-\mathrm{O}(1)-\mathrm{C}(4)-\mathrm{C}(3) & -16.2(4) \\ \mathrm{C}(7)-\mathrm{O}(3)-\mathrm{C}(6)-\mathrm{C}(5) & 179.5(3) \\ \mathrm{C}(6)-\mathrm{O}(3)-\mathrm{C}(7)-\mathrm{C}(8) & -175.3(3) \\ \mathrm{C}(7)-\mathrm{O}(3)-\mathrm{C}(6)-\mathrm{O}(2) & 0.2(5) \\ \mathrm{C}(6)-\mathrm{O}(3)-\mathrm{C}(7)-\mathrm{C}(10) & 66.5(4) \\ \mathrm{C}(6)-\mathrm{O}(3)-\mathrm{C}(7)-\mathrm{C}(9) & -58.8(4) \\ \mathrm{C}(12)-\mathrm{O}(5)-\mathrm{C}(15)-\mathrm{C}(16) & 53.4(3) \\ \mathrm{C}(15)-\mathrm{O}(5)-\mathrm{C}(12)-\mathrm{C}(13) & 22.3(3) \\ \mathrm{C}(12)-\mathrm{O}(5)-\mathrm{C}(15)-\mathrm{C}(14) & -13.8(3) \\ \mathrm{C}(17)-\mathrm{O}(7)-\mathrm{C}(18)-\mathrm{C}(21) & -64.3(4) \\ \mathrm{C}(17)-\mathrm{O}(7)-\mathrm{C}(18)-\mathrm{C}(20) & 60.9(4) \\ \mathrm{C}(18)-\mathrm{O}(7)-\mathrm{C}(17)-\mathrm{C}(16) & -175.8(2) \\ \mathrm{C}(17)-\mathrm{O}(7)-\mathrm{C}(18)-\mathrm{C}(19) & 178.1(3) \\ \mathrm{C}(18)-\mathrm{O}(7)-\mathrm{C}(17)-\mathrm{O}(6) & 4.7(5) \\ \mathrm{C}(23)-\mathrm{O}(9)-\mathrm{C}(26)-\mathrm{C}(25) & -12.9(4) \\ \mathrm{C}(23)-\mathrm{O}(9)-\mathrm{C}(26)-\mathrm{C}(27) & 55.4(4) \\ \mathrm{C}(26)-\mathrm{O}(9)-\mathrm{C}(23)-\mathrm{C}(24) & 22.1(3) \\ \mathrm{C}(28)-\mathrm{O}(11)-\mathrm{C}(29)-\mathrm{C}(31) & 175.9(3) \\ \mathrm{C}(28)-\mathrm{O}(11)-\mathrm{C}(29)-\mathrm{C}(32) & 57.6(4) \\ \mathrm{C}(29)-\mathrm{O}(11)-\mathrm{C}(28)-\mathrm{O}(10) & 3.5(6) \\ \mathrm{C}(29)-\mathrm{O}(11)-\mathrm{C}(28)-\mathrm{C}(27) & -179.6(3) \\ \mathrm{C}(28)-\mathrm{O}(11)-\mathrm{C}(29)-\mathrm{C}(30) & -66.4(4) \\ \mathrm{C}(34)-\mathrm{O}(13)-\mathrm{C}(37)-\mathrm{C}(38) & 50.8(4) \\ \mathrm{C}(37)-\mathrm{O}(13)-\mathrm{C}(34)-\mathrm{C}(35) & 25.8(4) \\ \mathrm{C}(34)-\mathrm{O}(13)-\mathrm{C}(37)-\mathrm{C}(36) & -16.0(4) \\ \mathrm{C}(40)-\mathrm{O}(15)-\mathrm{C}(39)-\mathrm{C}(38) & 177.1(3) \\ \mathrm{C}(40)-\mathrm{O}(15)-\mathrm{C}(39)-\mathrm{O}(14) & -1.8(5) \\ \mathrm{C}(39)-\mathrm{O}(15)-\mathrm{C}(40)-\mathrm{C}(42) & -178.7(3) \\ \mathrm{C}(39)-\mathrm{O}(15)-\mathrm{C}(40)-\mathrm{C}(43) & 63.9(4) \\ \mathrm{C}(39)-\mathrm{O}(15)-\mathrm{C}(40)-\mathrm{C}(41) & -60.5(4) \\ \mathrm{O}(1)-\mathrm{C}(1)-\mathrm{C}(2)-\mathrm{C}(3) & -25.2(4) \\ \mathrm{O}(1)-\mathrm{C}(1)-\mathrm{C}(2)-\mathrm{C}(11) & -150.3(3) \\ \mathrm{C}(1)-\mathrm{C}(2)-\mathrm{C}(11)-\mathrm{O}(4) & -64.8(4) \\ \mathrm{C}(1)-\mathrm{C}(2)-\mathrm{C}(3)-\mathrm{C}(4) & 15.4(3) \\ \mathrm{C}(1)-\mathrm{C}(2)-\mathrm{C}(3)-\mathrm{C}(5) & -49.5(4) \\ \mathrm{C}(3)-\mathrm{C}(2)-\mathrm{C}(11)-\mathrm{O}(4) & 176.8(3) \\ \mathrm{C}(11)-\mathrm{C}(2)-\mathrm{C}(3)-\mathrm{C}(4) & 139.4(3) \\ \mathrm{C}(11)-\mathrm{C}(2)-\mathrm{C}(3)-\mathrm{C}(5) & 74.5(4) \\ \mathrm{C}(2)-\mathrm{C}(3)-\mathrm{C}(4)-\mathrm{O}(1) & -0.3(4) \\ \mathrm{C}(2)-\mathrm{C}(3)-\mathrm{C}(5)-\mathrm{C}(6) & -160.7(3) \\ \mathrm{C}(5)-\mathrm{C}(3)-\mathrm{C}(4)-\mathrm{O}(1) & 110.9(3) \\ \mathrm{C}(4)-\mathrm{C}(3)-\mathrm{C}(5)-\mathrm{C}(6) & 105.3(3) \\ \mathrm{C}(2)-\mathrm{C}(3)-\mathrm{C}(5)-\mathrm{C}(4) & 94.1(3) \\ \mathrm{C}(2)-\mathrm{C}(3)-\mathrm{C}(4)-\mathrm{C}(5) & -111.3(3) \\ & \end{array}$

\begin{tabular}{|c|c|}
\hline$C(12)-C(13)-C(14)-C(15)$ & $13.3(3)$ \\
\hline$C(12)-C(13)-C(14)-C(16)$ & $-51.9(3)$ \\
\hline $\mathrm{C}(12)-\mathrm{C}(13)-\mathrm{C}(22)-\mathrm{O}(8)$ & $176.9(2)$ \\
\hline$C(13)-C(14)-C(15)-O(5)$ & $-0.5(3)$ \\
\hline$C(13)-C(14)-C(16)-C(15)$ & $95.1(3)$ \\
\hline$C(13)-C(14)-C(16)-C(17)$ & $-158.6(2)$ \\
\hline $\mathrm{C}(16)-\mathrm{C}(14)-\mathrm{C}(15)-\mathrm{O}(5)$ & $111.0(3)$ \\
\hline$C(15)-C(14)-C(16)-C(17)$ & 106.3(3) \\
\hline$C(13)-C(14)-C(15)-C(16)$ & $-111.5(3)$ \\
\hline $\mathrm{O}(5)-\mathrm{C}(15)-\mathrm{C}(16)-\mathrm{C}(17)$ & 157.3(3) \\
\hline $\mathrm{O}(5)-\mathrm{C}(15)-\mathrm{C}(16)-\mathrm{C}(14)$ & $-98.8(3)$ \\
\hline$C(14)-C(15)-C(16)-C(17)$ & $-103.8(3)$ \\
\hline $\mathrm{C}(15)-\mathrm{C}(16)-\mathrm{C}(17)-\mathrm{O}(7)$ & $-144.9(3)$ \\
\hline$C(14)-C(16)-C(17)-O(6)$ & $-30.0(4)$ \\
\hline $\mathrm{C}(14)-\mathrm{C}(16)-\mathrm{C}(17)-\mathrm{O}(7)$ & $150.5(2)$ \\
\hline$C(15)-C(16)-C(17)-O(6)$ & $34.6(4)$ \\
\hline $\mathrm{O}(9)-\mathrm{C}(23)-\mathrm{C}(24)-\mathrm{C}(25)$ & $-22.2(3)$ \\
\hline $\mathrm{O}(9)-\mathrm{C}(23)-\mathrm{C}(24)-\mathrm{C}(33)$ & $-148.2(3)$ \\
\hline$C(33)-C(24)-C(25)-C(27)$ & $72.3(4)$ \\
\hline$C(23)-C(24)-C(25)-C(26)$ & $14.3(3)$ \\
\hline $\mathrm{C}(25)-\mathrm{C}(24)-\mathrm{C}(33)-\mathrm{O}(12)$ & $-179.7(3)$ \\
\hline$C(23)-C(24)-C(25)-C(27)$ & $-50.4(4)$ \\
\hline$C(33)-C(24)-C(25)-C(26)$ & $137.0(3)$ \\
\hline $\mathrm{C}(23)-\mathrm{C}(24)-\mathrm{C}(33)-\mathrm{O}(12)$ & $-61.2(4)$ \\
\hline $\mathrm{C}(27)-\mathrm{C}(25)-\mathrm{C}(26)-\mathrm{O}(9)$ & $111.5(3)$ \\
\hline$C(24)-C(25)-C(27)-C(26)$ & $93.3(3)$ \\
\hline $\mathrm{C}(24)-\mathrm{C}(25)-\mathrm{C}(26)-\mathrm{O}(9)$ & $-1.5(4)$ \\
\hline $\mathrm{C}(26)-\mathrm{C}(25)-\mathrm{C}(27)-\mathrm{C}(28)$ & 104.1(3) \\
\hline $\mathrm{C}(24)-\mathrm{C}(25)-\mathrm{C}(27)-\mathrm{C}(28)$ & $-162.6(3)$ \\
\hline$C(24)-C(25)-C(26)-C(27)$ & $-112.9(3)$ \\
\hline $\mathrm{O}(9)-\mathrm{C}(26)-\mathrm{C}(27)-\mathrm{C}(25)$ & $-100.0(3)$ \\
\hline $\mathrm{O}(9)-\mathrm{C}(26)-\mathrm{C}(27)-\mathrm{C}(28)$ & $155.4(3)$ \\
\hline$C(25)-C(26)-C(27)-C(28)$ & $-104.6(3)$ \\
\hline $\mathrm{C}(26)-\mathrm{C}(27)-\mathrm{C}(28)-\mathrm{O}(11)$ & $-144.6(3)$ \\
\hline $\mathrm{C}(26)-\mathrm{C}(27)-\mathrm{C}(28)-\mathrm{O}(10)$ & $32.5(5)$ \\
\hline $\mathrm{C}(25)-\mathrm{C}(27)-\mathrm{C}(28)-\mathrm{O}(11)$ & 151.8(3) \\
\hline $\mathrm{C}(25)-\mathrm{C}(27)-\mathrm{C}(28)-\mathrm{O}(10)$ & $-31.2(5)$ \\
\hline $\mathrm{O}(13)-\mathrm{C}(34)-\mathrm{C}(35)-\mathrm{C}(36)$ & $-25.1(4)$ \\
\hline $\mathrm{O}(13)-\mathrm{C}(34)-\mathrm{C}(35)-\mathrm{C}(44)$ & $-148.8(3)$ \\
\hline $\mathrm{C}(34)-\mathrm{C}(35)-\mathrm{C}(44)-\mathrm{O}(16)$ & $-64.6(4)$ \\
\hline$C(34)-C(35)-C(36)-C(38)$ & $-50.1(4)$ \\
\hline $\mathrm{C}(44)-\mathrm{C}(35)-\mathrm{C}(36)-\mathrm{C}(37)$ & $139.9(3)$ \\
\hline$C(34)-C(35)-C(36)-C(37)$ & $15.3(3)$ \\
\hline $\mathrm{C}(36)-\mathrm{C}(35)-\mathrm{C}(44)-\mathrm{O}(16)$ & $177.7(3)$ \\
\hline $\mathrm{C}(44)-\mathrm{C}(35)-\mathrm{C}(36)-\mathrm{C}(38)$ & $74.5(4)$ \\
\hline $\mathrm{C}(37)-\mathrm{C}(36)-\mathrm{C}(38)-\mathrm{C}(39)$ & $105.4(3)$ \\
\hline
\end{tabular}




\begin{tabular}{ll|ll}
$\mathrm{O}(1)-\mathrm{C}(4)-\mathrm{C}(5)-\mathrm{C}(6)$ & $153.5(3)$ & $\mathrm{C}(35)-\mathrm{C}(36)-\mathrm{C}(37)-\mathrm{O}(13)$ & $-0.5(4)$ \\
$\mathrm{C}(3)-\mathrm{C}(4)-\mathrm{C}(5)-\mathrm{C}(6)$ & $-106.7(3)$ & $\mathrm{C}(35)-\mathrm{C}(36)-\mathrm{C}(37)-\mathrm{C}(38)$ & $-111.2(3)$ \\
$\mathrm{O}(1)-\mathrm{C}(4)-\mathrm{C}(5)-\mathrm{C}(3)$ & $-99.8(3)$ & $\mathrm{C}(38)-\mathrm{C}(36)-\mathrm{C}(37)-\mathrm{O}(13)$ & $110.7(3)$ \\
$\mathrm{C}(3)-\mathrm{C}(5)-\mathrm{C}(6)-\mathrm{O}(2)$ & $-25.8(5)$ & $\mathrm{C}(35)-\mathrm{C}(36)-\mathrm{C}(38)-\mathrm{C}(37)$ & $94.6(3)$ \\
$\mathrm{C}(4)-\mathrm{C}(5)-\mathrm{C}(6)-\mathrm{O}(3)$ & $-139.6(3)$ & $\mathrm{C}(35)-\mathrm{C}(36)-\mathrm{C}(38)-\mathrm{C}(39)$ & $-160.1(3)$ \\
$\mathrm{C}(3)-\mathrm{C}(5)-\mathrm{C}(6)-\mathrm{O}(3)$ & $155.0(3)$ & $\mathrm{O}(13)-\mathrm{C}(37)-\mathrm{C}(38)-\mathrm{C}(39)$ & $155.1(3)$ \\
$\mathrm{C}(4)-\mathrm{C}(5)-\mathrm{C}(6)-\mathrm{O}(2)$ & $39.6(5)$ & $\mathrm{C}(36)-\mathrm{C}(37)-\mathrm{C}(38)-\mathrm{C}(39)$ & $-105.6(3)$ \\
$\mathrm{O}(5)-\mathrm{C}(12)-\mathrm{C}(13)-\mathrm{C}(22)$ & $-146.0(3)$ & $\mathrm{O}(13)-\mathrm{C}(37)-\mathrm{C}(38)-\mathrm{C}(36)$ & $-99.3(3)$ \\
$\mathrm{O}(5)-\mathrm{C}(12)-\mathrm{C}(13)-\mathrm{C}(14)$ & $-21.7(3)$ & $\mathrm{C}(37)-\mathrm{C}(38)-\mathrm{C}(39)-\mathrm{O}(14)$ & $40.5(4)$ \\
$\mathrm{C}(22)-\mathrm{C}(13)-\mathrm{C}(14)-\mathrm{C}(16)$ & $70.0(3)$ & $\mathrm{C}(37)-\mathrm{C}(38)-\mathrm{C}(39)-\mathrm{O}(15)$ & $-138.4(3)$ \\
$\mathrm{C}(14)-\mathrm{C}(13)-\mathrm{C}(22)-\mathrm{O}(8)$ & $59.7(3)$ & $\mathrm{C}(36)-\mathrm{C}(38)-\mathrm{C}(39)-\mathrm{O}(14)$ & $-24.5(5)$ \\
$\mathrm{C}(22)-\mathrm{C}(13)-\mathrm{C}(14)-\mathrm{C}(15)$ & $135.2(3)$ & $\mathrm{C}(36)-\mathrm{C}(38)-\mathrm{C}(39)-\mathrm{O}(15)$ & $156.7(3)$
\end{tabular}

Table 7: Hydrogen-bonds for 140 [A and deg.].

\begin{tabular}{lcccc}
\hline $\mathrm{D}-\mathrm{H} \ldots \mathrm{A}$ & $\mathrm{d}(\mathrm{D}-\mathrm{H})$ & $\mathrm{d}(\mathrm{H} \ldots \mathrm{A})$ & $\mathrm{d}(\mathrm{D} \ldots \mathrm{A})$ & $<(\mathrm{DHA})$ \\
\hline $\mathrm{O}(8)-\mathrm{H}(8 \mathrm{O}) \ldots \mathrm{O}(16) \# 1$ & 0.8400 & 18.800 & $2.704(4)$ & 168.00 \\
$\mathrm{O}(16)-\mathrm{H}(16 \mathrm{O}) \ldots \mathrm{O}(9)$ & 0.8400 & 19.600 & $2.779(4)$ & 166.00 \\
$\mathrm{C}(9)-\mathrm{H}(9 \mathrm{~B}) \ldots \mathrm{O}(2)$ & 0.9800 & 24.300 & $2.982(5)$ & 116.00 \\
$\mathrm{C}(10)-\mathrm{H}(10 \mathrm{~A}) \ldots \mathrm{O}(2) \# 2$ & 0.9800 & 25.800 & $3.501(5)$ & 156.00 \\
$\mathrm{C}(10)-\mathrm{H}(10 \mathrm{~B}) \ldots \mathrm{O}(2)$ & 0.9800 & 25.500 & $3.097(5)$ & 115.00 \\
$\mathrm{C}(12)-\mathrm{H}(12 \mathrm{~A}) \ldots \mathrm{O}(6) \# 2$ & 0.9900 & 25.100 & $3.434(4)$ & 155.00 \\
$\mathrm{C}(16)-\mathrm{H}(16) \ldots \mathrm{O}(6) \# 2$ & 10.000 & 24.900 & $3.480(4)$ & 169.00 \\
$\mathrm{C}(19)-\mathrm{H}(19 \mathrm{~B}) \ldots \mathrm{O}(2)$ & 0.9800 & 25.800 & $3.537(5)$ & 167.00 \\
$\mathrm{C}(20)-\mathrm{H}(20 \mathrm{~B}) \ldots \mathrm{O}(6)$ & 0.9800 & 24.200 & $3.002(5)$ & 117.00 \\
$\mathrm{C}(21)-\mathrm{H}(21 \mathrm{~B}) \ldots \mathrm{O}(6)$ & 0.9800 & 24.300 & $3.007(5)$ & 117.00 \\
$\mathrm{C}(27)-\mathrm{H}(27) \ldots \mathrm{O}(10) \# 2$ & 10.000 & 25.200 & $3.517(4)$ & 174.00 \\
$\mathrm{C}(30)-\mathrm{H}(30 \mathrm{~B}) \ldots \mathrm{O}(10)$ & 0.9800 & 24.900 & $3.047(5)$ & 116.00 \\
$\mathrm{C}(32)-\mathrm{H}(32 \mathrm{~B}) \ldots \mathrm{O}(13) \# 3$ & 0.9800 & 24.500 & $3.378(5)$ & 158.00 \\
$\mathrm{C}(32)-\mathrm{H}(32 \mathrm{C}) \ldots \mathrm{O}(10)$ & 0.9800 & 23.500 & $2.956(5)$ & 119.00 \\
$\mathrm{C}(41)-\mathrm{H}(41 \mathrm{~A}) \ldots \mathrm{O}(1) \# 4$ & 0.9800 & 25.300 & $3.459(5)$ & 158.00 \\
$\mathrm{C}(41)-\mathrm{H}(41 \mathrm{~B}) \ldots \mathrm{O}(14)$ & 0.9800 & 24.400 & $3.004(4)$ & 116.00 \\
$\mathrm{C}(43)-\mathrm{H}(43 \mathrm{~B}) \ldots \mathrm{O}(14) \# 2$ & 0.9800 & 25.200 & $3.456(4)$ & 159.00 \\
$\mathrm{C}(43)-\mathrm{H}(43 \mathrm{C}) \ldots \mathrm{O}(14)$ & 0.9800 & 24.300 & $3.022(4)$ & 118.00 \\
$\mathrm{C}(44)-\mathrm{H}(44 \mathrm{~B}) \ldots \mathrm{O}(10) \# 2$ & 0.9900 & 25.800 & $3.548(5)$ & 166.00
\end{tabular}



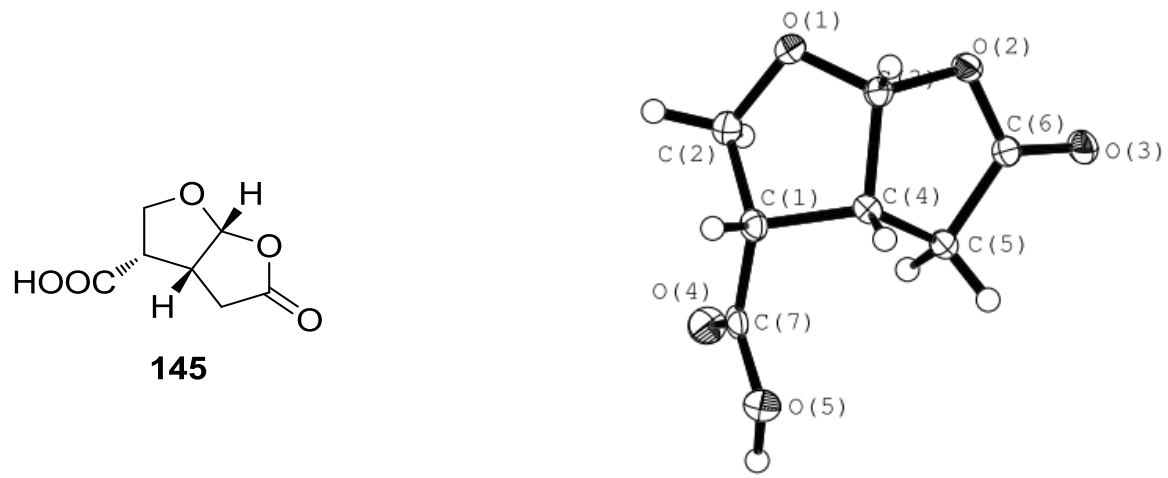

Table 1: Crystal data and structure refinement for $\mathbf{1 4 5}$.

\section{Crystal Data}

Empirical formula

Formula weight

Crystal size

Crystal description

Crystal colour

Crystal system

Space group

Unit cell dimensions

Volume

Z, Calculated density

Absorption coefficient

$\mathrm{F}(000)$

\section{Data Collection}

Measurement device type

Measurement method

Temperature

Wavelength

Monochromator

Theta range for data collection

Index ranges

Reflections collected / unique

Reflections greater $\mathrm{l}>2$ ls $(\mathrm{I})$

Absorption correction

Max. and min. transmission
C7 $\mathrm{H} 8 \mathrm{O} 5$

172.13

$0.1337 \times 0.0766 \times 0.0487 \mathrm{~mm}$

prism

colourless

Monoclinic

$\mathrm{P} 21 / \mathrm{n}$

$a=5.39904(17)$ A alpha $=90$ deg.

$b=14.8577(4) A \quad$ beta $=103.704(3) \mathrm{deg}$.

$c=8.6593(3)$ A gamma $=90 \mathrm{deg}$.

674.85(4) $A^{\wedge} 3$

4, $1.694 \mathrm{Mg} / \mathrm{m}^{\wedge} 3$

$1.277 \mathrm{~mm}^{\wedge}-1$

360

SuperNova, Single source at offset, Atlas Iw scans

$123 \mathrm{~K}$

$1.54184 \mathrm{~A}$

graphite

5.96 to $75.77 \mathrm{deg}$.

$=-5<=\mathrm{h}<=6-18<=\mathrm{k}<=18-9<=\mathrm{l}<=10$

$2478 / 1379$ [R(int) $=0.0260]$

1247

Analytical

0.946 and 0.910 


\section{Refinement}

Refinement method

Hydrogen treatment

Data / restraints / parameters

Goodness-of-fit on F^2

Final $R$ indices [l>2sigma(I)]

$R$ indices (all data)

Absolute structure parameter

Largest diff. peak and hole
Full-matrix least-squares on $\mathrm{F}^{\wedge} 2$

1379 / 0 / 112

1.045

$\mathrm{R} 1=0.0444, \mathrm{wR} 2=0.1187$

$\mathrm{R} 1=0.0487, \mathrm{wR} 2=0.1250$

0.313 and -0.282 e. $A^{\wedge}-3$

Table 2: Atomic coordinates $\left(x 1^{4}\right)$ and equivalent isotropic displacement parameters $\left(\AA^{2} \times 10^{3}\right)$ for 145 . $U(e q)$ is defined as one third of the trace of the orthogonalized Uij tensor.

\begin{tabular}{lllll}
\hline Atom & $\mathrm{x}$ & $\mathrm{y}$ & $\mathrm{z}$ & $\mathrm{U}(\mathrm{eq})$ \\
\hline $\mathrm{O}(1)$ & $4366(2)$ & $2897(1)$ & $3804(1)$ & $19(1)$ \\
$\mathrm{O}(2)$ & $4524(2)$ & $2787(1)$ & $1131(1)$ & $17(1)$ \\
$\mathrm{O}(3)$ & $4550(2)$ & $3613(1)$ & $-1004(1)$ & $21(1)$ \\
$\mathrm{O}(4)$ & $968(2)$ & $5427(1)$ & $3470(1)$ & $24(1)$ \\
$\mathrm{O}(5)$ & $-2719(2)$ & $4782(1)$ & $2260(1)$ & $21(1)$ \\
$\mathrm{C}(1)$ & $681(3)$ & $3805(1)$ & $3370(2)$ & $16(1)$ \\
$\mathrm{C}(2)$ & $3466(3)$ & $3746(1)$ & $4281(2)$ & $20(1)$ \\
$\mathrm{C}(3)$ & $2972(3)$ & $2663(1)$ & $2292(2)$ & $16(1)$ \\
$\mathrm{C}(4)$ & $683(3)$ & $3304(1)$ & $1807(2)$ & $15(1)$ \\
$\mathrm{C}(5)$ & $1324(3)$ & $3883(1)$ & $493(2)$ & $16(1)$ \\
$\mathrm{C}(6)$ & $3587(3)$ & $3436(1)$ & $91(2)$ & $16(1)$ \\
$\mathrm{C}(7)$ & $-291(3)$ & $4758(1)$ & $3073(2)$ & $16(1)$
\end{tabular}

Table 3: Bond lengths $[\AA]$ and angles [deg] for 145.

\begin{tabular}{ll|ll}
$\mathrm{O}(1)-\mathrm{C}(2)$ & $1.448(2)$ & $\mathrm{O}(1)-\mathrm{C}(3)-\mathrm{O}(2)$ & $110.16(13)$ \\
$\mathrm{O}(1)-\mathrm{C}(3)$ & $1.3909(19)$ & $\mathrm{C}(1)-\mathrm{C}(4)-\mathrm{C}(5)$ & $115.37(13)$ \\
$\mathrm{O}(2)-\mathrm{C}(3)$ & $1.4649(19)$ & $\mathrm{C}(3)-\mathrm{C}(4)-\mathrm{C}(5)$ & $104.04(13)$ \\
$\mathrm{O}(2)-\mathrm{C}(6)$ & $1.3343(19)$ & $\mathrm{C}(1)-\mathrm{C}(4)-\mathrm{C}(3)$ & $103.09(12)$ \\
$\mathrm{O}(3)-\mathrm{C}(6)$ & $1.214(2)$ & $\mathrm{C}(4)-\mathrm{C}(5)-\mathrm{C}(6)$ & $105.29(13)$ \\
$\mathrm{O}(4)-\mathrm{C}(7)$ & $1.2079(19)$ & $\mathrm{O}(2)-\mathrm{C}(6)-\mathrm{C}(5)$ & $111.23(13)$ \\
$\mathrm{O}(5)-\mathrm{C}(7)$ & $1.333(2)$ & $\mathrm{O}(3)-\mathrm{C}(6)-\mathrm{C}(5)$ & $127.41(14)$ \\
$\mathrm{O}(5)-\mathrm{H}(5 \mathrm{O})$ & $0.91(3)$ & $\mathrm{O}(2)-\mathrm{C}(6)-\mathrm{O}(3)$ & $121.36(15)$ \\
$\mathrm{C}(1)-\mathrm{C}(4)$ & $1.545(2)$ & $\mathrm{O}(4)-\mathrm{C}(7)-\mathrm{C}(1)$ & $125.01(15)$ \\
$\mathrm{C}(1)-\mathrm{C}(7)$ & $1.510(2)$ & $\mathrm{O}(5)-\mathrm{C}(7)-\mathrm{C}(1)$ & $111.95(13)$ \\
$\mathrm{C}(1)-\mathrm{C}(2)$ & $1.526(2)$ & $\mathrm{O}(4)-\mathrm{C}(7)-\mathrm{O}(5)$ & $123.01(14)$ \\
$\mathrm{C}(3)-\mathrm{C}(4)$ & $1.538(2)$ & $\mathrm{C}(2)-\mathrm{C}(1)-\mathrm{H}(1)$ & 109.00 \\
$\mathrm{C}(4)-\mathrm{C}(5)$ & $1.529(2)$ & $\mathrm{C}(4)-\mathrm{C}(1)-\mathrm{H}(1)$ & 109.00 \\
$\mathrm{C}(5)-\mathrm{C}(6)$ & $1.502(2)$ & $\mathrm{C}(7)-\mathrm{C}(1)-\mathrm{H}(1)$ & 109.00 \\
$\mathrm{C}(1)-\mathrm{H}(1)$ & 10.000 & $\mathrm{O}(1)-\mathrm{C}(2)-\mathrm{H}(2 \mathrm{~A})$ & 111.00 \\
$\mathrm{C}(2)-\mathrm{H}(2 \mathrm{~A})$ & 0.9900 & $\mathrm{O}(1)-\mathrm{C}(2)-\mathrm{H}(2 \mathrm{~B})$ & 111.00 \\
$\mathrm{C}(2)-\mathrm{H}(2 \mathrm{~B})$ & 0.9900 & $\mathrm{C}(1)-\mathrm{C}(2)-\mathrm{H}(2 \mathrm{~A})$ & 111.00
\end{tabular}




\begin{tabular}{ll|ll}
$\mathrm{C}(3)-\mathrm{H}(3)$ & 10.000 & $\mathrm{C}(1)-\mathrm{C}(2)-\mathrm{H}(2 \mathrm{~B})$ & 111.00 \\
$\mathrm{C}(4)-\mathrm{H}(4)$ & 10.000 & $\mathrm{H}(2 \mathrm{~A})-\mathrm{C}(2)-\mathrm{H}(2 \mathrm{~B})$ & 109.00 \\
$\mathrm{C}(5)-\mathrm{H}(5 A)$ & 0.9900 & $\mathrm{O}(1)-\mathrm{C}(3)-\mathrm{H}(3)$ & 110.00 \\
$\mathrm{C}(5)-\mathrm{H}(5 \mathrm{~B})$ & 0.9900 & $\mathrm{O}(2)-\mathrm{C}(3)-\mathrm{H}(3)$ & 110.00 \\
$\mathrm{C}(2)-\mathrm{O}(1)-\mathrm{C}(3)$ & $110.09(12)$ & $\mathrm{C}(4)-\mathrm{C}(3)-\mathrm{H}(3)$ & 110.00 \\
$\mathrm{C}(3)-\mathrm{O}(2)-\mathrm{C}(6)$ & $111.54(12)$ & $\mathrm{C}(1)-\mathrm{C}(4)-\mathrm{H}(4)$ & 111.00 \\
$\mathrm{C}(7)-\mathrm{O}(5)-\mathrm{H}(50)$ & $108.2(17)$ & $\mathrm{C}(3)-\mathrm{C}(4)-\mathrm{H}(4)$ & 111.00 \\
$\mathrm{C}(2)-\mathrm{C}(1)-\mathrm{C}(4)$ & $102.72(13)$ & $\mathrm{C}(5)-\mathrm{C}(4)-\mathrm{H}(4)$ & 111.00 \\
$\mathrm{C}(2)-\mathrm{C}(1)-\mathrm{C}(7)$ & $113.71(13)$ & $\mathrm{C}(4)-\mathrm{C}(5)-\mathrm{H}(5 \mathrm{~A})$ & 111.00 \\
$\mathrm{C}(4)-\mathrm{C}(1)-\mathrm{C}(7)$ & $111.97(12)$ & $\mathrm{C}(4)-\mathrm{C}(5)-\mathrm{H}(5 \mathrm{~B})$ & 111.00 \\
$\mathrm{O}(1)-\mathrm{C}(2)-\mathrm{C}(1)$ & $104.99(12)$ & $\mathrm{C}(6)-\mathrm{C}(5)-\mathrm{H}(5 \mathrm{~A})$ & 111.00 \\
$\mathrm{O}(1)-\mathrm{C}(3)-\mathrm{C}(4)$ & $108.83(12)$ & $\mathrm{C}(6)-\mathrm{C}(5)-\mathrm{H}(5 \mathrm{~B})$ & 111.00 \\
$\mathrm{O}(2)-\mathrm{C}(3)-\mathrm{C}(4)$ & $106.72(12)$ & $\mathrm{H}(5 \mathrm{~A})-\mathrm{C}(5)-\mathrm{H}(5 \mathrm{~B})$ & 109.00
\end{tabular}

Table 4: Anisotropic displacement parameters $\left(A^{2} \times 10^{3}\right)$ for 145 . The anisotropic

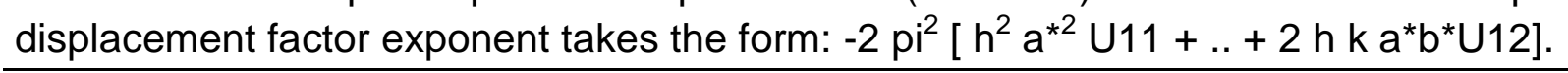

\begin{tabular}{lllllll}
\hline Atom & $\mathrm{U} 11$ & $\mathrm{U} 22$ & $\mathrm{U} 33$ & $\mathrm{U} 23$ & $\mathrm{U} 13$ & $\mathrm{U} 12$ \\
\hline $\mathrm{O}(1)$ & $21(1)$ & $20(1)$ & $16(1)$ & $1(1)$ & $2(1)$ & $5(1)$ \\
$\mathrm{O}(2)$ & $16(1)$ & $18(1)$ & $18(1)$ & $2(1)$ & $7(1)$ & $3(1)$ \\
$\mathrm{O}(3)$ & $23(1)$ & $24(1)$ & $19(1)$ & $4(1)$ & $11(1)$ & $5(1)$ \\
$\mathrm{O}(4)$ & $27(1)$ & $18(1)$ & $25(1)$ & $-1(1)$ & $4(1)$ & $-2(1)$ \\
$\mathrm{O}(5)$ & $20(1)$ & $19(1)$ & $24(1)$ & $1(1)$ & $5(1)$ & $2(1)$ \\
$\mathrm{C}(1)$ & $19(1)$ & $17(1)$ & $15(1)$ & $1(1)$ & $7(1)$ & $0(1)$ \\
$\mathrm{C}(2)$ & $22(1)$ & $20(1)$ & $16(1)$ & $-2(1)$ & $3(1)$ & $1(1)$ \\
$\mathrm{C}(3)$ & $16(1)$ & $17(1)$ & $15(1)$ & $1(1)$ & $5(1)$ & $0(1)$ \\
$\mathrm{C}(4)$ & $15(1)$ & $14(1)$ & $17(1)$ & $-1(1)$ & $5(1)$ & $1(1)$ \\
$\mathrm{C}(5)$ & $18(1)$ & $16(1)$ & $16(1)$ & $0(1)$ & $6(1)$ & $3(1)$ \\
$\mathrm{C}(6)$ & $17(1)$ & $16(1)$ & $15(1)$ & $-2(1)$ & $3(1)$ & $1(1)$ \\
$\mathrm{C}(7)$ & $21(1)$ & $18(1)$ & $12(1)$ & $0(1)$ & $9(1)$ & $1(1)$
\end{tabular}

Table 5: Hydrogen coordinates $\left(x 10^{4}\right)$ and isotropic displacement parameters $\left(A^{2} x\right.$ $\left.10^{3}\right)$ for $\mathbf{1 4 5}$.

\begin{tabular}{lllll}
\hline Atom & $x$ & $y$ & $z$ & $U($ eq $)$ \\
\hline$H(1)$ & -406 & 3470 & 3963 & 19 \\
$H(2 A)$ & 4462 & 4254 & 3997 & 23 \\
$H(2 B)$ & 3609 & 3758 & 5442 & 23 \\
$H(3)$ & 2375 & 2025 & 2280 & 19 \\
$H(4)$ & -941 & 2964 & 1409 & 18 \\
$H(5 A)$ & -133 & 3902 & -448 & 20 \\
$H(5 B)$ & 1748 & 4505 & 873 & 20 \\
$H(50)$ & $-3150(50)$ & $5365(18)$ & $2020(30)$ & 25
\end{tabular}


Table 6: Torsion angles [deg] for 145.

$\begin{array}{ll}\mathrm{C}(3)-\mathrm{O}(1)-\mathrm{C}(2)-\mathrm{C}(1) & 27.00(16) \\ \mathrm{C}(2)-\mathrm{O}(1)-\mathrm{C}(3)-\mathrm{O}(2) & 106.70(13) \\ \mathrm{C}(2)-\mathrm{O}(1)-\mathrm{C}(3)-\mathrm{C}(4) & -9.98(16) \\ \mathrm{C}(6)-\mathrm{O}(2)-\mathrm{C}(3)-\mathrm{C}(4) & 3.47(16) \\ \mathrm{C}(3)-\mathrm{O}(2)-\mathrm{C}(6)-\mathrm{O}(3) & -176.95(14) \\ \mathrm{C}(3)-\mathrm{O}(2)-\mathrm{C}(6)-\mathrm{C}(5) & 3.76(17) \\ \mathrm{C}(6)-\mathrm{O}(2)-\mathrm{C}(3)-\mathrm{O}(1) & -114.52(14) \\ \mathrm{C}(4)-\mathrm{C}(1)-\mathrm{C}(2)-\mathrm{O}(1) & -32.22(15) \\ \mathrm{C}(7)-\mathrm{C}(1)-\mathrm{C}(2)-\mathrm{O}(1) & -153.42(12) \\ \mathrm{C}(2)-\mathrm{C}(1)-\mathrm{C}(4)-\mathrm{C}(3) & 25.72(15) \\ \mathrm{C}(2)-\mathrm{C}(1)-\mathrm{C}(4)-\mathrm{C}(5) & -86.98(16) \\ \mathrm{C}(7)-\mathrm{C}(1)-\mathrm{C}(4)-\mathrm{C}(3) & 148.10(13) \\ \mathrm{C}(7)-\mathrm{C}(1)-\mathrm{C}(4)-\mathrm{C}(5) & 35.40(19)\end{array}$

\begin{tabular}{|ll}
$\mathrm{C}(2)-\mathrm{C}(1)-\mathrm{C}(7)-\mathrm{O}(4)$ & $1.4(2)$ \\
$\mathrm{C}(2)-\mathrm{C}(1)-\mathrm{C}(7)-\mathrm{O}(5)$ & $179.30(12)$ \\
$\mathrm{C}(4)-\mathrm{C}(1)-\mathrm{C}(7)-\mathrm{O}(4)$ & $-114.45(17)$ \\
$\mathrm{C}(4)-\mathrm{C}(1)-\mathrm{C}(7)-\mathrm{O}(5)$ & $63.42(17)$ \\
$\mathrm{O}(1)-\mathrm{C}(3)-\mathrm{C}(4)-\mathrm{C}(1)$ & $-10.77(16)$ \\
$\mathrm{O}(2)-\mathrm{C}(3)-\mathrm{C}(4)-\mathrm{C}(5)$ & $-8.85(15)$ \\
$\mathrm{O}(1)-\mathrm{C}(3)-\mathrm{C}(4)-\mathrm{C}(5)$ & $110.00(13)$ \\
$\mathrm{O}(2)-\mathrm{C}(3)-\mathrm{C}(4)-\mathrm{C}(1)$ & $-129.62(12)$ \\
$\mathrm{C}(1)-\mathrm{C}(4)-\mathrm{C}(5)-\mathrm{C}(6)$ & $122.83(14)$ \\
$\mathrm{C}(3)-\mathrm{C}(4)-\mathrm{C}(5)-\mathrm{C}(6)$ & $10.69(15)$ \\
$\mathrm{C}(4)-\mathrm{C}(5)-\mathrm{C}(6)-\mathrm{O}(3)$ & $171.37(16)$ \\
$\mathrm{C}(4)-\mathrm{C}(5)-\mathrm{C}(6)-\mathrm{O}(2)$ & $-9.39(17)$ \\
\end{tabular}

Table 7: Hydrogen-bonds for 145 [A and deg.].

\begin{tabular}{lcclc}
\hline $\mathrm{D}-\mathrm{H} \ldots \mathrm{A}$ & $\mathrm{d}(\mathrm{D}-\mathrm{H})$ & $\mathrm{d}(\mathrm{H} \ldots \mathrm{A})$ & $\mathrm{d}(\mathrm{D} \ldots \mathrm{A})$ & $<(\mathrm{DHA})$ \\
\hline $\mathrm{O}(5)-\mathrm{H}(5 \mathrm{O}) \ldots \mathrm{O}(3) \# 1$ & $0.91(3)$ & $1.83(3)$ & $2.7086(18)$ & $163(2)$ \\
$\mathrm{C}(2)-\mathrm{H}(2 \mathrm{~A}) \ldots \mathrm{O}(5) \# 2$ & 0.9900 & 25.100 & $3.374(2)$ & 146.00 \\
$\mathrm{C}(3)-\mathrm{H}(3) \ldots \mathrm{O}(3) \# 3$ & 10.000 & 25.500 & $3.237(2)$ & 126.00 \\
$\mathrm{C}(4)-\mathrm{H}(4) \ldots \mathrm{O}(2) \# 4$ & 10.000 & 24.200 & $3.327(2)$ & 151.00
\end{tabular}




\section{(R)-1-(4-chlorophenyl)ethanaminium (3S,3aS,6aS)-5-oxohexahydrofuro[2,3-} b]furan-3-carboxylate (57)<smiles>O=C1C[C@H]2OC[C@H](C(=O)[O-])[C@H]2O1</smiles>

\section{7 co-crystallized}

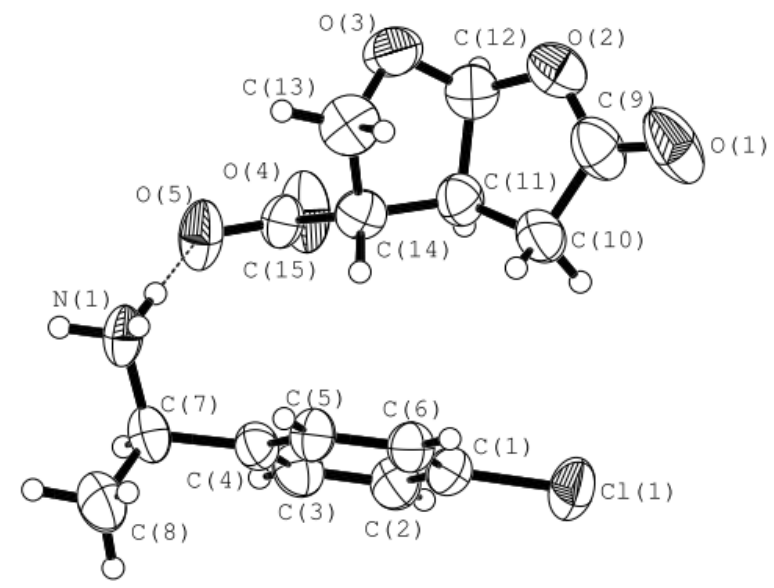

Table 1: Crystal data and structure refinement for 57.

\section{Crystal Data}

Empirical formula

Formula weight

Crystal size

Crystal description

Crystal colour

Crystal system

Space group

Unit cell dimensions

Volume

Z, Calculated density

Absorption coefficient

$\mathrm{F}(000)$

\section{Data Collection}

Measurement device type

Measurement method

Temperature

Wavelength

Monochromator

Theta range for data collection

Index ranges

Reflections collected / unique

Reflections greater $\mathrm{I}>2 \mid \mathrm{s}(\mathrm{I})$

Absorption correction

Max. and min. transmission

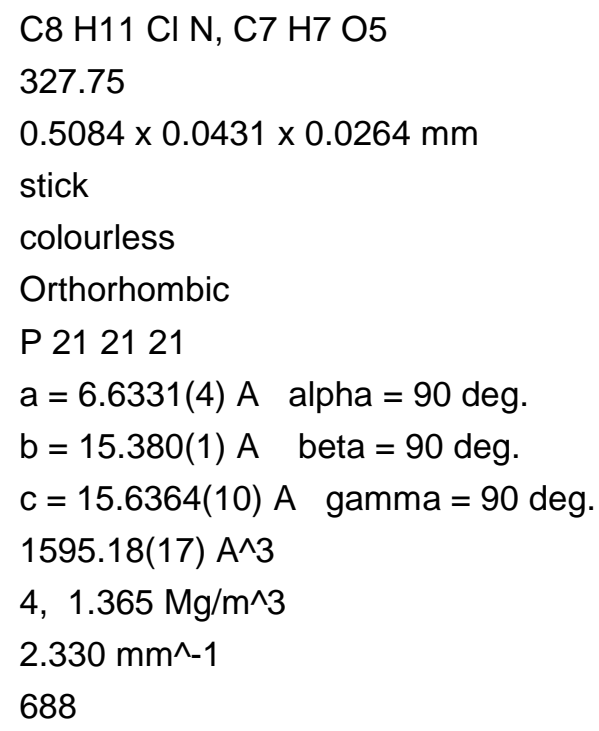

SuperNova, Single source at offset, Atlas Iw scans

$123 \mathrm{~K}$

$1.54184 \mathrm{~A}$

graphite

4.03 to 75.50 deg.

$=-8<=h<=8-19<=k<=19-19<=\mid<=19$

$11839 / 3283[R($ int $)=0.0618]$

2637

Analytical

0.943 and 0.589 


\section{Refinement}

Refinement method

Hydrogen treatment

Data / restraints / parameters

Goodness-of-fit on F^2

Final $R$ indices [l>2sigma(I)]

$R$ indices (all data)

Absolute structure parameter

Largest diff. peak and hole
Full-matrix least-squares on $\mathrm{F}^{\wedge} 2$$$
3283 \text { / } 0 \text { / } 201
$$

1.089

$\mathrm{R} 1=0.0738, \mathrm{wR} 2=0.2097$

$\mathrm{R} 1=0.0868, \mathrm{wR} 2=0.2274$

$-0.04(4)$

0.507 and -0.305 e. $A^{\wedge}-3$

Table 2: Atomic coordinates $\left(x 1^{4}\right)$ and equivalent isotropic displacement parameters $\left(\AA^{2} \times 10^{3}\right)$ for $57 . \mathrm{U}(\mathrm{eq})$ is defined as one third of the trace of the orthogonalized Uij tensor.

\begin{tabular}{lllll}
\hline Atom & $\mathrm{x}$ & $\mathrm{y}$ & $\mathrm{z}$ & $\mathrm{U}(\mathrm{eq})$ \\
\hline $\mathrm{Cl}(1)$ & $5443(2)$ & $1615(1)$ & $2341(1)$ & $71(1)$ \\
$\mathrm{N}(1)$ & $8548(5)$ & $-1868(2)$ & $4550(3)$ & $49(1)$ \\
$\mathrm{C}(1)$ & $6248(7)$ & $609(3)$ & $2725(3)$ & $50(1)$ \\
$\mathrm{C}(2)$ & $4995(7)$ & $-91(3)$ & $2635(3)$ & $54(1)$ \\
$\mathrm{C}(3)$ & $5650(8)$ & $-887(3)$ & $2933(3)$ & $53(1)$ \\
$\mathrm{C}(4)$ & $7539(7)$ & $-968(3)$ & $3310(3)$ & $45(1)$ \\
$\mathrm{C}(5)$ & $8742(6)$ & $-256(3)$ & $3389(3)$ & $46(1)$ \\
$\mathrm{C}(6)$ & $8114(7)$ & $556(3)$ & $3098(3)$ & $48(1)$ \\
$\mathrm{C}(7)$ & $8192(8)$ & $-1865(3)$ & $3612(3)$ & $55(2)$ \\
$\mathrm{C}(8)$ & $10098(14)$ & $-2183(4)$ & $3182(5)$ & $96(3)$ \\
$\mathrm{O}(1)$ & $4274(8)$ & $3086(3)$ & $5187(4)$ & $97(2)$ \\
$\mathrm{O}(2)$ & $3213(6)$ & $1989(3)$ & $5980(2)$ & $66(1)$ \\
$\mathrm{O}(3)$ & $3863(6)$ & $575(3)$ & $6426(2)$ & $66(1)$ \\
$\mathrm{O}(4)$ & $1760(5)$ & $-854(2)$ & $5021(3)$ & $75(2)$ \\
$\mathrm{O}(5)$ & $4752(5)$ & $-1465(2)$ & $5129(3)$ & $67(1)$ \\
$\mathrm{C}(9)$ & $3916(9)$ & $2323(3)$ & $5254(4)$ & $70(2)$ \\
$\mathrm{C}(10)$ & $4045(11)$ & $1629(3)$ & $4568(4)$ & $69(2)$ \\
$\mathrm{C}(11)$ & $3177(8)$ & $823(3)$ & $4968(3)$ & $53(1)$ \\
$\mathrm{C}(12)$ & $2720(8)$ & $1082(3)$ & $5889(3)$ & $57(2)$ \\
$\mathrm{C}(13)$ & $5566(8)$ & $262(4)$ & $5927(4)$ & $64(2)$ \\
$\mathrm{C}(14)$ & $4637(7)$ & $62(3)$ & $5067(3)$ & $50(1)$ \\
$\mathrm{C}(15)$ & $3618(6)$ & $-829(3)$ & $5067(3)$ & $45(1)$
\end{tabular}

Table 3: Bond lengths $[\AA]$ and angles [deg] for 57 .

$\begin{array}{ll}\mathrm{Cl}(1)-\mathrm{C}(1) & 1.743(5) \\ \mathrm{O}(1)-\mathrm{C}(9) & 1.202(7) \\ \mathrm{O}(2)-\mathrm{C}(12) & 1.440(7) \\ \mathrm{O}(2)-\mathrm{C}(9) & 1.330(7) \\ \mathrm{O}(3)-\mathrm{C}(12) & 1.374(6) \\ \mathrm{O}(3)-\mathrm{C}(13) & 1.455(7) \\ \mathrm{O}(4)-\mathrm{C}(15) & 1.235(5)\end{array}$

\begin{tabular}{|ll}
$\mathrm{C}(1)-\mathrm{C}(6)-\mathrm{C}(5)$ & $117.5(4)$ \\
$\mathrm{N}(1)-\mathrm{C}(7)-\mathrm{C}(4)$ & $110.8(4)$ \\
$\mathrm{C}(4)-\mathrm{C}(7)-\mathrm{C}(8)$ & $113.2(4)$ \\
$\mathrm{N}(1)-\mathrm{C}(7)-\mathrm{C}(8)$ & $107.8(5)$ \\
$\mathrm{C}(3)-\mathrm{C}(2)-\mathrm{H}(2)$ & 121.00 \\
$\mathrm{C}(1)-\mathrm{C}(2)-\mathrm{H}(2)$ & 121.00 \\
$\mathrm{C}(4)-\mathrm{C}(3)-\mathrm{H}(3)$ & 120.00
\end{tabular}




\begin{tabular}{|c|c|c|c|}
\hline $\mathrm{O}(5)-\mathrm{C}(15)$ & $1.238(5)$ & $\mathrm{C}(2)-\mathrm{C}(3)-\mathrm{H}(3)$ & 120.00 \\
\hline$N(1)-C(7)$ & $1.486(7)$ & $\mathrm{C}(6)-\mathrm{C}(5)-\mathrm{H}(5)$ & 119.00 \\
\hline$N(1)-H(1 O)$ & 0.9100 & $\mathrm{C}(4)-\mathrm{C}(5)-\mathrm{H}(5)$ & 119.00 \\
\hline$N(1)-H(1 P)$ & 0.9100 & $C(1)-C(6)-H(6)$ & 121.00 \\
\hline$N(1)-H(1 N)$ & 0.9100 & $\mathrm{C}(5)-\mathrm{C}(6)-\mathrm{H}(6)$ & 121.00 \\
\hline$C(1)-C(2)$ & $1.367(7)$ & $\mathrm{C}(4)-\mathrm{C}(7)-\mathrm{H}(7)$ & 108.00 \\
\hline$C(1)-C(6)$ & $1.371(7)$ & $\mathrm{N}(1)-\mathrm{C}(7)-\mathrm{H}(7)$ & 108.00 \\
\hline$C(2)-C(3)$ & $1.380(7)$ & $\mathrm{C}(8)-\mathrm{C}(7)-\mathrm{H}(7)$ & 108.00 \\
\hline$C(3)-C(4)$ & $1.390(7)$ & $\mathrm{C}(7)-\mathrm{C}(8)-\mathrm{H}(8 \mathrm{~B})$ & 109.00 \\
\hline$C(4)-C(5)$ & $1.361(6)$ & $\mathrm{C}(7)-\mathrm{C}(8)-\mathrm{H}(8 \mathrm{C})$ & 109.00 \\
\hline$C(4)-C(7)$ & $1.521(7)$ & $\mathrm{H}(8 \mathrm{~A})-\mathrm{C}(8)-\mathrm{H}(8 \mathrm{C})$ & 110.00 \\
\hline$C(5)-C(6)$ & $1.393(7)$ & $\mathrm{H}(8 \mathrm{~B})-\mathrm{C}(8)-\mathrm{H}(8 \mathrm{C})$ & 110.00 \\
\hline $\mathrm{C}(7)-\mathrm{C}(8)$ & $1.513(10)$ & $\mathrm{H}(8 \mathrm{~A})-\mathrm{C}(8)-\mathrm{H}(8 \mathrm{~B})$ & 109.00 \\
\hline $\mathrm{C}(2)-\mathrm{H}(2)$ & 0.9500 & $\mathrm{C}(7)-\mathrm{C}(8)-\mathrm{H}(8 \mathrm{~A})$ & 109.00 \\
\hline $\mathrm{C}(3)-\mathrm{H}(3)$ & 0.9500 & $\mathrm{O}(1)-\mathrm{C}(9)-\mathrm{O}(2)$ & $121.4(6$ \\
\hline $\mathrm{C}(5)-\mathrm{H}(5)$ & 0.9500 & $O(1)-C(9)-C(10)$ & $127.9(6$ \\
\hline $\mathrm{C}(6)-\mathrm{H}(6)$ & 0.9500 & $\mathrm{O}(2)-\mathrm{C}(9)-\mathrm{C}(10)$ & $110.6(4$ \\
\hline $\mathrm{C}(7)-\mathrm{H}(7)$ & 10.000 & $C(9)-C(10)-C(11)$ & $105.4(5$ \\
\hline $\mathrm{C}(8)-\mathrm{H}(8 \mathrm{~A})$ & 0.9800 & $C(10)-C(11)-C(12)$ & $104.7(4$ \\
\hline $\mathrm{C}(8)-\mathrm{H}(8 \mathrm{~B})$ & 0.9800 & $C(10)-C(11)-C(14)$ & $115.6(5$ \\
\hline $\mathrm{C}(8)-\mathrm{H}(8 \mathrm{C})$ & 0.9800 & $C(12)-C(11)-C(14)$ & $103.3(4$ \\
\hline$C(9)-C(10)$ & $1.516(8)$ & $\mathrm{O}(2)-\mathrm{C}(12)-\mathrm{O}(3)$ & $111.4(4$ \\
\hline$C(10)-C(11)$ & $1.503(7)$ & $O(2)-C(12)-C(11)$ & $107.5(4$ \\
\hline$C(11)-C(12)$ & $1.525(7)$ & $O(3)-C(12)-C(11)$ & $108.6(4$ \\
\hline$C(11)-C(14)$ & $1.527(7)$ & $O(3)-C(13)-C(14)$ & $103.2(4$ \\
\hline$C(13)-C(14)$ & $1.511(8)$ & $C(11)-C(14)-C(13)$ & $101.1(4$ \\
\hline$C(14)-C(15)$ & $1.528(6)$ & $C(11)-C(14)-C(15)$ & $114.0(4$ \\
\hline$C(10)-H(10 A)$ & 0.9900 & $C(13)-C(14)-C(15)$ & $111.3(4$ \\
\hline $\mathrm{C}(10)-\mathrm{H}(10 \mathrm{~B})$ & 0.9900 & $\mathrm{O}(4)-\mathrm{C}(15)-\mathrm{O}(5)$ & $125.9(4$ \\
\hline $\mathrm{C}(11)-\mathrm{H}(11)$ & 10.000 & $O(4)-C(15)-C(14)$ & $118.0(4$ \\
\hline $\mathrm{C}(12)-\mathrm{H}(12)$ & 10.000 & $\mathrm{O}(5)-\mathrm{C}(15)-\mathrm{C}(14)$ & $116.1(4$ \\
\hline$C(13)-H(13 A)$ & 0.9900 & $C(9)-C(10)-H(10 A)$ & 111.00 \\
\hline $\mathrm{C}(13)-\mathrm{H}(13 \mathrm{~B})$ & 0.9900 & $\mathrm{C}(9)-\mathrm{C}(10)-\mathrm{H}(10 \mathrm{~B})$ & 111.00 \\
\hline $\mathrm{C}(14)-\mathrm{H}(14)$ & 10.000 & $C(11)-C(10)-H(10 A)$ & 111.00 \\
\hline $\mathrm{C}(9)-\mathrm{O}(2)-\mathrm{C}(12)$ & $111.7(4)$ & $C(11)-C(10)-H(10 B)$ & 111.00 \\
\hline$C(12)-O(3)-C(13)$ & $106.8(4)$ & $H(10 A)-C(10)-H(10 B)$ & 109.00 \\
\hline$H(1 N)-N(1)-H(10)$ & 110.00 & $C(10)-C(11)-H(11)$ & 111.00 \\
\hline$C(7)-N(1)-H(1 P)$ & 109.00 & $C(12)-C(11)-H(11)$ & 111.00 \\
\hline $\mathrm{C}(7)-\mathrm{N}(1)-\mathrm{H}(1 \mathrm{O})$ & 109.00 & $C(14)-C(11)-H(11)$ & 111.00 \\
\hline$H(1 N)-N(1)-H(1 P)$ & 110.00 & $\mathrm{O}(2)-\mathrm{C}(12)-\mathrm{H}(12)$ & 110.00 \\
\hline$H(10)-N(1)-H(1 P)$ & 109.00 & $\mathrm{O}(3)-\mathrm{C}(12)-\mathrm{H}(12)$ & 110.00 \\
\hline $\mathrm{C}(7)-\mathrm{N}(1)-\mathrm{H}(1 \mathrm{~N})$ & 109.00 & $\mathrm{C}(11)-\mathrm{C}(12)-\mathrm{H}(12)$ & 110.00 \\
\hline $\mathrm{Cl}(1)-\mathrm{C}(1)-\mathrm{C}(2)$ & $118.5(4)$ & $\mathrm{O}(3)-\mathrm{C}(13)-\mathrm{H}(13 \mathrm{~A})$ & 111.00 \\
\hline $\mathrm{Cl}(1)-\mathrm{C}(1)-\mathrm{C}(6)$ & $118.4(4)$ & $\mathrm{O}(3)-\mathrm{C}(13)-\mathrm{H}(13 \mathrm{~B})$ & 111.00 \\
\hline$C(2)-C(1)-C(6)$ & $123.1(4)$ & $C(14)-C(13)-H(13 A)$ & 111.00 \\
\hline$C(1)-C(2)-C(3)$ & $118.2(4)$ & $C(14)-C(13)-H(13 B)$ & 111.00 \\
\hline$C(2)-C(3)-C(4)$ & $120.4(4)$ & $H(13 A)-C(13)-H(13 B)$ & 109.00 \\
\hline
\end{tabular}




\begin{tabular}{ll|lr}
$C(3)-C(4)-C(7)$ & $118.0(4)$ & $\mathrm{C}(11)-\mathrm{C}(14)-\mathrm{H}(14)$ & 110.00 \\
$\mathrm{C}(5)-\mathrm{C}(4)-\mathrm{C}(7)$ & $122.3(4)$ & $\mathrm{C}(13)-\mathrm{C}(14)-\mathrm{H}(14)$ & 110.00 \\
$\mathrm{C}(3)-\mathrm{C}(4)-\mathrm{C}(5)$ & $119.7(4)$ & $\mathrm{C}(15)-\mathrm{C}(14)-\mathrm{H}(14)$ & 110.00 \\
$\mathrm{C}(4)-\mathrm{C}(5)-\mathrm{C}(6)$ & $121.1(4)$ & &
\end{tabular}

Table 4: Anisotropic displacement parameters $\left(A^{2} \times 10^{3}\right)$ for 57 . The anisotropic displacement factor exponent takes the form: $-2 \mathrm{pi}^{2}\left[\mathrm{~h}^{2} \mathrm{a}^{* 2} \mathrm{U} 11+. .+2 \mathrm{~h} \mathrm{k} \mathrm{a} \mathrm{a}^{*} \mathrm{U} 12\right]$.

\begin{tabular}{lllllll}
\hline Atom & $\mathrm{U} 11$ & $\mathrm{U} 22$ & $\mathrm{U} 33$ & $\mathrm{U} 23$ & $\mathrm{U} 13$ & $\mathrm{U} 12$ \\
\hline $\mathrm{Cl}(1)$ & $80(1)$ & $58(1)$ & $75(1)$ & $17(1)$ & $-11(1)$ & $15(1)$ \\
$\mathrm{N}(1)$ & $35(2)$ & $35(2)$ & $76(2)$ & $14(2)$ & $0(2)$ & $-1(1)$ \\
$\mathrm{C}(1)$ & $55(2)$ & $51(2)$ & $45(2)$ & $4(2)$ & $-5(2)$ & $9(2)$ \\
$\mathrm{C}(2)$ & $49(2)$ & $56(2)$ & $56(2)$ & $-3(2)$ & $-12(2)$ & $5(2)$ \\
$\mathrm{C}(3)$ & $52(2)$ & $48(2)$ & $60(3)$ & $-8(2)$ & $-10(2)$ & $-6(2)$ \\
$\mathrm{C}(4)$ & $50(2)$ & $38(2)$ & $48(2)$ & $-3(2)$ & $-3(2)$ & $0(2)$ \\
$\mathrm{C}(5)$ & $36(2)$ & $45(2)$ & $56(2)$ & $4(2)$ & $-5(2)$ & $1(2)$ \\
$\mathrm{C}(6)$ & $46(2)$ & $45(2)$ & $52(2)$ & $1(2)$ & $0(2)$ & $-3(2)$ \\
$\mathrm{C}(7)$ & $63(3)$ & $34(2)$ & $68(3)$ & $-3(2)$ & $-1(2)$ & $2(2)$ \\
$\mathrm{C}(8)$ & $136(7)$ & $63(4)$ & $89(4)$ & $8(3)$ & $37(5)$ & $40(4)$ \\
$\mathrm{O}(1)$ & $92(3)$ & $48(2)$ & $152(5)$ & $-24(2)$ & $53(3)$ & $-17(2)$ \\
$\mathrm{O}(2)$ & $67(2)$ & $65(2)$ & $67(2)$ & $-15(2)$ & $2(2)$ & $-4(2)$ \\
$\mathrm{O}(3)$ & $67(2)$ & $83(3)$ & $49(2)$ & $5(2)$ & $3(2)$ & $9(2)$ \\
$\mathrm{O}(4)$ & $40(2)$ & $52(2)$ & $134(4)$ & $7(2)$ & $-22(2)$ & $-2(1)$ \\
$\mathrm{O}(5)$ & $44(2)$ & $50(2)$ & $106(3)$ & $25(2)$ & $14(2)$ & $7(1)$ \\
$\mathrm{C}(9)$ & $68(3)$ & $49(3)$ & $93(4)$ & $-12(3)$ & $17(3)$ & $-9(2)$ \\
$\mathrm{C}(10)$ & $96(4)$ & $45(2)$ & $66(3)$ & $-3(2)$ & $20(3)$ & $1(3)$ \\
$\mathrm{C}(11)$ & $59(2)$ & $43(2)$ & $57(2)$ & $-1(2)$ & $-2(2)$ & $-4(2)$ \\
$\mathrm{C}(12)$ & $51(2)$ & $59(3)$ & $62(3)$ & $1(2)$ & $2(2)$ & $-2(2)$ \\
$\mathrm{C}(13)$ & $42(2)$ & $77(3)$ & $74(3)$ & $0(3)$ & $-8(2)$ & $-6(2)$ \\
$\mathrm{C}(14)$ & $45(2)$ & $53(2)$ & $53(2)$ & $1(2)$ & $4(2)$ & $-5(2)$ \\
$\mathrm{C}(15)$ & $39(2)$ & $41(2)$ & $56(2)$ & $8(2)$ & $-3(2)$ & $-2(2)$
\end{tabular}

Table 5: Hydrogen coordinates $\left(x 10^{4}\right)$ and isotropic displacement parameters $\left(A^{2} x\right.$ $10^{3}$ ) for 57.

\begin{tabular}{lllll}
\hline Atom & $x$ & $y$ & $z$ & $U(e q)$ \\
\hline$H(1 N)$ & 8728 & -2425 & 4732 & 73 \\
$H(10)$ & 7466 & -1631 & 4821 & 73 \\
$H(1 P)$ & 9670 & -1550 & 4670 & 73 \\
$H(2)$ & 3708 & -31 & 2375 & 65 \\
$H(3)$ & 4804 & -1382 & 2881 & 64 \\
$H(5)$ & 10032 & -314 & 3647 & 55 \\
$H(6)$ & 8948 & 1054 & 3157 & 57 \\
$H(7)$ & 7084 & -2286 & 3482 & 66 \\
$H(8 A)$ & 9868 & -2234 & 2565 & 144 \\
$H(8 B)$ & 11191 & -1767 & 3287 & 144 \\
$H(8 C)$ & 10470 & -2752 & 3416 & 144
\end{tabular}




$\begin{array}{lllll}H(10 A) & 3257 & 1800 & 4058 & 83 \\ H(10 B) & 5463 & 1531 & 4396 & 83 \\ H(11) & 1922 & 637 & 4665 & 64 \\ H(12) & 1256 & 990 & 6012 & 69 \\ H(13 A) & 6158 & -266 & 6188 & 77 \\ H(13 B) & 6623 & 713 & 5877 & 77 \\ H(14) & 5691 & 86 & 4610 & 60\end{array}$

Table 6: Torsion angles [deg] for 57.

\begin{tabular}{ll|ll}
$\mathrm{C}(12)-\mathrm{O}(2)-\mathrm{C}(9)-\mathrm{C}(10)$ & $-2.1(6)$ & $\mathrm{C}(4)-\mathrm{C}(5)-\mathrm{C}(6)-\mathrm{C}(1)$ & $-0.4(7)$ \\
$\mathrm{C}(9)-\mathrm{O}(2)-\mathrm{C}(12)-\mathrm{C}(11)$ & $-0.4(6)$ & $\mathrm{O}(2)-\mathrm{C}(9)-\mathrm{C}(10)-\mathrm{C}(11)$ & $3.7(7)$ \\
$\mathrm{C}(9)-\mathrm{O}(2)-\mathrm{C}(12)-\mathrm{O}(3)$ & $118.5(5)$ & $\mathrm{O}(1)-\mathrm{C}(9)-\mathrm{C}(10)-\mathrm{C}(11)$ & $-172.7(6)$ \\
$\mathrm{C}(12)-\mathrm{O}(2)-\mathrm{C}(9)-\mathrm{O}(1)$ & $174.6(6)$ & $\mathrm{C}(9)-\mathrm{C}(10)-\mathrm{C}(11)-\mathrm{C}(14)$ & $-116.6(5)$ \\
$\mathrm{C}(13)-\mathrm{O}(3)-\mathrm{C}(12)-\mathrm{O}(2)$ & $-95.9(5)$ & $\mathrm{C}(9)-\mathrm{C}(10)-\mathrm{C}(11)-\mathrm{C}(12)$ & $-3.7(6)$ \\
$\mathrm{C}(12)-\mathrm{O}(3)-\mathrm{C}(13)-\mathrm{C}(14)$ & $-39.5(5)$ & $\mathrm{C}(10)-\mathrm{C}(11)-\mathrm{C}(12)-\mathrm{O}(2)$ & $2.7(6)$ \\
$\mathrm{C}(13)-\mathrm{O}(3)-\mathrm{C}(12)-\mathrm{C}(11)$ & $22.3(5)$ & $\mathrm{C}(12)-\mathrm{C}(11)-\mathrm{C}(14)-\mathrm{C}(13)$ & $-26.1(5)$ \\
$\mathrm{C}(6)-\mathrm{C}(1)-\mathrm{C}(2)-\mathrm{C}(3)$ & $-0.2(7)$ & $\mathrm{C}(12)-\mathrm{C}(11)-\mathrm{C}(14)-\mathrm{C}(15)$ & $93.4(5)$ \\
$\mathrm{C}(2)-\mathrm{C}(1)-\mathrm{C}(6)-\mathrm{C}(5)$ & $0.5(7)$ & $\mathrm{C}(10)-\mathrm{C}(11)-\mathrm{C}(12)-\mathrm{O}(3)$ & $-118.0(5)$ \\
$\mathrm{Cl}(1)-\mathrm{C}(1)-\mathrm{C}(2)-\mathrm{C}(3)$ & $179.4(4)$ & $\mathrm{C}(14)-\mathrm{C}(11)-\mathrm{C}(12)-\mathrm{O}(2)$ & $124.0(4)$ \\
$\mathrm{Cl}(1)-\mathrm{C}(1)-\mathrm{C}(6)-\mathrm{C}(5)$ & $-179.1(4)$ & $\mathrm{C}(14)-\mathrm{C}(11)-\mathrm{C}(12)-\mathrm{O}(3)$ & $3.4(5)$ \\
$\mathrm{C}(1)-\mathrm{C}(2)-\mathrm{C}(3)-\mathrm{C}(4)$ & $-0.3(7)$ & $\mathrm{C}(10)-\mathrm{C}(11)-\mathrm{C}(14)-\mathrm{C}(13)$ & $87.6(5)$ \\
$\mathrm{C}(2)-\mathrm{C}(3)-\mathrm{C}(4)-\mathrm{C}(5)$ & $0.4(7)$ & $\mathrm{C}(10)-\mathrm{C}(11)-\mathrm{C}(14)-\mathrm{C}(15)$ & $-152.9(4)$ \\
$\mathrm{C}(2)-\mathrm{C}(3)-\mathrm{C}(4)-\mathrm{C}(7)$ & $-179.0(4)$ & $\mathrm{O}(3)-\mathrm{C}(13)-\mathrm{C}(14)-\mathrm{C}(11)$ & $39.6(5)$ \\
$\mathrm{C}(5)-\mathrm{C}(4)-\mathrm{C}(7)-\mathrm{N}(1)$ & $62.1(6)$ & $\mathrm{O}(3)-\mathrm{C}(13)-\mathrm{C}(14)-\mathrm{C}(15)$ & $-81.8(5)$ \\
$\mathrm{C}(3)-\mathrm{C}(4)-\mathrm{C}(5)-\mathrm{C}(6)$ & $0.0(7)$ & $\mathrm{C}(11)-\mathrm{C}(14)-\mathrm{C}(15)-\mathrm{O}(4)$ & $-2.6(6)$ \\
$\mathrm{C}(5)-\mathrm{C}(4)-\mathrm{C}(7)-\mathrm{C}(8)$ & $-59.0(7)$ & $\mathrm{C}(11)-\mathrm{C}(14)-\mathrm{C}(15)-\mathrm{O}(5)$ & $178.6(4)$ \\
$\mathrm{C}(3)-\mathrm{C}(4)-\mathrm{C}(7)-\mathrm{C}(8)$ & $120.3(6)$ & $\mathrm{C}(13)-\mathrm{C}(14)-\mathrm{C}(15)-\mathrm{O}(4)$ & $111.0(5)$ \\
$\mathrm{C}(7)-\mathrm{C}(4)-\mathrm{C}(5)-\mathrm{C}(6)$ & $179.3(4)$ & $\mathrm{C}(13)-\mathrm{C}(14)-\mathrm{C}(15)-\mathrm{O}(5)$ & $-67.8(6)$ \\
$\mathrm{C}(3)-\mathrm{C}(4)-\mathrm{C}(7)-\mathrm{N}(1)$ & $-118.6(5)$ &
\end{tabular}

Table 7: Hydrogen-bonds for 57 [Å and deg.].

\begin{tabular}{lcccc}
\hline $\mathrm{D}-\mathrm{H} \ldots \mathrm{A}$ & $\mathrm{d}(\mathrm{D}-\mathrm{H})$ & $\mathrm{d}(\mathrm{H} \ldots \mathrm{A})$ & $\mathrm{d}(\mathrm{D} \ldots \mathrm{A})$ & $<(\mathrm{DHA})$ \\
\hline $\mathrm{N}(1)-\mathrm{H}(1 \mathrm{~N}) \ldots \mathrm{O}(5) \# 1$ & 0.9100 & 18.500 & $2.732(4)$ & 162.00 \\
$\mathrm{~N}(1)-\mathrm{H}(1 \mathrm{O}) \ldots \mathrm{O}(5)$ & 0.9100 & 18.800 & $2.747(5)$ & 158.00 \\
$\mathrm{~N}(1)-\mathrm{H}(1 \mathrm{P}) \ldots \mathrm{O}(4) \# 2$ & 0.9100 & 18.400 & $2.741(5)$ & 173.00 \\
$\mathrm{C}(2)-\mathrm{H}(2) \ldots \mathrm{O}(3) \# 3$ & 0.9500 & 24.100 & $3.268(6)$ & 150.00 \\
$\mathrm{C}(5)-\mathrm{H}(5) \ldots \mathrm{O}(4) \# 2$ & 0.9500 & 25.700 & $3.371(6)$ & 142.00 \\
$\mathrm{C}(7)-\mathrm{H}(7) \ldots \mathrm{Cl}(1) \# 4$ & 10.000 & 27.100 & $3.674(5)$ & 163.00 \\
$\mathrm{C}(11)-\mathrm{H}(11) \ldots \mathrm{O}(4)$ & 10.000 & 23.600 & $2.746(6)$ & 102.00
\end{tabular}



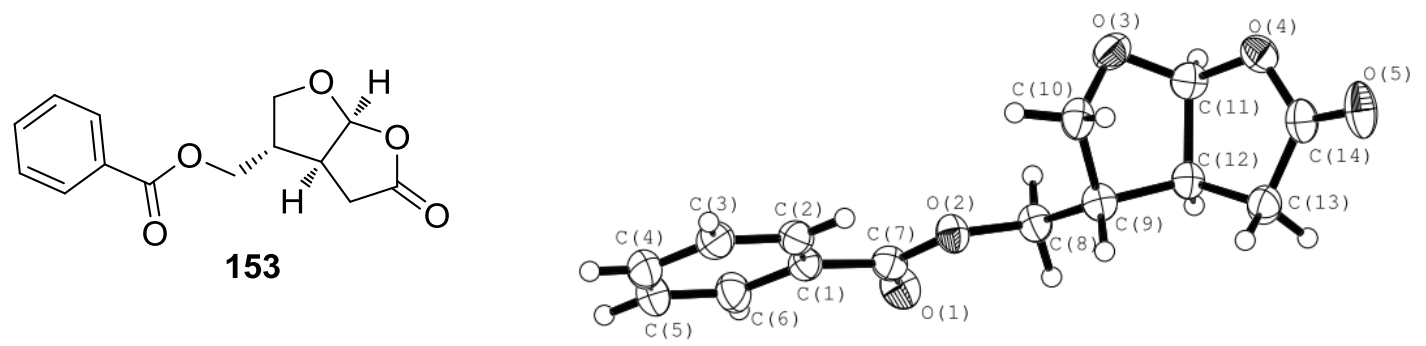

Table 1: Crystal data and structure refinement for 153.

\section{Crystal Data}

Empirical formula

Formula weight

Crystal size

Crystal description

Crystal colour

Crystal system

Space group

Unit cell dimensions

Volume

Z, Calculated density

Absorption coefficient

$\mathrm{F}(000)$

\section{Data Collection}

Measurement device type

Measurement method

Temperature

Wavelength

Monochromator

Theta range for data collection

Index ranges

Reflections collected / unique

Reflections greater $\mathrm{I}>2 \mid \mathrm{s}(\mathrm{l})$

Absorption correction

Max. and min. transmission
$\mathrm{C} 14 \mathrm{H} 14 \mathrm{O} 5$

262.25

$0.2101 \times 0.0992 \times 0.0510 \mathrm{~mm}$

plate

colourless

Orthorhombic

P 212121

$\mathrm{a}=6.55267(18) \mathrm{A}$ alpha $=90 \mathrm{deg}$.

$\mathrm{b}=8.8207$ (3) A beta $=90$ deg .

$\mathrm{c}=21.7464(7) \mathrm{A}$ gamma $=90 \mathrm{deg}$.

1256.92(7) $A^{\wedge} 3$

4, $1.386 \mathrm{Mg} / \mathrm{m}^{\wedge} 3$

$0.887 \mathrm{~mm}^{\wedge}-1$

552

SuperNova, Single source at offset, Atlas

Iw scans

$123 \mathrm{~K}$

$1.54184 \mathrm{~A}$

graphite

4.07 to 76.33 deg.

$=-7<=\mathrm{h}<=7 \quad-10<=\mathrm{k}<=10 \quad-26<=\mathrm{l}<=27$

4694 / 2540 [R(int) $=0.0322]$

2394

Analytical

0.959 and 0.907 


\section{Refinement}

Refinement method

Hydrogen treatment

Data / restraints / parameters

Goodness-of-fit on F^2

Final $R$ indices [l>2sigma(I)]

$R$ indices (all data)

Absolute structure parameter

Largest diff. peak and hole
Full-matrix least-squares on $\mathrm{F}^{\wedge} 2$$$
2540 / 0 / 172
$$

1.042

$\mathrm{R} 1=0.0459, \mathrm{wR} 2=0.1243$

$\mathrm{R} 1=0.0481, \mathrm{wR} 2=0.1275$

$0.2(2)$

0.211 and -0.233 e. $\mathrm{A}^{\wedge}-3$

Table 2: Atomic coordinates $\left(x 1^{4}\right)$ and equivalent isotropic displacement parameters $\left(\AA^{2} \times 10^{3}\right)$ for 153 . $U(e q)$ is defined as one third of the trace of the orthogonalized Uij tensor.

\begin{tabular}{lllll}
\hline Atom & $\mathrm{x}$ & $\mathrm{y}$ & $\mathrm{z}$ & $\mathrm{U}(\mathrm{eq})$ \\
\hline $\mathrm{O}(1)$ & $-7618(2)$ & $-3000(2)$ & $-8373(1)$ & $38(1)$ \\
$\mathrm{O}(2)$ & $-4434(2)$ & $-2337(2)$ & $-8634(1)$ & $30(1)$ \\
$\mathrm{O}(3)$ & $-1673(3)$ & $-3483(2)$ & $-10081(1)$ & $38(1)$ \\
$\mathrm{O}(4)$ & $707(2)$ & $-5381(2)$ & $-10253(1)$ & $35(1)$ \\
$\mathrm{O}(5)$ & $3597(2)$ & $-6343(2)$ & $-9900(1)$ & $48(1)$ \\
$\mathrm{C}(1)$ & $-6515(3)$ & $-452(2)$ & $-8214(1)$ & $30(1)$ \\
$\mathrm{C}(2)$ & $-4925(3)$ & $596(2)$ & $-8254(1)$ & $32(1)$ \\
$\mathrm{C}(3)$ & $-5239(4)$ & $2078(3)$ & $-8059(1)$ & $37(1)$ \\
$\mathrm{C}(4)$ & $-7111(4)$ & $2515(3)$ & $-7824(1)$ & $41(1)$ \\
$\mathrm{C}(5)$ & $-8687(4)$ & $1490(3)$ & $-7785(1)$ & $43(1)$ \\
$\mathrm{C}(6)$ & $-8409(4)$ & $2(3)$ & $-7982(1)$ & $38(1)$ \\
$\mathrm{C}(7)$ & $-6285(3)$ & $-2056(2)$ & $-8413(1)$ & $30(1)$ \\
$\mathrm{C}(8)$ & $-4150(3)$ & $-3837(2)$ & $-8892(1)$ & $31(1)$ \\
$\mathrm{C}(9)$ & $-1888(3)$ & $-4001(2)$ & $-9026(1)$ & $30(1)$ \\
$\mathrm{C}(10)$ & $-1145(3)$ & $-2840(2)$ & $-9491(1)$ & $34(1)$ \\
$\mathrm{C}(11)$ & $-1351(3)$ & $-5032(2)$ & $-10046(1)$ & $32(1)$ \\
$\mathrm{C}(12)$ & $-1468(3)$ & $-5508(2)$ & $-9364(1)$ & $29(1)$ \\
$\mathrm{C}(13)$ & $631(4)$ & $-6187(2)$ & $-9228(1)$ & $36(1)$ \\
$\mathrm{C}(14)$ & $1845(3)$ & $-6011(2)$ & $-9810(1)$ & $33(1)$
\end{tabular}

Table 3: Bond lengths $[\AA]$ and angles [deg] for 153.

$\begin{array}{ll}\mathrm{O}(1)-\mathrm{C}(7) & 1.210(2) \\ \mathrm{O}(2)-\mathrm{C}(7) & 1.329(2) \\ \mathrm{O}(2)-\mathrm{C}(8) & 1.448(2) \\ \mathrm{O}(3)-\mathrm{C}(10) & 1.444(3) \\ \mathrm{O}(3)-\mathrm{C}(11) & 1.385(2) \\ \mathrm{O}(4)-\mathrm{C}(11) & 1.455(2) \\ \mathrm{O}(4)-\mathrm{C}(14) & 1.339(3) \\ \mathrm{O}(5)-\mathrm{C}(14) & 1.201(2) \\ \mathrm{C}(1)-\mathrm{C}(2) & 1.396(3) \\ \mathrm{C}(1)-\mathrm{C}(6) & 1.398(3) \\ \mathrm{C}(1)-\mathrm{C}(7) & 1.487(3)\end{array}$

\begin{tabular}{|ll}
$\mathrm{O}(2)-\mathrm{C}(8)-\mathrm{C}(9)$ & $106.67(15)$ \\
$\mathrm{C}(8)-\mathrm{C}(9)-\mathrm{C}(10)$ & $112.13(16)$ \\
$\mathrm{C}(8)-\mathrm{C}(9)-\mathrm{C}(12)$ & $110.35(15)$ \\
$\mathrm{C}(10)-\mathrm{C}(9)-\mathrm{C}(12)$ & $101.89(16)$ \\
$\mathrm{O}(3)-\mathrm{C}(10)-\mathrm{C}(9)$ & $104.48(15)$ \\
$\mathrm{O}(3)-\mathrm{C}(11)-\mathrm{O}(4)$ & $109.44(16)$ \\
$\mathrm{O}(3)-\mathrm{C}(11)-\mathrm{C}(12)$ & $108.30(15)$ \\
$\mathrm{O}(4)-\mathrm{C}(11)-\mathrm{C}(12)$ & $106.62(15)$ \\
$\mathrm{C}(9)-\mathrm{C}(12)-\mathrm{C}(11)$ & $103.42(15)$ \\
$\mathrm{C}(9)-\mathrm{C}(12)-\mathrm{C}(13)$ & $113.97(16)$ \\
$\mathrm{C}(11)-\mathrm{C}(12)-\mathrm{C}(13)$ & $104.29(16)$
\end{tabular}




\begin{tabular}{|c|c|c|c|}
\hline$C(2)-C(3)$ & $1.390(3)$ & $C(12)-C(13)-C(14)$ & $105.90(17)$ \\
\hline$C(3)-C(4)$ & $1.384(4)$ & $\mathrm{O}(4)-\mathrm{C}(14)-\mathrm{O}(5)$ & $121.1(2)$ \\
\hline$C(4)-C(5)$ & $1.375(4)$ & $\mathrm{O}(4)-\mathrm{C}(14)-\mathrm{C}(13)$ & $110.70(17)$ \\
\hline$C(5)-C(6)$ & $1.393(4)$ & $\mathrm{O}(5)-\mathrm{C}(14)-\mathrm{C}(13)$ & $128.2(2)$ \\
\hline $\mathrm{C}(8)-\mathrm{C}(9)$ & $1.518(3)$ & $\mathrm{C}(1)-\mathrm{C}(2)-\mathrm{H}(2)$ & 120.00 \\
\hline$C(9)-C(10)$ & $1.520(3)$ & $\mathrm{C}(3)-\mathrm{C}(2)-\mathrm{H}(2)$ & 120.00 \\
\hline$C(9)-C(12)$ & $1.544(3)$ & $\mathrm{C}(2)-\mathrm{C}(3)-\mathrm{H}(3)$ & 120.00 \\
\hline$C(11)-C(12)$ & $1.543(3)$ & $\mathrm{C}(4)-\mathrm{C}(3)-\mathrm{H}(3)$ & 120.00 \\
\hline$C(12)-C(13)$ & $1.529(3)$ & $\mathrm{C}(3)-\mathrm{C}(4)-\mathrm{H}(4)$ & 120.00 \\
\hline$C(13)-C(14)$ & $1.502(3)$ & $\mathrm{C}(5)-\mathrm{C}(4)-\mathrm{H}(4)$ & 120.00 \\
\hline $\mathrm{C}(2)-\mathrm{H}(2)$ & 0.9500 & $\mathrm{C}(4)-\mathrm{C}(5)-\mathrm{H}(5)$ & 120.00 \\
\hline $\mathrm{C}(3)-\mathrm{H}(3)$ & 0.9500 & $\mathrm{C}(6)-\mathrm{C}(5)-\mathrm{H}(5)$ & 120.00 \\
\hline $\mathrm{C}(4)-\mathrm{H}(4)$ & 0.9500 & $\mathrm{C}(1)-\mathrm{C}(6)-\mathrm{H}(6)$ & 120.00 \\
\hline $\mathrm{C}(5)-\mathrm{H}(5)$ & 0.9500 & $\mathrm{C}(5)-\mathrm{C}(6)-\mathrm{H}(6)$ & 120.00 \\
\hline $\mathrm{C}(6)-\mathrm{H}(6)$ & 0.9500 & $\mathrm{O}(2)-\mathrm{C}(8)-\mathrm{H}(8 \mathrm{~A})$ & 110.00 \\
\hline $\mathrm{C}(8)-\mathrm{H}(8 \mathrm{~A})$ & 0.9900 & $\mathrm{O}(2)-\mathrm{C}(8)-\mathrm{H}(8 \mathrm{~B})$ & 110.00 \\
\hline $\mathrm{C}(8)-\mathrm{H}(8 \mathrm{~B})$ & 0.9900 & $\mathrm{C}(9)-\mathrm{C}(8)-\mathrm{H}(8 \mathrm{~A})$ & 110.00 \\
\hline $\mathrm{C}(9)-\mathrm{H}(9)$ & 10.000 & $\mathrm{C}(9)-\mathrm{C}(8)-\mathrm{H}(8 \mathrm{~B})$ & 110.00 \\
\hline$C(10)-H(10 A)$ & 0.9900 & $H(8 A)-C(8)-H(8 B)$ & 109.00 \\
\hline $\mathrm{C}(10)-\mathrm{H}(10 \mathrm{~B})$ & 0.9900 & $\mathrm{C}(8)-\mathrm{C}(9)-\mathrm{H}(9)$ & 111.00 \\
\hline $\mathrm{C}(11)-\mathrm{H}(11)$ & 10.000 & $C(10)-C(9)-H(9)$ & 111.00 \\
\hline $\mathrm{C}(12)-\mathrm{H}(12)$ & 10.000 & $\mathrm{C}(12)-\mathrm{C}(9)-\mathrm{H}(9)$ & 111.00 \\
\hline $\mathrm{C}(13)-\mathrm{H}(13 \mathrm{~A})$ & 0.9900 & $\mathrm{O}(3)-\mathrm{C}(10)-\mathrm{H}(10 \mathrm{~A})$ & 111.00 \\
\hline $\mathrm{C}(13)-\mathrm{H}(13 \mathrm{~B})$ & 0.9900 & $\mathrm{O}(3)-\mathrm{C}(10)-\mathrm{H}(10 \mathrm{~B})$ & 111.00 \\
\hline $\mathrm{C}(7)-\mathrm{O}(2)-\mathrm{C}(8)$ & $115.34(15)$ & $C(9)-C(10)-H(10 A)$ & 111.00 \\
\hline$C(10)-O(3)-C(11)$ & $107.57(15)$ & $C(9)-C(10)-H(10 B)$ & 111.00 \\
\hline$C(11)-O(4)-C(14)$ & $112.42(15)$ & $H(10 A)-C(10)-H(10 B)$ & 109.00 \\
\hline$C(2)-C(1)-C(6)$ & $119.70(18)$ & $\mathrm{O}(3)-\mathrm{C}(11)-\mathrm{H}(11)$ & 111.00 \\
\hline$C(2)-C(1)-C(7)$ & $122.44(17)$ & $\mathrm{O}(4)-\mathrm{C}(11)-\mathrm{H}(11)$ & 111.00 \\
\hline$C(6)-C(1)-C(7)$ & $117.86(18)$ & $C(12)-C(11)-H(11)$ & 111.00 \\
\hline$C(1)-C(2)-C(3)$ & $119.58(19)$ & $\mathrm{C}(9)-\mathrm{C}(12)-\mathrm{H}(12)$ & 112.00 \\
\hline$C(2)-C(3)-C(4)$ & $120.4(2)$ & $\mathrm{C}(11)-\mathrm{C}(12)-\mathrm{H}(12)$ & 112.00 \\
\hline$C(3)-C(4)-C(5)$ & $120.4(2)$ & $\mathrm{C}(13)-\mathrm{C}(12)-\mathrm{H}(12)$ & 112.00 \\
\hline$C(4)-C(5)-C(6)$ & $120.1(2)$ & $C(12)-C(13)-H(13 A)$ & 111.00 \\
\hline$C(1)-C(6)-C(5)$ & $119.8(2)$ & $C(12)-C(13)-H(13 B)$ & 111.00 \\
\hline $\mathrm{O}(1)-\mathrm{C}(7)-\mathrm{O}(2)$ & $123.80(17)$ & $C(14)-C(13)-H(13 A)$ & 111.00 \\
\hline $\mathrm{O}(1)-\mathrm{C}(7)-\mathrm{C}(1)$ & $124.13(18)$ & $C(14)-C(13)-H(13 B)$ & 111.00 \\
\hline $\mathrm{O}(2)-\mathrm{C}(7)-\mathrm{C}(1)$ & $112.06(16)$ & $H(13 A)-C(13)-H(13 B)$ & 109.00 \\
\hline
\end{tabular}

Table 4: Anisotropic displacement parameters $\left(A^{2} \times 10^{3}\right)$ for 153. The anisotropic displacement factor exponent takes the form: $-2 \mathrm{pi}^{2}\left[\mathrm{~h}^{2} \mathrm{a}^{* 2} \mathrm{U} 11+. .+2 \mathrm{~h} \mathrm{k} \mathrm{a*} \mathrm{b}^{*} \mathrm{U} 12\right]$.

\begin{tabular}{lllllll}
\hline Atom & U11 & U22 & U33 & U23 & U13 & U12 \\
\hline $\mathrm{O}(1)$ & $29(1)$ & $40(1)$ & $45(1)$ & $-5(1)$ & $5(1)$ & $-8(1)$ \\
$\mathrm{O}(2)$ & $25(1)$ & $29(1)$ & $38(1)$ & $-3(1)$ & $5(1)$ & $-2(1)$ \\
$\mathrm{O}(3)$ & $34(1)$ & $39(1)$ & $40(1)$ & $11(1)$ & $0(1)$ & $6(1)$ \\
$\mathrm{O}(4)$ & $31(1)$ & $40(1)$ & $34(1)$ & $-2(1)$ & $4(1)$ & $-1(1)$ \\
$\mathrm{O}(5)$ & $26(1)$ & $42(1)$ & $74(1)$ & $-18(1)$ & $2(1)$ & $6(1)$
\end{tabular}




$\begin{array}{lllllll}C(1) & 29(1) & 32(1) & 28(1) & 1(1) & 0(1) & 2(1) \\ C(2) & 31(1) & 34(1) & 29(1) & 0(1) & 1(1) & 1(1) \\ C(3) & 42(1) & 33(1) & 35(1) & -1(1) & -4(1) & -1(1) \\ C(4) & 50(1) & 39(1) & 35(1) & -5(1) & -2(1) & 12(1) \\ C(5) & 41(1) & 45(1) & 42(1) & -3(1) & 8(1) & 13(1) \\ C(6) & 33(1) & 38(1) & 42(1) & 0(1) & 8(1) & 3(1) \\ C(7) & 27(1) & 33(1) & 31(1) & 1(1) & 2(1) & -2(1) \\ C(8) & 30(1) & 26(1) & 37(1) & -2(1) & 4(1) & -4(1) \\ C(9) & 26(1) & 29(1) & 36(1) & -2(1) & 2(1) & -4(1) \\ C(10) & 27(1) & 27(1) & 48(1) & 2(1) & 8(1) & 0(1) \\ C(11) & 25(1) & 37(1) & 34(1) & 0(1) & -2(1) & -2(1) \\ C(12) & 24(1) & 28(1) & 35(1) & -1(1) & 1(1) & -1(1) \\ C(13) & 37(1) & 35(1) & 36(1) & -3(1) & -5(1) & 7(1) \\ C(14) & 27(1) & 28(1) & 44(1) & -9(1) & -2(1) & -1(1)\end{array}$

Table 5: Hydrogen coordinates $\left(x 10^{4}\right)$ and isotropic displacement parameters $\left(A^{2} x\right.$ $10^{3}$ ) for 153.

\begin{tabular}{lllll}
\hline Atom & $x$ & $y$ & $z$ & $U(e q)$ \\
\hline$H(2)$ & -3636 & 298 & -8413 & 38 \\
$H(3)$ & -4163 & 2796 & -8088 & 44 \\
$H(4)$ & -7309 & 3529 & -7689 & 50 \\
$H(5)$ & -9968 & 1797 & -7623 & 51 \\
$H(6)$ & -9503 & -702 & -7960 & 45 \\
$H(8 A)$ & -4954 & -3950 & -9274 & 37 \\
$H(8 B)$ & -4598 & -4621 & -8595 & 37 \\
$H(9)$ & -1073 & -3939 & -8638 & 36 \\
$H(10 A)$ & -1835 & -1853 & -9429 & 41 \\
$H(10 B)$ & 348 & -2691 & -9457 & 41 \\
$H(11)$ & -2385 & -5593 & -10296 & 38 \\
$H(12)$ & -2584 & -6262 & -9292 & 35 \\
$H(13 A)$ & 1296 & -5641 & -8885 & 43 \\
$H(13 B)$ & 505 & -7271 & -9116 & 43
\end{tabular}

Table 6: Torsion angles [deg] for 153.

$\begin{array}{ll}\mathrm{C}(7)-\mathrm{O}(2)-\mathrm{C}(8)-\mathrm{C}(9) & -171.59(16) \\ \mathrm{C}(8)-\mathrm{O}(2)-\mathrm{C}(7)-\mathrm{O}(1) & 6.2(3) \\ \mathrm{C}(8)-\mathrm{O}(2)-\mathrm{C}(7)-\mathrm{C}(1) & -174.38(16) \\ \mathrm{C}(11)-\mathrm{O}(3)-\mathrm{C}(10)-\mathrm{C}(9) & -37.9(2) \\ \mathrm{C}(10)-\mathrm{O}(3)-\mathrm{C}(11)-\mathrm{O}(4) & -92.25(18) \\ \mathrm{C}(10)-\mathrm{O}(3)-\mathrm{C}(11)-\mathrm{C}(12) & 23.6(2) \\ \mathrm{C}(14)-\mathrm{O}(4)-\mathrm{C}(11)-\mathrm{O}(3) & 117.86(17) \\ \mathrm{C}(11)-\mathrm{O}(4)-\mathrm{C}(14)-\mathrm{C}(13) & 0.7(2) \\ \mathrm{C}(14)-\mathrm{O}(4)-\mathrm{C}(11)-\mathrm{C}(12) & 0.9(2) \\ \mathrm{C}(11)-\mathrm{O}(4)-\mathrm{C}(14)-\mathrm{O}(5) & -178.55(18) \\ \mathrm{C}(6)-\mathrm{C}(1)-\mathrm{C}(2)-\mathrm{C}(3) & 0.4(3)\end{array}$

\begin{tabular}{|ll}
$\mathrm{C}(2)-\mathrm{C}(3)-\mathrm{C}(4)-\mathrm{C}(5)$ & $-0.5(3)$ \\
$\mathrm{C}(3)-\mathrm{C}(4)-\mathrm{C}(5)-\mathrm{C}(6)$ & $-0.1(4)$ \\
$\mathrm{C}(4)-\mathrm{C}(5)-\mathrm{C}(6)-\mathrm{C}(1)$ & $0.8(3)$ \\
$\mathrm{O}(2)-\mathrm{C}(8)-\mathrm{C}(9)-\mathrm{C}(10)$ & $-61.4(2)$ \\
$\mathrm{O}(2)-\mathrm{C}(8)-\mathrm{C}(9)-\mathrm{C}(12)$ & $-174.21(16)$ \\
$\mathrm{C}(8)-\mathrm{C}(9)-\mathrm{C}(10)-\mathrm{O}(3)$ & $-82.31(19)$ \\
$\mathrm{C}(12)-\mathrm{C}(9)-\mathrm{C}(10)-\mathrm{O}(3)$ & $35.68(19)$ \\
$\mathrm{C}(8)-\mathrm{C}(9)-\mathrm{C}(12)-\mathrm{C}(11)$ & $97.99(18)$ \\
$\mathrm{C}(8)-\mathrm{C}(9)-\mathrm{C}(12)-\mathrm{C}(13)$ & $-149.45(17)$ \\
$\mathrm{C}(10)-\mathrm{C}(9)-\mathrm{C}(12)-\mathrm{C}(11)$ & $-21.27(19)$ \\
$\mathrm{C}(10)-\mathrm{C}(9)-\mathrm{C}(12)-\mathrm{C}(13)$ & $91.30(19)$
\end{tabular}




\begin{tabular}{|c|c|c|c|}
\hline$C(7)-C(1)-C(2)-C(3)$ & $-179.88(19)$ & $\mathrm{O}(3)-\mathrm{C}(11)-\mathrm{C}(12)-\mathrm{C}(9)$ & $-0.3(2)$ \\
\hline$C(2)-C(1)-C(6)-C(5)$ & $-0.9(3)$ & $\mathrm{O}(4)-\mathrm{C}(11)-\mathrm{C}(12)-\mathrm{C}(13)$ & $-2.08(18)$ \\
\hline$C(7)-C(1)-C(6)-C(5)$ & $179.4(2)$ & $\mathrm{O}(3)-\mathrm{C}(11)-\mathrm{C}(12)-\mathrm{C}(13)$ & $-119.77(17)$ \\
\hline$C(2)-C(1)-C(7)-O(1)$ & $178.5(2)$ & $\mathrm{O}(4)-\mathrm{C}(11)-\mathrm{C}(12)-\mathrm{C}(9)$ & $117.37(16)$ \\
\hline $\mathrm{C}(6)-\mathrm{C}(1)-\mathrm{C}(7)-\mathrm{O}(1)$ & $-1.8(3)$ & $C(9)-C(12)-C(13)-C(14)$ & $-109.61(18)$ \\
\hline$C(6)-C(1)-C(7)-O(2)$ & $178.79(17)$ & $C(11)-C(12)-C(13)-C(14)$ & $2.43(19)$ \\
\hline$C(2)-C(1)-C(7)-O(2)$ & $-0.9(3)$ & $C(12)-C(13)-C(14)-O(5)$ & 177.2(2) \\
\hline$C(1)-C(2)-C(3)-C(4)$ & $0.3(3)$ & $\mathrm{C}(12)-\mathrm{C}(13)-\mathrm{C}(14)-\mathrm{O}(4)$ & $-2.0(2)$ \\
\hline
\end{tabular}

Table 7: Hydrogen-bonds for 153 [A and deg.].

\begin{tabular}{lcccc}
\hline $\mathrm{D}-\mathrm{H} \ldots \mathrm{A}$ & $\mathrm{d}(\mathrm{D}-\mathrm{H})$ & $\mathrm{d}(\mathrm{H} \ldots \mathrm{A})$ & $\mathrm{d}(\mathrm{D} \ldots \mathrm{A})$ & $<(\mathrm{DHA})$ \\
\hline $\mathrm{C}(9)-\mathrm{H}(9) \ldots \mathrm{O}(1) \# 1$ & 10.000 & 24.800 & $3.259(2)$ & 135.00 \\
$\mathrm{C}(10)-\mathrm{H}(10 \mathrm{~A}) \ldots \mathrm{O}(2)$ & 0.9900 & 24.600 & $2.883(2)$ & 105.00 \\
$\mathrm{C}(10)-\mathrm{H}(10 \mathrm{~B}) \ldots \mathrm{O}(3) \# 2$ & 0.9900 & 24.300 & $3.289(3)$ & 145.00
\end{tabular}




\section{((3S,3aS,6aS)-5-oxo-6a-(2-oxopropyl)hexahydrofuro[2,3-b]furan-3-yl)methyl} benzoate (5)
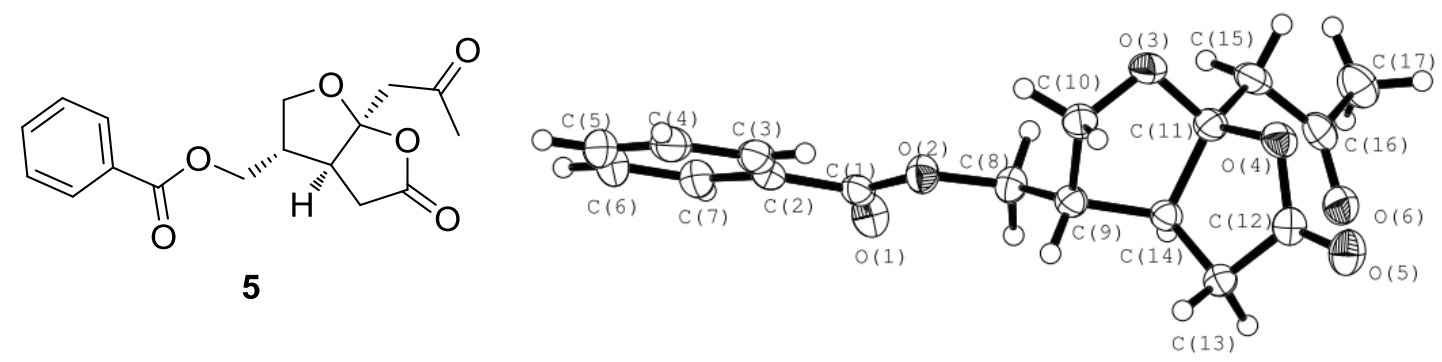

Table 1: Crystal data and structure refinement for 5.

\section{Crystal Data}

Empirical formula

Formula weight

Crystal size

Crystal description

Crystal colour

Crystal system

Space group

Unit cell dimensions

Volume

Z, Calculated density

Absorption coefficient

$\mathrm{F}(000)$

\section{Data Collection}

Measurement device type

Measurement method

Temperature

Wavelength

Monochromator

Theta range for data collection

Index ranges

Reflections collected / unique

Reflections greater $\mathrm{I}>2 / \mathrm{s}(\mathrm{I})$

Absorption correction

Max. and min. transmission

\author{
C17 H18 O6 \\ 318.31 \\ $0.2041 \times 0.0467 \times 0.0293 \mathrm{~mm}$ \\ stick \\ colourless \\ Monoclinic \\ $\mathrm{P} 21$ \\ $a=9.9890(2) A \quad$ alpha $=90 \mathrm{deg}$. \\ $\mathrm{b}=6.47394(13) \mathrm{A} \quad$ beta $=99.014(2) \mathrm{deg}$. \\ $\mathrm{c}=12.1110(3) \mathrm{A}$ gamma $=90 \mathrm{deg}$. \\ 773.52(3) $A^{\wedge} 3$ \\ 2, $1.367 \mathrm{Mg} / \mathrm{m}^{\wedge} 3$ \\ $0.870 \mathrm{~mm}^{\wedge}-1$ \\ 336
}

SuperNova, Single source at offset, Atlas Iw scans

$123 \mathrm{~K}$

$1.54184 \mathrm{~A}$

graphite

3.70 to 72.89 deg.

$=-12<=\mathrm{h}<=8 \quad-7<=\mathrm{k}<=7 \quad-14<=\mathrm{k}<=14$

$5084 / 2940[R($ int $)=0.0335]$

2830

Analytical

0.975 and 0.884 


\section{Refinement}

Refinement method

Hydrogen treatment

Data / restraints / parameters

Goodness-of-fit on $\mathrm{F}^{\wedge} 2$

Final $R$ indices [l>2sigma(I)]

$R$ indices (all data)

Absolute structure parameter

Largest diff. peak and hole
Full-matrix least-squares on $\mathrm{F}^{\wedge} 2$$$
2940 \text { / } 1 \text { / } 208
$$

1.036

$\mathrm{R} 1=0.0438, \mathrm{wR} 2=0.1160$

$\mathrm{R} 1=0.0452, \mathrm{wR} 2=0.1190$

$0.13(18)$

0.346 and -0.297 e. $\mathrm{A}^{\wedge}-3$

Table 2: Atomic coordinates $\left(x 1^{4}\right)$ and equivalent isotropic displacement parameters $\left(\AA^{2} \times 10^{3}\right)$ for 5 . $U(\mathrm{eq})$ is defined as one third of the trace of the orthogonalized Uij tensor.

\begin{tabular}{lllll}
\hline Atom & $\mathrm{x}$ & $\mathrm{y}$ & $\mathrm{z}$ & $\mathrm{U}(\mathrm{eq})$ \\
\hline $\mathrm{O}(1)$ & $3884(2)$ & $4619(2)$ & $4672(1)$ & $35(1)$ \\
$\mathrm{O}(2)$ & $2911(1)$ & $1556(2)$ & $4191(1)$ & $31(1)$ \\
$\mathrm{O}(3)$ & $357(1)$ & $-1675(2)$ & $5619(1)$ & $31(1)$ \\
$\mathrm{O}(4)$ & $855(1)$ & $-4031(2)$ & $7068(1)$ & $31(1)$ \\
$\mathrm{O}(5)$ & $2166(2)$ & $-6608(2)$ & $7829(1)$ & $39(1)$ \\
$\mathrm{O}(6)$ & $1779(2)$ & $-1494(2)$ & $9061(1)$ & $35(1)$ \\
$\mathrm{C}(1)$ & $3479(2)$ & $3351(3)$ & $3973(2)$ & $28(1)$ \\
$\mathrm{C}(2)$ & $3562(2)$ & $3603(3)$ & $2758(2)$ & $29(1)$ \\
$\mathrm{C}(3)$ & $3242(2)$ & $2012(4)$ & $1990(2)$ & $35(1)$ \\
$\mathrm{C}(4)$ & $3362(2)$ & $2339(5)$ & $872(2)$ & $42(1)$ \\
$\mathrm{C}(5)$ & $3779(2)$ & $4236(5)$ & $533(2)$ & $47(1)$ \\
$\mathrm{C}(6)$ & $4082(3)$ & $5826(5)$ & $1287(2)$ & $47(1)$ \\
$\mathrm{C}(7)$ & $3980(2)$ & $5518(4)$ & $2409(2)$ & $37(1)$ \\
$\mathrm{C}(8)$ & $2750(2)$ & $1233(3)$ & $5345(2)$ & $28(1)$ \\
$\mathrm{C}(9)$ & $2657(2)$ & $-1073(3)$ & $5533(2)$ & $26(1)$ \\
$\mathrm{C}(10)$ & $1368(2)$ & $-2015(3)$ & $4902(2)$ & $30(1)$ \\
$\mathrm{C}(11)$ & $981(2)$ & $-1885(3)$ & $6720(2)$ & $28(1)$ \\
$\mathrm{C}(12)$ & $2067(2)$ & $-4895(3)$ & $7434(2)$ & $29(1)$ \\
$\mathrm{C}(13)$ & $3200(2)$ & $-3483(3)$ & $7248(2)$ & $28(1)$ \\
$\mathrm{C}(14)$ & $2525(2)$ & $-1498(3)$ & $6764(2)$ & $25(1)$ \\
$\mathrm{C}(15)$ & $221(2)$ & $-563(3)$ & $7441(2)$ & $32(1)$ \\
$\mathrm{C}(16)$ & $793(2)$ & $-503(3)$ & $8663(2)$ & $32(1)$ \\
$\mathrm{C}(17)$ & $58(3)$ & $891(4)$ & $9352(2)$ & $43(1)$
\end{tabular}

Table 3: Bond lengths $[\AA \AA]$ and angles [deg] for 5 .

$\begin{array}{ll}\mathrm{O}(1)-\mathrm{C}(1) & 1.204(2) \\ \mathrm{O}(2)-\mathrm{C}(1) & 1.338(2) \\ \mathrm{O}(2)-\mathrm{C}(8) & 1.447(2) \\ \mathrm{O}(3)-\mathrm{C}(10) & 1.448(2) \\ \mathrm{O}(3)-\mathrm{C}(11) & 1.387(2) \\ \mathrm{O}(4)-\mathrm{C}(11) & 1.463(2)\end{array}$

\begin{tabular}{|ll}
$\mathrm{O}(3)-\mathrm{C}(10)-\mathrm{C}(9)$ & $104.67(15)$ \\
$\mathrm{O}(3)-\mathrm{C}(11)-\mathrm{O}(4)$ & $108.93(15)$ \\
$\mathrm{O}(3)-\mathrm{C}(11)-\mathrm{C}(14)$ & $108.08(15)$ \\
$\mathrm{O}(3)-\mathrm{C}(11)-\mathrm{C}(15)$ & $108.05(16)$ \\
$\mathrm{O}(4)-\mathrm{C}(11)-\mathrm{C}(14)$ & $105.82(15)$ \\
$\mathrm{O}(4)-\mathrm{C}(11)-\mathrm{C}(15)$ & $107.35(15)$
\end{tabular}




\begin{tabular}{|c|c|}
\hline $\mathrm{O}(4)-\mathrm{C}(12)$ & $1.344(2)$ \\
\hline $\mathrm{O}(5)-\mathrm{C}(12)$ & $1.206(2)$ \\
\hline $\mathrm{O}(6)-\mathrm{C}(16)$ & $1.211(2)$ \\
\hline$C(1)-C(2)$ & $1.496(3)$ \\
\hline $\mathrm{C}(2)-\mathrm{C}(3)$ & $1.390(3)$ \\
\hline$C(2)-C(7)$ & $1.394(3)$ \\
\hline$C(3)-C(4)$ & $1.395(3)$ \\
\hline$C(4)-C(5)$ & $1.380(4)$ \\
\hline$C(5)-C(6)$ & $1.378(4)$ \\
\hline$C(6)-C(7)$ & $1.393(3)$ \\
\hline $\mathrm{C}(8)-\mathrm{C}(9)$ & $1.515(3)$ \\
\hline $\mathrm{C}(9)-\mathrm{C}(10)$ & $1.518(3)$ \\
\hline $\mathrm{C}(9)-\mathrm{C}(14)$ & $1.542(3)$ \\
\hline$C(11)-C(14)$ & $1.555(3)$ \\
\hline$C(11)-C(15)$ & $1.509(3)$ \\
\hline$C(12)-C(13)$ & $1.499(3)$ \\
\hline$C(13)-C(14)$ & $1.526(3)$ \\
\hline$C(15)-C(16)$ & $1.502(3)$ \\
\hline$C(16)-C(17)$ & $1.497(3)$ \\
\hline $\mathrm{C}(3)-\mathrm{H}(3)$ & 0.9500 \\
\hline $\mathrm{C}(4)-\mathrm{H}(4)$ & 0.9500 \\
\hline $\mathrm{C}(5)-\mathrm{H}(5)$ & 0.9500 \\
\hline $\mathrm{C}(6)-\mathrm{H}(6)$ & 0.9500 \\
\hline $\mathrm{C}(7)-\mathrm{H}(7)$ & 0.9500 \\
\hline $\mathrm{C}(8)-\mathrm{H}(8 \mathrm{~A})$ & 0.9900 \\
\hline $\mathrm{C}(8)-\mathrm{H}(8 \mathrm{~B})$ & 0.9900 \\
\hline $\mathrm{C}(9)-\mathrm{H}(9)$ & 10.000 \\
\hline $\mathrm{C}(10)-\mathrm{H}(10 \mathrm{~A})$ & 0.9900 \\
\hline $\mathrm{C}(10)-\mathrm{H}(10 \mathrm{~B})$ & 0.9900 \\
\hline$C(13)-H(13 A)$ & 0.9900 \\
\hline $\mathrm{C}(13)-\mathrm{H}(13 \mathrm{~B})$ & 0.9900 \\
\hline $\mathrm{C}(14)-\mathrm{H}(14)$ & 10.000 \\
\hline$C(15)-H(15 A)$ & 0.9900 \\
\hline $\mathrm{C}(15)-\mathrm{H}(15 \mathrm{~B})$ & 0.9900 \\
\hline $\mathrm{C}(17)-\mathrm{H}(17 \mathrm{~A})$ & 0.9800 \\
\hline $\mathrm{C}(17)-\mathrm{H}(17 \mathrm{~B})$ & 0.9800 \\
\hline $\mathrm{C}(17)-\mathrm{H}(17 \mathrm{C})$ & 0.9800 \\
\hline $\mathrm{C}(1)-\mathrm{O}(2)-\mathrm{C}(8)$ & $115.54(15)$ \\
\hline$C(10)-O(3)-C(11)$ & $108.14(14)$ \\
\hline$C(11)-O(4)-C(12)$ & $112.12(15)$ \\
\hline $\mathrm{O}(1)-\mathrm{C}(1)-\mathrm{O}(2)$ & $124.03(19)$ \\
\hline $\mathrm{O}(1)-\mathrm{C}(1)-\mathrm{C}(2)$ & $123.66(18)$ \\
\hline $\mathrm{O}(2)-\mathrm{C}(1)-\mathrm{C}(2)$ & $112.31(17)$ \\
\hline$C(1)-C(2)-C(3)$ & $122.29(18)$ \\
\hline$C(1)-C(2)-C(7)$ & $117.38(18)$ \\
\hline$C(3)-C(2)-C(7)$ & $120.3(2)$ \\
\hline$C(2)-C(3)-C(4)$ & $119.4(2)$ \\
\hline
\end{tabular}

\begin{tabular}{|ll}
$\mathrm{C}(14)-\mathrm{C}(11)-\mathrm{C}(15)$ & $118.33(16)$ \\
$\mathrm{O}(4)-\mathrm{C}(12)-\mathrm{O}(5)$ & $121.79(19)$ \\
$\mathrm{O}(4)-\mathrm{C}(12)-\mathrm{C}(13)$ & $111.05(16)$ \\
$\mathrm{O}(5)-\mathrm{C}(12)-\mathrm{C}(13)$ & $127.14(19)$ \\
$\mathrm{C}(12)-\mathrm{C}(13)-\mathrm{C}(14)$ & $105.80(15)$ \\
$\mathrm{C}(9)-\mathrm{C}(14)-\mathrm{C}(11)$ & $103.33(15)$ \\
$\mathrm{C}(9)-\mathrm{C}(14)-\mathrm{C}(13)$ & $114.99(16)$ \\
$\mathrm{C}(11)-\mathrm{C}(14)-\mathrm{C}(13)$ & $104.72(15)$ \\
$\mathrm{C}(11)-\mathrm{C}(15)-\mathrm{C}(16)$ & $115.91(17)$ \\
$\mathrm{O}(6)-\mathrm{C}(16)-\mathrm{C}(15)$ & $122.59(18)$ \\
$\mathrm{O}(6)-\mathrm{C}(16)-\mathrm{C}(17)$ & $122.5(2)$ \\
$\mathrm{C}(15)-\mathrm{C}(16)-\mathrm{C}(17)$ & $114.89(18)$ \\
$\mathrm{C}(2)-\mathrm{C}(3)-\mathrm{H}(3)$ & 120.00 \\
$\mathrm{C}(4)-\mathrm{C}(3)-\mathrm{H}(3)$ & 120.00 \\
$\mathrm{C}(3)-\mathrm{C}(4)-\mathrm{H}(4)$ & 120.00 \\
$\mathrm{C}(5)-\mathrm{C}(4)-\mathrm{H}(4)$ & 120.00 \\
$\mathrm{C}(4)-\mathrm{C}(5)-\mathrm{H}(5)$ & 120.00 \\
$\mathrm{C}(6)-\mathrm{C}(5)-\mathrm{H}(5)$ & 120.00 \\
$\mathrm{C}(5)-\mathrm{C}(6)-\mathrm{H}(6)$ & 120.00 \\
$\mathrm{C}(7)-\mathrm{C}(6)-\mathrm{H}(6)$ & 120.00 \\
$\mathrm{C}(2)-\mathrm{C}(7)-\mathrm{H}(7)$ & 120.00 \\
$\mathrm{C}(6)-\mathrm{C}(7)-\mathrm{H}(7)$ & 120.00 \\
$\mathrm{O}(2)-\mathrm{C}(8)-\mathrm{H}(8 \mathrm{~A})$ & 110.00 \\
$\mathrm{O}(2)-\mathrm{C}(8)-\mathrm{H}(8 \mathrm{~B})$ & 110.00 \\
$\mathrm{C}(9)-\mathrm{C}(8)-\mathrm{H}(8 \mathrm{~A})$ & 110.00 \\
$\mathrm{C}(9)-\mathrm{C}(8)-\mathrm{H}(8 \mathrm{~B})$ & 110.00 \\
$\mathrm{H}(8 \mathrm{~A})-\mathrm{C}(8)-\mathrm{H}(8 \mathrm{~B})$ & 108.00 \\
$\mathrm{C}(8)-\mathrm{C}(9)-\mathrm{H}(9)$ & 110.00 \\
$\mathrm{C}(10)-\mathrm{C}(9)-\mathrm{H}(9)$ & 110.00 \\
$\mathrm{C}(14)-\mathrm{C}(9)-\mathrm{H}(9)$ & 110.00 \\
$\mathrm{O}(3)-\mathrm{C}(10)-\mathrm{H}(10 \mathrm{~A})$ & 111.00 \\
$\mathrm{O}(3)-\mathrm{C}(10)-\mathrm{H}(10 \mathrm{~B})$ & 111.00 \\
$\mathrm{C}(9)-\mathrm{C}(10)-\mathrm{H}(10 \mathrm{~A})$ & 111.00 \\
$\mathrm{C}(9)-\mathrm{C}(10)-\mathrm{H}(10 \mathrm{~B})$ & 111.00 \\
$\mathrm{H}(10 \mathrm{~A})-\mathrm{C}(10)-\mathrm{H}(10 \mathrm{~B})$ & 109.00 \\
$\mathrm{C}(12)-\mathrm{C}(13)-\mathrm{H}(13 \mathrm{~A})$ & 111.00 \\
$\mathrm{C}(12)-\mathrm{C}(13)-\mathrm{H}(13 \mathrm{~B})$ & 111.00 \\
$\mathrm{C}(14)-\mathrm{C}(13)-\mathrm{H}(13 \mathrm{~A})$ & 111.00 \\
$\mathrm{C}(14)-\mathrm{C}(13)-\mathrm{H}(13 \mathrm{~B})$ & 111.00 \\
$\mathrm{H}(13 \mathrm{~A})-\mathrm{C}(13)-\mathrm{H}(13 \mathrm{~B})$ & 109.00 \\
$\mathrm{C}(9)-\mathrm{C}(14)-\mathrm{H}(14)$ & 111.00 \\
$\mathrm{C}(11)-\mathrm{C}(14)-\mathrm{H}(14)$ & 111.00 \\
$\mathrm{C}(13)-\mathrm{C}(14)-\mathrm{H}(14)$ & 111.00 \\
$\mathrm{C}(11)-\mathrm{C}(15)-\mathrm{H}(15 \mathrm{~A})$ & 108.00 \\
$\mathrm{C}(11)-\mathrm{C}(15)-\mathrm{H}(15 \mathrm{~B})$ & 108.00 \\
$\mathrm{C}(16)-\mathrm{C}(15)-\mathrm{H}(15 \mathrm{~A})$ & 108.00 \\
$\mathrm{C}(16)-\mathrm{C}(15)-\mathrm{H}(15 \mathrm{~B})$ & 108.00 \\
&
\end{tabular}




\begin{tabular}{ll|ll}
$\mathrm{C}(3)-\mathrm{C}(4)-\mathrm{C}(5)$ & $120.0(3)$ & $\mathrm{H}(15 \mathrm{~A})-\mathrm{C}(15)-\mathrm{H}(15 \mathrm{~B})$ & 107.00 \\
$\mathrm{C}(4)-\mathrm{C}(5)-\mathrm{C}(6)$ & $120.9(2)$ & $\mathrm{C}(16)-\mathrm{C}(17)-\mathrm{H}(17 \mathrm{~A})$ & 109.00 \\
$\mathrm{C}(5)-\mathrm{C}(6)-\mathrm{C}(7)$ & $119.8(3)$ & $\mathrm{C}(16)-\mathrm{C}(17)-\mathrm{H}(17 \mathrm{~B})$ & 109.00 \\
$\mathrm{C}(2)-\mathrm{C}(7)-\mathrm{C}(6)$ & $119.6(2)$ & $\mathrm{C}(16)-\mathrm{C}(17)-\mathrm{H}(17 \mathrm{C})$ & 109.00 \\
$\mathrm{O}(2)-\mathrm{C}(8)-\mathrm{C}(9)$ & $107.83(15)$ & $\mathrm{H}(17 \mathrm{~A})-\mathrm{C}(17)-\mathrm{H}(17 \mathrm{~B})$ & 110.00 \\
$\mathrm{C}(8)-\mathrm{C}(9)-\mathrm{C}(10)$ & $112.80(16)$ & $\mathrm{H}(17 \mathrm{~A})-\mathrm{C}(17)-\mathrm{H}(17 \mathrm{C})$ & 110.00 \\
$\mathrm{C}(8)-\mathrm{C}(9)-\mathrm{C}(14)$ & $109.73(15)$ & $\mathrm{H}(17 \mathrm{~B})-\mathrm{C}(17)-\mathrm{H}(17 \mathrm{C})$ & 109.00 \\
$\mathrm{C}(10)-\mathrm{C}(9)-\mathrm{C}(14)$ & $102.74(15)$ & &
\end{tabular}

Table 4: Anisotropic displacement parameters $\left(A^{2} \times 10^{3}\right)$ for 5. The anisotropic displacement factor exponent takes the form: $-2 \mathrm{pi}^{2}\left[\mathrm{~h}^{2} \mathrm{a}^{* 2} \mathrm{U} 11+. .+2 \mathrm{hk} \mathrm{a}^{*} \mathrm{~b}^{*} \mathrm{U} 12\right]$.

\begin{tabular}{lllllll}
\hline Atom & $\mathrm{U} 11$ & $\mathrm{U} 22$ & $\mathrm{U} 33$ & $\mathrm{U} 23$ & $\mathrm{U} 13$ & $\mathrm{U} 12$ \\
\hline $\mathrm{O}(1)$ & $44(1)$ & $29(1)$ & $36(1)$ & $-4(1)$ & $13(1)$ & $-4(1)$ \\
$\mathrm{O}(2)$ & $35(1)$ & $30(1)$ & $28(1)$ & $2(1)$ & $5(1)$ & $-6(1)$ \\
$\mathrm{O}(3)$ & $22(1)$ & $37(1)$ & $32(1)$ & $0(1)$ & $0(1)$ & $-2(1)$ \\
$\mathrm{O}(4)$ & $28(1)$ & $27(1)$ & $38(1)$ & $1(1)$ & $5(1)$ & $-6(1)$ \\
$\mathrm{O}(5)$ & $51(1)$ & $25(1)$ & $43(1)$ & $5(1)$ & $10(1)$ & $-2(1)$ \\
$\mathrm{O}(6)$ & $36(1)$ & $38(1)$ & $31(1)$ & $1(1)$ & $8(1)$ & $2(1)$ \\
$\mathrm{C}(1)$ & $23(1)$ & $28(1)$ & $34(1)$ & $2(1)$ & $8(1)$ & $3(1)$ \\
$\mathrm{C}(2)$ & $21(1)$ & $37(1)$ & $31(1)$ & $4(1)$ & $6(1)$ & $4(1)$ \\
$\mathrm{C}(3)$ & $27(1)$ & $44(1)$ & $33(1)$ & $-1(1)$ & $6(1)$ & $4(1)$ \\
$\mathrm{C}(4)$ & $30(1)$ & $64(2)$ & $32(1)$ & $-3(1)$ & $4(1)$ & $5(1)$ \\
$\mathrm{C}(5)$ & $36(1)$ & $73(2)$ & $32(1)$ & $14(1)$ & $10(1)$ & $8(1)$ \\
$\mathrm{C}(6)$ & $41(1)$ & $60(2)$ & $43(1)$ & $18(1)$ & $15(1)$ & $0(1)$ \\
$\mathrm{C}(7)$ & $33(1)$ & $39(1)$ & $40(1)$ & $9(1)$ & $8(1)$ & $0(1)$ \\
$\mathrm{C}(8)$ & $32(1)$ & $26(1)$ & $26(1)$ & $1(1)$ & $4(1)$ & $-3(1)$ \\
$\mathrm{C}(9)$ & $24(1)$ & $26(1)$ & $28(1)$ & $2(1)$ & $4(1)$ & $-1(1)$ \\
$\mathrm{C}(10)$ & $29(1)$ & $32(1)$ & $28(1)$ & $-1(1)$ & $2(1)$ & $-4(1)$ \\
$\mathrm{C}(11)$ & $24(1)$ & $27(1)$ & $31(1)$ & $2(1)$ & $2(1)$ & $-4(1)$ \\
$\mathrm{C}(12)$ & $34(1)$ & $25(1)$ & $28(1)$ & $-1(1)$ & $7(1)$ & $-1(1)$ \\
$\mathrm{C}(13)$ & $26(1)$ & $27(1)$ & $30(1)$ & $4(1)$ & $5(1)$ & $2(1)$ \\
$\mathrm{C}(14)$ & $22(1)$ & $24(1)$ & $27(1)$ & $0(1)$ & $3(1)$ & $-2(1)$ \\
$\mathrm{C}(15)$ & $21(1)$ & $33(1)$ & $42(1)$ & $2(1)$ & $8(1)$ & $0(1)$ \\
$\mathrm{C}(16)$ & $30(1)$ & $28(1)$ & $40(1)$ & $0(1)$ & $13(1)$ & $-5(1)$ \\
$\mathrm{C}(17)$ & $43(1)$ & $41(1)$ & $47(1)$ & $-5(1)$ & $19(1)$ & $2(1)$ \\
& & & & & &
\end{tabular}

Table 5: Hydrogen coordinates $\left(x 10^{4}\right)$ and isotropic displacement parameters $\left(A^{2} x\right.$ $\left.10^{3}\right)$ for 5 .

\begin{tabular}{lllll}
\hline Atom & $x$ & $y$ & $z$ & $U($ eq $)$ \\
\hline$H(3)$ & 2944 & 714 & 2226 & 41 \\
$H(4)$ & 3156 & 1256 & 344 & 50 \\
$H(5)$ & 3859 & 4448 & -230 & 56 \\
$H(6)$ & 4359 & 7129 & 1042 & 56 \\
$H(7)$ & 4195 & 6605 & 2934 & 44 \\
$H(8 A)$ & 1916 & 1925 & 5502 & 34 \\
$H(8 B)$ & 3534 & 1816 & 5850 & 34
\end{tabular}




$\begin{array}{lllll}H(9) & 3472 & -1790 & 5331 & 31 \\ H(10 A) & 1104 & -1326 & 4170 & 36 \\ H(10 B) & 1490 & -3509 & 4775 & 36 \\ H(13 A) & 3745 & -4109 & 6719 & 33 \\ H(13 B) & 3802 & -3199 & 7962 & 33 \\ H(14) & 2833 & -283 & 7247 & 29 \\ H(15 A) & 190 & 868 & 7149 & 38 \\ H(15 B) & -724 & -1069 & 7361 & 38 \\ H(17 A) & 680 & 1958 & 9702 & 64 \\ H(17 B) & -282 & 81 & 9933 & 64 \\ H(17 C) & -705 & 1545 & 8871 & 64\end{array}$

Table 6: Torsion angles [deg] for 5 .

$\begin{array}{ll}\mathrm{C}(8)-\mathrm{O}(2)-\mathrm{C}(1)-\mathrm{O}(1) & 2.5(3) \\ \mathrm{C}(8)-\mathrm{O}(2)-\mathrm{C}(1)-\mathrm{C}(2) & -177.82(15) \\ \mathrm{C}(1)-\mathrm{O}(2)-\mathrm{C}(8)-\mathrm{C}(9) & -157.17(16) \\ \mathrm{C}(11)-\mathrm{O}(3)-\mathrm{C}(10)-\mathrm{C}(9) & -36.31(18) \\ \mathrm{C}(10)-\mathrm{O}(3)-\mathrm{C}(11)-\mathrm{O}(4) & -91.71(17) \\ \mathrm{C}(10)-\mathrm{O}(3)-\mathrm{C}(11)-\mathrm{C}(14) & 22.81(19) \\ \mathrm{C}(10)-\mathrm{O}(3)-\mathrm{C}(11)-\mathrm{C}(15) & 151.97(15) \\ \mathrm{C}(12)-\mathrm{O}(4)-\mathrm{C}(11)-\mathrm{O}(3) & 123.27(16) \\ \mathrm{C}(12)-\mathrm{O}(4)-\mathrm{C}(11)-\mathrm{C}(14) & 7.3(2) \\ \mathrm{C}(12)-\mathrm{O}(4)-\mathrm{C}(11)-\mathrm{C}(15) & -119.96(17) \\ \mathrm{C}(11)-\mathrm{O}(4)-\mathrm{C}(12)-\mathrm{O}(5) & 174.76(18) \\ \mathrm{C}(11)-\mathrm{O}(4)-\mathrm{C}(12)-\mathrm{C}(13) & -6.8(2) \\ \mathrm{O}(1)-\mathrm{C}(1)-\mathrm{C}(2)-\mathrm{C}(3) & 171.9(2) \\ \mathrm{O}(1)-\mathrm{C}(1)-\mathrm{C}(2)-\mathrm{C}(7) & -8.1(3) \\ \mathrm{O}(2)-\mathrm{C}(1)-\mathrm{C}(2)-\mathrm{C}(3) & -7.8(3) \\ \mathrm{O}(2)-\mathrm{C}(1)-\mathrm{C}(2)-\mathrm{C}(7) & 172.24(17) \\ \mathrm{C}(1)-\mathrm{C}(2)-\mathrm{C}(3)-\mathrm{C}(4) & -178.97(19) \\ \mathrm{C}(7)-\mathrm{C}(2)-\mathrm{C}(3)-\mathrm{C}(4) & 1.0(3) \\ \mathrm{C}(1)-\mathrm{C}(2)-\mathrm{C}(7)-\mathrm{C}(6) & 179.6(2) \\ \mathrm{C}(3)-\mathrm{C}(2)-\mathrm{C}(7)-\mathrm{C}(6) & -0.3(3) \\ \mathrm{C}(2)-\mathrm{C}(3)-\mathrm{C}(4)-\mathrm{C}(5) & -0.8(3) \\ \mathrm{C}(3)-\mathrm{C}(4)-\mathrm{C}(5)-\mathrm{C}(6) & 0.0(3) \\ \mathrm{C}(4)-\mathrm{C}(5)-\mathrm{C}(6)-\mathrm{C}(7) & 0.6(4) \\ \mathrm{C}(5)-\mathrm{C}(6)-\mathrm{C}(7)-\mathrm{C}(2) & -0.5(4) \\ & \\ & \end{array}$

\begin{tabular}{|ll}
$\mathrm{O}(2)-\mathrm{C}(8)-\mathrm{C}(9)-\mathrm{C}(10)$ & $-67.7(2)$ \\
$\mathrm{O}(2)-\mathrm{C}(8)-\mathrm{C}(9)-\mathrm{C}(14)$ & $178.40(15)$ \\
$\mathrm{C}(8)-\mathrm{C}(9)-\mathrm{C}(10)-\mathrm{O}(3)$ & $-84.02(18)$ \\
$\mathrm{C}(14)-\mathrm{C}(9)-\mathrm{C}(10)-\mathrm{O}(3)$ & $34.04(18)$ \\
$\mathrm{C}(8)-\mathrm{C}(9)-\mathrm{C}(14)-\mathrm{C}(11)$ & $100.04(17)$ \\
$\mathrm{C}(8)-\mathrm{C}(9)-\mathrm{C}(14)-\mathrm{C}(13)$ & $-146.47(16)$ \\
$\mathrm{C}(10)-\mathrm{C}(9)-\mathrm{C}(14)-\mathrm{C}(11)$ & $-20.16(18)$ \\
$\mathrm{C}(10)-\mathrm{C}(9)-\mathrm{C}(14)-\mathrm{C}(13)$ & $93.33(18)$ \\
$\mathrm{O}(3)-\mathrm{C}(11)-\mathrm{C}(14)-\mathrm{C}(9)$ & $-0.62(19)$ \\
$\mathrm{O}(3)-\mathrm{C}(11)-\mathrm{C}(14)-\mathrm{C}(13)$ & $-121.35(16)$ \\
$\mathrm{O}(4)-\mathrm{C}(11)-\mathrm{C}(14)-\mathrm{C}(9)$ & $115.95(16)$ \\
$\mathrm{O}(4)-\mathrm{C}(11)-\mathrm{C}(14)-\mathrm{C}(13)$ & $-4.79(18)$ \\
$\mathrm{C}(15)-\mathrm{C}(11)-\mathrm{C}(14)-\mathrm{C}(9)$ & $-123.74(18)$ \\
$\mathrm{C}(15)-\mathrm{C}(11)-\mathrm{C}(14)-\mathrm{C}(13)$ & $115.53(18)$ \\
$\mathrm{O}(3)-\mathrm{C}(11)-\mathrm{C}(15)-\mathrm{C}(16)$ & $-176.97(16)$ \\
$\mathrm{O}(4)-\mathrm{C}(11)-\mathrm{C}(15)-\mathrm{C}(16)$ & $65.7(2)$ \\
$\mathrm{C}(14)-\mathrm{C}(11)-\mathrm{C}(15)-\mathrm{C}(16)$ & $-53.8(2)$ \\
$\mathrm{O}(4)-\mathrm{C}(12)-\mathrm{C}(13)-\mathrm{C}(14)$ & $3.3(2)$ \\
$\mathrm{O}(5)-\mathrm{C}(12)-\mathrm{C}(13)-\mathrm{C}(14)$ & $-178.35(19)$ \\
$\mathrm{C}(12)-\mathrm{C}(13)-\mathrm{C}(14)-\mathrm{C}(9)$ & $-111.52(17)$ \\
$\mathrm{C}(12)-\mathrm{C}(13)-\mathrm{C}(14)-\mathrm{C}(11)$ & $1.15(19)$ \\
$\mathrm{C}(11)-\mathrm{C}(15)-\mathrm{C}(16)-\mathrm{O}(6)$ & $-2.0(3)$ \\
$\mathrm{C}(11)-\mathrm{C}(15)-\mathrm{C}(16)-\mathrm{C}(17)$ & $177.43(18)$ \\
& \\
&
\end{tabular}

Table 7: Hydrogen-bonds for 5 [Å and deg.].

\begin{tabular}{lcccc}
\hline $\mathrm{D}-\mathrm{H} \ldots \mathrm{A}$ & $\mathrm{d}(\mathrm{D}-\mathrm{H})$ & $\mathrm{d}(\mathrm{H} \ldots \mathrm{A})$ & $\mathrm{d}(\mathrm{D} \ldots \mathrm{A})$ & $<(\mathrm{DHA})$ \\
\hline $\mathrm{C}(9)-\mathrm{H}(9) \ldots \mathrm{O}(1) \# 1$ & 10.000 & 25.100 & $3.281(2)$ & 133.00 \\
$\mathrm{C}(10)-\mathrm{H}(10 \mathrm{~A}) \ldots \mathrm{O}(2)$ & 0.9900 & 25.900 & $2.980(2)$ & 103.00 \\
$\mathrm{C}(14)-\mathrm{H}(14) \ldots \mathrm{O}(5) \# 2$ & 10.000 & 26.000 & $3.458(2)$ & 144.00 \\
$\mathrm{C}(15)-\mathrm{H}(15 \mathrm{~A}) \ldots \mathrm{O}(5) \# 2$ & 0.9900 & 25.900 & $3.204(2)$ & 120.00
\end{tabular}




\section{List of publications}

Enantioselective Synthesis of (-)-Paeonilide

Klaus Harrar, Oliver Reiser

Manuscript in preparation

\section{Poster presentations and scientific meetings}

\section{Model Study towards Crassalactone D}

Klaus Harrar, Oliver Reiser

ESF-COST High-Level Research Conference on Natural Products Chemistry, Biology and Medicine II, Acquafredda di Maratea, Italy, 2009

Towards the Stereoselective Synthesis of Paeonilide

Klaus Harrar, Oliver Reiser

$3^{\text {rd }}$ EuCheMS Chemistry Congress, Nürnberg, Germany, 2010 


\section{Curriculum vitae}

\section{Personal Data}

Name: Klaus Harrar

Date of birth: $\quad 23.10 .1982$

Marital status: Married

Nationality: $\quad$ German

\section{Education}

10/2007-12/2011 PhD thesis at the University of Regensburg under supervision of Prof. Dr. Oliver Reiser

"Enantioselective Synthesis of (-)-Paeonilide"

$09 / 2007$

Graduation: Diplom Chemiker (diploma in chemistry, Master of Science equivalent)

01/2007-09/2007 Diploma thesis at the University of Regensburg under supervision of Prof. Dr. Oliver Reiser

"Studien zur asymmetrischen Synthese von Paeonilid"

10/2002-09/2007 Studies in Chemistry, University of Regensburg, Germany

09/1993-06/2002 Abitur (A-level)

Ludwigsgymnasium Straubing, Germany

(High school Certificate equivalent)

09/1989-08-1993 Primary school Rain, Germany 
E. Appendix

Languages

German (native)

English (fluently)

Professional References

Prof. Dr.Oliver Reiser

Institute für Organische Chemie

Universität Regensburg

Universitätsstr. 31

93053 Regensburg

Phone: +49-941-9434631

E-mail: oliver.reiser@chemie.uni-regensburg.de 


\section{F. References}

1. Xue, T. H.; Roy, R., Science 2003, 300, 740.

2. Oka, H.; Yamamoto, S.; Kuroki, T.; Harihara, S.; Marumo, T.; Kim, S. R.; Monna, T.; Kobayashi, K.; Tango, T., Cancer 1995, 76, 743.

3. Sheehan, M. P.; Rustin, M. H. A.; Atherton, D. J.; Buckley, C.; Harris, D. J.; Brostoff, J.; Ostlere, L.; Dawson, A., Lancet 1992, 340, 13.

4. Normile, D., Science 2003, 299, 188.

5. Kimura, M.; Kimura, I.; Nojima, H.; Takahashi, K.; Hayashi, T.; Shimizu, M.; Morita, N., Jpn J Pharmacol 1984, 35, 61.

6. Chen, L.; Wang, D.; Wu, J.; Yu, B.; Zhu, D., J Pharm Biomed Anal 2009, 49, 267.

7. Hatakeyama, S.; Kawamura, M.; Shimanuki, E.; Takano, S., Tet Lett 1992, 33, 333.

8. Hayashi, T.; Shinbo, T.; Shimizu, M.; Arisawa, M.; Morita, N.; Kimura, M.; Matsuda, S.; Kikuchi, T., Tet Lett 1985, 26, 3699.

9. Shimizu, M.; Hayashi, T.; Morita, N.; Kimura, I.; Kimura, M.; Kiuchi, F.; Noguchi, H.; litaka, Y.; Sankawa, U., Tet Lett 1981, 22, 3069.

10. Morita, N. The report of the results of studies on muscle relaxants from Paeony root; 1983, p 24, supported by a Grant-in-Aid for Scientific Research from the Ministry of Education, Science, and Culture of Japan.

11. Liu, J. K.; Ma, Y. B.; Wu, D. G.; Lu, Y.; Shen, Z. Q.; Zheng, Q. T.; Chen, Z. H., Biosci Biotechnol Biochem 2000, 64, 1511.

12. http://www.giftpflanzen.com/paeonia_delavayi.html (accessed 07.09.2011).

13. Good, W. http://www.paeonia.ch/weltd/einfd6.htm (accessed 05.09.2011).

14. Nakanishi, K.; Jaracz, S.; Stromgaard, K., J Org Chem 2002, 67, 4623.

15. Schmid, W., Nature 1997, 386, 755.

16. Jagel, A. http://www.ruhr-uni-bochum.de/boga/html/Ginkgo_biloba_Foto.html (accessed 06.09.2011).

17. DeFeudis, F. Y., Ginkgo biloba extract (EGB 761): Pharmacological Activities and Clinical Application. Elsevier: Paris, 1991; p 97.

18. Kleijnen, J.; Knipschild, P., Lancet 1992, 340, 1136.

19. Le Bars, P. L.; Katz, M. M.; Berman, N.; Itil, T. M.; Freedman, A. M.; Schatzberg, A. F., J Am Med Assoc 1997, 278, 1327. 
20. Braquet, P.; Hosford, D., J Ethnopharmacol 1991, 32, 135.

21. Sugimoto, T.; Tsuchimochi, H.; McGregor, C. G. A.; Mutoh, H.; Shimizu, T.; Kurachi, Y., Biochem Bioph Res Co 1992, 189, 617.

22. Plow, E. F.; Marguerie, G.; Ginsberg, M., Biochem Pharmacol 1987, 36, 4035.

23. Fuster, V.; Badimon, L.; Badimon, J. J.; Chesebro, J. H., N Engl J Med 1992, $326,310$.

24. Wang, C.; Liu, J.; Ji, Y.; Zhao, J.; Li, L.; Zhang, H., Org Lett 2006, 8, 2479.

25. Du, Y.; Liu, J.; Linhardt, R. J., J Org Chem 2007, 72, 3952.

26. Wang, C.; Zhang, H.; Liu, J.; Ji, Y.; Shao, Z.; Li, L., Synlett 2006, 1051.

27. Rubottom, G. M.; Gruber, J. M., J Org Chem 1978, 43, 1599.

28. Weisser, R.; Yue, W.; Reiser, O., Org Lett 2005, 7, 5353.

29. Bubert, C.; Cabrele, C.; Reiser, O., Synlett 1997, 1997, 827.

30. Salaün, J., Cyclopropane Derivatives and their Diverse Biological Activities, Small Ring Compounds in Organic Synthesis VI. de Meijere, A., Ed. Springer Berlin / Heidelberg: 2000; Vol. 207, pp 1.

31. Faust, R., Angew Chem Int Ed 2001, 40, 2251.

32. Gnad, F.; Reiser, O., Chem Rev 2003, 103, 1603.

33. Koglin, N.; Zorn, C.; Beumer, R.; Cabrele, C.; Bubert, C.; Sewald, N.; Reiser, O.; Beck-Sickinger, A. G., Angew Chem Int Ed 2003, 42, 202.

34. Patai, S.; Rappoport, Z., Biochemistry of the Cyclopropyl Group. Wiley: Chichester, New York, Brisbane, Toronto, Singapore, 1987, Chapter 16.

35. Saltykova, L. E.; Vasil'vitskii, A. E.; Shostakovskii, V. M.; Nefedov, O. M., Russ Chem B+ 1988, 37, 2557.

36. Wenkert, E.; Guo, M.; Lavilla, R.; Porter, B.; Ramachandran, K.; Sheu, J. H., J Org Chem 1990, 55, 6203.

37. Nosse, B.; Chhor, R. B.; Jeong, W. B.; Böhm, C.; Reiser, O., Org Lett 2003, 5, 941.

38. Jezek, E.; Schall, A.; Kreitmeier, P.; Reiser, O., Synlett 2005, 2005, 0915.

39. Kalidindi, S.; Jeong, W. B.; Schall, A.; Bandichhor, R.; Nosse, B.; Reiser, O., Angew Chem Int Ed 2007, 46, 6361.

40. Chhor, R. B.; Nosse, B.; Sörgel, S.; Böhm, C.; Seitz, M.; Reiser, O., Chem Eur J 2003, 9, 260.

41. Böhm, C.; Reiser, O., Org Lett 2001, 3, 1315. 
42. Noels, A. F.; Demonceau, A.; Petiniot, N.; Hubert, A. J.; Teyssié, P., Tetrahedron 1982, 38, 2733.

43. Divald, S.; Chun, M. C.; Joullie, M. M., J Org Chem 1976, 41, 2835.

44. Schinnerl, M.; Seitz, M.; Kaiser, A.; Reiser, O., Org Lett 2001, 3, 4259.

45. Evans, D. A.; Woerpel, K. A.; Nosse, B.; Schall, A.; Shinde, Y.; Jezek, E.; Haque, M. M.; Chhor, R. B.; Reiser, O., Org Synth 2006, 11, 821.

46. Diez-Barra, E.; De, I. H. A.; Moreno, A.; Sanchez-Verdu, P., J Chem Soc Perkin Trans 1 1991, 2589.

47. Aggarwal, V. K.; Bell, L.; Coogan, M. P.; Jubault, P., J. Chem. Soc., Perkin Trans. 1 1998, 2037.

48. Regitz, M., Angew Chem Int Edit 1967, 6, 733.

49. Nicewicz, D. A.; Breteche, G.; Johnson, J. S., Org Synth 2008, 85, 278.

50. Warner, P.; Sutherland, R., J Org Chem 1992, 57, 6294.

51. Silberrad, O.; Roy, C. S., J Chem Soc Transact 1906, 89, 179.

52. Davies, H. M. L., Tetrahedron 1993, 49, 5203.

53. Mann, J., Tetrahedron 1986, 42, 4611.

54. Piers, E., In Comrehensive Organic Synthesis. Trost, B. M. ed.; Pergamon Press: Oxford, 1991, Vol. 5, p 971; Vol. 5.

55. Hudlicky, T.; Fan, R.; Reed, J. W.; Gadamasetti, K. G., DivinylcyclopropaneCycloheptadiene Rearrangement. In Organic Reactions, John Wiley \& Sons, Inc.: 2004.

56. Hudlickly, T.; Reed, J. W., In Comprehensive Organic Synthesis. Trost, B. M., Fleming, I. ed.; Pergamon Press: Oxford, 1991, Vol. 5, p 899; Vol. 5, p 899.

57. Goldschmidt, Z.; Crammer, B., Chem Soc Rev 1988, 17, 229.

58. Hudlický, T.; Kutchan, T. M.; Naqvi, S. M., The VinylcyclopropaneCyclopentene Rearrangement. In Organic Reactions, John Wiley \& Sons, Inc.: 2004.

59. Nonhebel, D. C., Chem Soc Rev 1993, 22, 347.

60. Baird, M.; Reißig, H. U.; Salaün, J.; Reißig, H.-U., Donor-acceptor-substituted cyclopropanes: Versatile building blocks in organic synthesis, Small ring compounds in organic synthesis III. Springer Berlin / Heidelberg: 1988; Vol. 144, pp 73. 
61. Baird, M.; Reißig, H. U.; Salaün, J.; Salaün, J., Synthesis and synthetic applications of 1-donor substituted cyclopropanes with ethynyl, vinyl and carbonyl groups, Small ring compounds in organic synthesis III. Springer Berlin / Heidelberg: 1988; Vol. 144, pp 1.

62. Wong, H. N. C.; Hon, M. Y.; Tse, C. W.; Yip, Y. C.; Tanko, J.; Hudlicky, T., Chem Rev 1989, 89, 165.

63. Reissig, H.-U.; Zimmer, R., Chem Rev 2003, 103, 1151.

64. Wenkert, E., Acc Chem Res 1980, 13, 27.

65. Wenkert, E., Heterocycles 1980, 14, 1703.

66. Fraile, J. M.; García, J. I.; Martínez-Merino, V.; Mayoral, J. A.; Salvatella, L., J Am Chem Soc 2001, 123, 7616.

67. Rasmussen, T.; Jensen, J. F.; Østergaard, N.; Tanner, D.; Ziegler, T.; Norrby, P.-O., Chem Eur J 2002, 8, 177.

68. Lebel, H.; Marcoux, J. F.; Molinaro, C.; Charette, A. B., Chem Rev 2003, 103, 977.

69. Salomon, R. G.; Kochi, J. K., J Am Chem Soc 1973, 95, 3300.

70. Moser, W. R., J Am Chem Soc 1969, 91, 1135.

71. Doyle, M. P.; Protopopova, M. N.; Brandes, B. D.; Davies, H. M. L.; Huby, N. J. S.; Whitesell, J. K., Synlett 1993, 1993, 151.

72. Doyle, M. P.; Dorow, R. L.; Terpstra, J. W.; Rodenhouse, R. A., J Org Chem 1985, 50, 1663.

73. Haddad, N.; Galili, N., Tet Asym 1997, 8, 3367.

74. Fritschi, H.; Leutenegger, U.; Pfaltz, A., Helv Chim Acta 1988, 71, 1553.

75. Temme, O.; Taj, S.-A.; Andersson, P. G., J Org Chem 1998, 63, 6007.

76. Reiser, O.; Schinnerl, M.; Böhm, C.; Seitz, M., Tet Asym 2003, 14, 765.

77. Kim, C.; Brady, T.; Kim, S. H.; Theodorakis, E. A., Synth Commun 2004, 34, 1951.

78. Morizawa, Y.; Hiyama, T.; Nozaki, H., Tet Lett 1981, 22, 2297.

79. Patnode, W.; Schmidt, F., J Am Chem Soc 1945, 67, 2272.

80. Kantlehner, W.; Haug, E.; Mergen, W. W., Synthesis 1980, 460.

81. Sommer, L. H.; Kerr, G. T.; Whitmore, F. C., J Am Chem Soc 1948, 70, 445.

82. Bodensteiner, J.; Buschauer, A.; Reiser, O., New tetrahydrofurane based compounds as potential histamine $\mathrm{H} 3$ and $\mathrm{H} 4$ receptor ligands. In 5th Summerschool "Medicinal Chemistry" GRK 760, 2010, Regensburg, 2010. 
83. Zhang, M.; Zhu, L.; Ma, X.; Dai, M.; Lowe, D., Org Lett 2003, 5, 1587.

84. Weisser, R. Darstellung von asymmetrisch substituierten Tetrahydrofuranen als Bausteine in der Naturstoffsynthese. PhD Thesis, Universität Regensburg, Regensburg, 2006.

85. Ung, A. T.; Pyne, S. G.; Batenburg-Nguyen, U.; Davis, A. S.; Sherif, A.; Bischoff, F.; Lesage, A. S. J., Tetrahedron 2005, 61, 1803.

86. Hudlicky, T.; Sinai-Zingde, G.; Natchus, M. G., Tet Lett 1987, 28, 5287.

87. Peschko, C.; Winklhofer, C.; Steglich, W., Chem Eur J 2000, 6, 1147.

88. Müller, P.; Siegfried, B., Helv Chim Acta 1974, 57, 987.

89. Crawforth, J. M.; Fawcett, J.; Rawlings, B. J., J Chem Soc Perk Trans 1 1998, 1721.

90. Theodorakis, E. A.; Brady, T. P.; Kim, S. H.; Wen, K.; Kim, C., Chem-Eur J 2005, 11, 7175.

91. von E. Doering, W.; Buttery, R. G.; Laughlin, R. G.; Chaudhuri, N., J Am Chem Soc 1956, 78, 3224.

92. Arndtsen, B. A.; Bergman, R. G.; Mobley, T. A.; Peterson, T. H., Acc Chem Res 1995, 28, 154.

93. Dyker, G., Angew Chem Int Ed 1999, 38, 1698.

94. Guari, Y.; Sabo-Etienne, S.; Chaudret, B., Eur J Inorg Chem 1999, 1999, 1047.

95. Caballero, A.; Diaz-Requejo, M. M.; Belderrain, T. R.; Nicasio, M. C.; Trofimenko, S.; Perez, P. J., Organometallics 2003, 22, 4145.

96. Doyle, M. P., In Comprehensive Organometallic Chemistry II, Pergamon Press: Oxford, U.K.: 1995; Vol. 12, p 421.

97. Doyle, M. P.; McKervey, M. A.; Ye, T., Modern Catalytic Methods for Organic Synthesis with Diazo Compounds. John Wiley \& Sons: New York, 1998.

98. Scott, L. T.; DeCicco, G. J., J Am Chem Soc 1974, 96, 322.

99. Wulfman, D. S.; McDaniel Jr, R. S.; Peace, B. W., Tetrahedron 1976, 32, 1241.

100. Demonceau, A.; Noels, A. F.; Hubert, A. J.; Teyssie, P., J Chem Soc, Chem Commun 1981, 688.

101. Demonceau, A.; Noels, A. F.; Hubert, A. J.; Teyssie, P., B Soc Chim Belg 1984, 93, 945. 
102. Demonceau, A.; Noels, A. F.; Teyssie, P.; Hubert, A. J., J Mol Catal 1988, 49, L13.

103. Demonceau, A.; Noels, A. F.; Hubert, A. J., J Mol Catal 1989, 57, 149.

104. Demonceau, A.; Noels, A. F.; Costa, J. L.; Hubert, A. J., J Mol Catal 1990, 58, 21.

105. Doyle, M. P., In Comprehensive Organometallic Chemistry II, Pergamon Press: Oxford, U.K.: 1995; Vol. 12, p 115.

106. Blanksby, S. J.; Ellison, G. B., Acc Chem Res 2003, 36, 255.

107. Greuter, F.; Kalvoda, J.; Jeger, O., Proc Chem Soc 1958, 349.

108. Burke, S. D.; Grieco, P. A., Org. React. 1979, 26, 361.

109. Padwa, A.; Austin, D. J., Angew Chem Int Ed Engl 1994, 33, 1797.

110. Fraile, J. M.; Garcia, J. I.; Mayoral, J. A.; Roldan, M., Org Lett 2007, 9, 731.

111. Davies, H. M. L.; Hansen, T.; Churchill, M. R., J Am Chem Soc 2000, 122, 3063.

112. Diaz-Requejo, M. M.; Belderrain, T. R.; Nicasio, M. C.; Trofimenko, S.; Perez, P. J., J Am Chem Soc 2002, 124, 896.

113. Adams, J.; Poupart, M.-A.; Grenier, L.; Schaller, C.; Ouimet, N.; Frenette, R., Tet Lett 1989, 30, 1749.

114. Stork, G.; Kazuhiko, N., Tet Lett 1988, 29, 2283.

115. Kraus, G. A.; Landgrebe, K., Tetrahedron 1985, 41, 4039.

116. Juffermans, J. P. H.; Habraken, C. L., J Org Chem 1986, 51, 4656.

117. Rheingold, A. L.; Liable-Sands, L. M.; Incarvito, C. L.; Trofimenko, S., J Chem Soc, Dalton Trans 2002, 2297.

118. Caballero, A.; Díaz-Requejo, M. M.; Belderraín, T. R.; Nicasio, M. C.; Trofimenko, S.; Pérez, P. J., J Am Chem Soc 2003, 125, 1446.

119. Elschenbroich, C., Organometallics. 3rd, completely rev. and extended ed.; Wiley-VCH: Weinheim, 2006, p 610; p xiv.

120. Matsuda, S.; Yamanoi, T.; Watanabe, M., Tetrahedron 2008, 64, 8082.

121. Taft, R. W.; Bordwell, F. G., Acc Chem Res 1988, 21, 463.

122. Kende, A. S.; Fludzinski, P., Org Synth 1986, 64, 104.

123. Elsner, P.; Jetter, P.; Brodner, K.; Helmchen, G., Eur J Org Chem 2008, 2551.

124. Narasimhan, S.; Madhavan, S.; Prasad, K. G., J Org Chem 1995, 60, 5314.

125. Crimmins, M. T.; Ellis, J. M.; Emmitte, K. A.; Haile, P. A.; McDougall, P. J.; Parrish, J. D.; Zuccarello, J. L., Chem-Eur J 2009, 15, 9223. 
126. Smidt, J.; Hafner, W.; Jira, R.; Sedlmeier, J.; Sieber, R.; Rüttinger, R.; Kojer, H., Angew Chem 1959, 71, 176.

127. Jacques, M., Tetrahedron 2007, 63, 7505.

128. Takacs, J. M.; Jiang, X. T., Curr Org Chem 2003, 7, 369.

129. Tsuji, J., Synthesis 1984, 369.

130. Sharma, G. V. M.; Krishna, P. R., Curr Org Chem 2004, 8, 1187.

131. Han, J. S.; Lowary, T. L., J Org Chem 2003, 68, 4116.

132. Mitsudome, T.; Umetani, T.; Nosaka, N.; Mori, K.; Mizugaki, T.; Ebitani, K.; Kaneda, K., Angew Chem Int Edit 2006, 45, 481.

133. Shao, H. W.; Ekthawatchai, S.; Chen, C. S.; Wu, S. H.; Zou, W., J Org Chem 2005, 70, 4726.

134. Rogers, H. R.; McDermott, J. X.; Whitesides, G. M., J Org Chem 1975, 40, 3577.

135. Kitching, W., Organomet Chem Rev A 1968, 3, 61.

136. Zou, W.; Bhasin, M.; Vembaiyan, K.; Williams, D. T., Carbohyd Res 2009, 344, 1024.

137. Tomioka, H.; Oshima, K.; Nozaki, H., Tet Lett 1982, 23, 539.

138. Rydberg, D. B.; Meinwald, J., Tet Lett 1996, 37, 1129.

139. Stevens, R. V.; Chapman, K. T.; Stubbs, C. A.; Tam, W. W.; Albizati, K. F., Tet Lett 1982, 23, 4647.

140. Corey, E. J.; Ishiguro, M., Tet Lett 1979, 2745.

141. Stevens, R. V.; Chapman, K. T.; Weller, H. N., J Org Chem 1980, 45, 2030.

142. Schlessinger, R. H.; Lopes, A., J Org Chem 1981, 46, 5252.

143. Dess, D. B.; Martin, J. C., J Org Chem 1983, 48, 4155.

144. Horeau, A., Tet Lett 1969, 3121.

145. Evans, D. A.; Peterson, G. S.; Johnson, J. S.; Barnes, D. M.; Campos, K. R.; Woerpel, K. A., J Org Chem 1998, 63, 4541.

146. Glos, M.; Reiser, O., Org Lett 2000, 2, 2045.

147. Eisenbraun, E. J., Org Synth 1973, 5, 310. 


\section{G. Acknowledgement}

Bei Prof. Dr. Oliver Reiser möchte ich mich herzlichst für die interessante Themenstellung und für die Unterstützung während der gesamten Arbeit bedanken.

Bedanken möchte ich mich auch bei der Firma Schwabe GmbH \& Co. KG für das Durchführen der biologischen Testungen.

Priv. Doz. Dr. Kirsten Zeitler danke ich für die zahlreichen Diskussionen und die Hilfe bei vielen fachlichen Fragestellungen.

Herzlich bedanke ich mich auch bei Dr. Peter Kreitmeier, für seine ständige Hilfe bei allen Problemen, mit denen man im Laboralltag zu kämpfen hat.

Ganz besonderer Dank gilt meinen Laborkollegen, Dr. Markus Hager, Ludwig Pilsl, Dr. Woraluk Mansawat, Dr. Ramesh Rasappan, Dr. Gang Xu und Simon Lindner für die kollegiale und hilfsbereite Atmosphäre in den letzten Jahren. Dabei möchte ich im besonderen Markus und Ludwig für ihre Freundschaft danken!

Dank auch an alle derzeitigen und ehemaligen Mitarbeitern am Lehrstuhl, für die Hilfe bei der Arbeit, eine angenehme Atmosphäre und natürlich auch für alle Aktivitäten neben dem Labor wie Grillabende, Wanderungen, BBV, Public Viewing und vieles mehr. Dabei möchte ich besonders folgenden Kollegen danken: Ludwig Pilsl, Dr. Markus Hager, Sebastian Wittmann, Andreas Kreuzer, Kathrin Ulbrich, Paul Kohls, Dr. Alexander Schätz, Dr. Florian Sahr, Dr. Michael Kuhn, Michael Schwarz, Julian Bodensteiner, Roland Linhardt, Quirin Kainz, Dr. Tobias Olbrich, Dr. Hans Zwicknagel und Dr. Alexander Tereshchenko.

Für ihre Ausdauer beim Korrekturlesen der Arbeit danke ich Dr. Alexander Schätz, Dr. Markus Hager, Ludwig Pilsl, Sebastian Wittmann, Andreas Kreuzer und Agnes. 
Darüber hinaus danke ich Georg Adolin, Klaus Döring, Andrea Roithmeier, Helena Konkel und Robert Tomahogh für kleinere und größere Arbeiten am Lehrstuhl, die den Arbeitsalltag deutlich erleichtert haben. Das Selbe gilt auch für unsere Sekretärinnen Young Rotermund und Hedwig Ohli.

Nicht weniger möchte ich mich bei meinen Freunden außerhalb des Lehrstuhls bedanken: Dr. Matthias Stich, Rebecca Schreib, Dr. Anna Hezinger, Benjamin Gruber, Bernadette Streifinger, Judith Hager, August Breu, Dr. Nikola Pluym, Dr. Stefanie und Dr. Tobias Gärtner, Dr. Tobias Birnkammer, Tobias Negele, Inka Chia, Andreas Mandl, Robert Rolle und alle, die ich hier noch vergessen haben sollte.

Ich danke auch allen Mitarbeitern der Zentralen Analytik, deren unermüdliche Arbeit zum Gelingen dieser Dissertation maßgeblich beigetragen hat.

Letztendlich gilt mein größter Dank jedoch meiner Frau Agnes und meiner Familie, die immer hinter mir standen, mich gehalten und unterstützt haben. Ohne sie wären die letzten Jahre, das Studium und die Promotion, so nicht möglich gewesen. 

Herewith I declare that I have made this existing work single-handed. I have only used the stated utilities.

Regensburg, 19 $9^{\text {th }}$ December 2011

Klaus Harrar 